Emerson Cesar da Silva Gomes

\title{
RESPONSABILIDADE FINANCEIRA: UMA TEORIA SOBRE A RESPONSABILIDADE NO ÂMBITO DOS TRIBUNAIS DE CONTAS
}

Dissertação de Mestrado apresentada à Faculdade de Direito da Universidade de São Paulo como requisito para obtenção do grau de Mestre em Direito Financeiro, elaborada sob orientação do Professor Livre-Docente Dr. José Maurício Conti

USP

São Paulo

2009 


\section{FOLHA DE APROVAÇÃO}

Emerson Cesar da Silva Gomes

Responsabilidade Financeira: uma teoria sobre a responsabilidade no âmbito dos tribunais de contas

Dissertação de Mestrado apresentada à

Faculdade de Direito da Universidade de São

Paulo como requisito para obtenção do grau de

Mestre em Direito Financeiro.

Área de Concentração: Direito Financeiro

Aprovado em:

Banca Examinadora

Prof. Dr.

Instituição:

Assinatura:

Prof. Dr.

Instituição:

Assinatura:

Prof. Dr.

Instituição:

Assinatura:

Prof. Dr.

Instituição:

Assinatura:

Prof. Dr.

Instituição:

Assinatura: 


\section{RESUMO}

GOMES, Emerson Cesar da Silva. Responsabilidade financeira - uma teoria sobre a responsabilidade no âmbito dos Tribunais de Contas. 2008. 364 p. Dissertação (Mestrado) Faculdade de Direito, Universidade de São Paulo, São Paulo, 2008.

A responsabilidade financeira é uma espécie de responsabilidade jurídica existente nos países que adotam o modelo de Tribunais de Contas com função jurisdicional. No Brasil, existem duas modalidades de responsabilidade financeira: a reintegratória, que compreende o ressarcimento do dano causado ao erário (débito) e a sancionatória, que compreende a aplicação de uma multa, que pode ser cumulada ou não com a imputação de débito. É responsabilidade subjetiva que incide sobre um conjunto específico de sujeitos denominados de "agentes contábeis". Está vinculada às funções de fiscalização da gestão pública e de

julgamento das contas, o que reforça a sua finalidade preventiva e, não somente, reparadora ou punitiva. A responsabilidade financeira tem características, pressupostos e finalidades próprias que a diferenciam de outras espécies de responsabilidade, tais como, a responsabilidade civil, a penal, a disciplinar, a administrativa e a responsabilidade por ato de improbidade administrativa. Os Tribunais de Contas exercem uma jurisdição especial e limitada, relacionada às pretensões do Estado à Responsabilidade Financeira, o que em outros países é denominada jurisdição contábil ou financeira. Esta modalidade de jurisdição é compatível com as demais jurisdições, ainda que se sujeite a eventual controle pelo Poder Judiciário, restrito aos aspectos formais e de manifesta ilegalidade.

Palavras-chave: Responsabilidade financeira. Gestão Pública. Tribunal de Contas. Jurisdição Contábil. Recursos Públicos. Multa. Débito. Dano ao Erário. Regime Jurídico. 


\begin{abstract}
GOMES, Emerson Cesar da Silva. Responsabilidade financeira - uma teoria sobre a responsabilidade no âmbito dos Tribunais de Contas. 2008. 364 p. Dissertação (Mestrado) Faculdade de Direito, Universidade de São Paulo, São Paulo, 2008.

The accounting liability is a kind of legal responsibility present in the countries that adopt the model of "Courts of Auditors" with jurisdictional functions. In Brazil, there are two types of accounting liabilities: "reintegratory" liability, which comprise the compensation of the loss caused to the state treasury (debt); and the "sanctionatory" liability, which comprise the submission of a fine, cumulated or not with the debt imputation. It is a subjective liability upon specific group of individuals referred as "countable agents". It is closely related to the functioning roles as public auditing and accounting judgment, which reinforces its preventive purpose, instead of solely reparatory or punitive. The accounting liability has its own characteristics, requirements and purposes which differentiates it from the other types of responsibilities such as civil, criminal, disciplinary, administrative and the responsibility related to the administrative improbity. The Courts of Accounts employ a specific and limited jurisdiction, which is related to the State's pretensions regarding financial responsibility. In other countries this is regarded as countable or financial jurisdiction. This jurisdiction modality is compatible with other jurisdictions, even though it is eventually subjected to the control by the Judiciary Power which is restricted to formal aspects and to manifested illegality.
\end{abstract}

Keywords: Accounting Liability. Public Management. Court if Auditors. Accounting Jurisdiction. Public Funds. Public Money. Fine. Debt. Loss. State Treasury. Juridical Regime. 


\section{RESUMEN}

GOMES, Emerson Cesar da Silva. Responsabilidade financeira - uma teoria sobre a responsabilidade no âmbito dos Tribunais de Contas. 2008. 364 p. Dissertação (Mestrado) Faculdade de Direito, Universidade de São Paulo, São Paulo, 2008.

La responsabilidad financiera (en España, responsabilidad contable) es una especie de responsabilidad jurídica existente en los países que adoptan el modelo de Tribunales de Cuentas con función jurisdiccional. En Brasil, existen dos modalidades de responsabilidad financiera: la "reintegratoria" (o compensatoria), que comprende el resarcimiento del daño causado al erario (débito) y la sancionatoria, que comprende la imposicion de una multa, que puede ser acumulada o no con la imputación del debito. Es responsabilidad subjetiva que incide sobre un conjunto específico de sujetos denominados "cuentadantes". Esta vinculada a las funciones de fiscalización de la gestión pública y de enjuiciamiento de las cuentas, lo que refuerza su finalidad preventiva y, no solamente, reparadora o punitiva. La responsabilidad financiera tiene características, presupuestos y finalidades propias que la diferencian de otras especies de responsabilidad, tales como, la responsabilidad civil, la penal, la disciplinar, la administrativa y la responsabilidad por acto de "improbidade" administrativa. Los Tribunales de Cuentas ejercen una jurisdicción especial y limitada, desde el punto de vista personal y material, relacionada con las pretensiones del Estado de Responsabilidad Financiera, lo que en otros países se denomina jurisdicción contable o financiera. Esta modalidad de jurisdicción es compatible con las demás jurisdicciones, aunque se sujete a un eventual control por el Poder Judicial, restringido a los aspectos formales y de manifiesta ilegalidad.

Palabras llave: Responsabilidad financiera. Responsabilidad Contable. Gestión Publica. Tribunal de Cuentas. Jurisdicción Contable. Multa. Débito. Daño ao Erario. Regimén Jurídico. Cuentadantes. 


\section{AGRADECIMENTOS}

Esta Dissertação não poderia ser concluída sem a participação de algumas pessoas e instituições, às quais eu gostaria, nessa oportunidade, de expressar meus sinceros agradecimentos.

Ao Prof. Livre-Docente Dr. José Maurício Conti por ter acreditado no tema e pela sempre dedicada orientação e auxílio no desenvolvimento da pesquisa.

À minha família, em especial, à minha esposa Luciana, à minha filha Carolina, aos meus pais, Wilson e Ana, e aos meus irmãos, Willian e Wilton, pelo apoio, pela paciência e, até mesmo, pela cobrança na execução deste Trabalho.

Ao Tribunal de Contas da União, pelas oportunidades que me concedeu de estudar e aprofundar os conhecimentos na área Jurídica e, em especial, aos amigos Sérgio Ayres, Cyonil e Wilson, pelo apoio nos estudos e pelos profícuos debates em Direito.

Aos amigos do curso de Introdução ao Direito Alemão na Hochschule Bremen, David Figueiredo, de Portugal, e David Gonzalez, da Espanha, que me ajudaram a compreender o Direito e a Organização do Estado em seus países.

Ao Tribunal de Contas de Portugal, ao Tribunal de Cuentas da Espanha, ao Bundesrechnungshof da Alemanha e ao Rechnungshof da Áustria, pela presteza com que atenderam as minhas solicitações, fornecendo informações e publicações acerca da Responsabilidade dos Agentes Públicos nestes países.

Por fim, não poderia esquecer de agradecer, de modo geral, aos amigos e Professores da Faculdade de Direito da USP. 


\begin{abstract}
"(...) nella gestione della cosa pubblica, l'amministratore o il dipendente non deve sentirsi troppo con le mani legate, non deve esser frenato dall'ossessivo timore di sbagliare e pertanto non deve essere ritenuto responsabile di qualsiasi comportamento colposo, ed in particolare di quegli errori che, talvolta, come sottolinea un illustre civilista (...), per legge statistica 'debbono accadere'"'!1. (Paolo Maddalena, Juiz da Corte Constitucional Italiana)
\end{abstract}

\footnotetext{
${ }^{1}$ Na gestão da coisa pública, o administrador ou o funcionário não deve sentir-se demasiadamente com as mãos atadas, não deve ser freado pelo ostensivo temor de errar e, por isso, não deve ser considerado responsável por qualquer comportamento culposo e, em particular, por aqueles erros que, segundo sublinha um ilustre civilista, pela lei estatística devem acontecer.

Fonte: http://www.amcorteconti.it/mad_inquad_dogm.htm
} 


\section{SIGLAS UTILIZADAS}

ATC - Auto do Tribunal Constitucional (Espanha)

CDBF - Cour de Discipline Budgétaire et Financière (França)

CRTC - Chambre Regionale des Comptes (França)

CE - Constituição Espanhola de 1978

CF/88 - Constituição Federal Brasileira de 1988

CNJ - Conselho Nacional de Justiça (Brasil)

CNPq - Conselho Nacional de Desenvolvimento Científico e Tecnológico (Brasil)

CP - Código Penal (Brasil)

CPC - Código de Processo Civil (Brasil)

CPLP - Comunidade dos Países de Língua Portuguesa

CPM - Código Penal Militar (Brasil)

CTB - Código de Trânsito Brasileito

CTN - Código Tributário Nacional

EC - Emenda Constitucional

LDO - Lei de Diretrizes Orçamentárias (Brasil)

LFTCu - Ley de Funcionamiento del Tribunal de Cuentas (Espanha)

LOPTC - Lei de Organização e Processo no Tribunal de Contas de Portugal (Lei n 98/97, com suas alterações posteriores)

LOTCu - Ley Orgánica del Tribunal de Cuentas (Espanha)

LRF - Lei de Responsabilidade Fiscal (Lei Complementar n 101/2000 - Brasil)

MS - Mandado de Segurança (Brasil)

OSCIP - Organização da Sociedade Civil de Interesse Público (Brasil)

RCL - Receita Corrente Líquida (Lei de Responsabilidade Fiscal)

RE - Recurso Extraordinário (Brasil)

RGF - Relatório de Gestão Fiscal (Lei de Responsabilidade Fiscal)

RITCU - Regimento Interno do Tribunal de Contas da União (Brasil)

SAI (EFS) - Entidade Fiscalizadora Superior (Supreme Audit Institution)

SINAPI - Sistema Nacional de Pesquisa de Custos e Índices da Construção Civil

STC - Sentença do Tribunal Constitucional (Espanha) 
STF - Supremo Tribunal Federal (Brasil)

STJ - Superior Tribunal de Justiça (Brasil)

STN - Secretaria do Tesouro Nacional (Brasil)

TCE - Tomada de Contas Especial

TCE/(SIGLA) - Tribunal de Contas do Estado (Brasil)

TCU - Tribunal de Contas da União (Brasil)

TRF - Tribunal Regional Federal (Brasil) 


\section{ÍNDICE}

PARTE I - PARTE INTRODUTÓRIA

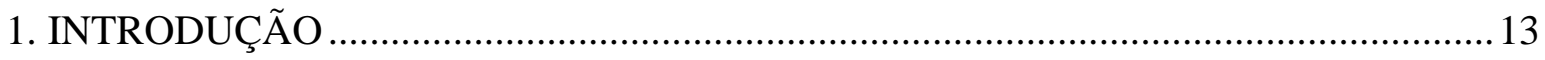

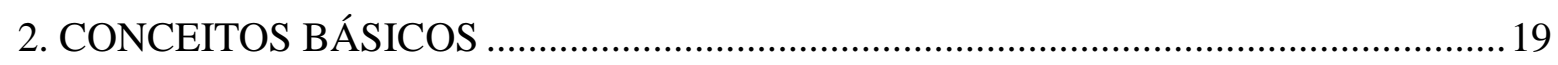

3. CONCEITO DE RESPONSABILIDADE FINANCEIRA …………............................... 32

4. FUNDAMENTOS DA RESPONSABILIDADE FINANCEIRA ……………….............4

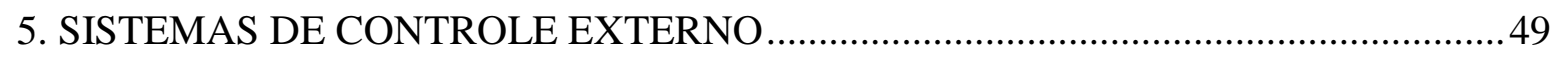

6. A RESPONSABILIDADE NO DIREITO ESTRANGEIRO …………………..............53

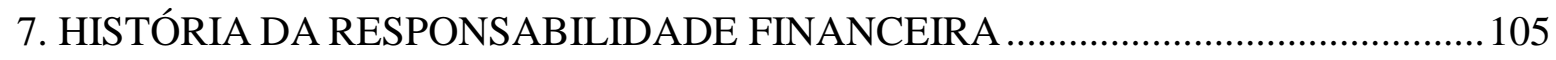

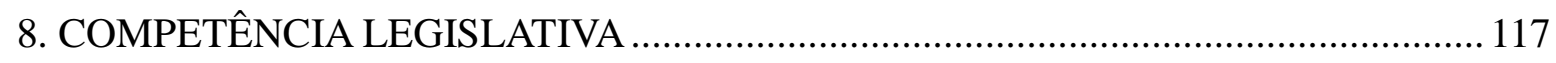

9. PRINCÍPIOS GERAIS DA REPRESSÃO.................................................................... 120

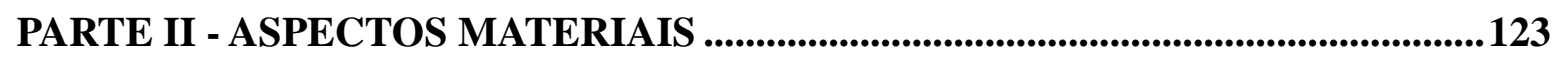

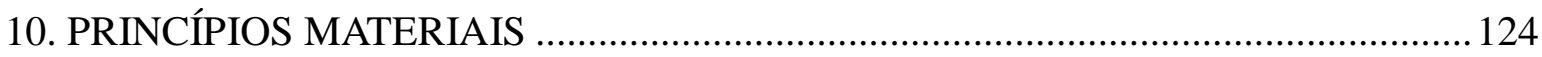

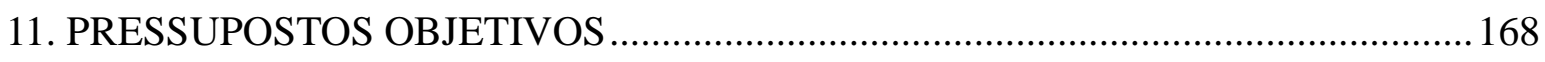

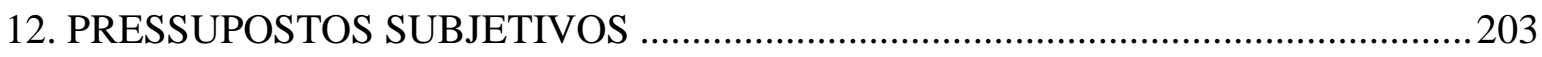

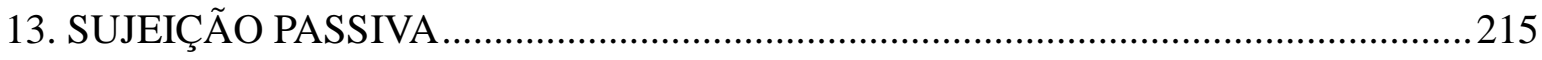

14. O PROBLEMA DA IDENTIFICAÇÃO DO RESPONSÁVEL.....................................238

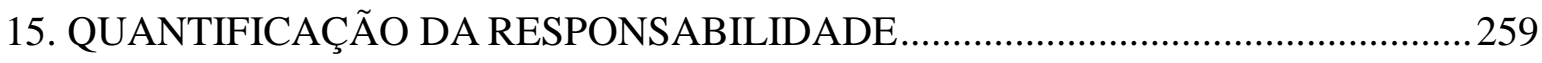

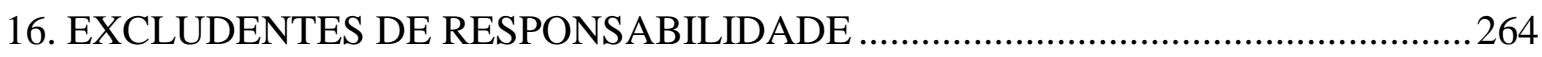

17. CAUSAS DE EXTINÇÃO DA RESPONSABILIDADE ............................................276

PARTE III - ASPECTOS PROCESSUAIS .................................................................285

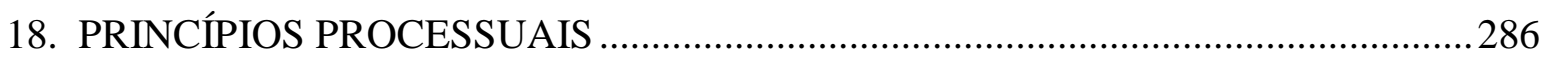

19. PROCEDIMENTO NO ÂMBITO DOS TRIBUNAIS DE CONTAS ............................306 
PARTE IV - CATEGORIA AUTÔNOMA

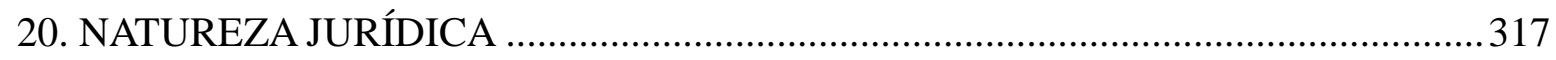

21. A JURISDIÇÃO CONTÁBIL-FINANCEIRA NO BRASIL ......................................328

22. COMPATIBILIDADE ENTRE AS SANÇÕES E JURISDIÇÕES ...............................347

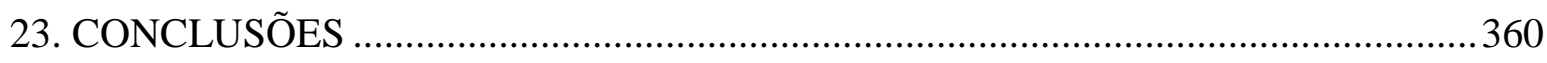

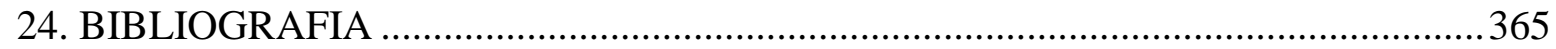


PARTE I - PARTE INTRODUTÓRIA INTRODUÇÃO À RESPONSABILIDADE FINANCEIRA 


\title{
1. INTRODUÇÃO
}

\author{
Esta dissertação tem por objeto o regime jurídico da responsabilidade \\ decorrente das infrações às normas que regulam a gestão de bens, dinheiros e valores \\ públicos e cujo processamento e aplicação competem, no Direito Brasileiro, aos Tribunais de \\ Contas.
}

A responsabilidade financeira ${ }^{2}$, denominação que adotamos para designar esta espécie de responsbilidade jurídica, manifesta-se na imputação de débito, ou seja, na condenação a repor aos cofres públicos uma determinada importância em dinheiro, e na aplicação de multa, sanção pecuniária que, no nosso Direito, pode ser de três espécies distintas: multa simples (limitada a um valor absoluto), multa proporcional ao dano ao erário e multa de até $30 \%$ dos vencimentos ${ }^{3}$.

A origem da responsabilidade financeira encontra-se na separação entre a gestão e a propriedade dos bens, típica das organizações modernas, públicas ou privadas. De fato, a gestão de recursos alheios, no Direito Público ou no Direito Privado, impõe ao gestor o cumprimento de regras e princípios jurídicos com o objetivo de promover o atendimento dos objetivos traçados pelo titular destes recursos. Dentre estas normas, podemos citar o dever de prestar contas (art. 70, parágrafo único, $\mathrm{CF} / 88$ ).

\footnotetext{
${ }^{2}$ Ante a falta de denominação específica deste instituto jurídico no Brasil e, com o fito de distingui-la das demais modalidades de responsabilidade jurídica, adoto a expressão "responsabilidade financeira" extraída do Direito Português e, também encontrada nos Estados da Comunidade dos Paises de Língua Portuguesa (CPLP).

${ }^{3}$ Excluo do objeto de pesquisa as duas outras sanções de competência do TCU previstas na Lei no ${ }^{\circ}$ 8.443/92 (Lei Orgância do Tribunal de Contas da União): a) a inabilitação para o exercício de cargo em comissão ou função de confiança, no âmbito da Administração Pública (art. 60) e b) declaração de inidoneidade do licitante fraudador, impossibilitando o licitante de participar de licitações com a administração pública federal (art. 46). A exclusão se deve, em primeiro lugar, à ausência de previsão expressa das referidas sanções na Constituição Federal de 1988, tal como ocorre com a imputação de débito e com a aplicação de multa. Em razão da ausência de previsão expressa na $\mathrm{CF} / 88$, não há também uniformidade no tocante à aplicação destas penalidades para as demais esferas de governo (Estados, Distrito Federal e Municípios). Em segundo lugar, não se tem notícia, no Direito Comparado, de sanções desta natureza aplicadas pelas Cortes de Contas. Por fim, são escassos os julgados proferidos pelo TCU em que tais penalidades foram cominadas. Além disso, estas penalidades foram são aplicadas em conjunto com a imputação de débito e com a multa.
} 
No Direito Público Brasileiro, este conjunto de normas está capitulado basicamente em dois ramos da ciência jurídica: no Direito Administrativo e no Direito Financeiro.

Como integrantes do sistema de controle externo da atividade financeira do Estado, os Tribunais ou Cortes de Contas, além da função fiscalizatória, cumulam as competências de julgamento das contas e de aplicação das sanções estabelecidas em lei.

A responsabilidade financeira, neste contexto, está diretamente vinculada à função fiscalizatória e à de julgamento das contas, fato que tem relevantes implicações no seu regime jurídico, mormente no tocante à delimitação dos sujeitos passivos da responsabilidade e na graduação das sanções financeiras.

A responsabilidade financeira encontra fundamentação no inciso VIII do artigo 71 da Constituição Federal e está regulamentada pelas Leis Orgânicas dos Tribunais de Contas, editadas pelo ente federado ao qual estas Cortes integram. Nada obstante, a Lei Orgânica do Tribunal de Contas da União (Lei Federal n ${ }^{\circ}$ 8.443/92), apesar de não ser lei nacional, é adotada como paradigma para diversas leis editadas no âmbito Estadual.

Ocorre que estas leis orgânicas são omissas no tocante a diversos aspectos pertinentes à efetivação da responsabilidade financeira, tais como, os pressupostos da responsabilidade; o conceito de dano ao erário e a sua delimitação; o conceito de grave infração à norma de natureza contábil, financeira, orçamentária, patrimonial ou operacional; os critérios de quantificação da responsabilidade financeira; os sujeitos ativo e passivo da responsabilidade financeira; as hipóteses de exclusão da responsabilidade; as hipóteses de extinção da responsabilidade, tais como a prescrição; a transmissibilidade da responsabilidade aos sucessores; os princípios de direito material e processual aplicáveis; os procedimentos aplicáveis à efetivação da responsabilidade financeira; as inter-relações da responsabilidade financeira com as de outra natureza decorrentes da mesma situação fática. 
A doutrina pátria, por sua vez, aborda de maneira desinteressada e superficialmente algumas destas questões, faltando uma visão global que permita o entendimento do tema como um todo coerente. A atenção dos doutrinadores está voltada exclusivamente para as competências legais e constitucionais dos Tribunais de Contas, para a posição do órgão dentre os Poderes da República e para a eficácia das suas deliberações.

Por outro lado, os estudos sobre a Responsabilidade do Agente Público não contemplam a responsabilidade no âmbito dos Tribunais de Contas. Com efeito, inúmeros trabalhos e obras científicas abordam a Responsabilidade Penal, Civil, Disciplinar, Política e por improbidade administrativa, sem sequer mencionar a atuação dos Tribunais de Contas.

Nada obstante este desinteresse da doutrina, a solução das questões apresentadas torna-se imprescindível no cotidiano dos Tribunais de Contas, no Supremo Tribunal Federal (quando do julgamento dos Mandados de Segurança contra atos do TCU) e nos órgãos do Poder Judiciário nos quais se processará a execução dos Acórdãos daquelas Cortes.

\subsection{Metodologia}

Adotar-se-á nesta pesquisa, para a colmatação das lacunas apresentadas, a analogia, conforme preconiza o art. $4^{\circ}$, da Lei de Introdução ao Código Civil; o método jurisprudencial, mediante consulta das soluções apresentadas pela jurisprudência dos Tribunais de Contas e do Supremo Tribunal Federal; e o método comparatístico, mediante análise da legislação e da jurisprudência das Cortes de Contas, nos Estados Estrangeiros que adotam Sistema de Controle Externo semelhante ao brasileiro, a saber, Espanha, Itália, França, Bélgica e os da Comunidade dos Países de Língua Portuguesa (CPLP).

Acerca da adoção de parâmetros alienígenas, convém fazer alguns esclarecimentos. Em primeiro lugar, cumpre observar que os Tribunais de Contas ocupam posição singular na estrutura do Estado, não se integrando, em sentido estrito, em nenhum dos 
Poderes da República ${ }^{4}$ e suas funções e competências não se encaixam, perfeitamente, nas tradicionais funções de Estado: administração, legislação e jurisdição. Desta forma, a analogia com instituições integrantes da Administração Pública ou do Poder Judiciário pode levar a conclusões equivocadas acerca da responsabilidade financeira.

João Franco do Carmo, nesta linha, ensina que o instituto da responsabilidade financeira (no ordenamento jurídico português) não deve ser alheio, nem imune à consideração das soluções acolhidas nos ordenamentos jurídicos estrangeiros (CARMO, 1995). Além disso, complementa: "O método comparativo permite, com efeito, compreender melhor e ponderar criticamente a solução consagrada na ordem interna, tal como fornece pontos de referência à iniciativa legislativa do seu aperfeiçoamento" (CARMO, 1995, p. 95). O autor português alerta, entretanto, para os riscos das adaptações irrefletidas ou das meras traduções precipitadas. As soluções que mais se aproximam do direito positivo português, segundo o autor, são aquelas relativas a ordenamentos em que é consagrada a existência de um Tribunal de Contas ou órgão jurisdicional de controle financeiro externo (CARMO, 1995).

O exame do Direito Estrengeiro será útil nas questões pertinentes ao regime jurídico da responsabilidade financeira. A título de exemplificação, a Lei de Organização e Processo do Tribunal de Contas de Portugal (LOPTC - Lei ${ }^{\circ}$ 98/97, alterada pelas Leis $\mathrm{n}^{\circ} 87$ B/98 e 1/2001) regula diversos aspectos que não foram considerados pelo legislador pátrio: hipóteses ensejadoras da responsabilidade financeira reintegratória (artigos $59^{\circ}$ e $60^{\circ}$ ), avaliação da culpa (artigo $64^{\circ}$ ), critérios de fixação das multas (artigo 65\%), as causas de extinção da responsabilidade (artigo $69^{\circ}$ ) e os prazos de prescrição e as hipóteses de suspensão da prescrição $\left(\operatorname{artigo} 70^{\circ}\right)$.

O foco do nosso estudo será a Legislação Federal Brasileira, adotada como paradigma em vários Estados Federados. Ademais, o art. 75, caput, da CF/88 dispõe que as normas constitucionais do Tribunal de Contas da União aplicam-se, no que couber, à

4 O Tribunal de Contas não integra o Poder Legislativo, pois, os art. 44, da CF/88, que define que o Poder Legislativo é composto pelo Senado Federal e pela Câmara dos Deputados. Não integra também o Poder Executivo, pois o art. 76, da CF/88 define que o Poder Executivo é composto pelo Presidente da República, auxiliado pelos Ministros de Estado. Por fim, não integra o Poder Judiciário, eis que não está contido no rol do art. 92 , da CF/88. 
organização, composição e fiscalização dos Tribunais de Contas dos Estados e do Distrito Federal, bem como dos Tribunais e Conselhos de Contas dos Municípios.

Parte-se da premissa de que a responsabilidade financeira constitui categoria jurídica autônoma, não a enquadrando, inicialmente, como espécie de outros institutos já consagrados: responsabilidade civil, penal e administrativa. Entretanto, tal posição será revisitada e confirmada no final deste Trabalho, quando da discussão da natureza jurídica da responsabilidade financeira.

\subsection{Estrutura do Trabalho}

Feitas estas considerações iniciais, faço um panorama do que pretendo discutir neste trabalho.

A dissertação está dividida em quatro partes: uma parte introdutória; uma parte referente aos aspectos materiais da responsabilidade financeira; uma parte referente aos seus aspectos processuais e uma parte final na qual examino as diferentes facetas da responsabilidade financeira como categoria jurídica autônoma.

Na Parte Introdutória (capítulos 2 a 7), discorro sobre os conceitos jurídicos fundamentais adotados como base na pesquisa; sobre o conceito de responsabilidade financeira, suas modalidades, características e fundamentos; sobre os modelos de responsabilidade adotados no Direito Estrangeiro e sobre o Panorama Histórico da Responsabilidade Financeira no Brasil.

Na Segunda Parte (capítulos 10 a 17), abordo os princípios materiais da responsabilidade financeira; os seus pressupostos objetivos e subjetivos; os parâmetros relacionados à quantificação da responsabilidade e as causas de exclusão e de extinção da responsabilidade financeira. 
Na Terceira Parte (capítulos 18 e 19), verso sobre os princípios processuais da responsabilidade financeira e sobre o procedimento de efetivação da responsabilidade.

Na Quarta Parte (capítulos 20 a 22), trato da natureza jurídica da responsabilidade financeira; do reconhecimento de uma jurisdição contábil-financeira e da compatibilidade das sanções financeiras com as sanções de outra natureza decorrentes do mesmo fato.

Por fim, são sintetizadas as conclusões da pesquisa e indicados a bibliografia e os sítios da Internet utilizados na execução do trabalho. 


\section{CONCEITOS BÁSICOS}

Neste capítulo, discorro sobre os conceitos jurídicos que servem de base para o desenvolvimento das análises contidas nesta monografia: dever jurídico, sanção e responsabilidade. Além disso, são apresentadas as funções das sanções jurídicas e os critérios que permitem distingui-las entre si.

\subsection{Dever Jurídico, Sanção e Responsabilidade}

Não se pode prescindir do Direito em qualquer sociedade em que se pretenda manter a ordem e promover o progresso econômico, cultural e social. Ao lado das normas de natureza moral, ética, religiosa e de trato social, as normas jurídicas constituem importante instrumento de harmonia social.

Com o fito de alcançar os objetivos assinalados, as normas jurídicas impõem aos seus destinatários deveres jurídicos. Dever jurídico, na lição de Paulo Nader, consiste na exigência que o direito objetivo faz a determinado sujeito para que assuma uma determinada conduta (NADER, 2005).

Dever jurídico e Obrigação jurídica não se confundem. Aquele tem escopo mais amplo que esta. Com efeito, esclarece Paulo Nader que: "Aquele se aplica a qualquer relação jurídica, para expressar a conduta exigida, enquanto o vocábulo obrigação diz respeito aos vínculos de conteúdo patrimonial, como os existentes nos contratos" (NADER, 2005, p. 318).

A sanção jurídica surge da violação do dever jurídico. Daniel Ferreira define sanção como sendo "a direta e imediata conseqüência jurídica, restritiva de direitos, de caráter repressivo, determinada pela norma jurídica a um comportamento proibido nela previsto, comissivo ou omissivo, dos seus destinatários" (FERREIRA, 2001, p. 25). 
De fato, a sanção importa na restrição ou na supressão de algum bem jurídico do indivíduo (vida, liberdade, patrimônio, patrimônio moral, etc.) com o objetivo genérico de assegurar a integridade do ordenamento jurídico. A propósito, ensina Hans Kelsen que "as sanções são estabelecidas pela ordem jurídica com o fim de ocasionar certa conduta humana que o legislador considera desejável" (KELSEN, 2005, p. 71).

O ilícito é o comportamento contrário ao dever jurídico estabelecido pela norma jurídica. É o pressuposto para a aplicação da sanção. Pressupõe-se, então, a existência de duas normas, uma primária estabelecendo o dever jurídico e outra secundária estabelecendo a sanção. Segundo Hans Kelsen (KELSEN, 2005, p. 86):

\footnotetext{
"Tal noção pressupõe que a norma jurídica seja dividida em duas normas separadas, dois enunciados de 'dever ser': um no sentido de que certo indivíduo 'deve' observar certa conduta e outro no sentido de que outro indivíduo deve executar uma sanção no caso de a primeira norma ser violada".
}

Fixados os conceitos de dever jurídico e de sanção, passamos a examinar o conceito de responsabilidade jurídica.

Na linguagem comum, a responsabilidade é o atributo de quem é consciente dos seus deveres. Na acepção técnica, responsabilidade é a sujeição às consequiências do ilícito (sanção) a que está submetido aquele que comete o ilícito ou alguém a ele vinculado por determinada relação prescrita na ordem jurídica. Trata-se, respectivamente, da responsabilidade por fato próprio e da responsabilidade por fato de terceiro. O dever originário é quem define, via de regra, o responsável (responsável por fato próprio - aquele que está obrigado a cumprir o dever), mas terceiro ligado por algum vínculo jurídico poderá também vir a ser responsabilizado (responsabilidade por fato de terceiro).

A Enciclopedia Garzanti del Diritto, por sua vez, define o vocábulo responsabilità (responsabilidade) como sendo a: "situazione in cui si trova un soggetto giuridico che ha violato un obbligo a lui imposto quando può essere chiamato a risponderne" (situação em que se encontra um sujeito jurídico que violou um dever a ele imposto, quando poderá ser chamado a responder por esta violação - tradução livre). 
Acerca do tema, a lição de Hans Kelsen é muito ilustrativa (KELSEN, 1998,

p. 133-134):

"Conceito essencialmente ligado com o conceito de dever jurídico, mas que dele deve ser distinguido, é o conceito de responsabilidade. Um indivíduo é juridicamente obrigado a uma conduta quando uma oposta conduta sua é tornada pressuposta de um ato coercitivo (como sanção). Mas este ato coercitivo, isto é, a sanção como conseqüência do ilícito, não tem de ser necessariamente dirigida - como já se fez notar - contra o indivíduo obrigado, quer dizer, contra o indivíduo cuja conduta é pressuposto do ato coercitivo, contra o delinqüente, mas pode também ser dirigido contra um outro indivíduo que se encontre com aquele numa relação determinada pela ordem jurídica. O indivíduo contra quem é dirigida a consequiência do ilícito responde pelo ilícito, é juridicamente responsável por ele. No primeiro caso, responde por ilícito próprio. Aqui o indivíduo obrigado e o individuo responsável são uma e a mesma pessoa. Responsável é o delinqüente potencial. No segundo caso, responde um indivíduo pelo delito cometido por um outro: o indivíduo obrigado e o indivíduo responsável não são idênticos. É-se obrigado a uma conduta conforme ao Direito e responde-se por uma conduta antijurídica". (grifo nosso)

João Franco do Carmo salienta que o termo responsabilidade apresenta, na linguagem comum, acepções diversas. Na acepção jurídica, o autor a define como a "situação jurídica em que se encontra o sujeito que, tendo praticado um comportamento ilícito, vê formar-se na sua esfera jurídica a obrigação de suportar certas sanções ou conseqüências desfavoráveis" (CARMO, 1995, p. 52).

Esclarece, ainda, o autor português que o conceito jurídico de responsabilidade leva ínsito o de imputabilidade e que, por isso, diz-se que a responsabilidade, em regra, é subjetiva, ou seja, baseada na imputação moral do ato ao sujeito. Somente desta forma, destaca Franco do Carmo, seria possível sujeitar alguém às consequiências desfavoráveis de um comportamento seu, ressalvados os casos em que a ordem jurídica não associa ao comportamento do responsável qualquer juízo de desvalor, tal como, na responsabilidade pelo risco ou na responsabilidade por fatos lícitos (CARMO, 1995).

A despeito de, regra geral, a responsabilidade ser conseqüência do ilícito, em algumas situações pode haver a responsabilidade pela prática de ato lícito. Como exemplos, cabe mencionar a responsabilidade objetiva pelo risco criado por uma atividade lícita e as hipóteses contidas no art. 929 e no art. 1313, §3 ${ }^{\circ}$ do Código Civil de 2002. 


\subsection{Funções das Sanções segundo Paulo Roberto Coimbra Silva}

Segundo Paulo Roberto Coimbra Silva, as sanções têm utilidade plúrima, podendo exercer as funções: preventiva, repressiva, reparatória, didática, incentivadora e assecuratória. A finalidade da sanção e a sua natureza jurídica são coisas distintas. A sanção de uma certa natureza pode exercer diferentes funções, que podem nelas cumular-se. (SILVA, P., 2007)

O estudo das funções das sanções tem especial relevância na determinação da aplicação cumulativa ou não de sanções de natureza diversa. Examinamos a seguir cada uma destas funções, na visão de Coimbra Silva.

A função preventiva compreende o desestímulo ao rompimento da ordem jurídica, mediante a intimidação de seus possíveis infratores a se sujeitarem aos seus indesejáveis efeitos. A sanção é, assim, o instrumento utilizado pelo sistema normativo para salvaguardar as leis das condutas contrárias aos seus preceitos (SILVA, P., 2007).

Citando Cesare Beccaria, Coimbra Silva ensina que "a função preventiva das penas não é mais bem exercida por força de sua intensidade, mas, muito antes, pela convicção de sua escorreita aplicação" (SILVA, P., 2007, p. 61).

Na função repressiva ou punitiva, "a sanção aplicada provê um castigo ou aflição como uma solução ordeira para aplacar o instintivo sentimento humano de demandar uma retribuição" (SILVA, P., 2007, p. 43). No exercício desta função, a sanção deve ser graduada de forma proporcional à gravidade do ilícito (SILVA, P., 2007, p. 64):

\footnotetext{
"(...) no comando normativo da norma sancionadora deve-se prever punição proporcional ao grau de lesividade e rejeição da ilicitude, que, como seu pressuposto fático, condiciona e enseja sua aplicação. A observância da proporcionalidade concernente à função punitiva das sanções há de merecer, dentre outros juizos, uma análise comparativa àquelas previstas para os demais atos ilícitos, devendo sua intensidade ser diretamente propocional à valorização social de sua gravidade. Desta forma, aos ilícitos mais graves devem corresponder às sanções mais severas e às sanções mais brandas devem ser correlatas às infrações de menor repulsa social" .
} 
Não atendidos estes pressupostos, "(...) a pena excessivamente atroz não implementa a justiça, mas, ao contrário, afasta-a para ainda mais distante, opondo-se diametralmente aos seus propósitos de pacificação social, de retribuição - que há de ser proporcional - e de reabilitação do infrator" (SILVA, P., 2007, p. 63).

$\mathrm{Na}$ função reparatória ou indenizatória pretende-se reestabelecer a paz e o equilíbrio perturbados pela prática de um ato lesivo, acarretando ao protagonista do dano, única e tão somente, a privação do que fora por ele ilegitimamente obtido ou reparação do que fora por ele injustificavelmente lesado (SILVA, P., 2007).

$\mathrm{O}$ ato ilícito não é, necessariamente, pressuposto do ressarcimento, mas sim o dano, com ou sem culpa. Diferentemente da sanção punitiva, a reparação é graduada segundo o dano (SILVA, P., 2007, p. 68):

\footnotetext{
"A dosimetria da sanção reparatória, diferentemente da punitiva, não se sujeita à consideração de aspectos subjetivos, tais como, v.g., a volição do infrator ou o grau de reprovabilidade , mas deve ser pautada por critérios objetivos, prendendo-se à extensão e à intensidade do dano que busca reparar. Por isso, pode-se afirmar ter a sanção indenizatória, diferentemente da punitiva, feição objetiva, não prescindindo jamais da demonstração e apuração dos danos a serem por ela reparados".
}

A sanção reparatória tem, portanto, caráter substitutivo", pois, "quando o perpetrante de uma lesão satisfaz a respectiva sanção, recompondo o patrimônio danificado, extingue o seu dever" (SILVA, P., 2007, p. 67).

Na função didática, a sanção deve contribuir para a educação e correição do perpetrante, auxiliando-o a aprender as lições a que não se dispôs espontaneamente seguir, impedindo-o, assim, de ser nocivo à sociedade no futuro (SILVA, P., 2007).

Tomando como base a complexidadade da legislação tributária, acrescenta Coimbra Silva que a preponderância da função didática das sanções deve ser diretamente proporcional à dificuldade de compreensão - pelo homem comum - dos preceitos cuja

\footnotetext{
${ }^{5}$ A reparação pode ser satisfeita voluntariamente pelo responsável, não necessitando de intervenção estatal, o que somente ocorre em caráter substitutivo.
} 
observância almeja salvaguardar e inversamente proporcional à estabilidade da legislação que os erige (SILVA, P., 2007).

Alguns autores admitem a existência da função premial da sanção: " (...) $a$ sanção deixaria de consistir apenas em punição imputada àquelas condutas avessas ao Direito, mas poderia servir de estímulo às condutas por ele consideradas convenientes ou desejáveis, mediante a concessão de prêmios ou incentivos" (SILVA, P., 2007, p. 70).

Não é pacífica, entretanto, a consideração do prêmio como uma espécie de sanção (SILVA, P., 2007, p. 71):

\footnotetext{
"Uma das razões apontadas para afastar o prêmio do conceito de sanção consiste no caráter coercitivo desta última, que, uma vez verificado seu pressuposto fático - o ato ilícito -,pode e deve ser imposta contra a vontade daquele que o realizou. Diferentemente, desde que realizado o pressuposto da norma premial, não se pode exigir que o adimplemente usufrua das benesses de seu prêmio. Surge-lhe um direito subjetivo, que poderá, ao seu alvedrio, ser exercido ou não. (...) Outra possível distinção reside na previsão eventual do prêmio, nem sempre imputado às condutas desejáveis. Sem dúvida, a utilização do prémio para estimular a fiel observância dos deveres jurídicos é útil e louvável, mas dispensável. Portanto, nem sempre o adimplemento dos deveres jurídicos ou, mesmo, sua superação são premiados, ao passo que sua infração deverá ser necessariamente punida".
}

A função assecuratória é exercida quando o legislador, prevendo a possibilidade da superveniência de fatos que possam comprometer, dificultar ou inviabilizar a realização de direitos, que considera caros, imputa-lhes determinadas consequiências tendentes a garantir sua satisfação (SILVA, P., 2007).

Conforme destaca Coimbra Silva, a legislação tributária é repleta de sanções assecuratórias, como ocorre, v.g., nas hipóteses de responsabilidade por transferência ou por extensão. Contudo, manifesta o autor que a inserção de previsões assecuratórias no conceito de sanção, ainda que admissível, revela-se inconveniente (SILVA, P., 2007).

\subsection{Funções das Sanções segundo José de Oliveira Ascensão}

Outra enumeração das funções das sanções foi elaborada pelo Professor Angolano José de Oliveira Ascensão: 

a) função compulsoria;
b) função reconstitutiva;
c) função compensatória;
d) função preventiva;
e) função punitiva.

A existência de diferentes tipos de sanções não significa que elas se excluam na sua aplicação (ASCENÇÃO, 2005, p. 58): "várias sanções podem cumular-se em reação a uma só violação. Um homicídio pode pôr em
ação por exemplo sanções compensatórias (indenização por danos não patrimoniais),
preventivas (cassação de porte de arma) e punitivas (prisão)".

As sanções compulsórias são "aquelas que se destinam a atuar sobre o infrator da regra para o levar a adotar, tardiamente embora, a conduta devida". São exemplos de sanções compulsórias: a prisão por dívida, o direito de retenção e os juros de mora (ASCENÇÃO, 2005, p. 59).

As sanções reconstitutivas compreendem a imposição de reconstituição em espécie, in natura, da situação a que se teria chegado com a observância da norma jurídica. Trata-se da reposição ou restauração natural (ASCENÇÃO, 2005).

Quando a reconstituição natural não é eqüitativa, não é atingível, ou ainda, não é sanção suficiente para violação havida, a sanção compensatória opera por meio de uma indenização de danos sofridos, podendo ser destinada a cobrir (ASCENÇÃO, 2005):
a) a falta do próprio bem devido;
b) outros danos patrimoniais;
c) danos não patrimoniais.

As sanções punitivas são impostas de forma a representar simultaneamente um sofrimento e uma reprovação para o infrator (ASCENÇÃO, 2005). 
As sanções preventivas têm por finalidade prevenir violações futuras, tal como ocorre com as medidas de segurança (ASCENÇÃO, 2005, p. 67):

"A situação é clara no caso das medidas de segurança. a quem pratica fatos previstos na lei penal podem-se aplicar providências desta ordem. Não têm função punitiva: função punitiva tem a pena, enquanto aqui a função é evitar a prática futura de crimes que concretizem a tendência para delinqüir que o passado do agente revela".

Outros exemplos de sanções preventivas são: a interdição do exercício de profissão, a inabilitação para o exercício de funções públicas e a inibição do exercício da tutela às pesssoas que tenham praticado fatos ou incorrido em situações cuja índole faz temer justamente um mau exercício do cargo (ASCENÇÃO, 2005).

Como será tratado nos capítulos a seguir, a responsabilidade financeira tem duas modalidades: a reintegratória e a sancionatória. $\mathrm{Na}$ modalidade reintegratória, a responsabilidade tem finalidade precipuamente compensatória ou reconstitutiva. $\mathrm{Na}$ modalidade sancionatória, a responsabilidade tem finalidade essencialmente punitiva.

\subsection{Tipos de Responsabilidade Jurídica}

Fornecida a noção jurídica de responsabilidade, cumpre esclarecer quais seriam as diferentes espécies de responsabilidade jurídica. Tais observações deverão ter repercussão na discussão relativa ao enquadramento ou não da responsabilidade financeira como categoria jurídica autônoma (Capítulo 20).

Dentre os critérios adotados pela doutrina para distinguir as espécies de responsabilidade jurídica, podemos citar:
a) a natureza jurídica do dever violado;
b) o órgão competente para aplicação da sanção;
c) a gravidade da ofensa ao ordenamento jurídico;
d) o bem jurídico restringido ou suprimido pela sanção;
e) a função da sanção; 
f) a cumulatividade entre as sanções;

g) uma combinação de critérios acima.

A Enciclopedia Garzanti del Diritto distingue os diversos tipos de responsabilidade segundo a natureza do dever violado (RESPONSABILITÀ, 2001, p. $1.123)$ :

"A seconda della natura dell'obbligo si possono distinguere diversi tipi di responsabilità: responsabilità amministrativa e contabile; responsabilità civile; responsabilità patrimoniale; responsabilità penale; responsabilità politica" ${ }^{6}$.

$\mathrm{Na}$ mesma linha, manifesta-se André Franco Montoro, ao classificar as sanções jurídicas em civis, penais, administrativas e processuais (MONTORO, 2005, p. 540541):

"As diversas espécies de sanções podem ser classificadas de acordo com critérios diferentes. Quanto ao ramo do direito a que correspondem, as sanções podem ser:

a) civis, tais como a nulidade de atos irregulares, a condenação pecuniária, a prescrição, e a decadência por decurso de prazo;

b) penais: a pena de morte que é excepcional; privativas de liberdade (reclusão e detenção); restritivas de direitos; e multa;

c) administrativa: multas, apreensão de mercadorias, interdição de estabelecimento, penas disciplinares aos servidores públicos etc.;

d) processuais: condenação nas custas e honorários do advogado da parte contrária, a revelia, a preclusão dos prazos etc".

Para João Franco do Carmo, as espécies de responsabilidade são definidas pela conjugação entre a posição jurídica assumida pelo sujeito e a natureza da norma jurídica violada (CARMO, 1995, p. 52):

\footnotetext{
"Naturalmente que a responsabilidade deriva de determinada qualidade ou posição jurídica assumida pelo sujeito (por exemplo, cidadão, contratante, funcionário) que, conjugando-se com a antijuridicidade dos factos a ele imputados (ou dito de outro modo, a natureza da norma jurídica violada), vai condicionar a aplicação da forma (ou formas, se se cumularem) de responsabilidade jurídica em que poderá o mesmo incorrer".
}

\footnotetext{
${ }^{6}$ Segundo a natureza da obrigação pode-se distinguir diversos tipos de responsabilidade: a responsabilidade administrativa-contábil, a responsabilidade civil, a responsabilidade patrimonial, a responsabilidade penal, a responsabilidade política - tradução livre.
} 
Para Montoro Puerto a diferença entre um ilícito e outro vem determinada pelo ordenamento jurídico infringido (apud OLIVEIRA, 2005). Regis Fernandes de Oliveira inicialmente refuta a distinção dos ilícitos em razão da sua maior ou menor ofensa ao ordenamento jurídico. Argumenta que (OLIVEIRA, 2005, p. 45):

"Tal critério carece de utilidade. Não nos informa sobre a efetiva distinção entre as sanções.
Assim, o legislador qualifica os comportamentos humanos através de critérios políticos,
sociais, valorativos, religiosos, econômicos, etc. Filtra-os pela hipótese normativa e lhes dá
conseqüência jurídica que entende correta. Apenas após tal emolduração jurídica, feita através
da norma, é que se pode falar em distinções sancionadoras. O fato de agredir com maior ou
menor intensidade a ordem jurídica não traz utilidade ao jurista. Logo, a análise da essência
do comportamento é inconveniente e despicienda, bem como o é a reação graduada do
ordenamento jurídico" (grifei).

Posteriormente, contesta a posição de Montoro Puero (OLIVEIRA, 2005, p.

48):

\begin{abstract}
"Refutando os argumentos expedidos pelo autor: a) a lesão ao tipo de norma jurídica (se administrativa ou penal) não serve como critério diferenciador. $O$ direito penal contém faltas administrativas previstas como crime. Outras faltas administrativas que 'deveriam' ou 'poderiam' estar previstas na codificação penal dela não constam. Mas a previsão do comportamento, em um ou em outro texto, é matéria de escolha exclusiva do legislador. Qualquer análise sobre dever ou não o fato estar previsto aqui ou ali é matéria que refoge à indagação estritamente jurídica".
\end{abstract}

Em conclusão, Regis Fernandes de Oliveira ressalta a inexistência de diferença substancial entre os ilícitos e considera fundamental para a sua distinção seu regime jurídico e, em especial, a eficácia jurídica do ato produzido, verbis (OLIVEIRA, R., 2005, p. 52):

"Não há diferença de conteúdo entre crime, contravenção e infração administrativa. Advém ela da lei, exclusivamente. Inexiste diferença de substância entre pena e sanção administrativa.

Inexistindo diferença ontológica entre crime, contravenção e infração e entre pena e sanção, deve o jurista buscar, em dado formal, o critério diferenciador. Crime e contravenção são julgados por órgão jurisdicional, enquanto a infração, por órgão administrativo. A decisão jurisdicional tem eficácia própria de coisa julgada, enquanto a decisão administrativa tem caráter tão-só de estabilidade, é presumidamente legal, imperativa, exequíivel e executória. Crime e contravenção são perquiríveis através da polícia judiciária e devem submeter-se a processo próprio previsto na legislação processual; a infração é apurável por qualquer forma de direito, desde que prevista em lei, independendo de rigorismo formal, à maneira do processo civil ou penal.

Em suma, o fundamental para a distinção é o regime jurídico e, em especial, a específica eficácia jurídica do ato produzido". 
Daniel Ferreira considera como critério de distinção entre os ilícitos penal e administrativo o regime jurídico a qual se subordina a sanção correspondente (FERREIRA, 2001).

Heraldo Garcia Vitta adota o critério formal de distinção de ilícitos, ou seja, segundo a autoridade competente para impor a sanção correspondente. Destaca Garcia Vitta que: "se for autoridade administrativa (judicial ou legislativa, na função administrativa ou do Poder Executivo), haverá ilícito dessa natureza" (VITTA, 2003, p.34).

Previamente, Garcia Vitta argumentou que (VITTA, 2003, p. 32-33):

"Afora os aspectos da transgressão militar e do crime militar definidos em lei, e também da prisão em flagrante (qualquer pessoa poderá realizá-la), com os quais não nos ocuparemos, pelos limites do trabalho, está evidenciado, antes os termos da norma jurídica, se a autoridade judiciária competente para determinar a prisão de alguém por infração penal.

(...)

Partindo desse referencial de natureza dogmática, podemos admitir ser a autoridade judiciária a única competente para impor sanção penal. Não pode outra autoridade fazê-lo, sob pena de ofensa à Constituição.

Assim, se o ordenamento jurídico, com leis editadas com base na Constituição, conferir à autoridade judiciária impor sanção, na atividade precisamente jurisdicional, diante da nãoobservância de determinado dever jurídico por parte do administrado, estaremos diante de um ilícito penal, mas não de um ilícito administrativo. Se a ordem normativa estabelecer competência para a autoridade administrativa impor sanção, falaremos em ilícito dessa natureza".

\subsubsection{Comentários}

Toda sanção (ou responsabilidade) importa na restrição ou, até mesmo, na supressão de um bem jurídico do responsável (vida, patrimônio, liberdade, etc.).

A distinção das espécies de sanções com base no bem jurídico restringido e na forma como se dá esta restrição deve ser, de plano, descartada. Com efeito, basta considerar as sanções de "multa" e de "prisão". A primeira pode ser enquadrada como sanção penal, civil, administrativa, disciplinar ou financeira. A segunda, pode ser enquadrada como sanção disciplinar, no caso das transgressões disciplinares militares (art. $5^{\circ}$, LXI, CF/88), e como sanção de natureza penal (Art. $5^{\circ}$, XLVI, a, CF/88), além de ser medida coercitiva para obrigações de direito civil (p. ex. prisão civil do devedor de pensão alimentícia). 
O critério do órgão competente também não pode ser isoladamente aceito como critério de distinção entre as espécies de sanções. Não permite, por exemplo, diferenciar a sanção civil da sanção penal, pois, ambas são da competência do Poder Judiciário. A responsabilidade civil também pode ser cumprida voluntariamente sem que seja necessária a interferência de qualquer órgão estatal. Ademais, o processamento e julgamento dos crimes de responsabilidade são de competência do STF (art. 102, I, c, CF/88) e do Senado Federal (art. 52, I e II, CF/88). São sanções da mesma natureza, mas aplicadas por órgãos distintos, o que torna insuficiente a adoção deste critério.

A gravidade da ofensa ao ordenamento jurídico também não é isenta de críticas. Só permite distinguir as sanções penais das demais sanções, uma vez que o Direito Penal tutela os bens jurídicos mais relevantes do nosso ordenamento. Entretanto, não permite, por exemplo, distinguir as sanções civis das sanções administrativas ou das financeiras ou políticas. Ainda assim, nem sempre as sanções penais são, de fato, as mais severas ou eficazes para a proteção dos bens jurídicos. Basta observar que a infração administrativa instituída pela vulgarmente denominada "Lei Seca" ${ }^{\prime 7}$, foi mais eficaz no combate à direção sob o efeito de álcool que o crime tipificado no art. 306, do CTB.

A função da sanção, conforme já mencionado por Coimbra Silva (item 2.2.), também não é critério distintivo. A sanção de uma natureza pode ter mais de uma finalidade e sanções de naturezas diversas podem ser a mesma função. Ex: a Indenização do Dano Moral tem função reparadora e punitiva.

A natureza do dever violado também não é parâmetro idôneo. Basta observar que a violação de uma norma de direito administrativo pode importar em responsabilidade penal (crime contra a administração pública), responsabilidade disciplinar, responsabilidade por ato de improbidade administrativa e, ainda, responsabilidade financeira.

\footnotetext{
${ }^{7}$ Lei n ${ }^{\circ}$ 11.705/2008, que alterou o art. 165, caput, do Código de Trânsito Brasileiro (CTB).
} 
Poderia-se considerar, também como critério distintivo, a cumulatividade das sanções. Se as sanções fossem cumuláveis em decorrência de um mesmo fato, pertenceriam a categorias distintas, se não, teriam a mesma natureza.

Ocorre que há situações em que sanções de natureza distinta podem não ser cumuláveis. Não são cumuláveis, por exemplo, a sanção penal militar com a sanção disciplinar militar decorrentes do mesmo fato, conforme art. 42, $\S 2^{\circ}$, da Lei ${ }^{\circ}$ 6.880/80 (Estatuto dos Militares), pois, no concurso de crime militar, contravenção ou transgressão disciplinar, aplica-se, somente, a pena relativa ao crime. Trata-se da absorção da sanção mais leve pela sanção mais severa.

Na busca de outro parâmetro, já que foram descartados todos os antecedentes, sugiro que os ilícitos e as sanções correspondentes devam ser classificados segundo o regime jurídico, material e processual, a que se submetem, o que abrange, inclusive, os fundamentos, os sujeitos, os pressupostos, a finalidade da sanção, o órgão competente para a sua aplicação e a eficácia do ato coator.

Ademais, a existência de um plexo característico de normas e princípios incidentes sobre um mesmo objeto, permite caracterizá-lo como uma categoria jurídica autônoma, justificando, inclusive, o seu estudo e tratamento de forma diferenciada das demais sanções (autonomia científica e didática). 


\section{CONCEITO DE RESPONSABILIDADE FINANCEIRA}

Diante da ausência de definição da responsabilidade financeira no Brasil, apresento os conceitos já firmados pela Doutrina e Legislação Estrangeiras.

Em Portugal, segundo o Tribunal de Contas (PORTUGAL, 1999, p. 8):

"existe responsabilidade financeira quando alguém possa vir a constituir-se na obrigação de repor fundos públicos ou suportar as sanções legalmente previstas, no âmbito do controlo jurisdicional do Tribunal de Contas, em virtude de violação de normas disciplinadoras da actividade financeira pública".

Na Espanha, o artigo 38.1, da Lei Orgânica do Tribunal de Contas (LOTCu), define "responsabilidad contable" como aquela que, desprendendo-se das contas que devem ser prestadas por aqueles que tenham ao seu cargo o manejo de bens e dinheiros públicos, quando, por dolo, culpa ou negligência graves, originarem "menoscabo" dos referidos bens ou dinheiros, em consequência de ações ou omissões contrárias às leis reguladoras do regime orçamentário e contábil aplicável às entidades do setor público ou, às pessoas privadas receptoras de subvenções, créditos, avais ou outras ajudas provenientes do dito setor ${ }^{8}$.

Entre nós, haja vista no que dispõe o art. 70, caput, da $\mathrm{CF} / 88$, é mais apropriado definir a responsabilidade financeira como sendo a obrigação de repor recursos públicos (imputação de débito) ou de suportar as sanções previstas em lei, no âmbito do controle exercido pelos Tribunais de Contas, em razão da violação de normas pertinentes à gestão de bens, dinheiros e valores públicos.

As sanções financeiras não se confundem com as medidas cautelares que possam vir a ser adotadas pelo Tribunal de Contas. De fato, compete ao Tribunal de Contas

8 Cf. Artículo 38.1, de la Ley Orgánica del Tribunal de Cuentas: "1. La jurisdicción contable conocerá de las pretensiones de responsabilidad que, desprendiendose de las cuentas que deban rendir todos cuentos tengan a su cargo el manejo de caudales o efectos públicos, se deduzcan contra los mismos, cuando por dolo, culpa o negligencia graves, originaren menoscabo en dichos caudales o efectos a consecuencia de acciones u omissiones contrarias a las leyes reguladoras del régimen presupuestario y de contabilidad que resulte aplicable a las entidades del sector público o, en su caso, a las personas o Entidades perceptoras de subvenciones, créditos, avales u otras ayudas procedentes de dicho sector". 
da União, nos termos do art. 44, da Lei n ${ }^{\circ}$ 8.443/93, determinar o afastamento temporário do responsável "se existirem indícios suficientes de que, prosseguindo no exercício de suas funções, possa retardar ou dificultar a realização de auditoria ou inspeção, causar novos danos ao erário ou inviabilizar o seu ressarcimento". Nas mesmas circunstâncias, pode o Tribunal, ainda, "decretar a indisponibilidade dos bens do responsável, todos quantos bastem para o ressarcimento dos danos em apuração, por prazo não superior a um ano", consoante art. $44, \S 2^{\circ}$, da Lei $n^{\circ} 8.443 / 92^{9}$.

As medidas cautelares são adotadas em caráter temporário e visam garantir a reparação do débito, prevenir a ocorrência de outros débitos ou assegurar a realização da fiscalização pela Corte de Contas. Por outro lado, a sanção financeira tem caráter definitivo, tendo por finalidade a recomposição dos cofres públicos ou a punição aos responsáveis.

As sanções financeiras também não se confundem com a sustação de atos e contratos ou com a fixação de prazo para adoção de providências. Apesar de Hélio Saul Mileski (MILESKI, 2003), incluí-las no capítulo das "sanções aplicáveis pelo Tribunal de Contas", é forçoso reconhecer que estas medidas têm caráter essencialmente corretivo (função corretiva do Tribunal de Contas), não incidindo sobre o patrimônio do agente contábil. O conceito de sanção anteriormente exposto não abarca, portanto, as chamadas "sanções de nulidade".

Por fim, a responsabilidade financeira também não se confunde com o julgamento das contas (art. 71, II, CF/88). Neste, há uma apreciação da gestão do responsável, apurando-se a legalidade, a legitimidade e a economicidade dos atos de gestão. A responsabilidade financeira pode ser decorrência do julgamento das contas pela irregularidade, mas não é a única consequência. O julgamento das contas também tem reflexos na esfera eleitoral, tornando inelegíveis os candidatos que "tiverem suas contas relativas ao exercício de cargos ou funções públicas rejeitadas por irregularidade insanável

\footnotetext{
${ }^{9}$ Convém lembrar que o afastamento cautelar e a decretação de indisponibilidade de bens não se incluem entre as medidas reservadas à autoridade judiciária pela Constituição Federal de 1988. As reservas à autoridade judiciária estão contidas nos seguintes dispositivos: a) art. $5^{\circ}$, XI (violação da casa); b) art. $5^{\circ}$, XII (interceptação telefônica); c) art. $5^{\circ}$, LXI (ordem de prisão fora das hipóteses de flagrante delito e transgressão disciplinar militar ou crime propriamente militar); d) art. $5^{\circ}, \mathrm{LXV}$ (relaxamento da prisão).
} 
e por decisão irrecorrível do órgão competente, salvo se a questão houver sido ou estiver sendo submetida à apreciação do Poder Judiciário, para as eleições que se realizarem nos 5 (cinco) anos seguintes, contados a partir da data da decisão" (art. 1º, I, g, Lei Complementar $n^{\circ}$ 64/1990). Tornar inelegível um candidato, entretanto, é medida de competência exclusiva da Justiça Eleitoral, limitando-se o Tribunal de Contas a enviar ao Ministério Público Eleitoral a lista dos responsáveis que tiveram as suas contas julgadas irregulares nos últimos cinco anos antes da realização de cada pleito (art. 91, Lei ${ }^{\circ}$ $8.443 / 92)$.

\subsection{Modalidades da Responsabilidade Financeira}

José F. F. Tavares noticia a existência, no Direito Português - Lei nº 98/97, de duas modalidades de responsabilidade financeira: a responsabilidade financeira reintegratória ${ }^{10}$ e a responsabilidade financeira sancionatória, sendo esta última subdividida em responsabilidade sancionatória por infrações essencialmente financeiras e responsabilidade sancionatória por infrações não essencialmente financeiras (TAVARES, 1998).

O Tribunal de Contas de Portugal esclarece a distinção entre estas modalidades (PORTUGAL, 1999, p. 9):

\footnotetext{
"As modalidades de responsabilidade financeira previstas na Lei portuguesa, são a reintegratória e a sancionatória.

A primeira, visa assegurar a reposição nos cofres do sector público de fundos públicos, objecto de, designadamente, desvio, pagamento indevido, ou falta de liquidação ou cobrança nos termos da Lei. Tem uma função eminentemente reintegratória, isto é, visa reconstituir a situação financeira do Estado que existiria se os referidos comportamentos não houvessem ocorrido.

A responsabilidade financeira sancionatória, por seu turno, traduz-se na aplicação de uma sanção pecuniária, uma multa, aos infractores de certas condutas expressamente tipificadas na Lei.

Nestas situações, o legislador entendeu que a gravidade dos comportamentos em causa justificava a aplicação de uma sanção, susceptível de prevenir e reprimir tais comportamentos, não bastando a mera reconstituição da situação patrimonial do Sector Público".
}

A responsabilidade financeira reintegratória tem função precípua de reconstituição ou de compensação do Patrimônio Público. Entretanto, a mera reposição ao

\footnotetext{
${ }^{10}$ Esta modalidade também é denominada "responsabilidade financeira stricto sensu" pela doutrina portuguesa.
} 
erário não é suficiente para prevenir o desvio de recursos públicos. Afinal, o infrator, na pior hipótese, seria obrigado a restituir (no máximo) o montante dos recursos desviados ${ }^{11}$. Há quem considere, ainda, que a recomposição do patrimônio não é propriamente sanção.

Além disso, em função do princípio da legalidade que vigora na gestão de recursos públicos, é necessário coibir situações que importam em grave violação dos princípios da administração pública, que, não necessariamente, acarretam dano ao erário. Para a punição dos responsáveis, requer-se a modalidade sancionatória da responsabilidade financeira, consistente na aplicação de uma penalidade pecuniária (multa). Além da função punitiva, não se pode negar que a multa aplicada pelo Tribunal de Contas tenha também por finalidade a prevenção dos ilícitos na gestão pública.

No art. $65^{\circ}$, da Lei de Organização e Processo do Tribunal de Contas de Portugal (LOPTC), são definidas as responsabilidades financeiras sancionatórias:

\section{"SECÇÃO III}

Da responsabilidade sancionatória

Artigo 65.

Responsabilidades financeiras sancionatórias

1 - O Tribunal de Contas pode aplicar multas nos casos seguintes:

a) Pela não liquidação, cobrança ou entrega nos cofres do Estado das receitas devidas;

b) Pela violação das normas sobre a elaboração e execução dos orçamentos, bem como da assunção, autorização ou pagamento de despesas públicas ou compromissos;

c) Pela falta de efectivação ou retenção indevida dos descontos legalmente obrigatórios a efectuar ao pessoal;

d) Pela violação de normas legais ou regulamentares relativas à gestão e controlo orçamental, de tesouraria e de património;

e) Pelos adiantamentos por conta de pagamentos nos casos não expressamente previstos na lei;

f) Pela utilização de empréstimos públicos em finalidade diversa da legalmente prevista, bem como pela ultrapassagem dos limites legais da capacidade de endividamento;

g) Pela utilização indevida de fundos movimentados por operações de tesouraria para financiar despesas públicas.

2 - Estas multas têm como limite mínimo metade do vencimento líquido mensal e como limite máximo metade do vencimento líquido anual dos responsáveis, ou, quando os responsáveis não percebam vencimentos, a correspondente remuneração de um director-geral. 3 - Se a infracção for cometida com dolo, o limite mínimo da multa é igual a um terço do limite máximo.

4 - Se a infracção for cometida por negligência, o limite máximo da multa será reduzido a metade.

\footnotetext{
${ }^{11}$ Não se pode negar, entretanto, que a modalidade reintegratória tenha função secundária de prevenir os ilícitos financeiros em razão da expectativa que pode surgir no gestor em ter que devolver os recursos irregularmente gastos, o que faria com que o mesmo agisse com mais diligência no tocante à administração de recursos alheios.
} 
5 - A aplicação de multas não prejudica a efectivação da responsabilidade pelas reposições devidas, se for caso disso.

6 - O Tribunal de Contas pode, quando não haja dolo dos responsáveis, converter a reposição em pagamento de multa de montante pecuniário inferior, dentro dos limites dos n.os 2 e 3.

No artigo subseqüente, são definidas hipóteses de "outras infrações" relativas à responsabilidade financeira sancionatória por atos essencialmente não financeiros:

"Artigo 66.

Outras infracções

1 - O Tribunal pode ainda aplicar multas nos casos seguintes:

a) Pela falta injustificada de remessa de contas ao Tribunal, pela falta injustificada da sua remessa tempestiva ou pela sua apresentação com deficiências tais que impossibilitem ou gravemente dificultem a sua verificação;

b) Pela falta injustificada de prestação tempestiva de documentos que a lei obrigue a remeter;

c) Pela falta injustificada de prestação de informações pedidas, de remessa de documentos solicitados ou de comparência para a prestação de declarações;

d) Pela falta injustificada da colaboração devida ao Tribunal;

e) Pela inobservância dos prazos legais de remessa ao Tribunal dos processos relativos a actos ou contratos que produzam efeitos antes do visto;

f) Pela introdução nos processos de elementos que possam induzir o Tribunal em erro nas suas decisões ou relatórios.

2 - As multas previstas no n. ${ }^{\circ} 1$ deste artigo têm como limite mínimo o montante de $50000 \$$ e como limite máximo o montante de $500000 \$$.

3 - Se as infracções previstas neste artigo forem cometidas por negligência, o limite máximo será reduzido a metade".

O Tribunal de Contas de Portugal esclarece que a modalidade sancionatória

pode decorrer da violação de um conjunto de deveres de colaboração que os responsáveis

financeiros tem para com o Tribunal de Contas (PORTUGAL, 1999, p. 28):

\begin{abstract}
"Na verdade, associado ao dever genérico de sujeição à fiscalização do Tribunal de Contas referido no ponto 1 do presente trabalho, nas suas várias modalidades (fiscalização prévia, concomitante e sucessiva), acrescem um conjunto de deveres acessórios daquele, cuja observância visa permitir ou facilitar o cumprimento integral do dever principal. A par da violação destes deveres, sancionam-se ainda comportamentos que visem induzir o Tribunal em erro nas suas decisões ou relatórios e a ultrapassagem dos prazos legais de remessa ao Tribunal dos processos relativos a actos ou contratos que produzam efeitos antes do visto".
\end{abstract}

No Direito Brasileiro, ambas as modalidades de responsabilidade financeira estão contempladas. Falta, entre nós, apenas utilizar uma terminologia técnica para designar este instituto jurídico ${ }^{12}$.

12 Entre nós, é usual empregar a expressão "responsabilidade por débito" para designar a modalidade reintegratória e a expressão "responsabilidade por multa" para designar a modalidade sancionatória. 
No âmbito federal, a responsabilidade financeira reintegratória, consistente na obrigação de repor aos cofres públicos, está regulada no art. 19, caput, da Lei n ${ }^{\circ}$ 8.443/92:

\begin{abstract}
"Quando julgar as contas irregulares, havendo débito, o Tribunal condenará o responsável ao pagamento da dívida atualizada monetariamente, acrescida dos juros de mora devidos, podendo, ainda, aplicar-lhe a multa prevista no art. 57 desta Lei, sendo o instrumento da decisão considerado título executivo para fundamentar a respectiva ação de execução".
\end{abstract}

A responsabilidade financeira sancionatória, por sua vez, está definida no art. 57 (multa proporcional ao dano ao erário) e no art. 58 (multa simples), ambos, da Lei $\mathrm{n}^{\circ}$ 8.443/92 e no art. $5^{\circ}$, da Lei n ${ }^{\circ} 10.028 / 2000$ (Lei dos Crimes Fiscais).

$\mathrm{O}$ art. 58, da Lei $\mathrm{n}^{\circ}$ 8.443/92 define hipóteses para as quais é cominada a sanção de multa simples, sujeita a um limite absoluto máximo (um teto que pode ser atualizado mediante Portaria do Presidente do Tribunal de Contas da União):

"Art. 58. O Tribunal poderá aplicar multa de até Cr\$ 42.000.000,00 (quarenta e dois milhões de cruzeiros), ou valor equivalente em outra moeda que venha a ser adotada como moeda nacional, aos responsáveis por:

I - contas julgadas irregulares de que não resulte débito, nos termos do parágrafo único do art. 19 desta Lei;

II - ato praticado com grave infração à norma legal ou regulamentar de natureza contábil, financeira, orçamentária, operacional e patrimonial;

III - ato de gestão ilegítimo ou antieconômico de que resulte injustificado dano ao Erário;

IV - não atendimento, no prazo fixado, sem causa justificada, à diligência do Relator ou à decisão do Tribunal;

V - obstrução ao livre exercício das inspeções e auditorias determinadas;

VI - sonegação de processo, documento ou informação, em inspeções ou auditorias realizadas pelo Tribunal;

VII - reincidência no descumprimento de determinação do Tribunal.

$\S 1^{\text {o }}$ Ficará sujeito à multa prevista no caput deste artigo aquele que deixar de dar cumprimento à decisão do Tribunal, salvo motivo justificado.

$\S 2^{\circ} \mathrm{O}$ valor estabelecido no caput deste artigo será atualizado, periodicamente, por portaria da Presidência do Tribunal, com base na variação acumulada, no período, pelo índice utilizado para atualização dos créditos tributários da União.

$\S 3^{\circ} \mathrm{O}$ Regimento Interno disporá sobre a gradação da multa prevista no caput deste artigo, em função da gravidade da infração".

Também é sancionada com multa a violação de deveres acessórios que visam permitir ou facilitar o trabalho do Tribunal (vide incisos IV, V e VI, do art. 58, da Lei $\mathrm{n}^{\circ}$ 8.443/92). Tais deveres (não obstruir as fiscalizações do Tribunal, dar acesso às informações e documentos necessários à fiscalização, etc), conforme mencionado 
anteriormente, não dizem respeito à atividade financeira estatal, sob o seu aspecto essencial, motivo pelo qual a responsabilidade decorrente da violação destes deveres é chamada de "responsabilidade financeira sancionatória por atos não essencialmente financeiros". Convém ressalvar que a omissão no dever de prestar contas, no Direito Brasileiro (diferentemente do que ocorre em Portugal e na França ${ }^{13}$ ), não se enquadra como hipótese de violação de deveres acessórios, mas sim como pressuposto da aplicação da responsabilidade financeira reintegratória (art. $8^{\circ}$, caput, da Lei n ${ }^{\circ}$ 8.443/92).

Além dos dispositivos mencionados, o art. $5^{\circ}$, da Lei $\mathrm{n}^{\circ}$ 10.028/2000, estabeleceu novos tipos de responsabilidade financeira sancionatória, por infrações essencialmente financeiras, concernentes às violações a preceitos da Lei de Responsabilidade Fiscal (LRF) ${ }^{14}$.

Convém lembrar que a LRF estabeleceu apenas sanções institucionais, ou seja, restrições que incidem apenas sobre os próprios entes públicos, tais como, a vedação ao recebimento de transferências voluntárias e a proibição de contratar operações de crédito. As sanções pessoais (crimes, infrações político-administrativas, infrações financeiras) aos preceitos da LRF foram cominadas pela Lei $\mathrm{n}^{\circ} 10.028 / 2000$, denominada impropriamente de Lei dos Crimes Fiscais.

\subsection{Características da Responsabilidade Financeira}

A Responsabilidade Financeira, consistente na imputação de débito e na aplicação de multa, é uma espécie do gênero Responsabilidade Jurídica que se distingue das demais espécies pelas características a seguir elencadas.

\footnotetext{
${ }^{13} \mathrm{Na}$ França, existe a chamada "Amende pour retard", que consiste de uma multa aplicada pela Cour des Comptes ou pelas Chambres Regionales et Territoriales des Comptes aos contábeis que não tenham apresentado suas contas ou respondido às ordens (injonctions) pronunciadas acerca das suas contas. Com efeito, segundo art. L131-6, do Code des Jurisdictions Financières (CJF), "La Cour des comptes peut condamner les comptables publics et les personnes qu'elle a déclarées comptables de fait à l'amende pour retard dans la production de leurs comptes".

${ }^{14}$ A Lei $\mathrm{n}^{\circ} 10.028 / 2000$ utilizou a expressão "infrações administrativas", a qual consideramos equivocada, conforme itens 3.3 e 20.2 a seguir.
} 
Em primeiro lugar, a Responsabilidade Financeira incide exclusivamente sobre determinados agentes, os "agentes contábeis", definidos em lei. São os responsáveis pela gestão de bens, dinheiros e valores públicos. O particular, pessoa física ou jurídica, também pode estar sujeito à responsabilidade financeira, desde que seja responsável pela gestão de recursos públicos (por exemplo, recebendo subvenções do Poder Público), ou que dê causa a dano ao Erário em conjunto com um agente contábil. No âmbito federal, este conjunto de pessoas físicas e jurídicas sob as quais poderá incidir a responsabilidade financeira está definido no art. $5^{\circ}$, da Lei n 8.443/92.

Em segundo lugar, a responsabilidade financeira tem caráter patrimonial, ou seja, o agente contábil responde com seu próprio patrimônio pelo dano causado ao Erário ou pela penalidade pecuniária aplicada. É inadmissível, portanto, o pagamento do dano causado ao erário ou da multa aplicada com recursos oriundos dos próprios cofres públicos. $\mathrm{Na}$ modalidade sancionatória, a responsabilidade financeira é personalíssima, enquanto que, na modalidade reintegratória, a responsabilidade pode ser transmitida aos sucessores (item 10.4).

Em terceiro lugar, a responsabilidade financeira é decorrente da atividade de gestão de bens, dinheiros ou valores públicos. Assim, um dano ou fato ilícito ocorrido fora da atividade de administração de recursos públicos não poderia estar sujeito à responsabilidade financeira. É o que se pode depreender da Súmula n 187 , do TCU:

\begin{abstract}
"Sem prejuízo da adoção, pelas autoridades ou pelos órgãos competentes, nas instâncias, próprias e distintas, das medidas administrativas, civis e penais cabíveis, dispensa-se, a juízo do Tribunal de Contas, a tomada de contas especial, quando houver dano ou prejuízo financeiro ou patrimonial, causado por pessoa estranha ao serviço público e sem conluio com servidor da Administração Direta ou Indireta e de Fundação instituída ou mantida pelo Poder Público, e, ainda, de qualquer outra entidade que gerencie recursos públicos, independentemente de sua natureza jurídica ou do nível quantitativo de participação no capital social".
\end{abstract}

Em quarto lugar, a responsabilidade financeira está vinculada às funções de fiscalização e de julgamento das contas públicas. É, portanto, é consequiência da atividade de gestão de bens, dinheiros e valores públicos. Em razão desta vinculação, na modalidade reintegratória, a responsabilidade está limitada às quantias efetivamente geridas, acrescidas, 
no máximo, de atualização monetária e de juros de mora. Distingue-se, assim, a obrigação de repor da obrigação de indenizar. Esta abarca não só as quantias efetivamente geridas, mas também, os lucros cessantes e o dano moral (item 11.3.2.).

Em quinto lugar, a responsabilidade financeira deve ser processada e efetivada pelos Tribunais de Contas, cujas deliberações que imputem débito ou apliquem multa geram título executivo apto à execução judicial (art. $71, \S 3^{\circ}, \mathrm{CF} / 88$ ), se a pretensão não for satisfeita voluntariamente pelo responsável ou administrativamente, por meio do desconto do débito em folha de pagamento.

Por fim, a responsabilidade financeira é uma responsabilidade de natureza subjetiva, pois exige que o responsável atue com dolo ou culpa, violando dever de cautela na gestão de bens, dinheiros e valores públicos (vide capítulo 12).

\subsection{Terminologia}

Conforme salienta Carles Rosiñol I Vidal, no Direito Espanhol, adota-se a terminologia "responsabilidad contable" para se referir às consequiências jurídicas da violação das normas do regime jurídico orçamentário e contábil que resultem no "menoscabo" dos bens ou dinheiros públicos (VIDAL, 1999, p. 32):

\footnotetext{
"La nueva definición de la responsabilidad contable se formula en los siguientes términos:

1. La jurisdicción contable conocerá de las pretensiones de responsabilidad que, desprendiéndose de las cuentas que se deban rendir todos cuantos tengan a su cargo el manejo de caudales o efectos públicos, se deduzcan contra los mismos, cuando por dolo, culpa o negligencia graves, originarem menoscabo en dichos caudales o efectos a consecuencia de acciones u omisiones contrarias a las leyes reguladoras del régimen presupuestario y de contabilidad que resulte aplicable a las entidades del sector público o, en su caso, a las personas o Entidades perceptoras de subvenciones, créditos, avales u otras ayudas procedentes de dicho sector"
}

No Direito Italiano, utiliza-se a expressão "Responsabilità Contabile" para designar uma responsabilidade peculiar em que (CARMO, 1995, p. 110)

\footnotetext{
"os sujeitos responsáveis podem ser apenas os que revestem a qualidade jurídica de agenti contabili, de direito ou de facto, isto é, funcionários ou agentes que têm a seu cargo, ou tenham tido efectivamente, a gestão material ou o manejo de valores ou dinheiros públicos, e
} 
que por essa razão são automaticamente submetidos ao julgamento das suas contas pela Corte dei Conti".

Citando GIUSEPPE FAZIO, João Franco do Carmo salienta que "la responsabilidade contabile, a differenza di quella amministrativa, è insita nella funzione degli agenti contabili e si coloca tra le cosidette responsabilità nascenti dalle obligazioni di restituizione" (CARMO, 1995, p. 110-111).

A responsabilidade administrativa, no Direito Italiano, apesar de julgada pela Corte dei Conti, é modalidade diversa da responsabilidade contábil e incide sobre os funcionários e empregados públicos em geral. Existem diferenças significativas entre estas modalidades de responsabilidade, conforme exposto no item 6.4.

A expressão "responsabilidade contábil" põe em evidência a violação às normas do Direito Contábil, que segundo Carlos Cubillo Rodriguez, é o conjunto de normas e princípios constitutivos do regime jurídico a que se deve submeter a contabilidade enquanto forma de expressão e valoração da atividade humana dotada de conteúdo econômicofinanceiro (RODRIGUEZ, 1999).

Sendo, entre nós, a contabilidade apenas um dos aspectos da atividade de gestão dos bens, dinheiros e valores públicos e o Direito Contábil, apenas um ramo do Direito Financeiro $^{15}$, a utilização desta expressão é inadequada aos nossos propósitos. Ademais, as implicações práticas da violação destas normas nem sempre são tão graves ao ponto de acarretar dano ao patrimônio público. A violação do direito contábil importa, via de regra, em prejuízo à informação que deve ser destinada aos usuários da contabilidade.

No Brasil, à falta de terminologia específica, costuma-se utilizar a expressão "responsabilidade administrativa", que julgamos inadequada. Segundo Daniel Ferreira, a sanção assume natureza administrativa desde que aplicada no exercício da função administrativa, ou seja, no exercício do "dever-poder operativo, compulsoriamente

\footnotetext{
${ }^{15}$ Vide as normas reguladoras da Contabilidade Pública constantes da Lei $\mathrm{n}^{\circ}$ 4.320/64 e da Lei Complementar $\mathrm{n}^{\circ}$ 101/2000 (Lei de Responsabilidade Fiscal).
} 
exercitado no uso das prerrogativas públicas e em prol da coletividade, concretizador dos comandos primários, gerais e abstratos contidos na norma legislativa ou, excepcionalmente, na norma constitucional" (FERREIRA, 2001, p. 32).

A responsabilidade administrativa, portanto, pressupõe o exercício dos chamados Poderes Administrativos: poder normativo, poder disciplinar, poder hierárquico e poder de polícia. Trata-se de um conjunto de prerrogativas conferidas ao Poder Público para que este as exerça em benefício da coletividade, permitindo que se sobreponha a vontade coletiva à vontade individual.

Ocorre que a responsabilização, no âmbito dos Tribunais de Contas, não faz uso dos Poderes da Administração e nem é exercida no âmbito da função administrativa do Estado. Com efeito, não há relação hierárquica entre o Tribunal de Contas e os agentes responsáveis pela Gestão de bens, dinheiros e valores públicos.

Não se pode falar, também, no exercício do Poder de Polícia do Tribunal, haja vista que a função de controle externo das Cortes de Contas passa longe do conceito legal de Poder de Polícia, conforme art. 78, do CTN:

\begin{abstract}
"considera-se poder de polícia atividade da administração pública que, limitando ou disciplinando direito, interesse ou liberdade, regula a prática de ato ou abstenção de fato, em razão de interesse público concernente à segurança, à higiene, à ordem, aos costumes, à disciplina da produção e do mercado, ao exercício de atividades econômicas dependentes de concessão ou autorização do Poder Público, à tranqüilidade pública ou ao respeito à propriedade e aos direitos individuais ou coletivos".
\end{abstract}

Neste sentido, cumpre relembrar a Decisão TCU n 1.020/2000 - Plenário, em que se discutiu a aplicabilidade da Lei n 9.784/99 (Lei de Processo Administrativo Federal) aos Processos no TCU. Naquela deliberação, ficou assentado, no âmbito da Corte Federal de Contas, que a função de controle externo não se identifica com a função administrativa, verbis:

\footnotetext{
"21. Tem-se, pois, que os misteres constitucionais dos Tribunais de Contas consistem em função de controle externo, pertencente à função legislativa, não dizendo qualquer respeito à função administrativa de que cuida a Lei $\mathrm{n}^{\circ}$ 9.784/99.

22. Disso, com as vênias ao saudoso Hely Lopes Meirelles, as Cortes de Contas não se constituem em órgãos jurisdicionais administrativos, como são os Conselhos de Contribuintes,
} 
os Conselhos Curadores de Fundos e o Tribunal Marítimo, todos vinculados ao Poder Executivo. Por conseqüência, as decisões dos Tribunais de Contas também não podem ser vistas como administrativas, situando-se em patamar superior a essas, diante de seu destaque constitucional, a despeito da possibilidade de revisão judicial. São elas, em verdade, atos de controle, pertencentes à atividade legislativa, ou ao exercício de função legislativa, tomada em amplitude, segundo o melhor entendimento".

A expressão "responsabilidade financeira", proveniente do Direito Português, é a mais adequada, diante de todas as alternativas examinadas, apesar de não traduzir perfeitamente toda a dimensão da gestão pública.

Nada obstante, a expressão já está presente, entre nós, em Acórdãos do Tribunal de Contas do Estado da Bahia (TCE/BA), do Tribunal de Contas do Estado do Mato Grosso (TCE/MT) e do Tribunal de Contas do Estado de Santa Catarina (TCE/SC).

Ademais, esta expressão também é utilizada nos Estados da Comunidade dos Países de Língua Portuguesa (CPLP). Com efeito, o art. 29² da Lei Orgânica do Tribunal de Contas de Angola (Lei $\mathrm{n}^{\circ}$ 05/96) adota a expressão "responsabilidade financeira" para designar a obrigação de reintegração de fundos.

Por fim, o art. $36^{\circ}$, da Lei Orgânica do Tribunal de Contas de Cabo Verde (Lei $n^{\circ}$ 84/IV/93, de 12 de julho) e o art. $27^{\circ}$ da Lei Orgânica do Tribunal de Contas de GuinéBissau (Decreto-lei $\mathrm{n}^{\circ}$ 7/92, de 27 de novembro), também fazem menção à responsabilidade financeira.

É bem verdade que a violação às normas oriundas de outros ramos do Direito também pode ensejar a responsabilidade financeira, seja no tocante à gestão de bens públicos (Direito Administrativo), seja no tocante aos atos e contratos administrativos que implicam ou fundamentam a realização de despesas públicas (Direito Administrativo).

Nada obstante, utilizar uma terminologia própria, já consagrada nos países de língua portuguesa, é o primeiro passo para o reconhecimento da autonomia deste instituto jurídico. 


\section{FUNDAMENTOS DA RESPONSABILIDADE FINANCEIRA}

O pano de fundo da presente discussão é a gestão de bens, dinheiros e valores públicos - atividade estatal mais ampla que a atividade financeira, que compreende a arrecadação, gestão e dispêndio de recursos financeiros (dinheiros públicos) ${ }^{16}$.

Não restrinjo a minha análise à atividade financeira em sentido estrito, uma vez que a Constituição Federal faz referência aos "dinheiros, bens e valores públicos" (art. 70, parágrafo único e art. 71, inciso II), não se atendo somente aos recursos de natureza financeira. Caso adotássemos o conceito mais restrito, atos de gestão patrimonial que não envolvem recursos financeiros (tais como, doação, conservação e permuta de bens públicos) estariam fora da fiscalização exercida pelo Sistema de Controle Externo.

A gestão deve ser entendida em sentido amplo, na qual estão englobados os atos que precedem ou que fundamentam a renúncia de receitas ou a realização da despesa pública. Os atos que integram o procedimento licitatório, a formalização dos contratos e sua execução, integram o conceito de gestão pública, bem como atos de gestão de recursos humanos com impactos na despesa pública (p. ex. concessão de vantagens a servidores públicos).

\footnotetext{
${ }^{16}$ Segundo Regis Fernandes de Oliveira: "Atividade financeira é, pois, a arrecadação de receitas, sua gestão e a realização do gasto, a fim de atender às necessidades públicas" (OLIVEIRA, R.,2006, p. 59). No mesmo sentido, conceitua José Juan Ferreiro Lapatza: "Cuando el Estados y los demás entes públicos obtienen y utilizan medios dinerarios para realizar las tareas que la coletividad les encomienda están desarrollando una actividad que tradicionalmente se conoce con el nombre de actividad financiera. Tal actividad se caracteriza por el sujeto que la realiza (el Estado y demás entes públicos); por el objeto sobre el que recae (los ingresos y gastos públicos o, si se quiere, los medios dinerarios en que éstos se materializan) y por su carácter instrumental. La actividad financiera no constituye, en efecto, un fin en sí mesma. Es una actividad medial o instrumental. Sirve para que tolas las demás actividades del Estado se puedan desarrollar" (LAPATZA, 2004, p. 19). Carlos M. Giuliani Fonrouge, por sua vez, conceitua a atividade financeira do estado de forma a abranger a gestão de bens e dinheiros públicos: "Concepto de Actividad Financiera - Parecería innecesario recordar, por sabido, que el Estado debe cumplir funciones complejas para la realización de sus fines, tanto en lo referente a la seleccíón de los objetivos, a las erogaciones, a la obtención de los medios para atenderlas - pecuniarios o de otra especie - y la gestíon y manejo de ellos, cuyo conjunto constituye la actividad financiera" (FONROUGE,1997, p. 3).
} 
Uma característica típica das organizações modernas de grande porte, sejam públicas ou privadas, é a separação entre a gestão e a propriedade dos recursos. Como exemplos destas organizações, podemos citar, o Estado, as Sociedades por Ações e, até mesmo, o Condomínio.

Os gestores destas organizações são escolhidos por algum critério (eleição, mérito, etc.). Possuem poderes para atuar em nome da pessoa jurídica a qual dirigem, criando direitos e obrigações para a organização, em busca de atingir os fins previstos nos Estatutos Sociais, para as sociedades por ações, ou na Constituição, para o Estado.

A propósito, esclarece Lucíola Fabrete Lopes Nerilo que (NERILO, 2003, p. 33):

\footnotetext{
"As pessoas jurídicas atuam no mundo através das pessoas naturais escolhidas para manifestar a vontade da sociedade. Essas pessoas se manifestam enquanto sociedade comercial e seus atos são atribuídos à pessoa jurídica, responsável pelos atos de seus administradores, que têm o poder para atuar em nome dela, sendo que tal poder tem origem nos estatutos".
}

São duas as conseqüências da separação entre gestão e propriedade. A primeira é a imposição do dever de prestar contas e a segunda é a imposição de normas e princípios para regular a gestão dos recursos. Ambos têm por finalidade garantir que a gestão fique adstrita às finalidades estabelecida pelo titular dos recursos.

No Brasil, o dever de prestar contas é exigência imposta pelas normas de Direito Público (art. 70, caput, da CF/88) e de Direito Privado. É tanto um dever do administrador público, quanto um direito fundamental do indivíduo, conforme prescreveu a Declaração dos Direitos do Homem e do Cidadão (França, 1789) ${ }^{17}$ :

\footnotetext{
"Art. 14". Todos os cidadãos têm direito de verificar, por si ou pelos seus representantes, da necessidade da contribuição pública, de consenti-la livremente, de observar o seu emprego e de lhe fixar a repartição, a coleta, a cobrança e a duração.

Art. 15 $^{\circ}$. A sociedade tem o direito de pedir contas a todo agente público pela sua administração".
}

17 Cf. http://www.direitoshumanos.usp.br 
No Direito Público, este dever tem um importante corolário: a inversão do ônus da prova. Desta forma, cabe ao gestor demonstrar o bom e regular emprego dos recursos públicos e não o contrário. Tal preceito está replicado no art. 93, do Decreto-lei n ${ }^{\circ}$ 200/67, no art. 113, caput, da Lei $\mathrm{n}^{\circ} 8.666 / 93^{18}$, sendo admitido, inclusive, pela Jurisprudência do STF (MS n 20.335-DF) e do TCU.

A segunda conseqüência é a imposição de normas e princípios para a atividade de gestão. Trata-se de regras voltadas para assegurar os interesses dos titulares dos recursos geridos.

No tocante às sociedades anônimas, Lucíola Fabrete Lopes Nerilo esclarece que (NERILO, 2003, p. 116):

"A atividade de gestão está intimamente ligada à noção de governo de um patrimônio. Para governar, o administrador tem poderes inerentes à sua atividade. $\mathrm{O}$ espaço de mobilidade do gestor é delimitado pela lei e pelo estatuto social e essa esfera de atuação livre, que lhe é dada, tem por finalidade propiciar-lhe a realização dos objetivos da sociedade".

Os objetivos estatais, por sua vez, são diversos dos das sociedades anônimas. Estas têm por fim o lucro (ou a valorização das ações nos mercados financeiros, no caso de sociedades abertas), o Estado, por sua vez, o bem comum. Nesta linha, ensina Michael H. Granof que, no setor público, a diferença entre receitas e despesas não constitui medida do desempenho da organização pública (GRANOF, 2005, p. 3$)^{19}$.

\footnotetext{
${ }^{18}$ Cf. Art. 113, da Lei ${ }^{\circ}$ 8.666/93: "O controle das despesas decorrentes dos contratos e demais instrumentos regidos por esta Lei será feito pelo Tribunal de Contas competente, na forma da legislação pertinente, ficando os órgãos interessados da Administração responsáveis pela demonstração da legalidade e regularidade da despesa e execução, nos termos da Constituição e sem prejuízo do sistema de controle interno nela previsto".

19 "The financial reports of governments and not-for-profits can provide information about an organization's inflows (revenues) and outflows (expenditures) of cash and other resources. As a general rule, an excess of expenditures over revenues, particularly for an extended period of time, signals financial distress or poor managerial performance. However, an excess of revenues over expenditures ist not necessarily commendable. An excess of revenues over expenditures may be achieved, for example, merely by reducing the services provided to constituents, which may be at odds with the entity's objectives.If the financial statements of a government or not-for-profit incorporate only monetary measures, such as dollars and cents, they cannot possibly provide the information necessary to assess the organization's performance. For an organization to report properly on its accomplishments, it must augment its financial statements to include non financial data that relate to its objectives. A school, for example, might include statistics on student achievement, such as test scores or graduation rates. A center for the homeless might present data on the number of people fed or adequately housed".
} 
Como consequiência do Estado de Direito, submete-se a gestão pública ao princípio da legalidade, cujo escopo atual não se restringe às intervenções na liberdade individual (art. $5^{\circ}$, inciso II, CF/88). A legalidade estende-se a um amplo escopo de atividades do Poder Público: administração de intervenção, serviços públicos, atividades de fomento e procedimento administrativo, conforme esclarece o jurista alemão Hartmut Maurer (MAURER, 2006, p. 125):

\begin{abstract}
"A reserva da lei, que se desenvolveu no século 19 como instrumento jurídico-constitucional do constitucionalismo, limitava-se originalmente à administração de intervenção (...) Ela tinha a função de assegurar o âmbito individual e social perante o executivo monárquico e de vincular intervenções necessárias à aprovação da representação popular em forma de lei. (...) A limitação da reserva da lei à administração de intervenção está antiquada. $O$ desenvolvimento para a democracia parlamentar, o significado crescente da administração de prestação e a penetração jurídico-constitucional em todos os âmbitos estatais pela Lei fundamental exigem sua extensão. (...) Disso não resulta nenhuma 'reserva total' que compreende toda a atividade administrativa. Mas as decisões fundamentais e importantes para a coletividade assim como para o cidadão particular devem ser tomadas pelo dador de leis e ser por ele respondidas".
\end{abstract}

\title{
Em Parecer $\mathrm{n}^{\circ}$ 1237, do Conselho Consultivo da Procuradoria Geral da
}

República de Portugal, menciona-se a submissão da atividade financeira às normas e princípios de direito financeiro como garantia do princípio da confiança (PORTUGAL, 2001):

\begin{abstract}
"Os dinheiros públicos são, pois, confiados a certos agentes político-administrativos que os administram segundo determinadas regras específicas, que constituem o direito financeiro, e que 'dão forma e garantia' a princípios que justificam a sua autonomia. Entre estes, o principio da confiança, como fundamento e regra básica de quaisquer poderes exercidos sobre bens ou dinheiros públicos, com algumas conseqüências claras: limitação funcional dos poderes de gestão financeira; sua partilha necessária entre diversos gestores ou órgãos de decisão, sujeição à legalidade genérica e à legalidade específica (orçamento), publicidade, transparência, clareza, responsabilização (<<accountability〉>).

A garantia do princípio da confiança, como fundamento e regra básica de quaisquer poderes exercidos sobre dinheiros públicos, efectiva-se, quer através da definição de regras específicas sobre actos e operações financeiras (gestão de dinheiros públicos), com pela obrigação de prestar contas, através da qual se procede ao respectivo controlo".
\end{abstract}

Ainda como consequiência do Estado Democrático de Direito (e sob a influência das novas tendências da Administração Pública), exige-se, que a gestão pública seja pautada pelos princípios da legitimidade, economicidade, eficiência, eficácia e efetividade (art. 37, caput e art. 70, caput, da CF/88). 
Violados estes princípios e normas de gestão, exsurge a responsabilidade financeira, nos Estados que adotam os Tribunais de Contas com função jurisdicional.

Nesta oportunidade, convém mencionar a lição de Lídio de Magalhães, Conselheiro do Tribunal de Contas de Portugal, que muito bem sintetizou a origem e a evolução da responsabilidade financeira (MAGALHÃES, 2004, p. 33-35):

"Como é sabido, a responsabilidade financeira tem a sua origem no conjunto de específicas
obrigações que impendiam sobre aqueles que tinham à sua guarda fundos públicos. Findo um
ciclo temporal - normalmente um ano -, havia que prestar contas destes fundos. Através da
prestação de contas se verificava-se, grosso modo, se o que transitara do ano anterior,
acrescido do que se recebera no ano considerado, era igual ao que se gastara somado ao saldo
final; e, também, se tudo isso batia certo com a documentação arquivada; e, finalmente, se, em
cofre, existia o dinheiro ou documentos comprovativos de sua saída. (...) A situação altera-se
profundamente com a densificação da malha administrativa pública, com o aumento do
número de entidades dotadas de autonomia suficiente para requisitar do Orçamento os fundos
necessários à sua atividade e com a intervenção na actividade administrativa de pessoas com
poderes (competência) bastantes para tomar decisões susceptíveis de, directamente,
implicarem o dispêndio de dinheiros públicos. Por outro lado, o orçamento transforma-se e
fica mais complexo. A seu lado surgem normas sobre a realização das despesas: interessa não
só o que se gasta (para ver se o orçamento comporta) mas também, por exemplo, se a despesa
é precedida de concurso público ou se diz respeito a esta ou aquela rubrica específica. Com
este conjunto de modificações o conceito de infracção financeira deixa de estar apenas ligado
ao dinheiro eventualmente em falta mas também à realização de uma despesa com violação
das regras legais que a disciplinam. A responsabilidade pelas infracções financeiras, por outro
lado, pressupunha a existência, como agente, de alguém que, por virtude de uma relação
jurídica - ou mesmo por virtude de uma situação de facto, como nos chamados 'agentes de
facto' - estava especialmente obrigado a cumprir as determinações legais relativas a despesas
públicas". São, ante todo o exposto, três os fundamentos da responsabilidade financeira: a separação da gestão e a titularidade dos recursos públicos, o Estado democrático de Direito e a existência de Tribunais ou Cortes de Contas com função jurisdicional, tópico que será analisado a seguir. 


\section{SISTEMAS DE CONTROLE EXTERNO}

Submetida a gestão pública às normas e princípios jurídicos, notadamente os de direito administrativo e financeiro, requer-se a existência de um conjunto de instituições e procedimentos voltados para assegurar seu cumprimento (mormente, quando a violação não importa em violação direta de direito individual) ${ }^{20}$. Estas Instituições e Procedimentos compõem o que a doutrina denomina de Sistemas de Controle Externo. Nas Companhias Abertas, do Setor Privado, esta função é exercida pelas Auditorias Independentes ${ }^{21}$.

Os Sistemas de Controle Externo apresentam variações nos diversos Estados, no tocante à sua composição, organização e competências e no tocante aos procedimentos e enfoques do controle. Algumas semelhanças entre estes sistemas e organizações refletem uma mesma influência histórica, valendo lembrar, a título de exemplo, os modelos de auditoria geral adotados pelos países de colonização inglesa (Estados Unidos, Canadá, Austrália e Nova Zelândia).

Segundo o National Audit Office (órgão de controle externo do Reino Unido) existem, nos países da União Européia, quatro tipos de instituições dedicadas à fiscalização de natureza orçamentária e financeira ${ }^{22}$, verbis (REINO UNIDO, 2006):

${ }^{20}$ Antônio L. Souza Franco ensina que (FRANCO, 2002, p. 453): "O controlo orçamental dos dinheiros públicos tem principalmente duas ordens de fundamentos: fundamentos jurídicos-políticos - assegurar que o Executivo se mantém dentro dos limites da lei e dos que lhe foram assinalados pelo Parlamento, através da aprovação da Lei de Orçamento - e fundamentos económicos - evitar os desperdícios e a má utilização dos recursos públicos. Por isso pode assumir as formas de controlo jurídico-político ou controlo económico, consoante o predomínio de um ou de outro tipo de critérios".

${ }^{21}$ Marcelo Cavalcanti Almeida (ALMEIDA, 1996, p. 21-22) aponta que a auditoria externa ou independente surgiu como evolução do sistema capitalista. Segundo o autor, a necessidade de ampliar as instalações e a insuficiência dos recursos dos proprietários fez com que a empresa tivesse que captar recursos junto a terceiros, seja por meio de empréstimos bancários, seja por meio da abertura do capital para novos acinonistas. Os futuros investidores precisavam conhecer a posição patrimonial e financeira, a capacidade de gerar lucros e como estava sendo feita a administração financeira dos recursos na empresa. Era necessário avaliar a segurança, liquidez e a rentabilidade do investimento, informações obtidas por meio das demonstrações contábeis da empresa (balanço patrimonial, demonstração do resultado do exercício, etc.). Como medida de segurança para manipulação da informação, os futuros investidores exigiam que essas demonstrações fossem examinadas por um profissional independente da empresa e com reconhecida capacidade técnica: o auditor externo ou independente.

${ }^{22}$ SAI - Supreme Audit Institution - também chamadas no Brasil de Entidades Fiscalizadoras Superiores. 
"There are four main types of supreme audit institution within the European Union, namely 'Court' with a judicial function; the 'collegiate' body without a judicial function; the independent audit office headed by an Auditor General; and the audit office headed by an Auditor General within the structure of government. In addition, the austrian Rechnungshof is a distinct model headed by a President and auditing at central, regional and local level.

Six SAIs (in France, Belgium, Portugal, Spain, Italy and Greece) can loosely be grouped together as 'courts' and in Greece and Portugal for example, the SAI is part of the judiciary and is constitutionally on a par with other courts. The second type is the 'collegiate' structure with no judicial function, as Netherlands, Germany and Luxembourg. The European Court of Auditors, despite its name, is also a collegiate body with no judicial role.

The model of an audit office headed by an Auditor General exists in the United Kingdom, Ireland and Denmark. The fourth model is a system developed in Sweden and Finland, with reflects their places as government bodies. Both states have two audit organisations, with the SAI responsible to government and carrying out detailed examinations, and a second body, headed by members of the Parliament and staffed by a small secretariat, responsible to the legislature. Constitutional change in Finland in 2000, however, will result in the SAI becoming independent of the Ministry of Finance and reporting to Parliament".

Mais adequada, entretanto, é a classificação proposta por José F. F. Tavares, que sugere a existência de três sistemas $^{23}$ : o sistema de tribunal de contas, o sistema de auditor geral e o sistema misto Tribunal de Contas/Auditor-Geral. Esclarece o autor português que (TAVARES, 1998, p. 32):

Em geral, os tribunais de contas tem natureza colegial e exercem a função de fiscalização/auditoria e a função jurisdicional de julgamento, maxime, da responsabilidade financeira. Nalguns casos, tendem a privilegiar o controlo da legalidade e da regularidade financeiras. O controle é exercido a posteriori (controle sucessivo) e, nalguns casos, também a priori (fiscalização prévia).

O sistema de auditor geral, acolhido sobretudo no mundo anglo-saxônico, caracteriza-se por haver um órgão singular, com funções exclusivas de auditoria, tendendo a privilegiar o controlo da boa gestão financeira. Em regra, o controlo exercido é concomitante e sucessivo, estando excluído o controle prévio.

Há, porém, Estados que instituíram um órgão de controlo financeiro de natureza mista, combinando as características dos sistemas de tribunal de contas e de auditor geral. $\underline{\mathrm{Na}}$ verdade, há exemplos de Tribunais de Contas, com a sua natureza colegial, que não têm poderes jurisdicionais, exercendo apenas a função de auditoria suprema e sem poderes de fiscalização prévia, mas tão só concomitante e sucessiva" (grifo nosso).

No Sistema de Controle Externo preconizado pela CF/88, integram os Tribunais

de Contas com função de julgamento da contas dos administradores e demais responsáveis pela gestão de bens, dinheiros e valores públicos (art. 71, II, da CF/88). Neste modelo,

${ }^{23}$ As Entidades Fiscalizadoras Superiores da Suécia e da Finlândia apontados pelo NAO não são, de fato, órgãos de controle externo. 
pressupõe-se uma regularidade e periodicidade do exame da legalidade, legitimidade e economicidade da gestão, por meio dos processos de contas submetidos obrigatoriamente para julgamento pelo Tribunal.

Optou-se, entre nós, por um modelo que privilegia a verificação regular e periódica das contas públicas, em geral anual, predominantemente sob o aspecto da legalidade e da legitimidade. Os gestores públicos são obrigados a submeter, assim, as prestações de contas para avaliação e julgamento dos Tribunais de Contas. Complementando este processo de julgamento das contas, existem as fiscalizações de natureza esporádica e seletiva, por critérios de amostragem, risco ou materialidade (ou outro critério relevante adotado pelos Tribunais de Contas ou por iniciativa do Parlamento).

Nos países de tradição anglo-saxônica, não há este procedimento periódico de verificação e julgamento das contas. Estes Estados privilegiam as fiscalizações sob os aspectos do desempenho (eficácia, economicidade, eficiência e efetividade) às fiscalizações de conformidade (legalidade, legitimidade).

No nosso sistema, apurada irregularidade no procedimento fiscalizatório ou nas prestações de contas, o agente responsável deve se sujeitar às conseqüências desta infração, o que pressupõe a existência de um procedimento em que lhe seja assegurada as garantias do devido processo legal e que culmine com o julgamento imparcial da autoridade competente.

Como não exercem função judicante, não há que se cogitar em responsabilidade financeira efetivada pelas EFS nos Estados que adotam os sistemas de auditoria ou controladoria geral (de tradição inglesa: Reino Unido, EUA, Irlanda, Canadá, Dinamarca, Noruega e Suécia) e naqueles que adotem os sistemas de controle de natureza mista (Tribunal de Contas Europeu e os Tribunais de Contas da Alemanha e Áustria - Rechnungshöfe e Holandês) ${ }^{24}$.

24 Além disso, o próprio enfoque adotado para avaliação da gestão dificulta a responsabilização, pois, inúmeros fatores alheios à conduta do gestor influenciam no desempenho do ente público. 
Neste sentido, João Franco do Carmo expõe que (CARMO, 1995, p. 95):

"(...), como já dexámos escrito, só há propriamente responsabilidade financeira (como categoria autônoma) onde se exercita (ou pode exercitar) jurisdição financeira (...) Consequentemente, não curamos dos sistemas de auditor geral, nem tampouco dos casos em que ao tribunal de contas é associada, apenas, a fiscalização de economicidade, eficácia e eficiência, ou mera competência consultiva. Em qualquer destas situações, o órgão de controlo financeiro externo e independente não exercita verdadeira jurisdição".

Os nossos tradicionais modelos de responsabilidade (civil, penal, disciplinar) não se ajustam a esta idéia de julgamento regular das contas públicas. Estão relacionadas a situações e apurações esporádicas. Não são aptas a um controle permanente.

No caso da responsabilidade disciplinar, o próprio gestor público é, na maioria das vezes, a autoridade competente para aplicação da penalidade desta natureza, o que torna este modelo insuficiente para o controle da gestão pública.

Faz-se necessário, então, um modelo específico de responsabilidade, aplicado por autoridade independente, e que seja integrado à função de julgamento das contas. Este modelo é o da responsabilidade financeira. 


\section{A RESPONSABILIDADE NO DIREITO ESTRANGEIRO}

Analisar o Direito Estrangeiro pode ajudar os operadores do direito a solucionar questões, interpretar normas e, especialmente, a desvendar a essência da responsabilidade financeira.

O estudo da responsabilidade no Direito Estrangeiro não pode prescindir da análise do Regime Político, da Forma de Estado, das Instituições que integram o Estado, incluindo os Tribunais de Contas, seus poderes, funções, competências e procedimentos.

Como será descrito a seguir, será desmentida a afirmação, erroneamente difundida entre nós, que o Tribunal de Contas integra o Contencioso Administrativo Ordinário, nos Estados que a Jurisdição Administrativa. Esta informação tem grande importância para o reconhecimento de uma jurisdição contábil ou financeira, restrita às questões relativas à responsabilidade financeira (capítulo 21).

\subsection{Bélgica}

A Bélgica é um Estado Federativo. A sua estrutura federativa é complexa e disposta em três níveis ${ }^{25}$ :

a) no nível mais elevado, encontram-se a esfera Federal, as Comunidades e as Regiões, todos os três submetidos a um igual tratamento jurídico;

b) num nível intermediário, encontram-se as províncias, sujeitas à supervisão das autoridades do nível acima;

c) num nível inferior, existem as comunas, nível de administração mais próximo dos cidadãos, também sujeitas à supervisão das autoridades do nível mais elevado.

\footnotetext{
${ }^{25}$ Cf. http://www.belgium.be/en/about_belgium/government/federale_staat/structure/
} 
O Governo Federal tem competências nas áreas de finanças públicas, defesa externa, sistema judicial, seguridade social, relações internacionais e, em parcela substancial, do sistema de saúde pública ${ }^{26}$.

Segundo a Constituição Belga de 17.02.1994, são três as comunidades: a comunidade francesa, a comunidade flaminga e a comunidade germânica.

O Estado Belga é uma Monarquia Parlamentarista.

O Poder Legislativo Federal é composto pelo Rei, pela Câmara de Representantes e pelo Senado. Alguns membros da Família Real são Senadores "de Direito". A Câmara tem a importante função de Controle do Governo Federal, no tocante à execução do orçamento e às contas públicas.

O Governo Federal é composto por um Conselho de Ministros, limitado a 15 membros, com participação igualitária de Ministros de origem Flaminga e de origem Francesa, com exceção ao Primeiro Ministro, que exerce o papel de Chefe de Governo.

O Poder Judiciário está regulado nos artigos 144 a 159 da Constituição Belga. O Poder Judiciário é composto pela Corte de Cassação, por Cortes Trabalhistas, Cortes de Apelação, Corte Comercial, Tribunal Industrial, Cortes Distritais, Cortes de Magistrados e Juízes de $\mathrm{Paz}^{27}$.

Na Bélgica existe Jurisdição Administrativa, regulada pelos artigos 160 e 161 da Constituição.

O Conselho de Estado ${ }^{28}$ (Conseil d'Etat - Raad van State) é o órgão supremo da jurisdição administrativa e julga ações tendentes à anulação ou suspensão de atos ou

\footnotetext{
${ }^{26} \mathrm{Cf}$. http://www.belgium.be

${ }^{27} \mathrm{Cf}$. http://ec.europa.eu/civiljustice/org_justice/org_justice_bel_en.pdf

${ }^{28} \mathrm{Cf}$. http://www.raadvst-consetat.be
} 
ordenações expedidas pelas autoridades administrativas. Atua também como jurisdição de cassação contra as decisões das jurisdições administrativas inferiores ${ }^{29}$.

A Corte de Contas da Bélgica está regulada no artigo 180 da Constituição, no Título V - Das Finanças (arts. 170 a 181), ao lado das normas e princípios jurídicos da tributação, do Orçamento, da "Loi des Comptes" e do sistema de financiamento das Comunidades e Regiões.

Dispõe o artigo 180 que:

"Os membros da Corte de Contas são nomeados pela Câmara dos Representantes e por um mandato fixado em lei. Esta Corte é encarregada do exame e da liquidação das contas da Administração Geral e de todos os 'comptables' do Tesouro Público. A Corte exerce igualmente um controle geral sobre as operações relativas ao estabelecimento e percepção da receita pública. Ela julga contas de diferentes administrações do Estado e é encarregada de recolher para este efeito toda informação e toda peça contábil necessária. As Contas Gerais do Estado são submetidas à Câmara dos Representantes com as observações da Corte de Contas. A organização da Corte de Contas é regulada em lei" ${ }^{30}$.

A Corte de Contas da Bélgica possui funções de controle financeiro, controle de legalidade e de bom emprego de dinheiros públicos (bon emploi dês deniers publics) ${ }^{31}$. No controle financeiro, "as contas são encaminhadas à Corte que verifica a exatidão, a credibilidade, a exaustividade da situação financeira, assegurando a conformidade das operações contábeis com a regulamentação sobre contabilidade pública" ${ }^{32}$.

\footnotetext{
${ }^{29}$ As competências consultivas e jurisdicionais do Conselho de Estado Belga, apresentadas no seu sítio eletrônico, são: "Suspendre et annuler des actes administratifs (actes individuels et règlements) contraires aux règles de droit en vigueur constituent donc les principales compétences du Conseil d'État. La protection contre l'arbitraire administratif n'est toutefois pas la seule mission du Conseil. Il a également une fonction d'organe consultatif dans les matières législatives et réglementaires. Le Conseil d'État est aussi juge de cassation qui connaît des recours contre les décisions des juridictions administratives inférieures".

${ }^{30}$ Article 180. Les membres de la Cour des comptes sont nommés par la Chambre des représentants et pour le terme fixé par la loi. Cette Cour est chargée de l'examen et de la liquidation des comptes de l'administration générale et de tous comptables envers le trésor public. Elle veille à ce qu'aucun article des dépenses du budget ne soit dépassé et qu'aucun transfert n'ait lieu. La Cour exerce également un contrôle général sur les opérations relatives à l'établissement et au recouvrement des droits acquis par l'État, y compris les recettes fiscales. Elle arrête les comptes des différentes administrations de l'État et est chargée de recueillir à cet effet tout renseignement et toute pièce comptable nécessaire. Le compte général de l'État est soumis à la Chambre des représentants avec les observations de la Cour des comptes. Cette Cour est organisée par la loi.

${ }^{31} \mathrm{Cf}$. http://www.ccrek.be/fr/missionsetcompetences.htm

${ }^{32} \mathrm{Cf}$. http://www.ccrek.be/fr/missionsetcompetences.htm
} 
No controle de legalidade, a Corte, atuando sobre as despesas e as receitas públicas $^{33}$,

"verifica a sua conformidade com a lei orçamentária (créditos suficientes no orçamento, exatidão das imputações, etc.) e assegura a aplicação correta das regras de direito a que se submete a operação controlada (em particular as normas aplicáveis em matéria de compras governamentais, outorgas, emprego de subsídios, recrutamento de pessoal, etc.)".

O controle do bom emprego de dinheiros públicos é definido com base em três $\operatorname{conceitos}^{34}$ :

a) economia (economicidade): "consiste em verificar se os recursos financeiros, humanos e materiais utilizados são, tanto do ponto de vista qualitativo, quanto do ponto de vista quantitativo, adquiridos nos momentos oportunos e ao melhor custo";

b) eficácia: "faz a medida na qual os objetivos e finalidades atribuídas foram atendidas";

c) eficiência: "mede a relação entre os meios utilizados e os resultados obtidos", ou, em outros termos, "visa assegurar que os recursos financeiros, humanos e materiais sejam utilizados de maneira ótima".

Além desta função de controle, a Corte de Contas Belga tem uma "missão jurisdicional", de examinar e liquidar as contas da administração geral e de todos os comptables do Tesouro Público. As contas são encaminhadas à Corte a cada ano, ainda que em caso de débito e de cessação das funções ${ }^{35}$.

A Organização do Tribunal de Contas da Bélgica e seus Procedimentos estão regulados pela Lei de 29.10.1846, com as alterações posteriores (Lei Orgânica do Tribunal de Contas Belga).

Nesta Lei, a responsabilidade dos "comptables" está vinculada à função de "verificação e liquidação" das contas, conforme dispõe o artigo $8^{\circ}$ :

\footnotetext{
${ }^{33}$ Cf. http://www.ccrek.be/fr/missionsetcompetences.htm

${ }^{34} \mathrm{Cf}$. http://www.ccrek.be/fr/missionsetcompetences.htm

${ }^{35}$ Cf. http://www.ccrek.be/fr/missionsetcompetences.htm
} 
"O Tribunal julga as contas dos responsáveis do Estado e das províncias. Esta missão é, em cada Câmara, exercida por um Conselheiro, designado, consoante o caso, pelo Primeiro Presidente ou pelo Presidente. A Corte estabelece se os responsáveis estão quites, se têm saldos ou débitos. Nos dois primeiros casos, a Corte dá quitação aos responsáveis e ordena a restituição de suas cauções e, se for o caso, o levantamento da penhora e inscrições hipotecárias existentes sobre os bens, em razão de sua gestão. Em todo caso, a Corte envia imediatamente as contas encerradas para o Departamento Ministerial competente ou para a Deputação permanente do Conselho Provincial. No caso de débito, o Ministro ou a Deputação decide se é o caso de citar o 'comptable' perante a Corte de Contas com vistas à reposição do débito. A autoridade administrativa só pode renunciar à citação do responsável, se considerar que é o caso de força maior ou que o débito não excede um montante fixado pelo Rei. Quando esta autoridade se abstém de citar um 'comptable' em débito, ele comunica à Corte de Contas por um documento motivado, acompanhado de todas as peças justificativas. A Corte comunica, nas suas observações anuais à Câmara dos Representantes, os casos em que a autoridade administrativa não exerceu seu direito de agir visando o reembolso do débito. $\mathrm{O}$ agente contábil citado pode, no exercício do contraditório, fazer valer a exatidão da conta em débito. A corte dá quitação, se ela concluir pela ausência de débito ou se o débito for oriundo de força maior. No caso contrário, ela condena o responsável ao ressarcimento do débito. Entretanto, conforme as circunstâncias, a Corte poderá condenar o responsável a ressarcir parcialmente o débito. Cinco anos após a cessação das suas funções, o agente contábil terá quitação definitiva se, neste período, não for condenado em decisão do Tribunal" (tradução livre). ${ }^{36}$

\section{Segundo J. Beckers, Conselheiro da Câmara Flamenga, os responsáveis perante} a Corte de Contas Belga podem ser classificados em (BECKERS, 2004, p. 96-97):

\section{a) responsáveis comuns ou regulares:}

\footnotetext{
"pessoas designadas de acordo com a lei da contabilidade do Estado e que são investidos em virtude dum título legal, e por isso, obrigados a prestar contas anualmente ao Tribunal de Contas. São encarregados de cobrar receitas e só podem fazer operações de despesas restritas";
}

\footnotetext{
${ }^{36}$ Art. 8. La Cour arrête les comptes des comptables de l'Etat et des provinces. Cette mission est accomplie, dans chaque chambre, par un conseiller unique désigné, selon le cas, par le premier président ou par le président. La Cour établit si ces comptables sont quittes, en avance ou en débet.

Dans les deux premiers cas, elle prononce leur décharge et ordonne la restitution des cautionnements et, s'il y a lieu, la mainlevée des oppositions et la radiation des inscriptions hypothécaires existant sur leurs biens, à raison de leur gestion. Dans tous les cas, la Cour transmet sans délai les comptes arrêtés au département ministériel ou à la députation permanente du conseil provincial. Lorsque le compte arrêté fait apparaître un débet, le ministre, ou la députation permanente du conseil provincial, décide s'il y a lieu de citer le comptable devant la Cour en remboursement du débet. L'autorité administrative visée à l'alinéa précédent ne peut s'abstenir de citer le comptable en débet que si elle le considère comme fondé à se prévaloir de la force majeure ou si le débet n'excède pas un montant fixé par le Roi. Quand cette autorité s'abstient de citer le comptable en débet, elle en avise la Cour par un écrit motivé, accompagné de toutes pièces justificatives. La Cour signale, dans ses observations annuelles aux Chambres, les cas dans lesquels l'autorité administrative n'a pas exercé son droit d'agir en remboursement du débet. Le comptable cité est recevable à contester l'exactitude du compte arrêté dont il ressort qu'il est en débet.

La Cour prononce la décharge si elle conclut à l'absence de débet ou si le comptable est fondé à se prévaloir de la force majeure. Dans le cas contraire, elle le condamne à solder son débet. Elle peut néanmoins, en s'inspirant de toutes les circonstances de l'espèce et notamment de l'importance des manquements du comptable à ses obligations, ne le condamner qu'à rembourser une partie du débet. Cinq ans après la cessation de ses fonctions, le comptable aura une décharge définitive si un arrêt de condamnation n'a été rendu dans ce délai.
} 
b) responsáveis extraordinários:

"pessoas que têm, como receita única, um adiantamento em dinheiro. Estes adiantamentos são postos à disposição dos serviços geridos de maneira doméstica ou para pequenas despesas dos departamentos ministeriais. Têm de prestar contas de quatro em quatro meses";

c) responsável de facto: "pessoas que, de maneira súbida e inopinada, tratam de dinheiros públicos";

d) responsáveis sem conta: funcionários que tratam de dinheiros públicos, se bem que não prestam contas ao Tribunal de Contas:

"Refere-se particularmente às pessoas que cobram os preços de entrada, ou que são encarregadas de vendas de brochuras públicas ou da cobrança de taxas a transmitir mais tarde ao responsável regular. Os funcionários do corpo diplomático e consultar pertencem a esta categoria".

Além das pessoas físicas, admite-se que instituição pública também seja responsável (embora o seu número esteja a diminuir), tal como é o caso do Banco Nacional da Bélgica, na sua função de caixa do Estado. Pessoas Jurídicas do setor privado também estão sujeitas à Jurisdição do Tribunal de Contas, se gerirem dinheiros públicos (BECKERS, 2004).

O procedimento de responsabilização financeira de gestores públicos na Bélgica ocorre em duas fases: administrativa e jurisdicional (BECKERS, 2004).

$\mathrm{Na}$ fase administrativa, trata-se de um procedimento de verificação da legalidade e regularidade das contas e de liquidação, feito sem contraditório. Conforme ensina J. Beckers (BECKERS, 2004, p. 101):

"Caso a conta seja apurada ou apresente um crédito, o Tribunal de Contas dá quitação ao responsável e no caso das contas em fim de gestão, ordena a restituição das cauções e, eventualmente, o levantamento da penhora e a anulação das inscrições hipotecárias existentes sobre os seus bens. Neste caso não haverá segunda fase. O Tribunal de Contas envia as contas encerradas às autoridades e o processo é dado por findo.

Também, se a conta apresenta um défice, a mesma é devolvida, mas neste caso começa a segunda fase do processo. No caso de défice, todavia, o responsável não é simplesmente julgado. A conta fechada é o ponto de partida duma fase de jurisdição eventual, com acção judicial que corre pelo Tribunal de Contas".

Na fase jurisdicional, há a citação do responsável, que não é feito pelo Tribunal de Contas, mas pela autoridade administrativa competente (BECKERS, 2004, p. 101): 
"No processo actual o Tribunal de Contas já não pode accionar o responsável oficiosamente. Com efeito não há no Tribunal de Contas Belga representação do Ministério Público. No caso de défice na contas fechada, o ministro decide se o responsável deve ou não ser citado pelo Tribunal de Contas com vista ao reembolso do défice.

A autoridade competente, todavia, não dispõe de uma competência soberana. Com excepção do caso em que o responsável restitui o débito antes da sua citação, a autoridade só pode renunciar à citação se é de opinião que o responsável pode invocar motivos de força maior ou se o défice é inferior a 1.240 Euros".

Um importante instituto da responsabilidade financeira na Bélgica é a quitação automática (prevista no artigo $8^{\circ}$ ), conforme descreve J. Beckers (BECKERS, 2004, p. 102):

\footnotetext{
"A lei contém uma regra de quitação automática se a condenação não é pronunciada dentro de um prazo determinado, a chamada 'quitação de ofício'. O prazo determinado pela lei é de cinco anos. O prazo anterior de três anos pareceu, em certos casos, muito breve. O processo em duas fases, com debates contraditórios, não favorece uma solução mais rápida de processos complicados."
}

No tocante à execução das decisões dos Acórdãos do Tribunal de Contas, J. Beckers esclarece que "seguem as mesmas regras de execução das sentenças e acórdãos do poder judiciário belga" (BECKERS, 2004, p. 105). Acrescenta que "o ministro das Finanças tem de tomar as medidas necessárias à garantia da boa execução dos acórdãos" (BECKERS, 2004, p. 105). Dos Acórdãos do Tribunal de Contas, cabe recurso ao Tribunal de Relação Belga (BECKERS, 2004).

\subsection{Portugal}

Em 1910, Portugal alterou o seu Regime Político, instaurando a República. Em 1926, a derrubada do Regime Parlamentar (I República) por uma ditadura militar inaugurou um dos mais longos regimes de exceção da História Ocidental, perdurando até 1974. Um ano depois, foi eleita a Assembléia Constituinte que promulgou a Constituição de 02.04.1976, em vigor até hoje $\mathrm{e}^{37}$.

Portugal é hodiernamente uma República Democrática Parlamentarista.

\footnotetext{
${ }^{37} \mathrm{Cf}$. http://www.portugal.gov.pt
} 
Segundo o art. $6^{\circ}$, da Constituição, Portugal é um Estado Unitário, com duas regiões autônomas (Açores e Madeira).

São considerados órgãos de soberania do Estado Português o Presidente da República, a Assembléia da República, o Governo e os Tribunais, dentro dos quais, está incluso o Tribunal de Contas (art. $\left.110^{\circ}\right)$.

O Presidente da República é o Chefe de Estado e "representa a República Portuguesa, garante a independência nacional, a unidade do Estado e o regular funcionamento das instituições democráticas e é, por inerência, Comandante Supremo das Forças Armadas" (art. 120). É eleito por sufrágio universal (art. 121 ${ }^{\circ}$ ).

Suas competências estão reguladas nos artigos $133^{\circ}$ a $140^{\circ}$, dentre as quais destacam-se a dissolução da Assembléia da República, a nomeação do Primeiro-Ministro, a promulgação ou veto de decretos da Assembléia da República (projetos de lei no Brasil) e a de requer ao Tribunal Constitucional a declaração de inconstitucionalidade de normas jurídicas.

A Assembléia da República é o Parlamento do Estado Português. Tem suas competências reguladas nos artigos $161^{\circ}$ a $163^{\circ}$, da Constituição, dentre as quais, destaca-se a de aprovar, sob proposta do governo, leis das grandes opções dos planos nacionais e o orçamento do Estado, sob proposta do Governo. Além disso, compete à Assembléia tomar as contas do Estado e das demais entidades públicas que a Lei determinar, com o parecer do Tribunal de Contas e demais elementos necessários à sua apreciação.

O Governo é o órgão de condução da política geral do país e é o órgão superior da Administração Pública (art. $182^{\circ}$ ). É constituído pelo Primeiro-Ministro, pelos Ministros e pelos Secretários e Subsecretários de Estado (art. 183º). 
Os membros do Governo são vinculados ao Programa de Governo, no qual constarão as principais orientações políticas e medidas a adotar ou a propor nos diversos domínios da atividade governamental (art. $\left.188^{\circ} / 189^{\circ}\right)$.

As competências do Governo estão estabelecidas nos artigos $197^{\circ}$ a $201^{\circ}$, dentre as quais, destacam-se as de "Elaborar os planos, com base nas leis das respectivas grandes opções, e fazê-los executar", de "Fazer executar o Orçamento do Estado", de "Dirigir os serviços e a actividade da administração directa do Estado, civil e militar, superintender na administração indirecta e exercer a tutela sobre esta e sobre a administração autônoma" e de "Aprovar os actos do Governo que envolvam aumento ou diminuição das receitas ou despesas públicas".

A Administração Pública está regulada no Título IX da Constituição Portuguesa (arts. $266^{\circ}$ a $272^{\circ}$ ).

No art. $266^{\circ}$, dispõe acerca os princípios aos quais se submete a Administração Pública Portuguesa:

"1. A Administração Pública visa a prossecução do interesse público, no respeito pelos direitos e interesses legalmente protegidos dos cidadãos.

2. Os órgãos e agentes administrativos estão subordinados à Constituição e à lei e devem actuar, no exercício das suas funções, com respeito pelos princípios da igualdade, da proporcionalidade, da justiça, da imparcialidade e da boa fé".

No Art. $271^{\circ}$, é abordada a responsabilidade dos agentes públicos, nas suas diversas modalidades. Entretanto, a responsabilidade financeira só será mencionada no art. $214^{\circ}$ da Constituição Portuguesa. São tratadas, ainda, as hipóteses de exclusão da responsabilidade (cumprimento de ordens superiores, salvo se implicar em prática de crime) e o direito de regresso do Estado contra os seus agentes:

"Artigo 271. ${ }^{\circ}$

(Responsabilidade dos funcionários e agentes)

1. Os funcionários e agentes do Estado e das demais entidades públicas são responsáveis civil, criminal e disciplinarmente pelas acções ou omissões praticadas no exercício das suas funções e por causa desse exercício de que resulte violação dos direitos ou interesses legalmente protegidos dos cidadãos, não dependendo a acção ou procedimento, em qualquer fase, de autorização hierárquica.

2. É excluída a responsabilidade do funcionário ou agente que actue no cumprimento de ordens ou instruções emanadas de legítimo superior hierárquico e em matéria de serviço, se 
previamente delas tiver reclamado ou tiver exigido a sua transmissão ou confirmação por escrito.

3. Cessa o dever de obediência sempre que o cumprimento das ordens ou instruções implique a prática de qualquer crime.

4. A lei regula os termos em que o Estado e as demais entidades públicas têm direito de regresso contra os titulares dos seus órgãos, funcionários e agentes".

Os Tribunais estão regulados nos artigos $202^{\circ}$ a $220^{\circ}$, da Constituição Portuguesa.

Ao Tribunal Constitucional compete especificamente administrar a justiça em matérias de natureza jurídico-constitucional (art. $221^{\circ}$ ). O Tribunal Constitucional Português exerce funções administrativas e jurisdicionais e atua também como um Tribunal Eleitoral. Exerce o controle de constitucionalidade preventivo (art. $278^{\circ}$ ), a fiscalização concreta de constitucionalidade (art. $280^{\circ}$ ) e a físcalização abstrata de constitucionalidade (art. $281^{\circ}$ ).

Além do Tribunal Constitucional, os Tribunais, órgãos de soberania do Estado Português, podem ser agrupados em três categorias (art. 209 ${ }^{\circ}$ ):

a) O Superior Tribunal de Justiça e os Tribunais Judiciais de $1^{\mathrm{a}}$. e $2^{\mathrm{a}}$. Instâncias;

b) O Superior Tribunal Administrativo e os demais Tribunais Administrativos e Fiscais;

c) O Tribunal de Contas.

Pode-se depreender desta classificação constante da própria Constituição Portuguesa que o Tribunal de Contas não integra a jurisdição administrativa. Os Tribunais Administrativos ou Fiscais são regulados pelo art. $212^{\circ}$ da Constituição Portuguesa (e pelo Estatuto dos Tribunais Administrativos e Fiscais - Lei ${ }^{\circ}$ 13/2002, de 19 de fevereiro) e tem por competência julgar ações e recursos contenciosos que tenham por objeto dirimir os litígios emergentes das relações jurídicas administrativas e fiscais.

Por sua vez, o Tribunal de Contas tem sua competência regulada no art. $214^{\circ}$, verbis: 
"1. O Tribunal de Contas é o órgão supremo de fiscalização da legalidade das despesas públicas e de julgamento das contas que a lei mandar submeter-lhe, competindo-lhe, nomeadamente:

a) Dar parecer sobre a Conta Geral do Estado, incluindo a da segurança social;

b) Dar parecer sobre as contas das Regiões Autónomas dos Açores e da Madeira;

c) Efectivar a responsabilidade por infracções financeiras, nos termos da lei;

d) Exercer as demais competências que lhe forem atribuídas por lei.

2. O mandato do Presidente do Tribunal de Contas tem a duração de quatro anos, sem prejuízo do disposto na alínea $\mathrm{m}$ ) do artigo $133 .^{\circ}$.

3. O Tribunal de Contas pode funcionar descentralizadamente, por secções regionais, nos termos da lei.

4. Nas Regiões Autónomas dos Açores e da Madeira há secções do Tribunal de Contas com competência plena em razão da matéria na respectiva região, nos termos da lei".

As competências, a organização e o processo no âmbito do Tribunal de Contas Português encontram-se regulados na Lei $\mathrm{n}^{\circ} 98 / 97^{38}$, de 27 de Agosto, com as alterações introduzidas pelas Leis nº $87-\mathrm{B} / 98,1 / 2001,55-\mathrm{B} / 2004$, 48/2006 e 35/2007.

Trata-se, diga-se de passagem, de Lei muito bem elaborada, bem estruturada e que regula (e soluciona) uma série de questões que, entre nós, estão ainda pendentes de solução, em razão da redação defeituosa (e lacunosa) da Lei n 8.443/92 e das Leis Estaduais que a adotaram como paradigma ${ }^{39}$.

A Lei ${ }^{\circ}$ 98/97 está estruturada da seguinte forma:

a) Capítulo I - Funções, Jurisdição e Competência (arts. $1^{\circ}$ a $6^{\circ}$ );

b) Capítulo II - Princípios Fundamentais (arts. $7^{\circ}$ a $13^{\circ}$ );

c) Capítulo III - Estrutura e Organização (arts. $14^{\circ}$ a $35^{\circ}$ );

d) Capítulo IV - Modalidades de Controle Financeiro (arts. $36^{\circ}$ a $56^{\circ}$ );

e) Capítulo V - Efetivação das Responsabilidades Financeiras (arts. $57^{\circ}$ a $\left.70^{\circ}\right)$

f) Capítulo VI - Funcionamento do Tribunal de Contas (arts. $71^{\circ}$ a $79^{\circ}$ );

g) Capítulo VII - Processo no Tribunal de Contas (arts. $80^{\circ}$ a $103^{\circ}$ );

h) Capítulo VIII - Seções Regionais (arts. $104^{\circ}$ a $109^{\circ}$ );

\footnotetext{
${ }^{38}$ Cf. Lei de Organização e Processo do Tribunal de Contas de Portugal.

${ }^{39}$ Considerando, ainda, os nossos traços culturais, históricos e jurídicos comuns, a Lei Portuguesa será, neste trabalho, utilizada como referência por excelência para, mediante analogia, colmatar as lacunas do Direito Brasileiro.
} 
i) Capítulo IX - Disposições Finais e Transitórias (arts. $110^{\circ}$ a $115^{\circ}$ ).

Isso posto, apresentamos os pontos-chave da Lei para o estudo da responsabilidade financeira.

De início, a Lei versa sobre a possibilidade de conflitos entre a Jurisdição Administrativa e a Jurisdição do Tribunal de Contas. Segundo Artigo 1\%3, da Lei n 98/97, a competência para a solução destes conflitos é do Tribunal de Conflitos, presidido pelo Presidente do Superior Tribunal de Justiça e composto por dois juízes de cada um dos Tribunais envolvidos: Superior Tribunal Administrativo e Tribunal de Contas.

$\mathrm{O}$ artigo $2^{\circ}$ versa sobre o âmbito de competência do Tribunal de Contas, ou seja, os órgãos e entidades que estão sujeitos aos poderes de controle financeiro do Tribunal de Contas. Entre estas, destacam-se as empresas públicas, as concessionárias e as fundações de direito privado que "recebam anualmente, com carácter de regularidade, fundos provenientes do Orçamento do Estado ou das autarquias locais". O poder de controle financeiro, neste último caso, está restrito à utilização destes fundos.

$\mathrm{O}$ artigo $5^{\circ}$ versa sobre as competências materiais essenciais do Tribunal de Contas, dentre as quais, merecem destaque:

a) a fiscalização prévia de legalidade e cabimento orçamental de atos e contratos de qualquer natureza que sejam geradores de despesa ou representativos de quaisquer encargos ou responsabilidades, diretas ou indiretas, para as entidades do art. $2^{\circ}$;

b) julgar a efetivação da responsabilidade financeira;

c) apreciar a legalidade, economia, eficiência e eficácia, segundo critérios técnicos, da gestão financeira das entidades do art. $2^{\circ}$ e o funcionamento e fiabilidade do Controle Interno;

d) verificar as contas dos organismos, serviços e entidades sujeitos à sua prestação. 
Convém mencionar que a Conta Geral do Estado e a das Regiões Autônomas são julgadas pela Assembléia da República ou pelas Assembléias Legislativas da Regiões, que, conforme o caso, encaminham o Parecer do Tribunal de Contas ao Ministério Público para efetivação das responsabilidades financeiras.

O princípio do contraditório assume no Direito Português especial relevância, pois está inserido no capítulo II, relativo aos princípios fundamentais do Tribunal de Contas. Segundo o art. $13^{\circ}$, o contraditório compreende:

a) a garantia de oitiva dos interessados prévia à instauração dos processos de efectivação de responsabilidade financeira;

b) o direito dos responsáveis de serem ouvidos sobre os fatos que the são imputados, sobre a qualificação, o regime legal aplicável e os montantes a pagar ou a repor;

c) a garantia de acesso à informação nos órgãos e entidades públicas para efeito do exercício do contraditório;

d) possibilidade dos responsáveis constituírem advogado para atuar junto ao Tribunal de Contas.

$\mathrm{O}$ artigo $51^{\circ}$ relaciona as entidades que devem prestar contas ao Tribunal de Contas de Portugal.

A Prestação de Contas é anual, ou seja, por "anos econômicos" (entre nós, exercício financeiro). Não vigora o princípio da pessoalidade da prestação de contas, uma vez que elas são elaboradas pelos responsáveis da respectiva gerência ou, se estes estiverem cessado suas funções, por aqueles que lhes sucederem, sem prejuízo do dever de recíproca colaboração (art. $52^{\circ}$ ). Se houver substituição de responsáveis durante o "ano econômico", as contas serão prestadas em relação a cada gerência $\left(\operatorname{art.} 52^{\circ}\right)$. 
$\mathrm{Na}$ falta de encaminhamento das contas, ou de outros documentos, o Tribunal de Contas fixará prazo para entrega (art. 68 ${ }^{\circ}$ ). Se este prazo for descumprido, resta configurado crime de desobediência qualificada, cabendo ao Ministério Público instaurar processo no Tribunal Competente (art. 68).

A verificação das contas poderá ser interna ou externa. A verificação interna compreende a análise e conferência da conta apenas para demonstração numérica de suas operações $\left(\operatorname{art} .53^{\circ}\right)$. A verificação externa tem por objeto verificar a legalidade e a regularidade das operações efetuadas; verificar se os sistemas de controle interno são fiáveis; se as contas e demonstrações financeiras refletem fidedignamente as operações e a situação patrimonial da entidade; e se foram realizadas de acordo com as regras contabilísticas fixadas $\left(\operatorname{art.} 54^{\circ}\right)$

A efetivação da responsabilidade financeira está detalhadamente regulada pelos artigos $57^{\circ}$ a $70^{\circ}$, da Lei ${ }^{\circ} 98 / 97$.

$\mathrm{O}$ art. $57^{\circ}$ preconiza o encaminhamento ao Ministério Público dos Relatórios das ações de controle que evidenciem fatos constitutivos da responsabilidade financeira.

$\mathrm{O}$ art. $58^{\circ}$ informa os processos em que tem lugar a responsabilidade financeira: os processos de julgamento de contas e de julgamento da responsabilidade financeira.O processo de julgamento de contas visa tornar efectivas as responsabilidades financeiras evidenciadas em relatórios de verificação externa de contas, com homologação. $\mathrm{O}$ processo de julgamento de responsabilidade financeira visa tornar efectivas as responsabilidades financeiras emergentes de factos evidenciados em relatórios das acções de controlo do Tribunal elaborados fora do processo de verificação externa de contas ou em relatórios dos órgãos de controlo interno (art. 58). 
Nos artigos $59^{\circ}$ e $60^{\circ}$ são apresentados os pressupostos objetivos da responsabilidade financeira reintegratória e nos artigos $65^{\circ}$ e $66^{\circ}$ os da responsabilidade financeira sancionatória ${ }^{40}$.

Há possibilidade de cumulação da responsabilidade financeira reintegratória com a sancionatória (art. 65\%).

No artigo $61^{\circ}$ são informados os sujeitos passivos da responsabilidade financeira, que, em Portugal, podem incluir os membros do governo (agentes políticos), dirigentes de órgãos de gestão administrativa e financeira e, até mesmo, os funcionários e agentes que nas informações prestadas aos membros do governo e dirigentes não esclareçam os assuntos de sua competência de harmonia com a lei.

Dispõe, ainda, o artigo $61^{\circ} / 5$, que a responsabilidade financeira é subjetiva, só ocorrendo se a ação for praticada com culpa.

A Lei $n^{\circ}$ 98/97 regula ainda os critérios de avaliação da culpa do responsável (art. 64 $4^{\circ}$, os critérios de graduação das multas aplicadas (art. 67) e as causas de extinção da responsabilidade financeira (art. $69^{\circ}$ e $70^{\circ}$ ), temas que serão apresentados, com o devido detalhe, quando tratarmos do Direito Brasileiro.

\subsection{Espanha}

A Constituição Espanhola (CE) em vigor foi aprovada em 31.10 .1978 e ratificada por referendo popular.

\footnotetext{
${ }^{40}$ A doutrina classifica a responsabilidade sancionatória em duas espécies: aquelas por atos essencialmente financeiros (art. 65) e aquelas por atos não essencialmente financeiros (art. 66), por violação aos deveres de colaboração do gestor para com o Tribunal de Contas.
} 
A Espanha é uma monarquia parlamentarista. É um Estado formalmente unitário, mas que garante o direito de autonomia das regiões e nacionalidades que o compõem (art. 2).

Segundo o artigo 143, é garantido o exercício da autonomia por parte das províncias limítrofes com características históricas, culturais e econômicas comuns, dos territórios insulares e das províncias com identidade regional histórica, que poderão constituir-se em Comunidades Autônomas (autogoverno).

A Constituição Espanhola estabelece as competências que poderão ser assumidas pelas Comunidades Autônomas (art. 148) e as competências que são de exclusiva competência do Poder Central (art. 149). Há, ainda, a possibilidade das "Cortes Generales" atribuírem às Comunidades Autônomas a faculdade de ditar, para si mesmas, normas legislativas em matéria de competência do Poder Central (art. 150).

O Rei é o Chefe de Estado, símbolo de sua unidade e permanência, arbitra e modera o fundamento das instituições, assume a mais alta representação do Estado Espanhol nas relações internacionais (art. 56). Dentre as funções do Rei, compete sancionar e promulgar as leis; convocar ou dissolver as "Cortes Generales"; propor o candidato a Presidente do Governo e nomeá-lo; nomear e exonerar os membros do Governo; e acreditar os embaixadores e representantes diplomáticos (art. 62 e 63).

O Parlamento do Governo Central, denominado "Cortes Generales", é bicameral, composto pelo "Congreso de los Diputados" e pelo Senado. Os membros do Congresso são eleitos em cada circunscrição eleitoral (província), atendendo a critérios de representação proporcional (art. 68). O Senado, por sua vez, é Câmara de Representação Territorial, sendo composto por 4 Senadores por cada província (art. 69).

O Parlamento pode nomear Comissões de Investigação sobre qualquer assunto de interesse público (art. 76). O resultado desta investigação é comunicado ao "Ministério Fiscal" para o exercício das ações cabíveis. 
Eleito pelas "Cortes Generales", o órgão "Defensor del Pueblo" tem por finalidade a proteção e defesa dos direitos fundamentais e das liberdades públicas dos cidadãos. Para tal fim, poderá o Defensor supervisionar a atividade da Administração Pública (art. 54).

O Governo, conforme dispõe o art. 97, dirige a Administração Civil e Militar, a Defesa do Estado, a Política Exterior e Interior, exerce a função executiva e o Poder Regulamentar de acordo com a Constituição e com as Leis. É composto pelo Presidente, Vice-Presidentes, Ministros e demais membros que a lei estabelecer.

$\mathrm{O}$ art. 103.1 estabelece os fins e princípios que regem a Administração Pública Espanhola: "La Administración Pública sirve con objetividad los intereses generales y actúa de acuerdo con los principios de eficacia, jerarquía, descentralización, desconcentración y coordinación, con sometimiento pleno a la ley y al Derecho" (A Administração Pública serve com objetividade aos interesses gerais e atua de acordo com os princípios da eficácia, hierarquia, descentralização, desconcentração e coordenação, com submissão plena à Lei e ao Direito - tradução livre).

O Governo tem a competência de elaborar a Lei de Orçamento Geral do Estado (Presupuestos Generales del Estado) e as Cortes Generales a de examiná-lo, emendálo e aprová-lo (art. 134.1). O Orçamento tem vigência anual e deverá incluir a totalidade de gastos e de ingressos do setor público, consignando os benefícios fiscais que afetem os tributos do Estado (art. 134.2).

Na Espanha, os Gastos Públicos devem atender aos princípios da equidade, da programação, da eficácia e da economicidade, segundo art. 31.2, da Constituição Espanhola: "El gasto público realizará una asignación equitativa de los recursos públicos, y su programación y ejecución responderán a los criterios de eficiencia y economía". Além de explicitar os princípios que regulam o aspecto material do gasto público, o que é interessante nesta disposição é que a mesma está localizada no título dos Direitos e Deveres 
Fundamentais. Ao lado, encontra-se o dever fundamental de cada cidadão de contribuir de com os gastos públicos (art. 31.1).

O Poder Judiciário ("Poder Judicial") está regulado nos artigos 117 a 127, da Constituição Espanhola.

O Artigo 117 dispõe que o exercício do Poder Jurisdicional corresponde exclusivamente aos juízes e Tribunais determinados pelas Leis, segundo as normas de competência e que o Princípio da Unidade Jurisdicional é a base do funcionamento e organização dos Tribunais.

Acerca do princípio, Angel Luis Alonso de Antonio e José Antonio Alonso de Antonio consideram que a unidade jurisdicional é uma das maiores conquistas obtidas pelo Estado de Direito, em oposição à pluralidade de jurisdições existentes na sociedade estamental (ANTONIO; ANTONIO, 2006, p. 497):

"El artículo 117.5 CE comienza señalando que el princípio de unidad jurisdiccional es la base de la organización y funcionamiento de los Tribunales. Es éste él último pronunciamiento en nuestra historia constitucional respecto a uno de los mayores logros conseguidos por el Estado de Derecho. En efecto, en la vieja sociedad estamental había una pluralidad de jurisdicciones en paralelo a los fueros y privilegios existentes según la divisíón de la estructura social. Los señoríos jurisdiccionales van a ceder progresivamente ante la justicia regia pero aún entonces se mantienen diversas jurisdicciones que formalmente desaparecen en España con la Ley de Unificación de Fueros de diciembre de 1868. Sin Embargo, incluso en el Régimen anterior se daba de hecho y de Derecho una abigarrada amalgama de órdenes jurisdiccionales especiales (contrabando, menores, emigración, ...) a la que trata de poner fin el citado artículo 117.5 CE."

Nada obstante, os autores admitem que o princípio não vigora de forma absoluta na Espanha, com exceções previstas na própria Constituição Espanhola (ANTONIO; ANTONIO, 2006, p. 498):

"El principio general es pues el de unidade. Ahora bien, la Constituición no lo proclama de forma absoluta pues admite la existencia de los 'Tribunales consuetudinarios y tradicionales' (art. 125), reducidos hoy en la práctia al Tribunal de las Aguas de la Vega Valenciana y al Consejo de Hombres Buenos de Murcia (art. 19.3y 4 LOPJ) cuyas notas básicas son el carácter limitado de sus competencias y la impossibilidad de impugnar sus decisiones en la vía judicial, siempre que se dicten dentro del círculo de sus competencias." 
O Tribunal Supremo é o órgão jurisdicional superior exceto em matéria de garantias constitucionais. Tem jurisdição em toda Espanha (art. 123).

Existe um Tribunal Constitucional, cujas competências estão reguladas no art. 161.

O "Ministério Fiscal", órgão semelhante ao nosso Ministério Público, tem por missão promover a ação de justiça em defesa da legalidade, do direito dos cidadãos e do interesse público tutelado pela Lei (art. 124). Trata-se de órgão integrado no Poder Judiciário que atua com autonomia no desempenho de suas funções e que exerce a sua missão por órgãos próprios, atuando de forma coordenada e unitária em todo território da Espanha ${ }^{41}$.

Na Espanha, o Contencioso administrativo não tem base constitucional, mas tão somente legal.

Segundo Letícia Fontestad Portalés, a Espanha adotou, inicialmente, com a Ley de Santamaria de Paredes (1888), um sistema misto entre as duas teorias contrapostas sobre a organização jurisdicional existentes: a teoria judicialista e a teoria administrativista (PORTALÉS, 2006).

Nas palavras da autora (PORTALÉS, 2006, p. 63):

"La Ley de Santamaría Paredes, de 1888, introduce un sistema mixto en el cual se crean unos órganos de naturaleza mixta (judiciales y administrativos), a los que se les atribuye competencia para resolver los conflictos contra la Administración que ante ellos se plantean y con poder de decisión propia, de forma que dichos órganos resolvían definitivamente".

Esta Lei excluia, entretanto, diversas matérias, tais como, as relacionadas ao excesso de poder (MERINO-BLANCO, 2006).

\footnotetext{
${ }^{41} \mathrm{Cf}$. http://www.mjusticia.es
} 
Mais adiante, editou-se a Ley de la Jurisdicción Contencioso-Administrativa (1956), optando-se por um sistema judicial puro. Entretanto, somente os órgãos da Administração poderiam fazer efetivas as sentenças (PORTALÉS, 2006, p. 63):

\begin{abstract}
"Es más adelante, con la Ley de la Jurisdicción Contencioso-Administrativa de 1956, cuando se optó por un sistema judicial puro, de tal manera que, para garantizar la división de poderes, la posibilidad de decisión del llamado "recurso contencioso-administrativo" solo podía recaer sobre el poder judicial por su clara naturaleza jurisdiccional. Aunque la teoría era buena y se trataba de atribuir la resolución de estos conflictos al órgano jurisdiccional, en la práctica, la Administración, entre otros privilegios, mantenía lo que se conocía como la retención de la potestad de ejecución, es decir, que efectivamente, los órganos jurisdiccionales resolvían los recursos contencioso-administrativos pero sus sentencias solo podían hacerlas efectivas los órganos de la Administración".
\end{abstract}

Elena Merino-Blanco destaca que, após a Lei de 1956, a jurisdição contencioso-administrativa passou aceitar todos os casos relacionados ao excesso de poder e excluir do controle tão somente os atos que recaem na categoria de atos políticos ou atos de governo (MERINO-BLANCO, 2006).

A Lei de 1956 permaneceu em vigor com o advento da Constituição Espanhola de 1978, só que interpretada com novos princípios informadores da jurisdição contidos no art. 117.3, da CE. A jurisdição compreende a capacidade de julgar e de fazer executar o julgado. Com efeito, destaca Letícia Fontestad Portalés (PORTALÉS, 2006, p. 63):

"La judicialización plena de la Administración llega de la mano de la Constitución española de 1978 (CE) que, en su artículo 117.3, define la función jurisdiccional de nuestros órganos jurisdiccionales como la potestad de juzgar y hacer ejecutar lo juzgado. Con la promulgación de la CE, obviamente, la ley sobre la jurisdicción contencioso-administrativa de 1956, aunque continuaba en vigor, iba a ser aplicada desde la perspectiva constitucional de la jurisdicción, con sus nuevos principios inspiradores".

Finalmente, foi editada a Lei $\mathrm{n}^{\circ} 29 / 1998$, de 13 de julho, a Ley de la Jurisdicción Contencioso Administrativa (LJCA), que definiu como objeto do processo contencioso-administrativo, todas as pretensões deduzidas em relação à atuação da Administração Pública. Segundo Letícia Fontestad Portalés (PORTALÉS, 2006, p. 64):

"Entrando en lo que constituye el objeto del proceso contencioso-administrativo, el artículo 1.1, LJCA, establece que conocerá de las pretensiones que se deduzcan en relación con la actuación de las Administraciones públicas. Se trata, por tanto, de una fórmula amplia ya que la actividad administrativa no siempre implica un acto administrativo, un contrato público o la 
emisión de un reglamento, sino que también cabe hablar de actividad administrativa cuando existe una actividad prestacional de la Administración, cuando realiza cualquier tipo de negocio, en definitiva, cualquier actuación material, inactividad u omisión de actuación debida supone actividad administrativa y, por tanto, debe estar sometida al imperio de la ley".

Por fim, convém elencar os órgãos que integram a jurisdição Administrativa da Espanha, segundo Letícia Fontestad Portalés (PORTALÉS, 2006, p. 65):

"Los órganos que integran el orden contencioso-administrativo son los siguientes:

a) Los juzgados de lo contenciosoadministrativo3, que no entran en funcionamiento hasta 1998, con la LJCA. Existe un juzgado o varios en cada provincia con sede en su capital y jurisdicción en toda ella, aunque también pueden crearse en determinadas poblaciones que la ley determine. También se prevé la extensión de su jurisdicción al correspondiente partido judicial y excepcionalmente con jurisdicción en más de una provincia siempre de la misma comunidad autónoma (artículo 90, LOPJ).

b) Juzgados centrales de lo contencioso-administrativo4. Estos juzgados se crean para descargar de trabajo fundamentalmente a la Audiencia Nacional, lo que no se acaba de lograr en la práctica, pues las competencias que tienen atribuidas serán conocidas por la Audiencia Nacional en segunda instancia.

c) Salas de lo contencioso-administrativo de los Tribunales Superiores de Justicia.

d) Sala de lo contencioso-administrativo de la Audiencia Nacional.

e) Sala de lo contencioso-administrativo del Tribunal Supremo - Sala III".

O Tribunal de Contas, que não integra os órgãos do contenciosoadministrativo espanhol, está regulado no Título VII da Constituição Espanhola referente à Economia e à Fazenda Pública. Segundo o art. 136, da Constituição Espanhola:

"1. El Tribunal de Cuentas es el supremo órgano fiscalizador de las cuentas y de la gestión económica de Estado, así como del sector público. Dependerá directamente de las Cortes Generales y ejercerá sus funciones por delegación de ellas en el examen y comprobación de la Cuenta General del Estado.

2. Las cuentas del Estado y del sector público estatal se rendirán al Tribunal de Cuentas y serán censuradas por éste. El Tribunal de Cuentas, sin perjuicio de su propia jurisdicción, remitirá a las Cortes Generales un informe anual en el que, cuando proceda, comunicará las infracciones o responsabilidades en que, a su juicio, se hubiere incurrido.

3. Los miembros del Tribunal de Cuentas gozarán de la misma independencia e inamovilidad y estarán sometidos a las mismas incompatibilidades que los Jueces.

4. Una ley orgánica regulará la composición, organización y funciones del Tribunal de Cuentas" ${ }^{\prime 2}$.

\footnotetext{
${ }^{42}$ O Tribunal de Contas é o órgão supremo fiscalizador das contas e da gestão econômica do Estado, assim como do setor público. Dependerá diretamente das Cortes Generales e exercerá suas funções por delegação delas no exame e na comprovação da Conta Geral do Estado. 2. As contas do Estado e do Setor Público Estatal serão prestadas ao Tribunal de Contas e apreciadas por este. O Tribunal de Contas, sem prejuízo da sua própria jurisdição, remeterá às Cortes Generales um relatório anual, no qual comunicará as infrações e responsabilidades em que, ao seu juízo, houver ocorrido. 3. Os membros do Tribunal de Contas gozará da mesma independência e inamovibilidade e estarão submetidos às mesmas incompatibilidades dos juízes. 4. Uma lei orgância regulará a composição, organização e funções do Tribunal de Contas (tradução livre).
} 
O Tribunal de Contas exerce, também, o Controle da atividade econômicofinanceira das Comunidades Autônomas, conforme, prevê o art. 153.d da Constituição Espanhola.

Entretanto, foram criados diversos órgãos de controle das Comunidades Autônomas, tais como:
a) a "Cámara de Comptos" de Navarra ${ }^{43}$;
b) a "Sindicatura de Comptes de Catalunya" ${ }^{44}$;
c) a "Sindicatura de Comptes de la Comunitat Valenciana" ${ }^{45}$;
d) o "Consello de Contas de Galicia" ${ }^{46}$;
e) o "Tribunal Vasco de Cuentas Públicas" ${ }^{47}$;
f) a "Camara de Cuentas da Andalúci" ${ }^{48}$;
g) a "Camara de Cuentas de Madrid" ${ }^{49}$;
h) o "Consejo de Cuentas" de Castilla e León ${ }^{50}$.

A criação de órgãos de controle pelas Comunidades Autônomas gerou, inicialmente, uma certa controvérsia, até que o Tribunal Constitucional Espanhol, na Sentença STC n 187/1988, declarou que, no âmbito da função fiscalizadora a competência do Tribunal de Cuentas (órgão central) não é exclusiva, o que permitia a intervenção de órgãos territoriais. No tocante à função jurisdicional (enjuiciamiento contable), entretanto, o Tribunal Constitucional reconheceu que é função exclusiva do Tribunal de Contas, sem prejuízo das delegações que possa fazer ${ }^{51}$.

Em Sentença STC $\mathrm{n}^{\circ}$ 18/1991, o Tribunal Constitucional reiterou a compatibilidade entre ambos sistemas de controle, sem prejuízo da supremacia do Tribunal

\footnotetext{
${ }^{43} \mathrm{http} / / / \mathrm{www} . c f$ navarra.es

${ }^{44} \mathrm{http}: / / \mathrm{www}$. sindicatura.org

${ }^{45} \mathrm{http}: / / \mathrm{www}$. sindicom.vga.es

${ }^{46} \mathrm{http}: / /$ www.ccontasgalicia.es

${ }^{47} \mathrm{http}: / /$ www.tvcp.org

${ }^{48} \mathrm{http}: / /$ www.ccuentas.es

${ }^{49} \mathrm{http}: / / \mathrm{www} . c a m a r a d e c u e n t a s m a d r i d . e s$

${ }^{50} \mathrm{http}: / / \mathrm{www} . c o n s e j o d e c u e n t a s . e s$

51 Cf. Fabio Pascua Mateo. Constitución española: sinopsis artículo 136. Disponível em: $<$ http://narros.congreso.es/constitucion>. Acesso em 05.12.2008.
} 
de Contas, justificada, entre outras razões, pela faculdade de controle atribuída pelo art. 153.d. da Constituição Espanhola ${ }^{52}$.

O Tribunal de Cuentas está regulado por duas Leis: a Lei n 02/1982, de 12 de maio, denominada Ley Orgánica (LOTCu) e a Lei nº 07/1988, de 5 de abril, denominada Ley de Funcionamiento (LFTCu).

A seguir, analiso inicialmente a Ley Orgânica ${ }^{\circ}$ 02/1982.

Segundo o art. 1.2, o Tribunal de Contas Espanhol é único em sua órdem e estende a sua jurisdição a todo o território nacional, sem prejuízo dos órgãos fiscalizadores de contas que possam estar previstos nos Estatutos de Autonomia das Comunidades Autônomas.

São duas as funções próprias do Tribunal de Contas: a função fiscalizadora e a função jurisdicional (art. 2).

A função fiscalizadora, regulada nos artigos 9 a 14 da Lei Orgânica, compreende a verificação da submissão da atividade econômico-financeira do Setor Público aos princípios da Legalidade, Economicidade e Eficácia (art. 9).

Integram o Setor Público, para fins desta lei, a Administração do Estado, as Comunidades Autônomas, as Corporações Locais, as Entidades Gestoras da Seguridade Social, os Organismos Autônomos e as Sociedades Estatais e demais Empresas Públicas (art. 4.1). Ademais, submete-se, também, à fiscalização do Tribunal as subvenções, créditos, avais e outras ajudas do setor público, recebidas por Pessoas Físicas ou Jurídicas (art. 4.2).

A função jurisdicional (enjuiciamiento contable) é exercida relativamente às contas que devam ser prestadas por aqueles que arrecadem, intervenham, administrem,

52 Cf. Fabio Pascua Mateo. Constitución española: sinopsis artículo 136. Disponível em: $<$ http://narros.congreso.es/constitucion>. Acesso em 05.12.2008. 
custodiem, manejem ou utilizem bens, dinheiros e valores públicos (art. 15.1). A Jurisdicção contábil se estende aos alcances de bens e dinheiros públicos, em como às obrigações acessórias constituídas em garantia da sua gestão (art. 15.2).

A Lei Orgânica faz uma delimitação da jurisdição contábil, excluindo da apreciação desta, os assuntos atribuídos à competência do Tribunal Constitucional, as questões submetidas ao contencioso administrativo, os fatos constitutivos de crime e as questões de índole civil, laboral ou de outra natureza submetidas à apreciação dos órgãos do Poder Judiciário (art. 16).

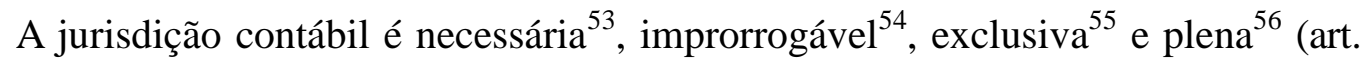
17.1). Se estenderá ao conhecimento e à decisão das questões prejudiciais e incidentais, salvo as de caráter penal, que constituam elementos necessários para a declaração da responsabilidade contábil (art. 17.2). Entretanto, as decisões relativas às questões prejudiciais ou incidentais só produzirão efeitos no âmbito da jurisdição contábil (art. 17.3).

A Lei Orgânica se preocupou, ainda, com a compatibilidade da jurisdição contábil com as demais jurisdições. Neste sentido, o art. 18 dispõe que:

"1. La jurisdicción contable es compatible respecto de unos mismos hechos con el ejercicio de la potestad disciplinaria y con la actuación de la jurisdicción penal. 2. Cuando los hechos fueren constitutivos de delito, la responsabilidad civil será determinada por la jurisdicción contable en el ámbito de su competencia" (1.A jurisdição contábil é compatível, com relação aos mesmos fatos, com o exercício do poder disciplinar e com a atuação da jurisdição penal.

\footnotetext{
${ }^{53}$ Segundo Francico José Carrera Raya (RAYA, 1995, p. 146): "Es necesaria en la medida en que es permanente y actúa sin necesidad de excitación de parte, de tal modo que el ejercicio de esta jurisdicción ni es eventual, ni está condicionada por la discrepancia de los interesados, sino que es necesaria toda vez que la función del Tribunal de Cuentas se halla predeterminada, no dependiendo de sucesos aleatorios, tales como el conflicto entre partes, la apariencia de un hecho presuntamente ilícito, etc.".

${ }^{54}$ Segundo Carrera Raya (RAYA, 1995, p. 146): "Es improrrogable puesto que las cuestiones de que conoce no podrán llevarse a otros órganos de decisión (...)".

${ }^{55}$ Segundo Carrera Raya (RAYA, 1995, p. 146): "Es una jurisdicción exclusiva porque la jurisdicción contable está atribuida al Tribunal de Cuentas con preferencia a cualquier otro órgano, sin que, por tanto, dentro de su ámbito quepa interferencia alguna de potestades ajenas".

${ }^{56}$ Segundo Carrera Raya (RAYA, 1995, p. 146-147): "es una jurisdicción plena porque para depurar eventuales responsabilidades contables, puede entrar a resolver todas aquellas cuestiones que se presenten, sean cuestiones de hecho como de derecho, extendiéndose, asimismo, al conocimiento y decisión de las cuestiones prejudiciales e incidentales, salvo las de carácter penal, que constituyan elemento previo necesario para la declaración de responsabilidad contable y estén con ella relacionadas directamente (art. 17.2 de la LOTCu)".
} 
2. Quando os fatos forem constitutivos de crime, a responsabilidade civil será determinada pela jurisdição contábil no âmbito de sua competência.)

A responsabilidade contábil está regulada no Título IV - "La responsabilidad contable", da Lei Orgânica (arts. 38 a 43).

Segundo o art. 38.1, aquele que por ação ou omissão contrária a Lei der causa a "menoscabo" de bens ou dinheiros públicos ficará obrigado à indenização dos danos causados. A responsabilidade contábil poderá ser direta (art. 42) ou subsidiária (art. 43), sendo transmissíveis aos sucessores dos responsáveis, pela aceitação tácita ou expressa da herança, limitada, neste caso, ao patrimônio líquido transferido (art. 38.5).

A exclusão da responsabilidade também foi objeto de regulação pela Lei Orgânica:

\begin{abstract}
"Ficarão excluídos da responsabilidade aqueles que atuarem em virtude de obediência devida, sempre que houverem advertido por escrito a imprudência ou ilegalidade correspondente à ordem, com as razões que fundamentam esta advertência" (art. 39.1 - Quedarán exentos de responsabilidad quienes actuaren en virtud de obediencia debida, siempre que hubieren advertido por escrito la imprudencia o legalidad de la correspondiente orden, con las razones en que se funden.).
\end{abstract}

A Lei n 7/1988 ("Ley de Funcionamiento del Tribunal de Cuentas") regula o funcionamento do Tribunal de Contas Espanhol, as atribuições de seus órgãos, os procedimentos de fiscalização por meio dos quais se exerce a jurisdição contábil e os Estatutos dos seus membros e do seu quadro de pessoal.

Uma das preocupações da referida Lei foi com a compatibilidade da jurisdição contábil com a jurisdição ordinária. Contemplando a jurisdição contábil como autêntica jurisdição, esta é interpretada restritivamente e dentro dos justos limites para torná-la compatível com os princípios da unidade e exclusividade. A jurisdição contábil tem por objeto as pretensões de responsabilidade contábil que se deduzam contra aqueles que, tendo a seu cargo o manejo de bens, dinheiros ou valores públicos, intervindo com dolo, culpa ou negligência graves, originem dano ao patrimônio público, em consequência de ações ou omissões contrárias às leis que regulam o regime orçamentário e de contabilidade aplicável 
às entidades do setor público ou aos particulares beneficiários de subvenções, avais, créditos ou ajudas do Poder Público (Preâmbulo da LFTCu).

\section{O preâmbulo da Lei é, a este respeito, cristalino:}

"En lo que se refiere a la función jurisdiccional, la Ley, al tratar de la naturaleza, extensión y límites de la jurisdicción contable, la contempla como una autentica jurisdicción, que goza del necesario respaldo constitucional, pero que, en orden a su contenido y de acuerdo con el criterio manifestado por el Consejo General del Poder Judicial en su mencionado informe, ha de ser interpretada restrictivamente y dentro de los justos límites para poder hacerla compatible con la unidad y exclusividad en el ejercicio de la jurisdicción que reconoce a la ordinaria, conforme antes se destacó, el artículo 117 de la Constitución. Por ello, le atribuye, como objeto, el conocimiento de las pretensiones de responsabilidad que se deduzcan contra quienes, teniendo a su cargo el manejo de caudales o efectos públicos e interviniendo dolo, culpa o negligencia graves exigencia esta derivada de la enunciación del principio por el artículo 140 de la Ley General Presupuestaria originan menoscabo en los mismos a consecuencia de acciones u omisiones contrarias a las leyes reguladoras del régimen presupuestario y de contabilidad aplicable a las entidades del sector público o a las personas o entidades beneficiarias o perceptoras de subvenciones, créditos, avales u otras ayudas provenientes de dicho sector. Y es que si la responsabilidad es contable, además de deber lucir de las cuentas que deban rendir todos cuantos manejen caudales o efectos públicos, como se desprende claramente del contenido delartículo 15 de la Ley Orgánica 2/1982, debe también significar la infracción de preceptos reguladores de la contabilidad a que están, en términos generales, sometidas las entidades del sector público o quienes manejan caudales o efectos que merezcan la misma conceptuación".

No mesmo sentido, o art. 49.1 conceitua jurisdição contábil:

"1. La jurisdicción contable conocerá de las pretensiones de responsabilidad que, desprendiéndose de las cuentas que deben rendir todos cuantos tengan a su cargo el manejo de caudales o efectos públicos, se deduzcan contra los mismos cuando, con dolo, culpa o negligencia graves, originaren menoscabo en dichos caudales o efectos a consecuencia de acciones u omisiones contrarias a las Leyes reguladoras del régimen presupuestario y de contabilidad que resulte aplicable a las entidades del sector público o, en su caso, a las personas o entidades perceptoras de subvenciones, créditos, avales u otras ayudas procedentes de dicho sector. Sólo conocerá de las responsabilidades subsidiarias, cuando la responsabilidad directa, previamente declarada y no hecha efectiva, sea contable."

A partir deste dispositivo, Carles Rosiñol I Vidal enumerou os requisitos objetivos e subjetivos da "responsabilidad contable":

a) infração à lei reguladora do regime orçamentário e de contabilidade;

b) dano efetivo aos bens e dinheiros públicos;

c) relação causal entre a infração da lei e o dano; 
d) as pretensões de responsabilidade contábil hão de se desprender das contas que deverão ser prestadas pelas pessoas que tem a seu cargo o manejo de bens e dinheiros públicos;

e) o prejuízo para o Erário deve ser consequência de uma conduta dolosa, culposa ou negligente grave.

Quanto à compatibilidade com as demais jurisdições, o art. 49.2, repete disposição da Lei Orgânica, no sentido de excluir da jurisdição contábil, as matérias de competência do Tribunal Constitucional ou das distintas órdens da jurisdição ordinária.

Nos termos do art. 49.3, quando os fatos forem constitutivos de crime, o Juiz ou Tribunal absterá de conhecer a responsabilidade contábil decorrente dos mesmos, transladando ao Tribunal de Contas os documentos necessários para que determine os danos ou prejuízos causados aos patrimônio público ${ }^{57}$.

Segundo art. 50, os conflitos suscitados entre os órgãos da Jurisdição Contábil e a Administração ou às demais Jurisdições serão solucionados em conformidade com a "Ley Orgánica de Conflictos Jurisdiccionales" (Lei nº 02/1987, de 18 de maio).

São três os procedimentos jurisdicionais no âmbito do Tribunal de Contas:

a) o juízo de contas;

b) o procedimento de reintegração por alcance;

c) o expediente de cancelamento de fianças.

Os dois primeiros são procedimentos contenciosos e visam exigir a responsabilidade contábil e o último é um procedimento de jurisdição voluntária.

O juízo de contas é um processo contábil que visa exigir a responsabilidade contábil em decorrência de um ilícito contábil distinto do alcance.

\footnotetext{
${ }^{57}$ Fato que reforça o caráter exclusivo da jurisdição contábil.
} 
São órgãos da jurisdição contábil são os Conselheiros de Contas e as Salas do Tribunal de Contas (art. 52).

Aos Conselheiros de Contas compete, em primeira instância, os procedimentos de reintegração por alcance e os juízos de contas (art. 53.1). As salas do Tribunal de Contas conhecerão, em segunda instância, as apelações deduzidas contra as resoluções ditadas em primeira instância pelos Conselheiros de Contas, nos procedimentos de exigência da responsabilidade contábil (art. 54.1.b).

Das sentenças pronunciadas pelas Salas do Tribunal de Contas, caberá recursos de cassação ou revisão à Sala de Contencioso-Administrativo do Tribunal Supremo, nos casos e nos motivos previstos na Lei (art. 52.2, 80 a 84).

Atua junto ao Tribunal de Contas, um órgão denominado "Fiscalía", que tem por funções, dentre outras: "Exercitar a ação de responsabilidade contábil e deduzir as pretensões desta natureza nos juízos de contas e procedimentos de reintegração por alcance" (art. 16.2.d).

\subsection{Itália}

Segundo a Constituição Italiana de 1947, a Itália é uma República Democrática fundada no trabalho (art. $1^{\circ}$ ).

Adota a forma de governo Parlamentarista, na qual o Presidente da República é o Chefe de Estado, representando a unidade nacional e o Presidente do Conselho de Ministros é o Chefe de Governo, sendo indicado pelo Presidente da República.

O Parlamento é bicameral composto pela Câmara dos Deputados (Camera dei Deputati - art. 56) e pelo Senado da República (Senato della Reppublica - art. 57). Enquanto os Deputados são eleitos por sufrágio direto e universal, os Senadores são eleitos em base regional. O Presidente da República pode também nomear Senadores Vitalícios (Senatore a 
vita) cinco cidadãos que demonstraram pela Pátria elevados méritos no campo social, científico, artístico e literário. Além disso, quem já tiver sido Presidente da República tem direito a ser Senador Vitalício.

A administração pública está organizada segundo os princípios do bom andamento e da imparcialidade (art. 97).

Na Itália, a função jurisdicional é dividida em: jurisdição ordinária e especial (ISTITUZIONI, 2008).

A jurisdição ordinária é composta pela jurisdição penal ("è competente per le violazioni di quelle norme che importano, como conseguenza, l'applicazione di una sanzione penale") e pela jurisdição civil ("si occupa della tutela giurisdizionale dei diritti dei privati e si svolge su iniziativa dei soggetti privati"). Fazem parte, também, da jurisdição ordinária os juízes de paz, os tribunais, a Corte d'Appello, a Corte d'Assise e a Corte d'Assise di appello, a Corte di Cassazione ("che svolge la funzione di garantire l'uniforme interpretazione della legge e delle norme di procedura attraverso la possibilità di un ricorso ad essa per le sole questioni di legitimità"), os Tribunais dos Menores e os Tribunais de "sorveglianza" (ISTITUZIONI, 2008).

As jurisdições especiais (aquelas que se ocupam de controvérsias particulares, segundo um critério de especialização requerido pela natureza técnica da matéria), na Itália, são (ISTITUZIONI, 2008):

a) a jurisdição administrativa: competente para todas as controvérsias que surgem entre as Administrações Públicas ou entre a Administração Pública e os sujeitos privados, relativas a relações de Direito Administrativo;

b) a jurisdição contábil: exercitada exclusivamente pela Corte dei Conti;

c) a jurisdição em matéria de águas públicas;

d) a jurisdição militar. 
Luigi Delpino e Federico del Giudice, nada obstante, qualificam a jurisdição contábil e a jurisdição em matéria de águas públicas como "jurisdições administrativas especiais" (DELPINO; GIUDICE, 2008).

Luigi Delpino e Federico del Giudice esclarecem que, na Itália, a jurisdição administrativa é organizada segundo o sistema de dupla jurisdição. Neste sistema, são previstas a jurisdição ordinária e a administrativa. Esta distinção é baseada na causa de pedir. É o chamado duplo binário: direito subjetivo e interesse legítimo. A Corte di Cassazione é competente para solucionar os conflitos entre a jurisdição ordinária e a jurisdição administrativa (DELPINO; GIUDICE, 2008).

À jurisdição comum, é competente para decidir violações de direitos subjetivos (DELPHINO; GIUDICE, 2008, p. 693): "L'autorità giudiziaria ordinaria (A.G.O.) è competente a decidere delle violazioni di diritti soggettivi, con il potere di disapplicare l'atto amministrativo che risulti illegittimo, e di dichiararne la illegittimità".

À jurisdição administrativa é competente para julgar violações de interesses legítimos e anular atos administrativos ilegítimos e, até mesmo, em alguns casos substituirlos ou reformá-los parcialmente (DELPHINO; GIUDICE, 2008, p. 693):

\footnotetext{
"L'autorità giudiziaria amministrativa (A.G.A.) è competente a giudicare delle violazioni degli interessi legittimi (salvo i casi eccezionali di c.d. giurisdizione esclusiva, in clui giudica anche per violazioni di diritti) e ad annullare gli atti amministrativi illegitimi, nonché, in alcuni casi tassativi (di giurisdizione di merito), anche a sostituirli con altri atti o a riformarli in parte (sostituendosi in tal caso alla P.A.)".
}

Neste sentido, dispõe o art. 103.1, da Constituição Italiana, que "Il Consiglio di Stato e gli altri organi di giustizia amministrativa hanno giurisdizione per la tutela nei confronti della pubblica amministrazione degli interessi legittimi e, in particolari materie indicate dalla legge, anche dei diritti soggettivi" (O Conselho de Estado e os outros órgãos da Justiça Administrativa tem jurisdição para a tutela dos interesses legítimos no confronto com a Administração Pública, e também dos direitos subjetivos, em matérias particulares indicadas pela lei. - tradução livre) 
A Corte dei Conti é órgão de relevância constitucional na Itália, regulado nos artigos 100 e 103. Segundo art. 100 da Constituição Italiana, a Corte dei Conti exercita o controle preventivo de legalidade sobre os atos do governo e, também, o controle sucessivo sobre a gestão orçamentária do estado. Participa, nos casos e nas formas estabelecidas pela Lei, do Controle sobre a Gestão Financeira dos Entes para os quais o Estado contribui em via ordinária. Reporta-se diretamente à Câmara dos Deputados acerca dos resultados das apurações realizadas. A lei assegura à Corte dei Conti a sua independência e a de seus compontentes em relação ao Governo ${ }^{58}$.

A Doutrina costuma dividir as funções da Corte dei Conti em:

a) função de controle;

b) função administrativa própria;

c) funções consultivas em matéria de contabilidade geral do Estado;

d) funções juridiscionais.

Segundo o art. 103.2, da Constituição Italiana, "La Corte dei conti ha giurisdizione nelle materie di contabilità pubblica e nelle altre specificate dalla legge" (A Corte de Contas tem jurisdição nas matérias de contabilidade pública ${ }^{59}$ e em outras especificadas pela lei - tradução livre).

Os funcionários públicos na Itália (impiegati pubblici) respondem não somente sob o plano penal ou disciplinar, mas também, sob o plano civil ou patrimonial, devendo ressarcir os danos causados à Administração ou a terceiros (LUCA, 2008).

\footnotetext{
${ }^{58}$ Cf. Art. 100, da Constituição Italiana: "Art. 100. La Corte dei conti esercita il controllo preventivo di legittimità sugli atti del Governo, e anche quello successivo sulla gestione del bilancio dello Stato. Partecipa, nei casi e nelle forme stabiliti dalla legge, al controllo sulla gestione finanziaria degli enti a cui lo Stato contribuisce in via ordinaria. Riferisce direttamente alle Camere sul risultato del riscontro eseguito. La legge assicura l'indipendenza dei due Istituti e dei loro componenti di fronte al Governo.".

${ }^{59} \mathrm{O}$ termo "contabilità pubblica" não tem o mesmo sentido de contabilidade pública, difundido entre nós. Segundo Gianni de Luca (LUCA, 2008, p. 8): "La contabilità pubblica può pertanto definirsi come il complesso delle norme que disciplinano l'attività gestoria dei pubblici poteri, comprendente l'organizzazione finanziariocontabile, la gestione patrimoniale, l'attività contratuale, la gestione del bilancio, il sistema dei controlli e le responsabilità degli amministratori della cosa pubblica".
} 
Esta modalidade de responsabilidade denomina-se "responsabilità patrimoniale" e se diferencia em três espécies (LUCA, 2008):

a) a responsabilidade administrativa;

b) a responsabilidade contábil;

c) a responsabilidade civil em relação a terceiros (responsabilità civile verso $i$ terzi).

Na responsabilidade administrativa, "o empregado ou funcionário por dolo ou por culpa viola as normas que regulam o seu serviço, ocasionando um dano econômico à Administração Pública" ${ }^{\prime 60}$ (LUCA,2008, p. 309)

No tocante à responsabilidade civil perante terceiros, o art. 28, da Constituição Italiana estabeleceu uma responsabilidade solidária entre a Administração e o Funcionário no caso de dano causado ao cidadão. O funcionário é responsável perante terceiros somente em caso de dolo ou culpa grave. No caso de culpa leve ou levíssima, responde somente a Administração. Isto visa garantir ao empregado uma "faixa de segurança", pois a preocupação de responder perante terceiros, até mesmo por uma leve negligência, poderia paralizar a atividade administrativa ${ }^{61}$ (LUCA, 2008).

A responsabilidade contábil difere da responsabilidade administrativa por incidir sobre aqueles que manejam dinheiros ou valores da Administração Pública, estando sujeitos à obrigação de prestar contas. São os denominados "agenti contabili". Eles são classificados entre os que podem exercer esta função com base em normas, relação de emprego ou contrato (contabile di diritto) e aqueles, de própria iniciativa ou necessidade, efetuaram o manejo de dinheiros ou bens (contabile di fatto) (LUCA, 2008).

\footnotetext{
${ }^{60}$ Cf. Gianni de Luca: "L'impiegato o il funzionario che per dolo o per culpa viola le norme che regolano il suo servizio, cagionando un danno economico alla Pubblica Amministrazione, incorre in responsabilità amministrativa nei confronti dell'amministrazione stessa" (LUCA, 2008, p. 309).

${ }^{61}$ Cf. Gianni de Luca: "(...) l'impiegato è responsabile verso i terzi solo per i danni ad essi arrecati agendo con dolo o colpa grave; in caso di colpa lieve o lievissima risponde soltanto l'Amministrazione: ciò va incontro all'esigenza di garantire all 'impiegato una fascia di sicurezza, perché la preoccupazione di dovere rispondere verso terzi anche di una lieve negligenza potrebbe paralizzare l'attività amministrativa".
} 
Na Lição de Eugenio Mele (MELE, 2004, p. 273):

\begin{abstract}
"È agente contabile il soggeto - che può essere um impiegato o un estraneo, un singolo individuo fisico o un ente o un'azienda - che abbia comunque maneggio di denaro, nel senso che opera i pagamenti per conto dell'ente pubblico ovvero ne riscuote i crediti, ovvero che abbia la consegna di beni di pertinenza pubblica (cosidetto consegnatario); in altre parole, sono agenti contabili pubblici tutti quei soggetti che, nell ambito delle rispective amministrazioni, svolgono le funzioni di cassiere, tesoriere, consegnatario, consegnatariocassiere, ecc., in forza delle quali hanno in consegna per un certo periodo di tempo una certa somma di denaro o altri beni di pertinenza pubblica".
\end{abstract}

Conforme salienta Avallone e Tarullo (AVALLONE; TARULLO, 2002), a doutrina utiliza a expressão "responsabilità finanziarie" para sublinhar a homogeneidade substancial entre a responsabilidade administrativa e a responsabilidade contábil. Nada obstante, algumas diferenças significativas entre os institutos não podem passar despercebidas.

Gianni de Luca, seguindo o esquema apresentado por BUSCEMA, aponta as seguintes diferenças entre os regimes jurídicos das duas modalidades de responsabilidade (LUCA, 2008).

Em primeiro lugar, a responsabilidade contábil deriva do inadimplemento da obrigação de restituir valores tidos em consignação, inspirando-se na responsabilidade do depositário, o qual é liberado da obrigação de restituição, somente se a perda não é devida a causa a ele não imputável. A responsabilidade administrativa, por sua vez, se basea na diligência no cumprimento dos deveres oriundos da relação de serviço (LUCA, 2008).

Em segundo lugar, a responsabilidade contábil é tem por objeto a obrigação de restituir coisa que já pertence à Administração Pública. A responsabilidade administrativa, por sua vez, deriva de um comportamento culposo ou doloso, consequência de uma prestação má-cumprida ou omissa, da qual deriva um dano patrimonial à Administração Pública (LUCA, 2008). 
Em terceiro lugar, a responsabilidade administrativa pressupõe, em todo caso, um rapporto di servizio, enquanto a responsabilidade contábil incide também sobre os contabili di fatto, levando em conta a existência objetiva de uma gestão (LUCA, 2008).

Em quarto lugar, na responsabilidade contábil, é excluído o denominado Poder Redutivo do Débito ${ }^{62}$. Na responsabilidade Administrativa, a lei atribui à Corte de Contas a faculdade de imputar o débito, total ou parcial, levando em conta o grau de culpabilidade do responsável (LUCA, 2008).

Em quinto lugar, o juízo de responsabilidade contábil é instaurado no ato de apresentação da prestação de contas, prescindindo de eventual denúncia de irregularidade. $\mathrm{O}$ juízo de responsabilidade administrativa é, por sua vez, promovida pelo Procurador-Geral perante a Corte dei Conti (LUCA, 2008).

\subsection{França}

A França, segundo a Constituição de 1958, é uma República indivisível, laica, democrática e social (art. 1). Adota o Sistema Parlamentarista. Tendo o Presidente da República como Chefe de Estado e o Primeiro Ministro, como Chefe de Governo.

O Presidente da República é eleito por Sufrágio Universal Direto para um Mandato de cinco anos (art. 6). Dentre as amplas competências do Presidente da República (arts. 5 a 19), podemos citar:

\footnotetext{
${ }^{62}$ Acerca do Poder Redutivo do Débito, Gianni de Luca (LUCA, 2008, p. 325) pronuncia-se que: "Una delle caratteristiche peculiari dei processo contabile è costituito dal potere riduttivo dell'addebito; si tratta della facoltà, gia prevista dalla legge di contabilità del 1869 e in seguito riprodotta nella legge del 1923, in base alla quale la Corte valutate le singole responsabilità può porre a carico dei responsabili tutto o una parte del danno arrretrato o del valore pertuto. Numerose sono state le tesi apportate a fondamento di tale previsione; parte della dottrina, per esempio, vi ha ravvisato l'esercizio di un potere meramente discrezionale. Altri, invece, hanno sostenuto la tesi della parziale rinuncia al credito, derivante dalla valutazione del giudice contabile piuttosto che del creditore. La giurisprudenza della Corte, da parte sua, ha configurato il podere riduttivo como il potere di stabilire se ed in che misura il danno erariale debba essere riferito al comportamento colposo del soggetto tenuto conto di una eventuale responsabilità concorrente dell'Amministrazione (omissione o carenze nelle attività di vigilanza, controllo o modulo organizzativo".
} 
a) assegurar o funcionamento regular dos Poderes Públicos, bem como, a continuidade do Estado, a independência nacional, a integridade do território e o respeito aos tratados (art. 5);

b) nomear o Primeiro Ministro (art. 8);

c) demitir o Governo (art. 8);

d) presidir o Conselho de Ministros (art. 9);

e) dissolver a Assembléia da República, após Consulta ao Primeiro Ministro e aos Presidentes de Assembléias (art. 12);

f) assinar as "ordonnances" e Decretos deliberados pelo Conselho de Ministros (art. 13);

g) chefiar o Exército (art. 15).

O Governo está regulado nos artigos 20 a 23 da Constituição Francesa. O Governo determina e conduz a Política da Nação, dispõe da Administração e das Forças Armadas e é responsável perante o Parlamento nas condições e procedimentos previstos no art. 49 e 50, da Constituição Francesa (Responsabilidade Política do Governo). No caso de aprovação de moção de censura ou desaprovação do Programa ou Política Geral do Governo, o Primeiro Ministro deve submeter ao Presidente da República o pedido de demissão do Governo (art. 50).

A Responsabilidade Penal dos Membros do Governo está regulada nos artigos 68-1 e 68-2, da Constituição Francesa.

O Primeiro Ministro (art. 21) tem como competências: dirigir a ação do governo, assegurar a execução das leis, nomear os empregados civis e militares e pode delegar poderes a outros Ministros.

O Parlamento, regulado nos artigos 24 a 33 da Constituição, é bicameral, composto pela Assembléia Nacional e pelo Senado. É responsável por votar as leis, controlar a ação do governo e avaliar as políticas públicas (art. 24). 
Os Deputados são eleitos por Sufrágio Direto e os Senadores por Sufrágio Indireto, assegurando a representação das Coletividades Territoriais da República (art. 24).

As relações entre o Governo e o Parlamento estão reguladas nos artigos 34 a 51. Dentre os pontos abordados por estes artigos, cabe destacar.

A Lei de Finanças determina os recursos e os encargos do Estado, nas condições e reservas previstas por uma Lei Orgânica (art. 34). As leis de financiamento da Seguridade Social determinam as condições gerais de seu equilíbrio financeiro e, tendo em conta as suas previsões de receitas, fixam seus objetivos de despesas, nas condições e sob as reservas previstas por uma Lei Orgânica (art. 34). As leis de programação determinam os objetivos da ação do estado e as orientações plurianuais das finanças públicas são definidas pelas Leis de programação (art. 34). Dentre as orientações, se inscreve o objetivo de equilíbrio das contas das Administrações Públicas (art. 34).

A iniciativa das Leis na França cabe concorrentemente ao Primeiro Ministro e aos Membros do Parlamento (art. 39). No tocante a lei de finanças e de financiamento da seguridade social, a Constituição determina que sejam submetidas em primeiro lugar à Assembléia Nacional (art. 39).

A Justiça, na França, organiza-se em duas grandes ordens: uma ordem judiciária e uma ordem administrativa, segundo a natureza dos litígios em causa, sua importância e gravidade das infrações ${ }^{63}$.

Conforme afirma Jean Rivero, a Jurisdição Administrativa na França nasceu de uma interpretação particular do Princípio da Separação de Poderes (RIVERO, 1981). Enquanto a Jurisdição Judiciária tem como órgão de cúpula a Corte de Cassação, a Jurisdição Administrativa tem como órgão de cúpula o Conselho de Estado (RIVERO, 1981).

\footnotetext{
${ }^{63}$ http://www.justice.gouv.fr
} 
Distintas das jurisdições judiciárias, independentes da Administração, as jurisdições de ordem administrativas são organizadas em três escalões hierarquizados. Os Magistrados da ordem administrativa tem um Estatuto e uma formação que difere dos Magistrados da Ordem Judiciária ${ }^{64}$.

Na Jurisdição Administrativa, julgamento em primeira instância é é proferido pelo "Tribunal Administratif". Existem, também, em primeiro grau jurisdições especializadas, tais como ${ }^{65}$ :
a) Comission des Recours des Réfugiés;
b) Commission Départamentale D'Aide Sociale;
c) Section Disciplinaire des Ordres Professioneles.

Em Segunda Instância, existe a Cour Administrative D'Apel. Se alguma das partes não estiver satisfeita com o julgamento em primeira instância, ela poderá fazer Apelação a Corte que irá reexaminar o "affaire" já julgado ${ }^{66}$.

O Conselho de Estado (Conseil D'Etat) é uma instância de controle. Ele verifica se as Cortes Administrativas de Apelação aplicaram corretamente a lei. Ele decide originariamente sobre certos casos relativos às decisões mais importantes das Autoridades do Estado. Para determinados casos (raros), o Conselho de Estado é um juízo de Apelação. Está situado em Paris, no Palais Royal ${ }^{67}$.

Na França existem, ainda, as "jurisdictions en dehors des ordres", que são situadas acima das ordens jurisdicionais. Trata-se do Tribunal de Conflitos e do Conselho Constitucional.

\footnotetext{
${ }^{64}$ http://www.justice.gouv.fr

${ }^{65} \mathrm{http}: / /$ www.justice.gouv.fr

${ }^{66} \mathrm{http} / / /$ www.justice.gouv.fr

${ }^{67}$ http://www.justice.gouv.fr
} 
O Tribunal de Conflitos, que designa o Tribunal Competente, em caso de dúvida ou contestação acerca de qual ordem jurisdicional é competente: administrativa ou judiciária $^{68}$.

O Conselho Constitucional está regulado nos artigos 56 a 63 da Constituição Francesa. O Conselho tem funções eleitorais e de controle prévio de constitucionalidade. No primeiro caso, o Conselho zela pela regularidade da eleição do Presidente da República (art. 58) e decide, em caso de contestação, sobre a regularidade da eleição dos deputados e senadores (art. 59). No segundo caso, as leis orgânicas, antes de sua promulgação, as proposições mencionadas no art. 11, antes de serem submetidas ao referendo, os regulamentos das assembléias legislativas antes de serem postos em aplicação, devem ser submetidos ao Conselho Constitucional que se pronuncia acerca da conformidade com a Constituição (art. 61).

Por fim, existem as jurisdições políticas que compreendem a Haute Cour de Justice e a Cour de Justice de la Republique. A Haute Cour de Justice julga o Presidente da República, no caso de falta aos seus deveres, que seja manifestamente incompatível com o exercício do mandato (art. 68). A destituição do Presidente da República é pronunciada pelo Parlamento constituído em Haute Cour (art. 68). A Cour de Justice de la Republique, por sua vez, julga os membros do Governo (Ministros) em caso de infrações penais (art. 68-1).

Antes de tratar sobre as Cortes integrantes da Jurisdição Financeira e sobre a Responsabilidade dos Gestores Públicos, convém descrever os aspectos peculiares da execução orçamentária na França.

\subsubsection{Execução Orçamentária na França}

A execução das receitas e das despesas na França repousa sobre um princípio básico: o da separação entre ordenadores e contábeis. Este princípio que remonta à época da Revolução Francesa deu lugar a um modelo de organização da gestão financeira pública em

\footnotetext{
${ }^{68} \mathrm{http}: / /$ www.justice.gouv.fr
} 
que a preocupação com a regularidade é essencial (BOUVIER; ESCLASSAN; LASSALE, 2008).

O princípio comporta dois elementos essenciais: uma divisão orgânica e funcional de competências e, de outra parte, a independência das autoridades e a incompatibilidade das funções (BOUVIER; ESCLASSAN; LASSALE, 2008).

Toda operação financeira requer a intervenção de duas categorias de agentes, cujas funções são claramente delimitadas: o ordenador e o contábil público (l'ordonnateur $e$ le comptable public) (BOUVIER; ESCLASSAN; LASSALE, 2008).

Na concepção francesa, o ordenador é um agente da autoridade, administrador eleito ou nomeado, que, colocado no topo de um Ministério, Coletividade, Estabelecimento, de um Serviço, exerce, entre suas funções principais, atribuições financeiras em receitas ou despesas públicas (BOUVIER; ESCLASSAN; LASSALE, 2008).

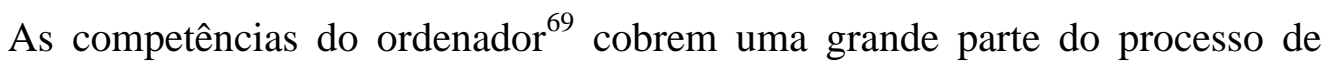
execução das receitas e das despesas, exceto quanto ao manejo de fundos públicos. No tocante às receitas, o ordenador constata os créditos dos organismos públicos, determina o seu montante (liquidação) e ordena o recolhimento. No tocante às despesas, o ordenador dispõe de competências mais amplas: ele se situa na origem do procedimento de emprego dos fundos, a ele compete de decidir a efetiva execução da despesa. Neste aspecto, o

\footnotetext{
${ }^{69}$ Nem todos os ordenadores possuem a mesma posição na hierarquia dos Serviços. O Direito da Contabilidade Pública (Droit de la Comptabilité Publique) distingue, tradicionalmente, duas categorias de ordenadores: os ordenadores principais e os secundários. Os ordenadores principais são os Ministros, para o Orçamento do Estado, os Diretores de Serviços, para os Orçamentos Anexos, o Diretor de Estabelecimento, para os Estabelecimentos Públicos. Os ordenadores secundários são agentes administrativos em exercício dentro de uma circunscrição territorial determinada, aos quais os ordenadores principais confiaram uma "ordonnance de délégation", no contexto de gestão desconcentrada dos serviços. Outra categoria de ordenadores é a dos ordenadores delegados. É uma prática frequente nos Ministérios a delegação de competência dos Ministros Ordenadores. Existe, também a categoria dos ordenadores suplentes, que são funcionários designados para o substituir temporariamente os ordenadores principais, secundários ou delegados, em caso de sua ausência ou de impedimento. Não significa que os ordenadores, por si mesmos, executaram a integralidade das tarefas necessárias ao processo de execução orçamentária. Elas podem ser feitas por funcionários que não tenham a qualidade de ordenador, mas as ordens de receitas e despesas só podem ser emitidas pelos próprios ordenadores (BOUVIER; ESCLASSAN; LASSALE, 2008).
} 
ordenador dispõe de um poder de apreciação da oportunidade (BOUVIER; ESCLASSAN; LASSALE, 2008).

À diferença dos ordenadores, os contábeis públicos ${ }^{70}$ intervéem no processo de execução sempre a título principal. Eles têm a exclusividade do manejo de fundos públicos, o que arrasta uma pesada responsabilidade pecuniária (BOUVIER; ESCLASSAN; LASSALE, 2008).

Os contábeis públicos são nomeados pelo Ministro das Finanças e formam uma categoria particular de agentes sujeitos à regras próprias do Direito da Contabilidade Pública, que definem as suas missões e responsabilidades (BOUVIER; ESCLASSAN; LASSALE, 2008).

A responsabilidade financeira dos contábeis é assegurada ou garantida por uma hipoteca legal sobre seus bens, ou por uma caução, ou o que é mais comum, por um sistema de caucionamento mútuo, ou seja, uma caução solidária. O montante da garantia, fixado por uma decisão do Ministro das Finanças, é apreciado em função do cargo contábil (BOUVIER; ESCLASSAN; LASSALE, 2008).

Os contábeis públicos têm a obrigação de recolher as receitas dos organismos públicos, pagar as despesas, assegurar a conservação dos fundos e valores, dos quais os organismos públicos são depositários, ter a contabilidade relativa as operações efetuadas e

70 Os contábeis, por sua vez, podem ser classificados em três categorias (BOUVIER; ESCLASSAN; LASSALE, 2008): a) os contábeis do Tesouro (Contables du Trésor); b) os contábeis encarregados pelo recolhimento de impostos indiretos e direitos de aduana; c) os contábeis dos orçamentos anexos. Os contábeis do Tesouro são divididos entre os contábeis diretos (comptables directs) do Tesouro, que tem competência geral na execução orçamentária e os contábeis especiais (comptables spéciaux), que tem competência em um ramo determinado (por exemplo, o agente contábil das chancelarias diplomáticas e consulares, o pagador geral do Exército,etc.). Os contábeis diretos do Tesouro se subdividem em diferentes categorias. Sob o ponto de vista hierárquico, dividem-se em contábeis superiores e contábeis subordinados. O agente contábil central do Tesouro, o recebedor geral das finanças, o pagador geral do Tesouro, instalados em Paris, são contábeis superiores. Os tesoureiros principais, os recebedores-perceptores, os perceptores, instalados no plano local, são contábeis subordinados. Do ponto de vista funcional, os contábeis são principais ou secundários. Os primeiros são obrigados a prestar diretamente suas contas ao "juge des comptes", os segundos prestam contas aos contábeis principais (BOUVIER; ESCLASSAN; LASSALE, 2008). 
conservar os documentos e peças justificativas das operações realizadas (BOUVIER; ESCLASSAN; LASSALE, 2008).

Aliás, os contábeis devem exercer um controle de regularidade das ordens de receitas e despesas emitidas pelos ordenadores. Este controle, que se exerce a priori, antes do recebimento ou do desembolso efetivo, é a base da separação orgânica das autoridades encarregadas da execução. O que supõe uma independência de uns frente a outros, pois em caso de irregularidade, o contábil público deverá recusar a execução da ordem do ordenador (BOUVIER; ESCLASSAN; LASSALE, 2008).

O elemento-chave da independência entre contábeis e ordenadores é o fato de que os contábeis pertencem a uma categoria de agentes públicos nomeados pelo Ministro das Finanças (ou com a sua concordância), que não são colocados em posição de subordinação perante os ordenadores. O contábil tem um dever de obediência limitada ao ordenador, podendo recusar uma ordem irregular, sem comprometer sua responsabilidade e se expor a ser sancionado (BOUVIER; ESCLASSAN; LASSALE, 2008).

Em certas condições, entretanto, o ordenador pode desconsiderar a recusa do contábil em deferir a ordem de pagamento, por meio de uma "réquisition de paiement". Este procedimento, todavia, é um meio excepcional de regulação a fim de evitar bloqueios prejudiciais ao bom funcionamento dos serviços e tem por consequência liberar a responsabilidade do contábil e transferí-la ao ordenador (BOUVIER; ESCLASSAN; LASSALE, 2008).

Fala-se, também, na independência dos contábeis e ordenadores perante terceiros. Os ordenadores não podem ter interesse nos negócios, em relação aos quais eles exercem, no todo ou em parte, administração ou supervisão. Além disso, durante o exercício de suas funções e até cinco anos após o término de suas funções, eles não podem adquirir ou conservar alguma participação nas empresas com as quais os organismos administrados tenham tido negócios ou contratos (BOUVIER; ESCLASSAN; LASSALE, 2008). 
O modelo francês também garante a incompatibilidade entre as funções de ordenador e contábil. A incompatibilidade compreende a vedação de que uma mesma pessoa possa cumular as duas funções, bem como a exclusividade das suas funções e tarefas, ou seja, um não pode invadir as esferas de atuação do outro (BOUVIER; ESCLASSAN; LASSALE, 2008).

O desrespeito às funções do contábil público é denominado de gestão de fato (gestion de fait), qualificação aplicável aos estratagemas de todos que se imiscuem irregularmente no manejo de dinheiros públicos, sem ter a qualidade de contábil público (BOUVIER; ESCLASSAN; LASSALE, 2008).

A qualificação de gestão de fato é reservada ao juiz de contas, sendo somente este competente para declará-la. A gestão de fato não é apenas a ingerência nas operações de despesas e receitas. Inclui, igualmente, a extração irregular de fundos públicos e valores por meio, por exemplo, de ordens de despesas fictícias ou indicações falsas quanto à realidade do serviço, fato que não pôde ser detectado pelo agente contábil (BOUVIER; ESCLASSAN; LASSALE, 2008).

O Comptable de fait é, portanto, aquele que irregularmente e conscientemente faz entrega de recursos públicos e que age sem autorização regular, ou seja, sem habilitação (BOUVIER; ESCLASSAN; LASSALE, 2008).

A gestão de fato, em caso de irregularidade de receitas e despesas, importa na obrigação do contábil de fato de recompor os recursos faltantes. Ele pode também ser reprimido por uma multa por gestão de fato, calculada com base na importância e na duração da detenção ou manejo de recursos públicos e no grau de sua participação nas operações financeiras irregulares (BOUVIER; ESCLASSAN; LASSALE, 2008). 


\title{
6.5.2. Jurisdições Financeiras na França
}

\author{
As jurisdições financeiras ${ }^{71}$ na França compreendem o conjunto de \\ instituiçõos que englobam a Corte de Contas, as Câmaras Regionais e Territoriais de Contas \\ (CRTC) e a Corte de Disciplina Orçamentária e Financeira (CDBF).
}

As Cortes da Jurisdição Financeira não integram a estrutura da Jurisdição Administrativa Ordinária, descrita na exposição inicial, apesar de suas decisões sujeitarem-se à cassação do Conselho de Estado. Com efeito, a Jurisdição Administrativa é regulada pelo Code de Justice Administrative, enquanto as jurisdições financeiras são reguladas pelo Code des Jurisdictions Financières.

Dispõe o art. 47-2, da Constituição Francesa que:

\begin{abstract}
"ARTICLE 47-2. La Cour des comptes assiste le Parlement dans le contrôle de l'action du Gouvernement. Elle assiste le Parlement et le Gouvernement dans Le contrôle de l'exécution des lois de finances et de l'application des lois de financement de la sécurité sociale ainsi que dans l'évaluation des politiques publiques. Par ses rapports publics, elle contribue à l'information des citoyens. Les comptes des administrations publiques sont réguliers et sincères. Ils donnent une image fidèle du résultat de leur gestion, de leur patrimoine et de leur situation financière" ${ }^{72}$.
\end{abstract}

A Corte de Contas Francesa está regulada nos artigos L 111-1 a L.142-1, do Code des Jurisdictions Financières $(\mathrm{CJF})^{73}$.

Segundo o Sítio da Cour des Comptes, a Corte de Contas Francesa tem por missão o controle da gestão pública, ou seja, o controle de todas as Administrações, Organismos Públicos e Parapúblicos nacionais. Pode controlar, também, o emprego de fundos públicos alocados a organismos privados. O controle incide sobre a qualidade e a

\footnotetext{
${ }^{71}$ Ensemble constitué par la Cour des comptes, les chambres régionales et territoriales des comptes et la Cour de discipline budgétaire et financière (http://www.ccomptes.fr/fr/JF/glossaire.html).

${ }^{72}$ A Corte de Contas auxilia o parlamento no controle da ação do governo. Ela auxilia o parlamento e o governo no controle da execução da lei de finanças e da aplicação da lei de financiamento da seguridade social, bem como, na avaliação das políticas públicas. Por meio de seus relatórios públicos, ela contribui para informação dos cidadãos. As contas das Administrações Públicas devem ser regulares e sinceras. Elas traçam uma imagem fiel do resultado da sua gestão, do seu patrimônio e da sua situação financeira.

73 http://www.ccomptes.fr/fr/CC/Missions.html.
} 
regularidade da gestão, sobre a eficiência e efetividade das ações conduzidas em relação aos objetivos fixados pelo Poder Público ${ }^{74}$.

A Cour des Comptes exerce uma atividade jurisdicional, consistente no julgamento das contas dos "comptables publics". Ela analisa as contas e as peças justificativas. Ela verifica se as receitas foram arrecadadas e se as despesas foram pagas conforme as regras em vigor. Por meio de uma Sentença $\left(\operatorname{arrê} t^{75}\right)$, ela concede quitação ao contábil, se as contas estiverem regulares ou imputa um débito, se as receitas não foram arrecadadas ou se as despesas foram irregularmente efetuadas ${ }^{76}$.

A Corte de Contas julga as contas de toda pessoa que, apesar de não ter título de contábil público, intervenha na gestão dos dinheiros da administração ou do órgão público. Esta pessoa é declarada "comptable du fait", por um julgamento e se encontra, então, submetida às mesmas obrigações e às mesmas responsabilidades que um "comptable public", ou seja, prestar contas, obter quitação ou ser declarado em débito ${ }^{77}$.

A Corte de Contas é uma Corte de Apelação para os julgamentos proferidos pelas Chambres Regionales et Territoriales des Comptes acerca dos organismos relevantes de sua competência ${ }^{78}$.

A Corte de Contas é encarregada, também, de certificar a regularidade (conformidade às regras), a sinceridade (aplicação de boa-fé das regras) e a fidelidade (correspondência à realidade) das Contas do Estado ${ }^{79}$.

Exerce, também, o Controle da Execução da Lei de Finanças e da Lei de Financiamento da Seguridade Social ${ }^{80}$.

\footnotetext{
74 http://www.ccomptes.fr/fr/CC/Missions.html.

75 O Arrêt é o ato pelo qual a Corte de Contas decide em matéria de julgamento das contas. As Câmaras Regionais e Territoriais pronunciam-se por meio dos "judgements".

76 http://www.ccomptes.fr/fr/CC/Missions.html.

77 http://www.ccomptes.fr/fr/CC/Missions.html.

78 http://www.ccomptes.fr/fr/CC/Missions.html.

79 http://www.ccomptes.fr/fr/CC/Missions.html.

80 http://www.ccomptes.fr/fr/CC/Missions.html.
} 
Uma outra competência da Cour des Comptes, que foi introduzida na Constituição em 2008, é a de Avaliação de Políticas Públicas ${ }^{81}$.

Por fim, a Corte executa o Controle dos Organismos que fazem apelo à generosidade Pública. Com efeito, ela controla o emprego dos fundos obtidos da generosidade do público, após campanhas nacionais de doação. Esta competência se exerce, ainda quando, os organismos privados sejam beneficiários. A Corte encaminha suas observações aos órgãos decisórios destes organismos, cabendo ao Presidente comunicar à Assembléia Geral e ao Conselho de Administração. Nada obstante, é com a publicação dos seus relatórios, possibilidade que foi aberta pela lei, que a Corte atende da melhor forma a sua missão de informação aos doadores ${ }^{82}$.

A Cour de Discipline Budgétaire et Financière (CDBF) é órgão ligado à Cour des Comptes, mas que constitui uma jurisdição financeira distinta. É encarregada de reprimir as infrações em matéria de finanças públicas ${ }^{83}$.

Foi criada pela Lei $\mathrm{n}^{\circ}$ 48, de 25 de setembro de 1948, para sancionar certos tipos de faltas cometidas no exercício da função por funcionários, agentes públicos ou equiparados, em prejuízo ao Estado, às Coletividades Públicas e os organismos financiados com fundos públicos ${ }^{84}$.

Suas sanções consistem em multas (amende) e são objeto de sentenças (arrêts). As sentenças podem ser publicadas em Jornal Oficial e podem ser objeto de recurso de cassação perante o Conselho de Estado ${ }^{85}$.

Entre as infrações sancionadas pela CDBF, podemos citar, a realização de despesas com infração às regras de controle financeiro; a imputação irregular de uma despesa

\footnotetext{
81 http://www.ccomptes.fr/fr/CC/Missions.html.

82 http://www.ccomptes.fr/fr/CC/Missions.html.

83 http://www.ccomptes.fr/fr/CDBF/Missions.html

${ }^{84} \mathrm{http}: / /$ www.ccomptes.fr/fr/CDBF/Missions.html

${ }^{85}$ http://www.ccomptes.fr/fr/CDBF/Missions.html
} 
tendende à dissimular a extrapolação de um crédito; a realização de despesa por pessoa não habilitada ${ }^{86}$.

Como será objeto do tópico a seguir, os membros do governo (Ministros) não são jurisdicionados à CDBF. E os ordenadores eleitos locais também não, salvo em casos excepcionais previstos no $\mathrm{CJF}^{87}$.

As Chambres Regionales et Territoriales des Comptes (CRTCs) tem jurisdição sobre as Coletividades Territoriais (Regiões, Departamentos, Comunas) e sobre os Estabelecimentos Públicos que lhes estão vinculados (Hospitais, Escolas, Comunidades de Comunas, etc.). As missões das CRTCs abrangem o julgamento das contas dos "comptables publics" das coletividades e seus estabelecimentos, o exame da gestão e o controle orçamentário $^{88}$.

\subsubsection{A Responsabilidade dos Ordenadores e dos Contábeis}

A separação entre os ordenadores e os contábeis, na França, não é apenas um modelo organizacional. Esta separação determina, igualmente, os sistemas de responsabilização próprios de uma ou outra destas categorias (BOUVIER; ESCLASSAN; LASSALE, 2008).

Conforme Michel Bouvier, Marie-Christine Esclassan e Jean-Piere Lassale, os sistemas parecem equilibrados, mas, de fato, não o são (BOUVIER; ESCLASSAN; LASSALE, 2008).

Segundo os autores, o descumprimento aos deveres inerentes às suas funções é igualmente objeto de um regime peculiar de responsabilização que, com certeza, não exclui as outras áreas (civil, penal, disciplinar e política) sob as quais as suas condutas podem ser

\footnotetext{
${ }^{86} \mathrm{http}: / / \mathrm{www} . c \mathrm{comptes} . \mathrm{fr} / \mathrm{fr} / \mathrm{CDBF} / \mathrm{Missions.html}$

$87 \mathrm{http}: / /$ www.ccomptes.fr/fr/CDBF/Missions.html

$88 \mathrm{http}: / /$ www.ccomptes.fr/fr/CRTC/Missions.html.
} 
igualmente reprimidas. No entanto, este regime de responsabilização é caracterizado, no estado atual do Direito, pela sua desigual efetividade, pois os ordenadores são pouco sancionados.

A responsabilidade dos ordenadores por violação das regras orçamentárias e financeiras foi introduzida tardiamente com a Lei de 15 de setembro de 1948, com a criação da Cour de Discipline Budgétaire (posteriormente, Cour de Discipline Budgétaire et Financière - CDBF) (BOUVIER; ESCLASSAN; LASSALE, 2008).

Anteriormente, os ordenadores só podiam ser responsabilizados pela Gestão de Fato (gestion $d u$ fait) perante a Cour des Comptes (BOUVIER; ESCLASSAN; LASSALE, 2008).

Entretanto, não estão sujeitos à jurisdição da CBDF os Ministros nem os ocupantes de cargos eletivos locais. Com efeito, descrevem Michel Bouvier, Marie-Christine Esclassan e Jean-Piere Lassale (BOUVIER; ESCLASSAN; LASSALE, 2008, p. 386):

\footnotetext{
"La violation des règles budgétaires et de comptabilité publique par les ministres ou par les élus locaux agissant en tant qu'ordonnateurs échappe ainsi en totalité (pour les ministres) ou en quasi-totalité (pour les élus locaux) aux sanctions spéciales conçues par le droit financier à l'égard des autres ordonnateurs et à la competénce de la Cour de discipline budgétaire et financière".
}

Há uma distinção, portanto, entre os Ministros, ordenadores principais do Estado, e os demais ordenadores. Os Ministros, nos termos do art. 9, do Decreto de 29 de dezembro de 1962, incorrem apenas nas responsabilidades previstas na Constituição (BOUVIER; ESCLASSAN; LASSALE, 2008).

Entretanto, conforme salientam os autores, a Responsabilidade Política prevista na Constituição é a Responsabilidade Coletiva do Governo perante o Parlamento (BOUVIER; ESCLASSAN; LASSALE, 2008). 
A Responsabilidade Penal dos Ministros, pelas infrações reprimidas pelo Código Penal Francês, é também de difícil aplicação. A Haute Cour de Justice, que é o Tribunal Competente para este julgamento, só pode ser acionada pelo Parlamento, nos termos da Constituição (BOUVIER; ESCLASSAN; LASSALE, 2008).

No Plano civil, como todos os ordenadores, os Ministros estão sujeitos a reparar o dano causado a terceiros. Entretanto, esta responsabilidade pecuniária é de aplicação extremamente difícil, considerando a desproporção entre os créditos colocados em prática e o patrimônio pessoal dos Ministros, que, diferentemente dos contábeis, não precisam constituir cauções (BOUVIER; ESCLASSAN; LASSALE, 2008).

Outros ordenadores que não os Ministros e os ocupantes de cargos eletivos nas Coletividades Locais são responsáveis perante a Cour de Discipline Budgetaire et Financière sem prejuízo das outras responsabilidades de Direito Comum. A Competência da CDBF não abrange somente os ordenadores. Ela engloba um vasto setor de pessoas que participam da execução das operações financeiras, tais como, membros dos gabinetes ministeriais, funcionários, agentes do estado e dos estabelecimentos públicos nacionais (BOUVIER; ESCLASSAN; LASSALE, 2008).

A Lei de 25 de Setembro de 1948, que criou a CDBF, apresenta uma lista de infrações puníveis por esta Corte, tais como, a infração às regras de direito orçamentário e de contabilidade pública, a outorga de uma vantagem injustificada a outrem em prejuízo do Tesouro e a inexecução de decisões da justiça. As infrações são sancionadas com multa (amende) (BOUVIER; ESCLASSAN; LASSALE, 2008).

Diferentemente da responsabilidade dos ordenadores, a responsabilidade dos contábeis públicos é uma responsabilidade pecuniária pessoal caracterizada pelo seu rigor extremo, apesar de ser temperada por mecanismos de atenuação da responsabilidade a priori e a posteriori (BOUVIER; ESCLASSAN; LASSALE, 2008). A responsabilidade dos comptables é efetivada no âmbito da Cour des Comptes ou das Chambres Regionales de Comptes. 
Para os comptables, há um mesmo regime de responsabilização pelas faltas e irregularidades cometidas no exerício das suas funções, sem excluir as responsabilidades de direito comum (civil, penal e disciplinar) (BOUVIER; ESCLASSAN; LASSALE, 2008).

A extensão da responsabilidade que pesa sobre os contábeis é ampla. De uma parte, eles não são só responsáveis pelas suas faltas próprias, mas, dentro de certas condições, também pelos atos dos subordinados e, até mesmo, pelos atos dos predecessores (BOUVIER; ESCLASSAN; LASSALE, 2008).

A Lei de 23 de fevereiro de 1963 criou uma presunção de responsabilidade dos comptables pela mera constatação de falta de fundos no caixa, de despesas pagas irregularmente, de receitas não arrecadadas, sem que a sua culpa seja previamente estabelecida.

Não se trata de uma Responsabilidade Objetiva, especialmente após a edição do Decreto de 21 de julho de 2004, mas de responsabilidade subjetiva com presunção de culpa. O comptable pode eximir-se da responsabilidade, mediante prova da regularidade da sua gestão ou do cumprimento regular do seu conjunto de obrigações de controle, ou demonstrando que a inexecução destas obrigações deu-se em razão de causas independentes de sua cautela e diligência (BOUVIER; ESCLASSAN; LASSALE, 2008).

Os mecanismos de atenuação da responsabilidade do comptable podem ser a priori ou a posteriori. Um mecanismo a priori é, no caso de despesas pagas irregularmente, a requisição do ordenador, que exonera o comptable de toda responsabilidade, transferindo-a para o requisitante (BOUVIER; ESCLASSAN; LASSALE, 2008).

Dentre os mecanismos a posteriori de atenuação ou exoneração da responsabilidade cumpre citar: a solicitação ao Ministro a quitação da responsabilidade por força maior e a solicitação ao Ministro das Finanças do desconto, total ou parcial, da dívida que cabe ao ordenador de boa-fé (BOUVIER; ESCLASSAN; LASSALE, 2008). 
No primeiro caso, só o Ministro é competente para estatuir, fora de qualquer controle do "juge des comptes". A quitação da responsabilidade exonera retroativamente o comptable de toda responsabilidade (BOUVIER; ESCLASSAN; LASSALE, 2008).

A responsabilidade financeira do comptable pode ser efetivada seja pela autoridade administrativa, seja pela Corte de Contas. Cada uma das autoridades pode efetivar a responsabilidade de maneira independente, mas, em caso de divergência, deve prevalecer a decisão da Corte de Contas (BOUVIER; ESCLASSAN; LASSALE, 2008).

Se, por exemplo, um contábil é beneficiado pela quitação pela Corte de Contas, o Ministro Interessado ou o Ministro das Finanças está privado de manter ou estabelecer um "arrêté de débet" (sentença ou decisão em que impute débito). Por outro lado, quando o Ministro tenha estabelecido a responsabilidade de um comptable, a Corte de Contas pode pronunciar um "arrêt de décharge" (decisão que concede quitação) (BOUVIER; ESCLASSAN; LASSALE, 2008).

Conforme Michel Bouvier, Marie-Christine Esclassan e Jean-Piere Lassale, os julgamentos ou sentenças de débito pronunciadas pela Corte de Contas não tem o caráter de sanção. Eles tem por objeto somente reparar o prejuízo sofrido pela coletividade. O débito, ressaltam os autores, é também contemporaneamente uma questão de reflexão. Se parece legítimo no caso dos pagamentos indevidos (paiements indûs) ou de receitas irregularmente não arrecadadas, ele é discutível no caso de "manquants", que são irregularidades que não ocasionaram prejuízos financeiros (BOUVIER; ESCLASSAN; LASSALE, 2008).

Quanto a procedimento de julgamento das contas, ao contrário do que ocorre no âmbito da CDBF, o acionamento da jurisdição de contas é feito de ofício, pois os comptables são obrigados a prestar contas anualmente (BOUVIER; ESCLASSAN; LASSALE, 2008). 
Por um lado, o procedimento é inquisitorial e escrito. Ele é conduzido por um Relator designado pelo Presidente da jurisdição competente (Cour des Comptes ou CRTC). Ele é, por outro lado, contraditório. No controle jurisdicional, o contraditório é garantido pela regra do duplo julgamento (double arrêt ou double jugement). Em caso de irregularidade, a jurisdição deve proferir inicialmente um julgamento ou arrêt provisório antes de pronunciar um definitivo. Este último não pode surgir antes de uma primeira fase, na qual o juiz de contas faz uma injonction (ordem) ao comptable, para que produza justificações suplementares ou recolha a quantia não arrecadada ou faltante (BOUVIER; ESCLASSAN; LASSALE, 2008).

Até uma data recente, o procedimento não era público: as partes e seus representantes não tinham direito de assistir às "auditions". Entretanto, mediante o Decreto de 18 de Abril de 1996, foi instituída a publicidade das audiências, nas quais o juiz de contas pronuncia multas contra os contábeis (BOUVIER; ESCLASSAN; LASSALE, 2008).

As decisões jurisdicionais financeiras são susceptíveis de recurso de revisão, recurso de apelação e recurso de cassação.

O recurso de revisão pode ser demandado pelo comptable ao qual foi imputado débito, para trazer justificativas posteriormente, as quais ele não havia podido produzir quando do procedimento de julgamento das contas. A revisão também pode se dar de ofício, ou seja, à iniciativa da jurisdição competente, quando constatado erro por ela mesma (BOUVIER; ESCLASSAN; LASSALE, 2008).

O recurso de apelação pode ser interposto perante a Cour des Comptes contra os julgamentos proferidos pelas Chambres Régionales des Comptes. Somente os julgamentos definitivos pelas Câmaras Regionais de Contas. Estão excluídas as disposições provisórias (injunctions) da mesma forma que os atos não jurisdicionais (BOUVIER; ESCLASSAN; LASSALE, 2008). 
O recurso de cassação é interposto perante o Conselho de Estado, que é o Tribunal de Cassação das deliberações da Cour des Comptes. Este recurso pode ser interposto pelo comptable, pelo Ministro das Finanças ou de outro Ministro interessado, ou ainda o Representante legal da Coletividade interessada. Pode ser invocada a incompetência, o vício de forma e a violação da lei (BOUVIER; ESCLASSAN; LASSALE, 2008).

O Conselho de Estado não julga o mérito das contas, mas simplesmente aprecia se a Corte de Contas, na sua decisão, fez uma aplicação correta das regras de Direito (BOUVIER; ESCLASSAN; LASSALE, 2008). 


\section{HISTÓRIA DA RESPONSABILIDADE FINANCEIRA}

Apresentar a história da Responsabilidade Financeira no Brasil exige acompanhar a história das instituições responsáveis pela sua efetivação. Somente após a criação e implementação de um órgão independente e com jurisdição própria, o Tribunal de Contas, é que se pode cogitar na autonomia deste instituto jurídico.

Na exposição a seguir, observar-se-á a evolução de vários elementos ligados à responsabilidade financeira, tais como, a jurisdição do Tribunal de Contas (que, no aspecto subjetivo, corresponde ao conjunto de sujeitos alcançados pelas deliberações do Tribunal de Contas), as garantias prestadas pelo gestor de recursos públicos, o julgamento das contas, a fiscalização da gestão pública, a quitação, as medidas cautelares, a prescrição das contas, dentre outras.

Inicialmente, apresento uma narrativa simplificada da Responsabilidade em Portugal, passando pelo Brasil Colonial e Imperial, para, então, adentrar no Brasil Republicano, período em que, entre nós, a Responsabilidade Financeira obteve o seu pleno desenvolvimento.

Segundo João Franco do Carmo, desde a época medieval, é possível observar normas que dispõem sobre a responsabilidade dos funcionários da fazenda régia em Portugal. Menciona o autor que se atribui à D. Afonso II uma lei que obrigava o tesoureiro, almoxarife ou recebedor que desviasse ou desse destino diverso ao que em nome do Rei houvesse de ser pago, a pagar "(...) quatro tanto a El-Rei d'aquello", sendo ainda degredado do Reino (CARMO, 1995, p. 81).

Nas Ordenações Manuelinas (Livro II, título XXVIII) consagram-se normas que determinavam a responsabilidade pecuniária dos oficiais da Fazenda e dos "tesoureiros $e$ almoxarifes que emprestam a fazenda del Rei ou a pagão contra seu regimento" (CARMO, 1995, p. 84), a que devia acrescer a perda do ofício e a pena de degredo. Os "oficiais d'El-Rei 
que lhe furtam, ou com malícia deixam perder a Fazenda do dito Senhor", teriam de pagarlhe "o preço, ou valia, daquilo que assim for furtado, ou levado (...)" (CARMO, 1995, p. 84)

As Ordenações Afonsinas (livro II, título XXXXII) determinavam aos funcionários que "por El-Rei e em seu nome algumas coisas houvessem de guardar, e receber, e despender (...), e fosse achado que nas ditas coisas ou em cada uma delas fizessem furto, ou engano", que "tornassem e restituíssem tudo aquilo que furtassem ou enganosamente levassem, ou deixassem levar a outrém, com três tanto aãlle o que assim levassem, segundo El-Rei fosse mandado, e além disso fossem cruelmente açoudados e degredados para sempre de todos seus Reinos" (CARMO, 1995, p. 82).

No Brasil Colonial, já se observava a preocupação da Coroa Portuguesa com a arrecadação dos seus tributos, os quais estavam vinculados ao patrimônio do Rei e não ao Estado Português.

Na criação do governo-geral, em meados do Século XVI, conforme relevam Fernando José Amed e Plínio José Negreiros, houve uma tentativa de centralizar a administração colonial, em razão da desorganização da prática tributária. Foram criados os cargos de Provedores da Coroa, aos quais incumbia fiscalizar a arrecadação de tributos e o seu recolhimento, bem como a produção de açucar nos engenhos. Havia o Proveder-Mor, que era a autoridade fazendária máxima, e os Provedores-Parciais (ou de capitania), estes responsáveis pela fiscalização da arrecadação nas Capitanias, devendo prestar contas ao Provedor-Mor, anualmente, em relação à receita e à despesa no âmbito do seu território (AMED;NEGREIROS, 2000).

$\mathrm{Na}$ época, haviam sido instituidas obrigações e formas de controle dos funcionários responsáveis pela fiscalização e cobrança de tributos. Dentre estas formas de garantia, exigia-se a prestação de fiança dos funcionários envolvidos na cobrança de tributos, os quais respondiam com o seu patrimônio pessoal pelos danos causados à Coroa Portuguesa (AMED;NEGREIROS, 2000, p. 50-51): 


\begin{abstract}
"Portugal tinha clareza da necessidade de uma exploração organizada sobre estas terras. Era preciso evitar que a desorganização administrativa resultasse em sangria para o tesouro real. Daí a importância especial do Provedor-Mor, assim como da sistematização das alfândegas. Junto às prerrogativas do Proveder-Mor, (...), também vinha uma série de obrigações. Era importante para a Coroa portuguesa ter o máximo de controle sobre os funcionários que cuidavam das coisas do fisco. Mesmo porque, por mais rigoroso que fosse esse controle, como já se viu, as fraudes contra as rendas do rei tornaram-se regra durante todo o período colonial. Entre estas obrigações, encontramos: Os provedores de capitania eram obrigados a dar anualmente conta da receita e da despesa ao Provedor-Mor; aos almoxarifes cumpria, também anualmente, enviar os saldos do exercício ao tesoureiro, na Bahia. Deviam ainda os almoxarifes, de cinco em cinco anos ir à capital prestar contas, levando para isso todos os livros do almoxarifado. O controle do Provedor-Mor sobre seus subordinados era ainda maior, pois em caso de falta grave destes caberia até a pena de prisão. Além disso, a desconfiança da Coroa Portuguesa era tanta, que os funcionários régios que estivessem envolvidos com a cobrança de tributos deveriam dispor de uma fiança, além de colocarem os seus bens para cobrir quaisquer prejuízos que causassem".
\end{abstract}

Antônio de Souza Franco chama a atenção para o fato de que, no Antigo Regime, o controle sobre as finanças públicas estava voltado para a cobrança das Receitas do Rei, enquanto, no Estado Moderno, a preocupação se volta à realização das despesas públicas (FRANCO, 1993).

No Brasil Imperial, foram propostos na Assembléia Geral diversos Projetos para instituição do Tribunal de Contas, substituto do Tribunal do "Thesouro Nacional" instituído pelo art. 170, da Constituição de 1824.

A despeito destas várias tentativas, o Tribunal de Contas só foi instituído (e não implementado) após a Proclamação da República, por meio do Decreto $\mathrm{n}^{\circ}$ 966-A, de 07.11.1890, do Governo Provisório. Tal Decreto, conforme revela Marcos Valério de Araujo, teve inspiração no Projeto de lei apresentado por Manoel Alves Branco, na época imperial em 1845 (ARAUJO, 1990).

Segundo o art. $4^{\circ}$ do Decreto $\mathrm{n}^{\circ}$ 966-A, compete ao Tribunal de Contas "Julgar annualmente as contas de todos os responsaveis por contas, seja qual for o Ministerio a que pertençam, dando-lhes quitação, condemnando-os a pagar, e, quando o não cumpram, mandando proceder na fórma de direito" (grifamos).

A responsabilidade financeira já se revela na possibilidade do Tribunal condenar a pagar os responsáveis pela gestão dos dinheiros públicos, ainda que, neste diploma 
normativo, não estivessem especificadas as hipóteses ensejadoras da responsabilização ${ }^{89}$, atribuição que foi delegada ao Regulamento, conforme dispõe o art. 11. do referido Decreto:

"Art. 11. O Ministerio da Fazenda expedirá regulamento, em decreto especial, estabelecendo a organização e as funcções do Tribunal de Contas, desenvolvendo-lhe a competencia, especificando-lhe as attribuições, estipulando os vencimentos ao seu pessoal, e determinandolhe a demais despeza necessaria, para a qual fica desde já autorizado o Governo".

Na Constituição de 1891, o art. 89 não versou expressamente sobre a responsabilidade dos gestores públicos, limitando-se a esclarecer que:

"Art 89 - É instituído um Tribunal de Contas para liquidar as contas da receita e despesa e verificar a sua legalidade, antes de serem prestadas ao Congresso. Os membros deste Tribunal serão nomeados pelo Presidente da República com aprovação do Senado, e somente perderão os seus lugares por sentença".

Tal dispositivo mereceu críticas de Ruy Barbosa, segundo o qual, o Tribunal de Contas foi "mantido" e não instituído pela Primeira Constituição Republicana. Ocorre que a Corte de Contas, apesar de ter sido criada pelo Decreto $\mathrm{n}^{\circ}$ 966-A/1890, só iniciou efetivamente as suas atividades em 17.01.1893 (no terceiro pavimento do prédio do Tesouro Nacional no Rio de Janeiro, hoje demolido), aguardando regulamentação das suas atividades. Havia uma forte oposição de membros do Governo à regulamentação, incluindo o então Presidente da República Marechal Floriano Peixoto, consoante descreve Marcos Valério de Araujo (ARAUJO, 1990, p. 85):

\begin{abstract}
"O projeto de Regulamentação do Tribunal de Contas, apresentado pelo Presidente da Comissão incumbida da sua elaboração,Barão de Paranapiacaba, não teve boa receptividade do Ministro Tristão de Alencar. Coube ao sucessor, Ministro Rodrigues Alves, a apresentação de novo projeto neste sentido, tendo este, no entanto, recebido críticas por retirar parte da independência conferida ao órgão pela própria Constituição de 1891. Nova espera e igual incumbência teve o próximo Ministro da Fazenda, o Tenente-Coronel Innocêncio Serzedello Corrêa, que, finalmente, através do Decreto $\mathrm{n}^{\circ} 1.166$, de 17 de dezembro de 1892, instituiu o Regulamento Provisório da Corte de Contas, em decorrência da Lei $\mathrm{n}^{\circ} 23$, de 30 de outubro de 1891 , que consignara as primeiras atribuições do órgão. Como exemplo da relutância do então Presidente da República, Marechal Floriano Peixoto, à implantação do novo órgão, tem-se a própria mensagem que ele proferiu no Congresso Nacional, na abertura dos trabalhos legislativos de 1892, quando questionou a economicidade, em função dos gastos que o Tribunal de Contas geraria e das modificações que acarretaria em outros órgãos, alguns dos quais já extintos, ou na iminência de sê-lo, como foi o caso do antigo Tribunal do Tesouro."
\end{abstract}

\footnotetext{
${ }^{89}$ Convém ressaltar que, desde esta configuração inicial, a responsabilidade financeira esteve relacionada à função de julgamento das contas pelos responsáveis por dinheiros públicos. Quando o Tribunal de Contas não condena o responsável, deve conceder quitação.
} 
O Decreto $\mathrm{n}^{\circ} 1.166 / 1892$, de fato, dedicou-se, na sua maior parte (arts. 27 a 89), a regular a jurisdição, as competências do Tribunal de Contas, o seu funcionamento, as atribuições e deveres dos seus empregados e directores, o processo de tomada de contas e os recursos às suas deliberações.

No artigo 28, do Decreto $n^{\circ} 1.166 / 1892$, atribuiu-se ao Tribunal de Contas o caráter de Tribunal de Justiça, o que denota que as suas decisões têm a força de sentença definitiva do Poder Judiciário, verbis: "Art. 28. O Tribunal de Contas tem jurisdicção propria e privativa sobre as pessoas e as materias sujeitas á sua competencia; funcciona como Tribunal de Justiça, e as suas decisões definitivas teem força de sentença com execução apparelhada".

No mencionado Regulamento, destacam-se, ainda, as competências do Tribunal de Contas de julgar as contas dos responsáveis por dinheiros e valores da República, de aplicar multas, propor medidas cautelares (prisão, sequestro e suspensão dos responsáveis), dar quitação aos responsáveis, liberar garantias (fianças, depósitos), conforme detalha o seu artigo 31:

"Art. 31 . Compete ao Tribunal, na tomada de contas dos responsaveis por dinheiros e valores
pertencentes á Republica:
$\S 1^{\circ}$ Julgar, em unica instancia, as contas de todas as repartições, empregados e quaesquer
outros responsaveis que, singular ou collectivamente, tiverem administrado, arrecadado ou
despendido dinheiros publicos ou valores pertencentes á Republica, ou por que esta seja
responsavel e estiverem sob sua guarda, e bem assim dos que, por qualquer motivo, as deverem
prestar perante o mesmo Tribunal, seja qual for o Ministerio a que pertencerem.
$\S 2^{\circ}$ Propôr ao ministro da fazenda a suspensão dos responsaveis, que não satisfizerem a
prestação de contas ou não entregarem os livros e documentos de sua gestão dentro dos prazos
fixados nas leis e regulamentos, ou quando, não havendo taes prazos, forem intimados para esse
fim.
$\S 3^{\circ}$ Propôr igualmente, nos termos do decreto n. 657 de 5 de dezembro de 1849 , a prisão dos
responsaveis que forem remissos ou omissos em fazer as entradas dos dinheiros a seu cargo nos
prazos marcados pelas leis, regulamentos, instrucções ou quaesquer outros actos, e a promover
contra elles e seus fiadores os sequestros e mais processos civis competentes para segurança e
embolso da Fazenda Federal.
$\S 4^{\circ}$ Impôr multas aos responsaveis que não apresentarem as contas, ou os livros e documentos
de sua gestão, nos prazos que lhes houverem sido marcados, quando não o tiverem feito nos
prescriptos nas leis, regulamentos, instrucções e ordens em vigor.
$\S 5^{\circ}$ Fixar e julgar, á revelia, o debito dos responsaveis, que deixarem de apresentar as contas ou
os livros e documentos de sua gestão, por quaesquer outras contas e documentos que lhes
fizerem carga.
$\S 6^{\circ}$ Mandar passar quitação aos thesoureiros, pagadores, recebedores, almoxarifes e a
quaesquer outros responsaveis quando correntes em suas contas; julgar desembaraçados os 
valores depositados e extinctas as cauções de qualquer natureza pela quitação dos responsaveis, e levantar o sequestro áquelles que declarar exonerados para com a Fazenda Federal.

$\S 7^{\circ}$ Avaliar as provas de facto, deduzidas por justificações e quaesquer outros documentos, da perda ou arrebatamento de dinheiros e valores publicos, por força maior, que forem apresentadas pelos responsaveis, e á vista dellas, resolver o que for de justiça sobre o abono da somma ou dos valores perdidos ou arrebatados".

\title{
Em 1896, houve um processo de reorganização do Tribunal, que resultou em
}

\section{ampliação de sua jurisdição e das suas competências, conforme esclarece Marcos Valério de}

Araujo (ARAUJO, 1990, p. 93):

\begin{abstract}
"Passados três anos de funcionamento do Tribunal, surgiram-lhe algumas mudanças institucionais: o Decreto Legislativo $\mathrm{n}^{\circ} 392$, de 8 de outubro de 1896, regulamentado pelo Decreto $\mathrm{n}^{\circ} 2.409$, de 23 de dezembro do mesmo ano, reorganizou a Corte de Contas. Sua jurisdição, agora ampliada, alcançava os responsáveis por materiais públicos. Quanto a receita, o exame passou a abranger os atos de arrecadação de impostos e taxas. Pelo reordenamento, o Tribunal tinha competência: a) como fiscal da administração financeira, para efeito de apreciar a execução das leis de receita e da despesa pública; b) como Tribunal de Justiça, com jurisdição contenciosa e graciosa, para o fim de julgar as contas dos responsáveis, mesmo por contrato, comissão ou adiantamento, estabelecendo a situação jurídica entre os mesmos e a Fazenda Pública, e decretando a liberação daqueles ou condenando-os ao pagamento do que devessem ao Tesouro por alcance, podendo também suspendê-los, ordenar-lhes a prisão e determinar o sequestro de seus bens".
\end{abstract}

A propósito, nos artigos 60 a 66 do Decreto $n^{\circ}$ 2.409/1896 são definidos os sujeitos à "jurisdicção" própria e privativa do Tribunal de Contas:

"Art. 60. A essa jurisdicção estão sujeitos todos os responsaveis por dinheiro, valores e material pertencentes á Republica, ainda que residam fóra do paiz.

Art. 61. O gestor de dinheiros publicos está sujeito á jurisdicção do Tribunal de Contas pelo simples facto da gestão e só por acto do Tribunal póde ser liberado da sua responsabilidade.

Art. 62. Todos quantos houverem tido sob sua guarda e administração valores e bens da Republica, por acto do Governo ou por contracto, estão adstrictos á prestação de contas perante o Tribunal.

Art. 63. Estão sujeitos á jurisdicção do Tribunal de Contas os funccionarios que houverem recebido, em nome da Republica, depositos de terceiros, pelos quaes a Republica responda como obrigada; si taes depositos forem subtrahidos ou extraviados, ao tribunal cabe julgar da responsabilidade pela subtracção ou pelo extravio.

Art. 64. Estão igualmente sujeitos á jurisdicção do Tribunal, para o effeito de prestação de contas, todos os funccionarios estipendiados pelos cofres da União, com excepção dos Ministros do Presidente da Republica, que derem causa á perda de valores pertencentes á União, ou pelos quaes esta deva responder.

Art. 65. A jurisdicção do Tribunal abrange as viuvas, os herdeiros, os representantes e os fiadores dos responsaveis e todos aquelles que pelas pessoas ou pelos bens dos mesmos responsaveis hajam contrahido qualquer onus que os constitua na obrigação de garantir sua gestão.

Art. 66. São considerados responsaveis e como taes sujeitos á jurisdicção do Tribunal de Contas, aquelles que receberem dinheiros por antecipação ou adeantamento, nos termos dos arts. $3^{\circ}$ e $8^{\circ}$ do decreto $n$. 10.145 de 5 de janeiro de $1889 "$. 
No art. 67, alínea b, do Decreto $\mathrm{n}^{\circ}$ 2.409/1896, o alcance é mencionado expressamente como hipótese de condenação dos responsáveis ao pagamento do débito (responsabilidade financeira reintegratória).

São conferidos, também, ao Tribunal de Contas poderes de suspensão dos responsáveis que não satisfizerem as prestações de contas e de prisão dos condenados ou intimados em razão de alcance, conforme art. 71 , do Regulamento ${ }^{90}$ :

"Art. 71. Compete ao Tribunal de Contas, como Tribunal de Justiça:

(...)

$\S 2^{\circ}$ Suspender os responsaveis que não satisfizerem as prestações das contas ou não entregarem os livros e documentos de sua gestão dentro dos prazos fixados nas leis e nos regulamentos ou, não havendo taes prazos fixados, quando forem intimados para esse fim. $\S 3^{\circ}$ Ordenar a prisão dos responsaveis que, estando condemnados ao pagamento do alcance fixado em sentença definitiva do Tribunal, ou tendo sido intimados para dizerem sobre o alcance verificado em processo corrente de tomada de contas, procurarem ausentar-se furtivamente, ou abandonarem o emprego, a commissão ou o serviço de que se acharem encarregados, ou que houverem tomado por empreitada".

Ademais, há que se mencionar a exigência de prestação de garantia por parte dos Gestores Públicos (cauções, fianças e hipotecas), que somente poderiam ser liberadas por deliberação do Tribunal de Contas com audiência do Ministério Público (jurisdição voluntária ou graciosa do Tribunal de Contas).

É o que revelam os arts. 69, 71 e 236, do Decreto $n^{\circ} 2.409 / 1896$ :

"Art. 69. Em referencia á receita compete-lhe [ao Tribunal de Contas]:

(...)

$\S 4^{\circ}$ Verificar as fianças e cauções que devem prestar todos os que arrecadarem, applicarem e conservarem sob sua guarda e administração dinheiros, valores e bens pertencentes á Republica, seja qual for o Ministerio a que pertençam, e approvar as que julgar idoneas e sufficientes".

(...)

Art. 71. Compete ao Tribunal de Contas, como Tribunal de Justiça:

(...)

$\S 8^{\circ}$ Julgar extinctas as cauções de qualquer natureza pela quitação dos responsaveis e livres os valores depositados e ordenar o levantamento do sequestro dos que declarar exonerados para com a Fazenda Publica.

(...)

Art. 236. Si o responsavel houver prestado contas finaes, por haver sido exonerada ou aposentado, o Tribunal ordenará no final da sentença que se dê baixa na fiança, que seja

\footnotetext{
${ }^{90}$ Sob a égide do Decreto n ${ }^{\circ} 1.166 / 1892$, cabia ao Tribunal de Contas apenas propor ao Ministério da Fazenda a adoção de tais medidas.
} 
cancellada a inscripção da hypotheca e que se faça restituição dos depositos feitos em caução da gerência do mesmo responsavel" (anotamos).

No final da República Velha, o Decreto $\mathrm{n}^{\circ} 13.147 / 1918$ promoveu uma significativa reorganização do Tribunal de Contas, com base no Decreto $\mathrm{n}^{\circ}$ 3.454/1918. Entretanto, em matéria de responsabilidade financeira, não houve alteração substancial (art. 33, incisos I a III). O julgamento das contas foi atribuído à $2^{\text {a }}$. Câmara do Tribunal (art. 36, incisos I e III).

Já sob a égide da Constituição Federal de 1934, foi editada a Lei ${ }^{\circ} 156$, de 24.12.1935, regulando o Funcionamento do Tribunal de Contas ${ }^{91}$. No tocante à responsabilidade financeira, convém citar trechos do art. 23:

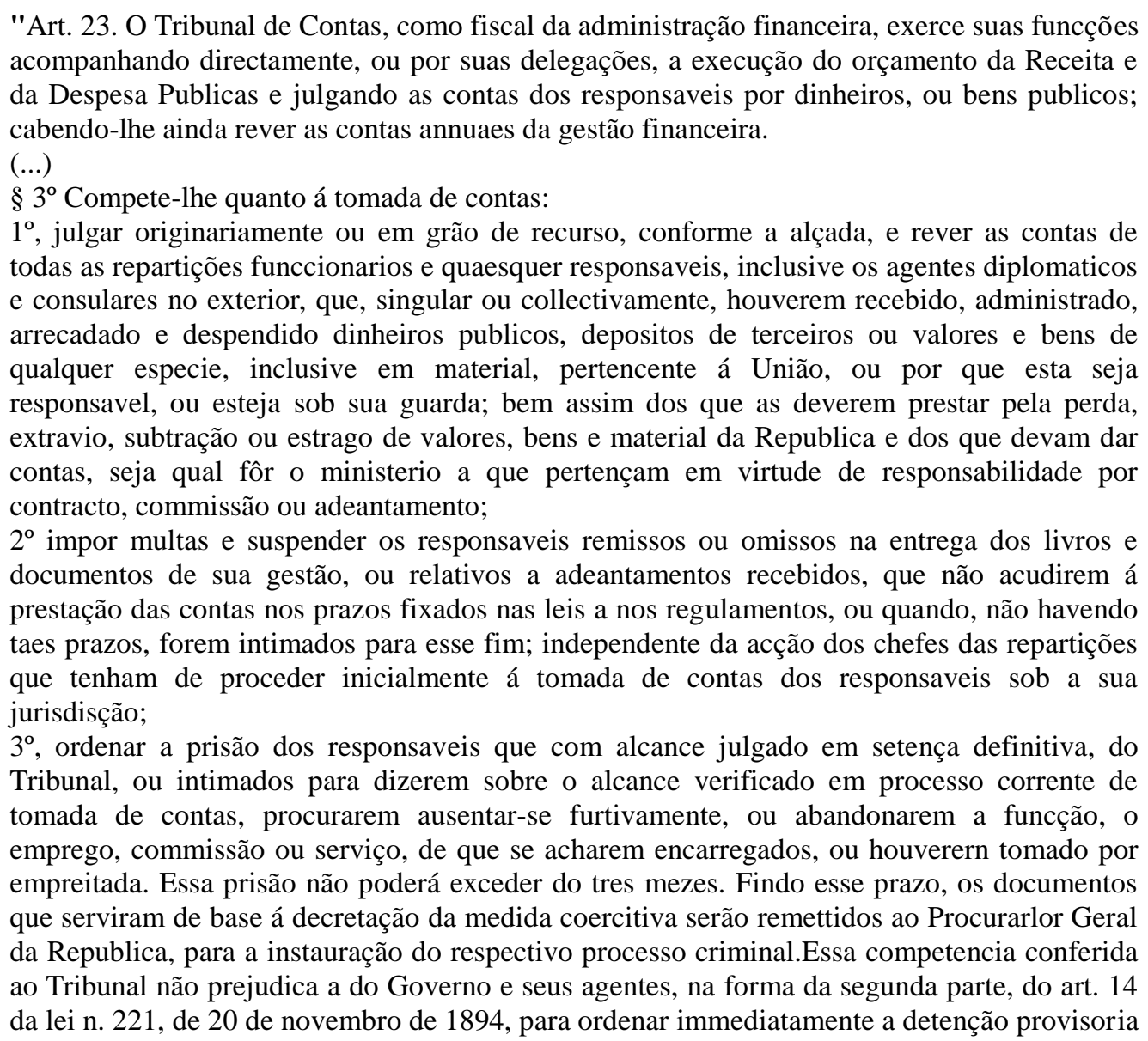

${ }^{91}$ A Constituição de 1934 também não abordou o tema da responsabilidade dos gestores de bens e dinheiros públicos. 
do responsavel alcançado, até que o Tribunal delibere sobre a dita prisão, sempre que assim o exigir a segurança da Fazenda Nacional;

(...)

$5^{\circ}$ fixar á revelia, o debito dos responsaveis que em tempo não houverem apresentado as suas contas nem entregue os livros e documentos de sua gestão.

$6^{\circ}$ ordenar o sequestro dos bens dos responsaveis ou seus fiadores, em quantidade sufficiente para a segurança da Fazenda;

$7^{\circ}$, mandar expedir quitação aos responsaveis correntes em suas contas;

$8^{\circ}$, autorizar a restituição das cauções dos responsaveis, quando canstituidas por hypothecas e a dos contractantes, provada a execução ou rescisão legal do contracto".

Outras hipóteses da responsabilidade também foram elencadas: o desfalque e o desvio de bens da União (art. 38, $\$ 5^{\circ}$ ). Fixou-se, também, um parâmetro para aplicação da multa pelo Tribunal de Contas aos chefes dos Serviços de Contabilidade, limitada a 50\% dos vencimentos, e aplicada independentemente da Responsabilidade Disciplinar a que estão sujeitos (art. 40).

A Lei $n^{\circ}$ 156/35, juntamente com outros diplomas subsequentes, também abordou o tema da "prescrição das contas", tema que mereceu comentários específicos de Marcos Valério de Araujo (ARAUJO, 1990, p. 102-108):

\footnotetext{
"Pela citada lei foram ainda consideradas prescritas as contas dos responsáveis anteriores a $1^{\circ}$ de janeiro de 1915, e ainda não julgadas, desde que nenhum alcance tivesse sido apurado. A Lei $\mathrm{n}^{\circ}$ 573/37 estendeu tal prescrição por mais de um ano, determinando simples exame aritmético para as contas de 1916 e 1934.

(...)

8.1 Prescrições de contas

Um entrave para a perfeita atuação do Tribunal de Contas no campo jurisdicional foram as prescrições de contas, através dos textos legais, nos casos em que os respectivos processos não foram organizados tempestivamente.

Diversas Leis Orgânicas contemplaram essa prática. A Lei $\mathrm{n}^{\circ}$ 156, de 24.12.1935, já declarara prescritas as contas anteriores a $1^{\circ}$ de janeiro de 1915. As Leis de ${ }^{\circ} 573$, de 8.11.37, e 426, de 12.5.38, foram elastecendo ainda mais esses prazos de prescrição. Finalmente, a Lei ${ }^{\circ} 830$, de 23.9.49, estendeu o mesmo prazo até 1923, considerando também em atraso as contas de 1924 a 1938. Dentro deste mesmo enfoque, a Lei $n^{\circ} 1.293$, de 27.12 .50 , determinou a quitação aos coletores e escrivães cujas contas não fossem julgadas no prazo de dois anos, a não ser que já constatassem como devedores da Fazenda Nacional ou tivessem processos pendentes de julgamento ou de cobrança executiva, com débito superior a Cr\$5.000,00."
}

Com o advento da Constituição de 1937, foi editado o Decreto-lei n ${ }^{\circ}$ 07, de

17.11.1937, que alterou o regime do registro prévio da despesa no âmbito do Tribunal, mas não revogou a Lei $\mathrm{n}^{\circ} 156 / 1935$ no tocante a outras matérias. 
A Constituição de 1946 também não abordou o tema nos arts. 76 e 77, que disciplinam o Tribunal de Contas. Sob a égide desta Constituição, entretanto, foi editada a Lei $\mathrm{n}^{\circ} 830$, de 23.09.1949.

A Lei $n^{\circ}$ 830/49 inovou pouco no tocante à Responsabilidade Financeira, no seu aspecto material, merecendo destaque a inclusão dos administradores autárquicos sob a jurisdição do Tribunal (art. 40, IV).

Acerca do assunto, Marcos Valério de Araujo menciona que (ARAUJO, 1990, p. 111-112):

"Com a inclusão das contas dos administradores autárquicos sob a jurisdição do Tribunal, abriu-se caminho, ainda que timidamente, para o enquadramento de administradores secundários e de todos os servidores públicos, em geral, sob a sua alçada jurisdicional. A esse respeito, o Tribunal esteve durante anos dividido em termos de opinião.

(...) e, em sessão de 20 de março de 1957, o Tribunal, usando a plenitude de suas prerrogativas, firmou jurisprudência também a este respeito, submetendo ao seu julgamento os administradores secundários que lidassem com dinheiro e bens públicos".

A oportunidade de defesa do gestor estava garantida pelo inciso II do artigo 93 da Lei $n^{\circ} 830 / 49$, segundo o qual, durante a fase de instrução dos processos, o Tribunal deverá promover: "a citação do responsável ou do seu fiador, para alegar o que tiver quando o exame das contas revelar achar-se aquêle em débito perante a Fazenda, Pública".

Quanto ao julgamento das contas, o art. 97 da Lei $\mathrm{n}^{\circ}$ 830/49 determina que:

"Ultimada a instrução do processo, com o parecer a que se refere o item III do art. 93, será o feito submetido a julgamento, no qual se declarará o responsável, quite, em crédito, ou em débito, perante a Fazenda Nacional, conforme o caso, lavrando o relator o competente acórdão".

No tocante à execução das decisões que importem em responsabilidade financeira, a Lei regula a execução administrativa do débito, conforme dispõe os arts. 99, 117 e 118, da Lei $n^{\circ} 830 / 49$ :

"Art. 99. Quando a sentença concluir pela condenação do responsável, ser-lhe-á assinado o prazo de trinta dias, a fim de entrar para os cofres públicos com a importância do alcance, sob pena de alienação administrativa da caução, cobrança executiva e demais medidas assecuratórias da indenização à Fazenda Nacional".

(...)

Art. 117. Na hipótese de ser o responsável julgado em débito com a Fazenda Pública será notificado para, no prazo de trinta dias, sob pena de revelia, apresentar defesa e, se não acudir 
o responsável ou seus herdeiros, proceder-se-á à alienação administrativa da caução e se prosseguirá na execução da sentença.

Art. 118. A alienação administrativa da caução será requerida pelo representante do Ministério Público ao Tribunal e, concedida, expedir-se-á ordem à repartição competente, para recolher imediatamente aos cofres públicos, como renda eventual, a totalidade da caução ou parte desta, suficiente para cobrir o alcance, juros de mora e quaisquer despesas, que porventura devam ser indenizados; o restante da caução ficará escriturado no cofre de Depósito Público em nome do seu possuidor.

$\S 1^{\circ}$ Recolhida aos cofres públicos a importância da caução, será o fato comunicado imediatamente ao Tribunal, mediante a transmissão do talão do recolhimento.

§ $2^{\circ}$ À vista desta comunicação, expedir-se-á quitação ao responsável, se a Fazenda Nacional houver sido integralmente indenizada; caso contrário, será feita a conta da importância a ser recolhida e enviar-se-á a conta ao representante do Ministério Público, com a cópia do acórdão, para o efeito do art. 122".

Não satisfeito o débito na execução administrativa, caberá a execução judicial,

nos termos do art. 122 e 123, da Lei ${ }^{\circ}$ 830/49:

"Art. 122. O representante do Ministério Público, recebidos os documentos a que se refere o art. 118, remetê-los-á ao Procurador da República competente para promover a cobrança da parte do alcance não indenizado; cabe-lhe, porém, fiscalizar o andamento dos respectivos feitos e representar sôbre qualquer irregularidade verificada, devendo ter para isso, os necessários registros das sentenças em execução.

Art. 123. O Procurador da República, a quem por lei competir a cobrança executiva, promoverá a execução da sentença do Tribunal e poderá solicitar do respectivo representante qualquer esclarecimento necessário ao processo judicial, o qual é obrigado a prestar ao Ministério Público, junto ao Tribunal, as informações que lhe forem pedidas".

Sob a égide do Regime Militar, foi editado o Decreto-lei $n^{\circ} 199 / 67$, Lei

Orgânica do Tribunal de Contas da União. Novidade deste diploma estava contida no art. 33, segundo o qual, a jurisdição do Tribunal só abarcava os administradores de entidades da administração indireta ou de outras entidades, se houvesse expressa previsão legal ${ }^{92}$. A respeito disso, pronuncia-se Marcos Valério de Araujo (ARAUJO, 1990):

"Percebe-se, pelo texto legal, que a atuação do Tribunal, embora abrangendo uma imensa vastidão de agentes e pessoas que poderiam ser simples entes físicos, até mesmo alheios ao Serviço Público Federal, deixava um vazio com relação aos administradores das entidades paraestatais (Administração Indireta) e outras entidades, entre as quais poder-se-iam incluir os órgãos autônomis, vez que, para estes casos, a interferência da Corte ficaria dependente de expressa disposição legal, subentendendo-se uma posterioridade. A única exceção a esta regra eram as autarquias, incluídas pelo Decreto-lei n 200/67 no rol das entidades da Administração Indireta, mas, que já constavam, por dispositivos anteriores, no universo jurisdicional do TCU".

\footnotetext{
92 Convém destacar que, no Decreto-lei $n^{\circ}$ 200/67, tais entidades estavam sujeitas à modalidade de controle denominada "Supervisão Ministerial".
} 
No Decreto-Lei ${ }^{\circ}$ 199/67, foram, entretanto, mantidas as medidas coercitivas contra os declarados em alcance pelo Tribunal de Contas. Com efeito, o inciso III do artigo 40 dispõe que o Tribunal de Contas:

\footnotetext{
"Ordenará a prisão dos responsáveis que, com alcance julgado em decisão definitiva do Tribunal, ou intimados para dizerem sôbre o alcance verificado em processo corrente de tomada de contas, procurarem ausentar-se furtivamente, ou abandonarem a função, o emprêgo, comissão ou serviço, de que se acharem encarregados".

Esta prisão não poderia ultrapassar o período de três meses. Além disso, o art. 40, inciso V, dispunha que o Tribunal "Ordenará seqüestro dos bens dos responsáveis ou
} seus fiadores, em quantidade suficiente para segurança da Fazenda".

No tocante à responsabilidade por débito, sua execução poderia ser feita através da liquidação da fiança ou caução do gestor, por meio de descontos em folha de pagamento, ou ainda, por meio da execução judicial, conforme dispunha o art. 50, do Decreto-Lei n 199/67.

A responsabilidade sancionatória também estava prevista no art. 53, do Decreto-lei n 199/67: "Art. 53. As infrações das leis e regulamentos relativos à administração financeira, sujeitarão seus autores a multa não superior a 10 (dez) vêzes o valor do maior salário-mínimo, independentemente das sanções disciplinares aplicáveis". Não havia a previsão de multa proporcional ao dano ao erário.

Até a nova ordem constitucional, foi editada a Lei $\mathrm{n}^{\circ}$ 6.223, de 14.07.1975, que incluíu as Sociedades de Economia Mista na jurisdição dos Tribunais de Contas (art. $7^{\circ}$, caput). Entretanto, a fiscalização conduzida pelas Cortes de Contas respeitará "as peculiaridades de funcionamento da entidade, limitando-se a verificar a exatidão das contas $e$ a legitimidade dos atos, e levará em conta os seus objetivos, natureza empresarial e operação segundo os métodos do setor privado da economia" (art. $\left.7^{\circ}, \S 1^{\circ}\right)$.

O Decreto-lei $n^{\circ}$ 199/67 não foi recepcionado, em alguns aspectos, pela Constituição de 1988 e foi revogado pela Lei n 8.443/92, nova Lei Orgânica do TCU, que é estudada ao longo desta Dissertação. 


\section{COMPETÊNCIA LEGISLATIVA}

Conforme mencionado, a responsabilidade no âmbito dos Tribunais de Contas vem sendo regulada por leis editadas no âmbito do ente federado a qual integra o órgão de controle.

Apesar da maioria das Leis Estaduais adotarem como paradigma a Lei Federal (Lei ${ }^{\circ}$ 8.443/92), não se justifica um tratamento diferenciado em matéria de responsabilidade financeira, bem como, dos procedimentos adotados pelos Tribunais de Contas.

Convém lembrar que, em determinadas situações, tais como, na realização de uma obra com recursos provenientes de mais de um ente federativo ${ }^{93}$, pode haver fiscalização conjunta dos Tribunais de Contas sobre um mesmo objeto, o que exige um procedimento similar a ser adotado pelas Cortes de Contas competentes.

Cleber Demétrio Oliveira da Silva ${ }^{94}$, nesta linha, defende a adoção de uma Lei Orgânica Nacional dos Tribunais de Contas. Conclui o autor que: "a criação de uma lei orgânica nacional para os tribunais de contas brasileiros é medida positiva a ser planejada, regulada e adotada no cenário nacional porque se constitui em perspectiva necessária e imprescindivel ao aprimoramento e fortalecimento das instituições brasileiras de controle externo" (SILVA, C., 2008).

A proposta de Cléber Demétrio Oliveira da Silva tem por base, dentre outros pontos (SILVA, C., 2008):

a) o fundamento constitucional comum dos Tribunais de Contas Brasileiros, ou seja, o fato do perfil normativo dos Tribunais de Contas estar delineado na Constituição Federal de 1988;

\footnotetext{
${ }^{93}$ Cf. Vide o Exemplo do Rodoanel Metropolitano de São Paulo. Caso houvesse recursos municipais, três Tribunais de Contas seriam, concorrentemente, competentes para fiscalizar a execução da obra: o Tribunal de Contas da União - TCU, o Tribunal de Contas do Estado de São Paulo - TCE/SP e o Tribunal de Contas do Município da São Paulo - TCM/SP.

${ }^{94}$ Cf. Lei Orgânica Nacional dos Tribunais de Contas: Instrumento de Aprimoramento das Instituições Brasileiras de Controle Externo. Disponível em: <http://www.camara.gov.br>. Acesso em: 01.10.2008.
} 
b) a similitude dos Ministros e Conselheiros dos Tribunais de Contas com a

Magistratura, para a qual é adotada uma Lei Orgânica Nacional;

c) a necessidade de uniformização de procedimentos entre os Tribunais de Contas.

Com o advento da Emenda Constitucional $n^{\circ} 40 / 2003$, alterou-se a redação do inciso $\mathrm{V}$ do art. 163 da CF/88 para atribuir à Lei Complementar a edição de normas gerais sobre a "fiscalização financeira da Administração Pública direta e indireta". A Lei Orgânica Nacional para os Tribunais de Contas deve, assim, ser adotada obrigatoriamente.

De fato, a Constituição Federal restringiu a competência legislativa dos entes federados para atribuir à lei nacional o papel de uniformizar procedimentos, poderes, sanções, medidas cautelares e matérias correlatas relativas à atuação dos Tribunais de Contas.

Esta uniformização, diga-se de passagem, encontra-se alinhada com o disposto no art. 75, da CF/88: "As normas estabelecidas nesta Seção aplicam-se, no que couber, à organização, composição e fiscalização dos Tribunais de Contas dos Estados e do Distrito Federal, bem como dos Tribunais e Conselhos de Contas dos Municípios".

José Afonso da Silva, discorrendo sobre a alteração constitucional promovida pela EC n ${ }^{\circ}$ 40/2003 (art. 163, V, CF/88), argumenta no mesmo sentido (SILVA, J., 2005, p. 685):

\footnotetext{
"Essa nova formulação normativa é mais apropriada no contexto do dispositivo, que trata de questões financeiras públicas, enquanto a fórmula anterior tinha a conotação de instituições financeiras privadas, que é matéria do art. 192 (infra). A conseqüência desta nova formulação está no fato de que a lei complementar pode estabelecer regras para a fiscalização financeira de todos os entes da Federação, se bem que a Constituição já tinha previsão de si bastante sobre essa fiscalização nos arts. 70 a 74, para a União; no art. 31, para os Municípios; e no art. 75, para os Estados, Distrito Federal e Municípios, conforme já vimos. (...) Outra conseqüência do novo enunciado está no fato de que ele amplia os fundamentos da Lei Complementar $\mathrm{n}^{\circ}$ 101/2000, especialmente seu Capitulo IX, sobre transparência, controle e fiscalização - que o texto anterior não fundamentava". (grifo nosso)
}

Em síntese, as peculiaridades locais não justificam a adoção de sanções de natureza financeira diferenciadas no âmbito de cada Estado Federado. Se a Lei 
Complementar, de caráter nacional, tem a função de estabelecer normas gerais sobre finanças públicas (art. 163, CF/88 - Lei n 4.320/64 e Lei Complementar n 101/2000), se há também normas gerais em matéria de licitações e contratações públicas (art. 22, XXVII, CF/88), nada mais razoável que as violações aos preceitos das normas de gestão sejam, também, reguladas por lei nacional, da espécie Lei Complementar. 


\section{PRINCÍPIOS GERAIS DA REPRESSÃO}

Antes de adentrarmos ao estudo dos princípios materiais e processuais da responsabilidade financeira, há de se mencionar a existência de um núcleo comum do direito repressor, composto por um conjunto de direitos e garantias mínimas das pessoas físicas e jurídicas aplicáveis a toda a atividade sancionatória do Estado. Alguns autores denominam este núcleo comum de "princípios gerais da repressão".

Tal conjunto de princípios, com as devidas adaptações, incidem sobre as sanções das mais variadas naturezas. Incidem sobre as sanções penais, administrativas, políticas e, também, as sanções financeiras, objeto deste estudo.

São princípios, implícitos ou explícitos, de natureza material ou processual, com fundamento na Constituição Federal, tais como, a legalidade, a tipicidade, a irretroatividade, vedação ao bis in idem, proporcionalidade, razoabilidade, devido processo legal, contraditório, ampla defesa, segurança jurídica e vedação da utilização no processo de provas obtidas por meios ilícitos.

Este núcleo de princípios e garantias teve origem no Direito Penal, que, até pouco tempo, era confundido como o Direito Sancionatório.

Muitos dos princípios aplicáveis à Responsabilidade Financeira, tal como no caso do Direito Administrativo Sancionador, terão origem no Direito Penal, devendo ser aplicados nas outras esferas com as devidas ponderações.

Apesar da inexistência de expressa previsão legal assegurando a transposição dos princípios do direito penal à responsabilidade financeira, tal aplicação encontra respaldo na Jurisprudência do Supremo Tribunal Federal (MS n 23.550/DF - Aplicação subsidiária da Lei de Processo Administrativo, que explicita Princípios Constitucionais, aos processo do TCU) e do Tribunal de Contas da União. 
Na lição de Fábio Medina Osório, "O Direito Punitivo, e aqui me refiro tanto ao Direito Penal quanto ao Direito Administrativo Sancionador, requer normas fundamentais, básicas, mínimas, para o balizamento das atividades punitivas do Estado" (OSORIO, 2005, p. 255).

Mais adiante, esclarece o autor que (OSORIO, 2005, p. 258):

"Há fundamentos para reconhecer substanciais e históricas distâncias entre as ramificações do Direito Punitivo, a partir da evolução penalista e administrativa do ius puniendi estatal. Porém, não se pode ignorar que progressivos processos de aproximações e globalização de fontes tentem a constituir direitos fundamentais comuns, senão similares, às relações expostas ao poder sancionador do Estado".

Sobre o tema, Fábio Medina Osório ensina que (OSORIO, 2005, p. 264):

"Não se previu a tipicidade ou a legalidade expressamente para o Direito Administrativo Sancionador, mas nem por isso as portas ficaram fechadas a essa possibilidade hermenêutica. Observe-se que o constituinte de 1988 consagra que 'ninguém será privado da liberdade ou de seus bens sem o devido processo legal' (art. $5^{\circ}$, LIV, CF/88) e que os direitos e garantias expressos na Constituição não excluem outros decorrentes do regime e dos princípios por ela adotados ou dos tratados internacionais em que a República Federativa do Brasil seja parte (art. $5^{\circ}, \S 2^{\circ}, \mathrm{CF} / 88$ ). Além disso, a mesma Carta consagrou um rol extenso de direitos fundamentais,tais como os direitos ao Estado de Direito, à segurança jurídica, à legalidade, à proporcionalidade, com um leque significativo de desdobramentos em outros direitos. Não se pode alimentar qualquer espécie de dúvida no sentido de que tais direitos afetam, muito especialmente, a atividade sancionadora do Estado, venha ela do Poder Executivo ou do Judiciário".

Paulo Roberto Coimbra Silva, ao tratar das sanções tributárias, admite a sujeição das sanções de diversas naturezas aos princípios gerais da repressão. Segundo o autor (SILVA, P., 2007,p. 277):

"existe, sim, um conjunto de princípios gerais da repressão, cuja observância é imperativa sempre quando se manifeste qualquer potestade punitiva do Estado, seja judicial ou administrativamente, que, contingencialmente, no mais das vezes, encontra-se científica e tecnicamente mais bem desenvolvida no Direito Penal, devido à maior maturidade teórica deste ramo da Ciência Jurídica no tratamento da ilicitude".

Sustenta o autor que a permeabilidade dos princípios está calcada na "na necessária coerência exigida pela adequação valorativa e unidade sistêmica do Direito" (SILVA, P., 2007, p. 273). Em alguns países, como na Alemanha, esclarece o autor, a comunicabilidade entre os princípios do ilícito penal para o ilícito fiscal tem expressa previsão legal. Em outros, como na França e Espanha, esta comunicabilidade não é expressa 
no texto legal, mas é amplamente reconhecida pela Doutrina e pela Jurisprudência (SILVA, P., 2007).

A origem histórica da comunicabilidade, segundo Paulo Roberto Coimbra Silva, estaria na Teoria da Separação dos Poderes do Estado, segundo a qual, a função repressiva deveria repousar sobre as "fortes e prudentes mãos" do Poder Judiciário, com todas as garantias do processo criminal (SILVA, P., 2007).

Entretanto, no século XX, com o crescimento do intervencionismo estatal, com a necessidade de instrumentos de eficácia imediata, passou-se a admitir que poderes sancionatórios fossem atribuídos às autoridades administrativas. A transferência do poder sancionatório para a Administração Pública não se fez sem o acompanhamento dos princípios gerais da repressão, que limitam e orientam o Poder (SILVA, P., 2007). 
PARTE II - ASPECTOS MATERIAIS

ASPECTOS MATERIAIS DA RESPONSABILIDADE FINANCEIRA 


\section{PRINCÍPIOS MATERIAIS}

Neste capítulo, são elencados os princípios que incidem sobre os aspectos materiais da responsabilidade, ou seja, os princípios pertinentes aos elementos constitutivos do direito de punir ou de ter seu patrimônio recomposto em decorrência de infração à norma de gestão pública (pressupostos, sujeitos, objeto, quantificação).

\subsection{Reserva Legal Relativa}

$\mathrm{O}$ art. $5^{\circ}$, II, da $\mathrm{CF} / 88$ preceitua que ninguém será obrigado a fazer ou deixar de fazer algo senão em virtude de lei. Trata-se do princípio da legalidade, entendido como direito fundamental, o que não se confunde com o homônimo contido no art. 37, caput, da $\mathrm{CF} / 88$ (princípio da administração pública) ${ }^{95}$.

O princípio da legalidade visa combater o poder arbitrário do Estado. Só por meio das espécies normativas devidamente elaboradas conforme as regras de processo legislativo constitucional podem-se criar obrigações para o indivíduo, pois são expressão da vontade geral. Com o primado soberano da lei, cessa o privilégio da vontade caprichosa do detentor do poder em benefício da lei (MORAES, 2006, p. 36).

O princípio da legalidade é de abrangência mais ampla do que o princípio da reserva legal. Segundo este princípio, qualquer comando jurídico impondo comportamentos forçados há de provir de uma das espécies normativas devidamente elaboradas conforme as regras do processo legislativo constitucional. Por sua vez, o princípio da reserva legal opera de forma mais restrita e diversa. Ele não é genérico e abstrato, mas concreto, incidindo tãosomente sobre os campos materiais especificados pela Constituição (MORAES, 2006, p. 37).

A reserva legal pde ser absoluta ou relativa. A reserva legal é absoluta, quando a Constituição exige a edição de lei formal para sua integral regulamentação. A reserva legal é relativa quando a Constituição Federal exige que a lei fixe tão-somente parâmetros de

\footnotetext{
${ }^{95}$ Vide citação de Hartmut Maurer - capítulo 04
} 
atuação para o órgão administrativo, que poderá complementá-la por ato infralegal, respeitados os limites ou requisitos estabelecidos pela legislação (MORAES, 2006, p. 37).

Segundo José Afonso da Silva, a doutrina não raro confunde ou não distingue suficientemente o princípio da legalidade e o princípio da reserva de lei. O primeiro significa a submissão e o respeito à lei, ou a atuação dentro da esfera estabelecida pelo legislador. O segundo consiste em estatuir que a regulamentação de determinadas matérias há de fazer-se necessariamente por lei formal. É de reconhecer-se a diferença entre ambos os princípios, pois, no caso de reserva de lei, o legislador deve ditar uma disciplina mais específica do que é necessário para satisfazer o princípio da legalidade (SILVA, J., 2005, p. 83).

Para José Afonso da Silva, é absoluta a reserva constitucional de lei quando a disciplina da matéria é reservada pela Constituição à lei, com exclusão de qualquer outra fonte infralegal - o que ocorre quando ela emprega fórmulas como: "a lei regulará", "a lei disporá", "a lei complementar organizará", "a lei criará", "a lei poderá definir", etc. É relativa quando a disciplina da matéria é em parte admissível a outra fonte diversa da lei, sob a condição de que esta indique as bases em que aquela deva produzir-se validamente. Neste caso, a Constituição emprega fórmulas como: "nos termos da lei", "no prazo da lei", "na forma da lei", "nos limites da lei", "segundo critérios da lei" (SILVA, J., 2005, p. 84).

No tocante às sanções administrativas, Regis Fernandes de Oliveira adverte acerca da divergência quanto ao exato alcance da exigência de previsão legal das infrações e sanções. Dentre os que admitem a possibilidade de previsão de infração e sanção sem lei, o autor cita Miguel Montoro Puerto, D. Papanicolaidis e Guido Zanobini (OLIVEIRA, R., 2005).

No tocante à Responsabilidade Financeira, a possibilidade de previsão das infrações e das sanções correspondentes em dispositivos infralegais é expressamente descartada pelo art. 71, VIII, CF/88, segundo o qual compete ao Tribunal de Contas da União: "aplicar aos responsáveis, em caso de ilegalidade de despesa ou irregularidade de contas, as sanções previstas em lei, que estabelecerá, entre outras cominações, multa proporcional ao dano ao Erário". 
Neste sentido, a Jurisprudência do Superior Tribunal de Justiça (STJ) é cristalina quanto à impossibilidade do Tribunal de Contas aplicar multa com base em previsão em norma infralegal (por exemplo, Regimento Interno):

\footnotetext{
"ADMINISTRATIVO. MULTA APLICADA PELO TRIBUNAL DE CONTAS BASEADA EM AUTORIZAÇÃO REGIMENTAL. OFENSA AO PRINCÍPIO DA LEGALIDADE.

(...) o Tribunal de Contas não pode, baseando-se em autorização regimental, aplicar multa a quem não entrega, ou o faz fora do prazo, documentos sujeitos à fiscalização. (Superior Tribunal de Justiça, $1^{\mathrm{a}}$. Turma, RMS $\mathrm{n}^{\circ}$ 15.620/PB, Rel. Min. Francisco Falcão, DJ 16.08.2004, p. 133)

ADMINISTRATIVO. MULTA CRIADA POR RESOLUÇÃO DO TRIBUNAL DE CONTAS DO ESTADO DA PARAÍBA. FALTA DE PREVISÃO LEGAL. ILEGALIDADE. OFENSA AO PRINCÍPIO DA LEGALIDADE DAS PENAS (ART. $5^{\circ}$, XXXIX, DA CF).

1. A Resolução no 12/2001 do Tribunal de Contas do Estado da Paraíba, ao regulamentar o art. 56 da Lei Orgânica daquele órgão, extrapolou os limites aí estabelecidos, criando nova hipótese de incidência de multa, o que ofende, além da própria Lei Orgânica, o princípio constitucional da legalidade.

2. A ilegalidade manifesta-se na criação de nova hipótese típica, não prevista na lei, bem como pelo caráter automático da multa, que não permite a sua gradação, o que afronta o comando contido no $\S 2^{\circ}$ do art. 56 da referida Lei Orgânica. (Superior Tribunal de Justiça, RMS $n^{\circ}$ 15.578/PB, Rel. Min. Francisco Falcão, DJ 09.12.2003, p. 210)
}

Esta Corte Superior também admitiu a possibilidade de que a Responsabilidade Financeira esteja genericamente prevista em lei, podendo, entretanto, ser regulamentada por atos normativos infralegais (Instruções Normativas do Tribunal de Contas):

\footnotetext{
"ADMINISTRATIVO - TRIBUNAL DE CONTAS DO ESTADO - IMPOSIÇÃO DE PENA PECUNIÁRIA: LEGALIDADE.

1. Os Tribunais de Contas dos Estados, com respaldo no art. 71, VIII da CF/88, podem estabelecer por lei sanção pecuniária.

2. O Estado de Minas Gerais conta com dispositivo em sua Constituição, de conteúdo idêntico ao da CF/88, regulamentado pela LC Estadual n. 33/94 e detalhada por Instruções da Corte de Contas". (Superior Tribunal de Justiça, 2 ${ }^{\mathrm{a}}$. Turma, RMS n ${ }^{\circ}$ 11.426/MG, Rel. Min. Eliana Calmon, DJ. 04.06.2001, p. 84)
}

Com base nestas considerações, a responsabilidade financeira encontra-se sujeita à reserva legal relativa, uma vez que, esta matéria, apesar requerer lei em sentido formal para a definição das infrações e sanções (Lei Complementar - após a edição da EC $n^{\circ}$ 41), admite que seu detalhamento seja tratado pela legislação infralegal. No âmbito Federal, com efeito, o art. 268, do Regimento Interno do TCU (RITCU), define as faixas de valores dentro das quais o TCU pode fixar multa para as infrações previstas no art. 58, da Lei ${ }^{\circ}$ 
8.443/92. Estas faixas não podem ultrapassar o teto fixado em lei (art. 58, caput, Lei $\mathrm{n}^{\circ}$ 8.443/92).

Como aplicação imediata deste preceito, não pode o Tribunal de Contas aplicar, no âmbito do processo contábil, multa por litigância de má-fé, ante à ausência de previsão legal, sendo vedada, neste caso, a aplicação analógica de dispositivo do Código de Processo Civil. Tal posicionamento encontra-se respaldado em deliberações do TCU (Acórdão n 215/2001-1 a . Câmara, Acórdão n 231/2002 - Plenário e Acórdão n 830/2002 $1^{\mathrm{a}}$. Câmara).

\subsection{Princípio da tipicidade aberta.}

O princípio da tipicidade, apesar de não estar expressamente contido no Texto Constitucional, é desdobramento necessário do princípio da legalidade. Seja na modalidade sancionatória, seja na modalidade reintegratória, o modelo de responsabilidade financeira submete-se, em especial, à chamada tipicidade aberta ${ }^{96}$.

Dentre os ramos do Direito Punitivo, é no Direito Penal que o tema encontrase mais desenvolvido. Assim, previamente à discussão do princípio aplicável à responsabilidade financeira, analisamos as lições dos autores de Direito Penal e de Direito Administrativo.

\subsubsection{Conceito de Tipo e Tipicidade no âmbito do Direito Penal}

Segundo o Dizionario Giuridico Simone On line ${ }^{97}$, no Direito penal a tipicidade é

\footnotetext{
"uma característica essencial do delito, o qual, com base no princípio da legalidade, deve ser descrito pelos tipos legais, ou seja, é a norma que deve individualizar especificamente o comportamento vedado. É típico, portanto, o fato que realiza todos os elementos essenciais requeridos pela norma de integração do delito. A conformidade com a "fattispecie" legal,

${ }^{96}$ Entretanto, os tipos previstos no art. $5^{\circ}$, da Lei ${ }^{\circ} 10.028 / 2000$ e em alguns incisos do art. 58, da Lei ${ }^{\circ}$ $8.443 / 92$ tem o caráter fechado.

${ }^{97} \mathrm{http}: / / \mathrm{www}$.dizionarionline.it
} 
notadamente ao fato abstratamente previsto pelo legislador, é que permite se considerar um fato concreto como um crime" (tradução livre) ${ }^{98}$.

Luiz Regis Prado esclarece que o Direito Penal é, por excelência, um direito tipológico. O tipo é uma descrição abstrata de um fato real que a lei proibe (tipo incriminador). O tipo é um modelo, esquema conceitual da ação ou omissão vedada, dolosa ou culposa (PRADO, L., 2006). Segundo Regis Prado, é expressão concreta dos específicos bens jurídicos amparados pela Lei Penal. Tipicidade é a subsunção ou adequação do fato ao modelo previsto no tipo legal. É um predicado, atributo da ação, que a considera típica (juízo de tipicidade positivo) ou atípica (juízo de tipicidade negativo). A tipicidade é a base do injusto penal (PRADO, L., 2006).

Dentre as funções do tipo penal, Regis Prado aponta (PRADO, L., 2006):

a) função seletiva: o tipo é que indica os comportamentos que são protegidos pela norma penal, que interessam ao Direito Penal.

b) função de garantia e de determinação: compreende o cumprimento do princípio da legalidade dos delitos e das penas, formal e materialmente, inclusive quanto ao requisito da taxatividade;

c) fundamento da ilícitude;

d) função indiciária da ilicitude: é a tipicidade a ratio cognoscendi da ilicitude;

e) criação do mandamento proibitivo: matéria proibida ou determinada;

f) determinação do iter criminis: assinala o início e o fim do processo executivo do crime.

Fernando Capez esclarece que o tipo é o molde criado pela lei, em que está descrito o crime com todos os seus elementos, de modo que as pessoas sabem que só cometerão algum delito se vierem a realizar uma conduta idêntica à constante do modelo legal. O tipo é criado com a função de garantia do direito da liberdade (CAPEZ, 2005). Neste sentido, o autor esclarece que a generalidade da descrição típica elimina a sua própria razão

\footnotetext{
98 È un carattere essenziale del reato, che in base al principio di legalità, deve essere descritto per tipi legali, cioè è la norma che deve individuare specificamente il comportamento vietato. È tipico, quindi, il fatto che realizza tutti gli elementi essenziali richiesti dalla norma ad integrazione del reato. La conformità alla fattispecie legale, cioè al fatto astrattamente ipotizzato dal legislatore, è ciò che consente di considerare un fatto concreto come reato.
} 
de existir, criando insegurança no meio social e violando o princípio da reserva legal. Não há propriamente tipo, exemplifica, quando se castiga "todo ato contrário à revolução" ou "qualquer conduta contrária aos interesses nacionais", etc (CAPEZ, 2005).

\subsubsection{Tipicidade como desdobramento do principio da legalidade}

Francisco de Assis Toledo menciona que o princípio da legalidade no Direito Penal (nullum crimen, nulla poena sine lege), na concepção atual de garantia da lei penal, é desdobrado em quatro outros princípios (TOLEDO, 2002, p. 22):

a) nullum crimen, nulla poena sine lege praevia - proibição de edição de leis retroativas que fundamentem ou agravem a punibilidade;

b) nullum crimen, nulla poena sine lege scripta - proibição de fundamentação ou agravamento da punibilidade pelo direito consuetudinário;

c) nullum crimen, nulla poena sine lege stricta - proibição da fundamentação ou do agravamento da punibilidade pela analogia;

d) nullum crimem, nulla poena sine lege certa - proibição de leis indeterminadas.

A exigência de lei certa diz com a clareza dos tipos, que não devem deixar margens a dúvidas nem abusar do emprego de normas muito gerais ou tipos incriminadores genéricos, vazios. Para que a lei penal possa desempenhar função pedagógica e motivar o comportamento humano, necessita ser facilmente acessível a todos, não só aos juristas (TOLEDO, 2002, p. 29).

A tipicidade é, assim, um dos desdobramentos da legalidade, juntamente como os princípios da irretroatividade e da proibição da analogia em matéria penal. 


\subsubsection{Classificação Tipos abertos e Tipos Fechados}

Dentre as diversas classificações dos tipos, interessa-nos a distinção entre Tipo Aberto e Tipo Fechado. Regis Prado esclarece que o tipo é fechado, se a descrição legal da ação proibida for completa em todos os seus aspectos fácticos. Por exemplo, nos crimes de homicídio simples e lesão corporal. Tipo aberto é aquele que descreve parte da ação proibida, devendo ser completado pelo julgador. A tipicidade, assim, depende de um juízo axiológico autônomo. Como exemplos, cita o homicídio e a lesão corporal culposos, os elementos normativos do tipo do arts. 177 e do art. 259 (PRADO, L., 2006).

Acerca desta distinção é interessante a lição de Francisco de Assis Toledo (TOLEDO, 2002, p. 136):

\footnotetext{
"Na criação dos tipos penais, pode o legislador adotar dois critérios. O primeiro consiste na descrição completa do modelo de conduta proibida, sem deixar ao intérprete, para verificação da ilicitude, outra tarefa além da constatação da correspondência entre a conduta concreta e a descrição típica, bem como a inexistência de causas de justificação. Tal critério conduz à construção dos denominados 'tipos fechados', do qual seria exemplo o homicídio do art. 121 do Código Penal. A descrição 'matar alguém', por ser completa, não exigiria do intérprete qualquer trabalho de complementação do tipo. (...) O segundo critério consiste na descrição incompleta do modelo de conduta proibida, transferindo-se para o intérprete o encargo de completar o tipo, dentro dos limites e das indicações nele próprio contidas. São os denominados 'tipos abertos', como se dá em geral com os delitos culposos que precisam ser completados pela norma geral que impõe a observância do dever de cuidado".
}

Como se verá a seguir, o tipo aberto aplicado à responsabilidade financeira tem a flexibilidade necessária para abranger diversas fraudes e irregularidades cometidas no âmbito da Administração Pública.

\subsubsection{Aplicação do princípio da tipicidade à Responsabilidade Administrativa}

Neste tópico, discorro sobre a aplicação do princípio da tipicidade às sanções administrativas, na visão dos autores brasileiros: Heraldo Garcia Vitta, Daniel Ferreira e Fábio Medina Osório. 
Segundo Garcia Vitta, "a tipicidade é a qualidade da norma de estabelecer, previamente, a conduta a respeito da qual se atribuirá uma determinada sanção a quem realiza-la" (VITTA, 2003, p. 88). Trata-se, segundo o autor, de corolário do princípio da legalidade. Além de a lei formal estabelecer as infrações e as sanções, deverá, taxativamente, determinar a conduta que corresponderá à sanção imposta (VITTA, 2003, p. 88).

O autor divide o tema da tipicidade em função de duas relações de supremacia do Estado: supremacia geral e supremacia especial (VITTA, 2003).

Nas relações de supremacia geral do Estado (em que a sujeição do particular não se atém a determinado liame jurídico prévio), o princípio da legalidade tem total intensidade. Somente a lei, salienta Garcia Vitta, poderá estipular infrações e penalidades administrativas, observada a impossibilidade de ampla disparidade de graduação de mínimo e máximo da pena: "(...) na supremacia geral, o mínimo que se espera é a lei garantir, tanto na causa como na conseqüência, a segurança necessária aos indivíduos do Estado. Por isso, ela deverá estipular as condutas e as conseqüentes sanções" (VITTA, 2003, p. 85).

Nas relações de sujeição especial, na qual há um liame prévio entre o Estado e o particular, poderá ocorrer um abrandamento do princípio da legalidade, na medida da intensidade do liame que liga o particular ao Estado (VITTA, 2003).

Estes abrandamentos, segundo Garcia Vitta, sujeitam-se a alguns limites (VITTA, 2003):

a) Seria possível a utilização de conceitos jurídicos indeterminados ${ }^{99}$ ou cláusulas gerais, apenas quando houver a impossibilidade do legislador prever todos os comportamentos que possam ser sancionados;

\footnotetext{
${ }^{99}$ Cf. Maria Sylvia Zanella Di Pietro esclarece que (DI PIETRO, 2001, p. 97) "A expressão conceito jurídico indeterminado, embora bastante criticável, ficou consagrada na doutrina de vários países, como Alemanha, Itália, Portugal, Espanha e, mais recentemente, no Brasil, sendo empregada para designar vocábulos ou expressões que não têm um sentido preciso, objetivo, determinado, mas que são encontrados com grande freqüência nas normas jurídicas dos vários ramos do direito. Fala-se em boa-fé, bem comum, conduta irrepreensível, pena adequada, interesse público, ordem pública, notório saber, notória especialização, moralidade, razoabilidade e tantos outros".
} 
b) No caso de utilização de conceitos jurídicos indeterminados e cláusulas gerais, somente a lei formal, editada pelo Poder Legislativo, poderá conte-las, a fim de garantir o mínimo de segurança aos indivíduos ligados à Administração; c) A lei, ao utilizar conceitos abertos ou indeterminados, ou cláusulas gerais, deverá determinar, taxativamente, as sanções correlatas;

d) A lei deverá restringir o alcance das palavras plurissignificativas.

Daniel Ferreira não aborda explicitamente o tema da tipicidade das sanções administrativas, mas sustenta que é legítimo admitir a possibilidade de outorga legislativa, explícita ou implícita, de certa parcela de discricionariedade à Administração Pública na circunscrição dos ilícitos administrativos, bem como na prévia cominação das respectivas sanções (FERREIRA, 2001).

Acrescenta que, quando a lei, por sua generalidade e abstração, não determina com precisão qual a conduta ou, melhor, a categoria de condutas que desde logo assinala como proibidas, deve o Executivo restringir as possibilidades, nos limites nela previstos, garantindo uma maior segurança jurídica e, sempre que possível, um tratamento isonômico a todos os administrados (FERREIRA, 2001).

O autor reconhece, também, a diferença de tratamento jurídico para as relações de sujeição geral e especial (FERREIRA, 2001, p. 100-102):

\footnotetext{
"Onde houver cogente submissão do particular à Administração Pública somente poderá lei formal prever as infrações e cominar as respectivas sanções. De modo diverso, nas situações de assunção voluntária (ou não-juridicamente obrigatória) de deveres a lei deverá, ainda que genericamente, estipular os ilícitos, bem como indicar as sanções imponíveis. Nestas duas hipóteses competirá à Administração Pública, ou quem lhe faça as vezes, quando necessário para fins de minimizar a discricionariedade (da lei decorrente) e garantir tratamento isonômico a todos, editar regulamentos e demais atos normativos infralegais para fins de regular a sua aplicação

(...)

A inexistência de regulamento, ao revés, não implica, necessariamente, a impossibilidade de legitimamente se impor uma sanção em virtude de o tipo infracional se fazer apresentar, e.g., por um conceito jurídico indeterminado (dotado de vagueza e imprecisão). O que urge é verificar, em cada caso concreto, se a conduta apresenta-se como típica, antijurídica e voluntária.".
} 
Segundo Fábio Medina Osório, a função do tipo é proporcionar segurança jurídica aos jurisdicionados e administrados. É o tipo que, segundo o autor, assegura uma previsibilidade mínima acerca das possibilidades de exercício da pretensão punitiva estatal. Além disso, o tipo exerce uma função pedagógica e preventiva ao anunciar formalmente os comportamentos reprimidos. Nas palavras do autor, "A sociedade deve estar habilitada a perceber, de uma perspectiva formal e material, o conteúdo das proibições, de modo que possam os tipos desempenhar importantes funções preventivas, evitando o cometimento de ilícitos" (OSORIO, 2005, p. 268).

Para o atendimento destas funções, "os tipos devem ser claros, suficientemente densos, dotados de um mínimo de previsibilidade quanto ao seu conteúdo" (OSORIO, 2005, p. 268).

Ao abordar o problema das normas excessivamente vagas, o Osório admite que a tipicidade do ilicito administrativo pode ser composta por conceitos ou termos indeterminados, vazados em cláusulas gerais, regras ou princípios, que descrevem abstratamente, as condutas proibidas, com um mínimo de previsibilidade (OSORIO, 2005).

O princípio da legalidade e da tipicidade, segundo Osório, apresentam enfoques distintos ao se tratar das relações jurídicas de sujeição geral e especial (OSORIO, 2005, p. 275):

\footnotetext{
"As pessoas que não estão submetidas a essas relações especial de sujeição possuem, em tese, uma liberdade de agir similar a dos particulares em geral, cuja posterior limitação se opera à luz de uma estrita legalidade, num marco acentuadamente mais garantista. Já os que se submetem a esses vínculos de sujeição especial ficam expostos a uma legalidade mais flexível e aberta, eis que ostentam uma primária restrição comportamental, de tal sorte que suas atuações dependem de permissões legais e a disciplina normativa do Estado pode ser encarada, na perspectiva sancionatória, de modo mais rigoroso. Maior expressão de relações de sujeição especial constitui, ao meu ver, a situação dos agentes públicos, dada a específica vinculação destes a um regime estatutário e a normas de conduta bastante estritas. Dependendo do estatuto, tanto maior será o regime de sujeição especial, tal como ocorre com as polícias, o exército e tantas outras classes de servidores ou funcionários públicos".
} 


\title{
10.2.5. Tipicidade dos Atos de Improbidade Administrativa
}

A improbidade administrativa não é sinônimo de ilicitude. É uma ilícitude qualificada pela desonestidade do sujeito ativo, motivo pelo qual muitos autores entendem que a improbidade administrativa só decorre de condutas dolosas (vide STJ, Resp. $\mathrm{n}^{\circ}$ 939.142/RJ). Os atos de improbidade administrativa estão classificados em três grupos distintos: atos que importam em enriquecimento ilícito (art. $9^{\circ}$ ), atos que causam prejuízo ao erário (art. 10) ou atos que atentam contra aos princípios da administração pública (art. 11).

Francisco Octavio de Almeida Prado aponta que o princípio da tipicidade está intimamente ligado ao princípio da legalidade e é, na verdade, um modo de realização da legalidade, que exige a definição precisa da conduta que a lei pretende erigir em constitutiva de infração, bem como a sanção que lhe corresponde (PRADO, F., 2001).

\begin{abstract}
Acrescenta o autor que (PRADO, F., 2001, p. 33):
"Ainda que se queria entender que a exigência da tipicidade no campo extrapenal possa sofrer alguma atenuação, será necessário que a norma legal defina com precisão o ato ou omissão constitutivo do ilícito e prefigure, também com clareza, a sanção aplicável. E a exigência de tipicidade revela-se mais intensa em relação aos atos de improbidade administrativa do que para a configuração de outras faltas administrativas, onde seria admissível maior flexibilidade. E isso pelo fato de que os atos de improbidade administrativa, sendo puníveis com a gravíssima sanção suspensiva dos direitos políticos, intensificam a exigência de segurança jurídica (...)".
\end{abstract}

Acerca da descrição, precisa ou genérica, dos atos de improbidade administrativa, o autor se manifesta (PRADO, F., 2001, p. 34):

\footnotetext{
"Cabe observar que o princípio da tipicidade exige um mínimo de precisão no delineamento das figuras infracionais, sendo inadmissíveis as tipificações imprecisas e ambíguas, com excesso de fórmulas abertas, cláusulas de extensão analógica e abuso de conceitos indeterminados. Assim, a vagueza e a imprecisão são sempre indesejáveis na definição de ilícitos, em face das exigências da legalidade e tipicidade. Sua presença contraria os imperativos de segurança jurídica e previsibilidade - valores que o princípio da tipicidade visa a preservar".
}

Nesta linha, o autor conclui que o elenco de atos de improbidade administrativa constantes do arts. $9^{\circ}$ a 11 , da Lei $n^{\circ} 8.429 / 92$ é taxativo (PRADO, F., 2001, p. 35): 
"Examinadas as disposições dos arts. 9, 10 e 11 da Lei $\mathrm{n}^{\circ}$ 8429, de 1992, em face dessas considerações, observa-se que as fórmulas dos capita desses três artigos são demasiado genéricas na sua formulação. E, de outra banda, percebe-se claramente que é perfeitamente possível a formulação de hipóteses claras e específicas a partir do núcleo formulado no caput de cada artigo, tanto assim que essas hipóteses estão efetivamente enunciadas nos diferentes incisos que se seguem.

(...)

Concluímos, portanto, que a pretensão de ver configurados outros ilícitos que não os definidos pelos incisos dos três artigos mostra incompatível com as exigências de legalidade e tipicidade - razão pela qual, em homenagem a tais princípios, entendemos resultarem taxativas as hipóteses enunciadas pelos incisos dos arts. $9^{\circ}, 10$ e 11, da Lei ${ }^{\circ} 8.429$, de 1992. De fato, não se pode pretender que o destinatário da norma preveja o que nem o legislador conseguiu prever, ou seja, outras figuras de ilícito além daquelas que foram desenvolvidas a partir do núcleo de cada categoria, enunciado nos capita dos três artigos referidos".

\section{Em posição oposta, Emerson Garcia e Rogério Pacheco Alves esclarecem que} a técnica adotada pelo legislador na Lei $\mathrm{n}^{\circ} 8.429 / 92$ foi descrever o tipo no "caput" com conceitos jurídicos indeterminados e, nos incisos, exemplificar situações em que o tipo é preenchido (GARCIA; ALVES, 2006, p. 245):

"da leitura dos referidos dispositivos legais, depreende-se a coexistência de duas técnicas legislativas: de acordo com a primeira, vislumbrada no caput dos dispositivos tipificadores da improbidade, tem se a utilização de conceitos jurídicos indeterminados, apresentando-se como instrumento adequado ao enquadramento do infindável número de ilícitos passíveis de serem praticados, os quais são frutos inevitáveis da criatividade e do poder de improvisação humanos; a segunda, por sua vez, foi utilizada na formação de diversos incisos que compõem os arts. $9^{\circ}, 10$ e 11, tratando-se de previsões, específicas ou passíveis de integração, das situações que comumente consubstanciam a improbidade, as quais além de facilitar a compreensão dos conceitos indeterminado veiculados no caput, têm natureza meramente exemplificativa, o que deflui do próprio emprego do advérbio 'notadamente'".

Em oposição aqueles que defendem a aplicação irrestrita dos preceitos de

Direito Penal aos atos de improbidade administrativa (incluindo a taxatividade dos atos de improbidade administrativa, inconstitucionalidade da utilização de conceitos jurídicos indeterminados, etc), os autores assim se manifestam (GARCIA; ALVES, 2006):

"Com a devida vênia, não encampamos esse entendimento. Não bastasse a letra da lei, acresça-se que os princípios afetos ao direito penal, subsidiariamente aplicáveis sempre que o Estado exerça seu poder sancionador, devem sofrer as necessárias compatibilizações quando transpostos para outros ramos do direito.(...) Aqui é importante distinguir a situação jurídica daquele que administra a coisa pública em relação aos cidadãos, que estão sujeitos ao ius puniendi do Estado pelo simples fato de viverem em seu território ou serem seus nacionais. Considerando que certamente se objetará que os agentes público também podem ser sujeitos ativos de infrações penais, devemos acrescer que as sanções penais atingem o status dignitatis do indivíduo de forma mais incisiva, gerando variados efeitos secundários; e somente o legislador - não o intérprete - (...) pode tipificar penalmente determinada conduta, o que, por via reflexa, tornará aplicáveis todos os princípios inerentes ao direito penal. Não cominando a 
Lei de Improbidade sanções de natureza penal, outros haverão de ser os princípios informativos".

\subsubsection{Aplicação do princípio da tipicidade à Responsabilidade Financeira}

A questão principal deste tópico é verificar como é a aplicação do princípio da tipicidade no âmbito da Responsabilidade Financeira e questionar se os tipos legais asseguram a segurança jurídica e a função pedagógica do tipo. É importante destacar, de plano, que a relação que se estabelece entre o gestor de recursos públicos e o Estado é uma relação de sujeição especial, o que, conforme as lições acima apresentadas, admite um abrandamento no princípio da tipicidade, com a utilização de conceitos jurídicos indeterminados.

\subsubsection{Tipicidade na Responsabilidade Financeira Reintegratória}

A Lei $n^{\circ}$ 8.443/92 não define precisamente as hipóteses que ensejam a aplicação da responsabilidade financeira reintegratória. Não há um elenco exaustivo ou exemplificativo de condutas abstratamente definidas que ensejam a obrigação de repor ao patrimônio público. Limita-se a Lei a mencionar o termo "débito", que, grosso modo, pode ser entendido como sinônimo de "dano ao erário"100.

A propósito, dispõe o art. 19, caput, da Lei $\mathrm{n}^{\circ}$ 8.443/92 que:

"Quando julgar as contas irregulares, havendo débito, o Tribunal condenará o responsável ao pagamento da dívida atualizada monetariamente, acrescida dos juros de mora devidos, podendo, ainda, aplicar-lhe a multa prevista no art. 57 desta lei, sendo o instrumento da decisão considerado título executivo para fundamentar a respectiva ação de execução".

A Constituição Federal também não teve o condão de definir ou delimitar os pressupostos para a obrigação de repor. Com efeito, a expressão "perda, extravio ou outra irregularidade de que resulte prejuízo ao erário público" contida no art. 71, inciso II, da $\mathrm{CF} / 88$ é muito genérica e não indica todos os pressupostos da responsabilidade contábil.

\footnotetext{
${ }^{100}$ Vide discussão sobre o conceito de dano em responsabilidade financeira no capítulo 11.
} 
Em Portugal, antes da alteração promovida pela Lei $n^{\circ} 48 / 2006$, a obrigação de repor só poderia surgir de quatro hipóteses típicas: o alcance, o desvio de dinheiros, o pagamento indevido e a renúncia indevida de receitas. Com efeito, o próprio Tribunal de Contas de Portugal já pronunciou que (PORTUGAL, 1999, p. 14):

"(...)o que verdadeiramente distingue a responsabilidade financeira reintegratória da figura da responsabilidade civil de Direito Privado, é o facto de, enquanto esta poder resultar de qualquer acção não tipificada na lei que seja susceptível de provocar um dano, aquela resulta apenas de um conjunto de ações tipificadas na lei susceptíveis de causar danos patrimoniais numa esfera pública".

Com a nova redação, o art. 61\%, da Lei $\mathrm{n}^{\circ}$ 98/97 (alterada pela Lei $\mathrm{n}^{\circ}$ 48/2006) assim dispõe: "Sempre que da violação de normas financeiras, incluindo no domínio da contratação pública, resultar para a entidade pública obrigação de indemnizar, o Tribunal pode condenar os responsáveis na reposição das quantias correspondentes". Desta forma, não subsiste, em Portugal, a tipicidade cerrada das condutas que podem dar ensejo à responsabilidade financeira reintegratória.

$\mathrm{Na}$ Espanha, as mesmas considerações são aplicáveis, pois, não apenas os alcances ou as "malversaciones" dão ensejo a responsabilidade contábil, conforme esclarece Carles Rosiñol I Vidal (VIDAL, 1999, p. 73-74):

"Entre la definición genérica de responsabilidad contable, establecida en el artículo 49 de la LFTCu, y las definiciones de alcance y malversación, establecidas en el artículo 72 de la LFTCu, hay un margen donde se hallan una serie de supuestos que pueden ser incluidos dentro del concepto de responsabilidad contable, pero que no son subsumibles en las definiciones del mencionado artículo 72. Estos supuestos de responsabilidad contable nacen como casos residuales, que podríamos calificar de innominados".

\subsubsection{Tipicidade na Responsabilidade Financeira Sancionatória}

A responsabilidade sancionatória compreende a aplicação de sanção pecuniária, multa, no caso de infrações essencialmente financeiras e infrações não essencialmente financeiras. No primeiro caso, vislumbramos três situações distintas: dano ao Erário (no qual é cominada multa proporcional ao dano ao erário, além da condenação em débito), infrações do art. $5^{\circ}$, da Lei $\mathrm{n}^{\circ}$ 10.028/2000 (multa de até 30\% da remuneração anual) 
e por grave infração à norma de natureza financeira e orçamentária (multa simples). No segundo caso, infrações não essencialmente financeiras, tratamos de hipóteses em que há violação ao dever de colaboração do agente público com o exercício do controle externo, cabendo, apenas, multa simples.

A seguir, apresentamos extratos das Leis Orgânicas do Tribunal de Contas da União e de alguns Tribunais de Contas dos Estados da federação, com o fito de ilustrar o que foi exposto. Por fim, são destacadas as hipóteses do art. $5^{\circ}$, da Lei Federal $n^{\circ}$ 10.028/2000 (sanções pessoais aos preceitos da LRF).

União - Lei Federal n ${ }^{\circ}$ 8.443/92

Art. 57. Quando o responsável for julgado em débito, poderá ainda o Tribunal aplicar-lhe multa de até cem por cento do valor atualizado do dano causado ao erário.

Art. 58. O Tribunal poderá aplicar multa de Cr\$42.000.000,00 (quarenta e dois milhões de cruzeiros), ou valor equivalente em outra moeda que venha a ser adotada como moeda nacional, aos responsáveis por:

I - contas julgadas irregulares de que não resulte débito, nos termos do parágrafo único do art. 19 desta lei;

II - ato praticado com grave infração à norma legal ou regulamentar de natureza contábil, financeira, orçamentária, operacional e patrimonial;

III - ato de gestão ilegítimo ou antieconômico de que resulte injustificado dano ao erário;

IV - não atendimento, no prazo fixado, sem causa justificada, a diligência do Relator ou a decisão do Tribunal;

V - obstrução ao livre exercício das inspeções e auditorias determinadas;

VI sonegação de processo, documento ou informação, em inspeções ou auditorias realizadas pelo Tribunal;

VII - reincidência no descumprimento de determinação do Tribunal.

$\S 1^{\circ}$ Ficará sujeito à multa prevista no caput deste artigo aquele que deixar de dar cumprimento à decisão do Tribunal, salvo motivo justificado.

Rio Grande do Sul - Lei Estadual n ${ }^{\circ} 11.424 / 2000$

Art. 67 As infrações às leis e regulamentos relativos à administração contábil, financeira, orçamentária, operacional e patrimonial sujeitarão seus autores à multa de valor não superior a 1.500 (um mil e quinhentas) Unidades Fiscais de Referência, independente das sanções disciplinares aplicáveis.

Santa Catarina - Lei Complementar n ${ }^{\circ}$ 202/2000

Art. 68. Quando o responsável for julgado em débito, além do ressarcimento a que está obrigado, poderá ainda o Tribunal aplicar-lhe multa de até cem por cento do valor do dano causado ao erário.

Art. 69. O Tribunal aplicará multa de até cinco mil reais aos responsáveis por contas julgadas irregulares de que não resulte débito, nos termos do parágrafo único do art. 21 desta Lei.

Art. 70. O Tribunal poderá aplicar multa de até cinco mil reais aos responsáveis por:

I - ato de gestão ilegal, ilegítimo ou antieconômico do qual resulte dano ao erário;

II - ato praticado com grave infração a norma legal ou regulamentar de natureza contábil, financeira, orçamentária, operacional e patrimonial; 
III — não-atendimento, no prazo fixado, à diligência ou recomendação do Tribunal;

IV — obstrução ao livre exercício das inspeções e auditorias determinadas;

$\mathrm{V}$ - sonegação de processo, documento ou informação, em inspeção ou auditorias;

VI - reincidência no descumprimento de decisão do Tribunal; e

VII - inobservância de prazos legais ou regulamentares para remessa ao Tribunal de balancetes, balanços, informações, demonstrativos contábeis ou de quaisquer outros documentos solicitados, por meios informatizado ou documental.

$\S 1$ o Fica ainda sujeito à multa prevista no caput deste artigo aquele que deixar de cumprir, injustificadamente, decisão do Tribunal, bem como o declarante que não remeter cópia da declaração de bens ao Tribunal ou proceder a remessa fora do prazo previsto no Regimento Interno.

§ 20 O responsável que não mantiver cópia de segurança de arquivos atualizados em meio eletrônico, magnético ou digital, contendo os demonstrativos contábeis, financeiros, orçamentários, patrimoniais e demais dados indispensáveis à fiscalização do Tribunal, fica sujeito à multa prevista no caput deste artigo, sem prejuízo de outras cominações legais.

São Paulo - Lei Complementar n 709/1993

Artigo 104 - O Tribunal de Contas poderá aplicar multa de até 2.000 (duas mil) vezes o valor da Unidade Fiscal do Estado de São Paulo (UFESP) ou outro valor unitário que venha a substituí-la, aos responsáveis por:

I - contas julgadas irregulares de que não resulte débito;

II - ato praticado com infração à norma legal ou regulamentar;

III - não atendimento, no prazo fixado, sem causa justificada, de diligência do Conselheiro Relator ou do Conselheiro Julgador Singular, ou de decisão do Tribunal de Contas;

IV - obstrução ao livre exercício das inspeções e auditorias determinada;

$\mathrm{V}$ - sonegação de processo, documento ou informação, em inspeções ou auditorias realizadas pelo Tribunal de Contas; e

VI - reincidência no descumprimento de determinação ou instruções do Tribunal de Contas.

$\S 1^{\circ}$ - Ficará sujeito à multa prevista neste artigo aquele que deixar de dar cumprimento à decisão do Tribunal de Contas, salvo motivo justificado.

Rio de Janeiro - Lei Complementar 63/1990

Art. 63 - O Tribunal de Contas poderá aplicar multa de até 1.000 (mil) vezes o valor da UFERJ aos responsáveis por:

I - contas julgadas irregulares de que não resulte débito, nos termos do art. 23, parágrafo único desta lei;

II - ato praticado com grave infração à norma legal ou regulamentar de natureza contábil, financeira, orçamentária, operacional e patrimonial;

III - ato ilegal, ilegítimo ou antieconômico, inclusive editais de licitação, de que resulte, ou possa resultar, dano, ao erário;

IV - não atendimento, no prazo fixado, sem causa justificada, a diligência ou a decisão do Tribunal;

V - obstrução ao livre exercício das inspeções ou auditorias determinadas;

VI - sonegação de processo, documento ou informação, em inspeções ou auditorias realizadas pelo Tribunal;

VII - reincidência no descumprimento da decisão do Tribunal.

$\S 1^{\circ}$ - Ficará sujeito à multa prevista no caput deste artigo aquele que deixará de cumprir a decisão do Tribunal, salvo, motivo justificado, a critério do Plenário.

Mato Grosso - Lei Complementar n 269/2007

Art. 75 O Tribunal aplicará multa de até 1000 (mil) vezes a Unidade Padrão Fiscal de Mato Grosso - UPF-MT, ou outra que venha sucedê-la, na gradação estabelecida no regimento interno, aos responsáveis por: 
I - contas julgadas irregulares;

II - ato de gestão ilegal, ilegítimo ou antieconômico de que resulte dano ao erário;

III - ato praticado com grave infração a norma legal ou regulamentar de natureza contábil, financeira, orçamentária, operacional e patrimonial;

IV - descumprimento de decisão, diligência, recomendação ou solicitação do Tribunal;

V - obstrução ao livre exercício das inspeções e auditorias determinadas;

VI - sonegação de processo, documento ou informação em inspeções ou auditorias;

VII - reincidência no descumprimento de decisão do relator ou do Tribunal de Contas;

VIII - não remeter dentro do prazo legal, por meio informatizado ou físico, os documentos e informações a que está obrigado por determinação legal, independentemente de solicitação do Tribunal.

Minas Gerais - Lei Complementar n 33/94

Art.95 - O Tribunal poderá aplicar multa de até 1.000 (mil) Unidades Padrão Fiscal do Estado de Minas Gerais - UPFMG - , aos responsáveis por:

I - contas julgadas irregulares de que não resulte débitos, nos termos do parágrafo único do art. 47 desta lei;

II - o ato praticado com grave infração à norma legal ou regulamentar de natureza contábil, financeira, orçamentária, operacional e patrimonial;

III - ato de gestão ilegítimo ou antieconômico de que resulte injustificado dano ao erário;

IV - não atendimento, no prazo fixado, sem causa justificada, a diligência do relator ou a decisão do Tribunal;

V - obstrução ao livre exercício das inspeções e auditorias determinadas;

VI - sonegação de processo, documento ou informação, em inspeções ou auditorias realizadas pelo Tribunal;

VII - omissão no cumprimento do dever funcional de levar ao conhecimento de órgão responsável pelo controle externo irregularidade ou ilegalidade de que tenha tido ciência, na qualidade de integrante do controle interno;

VIII - retenção de quantia a ser recolhida aos cofres públicos, por tempo superior ao previsto em lei;

IX - reincidência no descumprimento de determinação do Tribunal.

$\S 1^{\circ}$ - Ficará sujeito a multa prevista no "caput" deste artigo aquele que, sem motivo justificado, deixar de dar cumprimento à decisão do Tribunal.

Pernambuco - Lei nº 12.600/2004

Art. 73. O Tribunal de Contas, mediante deliberação de órgão colegiado, poderá aplicar multas, até o limite de $\mathrm{R} \$ 7.000,00$ (sete mil reais), independentemente da condenação ao ressarcimento dos prejuízos ou danos causados ao Erário e adotando, se necessário, outras providências legais cabíveis aos responsáveis por:

I - prática de ato de gestão ilegal, ilegítimo ou antieconômico que não seja de natureza grave e que não represente injustificado dano ao Erário: multa no valor compreendido entre 5\% (cinco por cento) e 50\% (cinqüenta por cento) do limite fixado no caput deste artigo, respeitado o teto máximo do valor correspondente ao prejuízo dado ao Erário;

II - ato de gestão ilegal, ilegítimo ou antieconômico de que resulte injustificado dano à Fazenda: multa no valor compreendido entre $20 \%$ (vinte por cento) e $100 \%$ (cem por cento) do limite fixado no caput deste artigo, respeitado o teto máximo do valor correspondente ao prejuízo dado ao Erário;

III - ato praticado com grave infração a norma legal ou regulamentar de natureza contábil, financeira, orçamentária, operacional ou patrimonial: multa no valor compreendido entre $20 \%$ (vinte por cento) e 50\% (cinqüenta por cento) do limite fixado no caput ;

IV - sonegação de processo, documento ou informação em inspeções ou auditorias realizadas pelo Tribunal: multa no valor compreendido entre 5\% (cinco por cento) e 50\% (cinqüenta por cento) do limite fixado no caput deste artigo; 
V - não atendimento, no prazo fixado e sem causa justificada, de diligência determinada pelo Relator: multa no valor compreendido entre $5 \%$ (cinco por cento) e $30 \%$ (trinta por cento) do limite fixado no caput ;

(...)

VII - atraso injustificado ou não envio da Prestação de Contas: multa no valor compreendido entre $20 \%$ (vinte por cento) e $100 \%$ (cem por cento) do limite fixado no caput ;

VIII - omissão injustificada da autoridade competente para a instauração de Tomada de Contas Especial: multa de 30\% (trinta por cento) do limite fixado no caput deste artigo;

IX - interposição de Embargos de Declaração julgados manifestamente protelatórios: multa de $10 \%$ (dez por cento) do limite fixado no caput deste artigo;

$\mathrm{X}$ - atraso injustificado no encaminhamento de documentos e/ou informações solicitadas pelo Tribunal na forma estabelecida no Regimento Interno: multa automática no valor de R\$ 500,00 (quinhentos reais), acrescidos de $\mathrm{R} \$ 50,00$ (cinquienta reais) por dia de atraso, contado a partir do segundo dia após o vencimento do prazo previsto, sendo limitado ao valor estipulado no caput deste artigo;

XI - descumprimento, por parte dos agentes e autoridades do Tribunal de Contas, de determinação constante de Provimento da Corregedoria Geral: multa de R\$ 500,00 (quinhentos reais).

XII - Descumprimento de Decisão colegiada do Tribunal de Contas: multa no valor compreendido entre $30 \%$ (trinta por cento) e $50 \%$ (cinqüenta por cento) do limite fixado no caput deste artigo.

Amazonas - Lei nº 2.423/1996.

Art. 53 - Quando o responsável for julgado em débito, poderá ainda o Tribunal aplicar-lhe multa até $100 \%$ (cem por cento) do valor do dano causado ao erário, corrigido monetariamente.

Art. 54 - O Tribunal poderá aplicar multa de até R\$ 14.894,73 (quatorze mil, oitocentos e noventa e quatro reais e setenta e três centavos), ou valor equivalente em outra moeda que venha a ser adotada como moeda nacional, aos responsáveis por:

I - contas julgadas irregulares de que não resulte débito, nos termos do parágrafo único, do artigo 25 desta Lei;

II - ato praticado com grave infração à norma legal ou regulamentar de natureza contábil, financeira, orçamentária, operacional e patrimonial;

III - ato de gestão ilegítimo ou antieconômico de que resulte injustificado dano ao erário;

IV - não atendimento, no prazo fixado, sem causa justificada, à diligência ou a decisão do Tribunal;

V - obstrução ao livre exercício das inspeções e auditorias determinadas;

VI - sonegação de processo, documento ou informação, em inspeções ou auditorias realizadas pelo Tribunal;

VII - reincidência no descumprimento de determinação do Tribunal. 24

$\S 1^{\circ}$ - Ficará sujeito à multa prevista no caput deste artigo aquele que deixar de dar cumprimento a decisão do Tribunal, salvo motivo justificado.

Infrações financeiras estabelecidas na Lei Federal n $10.028 / 2000$

Art. 50 Constitui infração administrativa contra as leis de finanças públicas:

I - deixar de divulgar ou de enviar ao Poder Legislativo e ao Tribunal de Contas o relatório de gestão fiscal, nos prazos e condições estabelecidos em lei;

II - propor lei de diretrizes orçamentárias anual que não contenha as metas fiscais na forma da lei;

III - deixar de expedir ato determinando limitação de empenho e movimentação financeira, nos casos e condições estabelecidos em lei;

IV - deixar de ordenar ou de promover, na forma e nos prazos da lei, a execução de medida para a redução do montante da despesa total com pessoal que houver excedido a repartição por Poder do limite máximo. 
$\S 1$ o A infração prevista neste artigo é punida com multa de trinta por cento dos vencimentos anuais do agente que lhe der causa, sendo o pagamento da multa de sua responsabilidade pessoal.

$\S 2$ o A infração a que se refere este artigo será processada e julgada pelo Tribunal de Contas a que competir a fiscalização contábil, financeira e orçamentária da pessoa jurídica de direito público envolvida.

Destaque-se que o art. $5^{\circ}$, da Lei ${ }^{\circ} 10.028 / 2000$ apresenta uma descrição das condutas ilícitas com razoável precisão, adequando-se ao princípio da tipicidade fechada. Também atende a tipicidade fechada, as denominadas infrações não essencialmente financeiras (dos deveres de colaboração com o Tribunal de Contas), tais como, a sonegação de documento, informação ou processo, o não atendimento à diligência ou ainda a imposição de obstáculos à fiscalização do Tribunal.

Entretanto, comum às Leis Orgânicas, conforme se pode observar acima, é a previsão de sanção financeira por "ato praticado com grave infração à norma legal ou regulamentar de natureza contábil, financeira, orçamentária, operacional e patrimonial". Trata-se da hipótese de responsabilidade mais frequentemente aplicada no dia a dia dos Tribunais de Contas.

Pode-se questionar se o tipo em questão não é excessivamente genérico, de forma a não atender a sua função de proporcionar ao destinatário um grau razoável de segurança jurídica, dando margem de arbítrio ao julgador.

Entendo que não, desde que a aplicação da sanção financeira atenda algumas exigências, conforme expomos a seguir.

Em primeiro lugar, tal previsão não é novidade no Direito Estrangeiro. O direito português, a propósito, estabelece como infração financeira sancionatória diversas hipóteses genéricas de violação às normas, conforme art. 65, item 1, alíneas b, d e 1, da Lei $n^{\circ}$ 98/97:

\footnotetext{
"Artigo 65"

Responsabilidades financeiras sancionatórias

1 - O Tribunal de Contas pode aplicar multas nos casos seguintes:
} 
(...)

b) Pela violação das normas sobre a elaboração e execução dos orçamentos, bem como da assunção, autorização ou pagamento de despesas públicas ou compromissos;

c) Pela falta de efectivação ou retenção indevida dos descontos legalmente obrigatórios a efectuar ao pessoal;

d) Pela violação de normas legais ou regulamentares relativas à gestão e controlo orçamental, de tesouraria e de património;

(...)

1) Pela violação de normas legais ou regulamentares relativas à admissão de pessoal".

Em segundo lugar, o princípio da legalidade aplicado ao cidadão comum (art. $5^{\circ}$, inciso II, da $\mathrm{CF} / 88$ ) não é o mesmo incidente sobre o gestor de bens, dinheiros e valores públicos.

Hely Lopes Meirelles ensina que (MEIRELLES, 1994, p. 82-83):

"na administração pública não há liberdade nem vontade pessoal. Enquanto na administração particular é lícito fazer tudo que a lei não proibe, na Administração Pública só é permitido fazer o que a lei autoriza. A lei para o particular significa 'pode fazer assim'; para o administrador público significa 'deve fazer assim'".

Na mesma linha de pensamento, Celso Antônio Bandeira de Mello esclarece que (MELLO, 2005, p. 95):

"O princípio da legalidade, no Brasil, significa que a Administração nada pode fazer senão o que a lei determina. Ao contrário dos particulares, os quais podem fazer tudo a lei não proíbe, a Administração só pode fazer o que a lei antecipadamente autorize".

Cumpre lembrar que o gestor público que pauta sua conduta na observância das normas e princípios de Direito Administrativo e Financeiro não estará sujeito à responsabilidade financeira sancionatória. Quando se exige a tipicidade fechada para sancionar o gestor público que se desvia dos parâmetros jurídicos, toma-se por base o princípio contido no art. $5^{\circ}$, inciso II, da $\mathrm{CF} / 88$, de liberdade individual e não o princípio contido no art. 37, caput, da CF/88, ao qual a administração pública e, consequentemente, seus gestores devem estar adstritos.

Ressalte-se, ainda, que o relacionamento entre o gestor público e o Estado, submetido o Controle Externo é semelhante ao que os autores do Direito Administrativo 
Sancionador denominam de "relações de sujeição especial", no qual, o princípio da legalidade e da reserva legal admite uma flexibilização.

Um outro ponto a ser ressaltado é a impossibilidade de previsão exaustiva de todas as condutas do gestor de bens, dinheiros e valores públicos que importem em violação das normas e princípios inerentes à Administração Pública, ainda que estas condutas não consigam ou não tenham por finalidade causar dano ao erário.

Se, por um lado, a informatização dos Sistemas de Administração Financeira impediu ou dificultou a realização de uma série de fraudes e condutas ilegítimas, por outro, a crescente complexidade do Estado, suas novas estruturas, funções e relações abrem porta a inúmeras outras irregularidades.

Por exemplo, desde 1995, com as transfomações promovidas na Administração Pública, na sua transição para a Administração Gerencial, as relações entre o Estado e Particulares passou a ser regulada por novos instrumentos como o Contrato de Gestão e o Termo de Parceria, houve a intensificação da utilização dos Contratos de Concessão de Serviços Públicos. Além disso, novas estruturas foram criadas: Agências Reguladoras e Executivas, Organizações Sociais, OSCIPs, etc. O próprio relacionamento entre o Estado e estas novas entidades foi também contaminado por diversas irregularidades, tendo sido instaurada, inclusive, uma Comissão Parlamentar de Inquérito (CPI) para investigar estas irregularidades.

Os processos de desestatização e de terceirização na Administração Pública se intensificaram. Se no passado as obras públicas eram a principal fonte de irregularidades no setor público, nos recentes escândalos do Mensalão (2005), os contratos de publicidade passaram a ter importante papel como fonte do "Caixa 2" de partidos políticos. São estes alguns poucos dos novos desafios impostos ao controle da gestão pública. Afinal, não existem limites à criatividade humana, quando se busca locupletar do patrimônio público. 
Compreende-se, assim, a razão pela qual o legislador preferiu adotar uma descrição genérica da conduta ilícita na responsabilidade financeira reintegratória, o que não significa que qualquer violação à norma da gestão de bens, dinheiros ou valores públicos possa ensejar a aplicação de multa pelos Tribunais de Contas. Apenas a "grave infração" à norma pode ensejar a aplicação de multa.

\subsection{Princípio da Razoabilidade e da Proporcionalidade}

A doutrina ainda se debate acerca do conteúdo dos princípios da razoabilidade e da proporcionalidade, acerca de sua forma de aplicação e, até mesmo, sobre sua qualificação como princípios jurídicos.

Virgilio Afonso da Silva, no artigo "O proporcional e o razoável", discute diversos problemas conceituais relativos à razoabilidade e à proporcionalidade (SILVA, V., 2002).

Em primeiro lugar, o autor afirma que a proporcionalidade não pode ser considerado um princípio, pelo menos não com base na classificação de Robert Alexy, segundo o qual, os princípios são normas que obrigam algo na maior medida possível (de acordo com as possibilidades fácticas e jurídicas). São verdadeiros mandamentos de otimização. Afonso da Silva afirma que a proporcionalidade é aplicada de forma constante, sem variações (SILVA, V., 2002).

Em segundo lugar, a regra da proporcionalidade também não se confunde com o conceito de "proibição de excesso" (Übermassverbot). Argumenta que, conquanto a regra da proporcionalidade seja instrumento de controle contra excesso de poderes estatais, cada vez mais vem ganhando importância a sua utilização com finalidade oposta, ou seja, contra a omissão ou ação insuficiente do Poder Público (Untermassverbot) (SILVA, V., 2002).

Em terceiro lugar, a regra da proporcionalidade também não se confunde com a razoabilidade, seja pela sua origem, seja pela sua estrutura ou forma de aplicação. O 
princípio da razoabilidade teria surgido em decisão judicial proferida em 1948, na Inglaterra, como teste da irrazoabilidade ou teste de Wednesbury: "se uma decisão é de tal forma irrazoável, que nenhuma autoridade a tomaria, então pode a corte intervir" (SILVA, V., 2002). A regra da proporcionalidade, por sua vez, teria surgido no controle de constitucionalidade das leis restritivas de direitos fundamentais, por desenvolvimento jurisprudencial do Tribunal Constitucional Alemão (Bundesverfassungsgericht) (SILVA, V., 2002).

Quanto à estrutura e forma de aplicação da regra da proporcionalidade, esclarece Afonso da Silva que (SILVA, V., 2002):

\footnotetext{
"na forma desenvolvida pela jurisprudência constitucional alemã, tem ela uma estrutura racionalmente definida, com sub-elementos independentes - a análise da adequação, da necessidade e da proporcionalidade em sentido estrito, que são aplicados em uma ordem prédefinida, e que conferem à regra da proporcionalidade a individualidade que a diferencia, claramente, da mera exigência de razoabilidade".
}

Os subelementos da regra da proporcionalidade são, portanto, a adequação, a necessidade e a proporcionalidade em sentido estrito. Eles devem ser aplicados, segundo Virgílio Afonso da Silva, nesta seqüência. A adequação do meio utilizado pelo legislador corresponde à aptidão para alcançar o resultado pretendido. Diz-se que um ato estatal que limita um direito fundamental é necessário, "caso a realização do objetivo perseguido não possa ser promovida, com a mesma intensidade, por meio de outro ato que limite, em menor medida, o direito fundamental atingido" (SILVA, V., 2002).

A proporcionalidade em sentido estrito consiste em um "sopesamento entre a intensidade da restrição ao direito fundamental atingido e a importância da realização do direito fundamental que com ele colide e que fundamenta a adoção da medida restritiva" (SILVA, V., 2002).

Quanto ao fundamento constitucional, Afonso da Silva ensina que (SILVA, V., 2002):

"a exigibilidade da regra da proporcionalidade para a solução de colisões entre direitos fundamentais não decorre deste ou daquele dispositivo constitucional, mas da própria estrutura dos direitos fundamentais. (...) Se se admite que a grande maioria dos direitos 
fundamentais são princípios, no sentido defendido por Robert Alexy, (...), admite-se que eles são mandamentos de otimização, isto é, normas que obrigam que algo seja realizado na maior medida possível, de acordo com as possibilidades fáticas e jurídicas. E a análise da proporcionalidade é justamente a maneira de se aplicar esse dever de otimização ao caso concreto".

Segundo Afonso da Silva, o STF tem invocado a proporcionalidade com caráter meramente retórico e não sistemático: "Em inúmeras decisões, sempre que se queria afastar alguma conduta considerada abusiva, recorre-se à fórmula 'à luz do princípio da proporcionalidade e da razoabilidade, o ato deve ser considerado inconstitucional"' (SILVA, V., 2002). Em conclusão, destaca que "a aplicação da regra da proporcionalidade pelo Supremo Tribunal Federal consiste apenas em um apelo à razoabilidade" (SILVA, V., 2002).

José Roberto Pimenta Oliveira dedica atenção à aplicação dos princípios da razoabilidade e da proporcionalidade na atividade sancionatória da Administração Pública (OLIVEIRA, J., 2006).

Segundo Pimenta Oliveira, a aplicação dos princípios da razoabilidade e da proporcionalidade à atividade sancionatória da Administração é corolário necessário do Estado Democrático de Direito, fundado nos princípios da dignidade da pessoa humana, no devido processo legal e na individualização da pena (PIMENTA, J., 2006).

A incidência dos princípios à atividade sancionatória ocorre em dois momentos distintos: o da previsão ou estatuição da sanção in abstrato e o da aplicação da sanção in concreto (PIMENTA, J., 2006).

Na previsão da sanção in abstrato, os princípios, segundo o autor, geram as consequências a seguir descritas (PIMENTA, J., 2006).

Em primeiro lugar, a descrição do tipo deverá ser adequada à finalidade perseguida pela atividade sancionatória (adequação). A sanção deverá ter aptidão para a tutela do bem jurídico protegido, sendo inválidas as penalidades que não tenham por finalidade o propósito da prevenção (PIMENTA, J., 2006). 
Em segundo lugar, as condutas devem ser reveladoras de significativa ofensa ao bem jurídico (PIMENTA, J., 2006).

Em terceiro lugar, a responsabilidade de terceiros deve ser admitida somente se representar justificado meio de atendimento à finalidade de prevenção geral e especial, que é a razão de ser da sanção (PIMENTA, J., 2006).

Em quarto lugar, deverão ser consideradas inconstitucionais as normas que deixam em branco o limite das sanções correspondentes a cada infração. Cabe à norma indicar os limites mínimos e máximos da sanção, bem como definir os fatores qualitativos sobre os quais deverá alicerçar-se sua gradação "in concreto" (PIMENTA, J., 2006).

Segundo o autor, a aplicação dos princípios à atividade sancionatória in concreto, por sua vez, tem destaque na interpretação dos conceitos legais indeterminados e na delimitação das zonas conceituais de certeza e de penumbra (PIMENTA, J., 2006).

O mandamento de idoneidade (adequação) exige, segundo o autor, o reconhecimento do caso fortuito e da força maior como excludentes de responsabilidade. Exige-se, também, por força deste requisito, que a responsabilidade seja subjetiva (PIMENTA, J., 2006).

Relacionada ao mandamento da necessidade, o autor entende que são consequências dos princípios, o princípio da insignificância e a irretroatividade da lei menos severa (PIMENTA, J., 2006).

No nosso tema, os princípios constituem importante parâmetro para a aplicação in concreto da responsabilidade financeira, considerando as lacunas existentes na legislação (Lei $\mathrm{n}^{\circ}$ 8.443/92). De pouca utilidade são os princípios para o momento da previsão ou espulação da sanção in abstrato, pois, na responsabilidade financeira, adota-se a 
tipicidade aberta, deixando grande margem de liberdade para o julgador no momento da aplicação.

Como aplicação das lições de Pimenta Oliveira à responsabilidade financeira, podemos citar a responsabilidade subjetiva (cap. 12), o princípio da irretroatividade (item 10.6) e o caso fortuito ou de força maior como excludente de responsabilidade (item 16.4).

É na modalidade sancionatória (multa) que o princípio ganha mais relevância. Com efeito, a Lei ${ }^{\circ} 8.443 / 92$ e o RITCU não estipulam valores fixos para as multas, em quaisquer de suas espécies (multa simples do art. 58, multa proporcional ao dano ao erário), mas uma faixa de valores, dentro da qual o intérprete deve fixar a multa a ser aplicada ao responsável. A Lei $\mathrm{n}^{\circ}$ 10.028/2000 estipulou multa fixa de 30\% da remuneração anual do agente, no caso de subsunção ao art. $5^{\circ}$ (infrações administrativas contra as leis de finanças públicas). Entretanto, o TCU tem se posicionado no sentido de que a multa prevista nesta Lei não é fixa e que o montante de $30 \%$ é um teto a ser respeitado na fixação do seu valor.

$\mathrm{Na}$ jurisprudência do Tribunal de Contas da União, diversos são os precedentes em que há redução do montante da multa com fundamento no princípio da proporcionalidade. Valem aqui, entretanto, as mesmas advertências de Virgílio Afonso da Silva, no tocante à aplicação não estruturada do princípio da proporcionalidade.

No Acórdão n 419/2005 - $1^{\text {a }}$. Câmara, verificou-se que um dos recorrentes não teve participação em diversos dos atos tidos por irregulares. Reduziu-se, assim, a multa a aplicada em atenção ao princípio da proporcionalidade.

No Acórdão n 1.559/2006 - Plenário, deliberou-se que "não fere o principio da razoabilidade e proporcionalidade a fixação da multa do art. 57 da Lei 8.443/92 com base no valor atualizado do débito e nas condições econômicas dos Responsáveis".

Não é só na dosimetria da sanção financeira que os princípios da razoabilidade e proporcionalidade têm aplicação. A própria decisão de aplicar ou não a multa deve estar 
permeada por critérios de adequação e necessidade. Não atendidos estes critérios, o Tribunal de Contas pode deixar de aplicar a sanção pecuniária e, apenas, determinar ao órgão ou à entidade pública que adote providências no sentido de evitar a repetição das irregularidades de pequena gravidade (julgando-se, também, as contas regulares com ressalvas, conforme art. 18, da Lei $\mathrm{n}^{\circ} 8.443 / 92$ ).

\subsection{Princípio da Pessoalidade e a Transmissibilidade aos Sucessores}

Neste item, abordo a pessoalidade das sanções financeiras e a possibilidade de sua transmissão aos sucessores, no caso de falecimento do responsável.

Previamente a esta discussão, vejamos como o tema é tratado nas diversas modalidades de sanções jurídicas, no Direito Estrangeiro e na Jurisprudência do Tribunal de Contas da União.

\subsubsection{Sanções Penais}

Dispõe o art. $5^{\circ}$, da XLV, da CF/88 que a pena não passará da pessoa do condenado, podendo a obrigação de reparar o dano e a decretação do perdimento dos bens ser estendido aos sucessores, no limite do patrimônio transferido. Com efeito, a morte do agente importa em extinção da punibilidade, nos termos do art. 107, inciso I, do Código Penal.

Acerca do dispositivo constitucional, José Afonso da Silva leciona que (SILVA, J., 2005, p. 143):

"A norma principal contém um princípio fundamental do direito penal moderno: o da personalização da pena. Era costume no direito penal autoritário a extensão de algum efeito da pena aos membros da família do condenado. As Ordenações Filipinas eram repletas de disposições penais extensivas para além do criminoso".

Foi a Constituição do Império que, pela primeira vez, estabeleceu a personalização da pena, consoante art. 179, XX: 'não haverá em caso algum confiscação de bens, nem a infâmia do réu se transmitirá aos parentes em qualquer grau, que seja' ".

Conforme Afonso da Silva, o princípio da personalização da pena (SILVA, J.,

2005, p. 143) 
"se harmoniza com a concepção de que a sanção penal tem finalidade retributiva, pois, se ela é uma reação ao mal do crime, claro está que só pode recair sobre quem praticou esse mal. No fundo, pois, a personalização da pena acaba sendo um princípio da justiça retributiva: premiar ou castigar segundo o merecimento do agente, só do agente, na mesma proporção do benefício ou do dano causado. Injusto fora - e mais seria no Estado Democrático de Direito- apenar alguém por fato de outrem".

A personalização da pena, entretanto, apresenta dois limites: a possibilidade de reparação de danos e a decretação do perdimento dos bens (em relação aos bens havidos por meios ilícitos) (SILVA, J., 2005).

\subsubsection{Sanções Administrativas}

Regis Fernandes de Oliveira, ao tratar do caráter pessoal das sanções administrativas, menciona que (OLIVEIRA, R., 2005, p. 34):

"Pode a lei prever a responsabilidade pessoal do infrator ou de terceiro (pai, tutor, curador, administrador, inventariante, síndico, comissário, escrivão ou escrevente, sócio, etc.). (...) Dependerá do texto legal a previsão da extensão da responsabilidade."

Sustenta o autor que, segundo a finalidade da sanção, ela será transmissível ou não (OLIVEIRA, R., 2005, p. 34-35):

\footnotetext{
"Deve-se distinguir, no entanto, a sanção meramente reparatória de algum dano, hipótese em que será transmissível, das sanções punitivas ou aflitivas, que não se transmitem. (...) Quando a sanção converter-se em pecúnia ou for apurável em cifra correspondente, caberá a transmissão. Caso contrário, quando objetiva apenas castigar o infrator, será intransmissível. A respeito grassa divergência jurisprudêncial, existindo acórdãos admitindo a transmissão, enquanto outros a inadmitem.

Parece-nos deva ter aplicação o princípio da pessoalidade das sanções, como prevê o inciso XLV do art. $5^{\circ}$ da CF. (...) Transmitem-se apenas as sanções reparatórias. Já as punitivas, como objetivam castigar o infrator, para que não torne a descumprir o comando normativo, aplicam-se apenas ao próprio infrator, em obediência ao princípio mencionado".

Daniel Ferreira classifica as sanções administrativas em sanções reais e sanções pessoais. As sanções reais "são as pecuniárias (multas) e as que, por sua natureza, gravam coisas, possuindo natureza real (por exemplo, as de perda de bens, interdição de estabelecimento e outras)". As sanções pessoais são "todas as demais, ou seja, as que atingem a 'pessoa' do sujeito passivo da sanção (infrator ou responsável), nelas se incluindo, por exemplo, as de prisão, de suspensão de atividades, etc" (FERREIRA, 2001, p. 46).
}

Acresce o autor que (FERREIRA, 2001, p. 46): 
"a específica utilidade desta classificação é separar as sanções transmissíveis das intransmissíveis, vale dizer, as que, na hipótese de não-cumprimento pelo sujeito passivo até seu desaparecimento (por morte ou extinção da pessoa jurídica), se transferem aos sucessores, bem como daqueloutras recaídas sobre bens que, inter vivos ou causa mortis, são transferidos a terceiros".

Outra classificação apresentada distingue entre sanções objetivas e subjetivas. As primeiras "impõem, objetivamente, sempre e a todos, uma fixa conseqüência jurídica, sempre desfavorável, pela simples violação da norma de conduta" (FERREIRA, 2001, p. 47). As últimas "são impostas pelo ilícito praticado, mas cuja gradação, quando juridicamente admitida, ocorre somente in concreto, caso a caso (dentro dos limites previstos em lei), tendo em vista a valoração da pessoa do infrator, das condições em que ocorreu a infração e, muitas vezes, dos danos dela decorrentes" (FERREIRA, 2001, p. 47).

Daniel Ferreira, por fim, considera constitucionalmente válido transmitir-se, na forma da lei, sanções administrativas reais e, de modo similar, vedado diretamente impor a terceiros sanções subjetivas. Divergindo do Prof. Regis Fernandes de Oliveira, o autor defende a possibilidade de que sanções não-reparatórias, mas de cunho pecuniário, tais como as multas de trânsito, sejam transferidas a terceiros "inter vivos" ou "causa mortis" (FERREIRA, 2001).

Acrescenta que: "se assim não fosse restaria mais do que fácil elidir sanções dessa natureza (reais), bastando para tanto, dentre outras possibilidades, a singela transferência do bem gravado" (FERREIRA, 2001, p. 75).

Heraldo Garcia Vitta classifica as sanções administrativas em sanções pessoais, reais e pecuniárias. As pecuniárias distinguem-se das reais apenas pelo fato de que concretizarem por meio de quantificação monetária. Entende o autor que: "as penalidades reais e as pecuniárias, além de admitirem a responsabilidade e a transmissibilidade, permitem a solidariedade entre os diversos responsáveis da infração" (VITTA, 2003, p. 124). 
Fábio Osório Medina, acerca do princípio da pessoalidade, tem posição radicalmente oposta, não admitindo qualquer forma de transmissibilidade das sanções administrativas (OSORIO, 2005, p. 461-463):

\footnotetext{
"A pena somente pode ser imposta ao autor da infração penal. A norma deve acompanhar o fato. Igual exigência acompanha o Direito Administrativo Sancionatório. Incabível responsabilidade objetiva, eis uma das consequiências do princípio da pessoalidade da sanção administrativa. Repele-se, fundamentalmente, a responsabilidade pelo fato de outrem e a responsabilidade objetiva. O delito é obra do homem, como o é a infração administrativa praticada por pessoa física, sendo inconstitucional qualquer lei que despreze o princípio da responsabilidade subjetiva.

O princípio da pessoalidade da pena, de natureza constitucional, se estende, em tese, ao Direito Administrativo Sancionatório e é um desdobramento do principio da culpabilidade. Trata-se de direito fundamental inerente ao devido processo legal punitivo.

A pena criminal somente pode atingir o sentenciado (art. $5^{\circ}, \mathrm{XLV}, \mathrm{CF}$ ), exigência que me parece incidente no campo do Direito Administrativo Sancionador. A pena administrativa somente pode atingir a pessoa sancionada, o agente efetivamente punido, não podendo ultrapassar de sua pessoa. (...)

Pessoalidade da sanção administrativa veda, por certo, a chamada responsabilidade solidária, ainda que estabelecida por lei, por que a lei não pode violentar um princípio constitucional regente do Direito Administrativo Sancionador".
}

\subsubsection{Jurisprudência do Tribunal de Contas da União}

A jurisprudência do Tribunal de Contas da União tem sido pacífica no sentido de que a responsabilidade financeira sancionatória (multa), em qualquer das suas espécies, é uma sanção de natureza eminentemente punitiva e que, portanto, não pode passar da pessoa do agente. Neste sentido, invoco os seguintes precedentes: Acórdão TCU n 92/1999 - $2^{\mathrm{a}}$. Câmara e Acórdão n 293/1998 - 2ª . Câmara. Não cabe, também, a realização de audiência (medida processual prévia à aplicação da multa) aos herdeiros e sucessores (Decisão $\mathrm{n}^{\circ}$ 186/1996 - 2a . Câmara).

No tocante à responsabilidade financeira reintegratória, o TCU admite a transmissibilidade da obrigação de repor aos herdeiros, no limite do patrimônio transferido. Nos casos em que não foi realizada a partilha dos bens, o TCU condenou em débito do espólio, conforme precendentes Acórdão n 132/2003 - 2ª . Câmara e Acórdão n 145/2003 $2^{\mathrm{a}}$. Câmara. Após a partilha, só respondem os herdeiros, cada qual, nos limites do quinhão que lhes coube (Acórdão n 353/1999 - 2ª . Câmara). 


\subsubsection{Doutrina Pátria}

Jorge Ulisses Jacoby Fernandes foi um dos poucos doutrinadores brasileiros a tratar de aspectos jurídicos da Responsabilidade no âmbito dos Tribunais de Contas. O autor aborda o tema do falecimento do responsável nos processos de Tomada de Contas Especial (FERNANDES, 1998, p. 96-97):

\footnotetext{
"Não há nenhum registro de aplicação de multa a agente falecido, mas vários em que, entre a aplicação da sanção e a sua execução, ocorre o falecimento. Nessa hipótese não há execução, do julgado contra os sucessores civis ou contra o agente que sucedeu o falecido no cargo. O término da personalidade jurídica extingue as obrigações personalíssimas.

(...) Descabe a aplicação de multa pela omissão no dever de prestar contas aos sucessores, mesmo que já lavrado o acórdão condenatório, porque esta penalidade é de cunho pessoal. Assim, não pode subsistir à vista de sua natureza jurídica, que, como toda penalidade, assume nítido caráter pedagógico, jamais satisfeito na pessoa dos sucessores. O princípio jurídico alcançou nível constitucional, tendo sido insculpido no art. $5^{\circ}$, XLV, do Estatuto Político Fundamental, que 'nenhuma pena passará da pessoa do condenado'. O teor desse mandamento foi aditado da possibilidade da obrigação de reparar o dano e a decretação de perdimento de bens ser estendida, nos termos da lei, aos sucessores, e contra eles executada, até o limite do patrimônio transferido".
}

Augusto Sherman Cavalcanti aborda o tema considerando as três dimensões do processos de contas, por ele definidas: o julgamento da gestão, a punibilidade do gestor faltoso (dimensão sancionatória) e a reparação do dano causado ao erário (dimensão reintegratória) (CAVALCANTI, 1999).

Na primeira dimensão, o autor considera que o destinatário do processo de contas é a coletividade, sendo o gestor mero destinatário secundário. Por conseguinte, a morte do gestor não é, por si só, obstáculo ao julgamento das contas nem causa de extinção do processo, pois, sempre que possível, deve subsistir a finalidade precípua do processo, de natureza política, que é a de dar ciência à coletividade acerca da utilização, boa ou má, dos seus recursos (CAVALCANTI, 1999).

Nas palavras do autor (CAVALCANTI, 1999, p. 19): "Assim, salvo situações excepcionais, faz-se necessário que, mesmo após o falecimento do gestor, sejam as contas julgadas para que se dê satisfação à coletividade de como foram aplicados os seus recursos". 
A dimensão sancionatória, segundo Augusto Sherman, se extingue com a morte do gestor, considerando que o cumprimento da sanção é personalíssimo e não ultrapassará a pessoa do condenado (CAVALCANTI, 1999).

Quanto à dimensão reintegratória, entende Augusto Sherman que, por força de edito constituicional, a responsabilidade patrimonial de reparar eventual dano causado ao erário transfere-se do gestor falecido aos sucessores, na medida do patrimonio recebido. Conclui, então, o autor que (CAVALCANTI, 1999, p. 20): "Dessa maneira, é de mister que, mesmo após a morte do gestor, o processo prossiga seu curso a fim de que também essa dimensão se concretize".

\subsubsection{Pessoalidade no Direito Estrangeiro}

No Direito Português, a Lei n 98/97 - Lei de Organização e Processo do Tribunal de Contas (LOPTC), com suas alterações posteriores, disciplina no art. 69, das hipóteses de extinção da responsabilidade financeira. Com efeito, a morte do responsável é considerada causa de extinção da responsabilidade sancionatória, mas não da responsabilidade reintegratória. Esta última só extingue em razão da prescrição ou do pagamento da sanção.

No Direito Espanhol, Carles Rosiñol I Vidal acerca da transmissão da "responsabilidad contable" (de natureza reparatória) aos sucessores (causahabientes) leciona que (VIDAL, 1999, p. 105):

"El artículo 38.5 de la LOTCu establece que las responsablidades contables, tanto directas como subsidiarias, se transmiten a los causahabientes de los responsables por la aceptación expresa o tácita de la herencia, pero sólo en la cuantía que ascienda el importe líquido de la misma.Este precepto ha sido analizado por la Sala de Apelación del Tribunal de Cuentas llegando a la conclusión que únicamente se transmite la deuda y no la culpa. El resultado de esta distinción es que solamente se transmite la responsabilidad contable a los causabientes cuanto esta responsabilidad contable ha sido declarada en vida del responsable, no siendo posible declararla una vez éste haya fallecido, ya que esto representaría trasladar dicha responsabilidad a los referidos causahabientes" (O artigo 38.5 da LOTCu [Lei Orgânica do Tribunal de Cuentas] estabelece que as responsabilidades contábeis, tanto diretas quanto subsidiárias, se transmitem aos sucessores dos responsáveis pela aceitação expressa ou tácita 
da herança, mas só na quantia que ascenda ao montante líquido da mesma. Este preceito foi analisado pela Sala de Apelação do Tribunal de Cuentas chegando a conclusão que unicamente se transmite a dívida e não a culpa. O resultado desta distinção é que somente se transmite a responsabilidade contábil aos sucessores quando esta responsabilidade houver sido declarada em vida do do responsável, não sendo possível declarar-la quando este tenha falecido, já que isto representaria transladar esta responsabilidade aos referidos sucessores.)

\subsubsection{Comentários}

No tocante à responsabilidade financeira reintegratória, é evidente a possibilidade de transmissão do débito aos sucessores do responsável falecido, por expressa previsão do art. $5^{\circ}$, inciso VIII, da Lei n ${ }^{\circ}$ 8.443/92, segundo o qual, a jurisdição do Tribunal de Contas da União abrange "os sucessores dos administradores e responsáveis a que se refere este artigo, até o limite do valor do patrimônio transferido, nos termos do inciso XLV do art. $5^{\circ}$ da Constituição Federal".

Por sua vez, a responsabilidade financeira sancionatória (multa) tem função eminentemente punitiva, cabendo aplicar, analogicamente, os preceitos de direito penal, conforme expressa referência do dispositivo legal supracitado.

Algumas ressalvas devem ser, entretanto, mencionadas.

Entendo que o dever de prestar contas é pessoal ${ }^{101}$, ou seja, não se pode exigir a prestação de contas dos herdeiros e legatários.

\footnotetext{
${ }^{101}$ Tem-se admitido, entretanto, que o dever de prestar contas seja transferido para aquele que tenha sucedido o gestor no cargo. No Brasil, a Súmula ${ }^{\circ} 230$, do TCU dispõe que: "Compete ao prefeito sucessor apresentar as contas referentes aos recursos federais recebidos por seu antecessor, quando este não o tiver feito ou, na impossibilidade de fazê-lo, adotar as medidas legais visando ao resguardo do patrimônio público com a instauração da competente Tomada de Contas Especial, sob pena de co-responsabilidade". Em Portugal, dispõe o art. $52^{\circ} / 1$, da LOPTC, que "As contas serão prestadas por anos económicos e elaboradas pelos responsáveis da respectiva gerência ou, se estes tiverem cessado funções, por aqueles que lhes sucederem, sem prejuízo do dever de recíproca colaboração". Nada obstante, o art. $52^{\circ} / 2$, da LOPTC, reforça a pessoalidade na prestação de contas: "Quando, porém, dentro de um ano económico houver substituição do responsável ou da totalidade dos responsáveis nas administrações colectivas, as contas serão prestadas em relação a cada gerência". Na França, o assunto está tratado no art. L 131-6-1, do CJF: "Le comptable passible de l'amende, pour retard dans la production des comptes, est celui en fonction à la date réglementaire de dépôt des comptes. Toutefois, en cas de changement de comptable entre la fin de la période d'exécution du budget et la date à laquelle le compte doit être produit, la Cour des comptes peut infliger l'amende à l'un des prédécesseurs du comptable en fonction à la date réglementaire de production des comptes" (O contábil passível de multa, pelo atraso na prestação de contas, é aquele em exercício na data regulamentar de depósito das contas. Todavia, em caso de alteração do
} 
Neste sentido, no caso da responsabilidade financeira reintegratória (transmissível aos herdeiros), na linha do que dispôs a Sala de Apelação do Tribunal de Contas Espanhol, é razoável condicionar esta transmissibilidade à realização de defesa prévia do responsável, ainda em vida. Isto porque, a defesa no âmbito dos Tribunais de Contas geralmente envolve razões, justificativas e informações técnicas (jurídicas, contábeis, etc.), acesso aos documentos públicos, que podem ou não ser sigilosos, de forma que, aos sucessores seria extremamente dificultoso obter após o falecimento do responsável, não possibilitando o desenvolvimento regular de um processo justo.

A propósito, dispõe o art. 213, do Regimento Interno do TCU que: "O Tribunal determinará o arquivamento do processo de prestação ou tomada de contas, mesmo especial, sem o julgamento do mérito, quando verificar a ausência de pressupostos de constituição e de desenvolvimento válido e regular do processo".

\subsection{Princípio da vedação ao bis in idem}

O presente tópico tem por finalidade analisar a aplicação do princípio da vedação ao "bis in idem" (ne bis in idem) na responsabilidade financeira. Esta análise abrange o exame da possibilidade de cumulação de sanções financeiras entre si, nas modalidades sancionatória e reintegratória. A análise da possibilidade de cumulação de sanções de natureza diversa será tradada no capítulo 22.

Daniel Ferreira, ao abordar o princípio da vedação ao "bis in idem", esclarece que, no Estado Democrático, ninguém pode ser reiteradamente sancionado por um mesmo ilícito. Segundo o autor, o princípio não implica na proibição de cumulação de pena criminal com uma sanção de natureza administrativa, bastando que seu comportamento tenha sido

contábil entre o fim do período de execução orçamentária e a data em que as contas devem ser prestadas, a Corte de Contas pode aplicar multa a um dos predecessores do contábil em exercicio no momento de prestação de contas - tradução livre). 
considerado reprovável nas duas ordens normativas. Para Daniel Ferreira, o princípio veda a possibilidade de múltipla e reiterada manifestação sancionatória da Administração Pública (FERREIRA, 2001).

Para Heraldo Garcia Vitta, a vedação ao "bis in idem" consiste na impossibilidade da pessoa ser responsabilizada mais de uma vez pela mesma conduta. $\mathrm{O}$ princípio relaciona-se com os princípios da tipicidade, legalidade e razoabilidade. $\mathrm{O}$ autor analisa a possibilidade de aplicação do princípio à cumulação entre sanção penal e sanção administrativa, bem como à cumulação de sanções administrativas (VITTA, 2003).

No primeiro caso, salienta que apesar da identidade ontológica entre a sanção penal e a sanção administrativa, tratam-se de responsabilidades independentes em função da tripartição dos Poderes. Não obstante, esclarece que o ordenamento jurídico pode regular o intercâmbio entre ambas as sanções (VITTA, 2003).

No segundo caso, o autor cita o exemplo da pessoa que importa de mercadoria sem autorização do órgão sanitário do país importador e que deixa de recolher o tributo. Para o autor, estaria o indivíduo sujeito à duas ordens administrativas: a sanitária e a tributária, pois dois deveres jurídicos foram descumpridos, ocorrendo violação de duas normas administrativas (VITTA, 2003). Conclui, assim, Heraldo Garcia Vitta que (VITTA, 2003, p. 119):

\footnotetext{
"Logo, é possível: 1) ser imposta mais de uma penalidade administrativa ao infrator ou responsável, quando houver o descumprimento de distintos deveres, estabelecidos em normas jurídicas (...) 2) ser imposta mais de uma penalidade administrativa ao infrator ou responsável, quando ocorre o descumprimento de um mesmo dever, porém, explicitamente, a norma determina a imposição, concomitante, de diferentes penalidades administrativas".
}

Regis Fernandes de Oliveira, ao discorrer sobre a compatibilidade entre a pena e a sanção, não admite a possibilidade de aplicação de nova sanção de mesma natureza, para o mesmo fato (OLIVEIRA, R., 2005, p. 83): 


\begin{abstract}
"Um só comportamento pode infringir normas de diversos conteúdos. Pode tipificar uma conduta criminosa e também caracterizar uma infração civil. (...) O que se pretende dizer é que a aplicação de sanção administrativa não implica isenção de outras obrigações decorrentes do comportamento antijurídico, pois infringiu ele outras normas que prevêem outras penas. $\mathrm{O}$ que não se aceita é a possibilidade de nova sanção, da mesma natureza, para o mesmo fato. $\mathrm{O}$ Supremo Tribunal Federal deixou assentado que, 'em tese, constituir o fato infração administrativa não afasta, por si só, que simultaneamente configure infração penal'".
\end{abstract}

Paulo Roberto Coimbra Silva afirma que a impossibilidade de cumulação de sanções no âmbito de cada ramo específico da ciência jurídica é tese pacífica no âmbito da doutrina e da jurisprudência, restando somente a discussão sobre a possibilidade de aplicação concomitante de sanções dos diversos ramos do Direito (SILVA, P., 2007, p. 353):

"Mas, se dentro dos limites de cada ramo específico da ciência jurídica, seja ele penal, administrativo, tributário, ambiental, etc., isoladamente considerado, a aplicação do princípio ne bis in idem tem sido reconhecida, a una voce, pela doutrina e jurisprudência como fator impeditivo da cumulação de sanções imputadas sobre um mesmo fato, não se revela tranqüila a aceitação de sua aplicação concomitante sobre os diversos ramos jurídicos. Muito pelo contrário, tem-se admitido, ao menos no Brasil, a cumulação de sanções de naturezas diversas - v.g., penal e tributária - sobre um mesmo ato ilícito".

Sustenta Coimbra Silva que, na Espanha, a cumulação de sanções de naturezas diversas prevaleceu no passado, sob o fundamento de serem os ilícitos penal, administrativo, ou tributário, ontológica ou teleológicamente distintos e de haver total independência entre as potestades sancionatórias administrativa e penal (SILVA, P., 2007).

Entretanto, acrescenta que, com a aproximação ontológica entre os ilicitos, reconheceu-se a extensão do princípio ne bis in idem para abarcar sanções de diferentes natureza. A mudança de orientação do Tribunal Constitucional Espanhol teria ocorrido por força da $\mathrm{STC} \mathrm{n}^{\circ} 177$, de 11.10.1999, ao reconhecer a íntima conexão entre os princípios da legalidade, tipicidade e proporcionalidade com o princípio do "ne bis in idem" (SILVA, P., 2007).

Mais adiante, Coimbra Silva enumera três pressupostos para a aplicação do princípio "ne bis in idem" (SILVA, P., 2007) 
O primeiro consiste na existência de uma conduta ilícita única. No caso de atos ilícitos, ainda que idênticos, ou de reincidência, não cabe a aplicação do princípio (SILVA, P., 2007).

O segundo requisito é o da identidade subjetiva: "Constatando-se a prática de uma única conduta ilícita sob a mira de diferentes normas sancionadoras, para que seja aplicável o ne bis in idem, imprescindível verificar se o(s) sujeito(s) ativo(s) da infração é(são) a(s) mesma(s) pessoa(s)" (SILVA, P., 2007, p. 367).

O terceiro requisito é a identidade teleológica ou identidade de fundamento (SILVA, P., 2007, p. 369):

\footnotetext{
"Importante perceber que a dita identidade de fundamento consiste na coincidência dos bens jurídicos protegidos e das funções primordialmente exercidas pela sanção. (...) Assim, admissível é a cumulação de sanções somente quando estas destinarem-se à tutela de bens ou interesses jurídicos distintos ou desempenharem funções diversas, a exemplo da concomitante incidência de uma sanção ressarcitória e uma repressiva".
}

Na sua conclusão, Coimbra Silva afirma que (SILVA, P., 2007, p. 370):

"A mera distinção de sua natureza jurídica não pode ensejar ou justificar a múltipla valorização de uma conduta ilícita mediante imposição de diferentes sanções ou penalidades.

Para evitar essa indesejável e, no mais das vezes, desproporcional cumulação, diferentes soluções têm sido forjadas para evitar a imputação cumulativa de duas ou mais sanções cominadas a uma mesma ação ilícita, ainda que veiculadas em normas de naturezas jurídicas distintas".

Dentre estes critérios, o autor manifesta especial apreço para o da absorção da sanção tributária pela sanção penal, sem, entretanto, deixar de reconhecer as suas limitações (SILVA, P., 2007).

Vale lembrar que não há que se falar em bis in idem na hipótese em que o Tribunal de Contas aplicar ao responsável, simultaneamente, uma sanção financeira e uma medida cautelar, tal como a de afastamento do responsável do cargo em que ocupa. Desta forma, além dos três pressupostos mencionados por Paulo Roberto Coimbra Silva, acrescemos um quarto requisito, o de que as restrições impostas ao responsável sejam da 
natureza de "sanção jurídica", consoante se pode concluir do precedente do STF (MS 22.643-SC):

"Na hipótese de haver obstrução ao livre exercício das auditorias determinadas pelo Tribunal de Contas da União, não configura bis in idem a imposição de multa (Lei 8.443/92, art. 58, V) e de afastamento temporário do responsável (Lei 8.443/92, art. 44), uma vez que aquela tem a natureza de sanção e este, de medida cautelar. Com base nesse entendimento, Tribunal indeferiu mandado de segurança impetrado pelo Conselho Regional de Medicina do Estado de Santa Catarina-CREMESC e por seu Presidente, contra acórdão do TCU que impusera multa e afastamento temporário do Presidente.Precedente citado: MS 21.466-DF (RTJ 151/153)"

Feitas estas considerações sobre os pressupostos para aplicação do "ne bis in idem", passamos as questões relativas à responsabilidade financeira.

A primeira questão diz respeito à possibilidade de cumulação entre a responsabilidade financeira reintegratória com a espécie sancionatória.

A resposta é afirmativa, pois não se atende ao terceiro requisito apresentado por Coimbra Silva (identidade de fundamento ou identidade teleológica). Além disso, a CF/88 deixa implícita a possibilidade de cumulação entre a responsabilidade sancionatória com a responsabilidade reintegratória.

Com efeito, o art. 71, inciso VIII, da CF/88, determina que a lei estabelecerá, dentre outras sanções, multa proporcional ao dano ao erário. Como a multa não tem função reparatória, há que se presumir que o legislador constituinte admitiu a cumulatividade da multa proporcional com a reparação ao dano causado ao Erário.

Neste sentido, dispõe o art. 19, da Lei n 8.443/92:

"Quando julgar as contas irregulares, havendo débito, o Tribunal condenará o responsável ao pagamento da dívida atualizada monetariamente, acrescida dos juros de mora devidos, podendo, ainda, aplicar-lhe a multa prevista no art. 57 desta lei, sendo o instrumento da decisão considerado título executivo para fundamentar a respectiva ação de execução".

Por sua vez, o art. 57, da Lei $\mathrm{n}^{\circ}$ 8.443/93 preceitua que: "Quando $o$ responsável for julgado em débito, poderá ainda o Tribunal aplicar-lhe multa de até cem por cento do valor atualizado do dano causado ao Erário". 
Esta cumulatividade justifica-se, na medida em que uma sanção tem por função precípua a punição (multa), enquanto a outra a reparação do dano ao erário. Além disso, a ausência de aplicação de multa, no caso do responsável julgado em débito, destituiria a sanção financeira de qualquer efeito preventivo sobre o responsável, pois, na pior das hipóteses, o individuo seria condenado a pagar o montante de recursos desviados.

No Direito Português, admite-se a cumulatividade destas sanções financeiras, consoante dispõe o art. 65\%/5, da Lei $\mathrm{n}^{\circ}$ 98/97: "A aplicação de multas não prejudica a efectivação da responsabilidade pelas reposições devidas, se for caso disso".

Outra questão pertinente à aplicação do princípio diz respeito à existência de vários processos em tramitação concomitante no âmbito dos Tribunais de Contas, tratando sobre o mesmo fato. $\mathrm{O}$ mesmo ato ilícito, ocorrido em um determinado exercício financeiro, pode estar sendo apurado em uma denúncia ou representação, em uma físcalização do Tribunal e, até mesmo, em um processo de contas, noticiado pelo órgão de controle interno. Nesta caso, a incidência do princípio exige que conduta do responsável só poderá ser sancionada e ele só poderá vir a ser obrigado a repor os recursos em um único processo ${ }^{102}$. Neste caso, mais comum é a juntada e encerramento de alguns do processos, para que o tratamento do tema seja dado em um único processo.

Muito comum também, no dia a dia dos Tribunais de Contas, é a prática da conduta ilícita por diversos exercícios financeiros. Neste caso, não incide o "ne bis in idem", pois a conduta deixa de ser única, ou seja, não há, no caso concreto, o primeiro pressuposto apontado por Coimbra Silva para a incidência do princípio. Neste caso, considerando a anualidade das prestações de contas, deverá a Corte de Contas utilizar critérios de sancionamento para reincidência, caso já tenha aplicado sanções anteriormente.

\footnotetext{
102 No Capítulo 19, defendemos a tese de que, apenas nos processos de contas, é possível efetivar a responsabilidade financeira, nas modalidades reintegratória ou sancionatória.
} 
Da mesma forma, não havendo ressarcimento integral, em atenção ao mesmo princípio, as parcelas devolvidas deverão ser descontadas do valor do débito (consideradas as datas de devolução, para fins de atualização monetária e incidência de juros moratórios).

Questão complexa é a cumulação da sanção financeira com as sanções de outra natureza, tais como a civil, penal, disciplinar com a de improbidade administrativa, assunto que será tratado no capítulo 22.

\subsection{Princípio da Irretroatividade da Lei Instituidora da Sanção}

Integrando o núcleo comum do Direito Punitivo, o princípio da irretroatividade da lei instituidora da sanção, conforme previsto no art. $5^{\circ}$, inciso XL da CF/88, aplica-se, também, à responsabilidade financeira.

Examinamos, inicialmente, o tema sob o ponto de vista dos autores do Direito Administrativo Sancionador, para, posteriormente, analisar a aplicação do princípio à responsabilidade financeira.

Heraldo Garcia Vitta leciona que (VITTA, 2003, p. 111-112):

"A irretroatividade da lei é princípio geral de Direito. As leis são editadas para regular os casos atuais e futuros (tempus regit actum) e não os fatos que já ocorram e foram regulados por norma diversa. Na verdade, a irretroatividade da lei é corolário do princípio da legalidade; é uma garantia do cidadão e também uma certeza do Direito, decorre do princípio da segurança jurídica, inerente ao regime democrático.

Significa, em termos de penas administrativas, a impossibilidade de a norma jurídica, que comina infração ou sanção administrativas, atingir condutas anteriores à edição dela (exceto para beneficiar o suposto infrator, como veremos depois)".

Nesta esteira, Garcia Vitta admite a aplicação retroativa da lei mais benigna na esfera administrativa (VITTA, 2003, p. 113-114):

\footnotetext{
"Com efeito, apesar de as leis serem editadas para regular fatos atuais ou futuros - como acontece anteriormente - as normas que beneficiem os infratores retroagem, a fim de prestigiar a nova realidade imposta pelo legislador, o qual tem a incumbência de acolher os anseios da sociedade num dado tempo e lugar. Não se justifica o Estado punir alguém, quando o legislador valora a conduta (antes ilícita ou pressuposto de pena mais grave), segundo as novas concepções sociais e entende já não ser ilícita, ou pressuposto de sanção menos grave.
} 
Devemos fazer importante ressalva, pois se ocorre ou redução ou abolição dos elementos de fato, que suscitaram a penalidade administrativa, o infrator não será beneficiado (...)".

Daniel Ferreira, no mesmo sentido, relaciona a irretroatividade à legalidade e à segurança jurídica, acrescentando que (FERREIRA, 2001, p. 137-138):

\begin{abstract}
"Referido princípio é reflexo imediato de outro - o da legalidade - que, em nível sancionador (inclusive penal), veda a imposição de qualquer consequiência jurídica restritiva de direitos de natureza repressiva (sanção ou pena) em decorrência de um ilícito (infração ou crime) até então - a época do seu cometimento - não reconhecido como tal

(...)

Se assim não fosse vigeria a insegurança jurídica, porque a ninguém seria dado escolher agir conforme o Direito e, pois, se afastar da imposição de sanções em caso de seu descumprimento".
\end{abstract}

No tocante à retroatividade da lei mais benígna, o autor leciona que

(FERREIRA, 2001, p. 138):

\begin{abstract}
"Intrinsecamente ligado ao anterior princípio (enquanto exceção) está o geral primado da retroação da lei mais benéfica, em virtude do qual a norma insculpida no art. $5^{\circ}$, XL, da Constituição constitui-se em garantia constitucional, não se limitando seu conteúdo a albergar o fato criminal, mas também o administrativo. É dedutível do ordenamento jurídico o entendimento".
\end{abstract}

Fábio Medina Osório aponta que, no Direito Espanhol, o princípio da irretroatividade das normas sancionadoras em geral está expresso no art. 9.3 e no art. 25.1, da Constituição Espanhola. No Direito Brasileiro, o autor aponta precedente do STF no sentido da restrição da incidência do art. $5^{\circ}$, inciso XL, da Constituição Federal apenas ao âmbito do Direito Penal (STF - 1 ${ }^{\mathrm{a}}$. Turma - AGCRAE 177.313-MG, Rel. Min. Celso de Mello, DJU 13.09.1996) (OSORIO, 2005).

Osório relaciona o princípio da irretroatividade com o da proporcionalidade e com o da segurança jurídica (OSORIO, 2005, p. 331):

\footnotetext{
"A irretroatividade das leis sancionadoras decorre, em realidade, dos princípios da proporcionalidade e da segurança jurídica, ambos de origem constitucional, mostrando-se inviável interpretar o sistema de modo a sancionar condutas que, antes, não admitiam determinadas sanções, eram lícitas ou não proibidas pela ordem jurídica".
} 
As normas processuais aplicam-se imediatamente aos processos em curso, independentemente dos fatos que lhes deram ensejo tenham ocorrido antes da vigência da norma, conforme leciona Osório (OSORIO, 2005, p. 332):

"Sem embargo, cabe sempre distinguir normas materiais de normas processuais ou
procedimentais, ao efeito de fixar o alcance temporal da lei administrativa. As normas
punitivas deverão submeter-se a essa lógica.
As leis que se aplicam a fatos em curso, regulando-lhes as consequiências a partir de sua
vigência, têm efeito imediato. Já se decidiu, por exemplo, que a decretação da
indisponibilidade de bens adquiridos anteriormente à vigência da Lei $8.429 / 92$ 'não pode ser
tachada de retroativa, uma vez que o art. $37,4^{\circ}$, da Constituição, estabelece que os atos de
improbidade importarão a indisponibilidade dos bens'.Norma processual de efeito imediato."
É importante distinguir os ílícitos permanentes ou continuados e os de consumação imediata (OSORIO, 2005, p. 333-334):

"Atos complexos, ilícitos permanente, consumação de atos de improbidade ou sua continuação, sob o império da Lei $\mathrm{n}^{\circ} 8.429 / 92$, autorizam o imediato incidir dessa legislação, dada a incidência de princípios de direito intertemporal que são importados inclusive da seara penal, revelando o agente, por ações ou omissões (no não estancar os efeitos e resultados da improbidade, quando houvesse tal dever jurídico), elemento subjetivo contrário aos ditames legais repressores, incorrendo, assim, nas sanções correspondentes aos atos de improbidade.

Diferente se mostra a hipótese em que o ílícito administrativo se consuma inteiramente, na conduta e em seus efeitos, em período anterior à legislação mais gravosa, pois nesse caso, efetivamente, não há possibilidade de efeito imediato da legislação e muito menos retroatividade, ainda que inexista, nesse caso, direito adquirido, ato jurídico perfeito ou coisa julgada em favor do agente agressor".

No âmbito da Responsabilidade Financeira, a instituição de novas sanções e infrações financeiras não atinge os fatos ocorridos antes da sua vigência, salvo quando estes fatos se protraem no tempo, conforme a lição de Fábio Medina Osório.

No âmbito federal, antes do advento da Lei ${ }^{\circ}$ 8.443/92 vigorava o Decreto-lei n ${ }^{\circ}$ 199/67, o qual não autorizava a cominação de multa simultaneamente à imputação de débito. Se o fato ocorreu na vigência do Decreto-Lei $n^{\circ} 199 / 67$, não se admite esta cumulação, ainda que o processo venha ser julgado após a edição da nova Lei Orgânica do Tribunal.

Com efeito, no Acórdão $n^{\circ}$ 2739/2005 - $1^{\text {a }}$. Câmara, que imputou débito ao responsável por fato ocorrido antes da vigência da Lei ${ }^{\circ}$ 8.443/92, o TCU deixou de aplicar multa proporcional ao dano ao Erário. Nas palavras do Ministro-Relator: 
"Não obstante a gravidade e a reprovabilidade da conduta do ex-empregado, fico impossibilitado de acolher a proposta de cominação de multa proporcional ao débito, por obediência ao princípio geral da irretroatividade das leis, visto que, na época das ocorrências, a legislação vigorante, liderada pelo Decreto-Lei no 199/67, não estabelecia esse tipo de apenação".

A retroatividade da lei mais benéfica, apesar de não freqüente na casuística do TCU, é cabível, por aplicação analógica do art. $5^{\circ}$, inciso XL, da CF/88. Um benefício inexistente na vigência do Decreto-lei $n^{\circ}$ 199/67, mas introduzido na Lei $n^{\circ}$ 8.443/92, constituiria direito do responsável, ainda que o ato ilícito tivesse ocorrido sob a égide da antiga Lei Orgânica do TCU ${ }^{103}$.

Impõe-se considerar, também, que não se aplica a retroatividade benéfica, no caso do advento de uma lei permitindo a realização de uma despesa que, à época do fato, era considerada ilegítima. Esta conclusão visa preservar o princípio da legalidade aplicado à despesa pública.

Caso diverso é o de uma nova interpretação jurisprudencial (do Tribunal de Contas, do STF, ou dos Tribunais Superiores), segundo a qual a despesa pública anteriormente impugnada passa a ser considerada legítima, com base nas fontes normativas existentes. Neste caso, haveria a retroatividade benigna da nova interpretação, uma vez que a conduta questionada não é mais nociva, segundo o entendimento vigente, cabendo, por isonomia, a aplicação a outros casos.

Cumpre mencionar, entretanto, que, no Relatório do Acórdão TCU n 2855/2005 - Primeira Câmara cogitou-se na possibilidade de aplicação retroativa de Instrução Normativa da STN:

"11.2 É de larga sabença que, em matéria de direito intertemporal, a regra geral é a da prevalência da lei do tempo do fato (tempus regit actum), salvo em se tratando de norma penal Tribunal a boa-fé, a liquidação tempestiva do débito atualizado monetariamente sanará o processo, se não houver sido observada outra irregularidade nas contas". Trata-se da oportunidade concedida ao acusado, cuja defesa tiver sido rejeitada pelo Tribunal, de liquidar o débito sem o acréscimo de juros de mora, condicionada a boa-fé e a inexistência de outra irregularidade nas contas. 
mais benigna, quando prevalece o princípio da retroatividade da lei $\left(\mathrm{CF} / 88\right.$, art. $5^{\circ}$, inciso XL e $\mathrm{CP}$, art. $2^{\circ}$, parágrafo único).

11.3 Tais dispositivos são, usualmente, adotados na área do direito penal, mas, por analogia, poderão, data venia, ser estendidos a outros ramos do direito, como o administrativo, desde que existam, em cada caso concreto, argumentos suficientes para tal procedimento.

(...) In casu, deve prevalecer, então, a nova redação dada pela IN/STN n. 02, de 25/03/2002, ao inciso II do art. $8^{\circ}$ da IN/STN n. 01/1997, que passou a considerar ilegal somente o 'pagamento, a qualquer título, a servidor ou empregado público, integrante de quadro de pessoal de órgão ou entidade pública da administração direta ou indireta, por serviços de consultoria ou assistência técnica' ".

Não concordo com este entendimento, pois o princípio da irretroatividade ou da retroatividade benigna refere-se à norma sancionatória e não à norma reguladora da gestão pública. 


\section{PRESSUPOSTOS OBJETIVOS}

O capítulo versa sobre os requisitos objetivos da responsabilidade financeira, nas suas modalidades sancionatória e reintegratória, tais como, a conduta ilícita, a violação à norma de gestão, o dano ao erário, o nexo de causalidade. Os requisitos subjetivos (sujeitos, culpabilidade) são tratados no capítulo 12.

\subsection{Responsabilidade Financeira Reintegratória}

A responsabilidade financeira reintegratória importa na obrigação de repor as quantias correspondentes ao dano causado ao Erário em razão da violação de normas e princípios pertinentes à gestão de bens, dinheiros e valores públicos.

Procedo, inicialmente, à análise da legislação e doutrina dos atos de improbidade administrativa em razão da semelhança entre os Atos de Improbidade Administrativa que causam lesão ao erário e as hipóteses de responsabilidade financeira reintegratória. Em seqüencia, estudamos os pressupostos desta responsabilidade no Direito Estrangeiro, para, então, passarmos ao Direito Brasileiro.

Os atos de improbidade administrativa que acarretam dano ao erário estão definidos no art. 10, da Lei $\mathrm{n}^{\circ}$ 8.429/92. Dentre as hipóteses, cabe mencionar, alienar bens integrantes do patrimônio público por preço inferior ao de marcado ou adquirir bem ou serviço por preço superior ao do mercado.

Por sua vez, o art. $5^{\circ}$, da mesma lei, dispõe que "ocorrendo lesão ao patrimônio público por ação ou omissão, dolosa ou culposa, do agente ou de terceiro, darse-á o integral ressarcimento do dano".

Eduardo Garcia e Rogério Pacheco Alves assinalam que os danos causados ao patrimônio público podem decorrer de atos dissonantes dos princípios da administração

pública, como também de atos em que haja a estrita observância destes. É imprescindível, 
para a configuração da improbidade, que a conduta que tenha causado dano tenha sido fruto da inobservância dos princípios que informam os atos do agente público. Quando fatores externos concorreram para causar o dano ou quando este ocorreu fora da esfera de previsibilidade do agente, não há que se falar em improbidade administrativa (GARCIA; ALVES, 2006).

Entretanto, os autores admitem a possibilidade do dano presumido, não havendo, segundo eles, a necessidade de demonstração da diminuição patrimonial efetiva, havendo inúmeras situações de lesividade presumida, previstas na legislação (GARCIA; ALVES, 2006).

Para os autores, o conceito de Erário não coincide com o de Patrimônio Público. Este é mais amplo que aquele, que se restringe aos bens e interesses de natureza econômico-financeira do Estado (GARCIA; ALVES, 2006, p. 261-262):

\begin{abstract}
"Entende-se por erário o conjunto de bens e interesses de natureza econômico-financeira pertencentes ao Poder Público (rectius: União, Estados, Distrito Federal, Municípios, entidades da administração indireta e demais destinatários do dinheiro público previstos no art. $1^{\circ}$ da Lei ${ }^{\circ}$ 8.429/92). Patrimônio público, por sua vez, é o conjunto de bens e interesses de natureza moral, econômica, estética, artística, histórica, ambiental e turística pertencentes ao Poder Público, conceito este extraído do art. $1^{\circ}$ da Lei $\mathrm{n}^{\circ} 4.717 / 65$ e da dogmática contemporânea, que identifica a existência de um patrimônio moral do Poder Público (...)".
\end{abstract}

Para os autores, a proteção conferida pela Lei $n^{\circ} 8.429 / 92$ não se restringe ao Dano ao Erário, mas tem um escopo mais amplo (GARCIA; ALVES, 2006, p. 263):

"(...) o sistema instituído pela Lei $\mathrm{n}^{\circ}$ 8.429/92 não visa unicamente a proteger a parcela de natureza econômico-financeira do patrimônio público, sendo ampla e irrestrita a abordagem deste, o que exige uma proteção igualmente ampla e irrestrita, sem exclusões dissonantes do sistema".

Em sentido contrário, manifesta-se Francisco Octavio de Almeida Prado

(PRADO, F., 2001, p. 96):

\footnotetext{
"'Erário' é Tesouro, Fazenda. Trata-se, pois, de conceito bem mais restrito que o de 'patrimônio público'. Sua utilização pelo legislador evidencia que o prejuízo cogitado pelo art. 10 é o estritamente financeiro, não se cogitando de danos ambientais, estéticos, etc. É essencial nas hipóteses elencadas em qualquer dos incisos do art. 10 que a conduta do agente tenha acarretado prejuízo financeiro, ou economicamente apreciável".
} 
Alguns autores sustentam que a lesão ao patrimônio público a que se refere o art. 10, da Lei $\mathrm{n}^{\circ} 8.429 / 92$ engloba o dano moral, tal como o Prof. Marcelo Figueiredo (FIGUEIREDO, 2004, p. 102):

\begin{abstract}
"O dispositivo alude a lesão que enseje perda patrimonial. Nele, por certo, está englobada a noção de lesão moral, porque no conceito de perda patrimonial, cremos, está englobada a idéia de prejuízo moral, dano moral. Ademais, a lesão ao patrimônio moral sempre será dimensionada sob o aspecto econômico. Em suma, não existe 'perda patirmonial' apenas sob a ótica econômica, ainda que recomposta a partir desse critério".
\end{abstract}

Eduardo Garcia e Rogério Pacheco Alves também aquiescem a possibilidade de reparação de dano moral (de natureza objetiva) como conseqüência do ato de improbidade (GARCIA; ALVES, 2006, p. 443):

\begin{abstract}
"Do mesmo modo que as pessoas jurídicas de direito privado, as de direito público também gozam de determinado conceito junto à coletividade, do qual muito depende o equilíbrio social e a subsistência de várias negociações, especialmente em relação: a) aos organismos internacionais, em virtude dos constantes empréstimos realizados; b) aos investidores nacionais e estrangeiros, ante a frequente emissão de títulos da dívida pública para a captação de receita; c) à iniciativa privada, para a formação de parcerias; d) às demais pessoas jurídicas de direito público, o que facilitará a obtenção de empréstimos e a moratória de dívidas já existentes. É plenamente admissível, assim, que o ato de improbidade venha a macular o conceito que gozam as pessoas jurídicas relacionadas no art. $1^{\circ}$ da Lei ${ }^{\circ} 8.429 / 92$, o que acarretará um dano de natureza não-patrimonial passível de indenização".
\end{abstract}

\title{
11.1.1. Direito Português
}

São três os pressupostos da responsabilidade financeira reintegratória no Direito Português: o dano, de caráter patrimonial, suscetível de avaliação pecuniária; a conduta humana, positiva ou negativa, culposa, por parte de certos agentes públicos e a idoneidade da ação para causar o referido dano.

Acerca da conduta humana, a Lei de Organização e Processo do Tribunal de Contas de Portugal explicita algumas ações ou comportamentos suscetíveis de gerar a Responsabilidade Financeira Reintegratória:

a) o alcance; 
b) o desvio de dinheiros e valores públicos;

c) o pagamento indevido;

d) a renúncia indevida de receitas.

Com efeito, o artigo 59\%/1, da Lei $n^{\circ}$ 98/97 dispõe que:

"Nos casos de alcance, desvio de dinheiros ou valores públicos e ainda de pagamentos indevidos, pode o Tribunal de Contas condenar o responsável a repor as importâncias abrangidas pela infracção, sem prejuízo de qualquer outro tipo de responsabilidade em que o mesmo possa incorrer".

Ademais, o artigo $60^{\circ}$ determina que:

"Nos casos de prática, autorização ou sancionamento, com dolo ou culpa grave, que impliquem a não liquidação, cobrança ou entrega de receitas com violação das normas legais aplicáveis, pode o Tribunal de Contas condenar o responsável na reposição das importâncias não arrecadadas em prejuízo do Estado ou de entidades públicas".

$\mathrm{O}$ alcance ocorre, segundo a lei, "quando, independentemente da acção do agente nesse sentido, haja desaparecimento de dinheiros ou de outros valores do Estado ou de outras entidades públicas" (art. 59\%2, Lei n 98/97).

O desvio de dinheiros ou valores ocorre "quando se verifique o seu desaparecimento por acção voluntária de qualquer agente público que a eles tenha acesso por causa do exercício das funções públicas que lhe estão cometidas" (art. 59\%/3, Lei $\mathrm{n}^{\circ}$ 98/97 - LOPTC).

Por fim, o pagamento indevido compreende (art. 59\%/4, LOPTC)

"os pagamentos ilegais que causarem dano para o erário público, incluindo aqueles a que corresponda contraprestação efectiva que não seja adequada ou proporcional à prossecução das atribuições da entidade em causa ou aos usos normais de determinada actividade".

Cabe lembrar que, antes da alteração promovida pela Lei $\mathrm{n}^{\circ} 48 / 2006$, não cabia a reposição, quando o montante devido fosse compensado com o enriquecimento sem causa de que o Estado tenha se beneficiado pela prática do ato ilegal ou pelos seus efeitos 
(art. 59\%/4, Lei $n^{\circ}$ 98/97, versão original). Atualmente, ainda que haja contraprestação em benefício da Fazenda Pública, esta só será compensada com o débito, quando houver correlação entre esta contraprestação e as atribuições do órgão ou entidade pública ou ainda, aos usos normais de determinada atividade.

Até a edição da Lei $n^{\circ} 48 / 2006$, exigia-se, ainda, a tipicidade das condutas para a configuração da responsabilidade financeira reintegratória, conforme ensinamento do próprio Tribunal de Contas de Portugal (PORTUGAL, 1999, p. 14):

"(...) Mas o que verdadeiramente distingue a responsabilidade financeira reintegratória da figura da responsabilidade civil do Direito Privado, é o facto de, enquanto esta poder resultar de qualquer acção não tipificada na lei que seja susceptível de provocar um dano, aquela resulta apenas de um conjunto de acções tipificadas na lei susceptíveis de causar danos patrimoniais numa esfera públicas.

Com efeito, as ações ou comportamentos susceptíveis de originar responsabilidade financeira reintegratória, são apenas: o desvio, o alcance, os pagamentos indevidos e a não arrecadação de receitas".

No mesmo sentido, o Parecer $\mathrm{n}^{\circ}$ 1237, de 31/05/2001, do Conselho Consultivo da Procuradoria Geral da República de Portugal (PORTUGAL, 2001):

\begin{abstract}
"A responsabilidade financeira tem como fonte a prática de factos financeiros directamente previstos na lei (alcance, desvio de dinheiros ou valores públicos, pagamentos indevidos ou não arrecadação de receitas); (...) A responsabilidade financeira reintegratória constitui os responsáveis na obrigação de repor os montantes determinados na lei, apurados objectivamente em função dos factos que constituem os pressupostos da responsabilidade".
\end{abstract}

Atualmente, conforme art. 59\% $/ 5$, da LOPTC, admite-se outras condutas que não apenas aquelas mencionadas, verbis: "Sempre que da violação de normas financeiras, incluindo no domínio da contratação pública, resultar para a entidade pública obrigação de indemnizar, o Tribunal pode condenar os responsáveis na reposição das quantias correspondentes".

Assim sendo, toda conduta que importe violação às normas financeiras acarretando dano ao erário enseja a responsabilidade financeira reintegratória. 


\title{
11.1.2. Direito Espanhol
}

Consoante informa Carles Rosiñol I Vidal o conceito atual de "Responsabilidad Contable", que estava previsto no art. 38.1, da Lei Orgânica do Tribunal del Cuentas (LOTCu, Lei 2/1982, de 12 de maio), foi restringido pela Ley de Funcionamiento del Tribunal de Cuentas (LFTCu, Lei 7/1988, de 05 de abril), no seu artigo 49.1, o qual dispõe que (VIDAL, 1999, p. 32):

\begin{abstract}
"La jurisdicción contable conocerá de las pretensiones de responsabilidad que, desprendiéndose de las cuentas que deben rendir todos cuantos tengan a su cargo el manejo de caudales o efectos públicos, se deduzcan contra los mismos cuando, con dolo, culpa o negligencia graves, originaren menoscabo en dichos caudales o efectos a consecuencia de acciones u omisiones contrarias a las leyes reguladoras del régimen presupuestario y de contabilidad que resulte aplicable a las entidades del sector público o, en su caso, a las personas o entidades perceptoras de subvenciones, créditos, avales u otras ayudas procedentes de dicho sector. Sólo conocerá de las responsabilidades subsidiarias, cuando la responsabilidad directa, previamente declarada y no hecha efectiva, sea contable".
\end{abstract}

Com base nesta definição, Carles Rosiñol I Vidal elenca os pressupostos da responsabilidade contábil (VIDAL, 1999):

a) infração à lei, restritas às leis reguladoras do regime orçamentário ou de contabilidade;

b) "menoscabo" efetivo dos recursos públicos;

c) relação causal entre a infração à lei e o "menoscabo";

d) as pretensões de responsabilidade contábil haverão de desprender-se das contas que devem ser prestadas por todas pessoas que têm a seu cargo o manejo de recursos públicos;

e) o prejuízo para o Erário há de ser conseqüência de uma conduta dolosa, culposa ou negligente grave.

Analisamos, a seguir, os pressupostos objetivos da responsabilidade contábil (itens a a c). Os itens d e e serão tratados no tópico referente aos pressupostos subjetivos. 
O primeiro pressuposto refere-se à infração às leis que regulam o regime orçamentário ou de contabilidade. Carles Rosiñol I Vidal esclarece que, antes da Lei de Funcionamento do Tribunal de Contas, vigorava a Lei Orgânica do Tribunal de Contas, a qual dispunha que a infração à lei em geral poderia dar ensejo à responsabilidade contábil (Art. 38.1, Ley 02/1982): "El que por acción u omisión contraria a la Ley originare el menoscabo de los caudales o efectos públicos quedará obligado a la indemnización de los daños y perjuicios causados" (VIDAL, 1999).

Entretanto, a jurisprudência da Sala de Apelação do Tribunal de Contas (Sentenças $n^{\circ}$ 04/1986, de 18 de abril e 10/87 de 10 de julho) restringiu as infrações que poderiam dar ensejo à responsabilidade contábil, admitindo apenas aquelas referentes às leis reguladoras do regime orçamentário e de contabilidade aplicável as entidades do setor público ou às pessoas/entidades receptoras de ajudas, créditos e subvenções do poder público.

Por fim, a Lei de Funcionamento do Tribunal de Contas Espanhol veio a positivar este entendimento juriprudencial no art. 49.1, conforme supramencionado.

Carles Rosiñol I Vidal, acerca do primeiro pressuposto, aponta duas questões. A primeira refere-se ao estabelecimento de critérios para afirmar se uma lei é reguladora ou não do regime orçamentário ou de contabilidade. A segunda questão consiste em determinar em que sentido o art. 49.1, da Lei de Funcionamento do Tribunal de Contas utiliza o termo "leyes", ou seja, seriam apenas as leis formais ou qualquer tipo de normas, incluindo, assim, os regulamentos (VIDAL, 1999).

Acerca da primeira questão, o autor entende que as normas que regulam a modificação e execução dos créditos orçamentários e as que atribuem competências relacionadas com esta matéria estão enquadradas como "normas reguladoras del régimen presupuestario". Por outro lado, "hay outro conjunto de normas que no pueden considerarse reguladoras del régimen presupuestario ni de contabilidad, como es el caso de las que regulan ciertos aspectos relacionados con la contratación" (VIDAL, 1999, p. 41). 
No tocante à segunda questão, concede interpretação ampla ao termo "leyes", considerando, dentre outras razões, a quantidade de regulamentos disciplinadores da contabilidade pública e privada no Direito Espanhol (VIDAL, 1999).

O segundo pressuposto compreende a "produccíon de un menoscabo de los caudales o efectos públicos".

Segundo Carles Rosiñol I Vidal, o dano há de ser efetivo, economicamente avaliável, e individualizável em relação a determinados bens ou dinheiros. Estas exigências afastam a responsabilidade contábil em relação aos danos morais, os danos eventuais e os danos possíveis. Em razão da exigência de dano efetivo, o alcance só se materializa, após materializada a saída irregular de fundos do erário público ${ }^{104}$ (VIDAL, 1999).

O terceiro pressuposto compreende a necessidade de que o "menoscabo" se reflita nas contas que deverão ser prestadas pelas pessoas que tem a seu cargo o manejo dos recursos públicos. O requisito impõe que o prejuízo econômico se desprenda das contas. Com base na Jurisprudência da Sala de Apelação do Tribunal de Contas, Carles Rosiñol I Vidal esclarece que o termo "cuentas" deve ser entendida em sentido amplo, abrangendo qualquer registro que possa representar uma prova irrefutável do prejuízo econômico, citando a propósito a Sentença n ${ }^{\circ}$ 27/1992, de 30 de outubro (VIDAL, 1999, p. 54):

\footnotetext{
"entendido el término cuenta en el sentido más amplio possible, como aquel documento público o privado, según los casos - de índole contable, en el que constan, se registran o figuran, con o sin valoraciones finales o ajustes numéricos, según técnicas habituales y generalmente normadas, operaciones relacionadas directa o indirectamente con la actividad económico financiera del sector público o de las personas físicas o jurídicas destinatárias de sus subvenciones o ayudas".
} salida alguna de fondos públicos y, en consecuencia, no faltan" (VIDAL, 1999, p. 47). 
O último pressuposto compreende a relação causal entre a infração da lei e o "menoscabo". Conforme leciona Carles Rosiñol I Vidal: "El menoscabo se ha de producir como una consecuencia de la infracción de una norma, de forma que si sólo se constata uno de estos dos elementos sin el otro, no nos hallamos ante un alcance" (VIDAL, 1999, p. 55).

Carlos Cubillo Rodriguez, por sua vez, apresenta o seguinte elenco de pressupostos da responsabilidade contábil (RODRIGUEZ, 1999):

a) que a ação ou omissão atribuível a uma pessoa que tenha a seu cargo o manejo de "caudales o efectos públicos";

b) que a ação ou omissão se desprenda das contas que devem ser prestadas pelos gestores públicos;

c) que tenha sido produzida uma violação às normas contábeis ou orçamentárias aplicáveis;

d) que a ação ou omissão que provoque danos ou prejuízos implique dolo, culpa ou negligência graves;

e) que tenha sido produzido "menoscabo" dos bens e direitos de titularidade pública;

f) que exista relação de causalidade entre a ação ou omissão imputável ao gestor de recursos públicos e o "menoscabo" dos mesmos.

Quanto aos pressupostos apresentados, o autor acrescenta novos comentários. O conceito de manejo de recursos públicos se concretiza com as seguintes atividades: "recaudacíon, intervencíon, administración, custodia, manejo y utilización de bienes, caudales y efectos públicos" (RODRIGUEZ, 1999, p. 139).

Salienta o autor que a Jurisprudência do Tribunal de Contas tem admitido a possibilidade de imputar responsabilidade contábil, ainda que, a atividade exercida pelo agente não implique em manejo direto e material (Sentença de 24 de setembro de 1998), assumindo um conceito amplo de gestão de recursos públicos (RODRIGUEZ, 1999). 
Acerca dos sujeitos jurisdicionados ao Tribunal de Contas Espanhol, ao quais denomina de "gestor de fondos públicos", Carlos Cubillo Rodriguez trata mais detalhadamente de dois casos: o dos receptores das subvenções e ajudas do setor público e das pessoas jurídicas (RODRIGUEZ, 1999).

No primeiro caso, a jurisprudência do Tribunal de Contas tem admitido a responsabilidade contábil em razão de artigos do Texto Refundido de la Ley General Presupuestaria e em razão do paralelismo entre as funçôes fiscalizadora e função jurisdicional do Tribunal de Contas, aquela aplicável expressamente aos receptores de subvenções e ajudas do setor público (RODRIGUEZ, 1999).

Além disso, o próprio Tribunal Supremo da Espanha, na Sentença de 22 de novembro de 1996, manifestou-se em favor da possibilidade de atribuir responsabilidades contábeis aos beneficiários de ajudas e subvenções, sejam eles pessoas físicas ou jurídicas (RODRIGUEZ, 1999).

Quanto às pessoas jurídicas, as Sentenças de 18 de abril e 28 de outubro de 1986, de 25 de junho e 29 de outubro de 1992 e de 26 de março e 20 de maio de 1993, da Sala de Justiça do tribunal de Contas, admitiram a possibilidade de imputar a responsabilidade contábil também às pessoas jurídicas (RODRIGUEZ, 1999).

Acerca do caráter público ou privado dos fundos de sociedades estatais e demais empresas públicas, menciona Rodriguez que a jurisprudência tem sido unânime em reconhecer a jurisdição e competência do Tribunal de Contas para conhecer e resolver os litígios relativos à gestão ilegal de fundos desenvolvida através de sociedades estatais e outras empresas públicos (RODRIGUEZ, 1999).

A delimitação do segmento do direito positivo que abrange o "regime orçamentário e de contabilidade", segundo assevera Rodriguez, é uma das atividades interpretativas mais importantes na configuração dos contornos da responsabilidade contábil. 
A propósito, cita deliberação da Sentença de 29 de Julho de 1992, da Sala de Justiça do Tribunal de Contas (RODRIGUEZ, 1999, p. 143):

"El daño, perjuicio o menoscabo en los fondos públicos requerido para que existan responsabilidades contables ha de ser consecuencia de una acción u omissión cuya antijuridicidad se predique en relación a leyes de carácter contable, para de esta forma crear un ilícito contable que presente rasgos propios y diferenciados en comparación al ilícito civil, penal, etc."

Outro ponto importante na configuração da "responsabilidad contable" diz respeito à interpretação da expressão "caudales o efectos públicos". Segundo Carlos Cubillo Rodriguez, a expressão deverá ser interpretada em sentido amplo, para abranger não somente os recursos financeiros, mas também o conjunto de bens e direitos de titularidade pública (RODRIGUEZ, 1999, p. 145):

\footnotetext{
"Una interpretación demasiado restritiva de tales preceptos podría llevar a considerar que sólo cabe apreciar responsabilidades contables si los daños y perjuicios originados en el Tesoro Público, han afectado a caudales o efectos públicos en sentido estricto. No es ésta, sin embargo, la doctrina jurisprudencial de la Sala de Justicia del Tribunal de Cuentas que, con buen criterio, interpreta la expresíon <<caudales o efectos públicos〉> en sentido amplio, es decir, como conjunto de bienes y derechos cuya titularidad esté residenciada en el Sector Público, y no sólo como sumas pecuniarias".
}

Para fins de exemplificação, Rodriguez cita a Sentença de 21 de outubro de 1994, em que admite que diminuições de grãos produzidas em decorrência de uma avaria do silo, de titularidade pública, em que se guardava tais grãos, podem originar responsabilidades contábeis das pessoas encarregadas da manutenção e custódia da mercadoria (RODRIGUEZ, 1999).

Resta, claro, segundo Rodriguez, que todo "menoscabo" de um patrimônio público pode dar lugar a responsabilidades contábeis se cumpridos os demais requisitos legais (RODRIGUEZ, 1999).

\subsubsection{Direito Italiano}

Conforme já foi objeto do item 6.4, a Responsabilidade no âmbito da Corte dei Conti compreende duas modalidades: a responsabilidade administrativa e a contábil. 
Segundo Gianni de Luca, "o empregado ou o funcionário que por dolo ou culpa viola as normas reguladoras do seu serviço, ocasionando um dano econômico à Administração Pública, incorre em responsabilidade administrativa em face da própria Administração" ${ }^{105}$ (LUCA, 2008, p. 309).

A responsabilidade administrativa é pessoal, sendo o débito transmitido aos sucessores apenas no caso de enriquecimento ilícito e do consequente enriquecimento ilícito dos próprios sucessores. A responsabilidade é limitada aos fatos e às omissões cometidas com dolo ou culpa grave (LUCA, 2008).

Os elementos constitutivos da responsabilidade administrativa não diferem da responsabilidade civil comum, salvo por incluir o rapporto di servizio (LUCA, 2008).

Segundo Gianni de Luca, eles são (LUCA, 2008):
a) o dano;
b) o dolo ou culpa grave (vide capítulo 12);
c) a relação de serviço;
d) o nexo de causalidade.

O dano que deve ser avaliável economicamente, efetivo e atual, compreendendo o dano emergente e o lucro cessante. O novo art. $1^{\circ}$, da Lei ${ }^{\circ}$ 20/1994, prescreve que a Corte dei Conti poderá julgar a responsabilidade dos funcionários e administradores ainda que o dano seja causado por sujeitos pertencentes à Administrações diversas. A partir da Sentença n 7642, de 10 de julho de 1991, da I Seção Civil da Corte Suprema di Cassazione, firmou-se na Itália uma tendência jurisprudencial a admitir a ressarcibilidade do dano moral causado à Administração Pública, consistente no descrédito subito ao Ente Público (dano à imagem) em consequência da atividade ilícita (LUCA, 2008).

\footnotetext{
${ }^{105}$ L'impiegato o il funcionario che per dolo o per colpa viola le norme que regulano il suo servizio, cagionando un danno economico alla Pubblica Amministrazione, incorre in responsabilità amministrativa nei confronti dell'amministrazione stessa.
} 
Segundo Gianni de Luca, recentemente a Corte dei Conti reconheceu que um funcionario culpado de corrupção ou concussão, durante e em razão de sua atividade, causa, além de um dano ao erário, um dano à imagem da Administração a qual pertence. Dano que, pela sua natureza, se projeta no futuro. Por isso, a Administração Pública, para contrastar a perda de imagem, deverá desenvolver uma gradual, assídua, e inevitavelmente onerosa obra de melhoramento dos serviços oferecidos pela Administração e de aperfeiçoamento da eficiência da sua organização de modo a reconquistar a confiança dos cidadãos (LUCA, 2008).

A Corte dei Conti procurou clarificar o significado de dano à imagem, definido pela Corte Suprema di Cassazione como a despesa necessária para recuperar a imagem da administração pública. Para a Corte dei Conti, o dano é, por exemplo, a despesa correlata à publicidade da administração em contraste com a atividade criminosa do administrador, ou a despesa para dar maior visibilidade externa positiva à atividade do administrador (AVALLONE; TARULLO, 2002).

A relação de serviço (rapporto di servizio) é o elemento que caracteriza a responsabilidade administrativa. Deve basear-se no princípio da voluntariedade, no sentido de que sejam postas a cargo do agente determinadas consequências, na medida em que ele tenha deliberadamente aceitado a fazer parte da administração (LUCA, 2008).

A responsabilidade contábil difere da responsabilidade administrativa por incidir sobre aqueles que manejam dinheiros ou valores da Administração Pública, estando sujeitos à obrigação de prestar contas. São os denominados "agenti contabili". Eles são classificados entre os que podem exercer esta função com base em normas, relação de emprego ou contrato (contabile di diritto) e aqueles, de própria iniciativa ou necessidade, efetuaram o manejo de dinheiros ou bens (contabile di fatto) (LUCA, 2008).

No tocante à diferença entre os pressupostos da responsabilidade contábil e da responsabilidade administrativa, Gianni de Luca aponta que (LUCA, 2008): 
a) a responsabilidade contábil se funda sobre o manejo, de direito ou de fato, sobre o dinheiro ou, de forma geral, dos valores da Administração Pública, enquanto a responsabilidade administrativa encontra seu fundamento em um dano patrimonial;

b) a responsabilidade contábil deriva do inadimplemento de uma obrigação de restituir os valores tidos em consignação, inspirando-se, por isso, na responsabilidade do depositário, o qual é liberado da obrigação de restituir somente se demonstrar que a perda é devida a causa a ele não imputável; a responsabilidade administrativa, ao invés, basea-se na diligência no adimplemento dos deveres nascidos na relação de serviço;

c) a responsabilidade administrativa pressupõe em todo caso uma relação de serviço; a responsabilidade contábil incide, também, sobre o contabili di fatto, derivando de uma existência objetiva de uma gestão.

Pierluigi Avallone e Stefano Tarullo afirmam, citando a Tese de Perin, que o ilícito contábil não realiza a transgressão de deveres de serviço, mas da obrigação de custódia, derivante da confiança e, de qualquer forma, do manejo de dinheiro e materiais de propriedade da administração, sobre os quais o contábil cumpre atos reais (AVALLONE; TARULLO, 2002).

\subsubsection{Direito Brasileiro}

A responsabilidade financeira reintegratória tem por paradigma a responsabilidade civil subjetiva, sem, entretanto, se confundir com esta espécie tradicional de responsabilidade jurídica. Acrescenta-se aos requisitos da responsabilidade civil, o exercício da gestão de bens, dinheiros e valores públicos e a violação de normas pertinentes.

Para a configuração da responsabilidade financeira reintegratória exige-se a conduta humana voluntária, o dano ao erário, a violação de normas pertinentes à gestão 
pública, o nexo de causalidade, a culpabilidade e a ausência de excludentes de responsabilidade. Os dois últimos temas são tratados em tópicos específicos.

Uma hipótese especial, que não se encaixa perfeitamente no modelo acima, é a da "omissão no dever de prestar contas". Nesta hipótese, admitida pelo art. $8^{\circ}$, caput, da Lei $\mathrm{n}^{\circ}$ 8.443/92, o dano ao Erário é presumido. Levando-se em conta que o dever constitucional de prestar contas exige uma conduta ativa do gestor público (ou do particular investido na função de gerir recursos públicos) no sentido de comprovar a regularidade da gestão dos recursos a ele confiados (vide item 18.7 - inversão do ônus da prova).

Trata-se de presunção relativa, ou seja, que admite prova em contrário. Nada obstante, a prestação de contas intempestiva (ainda que demonstre a regularidade da gestão), por si só, constitui irregularidade grave, que sujeita o responsável à responsabilidade financeira sancionatória (multa) ${ }^{106}$.

\subsubsection{Conduta Humana Voluntária e Gestão de Recursos Públicos}

A conduta, como pressuposto da responsabilidade civil, é o comportamento humano voluntário que se exterioriza através de uma ação ou omissão, produzindo consequiências jurídicas (CAVALIERI FILHO, 2002). A conduta deve importar violação do dever genérico de não prejudicar a ninguém (neminem laedere).

\footnotetext{
${ }^{106}$ Com efeito, diversas são as deliberações do TCU acolhendo este posicionamento, conforme trecho do voto do Ministro-Relator no Acórdão 3547/2006 - Primeira Câmara: "Em reiterados julgados este Tribunal tem entendido que a omissão no dever de prestar contas consiste em irregularidade grave, que impossibilita a averiguação do destino dado aos recursos públicos, autoriza a presunção da ocorrência de dano ao erário, enseja a condenação à restituição integral do montante transferido e torna legítima a aplicação de multa ao responsável (Acórdãos TCU no s 46/2005-1 ${ }^{\text {a }}$ Câmara; 903/2005-1 ${ }^{\text {a }}$ Câmara; 66/2005-2a Câmara; 197/2005-2 ${ }^{\mathrm{a}}$ Câmara;

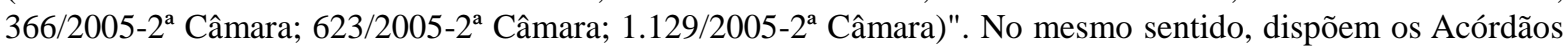
n ${ }^{\circ}$ s 2.624/2004 - 2 a . Câmara, 2.539/2004 - 2 ${ }^{\mathrm{a}}$. Câmara, 2.254/2004 - 2 ${ }^{\mathrm{a}}$. Câmara, 2.181/2004 - 2 ${ }^{\mathrm{a}}$. Câmara, 1.849/2004 - Plenário, 1.734/2004 - 2 ${ }^{\text {a }}$. Câmara: "Considero, para tanto, que a omissão no dever de prestar contas representa grave infração à norma legal, cumulada com dano presumido ao Erário, em vista do ato omissivo do gestor. Saliento que, após consumada, a omissão mostra-se insanável, exceto se apresentadas justificativas plausíveis. Por conseguinte, ainda que, em sede de recurso, o responsável venha posteriormente a afastar o débito, comprovando a aplicação dos valores questionados, mantêm-se as tipificações previstas nas alíneas a e b retrocitadas, afastando-se apenas a falta versada na alínea c do dispositivo em questão".
} 
No âmbito da Responsabilidade Financeira, exige-se que a conduta seja uma ação ou omissão voluntária ${ }^{107}$ na gestão de bens, dinheiros e valores públicos, praticada por gestor público ou particular que exerça esta função (gestor público equiparado). No caso do particular que acarrete dano ao erário (art. 71, II, CF/88 c/c art. 5 , II, Lei n ${ }^{\circ}$ 8.443/92), exige-se, como pressuposto da responsabilidade por débito, que a conduta seja realizada em conluio com o gestor de recursos públicos (Súmula nº 187 TCU).

Não se exige, no âmbito da Responsabilidade Financeira, que a conduta seja típica, mas apenas que viole norma ou princípio relativo à gestão de bens, dinheiros e valores públicos. Tais normas ou princípios devem estar previstos na legislação pertinente, ainda que de forma implícita. Constam, basicamente, de dois ramos da ciência jurídica: o Direito Administrativo $^{108}$ e o Direito Financeiro ${ }^{109}$.

A violação de normas técnicas e o descumprimento de diretrizes da Ciência da Administração e da Ciência Econômica também podem gerar responsabilidade financeira, quando referidas, explícita ou implicitamente, pela legislação pertinente. Por exemplo, o descumprimento das normas técnicas de avaliação de um imóvel a ser alienado pela Administração Pública, pode implicar em dano ao erário, por subavaliação do imóvel vendido. Neste caso, o art. 17, caput, da Lei n ${ }^{\circ} 8.666 / 93$ preceitua que os imóveis devem ser avaliados previamente à sua alienação, o que pressupõe a utilização de técnicas adequadas, segundo a área específica do conhecimento. Por outro lado, os conceitos de eficácia, legitimidade, eficiência e efetividade remetem a outras áreas não jurídicas do conhecimento.

A tipicidade da conduta era exigida em Portugal até a edição da Lei $n^{\circ}$ 48/2006. Exigia-se que a conduta fosse enquadrada como pagamento indevido, alcance,

${ }^{107}$ Segundo Heraldo Garcia Vitta, a voluntariedade da conduta compreende a posse de consciência e liberdade de quem produz a conduta. Segundo o autor, a voluntariedade supõe uma livre e consciente eleição entre dois comportamentos possíveis (VITTA, 2003).

108 Não apenas a violação das normas de direito financeiro pode importar em responsabilidade financeira reintegratória, mas também a violação das normas de direito administrativo, notadamente aquelas que incidem sobre a contratação pública. Em razão da incidência de normas de diversas naturezas, preferimos adotar nos referir genericamente às normas e princípios que regulam a gestão pública.

${ }^{109}$ No âmbito do Direito Financeiro, a responsabilidade financeira surge, via de regra, por violações às normas que regulam a execução orçamentária. O descumprimento de normas e princípios relativos à elaboração, votação ou aprovação do orçamento não ensejam responsabilidade financeira. 
desvio de dinheiros ou renúncia indevida de receitas. Tais tipos permanecem em vigor como pressupostos da responsabilidade financeira reintegratória. Nada obstante,

\footnotetext{
"Sempre que da violação de normas financeiras, incluindo no domínio da contratação pública, resultar para a entidade pública obrigação de indemnizar, o Tribunal pode condenar os responsáveis na reposição das quantias correspondentes" (artigo 59, item 5, da Lei n 98/97).
}

Convém mencionar que a ilicitude da conduta não depende da validade ou da nulidade do procedimento, conforme sustenta a Doutrina e a Jurisprudência Italianas. Um determinado procedimento formalmente legal, mas inoportuno sob o ponto de vista de mérito, pode causar um dano injusto à Administração Pública. Por outro lado, um procedimento ilícito não é condição suficiente para o surgimento da responsabilidade financeira. sendo necessária a existência de um evento danoso ao Erário (AVALLONE; TARULLO, 2002).

Segundo Pierluigi Avallone e Stefano Tarullo ${ }^{110}$, "a orientação consolidada da Corte de Conti, portanto, é no sentido de que a ilegalidade de um ato não determina a responsabilidade financeira, quando não demonstrado o dano à Administração Pública" (AVALLONE; TARULLO, 2002, p. 45).

\subsubsection{Dano ao Erário}

Ao tratar das competências do Tribunal de Contas, a Constituição Federal utiliza a expressão Erário (art. 71, II e VIII, CF/88), restringindo o escopo da atuação das Cortes de Contas ao conjunto de bens e valores de natureza patrimonial pertencentes ao Poder Público.

Assim sendo, a responsabilidade financeira reintegratória não é o instrumento jurídico adequado para o ressarcimento dos danos de natureza moral, ambiental, histórica ou cultural. Aquele que causar danos desta natureza ao Poder Público estará sujeito a outras modalidades de responsabilidade que não a financeira.

\footnotetext{
${ }^{110}$ L'orientamento consolidato del giudice contabile, quindi, è nel senso che la illegitimità di un atto non determini responsabilità amministrativa ove non risulti dimonstrato il danno subito dall'amministrazione.
} 
A utilização da expressão adotada pela legislação "dano ao erário" pode dar ensejo a falsas interpretações acerca do seu conteúdo e forma de mensuração. No Direito Privado, o dano emergente "será a diferença do valor do bem jurídico entre aquele que ele tinha antes e depois do ato ilícito" (CAVALIERI FILHO, 2002, p. 81).

No Setor Público, este conceito não pode ser utilizado, em qualquer situação, para mensuração do dano ao Erário. Imagine que uma entidade filantrópica receba subvenções sociais para conceder bolsas de Estudo para estudantes carentes, que tenham bom desempenho escolar. Se a entidade estiver usando correta ou irregularmente os recursos na finalidade estipulada, o patrimônio contábil do Poder Público que concedeu a subvenção será o mesmo. O patrimônio líquido do Estado será reduzido, em qualquer hipótese, do montade da subvenção. Nesta situação, mensurar a diferença do patrimônio líquido da entidade pública não nos fornece informações sobre a regularidade na aplicação dos recursos públicos.

O mesmo acontece com qualquer programa estatal que não importe diretamente uma contraprestação ao Estado, mas benefícios à sociedade. Isto se deve à finalidade não lucrativa do Estado. Enquanto que, numa entidade privada com fins lucrativos, os resultados da boa gestão dos recursos se refletem no patrimônio líquido da entidade (lucro), os resultados da boa gestão das entidades estatais, via de regra, não são captados pela Contabilidade Pública ${ }^{111}$. Conforme ensinamento de Michael H. Granof, para avaliar o desempenho das entidades públicas deve-se fazer uso de medidas não monetárias, tais como, as medidas de desempenho de estudantes nas escolas públicas, ou o número de pessoas alimentadas ou abrigadas, em programas sociais.

111 Em várias hipóteses, a Contabilidade Pública não nos fornece informações para a avaliação do dano ao erário. A Contabilidade Pública não contabiliza bens públicos de uso comum e, no caso dos bens contabilizados, não é comum a realização de reavaliação e depreciação. No caso de desvio de bens contabilizados, mas não sujeitos à reavaliação e à depreciação, o valor registrado deve ser desconsiderado para a avaliação do dano ao Erário (GOMES, 2008, p. 269-271) 
No Direito Espanhol, Carles Rosiñol I Vidal menciona que o dano deverá se efetivo, economicamente avaliável e individualizável em relação a determinados bens e dinheiros. Desta forma, sustentou o autor que o dano eventual e o dano provável estariam excluídos da responsabilidade contábil (VIDAL, 1999).

Ao primeiro requisito (dano efetivo), cabe, entre nós, algumas observações. Em alguns casos, a exigência se resume à "saída irregular de recursos públicos", já que, conforme outrora mencionado, há dano presumido na "omissão no dever de prestar contas" (art. $8^{\circ}$, caput, Lei n ${ }^{\circ} 8.443 / 92$ ).

Mas esta não é a única hipótese de dano presumido. A concessão de empréstimos ou financiamentos por instituições financeiras oficiais em descumprimento às normas internas de concessão de crédito (por exemplo, empréstimos sem garantia ou a empresas que não tenham condições de realizar o objeto do financiamento) importa em dano presumido à instituição. Isto porque não se sabe o montante que será efetivamente devolvido ou restituído aos cofres da instituição financeira, em pagamento ao empréstimo ou financiamento concedido.

Outra característica da responsabilidade financeira é que o dano seja referido a determinados bens, valores ou dinheiros. O dano está limitado às "quantias envolvidas na infração". Não se refere somente os recursos que deixaram o patrimônio público, mas também, dos recursos que deixaram indevidamente de ingressar, como no caso da renúncia indevida de receitas.

Nesta linha, o dano ao erário da responsabilidade financeira não abrange os lucros cessantes, ou seja, "na perda do ganho esperável, na frustração da expectativa de lucro, na diminuição potencial do patrimônio da vítima" (CAVALIERI FILHO, 2002, p. 81).

Seria interessante ilustrar com um exemplo. Imagine que a obra de um prédio público foi atrasada ou paralisada em razão de irregularidades graves na sua gestão, tais como superfaturamento. A obra tinha por finalidade centralizar alguns prédios existentes e 
locados pelo Poder Público. Se não houvesse irregularidade e, portanto, atraso na construção da obra, o Poder Público deixaria de pagar estes aluguéis. Logo, além do prejuízo decorrente do superfaturamento da obra, o Poder Público deixou de economizar a quantia referente aos aluguéis dos imóveis locados. Nesta hipótese, a responsabilidade financeira deverá abranger apenas o superfaturamento da obra, atendendo as "quantias envolvidas na infração" e à referibilidade ao montante de recursos gerido para a sua construção. Os lucros cessantes deverão ser ressarcidos por outra via que não a da jurisdição financeira.

Ainda nesta linha, cabe examinar a possibilidade de compensação entre o prejuízo ao erário e eventuais "lucros" ocorridos com a infração financeira, na apuração do montante a ser reposto aos cofres públicos.

Em primeira análise, se os "lucros" forem inerentes ao objeto contratado, não há que se falar em compensação ${ }^{112}$.

Um exemplo nos ajuda a elucidar a questão.Imagine que um órgão público contratou, com preços superfaturados (50\% acima do preço de mercado), um sistema para otimização de consumo de energia elétrica. Além disso, o sistema servia para adaptar os parâmetros elétricos do órgão aos exigidos pela legislação. A implantação deste sistema importou em economia ao órgão na sua conta de energia elétrica. Além disso, deixou de receber multas da concessionária em virtude dos parâmetros elétricos do órgão estarem fora do previsto pela legislação. A questão é se estes benefícios poderiam ser compensados com os prejuízos causados pelo superfaturamento. A resposta é negativa, eis que os mesmos benefícios seriam obtidos se o sistema fosse contratado a preços de mercado. O responsável pela contratação deverá ressarcir o erário no montante equivalente ao superfaturamento, ou seja, $50 \%$ do valor de mercado do sistema.

No exemplo citado, para o cálculo do dano ao erário, foi descontado do valor pago pelo sistema, a efetiva contraprestação recebida (valor efetivo do sistema). Os

\footnotetext{
${ }^{112}$ Eventualmente, os lucros podem ser levados em conta para o fim de adotar ou não medidas cautelares, tais como, a suspensão de um procedimento licitatório ou da execução de um contrato. Independemente da adoção ou não da medida cautelar, caberá o ressarcimento do dano ao erário.
} 
benefícios apontados (redução da conta de energia elétrica e a redução das multas) são inerentes ao próprio objeto contratado, não podendo ser descontados do superfaturamento.

Por sua vez, no caso de despesa ilegítima, a contraprestação só pode ser abatida ou compensada se relacionada com as atribuições ou finalidades do órgão ou entidade.

Imagine que uma Secretaria ou Ministério dos Transportes adquira Quadros Caros de Pintores Famosos para ornamentar o edifício-sede da Secretaria ou Ministério, ou ainda, o Gabinete do Secretário/Ministro. Ainda que tenha havido contraprestação ao Poder Público, esta contraprestação não tem qualquer relação as atribuições do órgão. Não pode, portanto, ser descontada para efeito de apuração do débito. O responsável pela contratação deverá ressarcir o erário das despesas com a contratação, e, para evitar o enriquecimento sem causa do erário, poderia receber os quadros. Além da responsabilidade financeira reintegratória, estaria o responsável sujeito à sancionatória, em razão do ato ilegítimo e antieconômico.

No Direito Italiano, Pierluigi Avallone e Stefano Tarullo debatem sobre o eventual aspecto vantajoso do evento danoso ao Erário. Argumentam que subsiste o dano quando não se realiza ou se realiza parcialmente a finalidade de interesse público para a qual foram destinados os recursos públicos. Para os autores, o dano às "finanças públicas" consiste no equilíbrio que vem a ser determinado entre o ônus financeiro, sustentado pela realização da despesa, e o benefício perdido pela coletividade ${ }^{113}$ (AVALLONE, TARULLO, 2002, p. 57).

No Direito Português, vale lembrar a lição de João Franco do Carmo. O autor distingue a obrigação de repor da obrigação de indenizar, o que constitui um elemento importante na distinção entre a responsabilidade financeira reintegratória e a

\footnotetext{
${ }^{113}$ Sussiste danno erariale quando non si realizzano o si realizzano solo parzialmente le finalità di pubblico interesse al quale sono destinate le risorce economiche pubblique; o, ancora più chiaramente, che il danno alla finanza pubblica consiste nello squilibrio che viene a determinarsi tra l'onere finanziario, sostenuto per l'erogazione della spesa, ed il mancato beneficio per la colettività.
} 
responsabilidade civil. O autor tem uma visão mais restritiva da compensação mencionada e sua interpretação acentua o caráter sancionatório da responsabilidade financeira (CARMO, 1995, p. 167-168):

\begin{abstract}
"A obrigação de repor não se confunde com a obrigação de indemnizar. Com efeito, a existência de responsabilidade financeira é independente de prejuízo efetivo suportado pelo Estado ou outro ente público, o que permite diferenciá-la da responsabilidade civil e acentuar a sua configuração sancionatória. Pode mesmo acontecer que a infracção financeira advenh, em sede patrimonial, um ganho ou enriquecimento, sem que por isso resulte prejudicada a condenação em responsabilidade financeira.

Não tem aqui aplicação, por isso, a regra 'compensatio lucri cum damno', o que levaria a deduzir o montante das quantias a repor o valor dos benefícios eventualmente decorrentes da infracção financeira (ex: pagamento indevido na aquisição de equipamento que reverteu, efectivamente, para o Estado).

A obrigação de repor nunca é, por natureza, de objecto indeterminado, ao contrário da obrigação de indemnizar. Quando o Tribunal condena alguém a repor não procede, rigorosamente, a qualquer fixação ou liquidação de prejuízos, mas à qualificação das infracções detectadas (cujo montante ficou determinado na fase administrativa - ajustamento do processo de fiscalização sucessiva) e sua imputação aos responsáveis.

Mesmo que se verifiquem prejuízos, não são tomadas em contas lucros cessante sou danos futuros eventualmente previsíveis. Nos termos da lei, a responsabilidade exigida pelo Tribunal de Contas tem por objeto a restituição ou devoluções estrita das quantias abrangidas pela infração. No caso de se apurar a existência de danos ou prejuízos de montante que ultrapasse o valor daquelas quantias, o conhecimento deles fica reservado aos tribunais comuns (jurisdição cível),para os quais deverão ser encaminhados quaisquer elementos indiciatórios ou probatórios relevantes para a fixação de indemnização, através do Procurador da República.".
\end{abstract}

\title{
11.1.4.3. Nexo de Causalidade
}

Nexo de Causalidade é a relação causa-efeito que se estabelece entre a conduta do responsável e o resultado. $\mathrm{Na}$ responsabilidade financeira reintegratória, o resultado é o dano ao Erário.

São três as teorias adotadas para verificar se um determinado fato é ou não causa de um resultado: a teoria da equivalência dos antecedentes, a teoria da causalidade adequada e a teoria da interrupção do nexo causal (ou da relação causal imediata).

Segundo Sérgio Cavalieri Filho, na Teoria da Equivalência dos Antecedentes, também denominada conditio sine qua non, não se faz distinção entre a causa (aquilo de que uma coisa depende quanto à existência), e condição (o que permite a causa produzir seus efeitos). Se várias condições concorrem para o resultado, todas se equivalem, não cabendo 
questionar se uma delas é mais eficaz ou mais adequada para produzir o resultado. Para verificar se uma condição é causa, elimina-se, por um processo mental-hipotético, esta mesma condição e verifica-se se o resultado permanece ou não. Se o resultado desaparecer, a condição é causa, mas, se persistir, não o será (CAVALIERI FILHO, 2002).

Conforme salienta Cavalieri Filho (CAVALIERI FILHO, 2002, p. 59):

"Critica-se essa teoria pelo fato de conduzir a uma exasperação da causalidade e a uma regressão infinida do nexo causal. Por ela, teria que indenizar a vítima de atropelamento não só quem dirigia o veículo com imprudência, mas também quem lhe vendeu o automóvel, quem o fabricou, quem forneceu a matéria-prima, etc.".

É a teoria adotada no Direito Penal, conforme art. 13, do CP. A regressão ao infinito é neutralizada, com base no elemento subjetivo da conduta, conforme esclarece Fernando Capez (CAPEZ, 2005, p. 157):

"Diante da teoria da equivalência dos antecedentes, uma pergunta se impõe: não poderia haver
uma responsabilização muito ampla, à medida que são alcançados todos os fatos anteriores ao
crime? Os pais não poderiam responder pelos crimes praticados pelo filho? Afinal, sem
aqueles, este não existiria e, não existindo, jamais poderia ter praticado o crime. Nessa linha
de raciocínio, não se chegaria a um regressus ad infinitum?
A resposta é não, pois, como já dissemos, a responsabilidade penal exige, além do mero nexo
causal, nexo normativo. A teoria da equivalência dos antecedentes situa-se no plano
exclusivamente físico, resultante da aplicação da lei natural da causa e efeito. Assim, é claro
que o pai e a mãe, do ponto de vista naturalístico, deram causa ao crime cometido pelo filho,
pois, se este não existisse, não teria realizado o delito. Não podem, contudo, ser
responsabilizados por essa conduta, ante a total ausência de voluntariedade. Se não
concorreram para a infração com dolo ou culpa, não existiu, de sua parte, conduta relevante
para o Direito Penal, visto que, como já estudado, não existe ação ou omissão típica que não
seja dolosa ou culposa".

Segundo a teoria da causalidade adequada, não basta que a causa seja um antecedente necessário ao resultado. Exige-se que o fato tenha aptidão, em abstrato, a causar o resultado, segundo as regras da experiência e da probabilidade.

Segundo Fernando Capez (CAPEZ, 2005, p. 158),

"o juizo de adequação causal realiza-se mediante um retorno à situação em que se deu a ação, a partir da qual se examinam em abstrato a possibilidade e a idoneidade da ação, segundo as leis da causalidade. Em outras palavras, ainda que contribuindo de qualquer modo para a produção do resultado, um fato não pode ser considerado sua causa quando, isoladamente, não 
tiver idoneidade para tanto. São necessários, portanto: contribuição efetiva e idoneidade individual mínima".

Conforme leciona Sérgio Cavalieri Filho, na teoria da causalidade adequada (CAVALIERI FILHO, 2002, p. 60):

"Deverá o julgador, retrocedendo ao momento da conduta, colocar-se no lugar do agente e, com base no conhecimento das leis da natureza, bem como nas condições particulares em que se encontrava o agente, emitir seu juízo sobre a idoneidade de cada condição".

Ainda segundo Cavalieri Filho, uma variante da causalidade adequada é a causalidade eficaz, segundo a qual, causa é a condição mais eficaz, segundo um critério quantitativo (CAVALIERI FILHO, 2002).

Segundo Pablo Stolze Gagliano e Rodolfo Pamplona Filho, a teoria da causalidade direta ou imediata, também denominada teoria da interrupção do nexo causal, dispõe que a causa "seria apenas o antecedente fático que, ligado por um vínculo de necessariedade ao evento danoso, determinasse este último como sua conseqüência sua, direta e imediata" (GAGLIANO; PAMPLONA FILHO, 2003).

Rui Stoco, citando João Batista Gomes Moreira, esclarece que a teoria da relação causal imediata "preconiza que deve considerar-se adequado o antecedente que aparecer em último lugar, e, portanto, tido como causa imediata, de sorte que a última condição, pelo simples aspecto cronológico, deve ser considerada como causa do dano" (STOCO, 2007).

Pablo Stolze Gagliano e Rodolfo Pamplona Filho defendem que o Código Civil de 2002 (Lei ${ }^{\circ}$ 10.406/2002) adotou a teoria da causalidade direta ou imediata, em função do artigo 403, o qual dispõe que (GAGLIANO; PAMPLONA FILHO, 2003): "Ainda que a inexecução resulte de dolo do devedor, as perdas e danos só incluem os prejuízos efetivos e os lucros cessantes por efeito dela direto e imediato, sem prejuízo do disposto na lei processual" (grifo nosso). 
Nada obstante, o Superior Tribunal de Justiça tem sido vacilante ao definir a teoria da causalidade adotada pelo nosso Código Civil. Nos precedentes AgRg no Ag n ${ }^{\circ}$ 682599/RS e Resp n 2821/RJ, o STJ faz referência à causalidade adequada, enquanto que, no Resp $n^{\circ} 719.738 / \mathrm{RS}$ e Resp $\mathrm{n}^{\circ}$ 858.511/DF, o Tribunal adota a "teoria do dano direto e imediato".

Por vezes, como no Resp $n^{\circ} 325.622 / \mathrm{RJ}$, o STJ confunde as teorias da causalidade adequada e do princípio do dano direto e imediato.

Resta-nos, então, indagar qual a teoria da causalidade adotada para se estabelecer a Responsabilidade Financeira Reintegratória.

Vejamos, inicialmente, a experiência estrangeira.

Em Portugal, adota-se aparentemente a teoria da causalidade adequada, tendendo a evoluir para uma teoria da causalidade normativa, conforme esclarece o Tribunal de Contas de Portugal (PORTUGAL, 1999, p. 14-15):

"O terceiro pressuposto da responsabilidade financeira reintegratória, é a idoneidade da acção para causar o referido dano. Esta idoneidade traduz-se no que a doutrina designa por nexo causal, isto é, a adequação da acç̧ão praticada pelo sujeito para causar o resultado típico da infracção. Na doutrina e na jurisprudência este instituto tem sofrido alguma evolução derivada do aperfeiçoamento contínuo da ciência jurídica, no sentido de tratar tanto quanto possível o igual de forma igual e o diferente de forma diferente, na medida dessa diferença. Na verdade, de uma concepção factual assente na experiência, no bom senso ou na ética, alguma doutrina tem evoluido para uma concepção que poderíamos chamar de normativista, designada por teoria da causalidade normativa".

Na Itália, adota-se a teoria da causalidade adequada, conforme leciona Luigi Mastroniani (MASTRONIANI, 2005):

"I giudici contabili applicano generalmente il principio della causalità adeguata, effettuando una valutazione ex ante volta a rilevare se la causa è risultata, da sola o unitamente ad altre, idone a produrre l'evento dannoso, escludendosi, però la sussistenza del nesso eziologico là dove il danno sia il risultato di un evento straordinario od eccezionale".

Por sua vez, Stefano Cosimo de Braco destaca que (BRACO, 2003, p. 104): 
"É stato autorevolmente rilevato che 'la giurisprudenza della Corte dei Conti ha sempre prediletto la teoria della causalità efficiente, e cioè quela teoria che individua nel comportamento del soggetto agente un evento determinante (sia pure in parte) per il prodursi il danno, mentre più di recente sempra orientata verso la teoria della causalità adeguata, e cioè a considerare, sulla base dell id quod plerumque accidit, un comportamento causa di un certo danno soltanto se quello era idoneo a determinare questo, con esclusione quindi ogni effetto straordinario e non normalmente prevedibile come effetto di questa causa".

Tendo adotado a matriz da responsabilidade civil, e, considerando a experiência Portuguesa e Italiana, deve-se adotar a teoria da causalidade adequada, exigindo que a ação tenha aptidão "in abstrato" para causar o resultado danoso, segundo as regras da experiência e da probabilidade.

No Brasil, a jurisprudência do TCU não é expressa ao definir qual teoria da causalidade é utilizada na imputação de débito. Entretanto, em alguns julgados, especialmente os de responsabilização de pareceristas técnicos e jurídicos (itens $14.4 \mathrm{e}$ 13.1.2), o TCU levado em conta a influência que este parecer pode ter na decisão principal. Deve-se levar em conta a aptidão do Parecer para produzir o resultado danoso, o que sugere a utilização da Teoria da Causalidade Adequada.

\subsection{Responsabilidade Financeira Sancionatória}

A responsabilidade financeira sancionatória compreende a aplicação de multa ao responsável, em razão das normas de gestão ou à violação dos deveres de colaboração com o Tribunal. A primeira espécie é denominada pela doutrina portuguesa de responsabilidade por atos essencialmente financeiros e a segunda, responsabilidade por atos não essencialmente financeiros.

São três as espécies de multas que podem se aplicadas aos responsáveis: multa simples, sujeita a um teto legal, multa proporcional ao dano ao erário e multa do art. $5^{\circ}$, da Lei n ${ }^{\circ}$ 10.028/2000 (de até 30\% da remuneração anual do agente).

$\mathrm{O}$ art. 71, inciso VIII, da CF/88 atribui competência ao Tribunal de Contas para aplicar sanções por ilegalidade de despesa ou irregularidade nas contas, dentre as quais 
destaca a multa proporcional ao dano ao erário. Esta sanção está prevista no art. 57, da Lei $\mathrm{n}^{\circ}$ $8.443 / 92$, até o limite de até $100 \%$ do dano ao erário.

\subsubsection{Infrações às normas de natureza financeira}

Trata-se de infrações às normas concernentes à gestão pública, sujeitas a multa simples (com teto fixo em valor monetário) previstas no art. 58, incisos I, II, III, VII e $\S 1^{\circ}$, da Lei $\mathrm{n}^{\circ} 8.443 / 92$. O art. 58 é aplicado se o ato ilícito não importa em dano ao erário ou se o dano não puder ser quantificado. Caso contrário, incide o art. 57, da Lei $n^{\circ}$ 8.443/92. Ademais, havendo conflito aparente entre o art. 58 da Lei $n^{\circ} 8.443 / 92$ e o art. $5^{\circ}$, da Lei $n^{\circ}$ 10.028/2000, será dada preferência a este último, por se tratar de norma especial.

O inciso I do art. 58, informa que o Tribunal poderá aplicar multa no caso de "contas julgadas irregulares de que não resulte débito, nos termos do parágrafo único do art. 19 desta lei". Este tipo legal pressupõe que as contas do responsável sejam julgadas irregulares, ou seja, que esteja configurada uma das hipóteses do art. 16, inciso III, da Lei $\mathrm{n}^{\circ}$ 8.443/92:

\footnotetext{
"Art. 16. As contas serão julgadas:

(...)

III - irregulares, quando comprovada qualquer das seguintes ocorrências:

a) omissão no dever de prestar contas;

b) prática de ato de gestão ilegal, ilegítimo, antieconômico, ou infração à norma legal ou regulamentar de natureza contábil, financeira, orçamentária, operacional ou patrimonial;

c) dano ao erário decorrente de ato de gestão ilegítimo ao antieconômico;

d) desfalque ou desvio de dinheiros, bens ou valores públicos.
}

As alíneas a, c, e d referem-se a hipóteses de dano ao Erário, que ensejam a aplicação da multa proporcional ao dano ao erário, nos termos do art. 57, da Lei n 8.443/92.

A alínea $\mathrm{b}$ corresponde ao tipo previsto no art. 58, inciso II, da Lei $\mathrm{n}^{\circ}$ $8.443 / 92$

Desta forma, o tipo previsto no inciso I, do art. 58, da Lei ${ }^{\circ}$ 8.443/92 é dispensável e sua aplicação, no caso concreto, acarretaria diversas dúvidas ao intérprete, ante ao aparente conflito de normas. 
O inciso II do art. 58 da Lei $\mathrm{n}^{\circ}$ 8.443/93 dispõe que o Tribunal poderá aplicar multa por "ato praticado com grave infração à norma legal ou regulamentar de natureza contábil, financeira, orçamentária, operacional e patrimonial". Trata-se do tipo legal mais aplicado pelos Tribunais de Contas, em razão de sua generalidade.

Conforme afirmamos anteriormente, a jurisprudência dos Tribunais de Contas não define o que é "grave infração", limitando-se a informar se, no caso concreto, a conduta importa ou não em grave infração.

Conceituo "grave infração à norma" como a conduta violadora de preceito legal ou regulamentar vigente à época do fato que vise ou acarrete, direta ou indiretamente, considerável lesão a princípio da administração pública, tais como, impessoalidade, finalidade, legitimidade, economicidade, eficiência, publicidade e transparência, dever de prestar contas, equilíbrio das contas públicas, dentre outros.

As hipóteses do art. $5^{\circ}$, da Lei $n^{\circ}$ 10.028/2000 também se encaixam no inciso II do art. 58, eis que violam princípios da transparência fiscal, do planejamento e do equilíbrio das contas públicas. Ocorre que, conforme já foi mencionado, a Lei dos Crimes Fiscais é norma especial, prevalecendo a sua aplicação no caso concreto.

O inciso III do art. 58 da Lei n ${ }^{\circ} 8.443 / 92$ dispõe que o Tribunal poderá aplicar multa em razão de "ato de gestão ilegítimo ou antieconômico de que resulte injustificado dano ao erário". Tal dispositivo gera perplexidades ao intérprete, eis que, se houver dano ao erário, cabível seria a multa prevista no art. 57, da Lei $n^{\circ}$ 8.443/92. Além disso, o ato de gestão ilegítimo ou antieconômico não deixa de ser uma grave infração à norma de natureza financeira, orçamentária, patrimonial ou operacional, pois constitui violação dos princípios de direito financeiro: legitimidade e da economicidade. No nosso entendimento, o dispositivo legal só poderá se referir à situações em que existe dano ao erário, mas que, por qualquer motivo, este não possa ser mensurado ou quantificado, restando inviabilizada a aplicação da multa proporcional. Convém mencionar que se trata de conduta mais grave que a do inciso II, que pressupõe a inexistência de dano ao erário.

O inciso VII e o $\$ 1^{\circ}$, do art. 58 da Lei $\mathrm{n}^{\circ} 8.443 / 93$ referem-se ao descumprimento de determinação ou decisão do Tribunal. No primeiro caso, o tipo 
compreende a "reincidência no descumprimento de determinação do Tribunal" e, no segundo, "deixar de dar cumprimento à decisão do Tribunal, salvo motivo justificado". Estes tipos estão relacionados à função pedagógica e corretiva do Tribunal de Contas, que tem por fundamento constitucional o art. 71, inciso IX, da CF/88 e como fundamento legal o art. 18, da Lei $n^{\circ} 8.443 / 92$, verbis:

"Quando julgar as contas regulares com ressalva, o Tribunal dará quitação ao responsável e lhe determinará, ou a quem lhe haja sucedido, a adoção de medidas necessárias à correção das impropriedades ou faltas identificadas, de modo a prevenir a ocorrência de outras semelhantes".

Vale lembrar que, mesmo no julgamento das contas irregulares, poderá o Tribunal expedir determinações destinadas à correção das irregularidades ou a evitar ocorrências semelhantes.

A grande semelhança entre as hipóteses previstas no art. 58, VII e no art. 58, $\S 1^{\circ}$, da Lei $\mathrm{n}^{\circ} 8.443 / 92$ poderá gerar confusões ao intérprete no exame do caso concreto. Cumpre, portanto, melhor distinguí-las.

A primeira distinção compreende a "reincidência" exigida para a aplicação do art. 58, inciso VII e não para a aplicação do $\S 1^{\circ}$. Exige-se que o Tribunal tenha proferido determinação ao órgão e que este tenha descumprido e, ainda, que tenha havido nova determinação e novo descumprimento, o que não acontece na $2^{\mathrm{a}}$. hipótese.

A segunda distinção diz respeito ao grau de generalidade ou de especificidade da determinação proferida pelo Tribunal. Enquanto, na primeira hipótese, o dispositivo refere-se a determinações genéricas, com vistas a evitar a ocorrência de situações semelhantes, na segunda, a deliberação do tribunal é específica, visando a correção de um ato ou contrato específico.

O voto-condutor do Acórdão TCU n ${ }^{\circ}$ 153/1995 - Plenário é bem elucidativo no tocante a estas duas hipóteses de responsabilização do gestor:

\footnotetext{
"Na minha concepção, a reincidência a que se reporta o mencionado inciso VII está ligada ao aspecto da prática da falha/irregularidade pelo responsável, não obstante a determinação expedida pelo Tribunal, com o intuito de prevenir ocorrências semelhantes, ou seja, exemplificativamente: constatada a ilegalidade, ilegitimidade e antieconomicidade dos atos de
} 
gestão e das despesas deles decorrentes, quando da fiscalização, e dirigida ao órgão/entidade a determinação respectiva, caberá a cominação de multa ao gestor, no caso de ser verificada a incidência novamente de falha/irregularidade de mesma natureza, posteriormente à deliberação ocorrida. A situação evidenciada nestes autos demonstra cabalmente a hipótese que acabo de reproduzir, pois a Universidade Federal do Ceará, na pessoa de seu Reitor à época da ocorrência, descumpriu uma determinação que foi endereçada àquela Entidade, tendo praticado o ato, anteriormente inquinado, pela segunda vez. A exegese dada ao referido dispositivo da Lei Orgânica afasta o entendimento defendido pelo Titular da SECEX/CE de que a reincidência estaria caracterizada quando também ocorresse o descumprimento de determinação, independentemente do fato gerador, pois, conforme já dito, e se torna imperioso repisar, a reincidência está vinculada à prática renovada de ato, que já foi objeto de determinação, visando à correção das impropriedades/irregularidades identificadas. Por outro lado, o disposto no $\S 1^{\circ}$ do art. 58 difere, a meu ver, do contido no inciso VII, acima discutido, porquanto se refere a decisões pontuais, em que o Tribunal determina que se tome medidas específicas, geralmente mediante a fixação de prazo para o seu cumprimento. Não se trata, portanto, de determinação que objetiva prevenir a ocorrência de atos semelhantes, em oportunidade futura, mas, sim, de deliberação que impõe a adoção de providências efetivas, no intuito de regularizar uma situação específica ou fornecer dados para atender uma necessidade esporádica, cujos resultados serão dados a conhecer ao Tribunal. Nesse caso, apenas na hipótese de motivo justificado para o não cumprimento da decisão, é que esta Casa poderá dispensar a aplicação de multa ao Responsável" (grifei).

Um ponto importante é o momento em que se considera descumprida uma determinação do Tribunal. Caso o Tribunal tenha fixado prazo para descumprimento da determinação, a questão não oferece maiores complicações (salvo se o prazo fixado for excessivamente curto para o atendimento ou se a própria determinação do Tribunal de Contas invadir a esfera de discricionariedade do gestor).

Não fixado prazo e tratando-se de uma conduta positiva, descumprida estará a determinação se, após um prazo razoável (consideradas as condições administrativas e financeiras para o cumprimento da determinação), contado da notificação, esta conduta não tiver sido praticada pelo gestor ou pelo seu sucessor. Tratando-se de abstenção, descumprida estará a determinação se a conduta vedada pelo Tribunal foi realizada após a notificação do Tribunal ou se, realizada antes, o gestor público não adotou providências para a suspensão do ato ou contrato questionado pelo Tribunal.

\subsubsection{Infrações aos deveres de colaboração}

As infrações previstas no art. 58, incisos IV, V e VI, da Lei $n^{\circ}$ 8.443/92 compreendem violações ao dever de colaboração que o agente público submetido ao Controle Externo do Tribunal de Contas deverá ter perante o órgão fiscalizador. A violação 
destes deveres, no direito português, é denominada de infração sancionatória por atos não essencialmente financeiros.

Os deveres de colaboração são aqueles fundamentais para o exercício do controle externo e, sem os quais, a atuação da Corte de Contas estaria severamente prejudicada. Estes deveres se assentam nos princípios da publicidade, transparência e impessoalidade da Administração Pública e no Dever de Prestar Contas. Desta forma, não pode o gestor deixar de cumprir-los sob pretexto do direito constitucional do silêncio do réu. Os princípios que dão suporte aos deveres mencionados também têm assento constitucional.

Também é dever de colaboração permitir o exercício das prerrogativas do servidor do Tribunal de Contas, no exercício da função de controle externo (art. , da Lei n ${ }^{\circ}$ $8.443 / 92)$.

Enquanto os incisos V e VI da Lei ${ }^{\circ} 8.443 / 92$ (obstrução ao livre exercício das inspeções e auditorias determinadas e sonegação de processo, documento ou informação, em inspeções ou auditorias realizadas pelo Tribunal) se referem a violações de deveres de colaboração nas fiscalizações do Tribunal de Contas, o inciso IV (não atendimento, no prazo fixado, sem causa justificada, a diligência do Relator ou a decisão do Tribunal) se refere à violação do dever nos processos em geral.

\subsubsection{Infrações à Lei de Responsabilidade Fiscal (Lei $\left.{ }^{\circ} \mathbf{1 0 . 0 2 8}^{12000}\right)$}

Conforme já mencionamos anteriormente, o art. 5, da Lei $\mathrm{n}^{\circ} 10.028 / 2000$, denominada de Lei dos Crimes Fiscais, estabeleceu as chamadas "infrações administrativas às leis de finanças públicas", cuja apuração e sancionamento compete aos Tribunais de Contas. Como será objeto de discussão no capítulo 20, não considero adequada a utilização da expressão "infrações administrativas". Prefiro adotar a expressão "infrações financeiras" pelas razões expostas no capítulo 20.

Os tipos previstos no art. $5^{\circ}$, se encaixam perfeitamente na modalidade sancionatória da responsabilidade financeira por atos essencialmente financeiros. 
Tratam-se de hipóteses que não importam em dano ao Erário e que tratam de assuntos regulados pela Lei de Responsabilidade Fiscal (Lei Complementar $n^{\circ}$ 101/2000).

Como já mencionado anteriormente, a LRF não estabeleceu sanções pessoais aos gestores públicos, mas, tão somente, sanções institucionais aos entes federados. A tarefa de prescrever sanções pessoais, de diferentes naturezas ficou a cargo do Lei ${ }^{\circ}$ 10.028/2000.

A primeira infração corresponde a "deixar de divulgar ou de enviar ao Poder Legislativo e ao Tribunal de Contas o relatório de gestão fiscal, nos prazos e condições estabelecidos em lei" (art. $5^{\circ}$, I).

O Relatório de Gestão Fiscal (RGF) tem por finalidade precípua demonstrar a compatibilidade dos parâmetros como despesas totais de pessoal, dívida consolidada, operações de crédito ou concessão de garantias com os seus respectivos limites. Deve ser enviado e divulgado pelos titulares de órgãos ou Poderes (art. 20), quadrimestral ou semestralmente, este último aplicável aos municípios de até 50 mil habitantes.

O RGF está normatizado nos artigos 54, 55 e 63, da Lei de Responsabilidade

Fiscal:

"Art. 54. Ao final de cada quadrimestre será emitido pelos titulares dos Poderes e órgãos referidos no art. 20 Relatório de Gestão Fiscal, assinado pelo:

I - Chefe do Poder Executivo;

II - Presidente e demais membros da Mesa Diretora ou órgão decisório equivalente, conforme regimentos internos dos órgãos do Poder Legislativo;

III - Presidente de Tribunal e demais membros de Conselho de Administração ou órgão decisório equivalente, conforme regimentos internos dos órgãos do Poder Judiciário;

IV - Chefe do Ministério Público, da União e dos Estados.

Parágrafo único. O relatório também será assinado pelas autoridades responsáveis pela administração financeira e pelo controle interno, bem como por outras definidas por ato próprio de cada Poder ou órgão referido no art. 20".

Art. 55. O relatório conterá:

I - comparativo com os limites de que trata esta Lei Complementar, dos seguintes montantes:

a) despesa total com pessoal, distinguindo a com inativos e pensionistas;

b) dívidas consolidada e mobiliária;

c) concessão de garantias;

d) operações de crédito, inclusive por antecipação de receita;

e) despesas de que trata o inciso II do art. 4o;

(...)

Art. 63. É facultado aos Municípios com população inferior a cinqüenta mil habitantes optar por:

(...)

II - divulgar semestralmente:

a) (VETADO) 
b) o Relatório de Gestão Fiscal"

Da leitura dos dispositivos supracitados, é possível observar que os sujeitos ativos da infração circunscrevem-se aos agentes públicos elencados no art. 54, da Lei de Responsabilidade Fiscal.

A segunda infração corresponde à conduta típica "propor lei de diretrizes orçamentárias anual que não contenha as metas fiscais na forma da lei" (art. 5², II). A Lei de Responsabilidade Fiscal impôs novas funções e requisitos à Lei de Diretrizes Orçamentárias, além daquelas contidas no art. $165, \S 2^{\circ}$, da $\mathrm{CF} / 88$.

Dentre estes novos requisitos, encontra-se o Anexo de Metas Fiscais, exigência do art. $4^{\circ}$, da LRF:

\footnotetext{
"Art. 4 - A lei de diretrizes orçamentárias atenderá o disposto no $§ 20$ do art. 165 da Constituição e:

(...)

$\S 1^{\circ}$ Integrará o projeto de lei de diretrizes orçamentárias Anexo de Metas Fiscais, em que serão estabelecidas metas anuais, em valores correntes e constantes, relativas a receitas, despesas, resultados nominal e primário e montante da dívida pública, para o exercício a que se referirem e para os dois seguintes"
}

O sujeito ativo da infração só pode ser o chefe do Poder Executivo, eis que a iniciativa das Leis de natureza orçamentária (Lei Orçamentária Anual, Lei de Diretrizes Orçamentárias e Plano Plurianual) é privativa do Prefeito, Governador ou Presidente da República (art. 165, CF/88).

Como a conduta descrita no tipo é positiva (uma ação descrita pelo verbo "propor"), uma dúvida que pode surgir é a seguinte: se o chefe do Poder Executivo deixar de propor a LDO, ele comete a infração tipificada no art. $5^{\circ}$, II, Lei ${ }^{\circ} 10.028 / 2000$ ?

Em não se tratando de infração penal, não há que se exigir legalidade estrita. Logo, se o chefe do Executivo deixou de propor a LDO, também deixou de estabelecer metas fiscais e deixou de adotar medidas voltadas ao planejamento fiscal. Ou seja, deixar de enviar a LDO também contraria o espírito do art. $5^{\circ}$, II, da Lei n ${ }^{\circ} 10.028 / 2000$. 
A terceira infração é "deixar de expedir ato determinando limitação de empenho e movimentação financeira, nos casos e condições estabelecidos em lei" (art. $5^{\circ}$, III). A limitação de empenho importa em limitação à assunção de obrigações e a limitação de movimentação financeira importa em restrição ao pagamento destas obrigações.

A LRF exige a adoção das medidas, segundo os critérios da LDO, em duas hipóteses: a do art. $9^{\circ}$ (quando a realização da receita apurada bimestralmente puder comprometer as metas fiscais) e a do art. 31 (excesso da dívida consolidada em relação o limite):

\begin{abstract}
Art. $9^{\circ}$ - Se verificado, ao final de um bimestre, que a realização da receita poderá não comportar o cumprimento das metas de resultado primário ou nominal estabelecidas no Anexo de Metas Fiscais, os Poderes e o Ministério Público promoverão, por ato próprio e nos montantes necessários, nos trinta dias subseqüentes, limitação de empenho e movimentação financeira, segundo os critérios fixados pela lei de diretrizes orçamentárias.

$\S 1$ o No caso de restabelecimento da receita prevista, ainda que parcial, a recomposição das dotações cujos empenhos foram limitados dar-se-á de forma proporcional às reduções efetivadas.

§ 20 Não serão objeto de limitação as despesas que constituam obrigações constitucionais e legais do ente, inclusive aquelas destinadas ao pagamento do serviço da dívida, e as ressalvadas pela lei de diretrizes orçamentárias.

Art. 31. Se a dívida consolidada de um ente da Federação ultrapassar o respectivo limite ao final de um quadrimestre, deverá ser a ele reconduzida até o término dos três subseqüentes, reduzindo o excedente em pelo menos $25 \%$ (vinte e cinco por cento) no primeiro.

$\S 1$ o Enquanto perdurar o excesso, o ente que nele houver incorrido:

I - estará proibido de realizar operação de crédito interna ou externa, inclusive por antecipação de receita, ressalvado o refinanciamento do principal atualizado da dívida mobiliária;

II - obterá resultado primário necessário à recondução da dívida ao limite, promovendo, entre outras medidas, limitação de empenho, na forma do art. $9^{\circ}$.
\end{abstract}

O titular dos Poderes e dos órgãos do art. 20, da LRF, detentores da competência para expedir os atos de limitação de empenho e movimentação financeira, é o sujeito ativo da infração.

Nos órgãos colegiados, o regimento interno poderá atribuir esta competência a algum dos órgãos internos (Mesa, Órgão Especial ou Câmara). Neste caso, os integrantes do órgão competente que votarem contra a expedição do ato, não ou se abstiverem poderão ser responsabilizados. 
A última infração é "deixar de ordenar ou de promover, na forma e nos prazos da lei, a execução de medida para a redução do montante da despesa total com pessoal que houver excedido a repartição por Poder do limite máximo" (art. $5^{\circ}$, IV).

O controle das despesas de pessoal, como mecanismo voltado à promoção do equilíbrio das contas públicas, já estava preconizado no art. 169, da CF/88. Na Lei de Responsabilidade Fiscal foram estabelecidos limites às despesas com pessoal ativo e inativo em função da Receita Corrente Líquida (RCL). Tais limites foram estabelecidos no art. 19, por ente federado, e no art. 20, discriminados por Poder ou órgão que goza de autonomia administrativa e financeira.

O art. 23, da LRF dispõe que:

\footnotetext{
"Se a despesa total com pessoal, do Poder ou órgão referido no art. 20, ultrapassar os limites definidos no mesmo artigo, sem prejuízo das medidas previstas no art. 22, o percentual excedente terá de ser eliminado nos dois quadrimestres seguintes, sendo pelo menos um terço no primeiro, adotando-se, entre outras, as providências previstas nos $\S \S 3^{\circ}$ e $4^{\circ}$ do art. 169 da Constituição"
}

As medidas voltadas para a eliminação do excesso das despesas de pessoal estão inclusas no art. $169, \S \S 3^{\circ}$ e $4^{\circ}$, da $\mathrm{CF} / 88$. As providências deverão ser adotadas em sequiência, somente fazendo uso da medida posterior se a anterior não for suficiente para se alcançar o limite legal.

Em primeiro lugar, deverá haver a "redução em pelo menos vinte por cento das despesas com cargos em comissão e funções de confiança". Caso não suficiente, deverá haver a "exoneração dos servidores não estáveis". Se ainda assim não for suficiente, poderá haver a exoneração de servidores estáveis (art. 169, §4, $\mathrm{CF} / 88$ ), mediante indenização.

A autoridade competente para expedir o ato de redução de pessoal é o sujeito ativo da infração. Geralmente, será o titular dos órgãos ou Poderes do art. 20, da LRF, No caso de órgãos colegiados, aplicam-se as mesmas considerações da infração anterior. 


\section{PRESSUPOSTOS SUBJETIVOS}

Neste capítulo, abordo a culpa em sentido amplo como pressuposto da responsabilidade financeira. No capítulo seguinte, abordo os sujeitos passivos da responsabilidade financeira.

Sérgio Cavalieri Filho define a culpa (em sentido estrito) como a "conduta voluntária contrária ao dever de cuidado imposto pelo Direito, com a produção de um evento danoso involuntário, porém previsto ou previsível" (CAVALIERI FILHO, 2002, p. 46).

O dever de cuidado objetivo é o dever de cautela, atenção ou diligência necessário para que, na vida em sociedade, o ser humano não cause dano a outrem.

Em inúmeras atividades humanas, a legislação procura estabelecer os deveres e cuidados que o agente deve ter. Entretanto, há também um dever indeterminado que justifica as hipóteses em que há culpa sem que o dever corresponda a um texto expresso de lei ou regulamento (CAVALIERI FILHO, 2002, p. 45).

Não havendo normas específicas, o conteúdo do dever objetivo de cuidado só pode ser determinado com base na comparação do fato concreto com o comportamento do homem médio ou do bonus pater familias (CAVALIERI FILHO, 2002, p. 46).

A gestão de recursos públicos é uma atividade extremamente normatizada. São inúmeras as fontes normativas, que variam desde a Constituição Federal até as Resoluções, Portarias e Ordens de Serviço editadas pelo Dirigente de uma Repartição Pública. Nada obstante, os deveres de cautela podem ser oriundos também de parâmetros de ciências extra-jurídicas, como a Administração Pública, as Finanças Públicas, a Economia do Setor Público e a Contabilidade. Afinal, não é à toa que o art. $73, \S 1^{\circ}$, III, da $\mathrm{CF} / 88$, exige como requisito para escolha do Ministro (ou Conselheiro) do Tribunal de Contas "notórios conhecimentos jurídicos, contábeis, econômicos e financeiros ou de administração pública". 
A doutrina costuma classificar a culpa, sendo vários critérios. Segundo o critério da gravidade, a culpa pode ser grave, leve ou levíssima. Há culpa leve "se a falta puder ser evitada com atenção ordinária, com o cuidado próprio do homem comum, de um bonus pater familias" (CAVALIERI FILHO, 2002, p. 49). A culpa levíssima "caracteríza-se pela falta de atenção extraordinária, pela ausência de habilidade especial ou conhecimento singular" (CAVALIERI FILHO, 2002, p. 49). A culpa é grave "se o agente atuar com grosseira falta de cautela, com o descuido injustificável ao homem normal, impróprio ao comum dos homens" (CAVALIERI FILHO, 2002, p. 49).

As modalidades da culpa, ou seja, as formas como a falta de cautela se exterioriza, são a imprudência, a negligência e a imperícia. A imprudência é "a falta de cautela ou cuidado por conduta comissiva, positiva, por ação" (CAVALIERI FILHO, 2002, p. 48). A negligência é "a falta de cuidado por conduta omissiva" (CAVALIERI FILHO, 2002, p. 48). A imperícia é a "falta de habilidade no exercício de atividade técnica, caso em que se exige, em regra, maior cuidado ou cautela do agente" (CAVALIERI FILHO, 2002, p. 48).

Alguns conceitos pertinentes à culpa muito utilizados são: a culpa "in eligendo", a culpa "in vigilando" e a culpa "in custodiando". A culpa "in eligendo" se caracteriza pela má escolha do preposto. A culpa "in vigilando" decorre da falta de atenção ou cuidado com o procedimento de outrem que está sob guarda ou responsabilidade do agente. A culpa "in custodiando" caracteríza-se pela falta de atenção em relação a animal ou coisa que estavam sob os cuidados do agente (CAVALIERI FILHO, 2002, p. 50). Fala-se, também, em culpa contra a legalidade, "quando o dever violado resulta de texto expresso de lei ou regulamento", sendo a mera infração da norma regulamentar fator determinante da responsabilidade civil. Cria-se em desfavor do agente uma presunção de ter agido culpavelmente, incumbindo-lhe o difícil ônus da prova em contrário (CAVALIERI FILHO, 2002, p. 52). 
O dolo, por sua vez, é "a vontade conscientemente dirigida à produção de um resultado ilícito", "é a infração consciente do dever preexistente, ou o propósito de causar dano a outrem" (CAVALIERI FILHO, 2002, p. 43)

A responsabilidade financeira tem como requisito subjetivo a culpa no sentido amplo, o que engloba o dolo e a culpa em sentido estrito, com todas as suas modalidades: negligência, imprudência e imperícia.

Isto se deve, em primeiro lugar, à aplicação analógica do art. $37, \S 6^{\circ}$, da $\mathrm{CF} / 88$, ante as lacunas na legislação pertinente. De fato, apesar de o dispositivo versar sobre a responsabilidade externa do agente público, ou seja, sobre as situações em que o agente, no exercício de função pública, causa dano a terceiro, ele define o espírito que deve orientar a responsabilização do agente público, em todas as suas modalidades, cabendo a aplicação analógica.

Tal analogia tem sido utilizada pelo Tribunal de Contas da União para sustentar a tese da responsabilidade subjetiva do "agente contábil". Com efeito, no Acórdão n 67/2003 - $2^{\mathrm{a}}$. Câmara, o Ministro-Relator pronunciou que ${ }^{114}$ :

"A responsabilidade dos administradores de recursos públicos, escorada no parágrafo único do art. 70 da Constituição Federal e no artigo 159 da Lei no 3.071/16, segue a regra geral da responsabilidade civil. Quer dizer, trata-se de responsabilidade subjetiva. $\mathrm{O}$ fato de o ônus de provar a correta aplicação dos recursos caber ao administrador público não faz com que a responsabilidade deixe de ser subjetiva e torne-se objetiva. Esta, vale frisar, é responsabilidade excepcional, a exemplo do que ocorre com os danos causados pelo Estado em sua interação com particulares - art. 37, $\S 6^{\circ}$, da Constituição Federal".

Reforça este entendimento, a Doutrina de João Franco do Carmo, segundo o qual, o conceito jurídico de responsabilidade leva ínsito o de imputabilidade. Por isso se diz

\footnotetext{
${ }^{114}$ No mesmo sentido, o voto do Acórdão no 46/2001 - Plenário, verbis: "A Constituição Federal - ao tempo em que adotou a teoria da responsabilidade objetiva, relativamente às pessoas jurídicas de direito público e às de direito privado prestadoras de serviços públicos - consagrou a teoria da responsabilidade subjetiva para fins de reparação do patrimônio dessas entidades em razão do dano causado pelo agente, conforme se observa no art. 37, $\S 6^{\circ}$, in verbis: ' $\$ 6^{\circ}$ As pessoas jurídicas de direito público e as de direito privado prestadoras de serviços públicos responderão pelos danos que seus agentes, nessa qualidade, causarem a terceiros, assegurado o direito de regresso contra o responsável nos casos de dolo ou culpa'".
} 
que a responsabilidade é, em regra, subjectiva, baseada na imputação moral do acto ao sujeito. Só assim será possível sujeitar alguém às consequiências desfavoráveis de um comportamento seu, ressalvados os casos em que a ordem jurídica não associa ao comportamento do responsável qualquer juízo de desvalor (como na responsabilidade pelo risco ou na responsabilidade por factos lícitos) (CARMO, 1995).

$\mathrm{Na}$ Itália, exige-se o dolo ou a culpa grave como pressuposto da responsabilidade administrativa. Com efeito, o art. $1^{\circ}$, 1 , da Lei $\mathrm{n}^{\circ} 20$, de 14 de janeiro de 1994, dispõe que: "La responsabilità dei soggetti sottoposti alla giurisdizione della Corte dei conti in materia di contabilità pubblica è personale e limitata ai fatti ed alle omissioni commessi con dolo o con colpa grave (...)" (A responsabilidade dos sujeitos submetidos à jurisdição da Corte de Contas em matéria de contabilidade pública é pessoal e limitada aos fatos e omissões cometidas com dolo ou culpa grave - tradução livre).

A frase de abertura desta dissertação, de Paolo Maddalena, Juiz da Corte Constitucional Italiana, é bem ilustrativa desta exigência:

\begin{abstract}
"(...) nella gestione della cosa pubblica, l'amministratore o il dipendente non deve sentirsi troppo con le mani legate, non deve esser frenato dall'ossessivo timore di sbagliare e pertanto non deve essere ritenuto responsabile di qualsiasi comportamento colposo, ed in particolare di quegli errori che, talvolta, come sottolinea un illustre civilista (...), per legge statistica 'debbono accadere'"115
\end{abstract}

Em Portugal, o art. 61\%, da LOPTC, dispõe que a responsabilidade financeira só ocorre se a acção for praticada com culpa. Entretanto, na ausência de dolo, pode o Tribunal converter a responsabilidade financeira reintegratória em sancionatória, nos termos do art. 65\% $/ 7$, LOPTC. No caso de negligência, o Tribunal de Contas poderá relevar a responsabilidade ou reduzi-la, nos termos do art. 64\%2, LOPTC.

\footnotetext{
${ }^{115} \mathrm{Na}$ gestão da coisa pública, o administrador ou o funcionário não deve sentir-se demasiadamente com as mãos atadas, não deve ser freado pelo ostensivo temor de errar e, por isso, não deve ser considerado responsável por qualquer comportamento culposo e, em particular, por aqueles erros que, segundo sublinha um ilustre civilista, pela lei estatística devem acontecer.

Fonte: http://www.amcorteconti.it/mad_inquad_dogm.htm
} 
No Brasil, não é comum a distinção entre as modalidades de culpa, tal como ocorre com Portugal. O Tribunal de Contas da União tem responsabilizado frequentemente os agentes contábeis por negligência, conforme relevam os julgados a seguir:

a) negligência na instauração da Tomada de Contas Especial, em razão de desvio ou não localização de bens (Acórdão n 11/2008 - Plenário);

b) negligência dos responsáveis na gestão da arrecadação da receita pública. (Acórdão n 33/2008 - 2ª . Câmara)

c) não adoção de medidas tempestivas para a renovação do contrato inicial, ensejando o pagamento de serviços sem a cobertura contratual (Acórdão $\mathrm{n}^{\circ}$ 87/2002 - Plenário);

d) negligência na conservação e reparo de bem público (Acórdãos nº 89/2004 $1^{\mathrm{a}}$. Câmara e 1.842/2003 - $1^{\mathrm{a}}$. Câmara);

e) negligência na gestão de recursos recebidos, por terem sido mantidos ociosos (Acórdão nº 136/2002 - Plenário);

f) negligência na manutenção de veículo objeto de convênio, com a danificação do motor proveniente do uso ininterrupto no transporte de veículos (Acórdão $\mathrm{n}^{\circ}$ 191/2005 - $1^{\text {a }}$. Câmara);

g) negligência na efetuação de pagamentos, sem verificar os recolhimentos dos encargos previdenciários resultantes da execução do convênio e sem reter as importâncias devidas (Acórdão n 191/2005 - 1ª . Câmara);

h) negligência no acompanhamento da execução do contrato, permitindo a utilização de mão de obra informal sobre a qual a contratada não recolhia os encargos sociais devidos (Acórdão n 275/2001 - Plenário).

\subsection{A avaliação da culpabilidade na gestão pública}

A avaliação da culpabilidade compreende a estipulação de critérios para o exame, no caso concreto, do grau de reprovabilidade da conduta do administrador.

Esta avaliação levar em conta as circunstâncias, os parâmetros e as informações disponíveis à época da conduta inquinada. É que o Controle, via de regra, é 
exercido a posteriori, e, portanto, já conhece as reais consequências da conduta e não apenas a previsão delas. Ademais, a decisão administrativa é tomada sob a pressão dos acontecimentos, com prazos exíguos, o que não acontece com o ato de Controle.

Na Legislação Brasileira, não estão definidos parâmetros para avaliação da culpabilidade do gestor público, o que exige um estudo sobre a Jurisprudência dos Tribunais de Contas e sobre o Direito Estrangeiro.

No Direito Português ${ }^{116}$, a avaliação da culpabilidade encontra-se regulada no art. $64^{\circ}$, da Lei $\mathrm{n}^{\circ}$ 98/97 (LOPTC), o qual leva em conta os seguintes fatores:
a) circunstâncias do caso concreto;
b) cargo ou índole das principais funções do responsável;
c) volume de valores e fundos movimentados;
d) montante material da lesão dos dinheiros e valores públicos;
e) meios humanos e materiais existentes no serviço, organismo ou entidade sujeitos à sua jurisdição.

O mesmo dispositivo pertinente à responsabilidade financeira reintegratória, dispõe que, quando verificar negligência, o Tribunal poderá reduzir ou relevar a

\footnotetext{
116 Acerca do tema, são pertinentes as considerações do Tribunal de Contas (PORTUGAL, 1999, p. 11): "Esta avaliação, faz-se, antes de mais, de harmonia com as circunstâncias do caso, tendo em conta a competência do cargo, ou a índole das principais funções de cada responsável, o volume dos valores e fundos movimentados, o montante material da lesão dos dinheiros ou valores públicos e os meios humanos e materiais existentes nos serviços, organismos ou entidades sujeitos à jurisdição do Tribunal de Contas. Não obstante a epígrafe do preceito em análise (avaliação da culpa), o seu $\mathrm{n}^{\circ} 2$ reporta-se à negligência, que, na doutrina tradicional e até na Lei, v.g. o art. $^{\circ} 483^{\circ}$ do Código Civil, é designada por mera culpa. O $\mathrm{n}^{\circ} 2$ do art. $^{\circ} 67^{\circ}$, em sede de responsabilidade sancionatória, estabelece que na graduação das multas a aplicar, o Tribunal de Contas deverá ter em consideração o grau de culpa do agente. No entanto, não fixa qualquer critério legal para a avaliação da

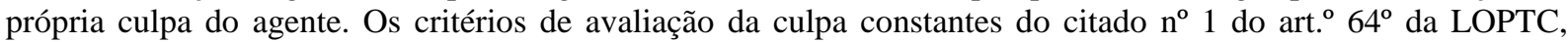
permitem concretizar o princípio ínsito no $\mathrm{n}^{\circ} 5$ do seu art. ${ }^{\circ} 61^{\circ}$, isto é, fornece ao Tribunal de Contas elementos jurídicos para em concreto determinar o grau de culpa do agente. Culpa esta que deverá ser tida em conta aquando da graduação da multa a aplicar em sede de responsabilidade financeira sancionatória. Deste modo, por força do $n^{\circ} 3$ do art. ${ }^{\circ} 67^{\circ}$ da LOPTC, deverão aplicar-se, com as necessárias adaptações, à avaliação da culpa do agente em sede de responsabilidade financeira sancionatória os mesmos critérios que o legislador consagrou para a responsabilidade financeira reintegratória".
} 
responsabilidade devendo, entretanto, motivar a sua decisão (vide relevação da responsabilidade como causa excludente da responsabilidade financeira - item 17.4.).

Além da responsabilidade financeira reintegratória, a avaliação da culpabilidade tem repercussão também sobre a de natureza sancionatória. Isto porque, consoante o art. $67^{\circ}$, item "2", da LOPTC, o grau da culpa é considerado, juntamente com outros fatores, na graduação da multa a ser aplicada ao responsável.

A seguir, analiso alguns dos fatores que podem ser usados na avaliação da culpabilidade na gestão pública.

\subsubsection{Dolo e Enriquecimento ilícito}

No Direito Penal, diz-se que a conduta é dolosa, quando o agente quis produzir o resultado ou assumiu o risco de produzí-lo (art. 18, I, CP).

O Dolo não é pressuposto subjetivo necessário da Responsabilidade Financeira (esta se contenta com a culpa), mas é um fator importante na reprovação da conduta do responsável.

No Direito Português, se a infração financeira foi cometida com dolo, o limite mínimo da multa a ser aplicada é elevado, conforme dispõe o art. 65\%, da LOPTC: "Se a infracção for cometida com dolo, o limite mínimo da multa é igual a um terço do limite máximo" (O Limite máximo a que se refere o dispositivo é de 150 Unidade de Conta - UC ${ }^{117}$ e o limite mínimo, sem o aumento, é de 15 UC).

\footnotetext{
${ }^{117}$ Unidade de conta (UC) é a quantia monetária equivalente a um quarto da remuneração mínima mensal mais elevada, garantida no momento da condenação, aos trabalhadores por conta de outrem, arredondada, quando necessário, para a unidade de euros mais próxima, ou se a proximidade for igual, para a unidade de euros imediatamente inferior (Fonte: Ministério da Justiça - http://www.dgaj.mj.pt).
} 
O enriquecimento ilícito também não é pressuposto da responsabilidade financeira, tal como ocorre com a responsabilidade por ato de improbidade administrativa (art. $9^{\circ}$, da Lei $n^{\circ}$ 8.429/92). A responsabilidade financeira tem por finalidade proteger a integridade dos recursos públicos como também a regularidade do processo de sua utilização (TAVARES; MAGALHÃES, 1990, p. 136). Nem sempre as infrações financeiras importam em enriquecimento ilícito, especialmente, se a conduta for meramente culposa.

Nada obstante, o enriquecimento ilícito é também um fator relevantíssimo na reprovação da conduta do responsável.

\subsubsection{Circunstâncias do Caso Concreto}

No Direito Penal, circunstância é "todo fato, relação ou dado concreto, determinado, que é considerado pela lei para medir a gravidade do injusto ou da culpabilidade" (PRADO, 2006, p. 500).

O rol de circunstâncias atenuantes e agravantes elencadas pelo Código Penal Brasileiro (arts. 61 e 65) é genérico. Por destinar-se a avaliar a reprovabilidade de um grande conjunto de condutas típicas, tem pouca utilidade na avaliação da gestão pública.

Não há, também, na Lei $n^{\circ}$ 8.443/92, um rol explícito de circunstâncias que devem ser sopeadas pelo intérprete, no momento da avaliação da culpabilidade.

$\mathrm{Na}$ avaliação da gestão, deve-se levar em conta, por exemplo, como circunstâncias atenuantes como a urgência na tomada de decisão, a pressão da sociedade para a resolução de um determinado problema, entre outras.

\subsubsection{Cargo e Índole das Principais Funções do Responsável}

Como será exposto no capítulo 14, a identificação do responsável tem por base a verificação do cumprimento ou não dos deveres interentes ao cargo, emprego ou função pública, que podem variar substancialmente. 
Com efeito, enquanto alguns cargos exercem funções opinativas, outros exercem funções decisórias. Há, ainda, aqueles que devem exercer funções de controle sobre a atividade de outros agentes públicos.

Convém lembrar também que, quanto mais prerrogativas um cargo detem, tanto maiores serão as exigências sobre o titular deste cargo. Na lição de Celso Antônio Bandeira de Mello (MELLO, 2005), os poderes conferidos à Administração Pública são, de fato, deveres-poderes, o que reforça a vinculação daqueles ao atendimento exclusivo de uma finalidade de interesse público.

\subsubsection{O volume de valores e fundos movimentados}

O volume de valores e fundos movimentados não é, por si só, um fator que agrava ou que atenua a culpabilidade do gestor. O que se deve levar em conta é o número de operações ou atividades efetuadas.

Se o gestor está responsável, por exemplo, por uma obra de grande porte, em que o volume de recursos envolvidos é muito grande, naturalmente, a cautela exigida do administrador é muito elevada. Uma falha na administração desta obra pode implicar em uma lesão considerável aos cofres públicos ou o não atendimento a um objetivo relevante do Estado (razão pela qual alocou este montante de recursos), motivo pelo qual, a irregularidade tem uma reprovabilidade mais elevada.

Se o gestor, por outro lado, efetua várias operações, ainda que o volume de recursos não seja tão relevante, é estatisticamente possível que falhas em uma ou outra operação aconteçam, pois, o ser humano gestor tem disponibilidade de tempo reduzida para dar atenção a cada uma das atividades que realiza. Nesta situação, a falha tem reprovabilidade reduzida. 


\subsubsection{Montante da Lesão aos recursos Públicos}

O montante da lesão, no Direito Brasileiro, não é propriamente um fator que agrava a culpabilidade, mas que agrava o montante do débito ou da multa proporcional a ser imposta ao administrador.

Em atendimento à razoabilidade, não seria juridicamente possível levar em conta por duas vezes um fator para o agravamento das sanções impostas ao gestor público.

\subsubsection{Meios Humanos e Materiais Disponíveis}

A administração de recursos públicos requer meios humanos e materiais para o seu regular andamento.

Por um lado, o responsável não executa todas as atividades de forma isolada e sem os seus colaboradores. Há uma divisão de trabalho no âmbito da Administração Pública. Se faltam servidores em determinada repartição, há uma maior concentração de encargos na pessoa do gestor, o que pode atenuar a sua culpabilidade.

Por outro, se faltam recursos materiais (por causas alheias à vontade do gestor), não é possível exigir do administrador condutas que sejam dependentes destes recursos.

Por exemplo, se a repartição não dispõe de computadores e acesso à Internet, não se pode exigir que, o gestor fizesse uma pesquisa de preços "on line" na fase interna de um procedimento licitatório.

\subsubsection{Complexidade da Legislação e Divergência Jurisprudêncial}

A legislação que regula a gestão de bens, dinheiros e recursos públicos é vasta

e complexa. É composta por fontes que variam desde a Constituição Federal até a Portaria do 
Dirigente da Repartição Pública. Não é incomum o fato das normas infralegais contrariarem a lei ou até mesmo a Constituição Federal. Não são incomuns as lacunas existentes na legislação e as dúvidas na interpretação de um ou outro dispositivo normativo, sem contar com a terrível falta de técnica legislativa de alguns legisladores.

Nestas hipóteses, a culpabilidade do gestor, que está vinculado à legalidade, deve ser atenuada. A propósito, no Direito Penal, conforme art. 21, do $\mathrm{CP}$, "O desconhecimento da lei é inescusável. O erro sobre a ilicitude do fato, se inevitável, isenta de pena; se evitável, poderá diminuí-la de um sexto a um terço".

Da mesma forma, a avaliação da culpabilidade deve legar em conta se há divergências jurisprudênciais acerca da legalidade ou não de determinada conduta no tocante à gestão. Não são incomuns as divergências de entendimento entre Tribunais do Poder Judiciário, ou entre Tribunais de Contas e os Tribunais do Poder Judiciário, ou ainda, entre as Câmaras ou Turmas de um mesmo Tribunal. Extrapola as atribuições do administrador público, advinhar qual será a corrente a ser adotada pelo órgão de controle externo.

\subsubsection{Atendimento às Recomendações e Determinações do Tribunal de Contas}

Ao Tribunal de Contas, no exercício da sua função corretiva (art. 71, inciso IX, da CF/88), compete "assinar prazo para que o órgão ou entidade adote as providências necessárias ao exato cumprimento da lei, se verificada ilegalidade". Tais determinações são de cumprimento obrigatório pelo órgão ou entidade pública, sob pena de multa nos termos do art. 58, inciso VII e $\S 1^{\circ}$, da Lei ${ }^{\circ} 8.443 / 92$.

As recomendações são orientações formuladas no âmbito da função pedagógica do Tribunal. Geralmente, são resultantes de fiscalizações de natureza operacional. Não são de cumprimento obrigatório pelo órgão ou entidade pública, mas servem como importante referência na para a melhoria da gestão. 
$\mathrm{O}$ não atendimento às determinações e a não implementação das recomendações do Tribunal é um fator que deve ser levado em conta na avaliação da culpabilidade, especialmente, se com o cumprimento destas o resultado indesejado pudesse ser evitado. As determinações e recomendações consistem numa explicitação dos deveres de cautela e diligência que o administrador público deve ter, na visão do Tribunal de Contas.

Por exemplo, imagine um órgão que, usualmente, promove transferências voluntárias para Estados e Municípios por meio de convênios. O Tribunal de Contas, após auditoria operacional, recomendou ao órgão que avalie as condições técnicas, humanas e materiais do ente receptor antes de promover a transferência, com vistas a transferir recursos apenas para os governos e prefeituras que tenham efetivamente condição de realizar o objeto pactuado (uma obra, por exemplo).

O não atendimento da recomendação, por si só, não é pressuposto da
responsabilidade financeira sancionatória, mas pode ser elemento de avaliação da
culpabilidade, para responsabilizar o agente no futuro ou para a graduação da multa.

Assim, havendo dano ao erário em razão da transferência para uma prefeitura que não tenha a menor condição de executar o pactuado, a responsabilidade financeira reintegratória deve ser imputada também ao gestor do órgão que concedeu a transferência e a multa proporcional deve ser graduada levando-se em conta que o gestor, mesmo após alertado pelo Tribunal, deixou de tomar cautela para evitar a ocorrência do dano. 


\section{SUJEIÇÃO PASSIVA}

Conforme já mencionado anteriormente, a responsabilidade financeira é uma responsabilidade típica dos "agentes contábeis", ou seja, daqueles que utilizem, arrecadem, guardem, gerenciem ou administrem bens, dinheiros e valores públicos, ou aqueles que causem dano ou outro prejuízo ao erário. O conceito de gestor deve ser entendido no sentido amplo, o que abrange todo aquele que atue ao longo do procedimento de gestão (desde os atos preparatórios até os de execução), com influência no processo decisório.

Os particulares também estão sujeitos à responsabilidade financeira em duas situações. Na primeira hipótese, se os particulares efetuam a gestão de recursos públicos (em razão do recebimento de uma subvenção, auxílio, etc.), os particulares são agentes contábeis por equiparação, com os mesmos deveres, obrigações e responsabilidades dos agentes contábeis em geral. Na segunda, são responsáveis os particulares que, em conluio com agentes públicos, dêem causa a dano ao erário.

$\mathrm{O}$ art. $5^{\circ}$, da Lei $\mathrm{n}^{\circ} 8.443 / 93$ define, no âmbito Federal, os sujeitos passivos da Responsabilidade Financeira:

"I - qualquer pessoa física, órgão ou entidade a que se refere o inciso I do art. $1^{\circ}$ desta lei, que utilize, arrecade, guarde, gerencie ou administre dinheiros, bens e valores públicos ou pelos quais a União responda, ou que, em nome desta assuma obrigações de natureza pecuniária;

II - aqueles que derem causa a perda, extravio ou outra irregularidade de que resulte dano ao erário;

III - os dirigentes ou liquidantes das empresas encampadas ou sob intervenção ou que de qualquer modo venham a integrar, provisória ou permanentemente, o patrimônio da União ou de outra entidade pública federal;

IV - os responsáveis pelas contas nacionais das empresas supranacionais de cujo capital social a União participe, de forma direta ou indireta, nos termos do tratado constitutivo.

$\mathrm{V}$ - os responsáveis por entidades dotadas de personalidade jurídica de direito privado que recebam contribuições parafiscais e prestem serviço de interesse público ou social;

VI - todos aqueles que lhe devam prestar contas ou cujos atos estejam sujeitos à sua fiscalização por expressa disposição de lei;

VII - os responsáveis pela aplicação de quaisquer recursos repassados pela União, mediante convênio, acordo, ajuste ou outros instrumentos congêneres, a Estado, ao Distrito Federal ou a Município;

VIII - os sucessores dos administradores e responsáveis a que se refere este artigo, até o limite do valor do patrimônio transferido, nos termos do

IX - os representantes da União ou do Poder Público na assembléia geral das empresas estatais e sociedades anônimas de cujo capital a União ou o Poder Público participem, 
solidariamente, com os membros dos conselhos fiscal e de administração, pela prática de atos de gestão ruinosa ou liberalidade à custa das respectivas sociedades".

Para os efeitos deste tópico, o termo "jurisdição" deve ser entendido como escopo ou limite subjetivo da atuação do Tribunal de Contas da União ${ }^{118}$. Tais limites não podem ser objeto de interpretação extensiva. Desta forma, toda pessoa, física ou jurídica, ou ente despersonalizado que não esteja inserido no rol do art. $5^{\circ}$, da Lei $n^{\circ} 8.443 / 92$, não se sujeita à responsabilidade financeira ${ }^{119}$.

Acerca desta interpretação restritiva, Carles Rosiñol I Vidal reproduz trecho de Sentença do Tribunal de Contas Espanhol em que destaca a preocupação em não se invadir outras esferas jurisdicionais (VIDAL, 1999, p. 88):

\begin{abstract}
"la extensión subjetiva de la responsabilidad contable compreende, de acordo con una interpretación sistemática de los artículos 38.1, 15.1 y 2.b) de la aludida Ley Orgánica del Tribunal no a cualquier persona sino, solamente, a 'quienes recauden, intervengan, administren, custodien, manejen o utilicen bienes o caudades o efectos públicos', ya que de lo contrario la responsabilidad contable incluiría, en términos generales, la responsabilidad civil de terceros frente a la Administración pública, con la consiguiente invasíon en la esfera de competencias de otros órdenes jurisdiccionales".
\end{abstract}

Cumpre observar que o conjunto de sujeitos jurisdicionados ao Tribunal de Contas engloba o conjunto de aqueles obrigados ao dever de prestar de contas (art. 70, caput, $\mathrm{CF} / 88$ ). Salvo na hipótese de prestação de contas pelo gestor sucessor ${ }^{120}$, não haveria sentido obrigar alguém a prestar contas, sem sujeitar o obrigado, se for o caso, às conseqüências jurídicas da gestão irregular dos recursos públicos. Conforme se pode depreender do art. $6^{\circ}$, da Lei $\mathrm{n}^{\circ} 8.443 / 92$, nem todo jurisdicionado está obrigado à tomada de $\operatorname{contas}^{121}$, verbis:

\footnotetext{
${ }^{118}$ A discussão sobre a jurisdição do Tribunal de Contas em matéria de responsabilidade financeira está contida no capítulo 21 .

119 O Dirigente do Controle Interno, apesar de não constar do rol do art. $5^{\circ}$, da Lei $n^{\circ} 8.443 / 92$, é jurisdicionado ao Tribunal de Contas, por força do art. $74, \S 1^{\circ}$, da $\mathrm{CF} / 88$.

120 Cf. Súmula ${ }^{\circ} 230$, do TCU: "Compete ao prefeito sucessor apresentar as contas referentes aos recursos federais recebidos por seu antecessor, quando este não o tiver feito ou, na impossibilidade de fazê-lo, adotar as medidas legais visando ao resguardo do patrimônio público com a instauração da competente Tomada de Contas Especial, sob pena de co-responsabilidade".

121 Convém não confundir a prestação de contas, no sentido lato, dever constitucional imposto pelo art. 70, parágrafo único, da $\mathrm{CF} / 88$, com as espécies de processos com esta natureza (processos de contas) que podem ser submetidos à apreciação da Corte de Contas. No âmbito do TCU, existem três processos de contas: as tomadas de contas, referentes aos órgãos da administração direta, as prestações de contas em sentido estrito, referentes às
} 
"Estão sujeitas à tomada de contas (...) as pessoas indicadas nos incisos I a VI do art. $5^{\circ}$ desta lei".

A seguir, analiso alguns casos controvertidos acerca dos sujeitos passivos da responsabilidade financeira no Brasil, para, em seguida, abordar o tema no Direito Português e Espanhol.

\subsection{Pessoa Jurídica de Direito Público (Ente Federado)}

Com o advento da Emenda Constitucional $n^{\circ}$ 19/98, alterou-se o texto constitucional de forma a incluir entre os obrigados a prestar contas também as pessoas jurídicas que utilizem, arrecadem, guardem, gerenciem ou administrem bens, dinheiros e valores públicos (art. 70, parágrafo único, $\mathrm{CF} / 88$ ).

Tal alteração deu ensejo à imputação de débito pelo TCU às pessoas jurídicas de direito público, quando estas forem beneficiárias da aplicação irregular de recursos federais transferidos à municipalidade. Neste sentido, dispõe a Decisão Normativa TCU n ${ }^{\circ}$ 57/2004, de 05/05/2004:

\footnotetext{
"Art. $1^{\circ}$ Nos processos de Tomadas de Contas Especiais relativos a transferências de recursos públicos federais aos Estados, ao Distrito Federal e aos Municípios, ou a entidades de sua administração, as unidades técnico-executivas competentes verificarão se existem indícios de que esses entes da federação se beneficiaram com a aplicação irregular dos recursos.

Art. $2^{\circ}$ Configurada a hipótese de que trata o artigo anterior, a unidade técnico-executiva proporá que a citação seja feita também ao ente político envolvido, na pessoa do seu representante legal, solidariamente com o agente público responsável pela irregularidade.

Art. $3^{\circ}$ Caso comprovado que o ente federado se beneficiou pela aplicação irregular dos recursos federais transferidos, o Tribunal, ao proferir o julgamento de mérito, condenará diretamente o Estado, o Distrito Federal ou o Município, ou a entidade de sua administração, ao pagamento do débito, podendo, ainda, condenar solidariamente o agente público responsável pela irregularidade e/ou cominar-lhe multa".
}

Jatir Batista da Cunha concorda em imputar débito ao ente federado. Entende o autor que não há infringência ao princípio federativo e menciona, ainda, a possibilidade de

entidades da administração indireta e as tomadas de contas especiais, previstas no art. $8^{\circ}$, caput, da Lei ${ }^{\circ}$ 8.443/92. 
execução judicial contra a Fazenda Pública Municipal com base em título executivo extrajudicial (CUNHA, 2001).

Não há, entretanto, como prosperar este entendimento. As pessoas jurídicas de direito público não se sujeitam à Jurisdição do TCU, mas tão somente os seus agentes, na qualidade de gestores de recursos federais.

Em primeiro lugar, é o inciso VII do artigo $5^{\circ}$ da Lei $\mathrm{n}^{\circ} 8.443 / 92$ que se refere a sujeição à jurisdição do TCU dos responsáveis pela aplicação de recursos repassados pela União, mediante convênios, acordos, ajustes ou instrumentos congêneres.

No dispositivo em tela, não há referência às pessoas jurídicas, não cabendo interpretação extensiva, conforme foi exposto anteriormente, sob pena de invasão de outras esferas jurisdicionais. Com efeito, a Solução de conflitos entre Estado Federado e a União é de competência do Supremo Tribunal Federal, nos termos do art. 102, inciso I, alínea f, da CF/88 e entre o Município e a União é de competência da Justiça Federal, nos termos do art. 109, inciso I, da CF/88 (vide capítulo 21 - jurisdição contábil-financeira dos Tribunais de Contas).

Em segundo lugar, os repasses mencionados são transferências voluntárias ou discricionárias. Esta espécie de transferências intergovernamentais é utilizada para implementação de ações constantes do Orçamento da União, mas que, por motivos de ordem administrativa (por exemplo, inexistência de estrutura administrativa federal no Estado ou Município), são executadas pelo ente subnacional (GOMES, 2007). Só ações cuja competência material é concorrente (art. 23, da CF/88) podem ser objeto destas transferências. O responsável presta contas para o Governo Federal. Compete ao TCU a fiscalização da aplicação destes recursos (art. 71,VI, da CF/88). Em caso de débito ou de recursos não utilizados, estes deverão ser devolvidos ao Poder Público Federal.

Neste contexto, os responsáveis pela aplicação (pessoas físicas) integrantes do ente federado receptor atuam na qualidade de agentes federais equiparados, somente fazendo 
uso da infra-estrutura material e de recursos humanos local para o gerenciamento e execução do ação transferida. Desta forma, em caso de aplicação irregular dos recursos, ainda que em benefício do ente federado, não cabe condenação do ente receptor, mas, tão somente, do gestor. Caberia a este, eventualmente, propor ação regressiva contra o município pelo valor ressarcido.

Em terceiro lugar, se adotado o entendimento do TCU, haverá uma dupla punição aos membros daquela coletividade e, o que é mais grave, a sanção financeira não cumprirá sua função preventiva (secundária), pois, se o infrator não sofrer as conseqüências jurídicas de sua atuação, as irregularidades tendem a ser praticadas de forma reiterada.

No Direito Espanhol, a questão da legitimidade passiva das pessoas jurídicas de Direito Público à "responsabilidad contable" foi abordada por Carlos Cubillo Rodriguez (RODRIGUEZ, 1999, p. 168):

\begin{abstract}
"Otra cuestión importante que puede suscitarse en relación con los elementos subjetivos de los juicios de responsabilidad contable por gestión ilegal de subvenciones públicas, es la relativa a la legitimación pasiva en ellos de las Administraciones y otras Entidades del Sector Público. Puede exigirse responsabilidad contable a una Administración o Entidad Pública por la gestión irregular de una ayuda económica recibida de otra? La respuesta a esta pregunta tiene que ser negativa. La esencia de la responsabilidad contable, tal y como se regula en los artículos 38 de la Ley Orgánica 2/82, de 12 de mayo y 49 de la Ley 7/88, de 5 de abril, consiste en la reparación de unos daños y perjuicios originados en el Patrimonio Público. Podrá haber responsabilidad de esta índole, por tanto, siempre que unos bienes y derechos de titularidad pública resulten menoscabados sin beneficio paralelo para ningún otro patrimonio o con enriquecimiento injusto de un patrimonio privado. Si el detrimento patrimonial experimentado por una Administración o Ente Público trae causa de un incremento patirmonial en otra Entidad también pública, el perjuicio a los bienes y derechos que pertenecen a todos los ciudadanos (que es uno de los requisitos de la responsabilidad contable) no se cumpre. Lo que se procude, en estos casos, es un desplazamiento patrimonial entre personas jurídico-públicas que genera un desequilibrio cuya corrección no puede perseguirse a través del enjuiciamiento contable atribuido al Tribunal de Cuentas, sino más bien mediante el mecanismo de la responsabilidad patrimonial regulada en los artículos 139 y siguientes de la Ley 30/92, de 26 de noviembre (...)".
\end{abstract}

Podia, ainda, tecer outras considerações acerca da violação do princípio federativo $^{122}$ e do duplo grau de jurisdição obrigatório (art. 475, I, do CPC). Entretanto, o

\footnotetext{
${ }^{122}$ Assumindo a hipótese de que Tribunal de Contas da União possa condenar os entes subnacionais que recebem recursos federais, poderiam, por conseguinte, os Tribunais de Contas dos Estados e do(s) Município(s) condenar a União no caso de transferências do município ou Estado para um órgão da Administração Pública Federal.
} 
que se deve salientar, para fins deste estudo, é que a responsabilização do ente subnacional estará calcada em institutos jurídicos alheios ou estranhos à responsabilidade financeira, tais como, o enriquecimento sem causa, ou ainda, a responsabilidade prevista no art. $37, \S 4^{\circ}$, da CF/88.

Portanto, na hipótese prevista na Decisão Normativa $n^{\circ} 57 / 2004$, caberá ao Tribunal de Contas da União, sem prejuízo da responsabilidade sancionatória, imputar débito integral ao gestor dos recursos transferidos e desviados da sua finalidade, o qual, após promover o ressarcimento aos cofres da União, poderá ingressar com ação regressiva contra o Município, na qual deverá demonstrar que o ente subnacional efetivamente beneficiou-se dos recursos transferidos.

\subsection{Advogado ou Parecerista Jurídico}

Outro caso polêmico compreende o enquadramento ou não do parecerista jurídico dentre os jurídicionados ao Tribunal de Contas.

Acerca do tema, a jurisprudência do Supremo Tribunal Federal manifestou-se por diversas oportunidades.

Em princípio, no julgamento do MS n²4.067-DF (Informativo STF $\mathrm{n}^{\circ} 290$ ), o STF deferiu a ordem para afastar a responsabilidade dos pareceristas, argumentando o Relator que o parecer emitido tem caráter não vinculante e que, portanto, não constitui ato decisório. Além disso, o fundamento considerado de maior relevância, segundo o Acórdão, foi a inviolabilidade do advogado, nos termos do que dispõe a Lei $\mathrm{n}^{\circ}$ 8.906/94 (Estatuto da Advocacia). Ademais, segundo a decisão, as divergências doutrinárias ou a discordância de interpretação não ensejam a responsabilização solidária do parecerista, o qual, apenas por culpa grave poderia estar sujeito a apenação pela Ordem dos Advogados do Brasil (art. 34, XXIV, Lei $\left.n^{\circ} 8.906 / 94\right)$. 
No julgamento do MS n 24.584 (Informativo STF $\mathrm{n}^{\circ} 475$ ), o STF entendeu

que:

"(...) a aprovação ou ratificação de termo de convênio e aditivos, a teor do que dispõe o art. 38 da Lei 8.666/93, e diferentemente do que ocorre com a simples emissão de parecer opinativo, possibilita a responsabilização solidária, já que o administrador decide apoiado na manifestação do setor técnico competente (Lei 8.666/93, art. 38, parágrafo único: "As minutas de editais de licitação, bem como as dos contratos, acordos, convênios ou ajustes devem ser previamente examinadas e aprovadas por assessoria jurídica da Administração.")."

No MS n 24.631 (Informativo STF $n^{\circ} 475$ ), o STF, apesar de deferir a ordem por outras razões, admitiu a possibilidade de responsabilização do parecerista em solidariedade com o administrador na hipótese da consulta ser vinculante:

\begin{abstract}
"Salientando, inicialmente, que a obrigatoriedade ou não da consulta tem influência decisiva na fixação da natureza do parecer, fez-se a distinção entre três hipóteses de consulta: 1) a facultativa, na qual a autoridade administrativa não se vincularia à consulta emitida; 2) a obrigatória, na qual a autoridade administrativa ficaria obrigada a realizar o ato tal como submetido à consultoria, com parecer favorável ou não, podendo agir de forma diversa após emissão de novo parecer; e 3) a vinculante, na qual a lei estabeleceria a obrigação de "decidir à luz de parecer vinculante", não podendo o administrador decidir senão nos termos da conclusão do parecer ou, então, não decidir. Ressaltou-se que, nesta última hipótese, haveria efetivo compartilhamento do poder administrativo de decisão, razão pela qual, em princípio,o parecerista poderia vir a ter que responder conjuntamente com o administrador, pois seria também administrador nesse caso. Entendeu-se, entretanto, que, na espécie, a fiscalização do TCU estaria apontando irregularidades na celebração de acordo extrajudicial, questão que não fora submetida à apreciação do impetrante, não tendo havido, na decisão proferida pela Corte de Contas, nenhuma demonstração de culpa ou de seus indícios, e sim uma presunção de responsabilidade. Os Ministros Carlos Britto e Marco Aurélio fizeram ressalva quanto ao fundamento de que o parecerista, na hipótese da consulta vinculante, pode vir a ser considerado administrador" (grifei).
\end{abstract}

Convém apontar como vem deliberando, recentemente, o Tribunal de Contas da União acerca do tema.

Nos Acórdãos n 62/2007 - 2a . Câmara e 342/2007 - 1ª . Câmara, o TCU condicionou a responsabilização à presença de dois requisitos (importância do parecer do profissional para o processo decisório e existência de erro técnico de difícil detecção):

"Nos casos em que o parecer do profissional é de fundamental importância para embasar o posicionamento a ser adotado pelas instâncias decisórias, uma manifestação contaminada por erro técnico, de difícil detecção, acarreta a responsabilidade civil do parecerista pelos possíveis prejuízos daí advindos". 
Conforme manifestação contida no Acórdão n 1.923/2006 - Plenário, afastase a responsabilidade do advogado se o seu parecer sustentar tese juridicamente razoável, fundada em lição doutrinária ou jurisprudencial:

\footnotetext{
"Nos casos em que o parecer do profissional é de fundamental importância para embasar o posicionamento a ser adotado pelas instâncias decisórias, apenas admite-se o afastamento da responsabilidade do consultor jurídico se seu parecer estiver devidamente fundamentado em tese aceitável e alicerçado em lição doutrinária ou jurisprudencial".
}

No mesmo sentido, o Acórdão n ${ }^{\circ}$ 2.189/2006 - Plenário informa que: "É possível aplicar sanção aos gestores e aos assessores jurídicos pelos pareceres que não estejam fundamentados em razoável interpretação das normas e com grave ofensa à ordem jurídica".

Por fim, destacamos o Acórdão n²26/2004 - Plenário, por haver sido proferido após o julgamento pelo STF do MS n² 24.073-DF, no qual, consta do Relatório do Ministro-Relator a possibilidade de enquadramento do parecerista na hipótese do inciso II, do art. $5^{\circ}$, da Lei ${ }^{\circ} 8.443 / 92$ :

\footnotetext{
"O fato de o autor de parecer jurídico não exercer função de execução administrativa, não ordenar despesas e não utilizar, gerenciar, arrecadar, guardar ou administrar bens, dinheiros ou valores públicos não significa que se encontra excluído do rol de agentes sob jurisdição deste Tribunal, nem que seu ato se situe fora do julgamento das contas dos gestores públicos, em caso de grave dano ao Erário. Os particulares, causadores de dano ao Erário, também estão sujeitos à jurisdição do TCU".
}

Concordo com a possibilidade de responsabilização do parecerista jurídico, atendidas as considerações a seguir.

A gestão de recursos públicos envolve, via de regra, uma sucessão de atos administrativos e a participação de diversos agentes públicos e, até mesmo, de particulares.

Para efeito de exemplificação, citamos o procedimento relativo à realização de despesa pública decorrente de contratos de serviços continuados. Inicialmente, há um procedimento licitatório, com suas fases interna e externa. A fase externa pode ser 
desdobrada em edital, habilitação, julgamento, recursos, adjudicação e homologação. Na fase interna, participam os setores administrativos interessados, a assessoria jurídica, os setores de contabilidade e orçamento. Na fase externa, participam a comissão de licitação e a autoridade responsável pela homologação. Terminado o procedimento licitatório, há a contratação do vencedor. Geralmente, trata-se ato de competência do dirigente máximo do órgão ou entidade. Emite-se a Nota de Empenho relativa à parcela do contrato referente ao exercício financeiro corrente. Após isso, o contratado presta os serviços contratados no mês. Há fiscalização da prestação de serviços e medição dos serviços prestados por agente público designado. É a fase da liquidação. Só, então, o ordenador de despesas autoriza o pagamento da fatura emitida pela empresa, tomando esta decisão com base na atuação de diversos outros agentes, cada um dos quais exercendo a sua competência específica.

O exercício destas competências exige o cumprimento, por cada um dos agentes públicos e privados mencionados, dos deveres jurídicos inerentes às suas atividades, os quais, de alguma forma, impactam na decisão final do ordenador de despesas de autorizar o pagamento. Pode-se, concluir, assim, que todos os agentes públicos que atuam no processo de realização da despesa pública (e que possuem influência relevante na decisão de realizar a despesa ou de renunciar a receita) são gestores públicos em sentido amplo, sujeitando-se, portanto, à jurisdição do Tribunal de Contas

Nesta linha, Carlos Cubillo Rodriguez esclarece que, no Direito Espanhol, a Sentença de 24 de setembro de 1998, da Sala de Justiça do Tribunal de Contas entendeu que o termo "gestión" deve ser entendido no sentido amplo, admitindo a possibilidade da responsabilidade contábil ainda que a atividade exercida pelo responsável não implique no manejo direto e material dos recursos públicos desviados (RODRIGUEZ, 1999)

No Direito Português, o art. 61\%, da Lei $\mathrm{n}^{\circ}$, 98/97, dispõe que a responsabilidade financeira reintegratória "pode recair ainda nos funcionários ou agentes que, nas suas informações para os membros do Governo ou para os gerentes, dirigentes ou outros administradores, não esclareçam os assuntos da sua competência de harmonia com a $l e i^{\prime \prime}$. 
A situação do parecerista jurídico não poderia ser diferente, uma vez que suas opiniões, caso maculadas por erro grave, podem acarretar decisões que violam normas e princípios reguladores da gestão pública. Isto sem levar em conta a possibilidade de conluio entre o gestor principal (ordenador de despesas) e o parecerista, com a conseqüente elaboração de pareceres "sob encomenda" com o fito de respaldar decisões administrativas ilícitas já tomadas.

Inerente à atividade do parecerista é a possibilidade de divergência no tocante à interpretação jurídica. É possível que o advogado sustente opinião diversa dos entendimentos do órgão de controle externo. Entretanto, muito acertada é a opinião do TCU ao exigir que a tese sustentada pelo parecerista seja juridicamente razoável e calcada em lições da doutrina e da jurisprudência dominantes. Não cabe ao parecerista, nesta condição, inovar, invocando teses acadêmicas minoritárias. É seu dever, na tarefa de aconselhamento jurídico, buscar teses razoáveis que sustentem os atos de gestão de seu aconselhado.

Além disso, outro requisito importante para a responsabilização é o da possibilidade de que o parecer influencie a decisão administrativa que acarretou dano ao erário ou grave infração à norma aplicável (nexo de causalidade - teoria da causalidade adequada).

\subsection{Administradores de Sociedades de Economia Mista}

Outra controvérsia no que tange aos sujeitos à "jurisdição" dos Tribunais de Contas diz respeito aos administradores, gerentes e demais responsáveis das sociedades de economia mista.

Em 2004, o STF considerou que os Tribunais de Contas não têm competência para julgamento das contas de administradores de sociedades de economia mista, a despeito ao art. 71, II, da CF/88, de julgamento das contas dos administradores de entidades da 
Administração Indireta, "incluídas as fundações e sociedades instituídas e mantidas pelo Poder Público federal" e à Lei n 6.223/75 (recepcionada pela CF/88):

"O TCU não tem competência para julgar as contas dos administradores de entidades de direito privado. A participação majoritária do Estado na composição do capital não transmuda seus bens em públicos. Os bens e valores questionados não são os da administração pública, mas os geridos considerando-se a atividade bancária por depósitos de terceiros e administrados pelo banco comercialmente. Atividade tipicamente privada, desenvolvida por entidade cujo controle acionário é da União." (STF, MS 23.875, Rel. Min. Nelson Jobim, DJ 30/04/04)

Após os escândalos envolvendo empresas estatais que vieram à tona em meados de 2005 (Mensalão), o STF reformulou este entendimento em julgamento proferido em novembro de 2005:

"Ao Tribunal de Contas da União compete julgar as contas dos administradores e demais
responsáveis por dinheiros, bens e valores públicos da administração direta e indireta,
incluídas as fundações e sociedades instituídas e mantidas pelo poder público federal, e as
contas daqueles que derem causa a perda, extravio ou outra irregularidade de que resulte
prejuízo ao erário (CF, art. 71, II; Lei 8.443 , de 1992 , art. $1^{\circ}$, I). As empresas públicas e as
sociedades de economia mista, integrantes da administração indireta, estão sujeitas à
fiscalização do Tribunal de Contas, não obstante os seus servidores estarem sujeitos ao regime
celetista." (MS 25.092, Rel. Min. Carlos Velloso, DJ 17/03/06)

No Brasil, as empresas estatais, apesar de constituirem Pessoa Jurídica de Direito Privado, estão vinculadas a um Ministério ou Secretaria de Estado ou Município (Supervisão Ministerial). Seus dirigentes são nomeados e exonerados pelo Chefe do Executivo (geralmente por indicações de Partidos Políticos), o qual exerce, de fato, importante influência nas decisões da Empresa. Há considerável participação do Poder Público no capital das Estatais. Algumas empresas recebem, ainda, subvenções econômicas para a cobertura de déficits operacionais. Portanto, devem ser objeto de fiscalização (poderes de controle) do Tribunal de Contas, estando, também, sob sua jurisdição.

A experiência estrangeira indica que nem sempre há este paralelismo entre as funções fiscalizatórias e jurisdicionais sobre as sociedades empresariais.

Em Portugal, estão sujeitas aos poderes de controle do Tribunal de Contas: as empresas públicas, incluindo as entidades públicas empresariais (art. 2\%/2, b, LOPTC) e as empresas municipais, intermunicipais e regionais (art. $2^{\circ} / 2$, c, LOPTC). Entretanto, no art. 
$61^{\circ}$, da LOPTC, que versa sobre os sujeitos passivos da Responsabilidade Financeira, não há referência expressa às sociedades estatais.

De fato, o Setor Público Empresarial (SPE), em Portugal, está sujeito apenas aos Poderes de Controle Financeiro do Tribunal de Contas, e não aos Poderes Jurisdicionais (PORTUGAL, 1999, p. 5). A manifestação do Tribunal de Contas, neste caso, é meramente opinativa, não originando qualquer responsabilidade financeira por parte dos agentes que não observem a legalidade, a regularidade ou os critérios de boa gestão que devem presidir à sua atuação financeira (PORTUGAL, 1999, p. 6).

Na Espanha, integram o Setor Público submetido à fiscalização externa, permanente e consultiva do Tribunal de Contas, as Sociedades Estatais e as demais Empresas Públicas (art. 2.a c/c art. 4.f, da LOTCu). Além disso, o art. 127.1.c e d, do Texto Refundido de la Ley General Presupuestaria, aprovado pelo Real Decreto n 1.091/1988, de 23 de Setembro, dispõe que serão "cuentadantes" os titulares das entidades e órgãos sujeitos à obrigação de prestar contas, incluindo os Presidentes ou Diretores das Sociedades Públicas Empresariais e demais entidades do Setor Público Estatal e, ainda, os Presidentes dos Conselhos de Administração das Sociedades Mercantis Estatais.

\subsection{Particular - Pessoa Física ou Jurídica}

O segundo inciso submete a jurisdição do TCU "aqueles que derem causa a perda, extravio ou outra irregularidade de que resulte dano ao erário", disposição que encontra respaldo no art. 71, inciso II, da Constituição Federal, segundo o qual, compete ao Tribunal julgar "contas daqueles que derem causa a perda, extravio ou outra irregularidade de que resulte prejuízo ao erário público".

Tal disposição permite que particulares sejam alcançados pela jurisdição do Tribunal de Contas e, consequientemente, estejam sujeitos à responsabilidade financeira. 
Entretanto, a doutrina e a jurisprudência manifestam-se no sentido de que particular estranho ao serviço público e sem conluio com agentes públicos não está abrangido pela Jurisdição do Tribunal de Contas, ainda que tenha causado dano ao Erário.

\title{
Jorge Ulisses Jacoby Fernandes leciona que (FERNANDES, 1998, p. 85):
}

\begin{abstract}
"Quando ocorrer um dano ao erário e, no curso da TCU, for constatado que o causador foi exclusivamente um terceiro, sem vínculo com a Administração Pública, impõe-se o encerramento do processo. Há emissão de um juízo de mérito, devidamente fundamentado, e o reconhecimento de que o agente responsável não está sujeito ao processo de TCE.

(...)

Há duas exceções a essa premissa em que o particular sem vínculo com a Administração fica sujeito à jurisdição do Tribunal de Contas: a primeira, quando em co-autoria com servidor, causa lesão aos cofres públicos, ficam ambos sujeitos a julgamento pelo TC, em virtude da universalidade do juízo; e a segunda, por expressa disposição de lei, quando está sujeito ao dever de prestar contas por haver gerido recursos públicos".
\end{abstract}

A propósito, editou o TCU a Súmula $\mathrm{n}^{\circ} 187^{123}$. No mesmo sentido, esclarecedor é o Parecer do Ministério Público junto ao TCU no Acórdão nº 149/2001 -

Plenário:

\begin{abstract}
"Assim, o dano ao erário, por si só, não é causa para instauração de TCE. Temos sustentado em outros feitos (TC-500.342/1995-4, TC-550.151/1997-4 e TC-927.313/1998-7, para citar alguns exemplos) que, quando o particular causa dano ao erário sem que para isso concorra pelo menos um agente público, não há que se falar em instauração de tomada de contas especial. Ou seja, não é qualquer dano ao erário causado por terceiro desvinculado da Administração e sem o dever legal de prestar contas que se submete à jurisdição do TCU. Esse terceiro estará sob a jurisdição do Tribunal se houver contribuído para o dano em conjunto com um daqueles que têm o dever de prestar contas. Não é possível ao Tribunal condenar individualmente o terceiro desvinculado da Administração quando não há participação - culposa, pelo menos - do gestor público. Nesse caso, cabe à Administração tãosomente adotar os procedimentos necessários, inclusive acionando os órgãos judiciais competentes, visando à indenização pelos danos sofridos. Vale lembrar que esse ponto de vista foi expressamente defendido no voto condutor da Decisão n. 301/99 - TCU - Plenário, em sessão realizada em 02/06/1999.

Há casos, porém, em que o particular, causando dano ao erário, ainda que sem a concorrência de um agente público, deve ser responsabilizado em tomada de contas especial. Isso acontece quando esse particular é investido pelo Poder Público em uma função pública lato sensu, cujo exercício destina-se a atingir um interesse público. Tal situação é a que ocorre, por exemplo, nos corriqueiros casos de tomadas de contas especiais tratados no âmbito do TCU em que particulares equiparam-se a gestores públicos ao figurarem naqueles processos como beneficiários de subvenções sociais, cujos recursos deveriam ter sido aplicados em finalidades
\end{abstract}

123 "Sem prejuízo da adoção, pelas autoridades ou pelos órgãos competentes, nas instâncias, próprias e distintas, das medidas administrativas, civis e penais cabíveis, dispensa-se, a juízo do Tribunal de Contas, a tomada de contas especial, quando houver dano ou prejuízo financeiro ou patrimonial, causado por pessoa estranha ao serviço público e sem conluio com servidor da Administração Direta ou Indireta e de Fundação instituída ou mantida pelo Poder Público, e, ainda, de qualquer outra entidade que gerencie recursos públicos, independentemente de sua natureza jurídica ou do nível quantitativo de participação no capital social". 
públicas específicas. É o que ocorre, citando outro exemplo, nos casos de desvios de recursos públicos praticados no âmbito de clínicas e hospitais privados que atuam de forma complementar no Sistema Único de Saúde".

Convém esclarecer que não se está isentando o particular sem vínculo e sem conluio com o agente público de ressarcir o Poder Público pelo dano que tenha sido causado. O que não se aplica ao particular, nesta hipótese, é a responsabilidade financeira. Entretanto, o mesmo estará sujeito a outras modalidades de responsabilidade na esfera cível e criminal.

Segundo os trechos supracitados, o particular também pode estar sujeito à responsabilidade financeira, quando administre bens, dinheiros e valores públicos. O particular é gestor público por equiparação, quando, por exemplo, receba subvenções, auxílios ou outras transferências do Poder Público para que exerça uma atividade de finalidade pública.

Os recursos devem permanecer sob a administração do particular sob a condição de "públicos", ou seja, devendo ser geridos segundo normas e princípios da gestão pública, em especial, ao dever de prestar contas.

Convém mencionar que o caráter público ou não de um determinado recurso financeiro não é característica inerente ao recurso em si. Os recursos são sempre originários do setor privado e tendem a retornar ao setor privado. A condição de "público" é, portanto, apenas uma situação temporária do recurso financeiro.

A propósito, Carles Rosiñol I Vidal (VIDAL, 1999) se debruça sobre duas questões: a partir de que momentos os recursos adquirem o caráter público e a partir de que momento os recursos de origem pública deixam de ter este caráter. No primeiro caso, é o momento em que o sujeito passivo da obrigação tributária entrega os recursos a alguém na condição de representante da Administração Tributária (entre nós, o momento da arrecadação). A falta de ingresso da dívida por parte do sujeito passivo, salienta o autor, poderá originar responsabilidades, inclusive no âmbito penal, mas não poderá originar responsabilidades contábeis, pois estes recursos não tem o caráter público. No segundo caso, Vidal não responde diretamente a questão. $\mathrm{O}$ autor trata especificamente das subvenções e 
outros benefícios transferidos a particulares, manifestando-se que: "Nos encontramos, pues, ante un curioso supuesto de caudales o efectos considerados como públicos, sometidos incluso a un régimen especial de control, que no están gestionados por un ente público".

Seria interessante ilustrar com um exemplo. Tanto um contratado para prestação de serviços, quanto uma entidade beneficente receptora de subvenções sociais, podem receber recursos financeiros do Poder Público. No primeiro caso, o pagamento é feito na conta particular do contratado em decorrência da sua contraprestação ao Estado. Os recursos recebidos não recebem mais este caráter público e não estão sujeitos à prestação de contras pelo contratado. A entidade beneficente, por sua vez, recebe subvenções sociais para prestação de serviços na área de educação, saúde ou assistência social às comunidades carentes. Os recursos são transferidos para uma conta específica e devem ser aplicados estritamente na finalidade prevista no seu ato de concessão, cabendo ao gestor, ainda que privado, o dever de prestar contas da sua utilização.

Há situações em que se torna difícil saber se um particular recebeu recursos na condição de "recursos públicos" ou não, especialmente, se considerarmos os novos interrelacionamentos entre os atores públicos e privados, especialmente, no contexto na Reforma Administrativa Gerencial. Como exemplos dos possíveis inter-relacionamentos, podemos citar: o contrato administrativo, o convênio, as subvenções (econômicas e sociais), o contrato de gestão e o termo de parceria.

Proponho, para os casos de dúvida, alguns critérios indicativos que permitem distinguir se os recursos transferidos aos particulares permanecem ou não na condição de públicos. O primeiro e mais importante é o regime de controle. Se houver obrigatoriedade de prestação de contas detalhada sobre a utilização dos recursos, os recursos permanecem na condição de públicos. O segundo diz respeito à conta corrente na qual foram depositados os recursos. Se a conta for privada, é indicativo de que os recursos deixaram de ter o caráter público, considerando a proteção conferida ao Sigilo Bancário (Lei Complementar $n^{\circ}$ 105). Recursos públicos são geralmente são transferidos para contas correntes específicas, diferentes das habituais do particular, para fins de controle. Estas não estão sujeitas ao Sigilo 
Bancário. O terceiro diz respeito ao vínculo jurídico estabelecido entre o particular e o Poder Público. Se o vinculo basear-se em interesses contrapostos, como p. ex. no Contrato, os recursos transferidos deixam de ter caráter particular. Caso contrário, os recursos permanecem com o caráter público. Um último critério, que é apenas indicativo e não exato, é o do destinatário imediato da contraprestação do particular. Se o destinatário for o Estado, há indicios de que os recursos perderam o caráter público, pois se trata de um contrato. Se a Sociedade for a destinatária, há indicativo de que tais recursos mantiveram sua condição de públicos.

\subsection{Responsáveis por empresas supranacionais}

Outro inciso que merece comentários é o inciso IV do art. $5^{\circ}$ da Lei $n^{\circ}$ 8.443/92, que trata dos "os responsáveis pelas contas nacionais das empresas supranacionais de cujo capital social a União participe, de forma direta ou indireta, nos termos do tratado constitutivo".

Trata-se de um dispositivo relacionado à competência contida no art. 71, V, da $\mathrm{CF} / 88$. Encontram-se, nesta situação, as empresas ITAIPU BINACIONAL (Brasil Paraguai) e a Companhia de Promoção Agrícola (Brasil - Japão). No caso da ITAIPU BINACIONAL, tendo em conta o aspecto igualitário que norteia a administração da referida empresa e a inexistência de contas nacionais, o TCU, mediante Decisão n 279/95 - Plenário, entendeu que o Tribunal encontra-se impossibilitado de exercer a fiscalização e sugeriu ao Presidente da República a modificação dos Tratados Constitutivos da empresa, em acordo com o Governo do Paraguai, com vistas ao cumprimento do comando constitucional:

\footnotetext{
"O Tribunal Pleno, diante das razões expostas pelo Relator, DECIDE: 1. levar ao conhecimento do Excelentíssimo Senhor Presidente da República, para adoção das providências que Sua Excelência entender cabíveis à espécie, que o Tribunal de Contas da União encontra-se impossibilitado de exercer a ação jurisdicional sobre a empresa ITAIPU BINACIONAL, em cumprimento ao disposto no art. 71, inciso V, da Constituição Federal, ante a ausência de previsão nesse sentido nos atos que a regem, considerando a submissão da mencionada Empresa ao regime de direito internacional, fazendo-se imperiosa, nessas circunstâncias, a modificação das normas estatutárias e regimentais da ITAIPU, em comum acordo com o Governo do Paraguai, com vistas a incluir esse procedimento de fiscalização, o qual também está previsto na Constituição daquele País; 2. dar ciência ao Exmo. Sr. Presidente do Congresso Nacional, para as providências cabíveis à espécie, que a competência
} 
atribuída ao Tribunal, nos termos do art. 71, inciso V, da Constituição Federal, relativamente à fiscalização das contas nacionais da empresa ITAIPU BINACIONAL, encontra-se prejudicada, uma vez que a administração dessa Entidade é conduzida de forma paritária entre Brasil e Paraguai, encaminhando-se-lhe, para maior compreensão da matéria, cópia desta Decisão, bem como do Relatório e Voto respectivos;"

\subsection{Responsabilidade do Bolsista do CNPQ/CAPES no Exterior}

A responsabilidade financeira do bolsista do CNPQ ou de outros órgãos oficiais de fomento a pesquisa (CAPES, etc.) já foi objeto de diversas deliberações do Tribunal de Contas da União e do Supremo Tribunal Federal.

Em simples pesquisa no sítio eletrônico do TCU, catalogamos decisões ${ }^{124}$ que imputaram débito aos bolsistas do CNPQ no exterior que porventura tenham descumprido o Termo de Compromisso ou, até mesmo, Resoluções do CNPQ. Nos casos analisados, em regra, descumpre-se a obrigação de retornar ao país, após o encerramento do curso e aqui permanecer por um prazo mínimo exercendo atividade que faça uso dos conhecimentos adquiridos no exterior. Há casos em que a responsabilização decorre da não conclusão do curso no exterior. O TCU já considerou como fundamento das suas decisões a suposta semelhança entre o compromisso firmado com o CNPQ e os convênios celebrados entre entes federados.

Recentemente, o STF, no MS $\mathrm{n}^{\circ}$ 26.210/DF (Rel. Min. Ricardo

Lewandowski) confirmou decisão do TCU, proferindo o seguinte julgamento:

"EMENTA: MANDADO DE SEGURANÇA. TRIBUNAL DE CONTAS DA UNIÃO. BOLSISTA DO CNPq. DESCUMPRIMENTO DA OBRIGAÇÃO DE RETORNAR AO PAÍS APÓS TÉRMINO DA CONCESSÃO DE BOLSA PARA ESTUDO NO EXTERIOR. RESSARCIMENTO AO ERÁRIO. INOCORRÊNCIA DE PRESCRIÇÃO. DENEGAÇÃO DA SEGURANÇA. I - O beneficiário de bolsa de estudos no exterior patrocinada pelo Poder Público, não pode alegar desconhecimento de obrigação constante no contrato por ele subscrito e nas normas do órgão provedor. II - Precedente: MS 24.519, Rel. Min. Eros Grau. III - Incidência, na espécie, do disposto no art. $37, \S 5^{\circ}$, da Constituição Federal, no tocante à alegada prescrição. IV Segurança denegada."

\footnotetext{
${ }^{124}$ Vide Acórdãos n ${ }^{\circ}$ s 257/2003 - $1^{\text {a }}$. Câmara, 261/2002 - $1^{\text {a }}$. Câmara, 459/2003 - 2 ${ }^{\mathrm{a}}$. Câmara, 542/2004 - $2^{\mathrm{a}}$. Câmara, 592/2002 - $1^{\text {a }}$. Câmara, 1.617/2004 - $1^{\text {a }}$. Câmara, 2020/2004 - $2^{\mathrm{a}}$. Câmara, 257/2003 - $1^{\mathrm{a}}$. Câmara, 261/2002 - $1^{a}$ Câmara, 459/2003 - 2 ${ }^{a}$. Câmara, 542/2004 - 2 ${ }^{a}$. Câmara, 592/2002 - $1^{a}$. Câmara, 1.617/2004 $2^{\text {a }}$. Câmara, 2.077/2003 - $1^{\text {a }}$. Câmara e 2.166/2003 - 1ª . Cãmara.
} 
Não há que se discutir a "justiça" desta decisão que determinou o ressarcimento dos recursos concedidos a título de bolsa de estudos. A alocação de um volume considerável recursos públicos, escassos por natureza, num país cercado de problemas e desigualdades sociais, pressupõe a obrigação do estudante retornar ao país e aplicar os conhecimentos adquiridos em benefício da nossa sociedade.

Ocorre que tal ressarcimento não pode ser feito por meio do instituto da responsabilidade financeira. A solução dos conflitos entre o bolsista e o órgão de fomento não é de competência do Tribunal de Contas, mas sim da jurisdição ordinária.

No caso, houve desvirtuamento do instituto da responsabilidade financeira por duas razões.

Em primeiro lugar, o bolsista não é gestor de recursos públicos em sentido amplo $^{125}$. Ele não deve satisfação ao Poder Público sobre a forma como foram gastos os recursos da bolsa de estudos, até, porque, o crédito é feito em conta individual, particular, do beneficiário, protegida pelo sigilo bancário. Não há também obrigação de devolução dos recursos caso não utilizados. Trata-se de um valor arbitrado, com o qual se presume o bolsista irá atender as suas despesas de sobrevivência no exterior.

No termo de compromisso, são assumidas obrigações, cuja violação importa em responsabilidade de outra natureza, que não a financeira. Por outro lado, as informações a serem prestadas pelo bolsista não constituem prestação de contas do uso dos recursos públicos (art. 70, parágrafo único, CF/88), mas sim, tão somente, obrigações de fazer.

$\mathrm{Na}$ linha do que foi exposto no item anterior, o recurso, ao ingressar na conta corrente particular do bolsista, deixou de ter o atributo público, tal como ocorre com as diárias, a remuneração dos agentes públicos, ou ainda com os pagamentos de empresas contratadas. Só permanece com o atributo público, os recursos que, depositados em conta

\footnotetext{
${ }^{125}$ A outra hipótese em que se poderia cogitar é a do conluio entre o gestor e o particular para a lesão dos cofres públicos. Entretanto, tal particularidade fáctica não foi mencionada nos julgados do TCU ou do STF.
} 
particular, requererem uma prestação de contas da gestão, ou seja, os quais exigem uma satisfação sobre a forma como os recursos foram geridos, o que não acontece no caso em debate. Pode ser o caso dos auxílios do CNPQ destinados à promoção de eventos ou congressos científicos ou de apoio a projetos de pesquisa, mas não de bolsa.

Portanto, as decisões que imputam débito ao bolsista contrariam a Jurisprudência firmada pelo próprio TCU na Súmula $\mathrm{n}^{\circ}$ 187, segundo a qual, o particular estranho ao serviço público não se sujeita à Tomada de Contas Especial, e, portanto, à responsabilidade financeira.

Em segundo lugar, não há violação de normas de gestão pública, mas sim descumprimento de um vínculo obrigacional (Termo de Compromisso). A obrigação de retornar ao Brasil ou a de concluir o curso não tem natureza de normas de gestão pública.

Merece, por fim, destaque trecho do voto do Ministro Marco Aurélio de Mello, ao qual alinho o meu pensamento, no MS n² 26.210/DF:

\footnotetext{
"Senhor Presidente, em primeiro lugar, observo que a apuração do débito resultou de tomada de contas. E a tomada de contas se faz relativamente aos administradores do órgão. (...) Então, o que verifico? Verifico que, se a própria beneficiária claudicou, não retornando ao Brasil como se comprometera, os dirigentes do CNPQ é que teriam inobservado a cláusula alusiva à Bolsa, deixando de promover a cobrança do ressarcimento, o reembolso das despesas efetuadas.(...) Não adentro, portanto, a questão referente à possível responsabilidade dos dirigentes do CNPq, no que silenciaram, sabendo do término do curso - e presumo o que normalmente ocorre - de pós-graduação, do prazo para apresentação de tese, diante da ausência de retorno da bolsista ao Brasil, e deixaram de acionar a Advocacia-Geral da União para o ingresso de ação visando a cobrar o que devido. (...)"
}

Desta forma, o caso é de responsabilidade civil, a ser processada na jurisdição ordinária e não de responsabilidade financeira, processada nos Tribunais de Contas.

\subsection{Sujeição Passiva no Direito Português}

Antônio de Souza Franco ensina que a responsabilidade financeira é pessoal solidária ou subsidiária -, nunca dos órgãos, organismos ou serviços (FRANCO, 2002). 


\section{Consoante esclarece o Parecer $\mathrm{n}^{\circ}$ 1237, do Conselho Consultivo da}

\section{Procuradoria Geral da República de Portugal (PORTUGAL, 2001):}

"a responsabilidade financeira, qualificada na Lei $\mathrm{n}^{\circ}$ 98/97, de 26 de agosto (Lei de Organização e Processo do Tribunal de Contas) como reintegratória e sancionatória, constitui a forma de responsabilidade específica dos <<contábeis〉>, isto é, dos agentes sujeitos à jurisdição do Tribunal de Contas directamente definidos na lei".

São responsáveis financeiros aqueles elencados no art. 61. da Lei n 98/97:

"Dos responsáveis

1 - Nos casos referidos nos artigos anteriores, a responsabilidade pela reposição dos respectivos montantes recai sobre o agente ou agentes da acção.

2 - A responsabilidade prevista no número anterior recai sobre os membros do Governo nos termos e condições fixados para a responsabilidade civil e criminal no artigo $36^{\circ}$ do Decreto n. 22 257, de 25 de Fevereiro de 1933.

3 - A responsabilidade financeira reintegratória recai também nos gerentes, dirigentes ou membros dos órgãos de gestão administrativa e financeira ou equiparados e exactores dos serviços, organismos e outras entidades sujeitos à jurisdição do Tribunal de Contas.

4 - Essa responsabilidade pode recair ainda nos funcionários ou agentes que, nas suas informações para os membros do Governo ou para os

gerentes, dirigentes ou outros administradores, não esclareçam os assuntos

da sua competência de harmonia com a lei".

Entretanto, é o art. $2^{\circ}$, da Lei que define, mais propriamente, a amplitude da

jurisdição do Tribunal de Contas de Portugal, no tocante aos órgãos e entidades sujeitos à fiscalização e à prestação de contas:

"Artigo 2. ${ }^{\circ}$

Âmbito de competência

1 - Estão sujeitas à jurisdição e aos poderes de controlo financeiro do Tribunal de Contas as seguintes entidades:

a) O Estado e seus serviços;

b) As Regiões Autónomas e seus serviços;

c) As autarquias locais, suas associações ou federações e seus serviços, bem como as áreas metropolitanas;

d) Os institutos públicos;

e) As instituições de segurança social.

2 - Também estão sujeitas à jurisdição e aos poderes de controlo financeiro do Tribunal as seguintes entidades:

a) As associações públicas, associações de entidades públicas ou associações de entidades públicas e privadas que sejam financiadas maioritariamente por entidades públicas ou sujeitas ao seu controlo de gestão;

b) As empresas públicas, incluindo as entidades públicas empresariais;

c) As empresas municipais, intermunicipais e regionais;

(...)

f) As empresas concessionárias da gestão de empresas públicas, de sociedades de capitais públicos ou de sociedades de economia mista controladas, as empresas concessionárias ou gestoras de serviços públicos e as empresas concessionárias de obras públicas; 
g) As fundações de direito privado que recebam anualmente, com carácter de regularidade, fundos provenientes do Orçamento do Estado ou das autarquias locais, relativamente à utilização desses fundos.

3 - Estão ainda sujeitas à jurisdição e ao controlo financeiro do Tribunal de Contas as entidades de qualquer natureza que tenham participação de capitais públicos ou sejam beneficiárias, a qualquer título, de dinheiros ou outros valores públicos, na medida necessária à fiscalização da legalidade, regularidade e correcção económica e financeira da aplicação dos mesmos dinheiros e valores públicos"

\subsection{Sujeição Passiva no Direito Espanhol}

Carles Rosiñol I Vidal considera a responsabilidade contábil uma espécie de responsabilidade civil restrita a um conjunto específico de sujeitos (VIDAL, 1999, p. 83):

"La delimitación de la legitimación pasiva en los procedimientos para la exigencia de responsabilidades contables resulta especialmente transcedental, pues la responsabilidad contable es una modalidad de responsabilidad civil aplicada a unos supuestos muy concretos, y en la concreción de estos supuestos, que se realiza en la definición de la responsabilidad contable del artículo 49 de la LFTCu, se incorpora el elemento subjetivo. De esta forma, inicialmente, no puede incurrir cualquer persona en este subtipo de responsabilidad civil, que es la responsabilidad contable".

O principal requisito para se estar sujeito à responsabilidade contábil é, segundo o autor, o fato de ser "cuentadante", ou seja, ter a seu cargo o manejo de recursos públicos. Não é todo o funcionário público que está sujeito a esta modalidade específica de responsabilidade (VIDAL, 1999).

Neste sentido, aponta o autor que "la Sala de Apelación del Tribunal de Cuentas sostiene que la actuación de una secretaria, que no tiene la responsabilidad de gestionar fondos publicos, queda fuera de la jurisdición del Tribunal de Cuentas" (VIDAL, 1999, p. 87).

Consoante mencionamos anteriormente, não cabe a interpretação extensiva do rol de jurisdicionados ao Tribunal de Contas, sob pena de invasão das áreas de competência de outros órgãos jurisdicionais.

O artigo 127 do Real Decreto Legislativo 1091/1988, de 23 de setembro, define o termo "cuentadante" abrangendo (VIDAL, 1999): 
a) Os funcionários que administrem ingressos e gastos, assim como outras operações da Administração Geral do Estado;

b) Os presidentes ou diretores dos organismos autônomos, sociedades estatais e outros entes que configuram o setor público;

c) Os particulares que administram, arrecadam ou custodiam fundos ou valores do Estado;

d) Os receptores de subvenções correntes.

Acerca da possibilidade de figurar pessoas jurídicas como sujeitos passivos nos procedimentos de responsabilidade contábil, Carles Rosiñol I Vidal informa que (VIDAL, 1999, p. 91):

\footnotetext{
"En cuanto a la posibilidad de atribuir responsabilidades contables a personas jurídicas, la Sala de Apelación del Tribunal de Cuentas ha diferenciado entre personas jurídicas públicas y privadas. Respecto a las públicas, en la sentencia 12/1992, de 20 de junio, se considera que no es concebible, por economia procesal, atribuir responsabilidades contables a outras personas jurídicas públicas, del cual seria responsable, finalmente, una persona física. En este sentido se pronuncian Pascual SALA y Jesús Garcia, que descartan la posibilidad de que unas Administraciones exijan responsabilidades contables a outras. P. SALA considera que en dichos supuestos no se dilucidarían pretensiones de responsabilidad civil de unas Administraciones respecto a otras".
}

No tocante às pessoas jurídicas privadas, tem-se admitido a legitimação passiva na hipótese, por exemplo, de que a pessoa jurídica seja beneficiária ou receptora de subvenções públicas.

Outra categoria sujeita à responsabilidade contábil é a dos sucessores dos responsáveis anteriormente assinalados. Tal tema foi tratado no tópico referente ao Princípio da Pessoalidade da Responsabilidade Financeira.

Por fim, convém mencionar que, no direito espanhol, faz-se uma distinção entre responsáveis diretos e responsáveis subsidiários. Fala-se em classes ou categorias de responsabilidades contábeis (diretas e subsidiárias).

São responsáveis direitos, segundo Carlos Cubillo Rodriguez, "quienes hayan ejecutado, forzado o inducido a ejecutar o cooperado en la comisión de los hechos o 
participado con posterioridad para ocultarlos o impedir su persecución" (RODRIGUEZ, 1999, p. 147).

Segundo o autor, a responsabilidade direta tem caráter solidário, compreende todos os prejuízos causados e não pode ser objeto de isenção nas hipóteses previstas no art. 40 da Lei Orgânica do Tribunal de Contas, nem de moderação em nenhum caso (RODRIGUEZ, 1999).

Por sua vez, são responsáveis subsidiários (RODRIGUEZ, 1999, p. 148)

"quienes por negligencia o demora en el cumplimiento de sus obligaciones atribuidas de modo expreso por las leyes o reglamentos hubieren dado ocasión directa o indirecta a que los caudales públicos resulten menoscabados o a que no pueda conseguirse el resarcimiento total o parcial del importe de las responsabilidades directas".

A responsabilidade subsidiária só é exigida quando não for possível exigir as diretas, se limita aos prejuízos que sejam conseqüência dos atos imputáveis aos responsáveis e, ainda, poderá sofrer moderação de forma prudencial e eqüitativa. 


\section{O PROBLEMA DA IDENTIFICAÇÃO DO RESPONSÁVEL}

Constatada pelo Tribunal de Contas uma irregularidade na gestão de recursos públicos, caberá ao Relator do Processo ou ao Tribunal verificar a existência dos pressupostos objetivos e subjetivos da responsabilidade financeira e, se atendidos tais requisitos, identificar os responsáveis pela conduta ilícita. Caberá, ainda, ao Tribunal de Contas verificar se a responsabilidade é individual ou solidária.

Com efeito, o art. 12, da Lei ${ }^{\circ}$ 8.443/92 dispõe que, verificada a irregularidade nos processos de contas, o Relator ou Tribunal, definirá a responsabilidade, individual ou solidária, pelo ato de gestão inquinado. Nos processos de fiscalização, o art. 43, II, da referida Lei, determina a realização de audiência do responsável, o que pressupõe que o responsável seja identificado antes da adoção desta medida preliminar (Entretanto, defendo a tese de que apenas nos processos de contas poderá se efetivar a responsabilidade financeira capítulo 19).

Inicialmente fazemos uma advertência. É preferível utilizar o verbo "identificar" ao verbo "definir" constante do texto legal. Definir traduz a idéia de estabelecer, convencionar, ou seja, algo feito de forma arbitrária, enquanto o verbo "idenficar" revela uma atividade criteriosa voltada à descoberta do responsável, se é que, no caso em análise, seja possível imputar a alguem responsabilidade pelo ato irregular.

Convém reforçar que a identificação do responsável não pode ser arbitrária, mas deve ser pautada por critérios predominantemente jurídicos, e, subsidiariamente, podem ser também econômicos, financeiros, administrativos ou, ainda, contábeis.

Trata-se de tarefa que, em determinadas situações, pode se tornar extremamente difícil, haja vista que a irregularidade pode ser produto da ação ou omissão de diversos agentes públicos ou privados. Ademais, pode haver uma complexa interação entre os diversos agentes no curso do procedimento administrativo, em que, por exemplo, a conduta de um agente se fundamenta em uma conduta anterior (relação de dependência, tal como, no 
caso dos pareceres técnicos ou jurídicos) ou a conduta de um agente atua de forma a controlar a conduta anterior.

Pierluigi Avallone e Stefano Tarullo formularam duas hipóteses para a identificação do responsável, no Direito Italiano (AVALLONE; TARULLO, 2002, p. 46) ${ }^{126}$ :

"Sobre o tema, pode-se formular, em princípio, duas hipóteses:

a) Quando o dano deriva de uma atividade material do servidor público, será, obviamente, responsável aquele que pôs em prática a referida atividade.

(...)

b) Quando o dano deriva de um procedimento administrativo, o seu autor será individualizado com base nas normas que repartem as competências entre os sujeitos inseridos no aparato ao qual é atribuída a atividade procedimental" (tradução livre).

O que apresentamos a seguir são um conjunto de diretrizes para identificação do(s) responsável(is) e, em seguida, a solução de alguns casos-modelo, fundados na doutrina e na jurisprudência do Tribunal de Contas da União. Convém ressalvar que cada caso concreto apresenta as suas peculiaridades e nuancias que devem ser examinadas pela Corte de Contas.

Em primeiro lugar, só poderão ser responsáveis financeiros os sujeitos à jurisdição do Tribunal de Contas. A responsabilidade financeira é uma espécie de responsabilidade típica de um conjunto de sujeitos, os denominados "agentes contábeis". Na esfera federal, são os sujeitos contidos no art. $5^{\circ}$, da Lei n ${ }^{\circ} 8.443 / 92$, rol de caráter exaustivo, sob pena de invasão, pelo Tribunal de Contas, de outras jurisdições.

Em segundo lugar, convém relembrar que a responsabilidade financeira é subjetiva, ou seja, exige-se uma conduta, culposa ou dolosa, por parte do agente, que dê causa, ou tenha por objetivo dar causa, a um dano ao erário, ou a uma grave infração à norma reguladora da gestão pública ou, ainda, a um dever de colaboração. Pressupõese uma conduta, ativa ou omissiva, violadora de um dever de cautela imposto por norma

\footnotetext{
126 "Sul tema si possono formulare, in linea di massima, due ipotese: a) Quando il danno derivi da un'attività materiale del dipendente sarà, ovviamente, responsabili colui che ha posto in essere l'attività stessa. (...) b) Quando il danno derivi da un provvedimento amministrativo il suo autore sarà individuato in base alle norme che ripartiscono le competenze tra i soggetti inseriti nell'apparato al quale è riconducibile l'attività provvedimentale".
} 
legal ou regulamentar, de direito administrativo ou financeiro, ou ainda, por norma de boa gestão preconizada por outras ciências (administração, economia, contabilidade e finanças públicas).

No caso de agente público, o dever jurídico deve ser interente à sua atuação profissional. Para os nossos fins, inclui-se no conceito de agente público, toda pessoa física, pública ou privada, ou ainda pessoa jurídica privada que, em caráter transitório ou permanente, efetue a gestão de bens, dinheiros e valores públicos.

Exclui-se, assim, do rol de responsáveis, os agentes que não tenham agido com infração à violação funcional, pois não cabe falar em responsabilidade financeira objetiva.

Em terceiro lugar, deve-se ter em mente que há uma divisão do trabalho na atividade de gestão pública. A gestão pública deve ser entendida em sentido amplo, ou seja, abrangendo todas as etapas da realização da despesa pública, desde o planejamento da contratação (fase interna da licitação) até a apreciação da prestação de contas.

Não é justo, em princípio, imputar responsabilidade a um dos agentes públicos em função da conduta irregular de outro. Há que se levar em conta, entretanto, a separação de atribuições na Administração Pública, que, por vezes, exige o controle de um agente público sobre a conduta de outro.

No tocante à culpa "in vigilando", considero razoável que o dirigente só possa ser responsabilizado por atos praticados pelos agentes situados sob sua chefia imediata.

Em quarto lugar, a responsabilização de terceiros, agentes públicos ou privados que não efetuam a gestão de recursos públicos em sentido amplo, pressupõe o nexo de causalidade entre a sua conduta e a perda, extravio ou prejuízo ao erário, nos termos do inciso II do artigo 71, da CF/88. 
Em quinto lugar, a teoria da causalidade adotada é a da causalidade adequada, ou seja, a conduta deve ser apta, em abstrato, para gerar o resultado, segundo as regras da experiência e da probabilidade (vide item 11.1.4.3). No caso, deve-se verificar a aptidão da conduta para influenciar (ou realizar) a decisão administrativa e/ou a despesa considerada irregular.

Conforme se poderá analisar nos casos-modelo a seguir, a identificação dos responsáveis poderá ter por base a formação do ato irregular ou a natureza do agente envolvido. Neste último caso, confronta-se a conduta realizada pelo agente e o(s) dever(es) jurídico(s) extraído(s) das normas que regulam a gestão pública.

\subsection{Responsabilidade do Agente Político}

Na lição de Hely Lopes Meirelles, os agentes políticos são "os componentes do Governo nos seus primeiros escalões, investidos em cargos, funções, mandatos ou comissões, por nomeação, eleição, designação ou delegação para o exercício de atribuições constitucionais". Incluem-se, dentre os agentes políticos, os Chefes do Executivo e seus auxiliares (Ministros de Estado, Secretários de Estado, Secretários Municipais), os membros do Poder Legislativo (Vereadores, Deputados, Senadores), Judiciário ou do Ministério Público, do Tribunal de Contas e os representantes diplomáticos (MEIRELLES, 1994, p. 7273).

Ainda segundo Meirelles, os agentes políticos gozam de plena liberdade funcional, desempenhando suas atribuições com prerrogativas e responsabilidade próprias e gozam de independência comparável a dos juízes, nos seus julgamentos, ficando a salvo de responsabilização civil por seus eventuais erros de atuação, a menos que tenham agido com culpa grosseira, má-fé ou abuso de poder (MEIRELLES, 1994).

Nesta matéria, o STF na Reclamação $n^{\circ} 2.138 / \mathrm{DF}$, deliberou que os agentes políticos deveriam estar submetidos a um regime de responsabilização políticoadministrativa distinto dos demais agentes públicos. Não caberia a submissão a um duplo 
regime de responsabilização. Ou seja, aqueles sujeitos aos crimes de responsabilidade previstos na Lei $\mathrm{n}^{\circ} 1.079 / 1950$, não poderiam estar sujeitos à Lei de Improbidade administrativa (Lei $\left.\mathrm{n}^{\circ} 8.429 / 92\right)$ :

\begin{abstract}
"EMENTA: RECLAMAÇÃO. USURPAÇÃO DA COMPETÊNCIA DO SUPREMO TRIBUNAL FEDERAL. IMPROBIDADE ADMINISTRATIVA. CRIME DE RESPONSABILIDADE. AGENTES POLÍTICOS. I. PRELIMINARES. QUESTÕES DE ORDEM. (...) II.1.Improbidade administrativa. Crimes de responsabilidade. Os atos de improbidade administrativa são tipificados como crime de responsabilidade na Lei $\mathrm{n}^{\circ}$ 1.079/1950, delito de caráter político-administrativo. II.2.Distinção entre os regimes de responsabilização político-administrativa. O sistema constitucional brasileiro distingue o regime de responsabilidade dos agentes políticos dos demais agentes públicos. A Constituição não admite a concorrência entre dois regimes de responsabilidade político-administrativa para os agentes políticos: o previsto no art. $37, \S 4^{\circ}$ (regulado pela Lei $\left.\mathrm{n}^{\circ} 8.429 / 1992\right)$ e o regime fixado no art. 102, I, "c", (disciplinado pela Lei $\mathrm{n}^{\circ} 1.079 / 1950$ ). Se a competência para processar e julgar a ação de improbidade (CF, art. $37, \S 4^{\circ}$ ) pudesse abranger também atos praticados pelos agentes políticos, submetidos a regime de responsabilidade especial, ter-se-ia uma interpretação ab-rogante do disposto no art. 102, I, "c", da Constituição. II.3.Regime especial. Ministros de Estado. Os Ministros de Estado, por estarem regidos por normas especiais de responsabilidade (CF, art. 102, I, "c"; Lei n ${ }^{\circ}$ 1.079/1950), não se submetem ao modelo de competência previsto no regime comum da Lei de Improbidade Administrativa (Lei $\mathrm{n}^{\circ}$ 8.429/1992). (...) III. RECLAMAÇÃO JULGADA PROCEDENTE."
\end{abstract}

Poderia-se, nesta linha de raciocínio, argumentar que os chefes do Executivo (agentes políticos) estariam excluídos deste regime de responsabilização financeira. Isto porque, segundo o art. 71, inciso I, da CF/88, compete ao Tribunal de Contas apenas a emissão de parecer prévio às contas de governo prestadas pelo chefe do executivo. Ao Parlamento, conforme dispõe o art. 49, inciso IX, da CF/88, compete julgar as referidas contas. Neste caso, atuaria o Tribunal de Contas como órgão auxiliar do Parlamento, exercendo função meramente opinativa.

No nosso Direito, instituiu-se um duplo sistema de controle, o controle de natureza técnica, pelo Tribunal de Contas, e o controle de natureza política, de competência do Parlamento.

O julgamento das contas pelo Tribunal de Contas (art. 71, inciso II, CF/88) tem por base a verificação da legalidade, da legitimidade e da economicidade dos atos de gestão, enquanto o julgamento das contas pelo Parlamento (art. 49, inciso IX, CF/88) tem por base a verificação do cumprimento dos planos de governo, conforme esclarece Hélio Saul Mileski 
(MILESKI, 2003, p. 267): "A verificação do cumprimento do plano de governo para o qual foi eleito o Presidente da República dá-se mediante avaliação e julgamento político do Parlamento, na medida em que é no Poder Legislativo que se encontram os representantes do povo, com poderes para procederem a este tipo de avaliação política".

Pressupõe-se que o Chefe do Poder Executivo atua, tão somente, como um Administrador de Alto Nível, traçando diretrizes e tomando decisões estratégicas, atuando como lider com visão sistêmica sobre a organização pública. Pressupõe-se que o dirigente não se envolve pessoal ou diretamente com a gestão de bens, dinheiros e recursos públicos. É somente neste sentido que devemos enxergar a isenção de responsabilidade proposta por Hely Lopes Meirelles.

Ocorre que, em determinadas situações, o chefe do Poder Executivo atua diretamente como ordenador de despesas, fato muito comum em Estados e Municípios de pequeno porte. Por exemplo, o Prefeito Municipal, ao celebrar um convênio com o Governo Federal para execução de uma determinada obra, atua como gestor direto e imediato dos recursos, respondendo pela sua boa e regular aplicação.

O Tribunal Superior Eleitoral, com efeito, vem distinguindo, para efeito de apuração da inelegibilidade prevista no art. $1^{\circ}$, inciso I, letra g, da Lei Complementar $\mathrm{n}^{\circ} 64$, o julgamento das contas de governo e o julgamento das contas de convênios ${ }^{127}$ celebrados com o Estado ou com a União. No primeiro caso, o Tribunal de Contas atua como órgão auxiliar, tendo função meramente opinativa. No segundo, o Tribunal de Contas tem competência judicante e a rejeição ou julgamento irregular das contas por esta Corte implica em inelegibilidade, nos termos do dispositivo supramencionado.

A título de ilustração, citamos o Acórdão proferido pelo TSE, no Agravo Regimental em Recurso Ordinário nº 1132:

\footnotetext{
${ }^{127}$ Convém relembrar que, se as contas do convênio forem julgadas irregulares, há, por conseqüência, aplicação de sanção financeira, seja a imputação de débito, seja a aplicação de multa.
} 
Agravo regimental. Recurso ordinário. Eleições 2006. Registro. Candidato. Deputado federal. Contas. Prefeito. Contas aprovadas pela Câmara Municipal. Convênio. Tribunal de Contas da União. Rejeição. Competência. Ação judicial. Propositura. Fundamentos atacados. Provimento liminar. Ausência. Inelegibilidade. Art. $1^{\circ}, \mathrm{I}, \mathrm{g}$, da Lei Complementar $n^{\circ}$ 64/90. Súmula $n^{\circ} 1$ do Tribunal Superior Eleitoral. Não-incidência.

1. A competência para julgamento das contas de prefeito é da Câmara Municipal, consistindo o parecer do Tribunal de Contas em peça meramente opinativa.

2. No tocante às contas relativas a convênios, o julgamento da Corte de Contas assume caráter definitivo.

3. Para afastar a inelegibilidade prevista no art. $1^{\circ}$, I, g, da LC $n^{\circ} 64 / 90$, não basta a mera propositura de ação desconstitutiva, antes, faz-se necessário a obtenção de provimento judicial, mesmo em caráter provisório, suspendendo os efeitos da decisão que rejeitou a prestação de

contas. (Tribunal Superior eleitoral, ARO-1132, Min. Relator Caputo Bastos, Data de Julgamento: 31/10/2006).

Em síntese, havendo atuação do chefe do executivo na gestão direta de recursos públicos, poderá este ter as contas julgadas pelo Tribunal de Contas, nos termos do art. 71, inciso II, da CF/88 e, por conseguinte, sujeitar-se à responsabilidade financeira.

Os demais agentes políticos, integrantes de outros Poderes ou do Ministério Público e Tribunal de Contas, também sujeitam-se à responsabilidade financeira, se exercerem, de forma atípica, função administrativa.

\subsection{Responsabilidade do Ordenador de Despesas}

O Ordenador de Despesas é a figura central dentre os gestores de um órgão ou entidade pública. Suas atribuições foram definidas no art. $80, \S 1^{\circ}$, do Decreto-lei $\mathrm{n}^{\circ}$ 200/67, segundo o qual: "Ordenador de despesas é tôda e qualquer autoridade de cujos atos resultarem emissão de empenho, autorização de pagamento, suprimento ou dispêndio de recursos da União ou pela qual esta responda".

Além das competências acima assinaladas, pode, também, o ordenador de despesas reconhecer dívidas e assumir obrigações em nome do ente público, com eficácia de título executivo extrajudicial (STJ, Resp n 599.047/MA - Rel. Min. José Arnaldo da Fonseca), bem como promover a inscrição de inadimplentes no SIAFI (art. 31, Instrução Normativa STN n 01/97 e Acórdãos do STJ no MS n 11.466 - Rel. Min. Luiz Fux e AgRg no MS n 12.495 - Rel. Min. Eliana Calmon). 
Em vários órgãos e entidades públicas, o Ordenador de Despesas costuma ser o dirigente máximo da instituição. Também é comum a figura do Ordenador de Despesas por Delegação de Competência do dirigente máximo.

No tocante à responsabilidade, o Ordenador de Despesas sempre foi visto como uma espécie de responsável presumido pelos atos que importem em realização de despesa pública. Nesta linha, dispõe o art. 90, do Decreto-Lei $n^{\circ}$ 200/67, verbis: "Responderão pelos prejuízos que causarem à Fazenda Pública o ordenador de despesas e o responsável pela guarda de dinheiros, valôres e bens".

Além disso, sob a égide da Constituição Anterior, o STF deliberou no Mandado de Segurança $\mathrm{n}^{\circ}$ 20.335/DF (Rel. Min. Moreira Alves) que: "Em Direito Financeiro, cabe ao Ordenador de Despesas provar que não é responsável pelas infrações, que lhe são imputadas, das Leis e Regulamentos na Aplicação do Dinheiro Público".

Esta concepção, entretanto, deve ser vista com reservas. Em primeiro lugar, o ordenador de despesas não é um "super-agente" público, onisciente e presente em todas as etapas da realização da despesa pública. Com efeito, o ordenador de despesas pode não ser o responsável pela liquidação (recebimento do bem ou do serviço), pela elaboração do edital, pela condução do processo licitatório, pela contratação, pela concessão de vantagens indevidas a funcionários ou pela contratação irregular de funcionários. Todos estes atos podem acarretar irregularidade na despesa pública.

Se é verdade que o ordenador de despesas deve zelar pela regularidade na execução da despesa, negando-se a emitir empenho ou a autorizar pagamento, em caso de vício nas etapas anteriores, também é verdade que tal competência deve ser execida no limite da razoabilidade. Tais observações aplicam-se, especialmente, em organizações públicas de porte, em que há uma grande divisão do trabalho entre os agentes encarregados da despesa pública. 
Não cabe, assim, responsabilizar o Ordenador em caso de vícios de difícil detecção. Não cabe, também, ao Ordenador rediscutir pareceres técnicos, fora da sua especialidade. Neste caso, a verificação a ser realizada tem caráter formal, sem adentrar no mérito.

Outra observação cabível, diz respeito ao ordenador de despesas por delegação, que, pode se tornar um "bode expiatório", respondendo por decisões tomadas pelo dirigente máximo da entidade. Neste caso, o ordenador, que via de regra exerce função de confiança e que pode ser destituído a qualquer momento pelo dirigente máximo, apenas atende a solicitação informal do dirigente. Em sendo irregular, deverão responder os dois agentes (podendo ser solidariamente, em caso de débito): o dirigente que foi o gestor de fato e o ordenador, que executou ordem manifestamente ilegal. Afinal, não se aplica a excludente obediência hierárquica, quando manifesta a ilegalidade (item 16.5.).

Nas deliberações do TCU, observamos precedentes no sentido de afastar a responsabilidade do ordenador de despesas, com base em vícios ocorridos na liquidação da despesa.

No Acórdão TCU n 147/2000 - Plenário, o Tribunal excluiu a responsabilidade do ordenador geral de despesa do INAMPS, lotado no Rio de Janeiro, considerando que era humanamente impossível para este agente atestar pessoal e individualmente cada documento de despesa antes de sua liquidação, principalmente aqueles documentos relativos a hospitais de todo o país.

No Acórdão TCU n 695/2003 - 1 $^{\text {a }}$. Câmara, foi afastada a responsabilidade do ordenador de despesas pela inexecução do objeto pactado em convênio, haja vista que os relatórios de fiscalização, única informação de que dispunha para tomada de decisões, indicam a execução integral do objeto pactuado.

Em outras deliberações, o Tribunal aplicou imputou débito e aplicou multa ao ordenador de despesas. No Acórdão n 3.056/2003 - $1^{\text {a }}$. Câmara, o TCU negou provimento à 
recurso contra deliberação que condenou o ordenador de despesas, em razão de pagamento antecipado dos serviços ${ }^{128}$, que, acompanhado da inadimplência da contratada, acarretou dano ao erário:

\begin{abstract}
"Segundo o laudo judicial de fls. 113/128 do principal, a empresa referida executou, apenas, $18,59 \%$ da obra. Não obstante, o pagamento dos serviços contratados foi efetuado em três parcelas: a primeira parcela, correspondente a 50\% do valor da avença, satisfeita em 16/6/94 (NF 55), antes mesmo da celebração do contrato, ocorrida em 20/6/95; as demais parcelas, em percentual de $25 \%$ cada, foram pagas nos dias 19/7 e 10/8/1994 (NFs. 58 e 68).

Sobre tais fatos não há controvérsia, pois confirmados pelo recorrente, que se limitou a justificar as providências adotadas a seu cargo para ressarcir o prejuízo sofrido pela Administração Pública, decorrentes da inadimplência da empresa contratada.

Convém salientar, contudo, que a incúria do ex-prefeito foi o fator determinante da materialização do dano, porquanto deixou de adotar as devidas cautelas, em contrato, para garantir que os recursos públicos fossem desembolsados somente mediante a regular liquidação da despesa, ou seja, após o recebimento definitivo da obra.

A eventual adoção de medidas administrativas ou judiciais, por parte do ex-administrador, não elide a culpa, em não haver resguardado, no momento oportuno, o interesse público".
\end{abstract}

No tocante á delegação de competências, o TCU, ora entendeu cabível a responsabilização do ordenador de despesas principal, solidariamente ao delegado, e ora excluiu a responsabilidade daquele.

No Acórdão $\mathrm{n}^{\circ}$ 1.161/2004 - Plenário, que versa sobre pagamentos em duplicidade à empresa contratada, por sobreposição de vários contratos firmados, deliberou o Tribunal que, mesmo que não houvesse conluio, o ordenador principal deveria fiscalizar, com um mínimo de eficiência, as ações afetas à divisão que lhe era diretamente subordinada. Manifestou-se, no caso, o Ministro-Relator: "Nesse aspecto, entendo demonstrada a desídia. Com efeito, se foi possível que subsistisse falha tão clamorosa e durante tanto tempo em unidade sob sua direta supervisão, conclui-se que a fiscalização, antes que ineficiente, era na verdade inexistente".

\title{
14.3. Responsabilidade dos Membros da Comissão de Licitação
}

A Comissão de Licitação, nos termos do artigo $6^{\circ}$, inciso XVI, da Lei ${ }^{\circ}$ 8.666/93, tem por atribuições "receber, examinar e julgar todos os documentos $e$

\footnotetext{
${ }^{128} \mathrm{O}$ pagamento antecipado é expressamente vedado pelo art. 62 , da Lei ${ }^{\circ}$ 4.320/64: "o pagamento da despesa só será efetuado quando ordenado após sua regular liquidação".
} 
procedimentos relativos às licitações e ao cadastramento de licitantes". Tais atribuições podem ser resumidas em:
a) recebimento das propostas e dos documentos de habilitação;
b) deliberar sobre a habilitação dos interessados;
c) julgar e classificar as propostas comerciais.

A Comissão de Licitação não é responsável pela elaboração do instrumento convocatório. Tal atribuição não se insere no rol de atribuições da comissão. A atuação da Comissão de licitação cinge-se à fase externa da licitação, não podendo ser responsabilizada por atos ocorridos na fase interna, salvo manifesta ilegalidade.

Deve ser composta por "no mínimo, 3 (três) membros, sendo pelo menos 2 (dois) deles servidores qualificados pertencentes aos quadros permanentes dos órgãos da Administração responsáveis pela licitação" (art. 51, caput, da Lei no 8.666/93).

Os membros da Comissão de Licitação são gestores públicos em sentido amplo, uma vez que seus atos integram as etapas da despesa pública, tendo natureza preparatória. Com efeito, a licitação, via de regra, é o antecedente necessário ao contrato celebrado pela Administração Pública, nos termos do art. 37, XXI, da CF/88. Ademais, há uma vinculação entre o contrato e os termos da licitação (art. 54, §1 ${ }^{\circ}$, da Lei ${ }^{\circ}$ 8.666/93) que se manifesta, inclusive, pelo fato da nulidade da licitação importar na nulidade do contrato (art. $49, \S 2^{\circ}$, da Lei $n^{\circ} 8.666 / 93$ ).

Os membros da Comissão de Licitação devem atender aos preceitos da Lei $n^{\circ}$ 8.666/93, que estabelece normas gerais sobre licitações e contratos. Em especial, compete aos membros da comissão atentar para os princípios da licitação, explícitos (art. $3^{\circ}$, caput, da Lei $\mathrm{n}^{\circ}$ 8.666/93) ou implícitos: legalidade, moralidade, impessoalidade, publicidade, julgamento objetivo, igualdade/isonomia, vinculação ao instrumento convocatório, economicidade, competitividade, razoabilidade e formalismo moderado. Dentre as regras de 
julgamento, merece destaque a disposição contida no art. 43, inciso IV, da Lei $\mathrm{n}^{\circ}$ 8.666/93, segundo a qual, compete à comissão de licitação a

"verificação da conformidade de cada proposta com os requisitos do edital e, conforme o caso,
com os preços correntes no mercado ou fixados por órgão oficial competente, ou ainda com os
constantes do sistema de registro de preços, os quais deverão ser devidamente registrados na ata
de julgamento, promovendo-se a desclassificação das propostas desconformes ou
incompatíveis".

No tocante à responsabilidade dos membros da comissão, vigora a regra contida no art. 51, $\S 3^{\circ}$, da Lei ${ }^{\circ}$ 8.666/93, segundo a qual, "Os membros das Comissões de licitação responderão solidariamente por todos os atos praticados pela Comissão, salvo se posição individual divergente estiver devidamente fundamentada e registrada em ata lavrada na reunião em que tiver sido tomada a decisão".

Convém lembrar que tal regra de responsabilização não tem a sua aplicação restrita às Comissões de Licitação, mas a todo órgão colegiado de deliberação administrativa.

\subsection{Responsabilidade do Parecerista Técnico}

O parecerista técnico é também gestor público em sentido amplo. Designamos, para fins deste estudo, técnico como todo aquele profissional especializado que atua nas etapas de realização de realização da despesa pública e que tal atuação consista na elaboração de um projeto, parecer ou avaliação.

Apesar do parecer consistir em peça opinativa e não decisória, as opiniões técnicas manifestadas pelo parecerista (da mesma forma que as do parecerista jurídico) podem embasar ou servir de fundamento para a realização de atos de gestão viciados, irregulares ou danosos ao Erário.

Imagine, por exemplo, um perito que avalie, por negligência ou dolo, um bem a ser desapropriado em valores superiores aos do mercado. Caso o gestor princípal acate a avaliação efetuada, haverá um dano ao erário, decorrente da conduta deste perito. 
Um outro exemplo, o responsável pela elaboração de um projeto básico de uma obra, que não atenda os requisitos previstos no art. $6^{\circ}$, da Lei $n^{\circ} 8.666 / 93$, dá causa a um Edital de Licitação viciado, uma vez que o Projeto Básico é parte integrante do Instrumento Convocatório. Ademais, a deficiência na elaboração do Projeto Básico poderá se refletir na necessidade de alterações contratuais exorbitantes na execução da obra, o que, de certa forma, macula o próprio certame licitatório, uma vez que o vencedor da licitação poderá não ter a melhor proposta para a administração, considerados os parâmetros adotados nas alterações contratuais.

Na Lei Orgânica do Tribunal de Contas de Portugal (Lei $n^{\circ}$ 98/97), a possibilidade de responsabilização do parecerista técnico (e também do parecerista jurídico) é expressa no art. 61\%: "Essa responsabilidade pode recair ainda nos funcionários ou agentes que, nas suas informações para os membros do Governo ou para os gerentes, dirigentes ou outros administradores, não esclareçam os assuntos da sua competência de harmonia com a lei."

O TCU tem admitido a responsabilização do Parecerista Técnico, seja em conjunto com o gestor principal, seja de maneira isolada. $O$ gestor principal não está vinculado ao parecer. $\mathrm{O}$ que determina sua a responsabilização ou não, em conjunto o parecerista, é a dificuldade de detecção do erro técnico.

A seguir, cito alguns precedentes do TCU.

No Acórdão n² 206/2007 - Plenário, o Tribunal decidiu que cabe ao gestor público examinar a correção dos pareceres que lhe são submetidos, até mesmo, para corrigir eventuais disfunções na atividade administrativa:

"PEDIDO DE REEXAME. LICITAÇÃO. AUSÊNCIA DE FIXAÇÃO DE CRITÉRIOS DE ACEITABILIDADE DE PREÇOS. RESPONSABILIZAÇÃO PELA APROVAÇÃO DE EDITAL. AUSÊNCIA DE VINCULAÇÃO A PARECER JURÍDICO/TÉCNICO. NEGADO PROVIMENTO.

1. É obrigação do gestor, e não faculdade, estabelecer os critérios de aceitabilidade de preços unitários. 
2. A aprovação, por órgão colegiado, de edital de licitação eivado de irregularidade implica na responsabilização de todos os membros que não tenham manifestamente registrado sua discordância à deliberação.

3. O parecer jurídico e técnico não vincula o gestor, que tem a obrigação de examinar a correção dos pareceres, até mesmo para corrigir eventuais disfunções na administração e, portanto, não afasta, por si só, a sua responsabilidade por atos considerados irregulares pelo Tribunal de Contas da União." (grifo nosso)

O Acórdão $n^{\circ}$ 62/2007 - $2^{\mathrm{a}}$. Câmara versa sobre a concessão de um empréstimo, por Banco Público, contrariando as normas de concessão de crédito e ignorando as restrições cadastrais da beneficiária da operação. Os pareceres técnicos levados à Diretoria do Banco, responsável pela aprovação da operação, eram amplamente favoráveis ao empréstimo, com exceção de um que aparentemente não foi levado ao conhecimento da Diretoria do Banco. No caso, o Tribunal excluiu a responsabilidade do gestor principal, por tratar-se de erro técnico de difícil detecção.

\begin{abstract}
"RECURSO DE RECONSIDERAÇÃO. PROCESSUAL. RESPONSABILIDADE CIVIL DE PARECERISTA. DESCARACTERIZAÇÃO DE DOLO, CULPA OU NEXO DE CAUSALIDADE ENTRE A CONDUTA E O PREJUÍZO. PROVIMENTO.

1. Nos casos em que o parecer do profissional é de fundamental importância para embasar o posicionamento a ser adotado pelas instâncias decisórias, uma manifestação contaminada por erro técnico, de difícil detecção, acarreta a responsabilidade civil do parecerista pelos possíveis prejuízos daí advindos.

2. Descaracterizada a conduta dolosa ou culposa do agente público ou do nexo de causalidade entre a sua conduta e o prejuízo causado ao erário, impõe o provimento, no todo ou em parte, da peça recursal, com a exclusão da responsabilidade dos agentes envolvidos.
\end{abstract}

Diversos foram os julgados em que o Tribunal apreciou a conduta dos pareceristas em Processos de Prestação de Contas.

No Acórdão n 1464/2008 - Plenário, por exemplo, constatou-se negligência na análise e homologação das contas prestadas pelo convenente. Houve a emissão de parecer financeiro sugerindo a aprovação e homologão das contas eivadas de irregularidades, que poderiam ter sido detectadas a ponto de evitar novos prejuízos. Elucidativo é o seguinte trecho do voto condutor do referido Acórdão:

59. O Sr. Herbert Marcuse Megeredo Leal, Chefe do Sv. de Supervisão Técnica/DF, a Sr ${ }^{a}$ Eneida Coelho Monteiro, Chefe do DF/DAF e o Sr. Luiz Francisco Silva Marcos, Diretor de Administração e Finanças, servidores do extinto DNER, foram arrolados nesta tomada de contas especial, em solidariedade pelo débito correspondente à primeira parcela dos recursos federais transferidos, em razão, no caso dos dois primeiros, de terem emitido parecer favorável à aprovação das contas - relativas ao primeiro repasse federal - e o último por tê-la 
homologado, quando flagrantemente violados dispositivos da IN-STN 01/97 (art. 28, VII, X, art. 30) e da Lei 4.320/64 (arts. 62 e 63), porquanto constatada a ausência dos extratos bancários, da cópia do despacho adjudicatório e da homologação das licitações, a não identificação das notas fiscais apresentadas com o número do convênio e, ainda, a realização de despesas sem prévias medições do DNER.

60. Todos esses servidores foram responsáveis pelo exame e aprovação da prestação de contas parcial apresentada, sob o aspecto financeiro, sendo que o Sr. Luiz Francisco Silva Marcos, Diretor de Administração e Finanças, homologou a aprovação das contas sob os aspectos técnicos e financeiros, como ordenador de despesas do extinto DNER.

61. Acerca das alegações de defesa oferecidas, concordo integralmente com o exame empreendido pelos pareceres da unidade técnica e do Ministério Público.

62. De se ressaltar, a propósito, que as irregularidades tratadas nestes autos poderiam ter sido detectadas com a simples análise da documentação de prestação de contas. Bastaria folhear o processo para se constatar que as notas fiscais apresentadas não continham a identificação do convênio, contrariando o art. 30 da IN/STN 01/97. A verificação das ordens bancárias emitidas pelo DER/RR e do extrato bancário traria de pronto a detecção de outras irregularidades, como a transferência dos recursos do convênio para conta bancária não específica, em desacordo com o art. 20 da IN/STN 01/97, a confusão de recursos de diversas origens, a inexistência de saldo de rendimentos financeiros auferidos com os recursos e a falta de correspondência entre os lançamentos nos extratos e as ordens bancárias apresentadas. Vêse claramente que tais constatações não demandariam uma análise pormenorizada da prestação de contas.

63. Caso os referidos problemas houvessem sido apontados já na primeira prestação de contas parcial, o débito apurado nos autos poderia ter sido substancialmente reduzido. Diante disso, a conclusão a que chego é que houve, no mínimo, negligência no controle efetuado pelos responsáveis sobre a prestação de contas, já que tais contas tramitaram no âmbito da DAF sem que fossem abordadas as irregularidades graves ora apontadas, as quais impedem fazer a correlação entre as obras e os recursos transferidos.

Convém, por fim, destacar que, nas fiscalizações de obras, o Tribunal de

Contas da União vem se preocupando com a atuação dos pareceristas, técnicos e jurídicos a ponto de orientar suas equipes de fiscalização a identificar as condutas destes profissionais que venham a dar causa a ilicitudes na gestão. No item 9.3, do Acórdão 2006/2006 Plenário, o Tribunal decidiu

"determinar à Segecex que oriente as Unidades Técnicas deste Tribunal, na hipótese de serem constatados indícios de irregularidades graves na condução de obras pela Infraero, a avaliar a responsabilidade de todos os agentes - em especial daqueles integrantes da área técnica e da consultoria jurídica - que tenham contribuído de alguma forma para a consumação de suposta ilicitude, especialmente aquelas relacionadas à elaboração de projeto básico e de orçamento da obra, à revisão do orçamento e à alterações contratuais, a fim de que não se restrinja essa investigação unicamente aos dirigentes signatários de contratos e de seus aditivos"

\subsection{Responsabilidade pela Fiscalização e pelo Recebimento do Objeto Contratual}

O fiscal do contrato é um agente designado pela Administração Pública para o acompanhamento e fiscalização da execução contratual. Suas atribuições estão definidas no 
art. 67, da Lei $\mathrm{n}^{\circ}$ 8.666/93. O fiscal pode ser auxiliado por pessoa física ou jurídica contratada pela Administração, com o objetivo específico de subsidiá-lo nesta tarefa.

É gestor público no sentido amplo, uma vez que as informações prestadas pelo fiscal embasam a etapa de liquidação da despesa pública. Suas informações subsidiam a aplicação de penalidades ao contratado, quando for o caso, bem como a determinação da correção dos erros de execução do contrato.

Diversas são as irregularidades que podem ser cometidas pelo Fiscal do Contrato, cabendo citar a realização de medições em quantitativos superiores aos efetivamente executados, importando em dano ao Erário. Ademais, a atuação do fiscal é de importância fundamental para a qualidade do objeto executado.

A negligência na execução das tarefas que lhe forem cometidas pode importar em responsabilidade do fiscal do contrato.

Via de regra, não cabe ao fiscal do contrato a tomada de decisões fundamentais na Administração do Contrato.

Neste sentido, Marçal Justen Filho, comentando o art. 67, esclarece que (JUSTEN FILHO, 2005, p. 560-561):

\footnotetext{
"Incumbe ao agente da Administração acompanhar o desenvolvimento da atividade do particular, anotando as ocorrências relevantes e documentando eventuais equívocos a serem corrigidos. Exceto se previsto diversamente no contrato, o agente administrativo não disporá de faculdade de intervenção. Não lhe incumbirá o poder de interferir sobre a atividade do contratante para, por exemplo, expedir determinações acerca da correção dos defeitos verificados. $\mathrm{O}$ agente administrativo transmitirá suas anotações às autoridades competentes, às quais competirá adotar as providências adequadas. Se a providência for urgente, a autoridade competente deverá ser imediatamente alertada".
}

No caso de necessidade de intervenção no contrato ou determinação ao contratado, compete ao fiscal provar que alertou os seus superiores hierárquicos, sob pena de responsabilização solidária, conforme ilustra Cláudio Sarian Altounian (ALTOUNIAN, 2007, p. 224-225): 


\begin{abstract}
"Não é raro em processos de tomada de contas especiais para imputação de débito, serem apresentadas, por esses representantes, alegações de defesa no sentido de que não tinham conhecimento da matéria ou de que alertaram verbalmente seus superiores sem que as providências fossem adotadas. Nesse caso, a inexistência de documento comprobatório impossibilita o acolhimento dessas alegações, visto que a permissão para a continuidade da obra sem a adoção das medidas corretivas é de responsabilidade imediata do representante da Administração, a não ser que tenha, comprovadamente, obedecido a ordens superiores, desde que não manifestamente ilegais".
\end{abstract}

O Tribunal de Contas da União tem imputado débito aos fiscais de contrato que, em razão de falha na fiscalização ou na prestação de informações, tenham causado dano ao Erário.

Nos Acórdãos n 1.231/2004 - Plenário e 1.032/2004 - 1ª . Câmara, o Tribunal entendeu que a ausência de designação formal do fiscal não exclui a responsabilidade, se ficou evidenciada a sua atuação de fato como tal.

Uma situação distinta é a do pagamento de serviços não realizados em decorrência de ausência de fiscalização do contrato. Neste caso, cabia ao dirigente do órgão ou entidade pública designar fiscal e, se não o fez, ele é o responsável pelos danos decorrentes da ausência de fiscalização e do pagamento indevido.

\title{
14.6. Responsabilidade do Responsável pelo Controle Interno
}

Dispõe o art. $74, \S 1^{\circ}$, da $\mathrm{CF} / 88$, que os responsáveis pelo Controle Interno, ao tomarem connhecimento de qualquer irregularidade ou ilegalidade, dela darão ciência ao Tribunal de Contas, sob pena de responsabilidade solidária.

É dever de todo servidor público e, dos agentes públicos em geral, a comunicação das irregularidades que tenha ciência em razão do cargo. Com efeito, o art. 116, incisos VI e XII, da Lei $n^{\circ} 8.112 / 90$ dispõem que são deveres do servidor levar ao conhecimento da autoridade superior as irregularidades que tiver ciência em razão do cargo e representar contra ilegalidade, omissão ou abuso de poder. 
Nada obstante, esta última difere da comunicação em epígrafe por ser uma comunicação encaminhada pela via hierárquica. A comunicação de que trata o art. $74, \S 1^{\circ}$, da CF/88 é dirigida a um órgão de Controle Externo, desvinculado da hierarquia do Controle Interno.

O dirigente do Controle Interno passa a ser jurisdicionado ao Tribunal de Contas, por força de disposição Constitucional.

Na Interpretação do dispositivo, a utilização da expressão "responsabilidade solidária" pode dar idéia de que a responsabilidade do dirigente do dirigente do Controle Interno seria restrita à modalidade reintegratória.

Não é o caso, pois a Constituição de 1988 é expressa ao exigir que qualquer ilegalidade ou irregularidade seja comunicada ao Tribunal de Contas. Assim, se deixar de comunicar uma irregularidade que não importe em dano ao erário, será responsabilizado como se ele próprio tivesse praticado o ato irregular, não havendo solidariedade para o pagamento da multa.

Obviamente, para que se possa exigir tal comunicação, o processamento e julgamento da irregularidade devem ser de competência do Tribunal de Contas.

No TCU, um dos poucos casos em que o tema foi abordado é o Acórdão $\mathrm{n}^{\circ}$ 635/2007 - Plenário, no qual considerou-se que a Dirigente do Controle Interno de um órgão deveria informar patentes irregularidades no seu Relatório constante do Processo de Tomada de Contas a ser remetido para julgamento. Nas palavras do Ministro-Relator:

\footnotetext{
"A $\mathrm{Sr}^{\mathrm{a}}$ (...) (Dirigente do Controle Interno) também deve ser responsabilizada pelas irregularidades, pelas razões apontadas pela unidade técnica e especialmente em razão da omissão no Relatório de Tomada de Contas em relação às irregularidades que não se encontravam descritas no Relatório de Gestão e que eram dever de ofício do Controle Interno averiguar, como é o caso da realização de despesas e a assunção de obrigações que excederam os créditos orçamentários e a admissão de servidores sem prévia dotação orçamentária".
} 


\subsection{Responsabilidade no caso de delegação de competência}

Como o termo delegação pode se referir a diferentes institutos jurídicos (delegação legislativa, desconcentração, etc.), convém fixar a atenção numa acepção mais estrita: a delegação de competência administrativa.

A delegação de competência foi erigida como Princípio Fundamental da Administração Pública Federal, conforme art. 6 , IV, do Decreto-lei n 200/67.

Consoante o art. 11, do Decreto-lei $\mathrm{n}^{\circ}$ 200/67, a delegação de competência é um "instrumento de descentralização administrativa, com o objetivo de assegurar maior rapidez e objetividade às decisões, situando-as na proximidade dos fatos, pessoas ou problemas a atender".

Regis Fernandes de Oliveira, acerca da responsabilidade por atos delegados, aponta as opinões de Caio Tácito, Odete Medauar, Themistocles Cavalcanti e Agostín Gordillo no sentido de que, transferida a competência para a prática do ato, nenhuma reserva cabe mais à autoridade delegante, sendo o delegado responsável pelo exercício ou prática das atividades delegadas (OLIVEIRA, R., 1985).

Acerca da possibilidade de responsabilização solidária do delegante por culpa "in vigilando" ou "in eligendo", Oliveira diverge da posição de Agostin Gordilho, que admite esta possibilidade. Argumenta que, em princípio, todos os agentes públicos estão aptos para exercer as funções a ele cometidas (OLIVEIRA, 1985, p. 197-198):

\footnotetext{
"Inclusive, a própria Administração Pùblica, por força da desconcentração, fixa as competências próprias de cada órgão. Nela investe, segundo se supõe, os mais aptos. Se existe a previsão legal da possibilidade de delegação e é ela transferida a um órgão que é ocupado por determinado agente irresponsável, a este será imputado eventual excesso ou responsabilidade pelo descumprimento, alteração ou indevido cumprimento da matéria delegada".
} 
No Tribunal de Contas da União, a delegação de competência não tem afastado a responsabilidade da autoridade delegante, em razão do seu dever de fiscalizar os atos da delegada.

No Acórdão n 292/2001 - Plenário, segundo informa o Relatório do Ministro-

Relator:

\begin{abstract}
"4.8.Outra consideração a ser feita diz respeito à delegação de competência, utilizada pelo responsável como justificativa pelo não-cumprimento dos dispositivos legais que regem a contratação de serviços pela administração pública. Esse instrumento, previsto no Decreto-Lei 200/67 (art. 10, "caput", § 5 $5^{\circ}$ e no Decreto n $^{\circ}$ 93.872/86 (arts. 49, 54, 142), não retira a responsabilidade do delegante. No processo de delegação remanesce a responsabilidade do nível delegante em relação aos atos do delegado. Tal entendimento é pacífico e está consubstanciado em diversas decisões deste Tribunal, entre essas podemos citar: TC 674.011/90-2, Ata 07/93 - 2 2 Câmara; TC 000.355/96-8, Ata 07/98 - Plenário; e TC 374.048/91-6, Ata 14/93 - Plenário".
\end{abstract}

Mais recentemente, o Tribunal entendeu que "A delegação de competência não exime o responsável de exercer o controle adequado sobre seus subordinados incumbidos da fiscalização do contrato." (Acórdão n 1843/2005 - Plenário). O Acórdão versava sobre celebração de Contrato Emergencial Verbal e por Prazo Superior ao Legal. Segundo o voto-condutor do Acórdão n 1.843/2005 - Plenário:

\footnotetext{
"Suas argumentações não obtiveram êxito na pretensão de afastar sua responsabilidade. A delegação de competência não exime o responsável de exercer o controle adequado sobre seus subordinados incumbidos da fiscalização do contrato. Da mesma forma, a irregularidade consistente na manutenção de contrato celebrado com fundamento no art. 24, inciso IV, da Lei 8.666/93, por prazo superior a 180 dias não foi elidida. É obrigação do ordenador de despesas supervisionar todos os atos praticados pelos membros de sua equipe, a fim de assegurar a legalidade e a regularidade das despesas, pelas quais é sempre o responsável inafastável".
}

No Acórdão n 2.345/2006 - Plenário, deliberou o Tribunal no mesmo sentido: "2. O instrumento da delegação de competência não afasta da autoridade delegante, hierarquicamente superior, a responsabilidade pelos atos do delegado". Tratava-se de uma Tomada de Contas Especial instaurada contra Prefeito Municipal acerca em razão da aplicação irregular de recursos federais por um município do interior do Estado do Ceará. 
A deliberação no Acórdão $n^{\circ} 2.396 / 2006$ - $1^{\text {a }}$. Câmara foi no mesmo sentido: "A delegação de competência a subordinado não isenta a responsabilidade do gestor de recursos públicos". Nas palavras do Ministro-Relator:

\begin{abstract}
"13. Desse modo, o Sr. (...) não pode intentar ser alçado à condição de agente acima de qualquer tipo de responsabilidade, mesmo porque ele responde, de uma forma ou de outra, pelos atos de seus subordinados e a própria ligação hierárquica entre Prefeito e Secretários estabelece, sem embargo, um vínculo de responsabilidade que há de ser reconhecido. Nesse sentido, diversos são os julgados dessa Corte (Acórdão n ${ }^{\circ}$ 277/1997 - Plenário, Acórdão no 428/1996 - $1^{\text {a }}$ Câmara, Decisão no 268/1997 - 2 Câmara, Acórdão nº 12/1997 - $2^{\text {a }}$ Câmara, Acórdão no ${ }^{\circ}$.551/1996 - $2^{\text {a }}$ Câmara, dentre outros).

14. Outrossim, como bem esclareceu o ilustre representante do Ministério Público/TCU, no Parecer transcrito no voto que acompanha o Acórdão no 197/2001 - Plenário, "O fato de o ato de gestão inquinado não ter sido praticado pelo Sr. José Alves não afasta a responsabilidade por ele assumida perante a União, até porque ele era o Chefe do Executivo Municipal e o ato foi praticado por subordinados seus, dentro do limite de discricionariedade que lhes era permitido, sem que o ex-Prefeito tivesse tomado qualquer providência para regularizar o ocorrido."
\end{abstract}

No meu entendimento, a responsabilidade do delegante por ato do delegado deve levar em conta a sua efetiva capacidade e disponibilidade para fiscalizar os atos praticados pelo subordinado. A delegação é um instrumento de racionalização e de eficiência administrativa, logo, imputar sempre a responsabilidade à delegante poderia tornar inútil o instituto da delegação de competência, pois este deveria exercer uma fiscalização rigorosa sobre os atos do subordinado. 


\section{QUANTIFICAÇÃO DA RESPONSABILIDADE}

Como as sanções financeiras não são penalidades fixas, uma vez constatados os pressupostos da responsabilidade financeira e identificado o responsável, cabe ao Tribunal de Contas quantificar o débito ou a multa a ser aplicável.

Conforme já mencionado, o art. $5^{\circ}$, da Lei n ${ }^{\circ} 10.028 / 2000$, estabelece multa de $30 \%$ dos vencimentos anuais do agente responsável pelas infrações definidas no artigo. Entretanto, a jurisprudência do TCU tem interpretado o dispositivo legal à luz do princípio da proporcionalidade e da razoabilidade, entendendo o montante de $30 \%$ dos vencimentos como um teto, um valor máximo da multa aplicada (item 10.3.).

Não se trata de tarefa fácil, mormente no que tange à responsabilidade financeira sancionatória.

Uma vez que não há, entre nós, parâmetros legais para avaliação da culpabilidade do gestor faltoso, bem como de quantificação da multa, os Tribunais de Contas vem se pautando por critérios subjetivos, muitas vezes aleatórios, escusos e imotivados, para a fixação da penalidade. Por vezes, estabelece-se um montante mínimo, mas desproporcional ao ilícito perpetrado pelo gestor, para viabilizar a cobrança executiva pelas Procuradorias do Estado ou da União.

Neste sentido, Francisco Eduardo Carrilho Chaves critica a enorme subjetividade na cominação da multa prevista no art. 57, da Lei $\mathrm{n}^{\circ}$ 8.443/92 (multa proporcional ao dano ao erário, de até 100\% do dano) (CHAVES, 2007, p. 302):

\footnotetext{
"O art. 57 da Lei n ${ }^{\circ}$ 8.443/92, fixa a amplitude da multa aplicável aos responsáveis por contas irregulares com débito entre 0 e $100 \%$ desse valor. Não há qualquer outro parâmetro para informar o aplicador da norma. Em razão do espectro tão amplo da sanção, é tarefa irrealizável procurar estabelecer critério na imposição dessa sanção pelo Tribunal. Tamanha liberdade faz com que os relatores dos processo não sigam uma diretriz uniforme. Naturalmente, há casos em que é possível vislumbrar certa coerência em acórdãos conduzidos por votos de um mesmo relator, mas é infrutífero tentar encontrar coerência entre os diversos relatores, que conduziria a uma conseqüente coerência da atuação da Corte.

Afigura-se mais apropriado criar faixas para a multa no texto legal, dentro das quais o responsávei seria enquadrado em função de critérios objetivos, também estabelecidos em lei.
} 


\begin{abstract}
Alternativamente, poderia ser estabelecida uma cominação básica in abstrato, em cima da qual se aplicariam agravantes e atenuantes do caso concreto, nos moldes do Direito Penal, mantidos os limites do montante do débito, a conduta do responsável, o alcance social da lesão causada, a condição pessoal do responsável - como o cargo ou função que ocupava à época das irregularidades, entre outros. Esses elementos certamente são avaliados pelos relatores, mas dado que não existem parâmetros objetivos para orientar a imposição da sanção, fica franqueado a cada um imprimir excessivo grau de subjetividade em seus votos."
\end{abstract}

Proponho, assim, alguns parâmetros para a quantificação da responsabilidade financeira.

Os critérios de quantificação da responsabilidade financeira são diversos, dependendo da modalidade reintegratória ou sancionatória.

Iniciamos a tratar da quantificação da responsabilidade financeira reintegratória, ou seja, o dano causado ao Erário, também denominado "débito".

Já mencionamos que a responsabilidade financeira reintegratória é uma espécie de responsabilidade limitada às quantias envolvidas na infração ou às quantias efetivamente geridas. Não cabendo falar em lucros cessantes ou em dano moral à Pessoa Jurídica de Direito Público (item 11.1.4.2).

No caso de pagamento indevido, regra geral, o débito será a diferença entre o valor pago (desembolsado) e o valor da contraprestação efetiva correspondente ao valor pago. Não se considera como contraprestação, as prestações efetuadas que não se relacionem à finalidade ou às atribuições do órgão ou entidade pública que despendeu os recursos.

Se a contraprestação for feita ao Estado, esta será, via de regra, calculada com base nas quantidades dos itens prestados multiplicadas pelos correspondentes preços unitários de mercado. O preço de mercado é o parâmetro previsto no art. $43, \mathrm{X}$, da Lei $\mathrm{n}^{\circ}$ 8.666 e na Lei ${ }^{\circ}$ 8.429/92 (Lei de Improbidade Administrativa).

No caso de compras, o parâmetro legal de preço não é o de mercado, mas o preço praticado no âmbito da Administração Pública, conforme art. 15, da Lei n 8.666/93. 
No caso de obra executada com recursos do Orçamento da União, as Leis de Diretrizes Orçamentárias (LDOs) estabelecem que os valores dos preços unitários dos serviços que a compõem não poderão ultrapassar aqueles constantes do sistema SINAPI ${ }^{129}$, gerido pela Caixa Econômica Federal. Desta forma, são estes os parâmetros legais a serem utilizados no cálculo do débito. Convém ressaltar que nem todos tipos de obras têm seus preços registrados no Sistema SINAPI.

Se a contraprestação não for ao Estado, mas à Sociedade, na forma de prestação de bens e serviços específicos, o valor da contraprestação corresponderá à quantidade de bens e serviços efetivamente prestados, multiplicado pelo valor unitário correspondente a cada prestação.

No caso de subvenções sociais, por exemplo, o montante transferido para uma entidade conceder bolsa a alunos carentes é de $\mathrm{R} \$ 100.000,00$ (cem mil reais), correspondente a 100 bolsas de estudo anuais. Desta forma, cada bolsa equivale a R\$ 1.000,00 (mil reais). Logo, se a entidade utilizou os recursos para conceder apenas 40 bolsas, deverá ressarcir o montante correspondente a 60 bolsas, ou seja, R \$60.000,00 (sessenta mil reais).

Nas contratações irregulares de pessoal, em que não houver prestação efetiva de serviços, o valor do débito corresponderá à remuneração dos agentes contratados.

No caso de renúncia indevida de receitas, o montante do débito corresponde ao montante ao valor da renúncia indevidamente renunciada (vide art. $60^{\circ}$, da LOPTC).

No caso de omissão no dever de prestar contas, o débito corresponde ao valor integral gerido pelo gestor omisso, pois, conforme já mencionei no item 11.1.4.2, há presunção relativa de débito, no montante integral gerido, do gestor faltoso em dar satisfação sobre a forma como gere os recursos públicos.

${ }^{129}$ Sistema Nacional de Pesquisa de Custos e Índices da Construção Civil. 
Calculado o montante do débito, incidem, ainda, sobre os mesmos a atualização monetária e os juros de mora, nos termos da legislação em vigor. A Lei admite, entretanto, em caso de boa-fé e liquidação tempestiva do débito, a incidência apenas de atualização monetária, se outra irregularidade não houver sido observada nas contas, conforme art. $12, \S 2^{\circ}$, da Lei ${ }^{\circ}$ 8.443/92: "Reconhecida pelo Tribunal a boa-fé, a liquidação tempestiva do débito atualizado monetariamente sanará o processo, se não houver sido observada outra irregularidade nas contas".

No caso da responsabilidade financeira sancionatória, há que se distinguir, inicialmente, as três modalidades de multa aplicáveis pelo Tribunal: a multa simples, a multa proporcional ao dano ao Erário e a multa do art. $5^{\circ}$, da Lei $n^{\circ} 10.028 / 2000$. Estas espécies definem a base de cálculo (ou faixa de valores) usada para o cálculo do montante da penalidade pecuniária. As faixas de valores da multa simples estão definidas no art. 268, do RITCU.

Por óbvio, a aplicação da sanção proporcional ao dano ao erário pressupõe a condenação do responsável em débito (responsabilidade financeira reintegratória). Exige-se a mensuração do dano ao erário, montante que servirá de base de cálculo da penalidade pecuniária a ser aplicada.

Ressalto que, para que a sanção seja efetivamente proporcional ao dano ao erário (e não uma sanção com teto de $100 \%$ do dano), a dosimetria da pena deverá ser feita por meio de um percentual fixado e não pelo montante em valores monetários.

Desta forma, duas condutas ilícitas equivalentes deverão ser sancionadas com o mesmo percentual e não com o mesmo valor expresso em moeda nacional. Por exemplo, a omissão no dever de prestar contas dos recursos transferidos por meio de convênio para uma Prefeitura de Pequeno Porte deverá ser sancionada com o mesmo percentual, digamos, 20\% do dano ao Erário. Assegura-se, assim, a proporcionalidade com o dano ao erário, conforme pretendeu o Legislador Constituinte. 
Definida, assim, esta base de cálculo, a multa será graduada com base na avaliação da culpabilidade do responsável, com a remuneração ${ }^{130}$ do responsável e com os seus antecedentes (p. ex. reincidência).

${ }^{130}$ A remuneração é critério adotado para fixação de multa pelo art. $5^{\circ}$, da Lei ${ }^{\circ} 10.028 / 2000$ e pelo art. $65^{\circ}$, da LOPTC (Portugal). 


\section{EXCLUDENTES DE RESPONSABILIDADE}

Na Legislação Brasileira, não estão definidas as hipóteses de exclusão da responsabilidade financeira, cabendo, assim, por analogia, adotar os paradigmas do Direito Civil e do Direito Penal.

As excludentes de responsabilidade são circunstâncias que afastam a responsabilidade do agente pelo ato praticado.

Segundo Pablo Stolze Gagliano e Rodolfo Pamplona Filho (GAGLIANO; PAMPLONA FILHO, 2003, p. 112):

\footnotetext{
"como cláusulas excludentes de responsabilidade civil devem ser entendidas todas as circunstâncias que, por atacar um dos elementos ou pressupostos gerais da responsabilidade civil, rompendo o nexo causal, terminam por fulminar qualquer pretensão indenizatória".
}

A doutrina denomina de "excludentes de ilicitude", circunstâncias como o estado de necessidade, a legítima defesa, o estrito cumprimento do dever legal e o exercício regular de direito e de "excludentes de nexo casual", circunstâncias que rompem este liame causal, tais como, caso fortuito ou de força maior ou culpa exclusiva da vítima ou fato de terceiro.

Luiz Regis Prado denomina as excludentes de ilicitude de "causas de justificação", salientando que, o ordenamento jurídico, nestas hipóteses, permite ou admite a realização de um comportamento típico. A tipicidade, conforme esclarece o autor, é apenas um indício da ilicitude. Ou seja, o fato típico é ilícito, desde que não haja causa justificadora (PRADO, L., 2006).

Nas palavras do autor (PRADO, L., 2006, p. 380-381):

"Toda ação compreendida em um tipo de injusto (doloso ou culposo) será ilícita se não estiver presente uma causa de justificação. Tem-se, pois, que a existência de uma causa justificante faz da ação típica uma ação lícita ou permitida. As causas de justificação contêm um preceito autorizante ou permissivo. Podem ser definidas como sendo particulares situações diante das quais um fato, que de outro modo seria delituoso, não o é porque a lei o impõe ou o consente". 
A seguir, apresentamos as excludentes de responsabilidade previstas no

Direito Civil e Penal pertinentes à responsabilidade financeira.

\title{
16.1. Estado de Necessidade
}

O Estado de Necessidade constitui uma excludente de ilicitude definida no art. 24, do Código Penal ${ }^{131}$ :

\begin{abstract}
"Art. 24 - Considera-se em estado de necessidade quem pratica o fato para salvar de perigo atual, que não provocou por sua vontade, nem podia de outro modo evitar, direito próprio ou alheio, cujo sacrifício, nas circunstâncias, não era razoável exigir-se.

$\S 1^{\circ}$ - Não pode alegar estado de necessidade quem tinha o dever legal de enfrentar o perigo.

$\S 2^{\circ}$ - Embora seja razoável exigir-se o sacrifício do direito ameaçado, a pena poderá ser reduzida de um a dois terços".
\end{abstract}

O estado de necessidade, segundo a doutrina dominante, constitui o sacrifício de um determinado bem jurídico de menor valor, para salvar outro bem jurídico de valor idêntico ou superior. Luiz Regis Prado, entretanto, restringe o campo de abrangência do estado de necessidade justificante, para admitir a excludente de ilicitude somente quando a conduta realizada não implique violação à dignidade da pessoa humana (PRADO, L., 2006).

A partir do disposto no art. 24, do Código Penal, Regis Prado enumera e esclarece os requisitos do estado de necessidade (PRADO, L., 2006, p. 388-389):

a) perígo atual e inevitável:

"significa perigo concreto, presente, imediato, com real possibilidade de dano (insuficiente a mera possibilidade), e que ainda seja dotado de certeza e objetividade. Pode originar-se de ação humana ou de acontecimento natural negativo (v.g., inundação, investida de cão bravo, etc.). Deve ser também não evitável por outro modo, quer dizer, sem o sacrifício do direito, interesse ou bem de outrem. Não se verifica o estado de necessidade se o perigo puder ser arrostado sem ofensa a direito alheio;"

\footnotetext{
${ }^{131}$ No Direito Civil, semelhante excludente de ilicitude encontra-se prevista no art. 188, inciso II, do Código Civil, segundo o qual, não constitui ato ilícito a deterioração ou a destruição da coisa alheia, ou a lesão a pessoa, a fim de remover perigo iminente. $\mathrm{O}$ ato só será legítimo quando as circunstâncias o tornarem absolutamente necessário, não excedendo os limites do indispensável para a remoção do perigo (art. 188, parágrafo unico, CC). Se a pessoa lesada, ou o dono da coisa não forem culpados do perigo assistir-lhes-à direito à indenização do prejuízo que sofreram (art. 929, CC). Se o perigo ocorrer por culpa de terceiro, contra este terá o autor do dano ação regressiva para haver a importância que tiver ressarcido ao lesado (art. 930, CC). O Conceito de Estado de Necessidade do Código Penal é mais abrangente que o do Código Civil, sendo, portanto, mais adequado para aplicação analógica à Responsabilidade Financeira.
} 
b) direito próprio ou alheio, cujo sacrifício não era razoável exigir-se:

"o direito que se pretende salvar pode ser próprio ou de outrem (socorro a terceiro),por motivo de ordem pessoal (amizade, parentesco) ou solidariedade humana. Alcança, portanto, todos os bens jurídicos, como na legítima defesa. $\mathrm{O}$ aspecto da razoável inexigibilidade implica na ponderação objetiva dos bens e interesses em confronto (o bem posto a salvo deve ser superiro ao sacrificado), Faz-se necessária uma proporcionalidade entre a gravidade do perigo e a lesão produzida (entre o em que se sacrifica e o que se sacrifica)".

c) perigo não provocado pela vontade do agente:

"evidencia-se que o agente não pode, por vontade própria, ou de modo intencional, causar a situação de perigo. Isso quer dizer: se agiu com dolo não poderá alegar estado de necessidade. Porém, deve ser ressalvada a conduta culposa (exemplo do incêndio causado em um edifício por culpa do agente, que, para fugir do fogo, produz lesões corporais ou danos)"

d) inexistência do dever de enfrentar o perigo:

"o dever de enfrentar o perigo, dever de auto-sacrifício, de arriscar, é obrigação exclusivamente legal, não compreendendo o dever constratual, ético ou social, inerente a algumas atividades ou profissões (v.g., capitão de navio, bombeiro, policial - art. $24, \S 1^{\circ}$, CP)."

e) requisito subjetivo: ciência da situação fática, vontade ou ânimo (animus salvationis) de salvar o bem ou direito em perigo:

"O agente, além do conhecimento dos elementos objetivos da justificante, deve atuar com o fim, com a vontade de salvamento. Esse requisito subjetivo é indispensável em ambas as espécies de estado de necessidade (justificante ou exculpante)."

No âmbito da Responsabilidade Financeira, o estado de necessidade corresponde à violação de norma de gestão em função de outro valor ou bem jurídico mais relevante, tal como, o direito à saúde. Tal descumprimento deve estar limitado, tão somente, ao indispensável para a proteção do bem jurídico tutelado.

Nosso ordenamento jurídico, entretanto, já prescreve exceções às normas e princípios gerais da gestão, tais como, o da licitação e o do concurso público, destinados à atender situações emergenciais. No art. 24, IV, da Lei $n^{\circ}$ 8.666/93, já está prevista a contratação direta por emergência, na qual, a licitação é vista como um valor de menor importância em relação ao prejuízo ou comprometimento à segurança de pessoas, obras, serviços, equipamentos e outros bens públicos e particulares. Igualmente, no art. 37, IX, da $\mathrm{CF} / 88$, encontra-se prevista a contratação por tempo determinado para atender necessidade temporária de excepcional interesse público. 
Portanto, para que o Estado de Necessidade esteja configurado, a situação poderá ser resolvida com base nestas regras excepcionais previstas no nosso ordenamento jurídico.

São poucos os casos catalogados na Jurisprudência do TCU em que o Estado de Necessidade foi admitido.

No Acórdão n 107/2002 - Plenário (TC n 649.069/1994-1), foi reconhecida a situação de necessidade por parte de um Hospital, quando da contratação direta de pessoal sem concurso público. Entendeu-se que prescindir da mão-de-obra contratada significaria negação ao Direito à Saúde ${ }^{132}$.

No Acórdão n 312/2002 - Plenário, o Tribunal admitiu a contratação de advogados sem concurso público e sem licitação, diante da impossibilidade de nomeação de novos servidores e do elevado número de ações judiciais de interesse da Entidade Pública.

Não obstante, há precedente em que não foi admitida a excludente de ilicitude. Trata-se do Acórdão $n^{\circ}$ 2.202/2008 - $1^{\text {a }}$. Câmara, no qual, a utilização de recursos transferidos para pagamento de folha de pessoal. A justificativa de estado de necessidade caracterizado por débitos com bancos e fornecedores, dívidas trabalhistas, tributárias e

\footnotetext{
${ }^{132}$ Nas palavras do Ministro-Relator: "3. Quanto à contratação direta de pessoal, sem concurso público, tratada no TC 002.272/1994-4, foi denúncia comum aos componentes do complexo a que pertence o Hospital Cristo Redentor, incluindo os Hospitais Nossa Senhora da Conceição e Fêmina. Na assentada referente àqueles autos foram feitas as determinações julgadas necessárias, ficando a apreciação do cabimento de multa com o mérito das contas nos presentes autos. Daí, a unidade técnica opina agora pela aplicação de multa. 4. Todavia, em ocasiões mais recentes, foi concedido, excepcionalmente, registro a atos de admissão na modalidade contestada, realizadas nos anos de 1992, 1993 e 1994 pelo Hospital Conceição. São os TCs 013.011/1996-0 (Decisão 406/2000 Segunda Câmara) 013.012/1996-7 (Decisão 407/2000 - Segunda Câmara) e 013.013/1996-3 (Decisão 408/2000 Segunda Câmara). Assim, entendo que foi reconhecida a situação de necessidade, por parte do Hospital, da manutenção da prestação dos serviços públicos de saúde, sendo que, prescindir da mão-de-obra contratada, poderia significar negação ao direito à saúde, previsto no artigo $6^{\circ}$ da Constituição Federal. Dessa forma, deixo de acatar as proposições de irregularidade das contas e aplicação de multa aos responsáveis".
} 
bloqueio de contas não foi acatada. Asseverou o Ministro-Relator que não foi configurado o Estado de Necessidade, pois, não foi resultante de caso fortuito ou de força maior ${ }^{133}$.

\subsection{Estrito Cumprimento do Dever Legal}

O estrito cumprimento do dever legal é causa justificante prevista no art. 23, inciso III, do Código Penal. Tem por fundamento o princípio lógico da não-contradição, pois, quem cumpre exatamente um dever imposto pela ordem jurídica não comete ato ilícito.

Nas palavras de Regis Prado (PRADO, L., 2006, p. 393):

"Não é possível, pela regra lógica da não-contradição, considerar-se ilícito o comportamento realizado por imposição legal, ressalvada a hipótese de excesso, isto é, cumprimento de um dever legal não estrito, fora da delimitação feita pela lei, e, portanto, abusivo e ilegal. É indispensável, para configurar essa causa de justificação, a rigorosa obediência às condições objetivas a que o dever está subordinado".

Para que se configure a excludente de responsabilidade, o agente deverá cumprir, estrita e regularmente, o dever imposto pela norma, tendo conhecimento do dever e vontade de cumpri-lo, nos exatos limites da lei (PRADO, L., 2006).

Regis Prado salienta que "o indivíduo que realiza uma ação típica em cumprimento de um dever jurídico se encontra em uma situação de colisão de deveres", ou seja, o dever de omitir a ação proibida (ou de realizar a ação, nos crimes omissivos), entra em conflito com o outro dever derivado de outra norma de qualquer setor do ordenamento jurídico (PRADO, L., 2006, p. 394).

A solução do conflito de deveres se dá com base no princípio do interesse preponderante. No caso de dois deveres de mesmo nível, a conduta do sujeito que cumpra qualquer dos deveres será lícita. No caso de deveres diversos, se o dever cumprido for de nível inferior ao infringido, a conduta será ilícita. Há excludente de ilicitude se o sujeito

\footnotetext{
${ }^{133}$ Divirjo, respeitosamente, desta decisão, pois, conforme mencionado por Luiz Regis Prado, o estado de necessidade configura-se, se a situação de perigo não foi gerada pela vontade do agente, não exigindo que seja resultante de caso fortuito ou de força maior. Convém reforçar que tão somente a atuação dolosa do agente na criação do perigo é capaz de descaracterizar o estado de necessidade.
} 
realiza a ação típica em cumprimento de dever jurídico de nível superior ou igual ao de omitir a ação proibida ou de realizar a ação ordenada (PRADO, L., 2006).

No âmbito da gestão pública, a excludente de ilicitude deve ser devidamente ponderada, pois, com base no interesse preponderante, poderia-se simplesmente desprezar o princípio da legalidade em função do atendimento do dever de prestar os serviços públicos, o que é juridicamente impossível em face do art. 37, caput, da CF/88.

Não encontramos, em pesquisa na Jurisprudência do TCU, precedente em que a responsabilidade financeira foi excluída em razão do estrito cumprimento do dever legal. Nada obstante, vislumbramos a possibilidade de exclusão na hipótese em que o gestor cumpra ordem judicial executando determinado pagamento, que na opinião da Corte de Contas seja ensejador da Responsabilidade Financeira. Neste caso, o dever de atender a ordem judicial prevalece sobre os demais deveres constantes da norma de gestão.

\subsection{Exercício Regular de Direito}

O exercício regular de direito, previsto no art. 23, inciso III, do Código Penal, também se fundamenta no princípio lógico da não contradição, pois uma conduta não pode ser, ao mesmo tempo, permitida e proibida pelo Direito.

Segundo Francisco de Assis Toledo, o exercício regular é aquele que se contém nos limites impostos pelo fim econômico ou social do Direito em causa, pela boa-fé e pelos costumes (TOLEDO, 2002). O exercício de um direito com o intuito de prejudicar caracteriza o seu exercício irregular e, nesta hipótese, de abuso de direito, fica excluída a causa de justificação (TOLEDO, 2002).

No âmbito da Administração Pública, esta excludente de ilicitude sofre adaptações, pois ao gestor público não são conferidos direitos, mas sim deveres e poderes, os quais são denominados "deveres-poderes" por Celso Antônio Bandeira de Mello, que 
enfatiza que os poderes são instrumentais em prol do atendimento da finalidade pública (MELLO, 2005).

Desta forma, o exercício regular de uma prerrogativa ou poder da administração constitui causa de justificação de uma conduta tipificada como ilícito de gestão.

Nesta linha, a doutrina italiana, com base na Lei $n^{\circ} 639 / 1996$, sustenta a exclusão da jurisdição da Corte dei Conti, no caso de escolhas discricionárias de mérito.

\subsection{Caso fortuito ou de Força Maior}

A doutrina brasileira diverge significativamente sobre a diferença entre os conceitos de caso fortuito e de força maior. Nada obstante, como suas conseqüências jurídicas são as mesmas (ou seja, exclusão da responsabilidade), convém tratá-las de maneira conjunta.

O art. 393, parágrafo único, do Código Civil define o caso fortuito ou de força maior como o fato necessário, cujos efeitos não era possível evitar ou impedir.

O caso fortuito e a força maior excluem o nexo causal por constituirem causa estranha à conduta aparente do agente, ensejadora direta do evento (CAVALIERI, 2002).

No âmbito dos Tribunais de Contas, o caso fortuito ou força maior é excludente de responsabilidade financeira, bem como, pode atuar como causa de trancamento das contas, se houver impossibilidade material de julgá-las. Convém ressaltar que, em todo caso, é ônus do responsável demonstrar a ocorrência da excludente, não sendo suficiente a mera alegação.

Acerca deste último tópico, dispõe o art. 20, da Lei $\mathrm{n}^{\circ}$ 8.443/92, que "as contas serão consideradas iliquidáveis quando caso fortuito ou de força maior, 
comprovadamente alheio à vontade do responsável, tornar materialmente impossível o julgamento de mérito a que se refere o art. 16 desta lei". Em seguida, o art. 21 da referida Lei preceitua que: "O Tribunal ordenará o trancamento das contas que forem consideradas iliquidáveis e o consequente arquivamento do processo".

A Jurisprudência do TCU tem sido rigorosa na admissão desta excludente de responsabilidade, conforme demonstram os precedentes a seguir.

No Acórdão nº 114/2000 - $1^{\text {a }}$. Câmara, o Tribunal deliberou que a ocorrência de caso fortuito não exime os gestores de dinheiros públicos de demonstrar a correta aplicação dos recursos. No caso concreto, houve um suposto incêndio na Prefeitura com a conseqüente destruição dos docmentos contábeis. O Tribunal entendeu que após esgotado o prazo de prestação de contas dos recursos transferidos, responde o gestor por caso fortuito ou de força maior ocorrido durante o atraso, por aplicação subsidiária do art. 957, do Código Civil (atual art. 399, do CC 2002).

No Acórdão $n^{\circ}$ 115/2005 - 2 $2^{\text {a }}$. Câmara, houve alegação de inacessibilidade de documentos em razão da ocorrência de caso fortuito ou de força maior, consistente na subtração de documentos pelo ex-tesoureiro da Prefeitura. O Tribunal não acatou a alegação em razão, pois, os documentos necessários para a prestação de contas são outros que não os subtraídos e, na época da subtração, o responsável já estava em mora com a prestação de contas.

No Acórdão $\mathrm{n}^{\circ}$ 127/2005 - $2^{\mathrm{a}}$. Câmara, abordou-se a irregularidade: Pagamento fora da vigência do convênio. Foi alegado que o período de inverno obrigou a paralização de obras de construção de um açude, fato alheio à vontade do gestor. As contas do responsável foram julgadas regulares com ressalvas.

No Acórdão n 193/2000 - 1 ${ }^{\text {a }}$. Câmara, o Tribunal não acatou a alegação de destruição dos arquivos da Prefeitura para a omissão no dever de prestar contas, pois o caso 
fortuito ou força maior teria ocorrido durante o atraso e havia a possibilidade de comprovação por outros meios.

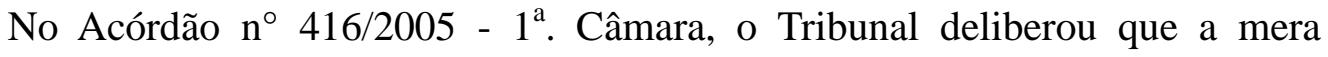
alegação de furto da documentação pertinente não é bastante para suprir a omissão no dever de prestar contas, sendo indispensável, para configurar a ocorrência de caso fortuito ou de força maior que o fato torne materialmente impossível o julgamento das contas, a comprovação de fato impeditivo da vontade do agente de prestá-las.

No Acórdão $\mathrm{n}^{\circ}$ 1.652/2004 - 2 $2^{\mathrm{a}}$. Câmara, o Tribunal acatou as justificativas apresentadas pelo responsável, relativas às irregularidades em conclusão de obra de unidade escolar, em razão da renúncia do Prefeito antes do término do Convênio e da Elevação Extraordinária dos ìndices pluviométricos prejudicando a Construção Civil.

\subsection{Obediência Hierárquica}

Dispõe o art. 22, do Código Penal que, se o fato é cometido sob coação irresistível ou em estrita obediência a ordem, não manifestamente ilegal, de superior hierárquico, só é punível o autor da coação ou da ordem.

Trata-se de excludente de culpabilidade, pois, a possibilidade do indivíduo de agir conforme a norma encontra-se fortemente atenuada. Para que a conduta possa ser reprovável, é indispensável que se lhe possa exigir um comportamento diverso do que teve. De fato, a reprobabilidade da conduta repousa no fato de que o autor devia e podia adotar uma resolução de vontade de acordo com o ordenamento jurídico e não uma decisão voluntária ilícita (PRADO, 2003).

Luiz Regis Prado aponta os requisitos para se admitir a excludente de responsabilidade (PRADO, 2003, p. 135):

\footnotetext{
"Requisitos legais: a) relação de subordinação fundada no Direito Público - vale dizer, a ordem deve advir de uma autoridade pública, dentro da organização do serviço público, o que também inclui os cidadãos, nos casos em que atuam por odem destas autoridades. Excluem-
} 
se, portanto, os casos de subordinação doméstica ou privada; b) ordem não manifestamente ilegal - é preciso que a ordem se refira às relações habituais existentes entre aquele que manda e quem obedece, estando dentro da esfera de competência do primeiro. Se a ordem é manifestamente ilegal, incumbe ao subordinado não cumpri-la. Cumprindo-a, responde pelo ilícito em co-autoria com o superior de quem emanou a ordem; c) estrita obediência da ordem

- é necessário que o cumprimento da ordem do superior fique adstrito aos limites do que nela se contém".

Regis Prado admite que, no caso de não configurada a excludente, poderá o responsável se beneficiar de circunstância atenuante (art. 65, III, $c, 2^{\mathrm{a}}$. parte, CP) (PRADO, 2003).

Em Portugal, o tema é tratado na própria Constituição, conforme art. 271\%/2 e

art. $271 \%$, verbis:

"Artigo 271.

(Responsabilidade dos funcionários e agentes)

(...)

2. É excluída a responsabilidade do funcionário ou agente que actue no cumprimento de ordens ou instruções emanadas de legítimo superior hierárquico e em matéria de serviço, se previamente delas tiver reclamado ou tiver exigido a sua transmissão ou confirmação por escrito.

3. Cessa o dever de obediência sempre que o cumprimento das ordens ou instruções implique a prática de qualquer crime".

$\mathrm{Na}$ Espanha, o art. 39.1, da LOTCu, dispõe que: "Quedarán exentos de responsabilidad quienes actuaren en virtud de obediencia debida, siempre que hubieren advertido por escrito la imprudencia o legalidad de la correspondiente orden, con las razones en que se funden".

Na Itália, Gianni de Luca menciona expressamente a obediência hierárquica como excludente de culpabilidade da responsabilidade administrativa (LUCA, 2008, p. 311):

\footnotetext{
"A obediência às ordens dos superiores hierárquicos constitue um dever específico do funcionário público. Todavia, para que a execução de uma ordem ilegítima não seja fonte de responsabilidade, devem ser seguidas as seguintes condições:

- a competência do órgão superior a emanar a ordem e aquela do órgão inferior de seguí-la;

- a regularidade formal da ordem;

- o ato ordenado não constituir um crime;
} 
- a ordem não deve ser patentemente ilegítima, mas, mesmo neste caso, o funcionário que houver seguido não é responsável se a ordem é renovada por escrito" ${ }^{134}$.

\author{
Na Alemanha ${ }^{135}$, o dever de obediência também não é absoluto. Ele não exime \\ o funcionário da sua responsabilidade pessoal, salvo se suas objeções forem desconsideradas \\ por dois níveis hierárquicos (ALEMANHA, 2009, p. 40) ${ }^{136}$ :
}

\begin{abstract}
"Os funcionários públicos devem aconselhar e apoiar seus superiores, executar as ordens destes últimos e seguir as suas diretrizes gerais. O dever de obediência, entretanto, não os libera da sua responsabilidade pessoal completa. Eles devem examinar a legalidade de uma ordem oficial para seus superiores sem atraso (dever de oposição). Se as ordens são confirmadas, sem que as reservas do funcionário terem sido remediadas, eles devem submetêlas para o próximo nível hierárquico superior. Se o superior confirma a ordem, o funcionário deve executá-la. Neste caso, ele ou ela é liberado de qualquer responsabilidade pessoal. O dever de obediência cessa, em qualquer caso, em que o funcionário violaria a dignidade da pessoa humana ou cometeria um ilícito criminal ou administrativo, se executasse a ordem. $\mathrm{O}$ dever de obediência e o dever de oposição servem para assegurar a habilidade da Administração Pública em funcionar, a qual, caso contrário, poderia ser prejudicada, caso todo funcionário estivesse em posição de negar-se a executar um ato oficial devido às suas reservas quanto à legalidade deste ato" (tradução livre).
\end{abstract}

\title{
O Tribunal de Contas da União é rigoroso também ao admitir esta excludente
}

de responsabilidade.

134 "L' obbedienza agli ordini dei superiori gerarchici costituisce un dovere specifico dell'impiegato pubblico. Tuttavia, perché l'esecuzione di un ordine illegittimo non sia fonte di responsabilità, ocorre che sussistano le seguenti condizioni:

- la competenza dell' organo superiore ad emanare l'ordine e quella dell' organo inferiore ad eserguirla;

- la regolarità formale dell' ordine;

- 1' atto ordinato non deve costituire un reato;

- l' ordine non deve essere palesemente illegitimo, ma, anche in questo caso, l' impiegato che lo ha eseguito non è responsabile se l' ordine è rinnovato per iscritto".

${ }^{135} \mathrm{Na}$ Alemanha, os Tribunais de Contas não possuem sanção sancionatória, portanto, estamos referindo às outras modalidades de responsabilidade.

136 "Civil servants are to advise and support their superiors, carry out the latters' orders and follow their general guidelines. Their duty of obedience does not however release them from full personal responsibility. They must examine the lawfulness of an official order to their immediate superiors without delay (duty of remonstration). If the orders is upheld without the reservations of the civil servant being remedied, they are to turn to the next higher level. If that superior confirms the order, the civil servant must carry it out. In this case, he/she is released from any personal responsability. The duty to obey ceases to apply in any case in which the civil servant would violate human dignity or commit a criminal or administrative offence by carrying it out. The duty of obedience and the duty of remonstration serve to ensure the public administration's ability to function, which otherwise would be impaired if every civil servant were in a position to refrain from carrying out an official act because of the reservations as to the lawfulness of this act". 
No Acórdão n 214/2004 - Plenário, o Tribunal abordou a movimentação irregular de valores, fora da conta única, pelos responsáveis de uma unidade militar. Não foi atribuído o mesmo grau de responsabilidade a todos os responsáveis indicados nos autos, considerando a rigidez e o grau de subordinação hierárquica exigida pelas instituições militares. Segundo o Ministro-Relator, as irregularidades foram cometidas por culpa exclusiva dos seus superiores hierárquicos.

\footnotetext{
No Acórdão $\mathrm{n}^{\circ} 1.978 / 2006$ - $2^{\mathrm{a}}$. Câmara, o Tribunal deliberou que o cumprimento de ordem manifestamente ilegal e a coação resistível não excluem a culpabilidade. Entendeu que são três os requisitos para afastamento da culpabilidade: relação de hierarquia, ordem superiro e ilegalidade da ordem não evidente. O Tribunal considerou que a ordem para assinar laudo de medição atestando a realização da obra é manifestamente ilegal e que, além disso, só havia um depoimento como prova sobre a coação.
}

No Acórdão n 1.380/2008 - Plenário (Acórdão n 2.453/2008 - Plenário), o Tribunal entendeu que a obediência hierárquica vai até onde as ordens superiores não se tornem manifestamente ilegais. Considerou que, ainda que com possibilidade de prejuízo dos seus interesses mais imediatos, os dirigentes subordinados tinham a faculdade e o dever, na época do fato, de se recusarem a assinar os atos de aprovação do projeto irregular. 


\section{CAUSAS DE EXTINÇÃO DA RESPONSABILIDADE}

As causas de extinção da responsabilidade financeira são situações que importam, ou na extinção da obrigação de repor aos cofres públicos, ou na extinção da obrigação de pagar a multa aplicada pelo Tribunal.

A Lei $n^{\circ} 8.443 / 92$ não estabelece as hipóteses de extinção da responsabilidade financeira, cabendo, também, ao intérprete recorrer à analogia com o Direito Estrangeiro e com o Direito Civil Brasileiro.

No Direito Português, as causas extintivas da responsabilidade encontram-se previstas no art. 69, da Lei ${ }^{\circ}$ 98/97:

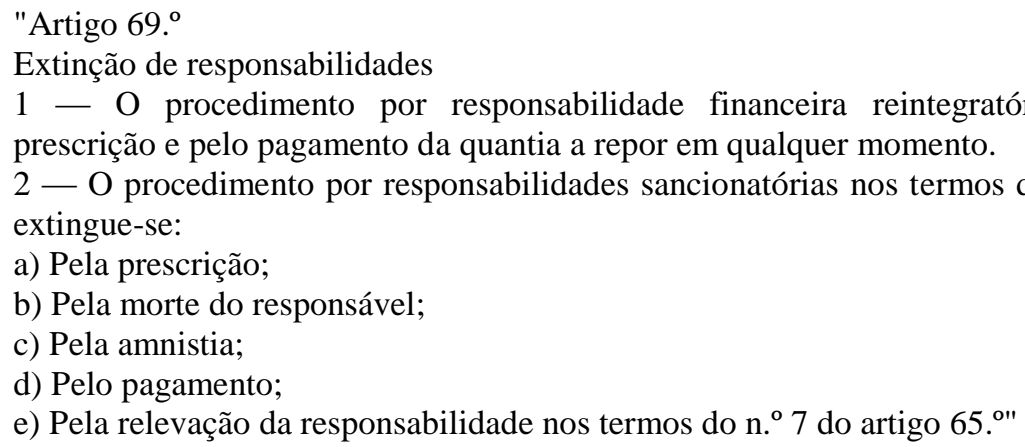

No direito brasileiro, são apenas três as causas de extinção da responsabilidade financeira:
a) o pagamento;
b) o falecimento do responsável, exclusivamente para a responsabilidade financeira sancionatória;
c) a prescrição. 


\subsection{Pagamento}

O pagamento pode ser feito voluntariamente, por meio do depósito nos cofres do Tesouro ou da Entidade da Administração Indireta da quantia fixa, acrescida, se for o caso, de juros de mora e correção monetária, ou ainda, compulsoriamente, mediante desconto nos vencimentos e proventos ou mediante a execução judicial.

O pagamento também pode ser feito parceladamente, por requisição do responsável, nos termos do art. 26, da Lei n 8.443/92. Incide, entretanto, sobre cada parcela os encargos legais. A falta de pagamento de qualquer parcela importa no vencimento antecipado da dívida.

Após o pagamento, o Tribunal concederá quitação (discharge, décharge, discarico) ao responsável. Nas palavras de Augusto Sherman Cavalcanti a quitação (CAVALCANTI, 1999, p. 23):

\footnotetext{
"(...) é um ato administrativo unilateral, vinculado, de competência privativa do Tribunal de Contas da União, em que este declara desonerado o responsável perante a coletividade, em face do adimplemento do dever de comprovar a boa gestão dos bens ou valores públicos colocados à sua disposição, ou, na hipótese de má gestão, de ressarcir o prejuízo causado ao erário e/ou de cumprir a sanção que lhe tenha sido aplicada. A quitação é, portanto, ato administrativo unilateral de natureza declaratória, expedido em face do adimplemento do dever, seja de comprovar a boa gestão dos bens ou valores públicos, seja de ressarcir o prejuízo causado e/ou de cumprir a sanção aplicada. Convém salientar que a expedição da quitação não implica necessariamente a boa gestão dos bens ou valores públicos. A quitação é a declaração de que resta adimplido um dever".
}

\subsection{Falecimento do Responsável}

A morte importa em extinção da responsabilidade financeira sancionatória, mas não da reintegratória, conforme já discutido no princípio da pessoalidade (item 10.4.). Apesar de inexistir previsão legal expressa, a Jurisprudência do TCU tem considerado que a morte é causa de extinção da multa. A responsabilidade reintegratória é transmissível aos sucessores, até o limite do patrimônio transferido na sucessão. 
No caso da responsabilidade financeira reintegratória, que é transmissível aos herdeiros, é razoável condicionar a transmissibilidade à realização de defesa prévia do responsável, ainda em vida. Isto porque, a defesa no âmbito dos Tribunais de Contas geralmente envolve razões, justificativas e informações técnicas (jurídicas, contábeis, etc.), acesso aos documentos públicos, que podem ou não ser sigilosos, de forma que, aos sucessores seria extremamente dificultoso obter após o falecimento do responsável, não possibilitando o desenvolvimento regular de um processo justo (vide art. 213, do RITCU). Ademais, entendo que o dever de prestar contas não é transmissível aos herdeiros e legatários do responsável, mas, tão somente, aos sucessores no cargo, quando admitida a transmissibilidade.

Portanto, caso não seja possível a defesa prévia do responsável em vida, a morte do responsável também será causa de extinção da responsabilidade financeira reintegratória.

\subsection{Prescrição}

A prescrição da responsabilidade financeira é uma das questões mais polêmicas no âmbito do o Tribunal de Contas da União. No tocante à responsabilidade reintegratória, recentemente, o Tribunal tem pacificado sua orientação jurisprudencial para aplicar, analogicamente, o disposto no art. 205, do Código Civil (prescrição residual): "Art. 205. A prescrição ocorre em dez anos, quando a lei não the haja fixado prazo menor". Adotou-se, também, a regra de direito intertemporal prevista no art. 2028, do Código Civil. Neste sentido, podemos citar os Acórdãos ns 330/2007 - 1ª . Câmara, 1.962/2006 - Plenário e 2.103/2006 - Plenário.

Neste sentido, o art. $5^{\circ}, \$^{\circ}$, da Instrução Normativa TCU n ${ }^{\circ} 56 / 2007$, que regula a instauração dos processos de Tomada de Contas Especiais, determina que: "Salvo determinação em contrário do Tribunal, fica dispensada a instauração de tomada de contas especial após transcorridos dez anos desde o fato gerador, sem prejuízo de apuração da responsabilidade daqueles que tiverem dado causa ao atraso, nos termos do art. $1^{o}, \S 1^{o \prime \prime}$. 
No tocante à responsabilidade financeira sancionatória, o Tribunal não firmou sua jurisprudência a respeito do prazo prescricional, limitando-se a decidir não aplicar os prazos previstos na Lei n ${ }^{\circ} 9.873 / 99$ (Acórdãos n $1.727 / 2003-1^{\text {a }}$.Câmara ${ }^{137}$ ).

Sustentou-se, até mesmo, a imprescritibilidade do débito (responsabilidade reintegratória), com base no art. $37, \S 5^{\circ}$, da $\mathrm{CF} / 88$ : "A lei estabelecerá os prazos de prescrição para ilícitos praticados por qualquer agente, servidor ou não, que causem prejuízos ao erário, ressalvadas as respectivas ações de ressarcimento" (grifei).

O Supremo Tribunal Federal acatou a tese da imprescritibilidade no $\mathrm{MS} \mathrm{n}^{\circ}$ 26.210/DF (Rel. Min. Ricardo Lewandowski):

"EMENTA: MANDADO DE SEGURANÇA. TRIBUNAL DE CONTAS DA UNIÃO. BOLSISTA DO CNPq. DESCUMPRIMENTO DA OBRIGAÇÃO DE RETORNAR AO PAÍS APÓS TÉRMINO DA CONCESSÃO DE BOLSA PARA ESTUDO NO EXTERIOR. RESSARCIMENTO AO ERÁRIO. INOCORRÊNCIA DE PRESCRIÇÃO. DENEGAÇÃO DA SEGURANÇA. I - O beneficiário de bolsa de estudos no exterior patrocinada pelo Poder Público, não pode alegar desconhecimento de obrigação constante no contrato por ele subscrito e nas normas do órgão provedor. II - Precedente: MS 24.519, Rel. Min. Eros Grau. III - Incidência, na espécie, do disposto no art. $37, \S 5^{\circ}$, da Constituição Federal, no tocante à alegada prescrição. IV - Segurança denegada".

Acerca da prescrição nas ações de ressarcimento ao erário, a Superior Tribunal de Justiça (STJ) não firmou jurisprudência, apresentando decisões reconhecendo a imprescritibilidade e, outras, reconhecendo a ausência de regulamentação e aplicando a prescrição residual do Código Civil (no caso, o art. 177, do Código Civil de 1917).

No Resp n ${ }^{\circ}$ 705.715/SP (Rel. Min. Francisco Falcão), o STJ deliberou que " $a$ ação de ressarcimento de danos ao erário não se submete a qualquer prazo prescricional, sendo, portanto, imprescritível". No mesmo sentido, no Resp n 586.248/MG (Rel. Min. Francisco Falcão), o STJ entendeu que: "A ação civil pública é imprescritível, porquanto

\footnotetext{
${ }^{137}$ Nas palavras do Ministro-Relator Augusto Sherman: "Não se poderia argüir, tampouco, a utilização da prescrição qüinqüenal prevista na Lei $\mathrm{n}^{\circ}$ 9.873, de 23 de novembro de 1999, tendo em vista, conforme entendimento deste Tribunal, que a referida Lei regula a ação punitiva movida pela Administração Pública Federal e que a atividade judicante desta Corte não tem como fundamento o exercício do poder de polícia, mas sim o exercício do controle externo, de previsão constitucional (Acórdão 71/2000 - Plenário, Acórdão 248/2000 - Plenário e Acórdão 61/2003 - Plenário)".
} 
inexiste disposição legal prevendo o seu prazo prescricional, não se aplicando a ela os ditames previstos na Lei $n^{\circ} 4.717 / 65$, específica para a ação popular".

Em sentido contrário, o Resp n ${ }^{\circ}$ 601.961/MG (Rel. Min. João Octavio de Noronha) entendeu que "A norma constante do art. 23 da Lei $n$. 8.429 regulamentou especificamente a primeira parte do $\S 5^{\circ}$ do art. 37 da Constituição Federal. À segunda parte, que diz respeito às ações de ressarcimento ao erário, por carecer de regulamentação, aplica-se a prescrição vintenária preceituada no Código Civil (art. 177 do CC de 1916)". No mesmo sentido, o AgRG no Ag 993.527/SC (Rel. Min. Castro Meira).

Com a devida vênia, não merece prosperar a tese da imprescritibilidade do ressarcimento ao erário, no âmbito da responsabilidade financeira.

A prescrição é um instituto ligado ao princípio geral da segurança jurídica. Nas palavras de J. J. Gomes Canotilho: "O homem necessita de segurança para conduzir, planificar e conformar autónoma e responsavelmente a sua vida" (CANOTILHO, 2003, p. 257). A imprescritibilidade é, portanto, exceção ao direito fundamental da segurança jurídica, devendo, conforme preconizam as regras elementares de hermenêutica, sofrer interpretação restritiva. No Direito Constitucional Brasileiro, são apenas três os casos de imprescritibilidade, considerando a relevância e a gravidade da matéria. Trata-se do crime de racismo (art. $5^{\circ}, \mathrm{XLII}, \mathrm{CF} / 88$ ), do crime relativo à ação de grupos armados, civis ou militares, contra a ordem constitucional e o Estado Democrático (Art. $5^{\circ}, \mathrm{XLIV}, \mathrm{CF} / 88$ ) e o direito imprescritível dos índios às terras tradicionalmente por eles habitadas em caráter permanente (art. $231, \S 4^{\circ}$, da CF/88).

Convém mencionar que o art. $37, \S 5^{\circ}$, da $\mathrm{CF} / 88$ não utiliza a palavra "imprescritível(is)", como nos demais casos, o que dá ensejo à interpretação de que o prazo prescricional segue o prazo residual do Código Civil, tal como entendeu o STJ. Se, por hipótese, admitíssemos a imprescritibilidade do ressarcimento ao erário, devemos restringir esta interpretação aos ilícitos de maior gravidade. De fato, devemos restringir esta possibilidade aos crimes cuja reprovabilidade está equiparada ao racismo e à ação de grupos armados contra o Estado Democrático. Não se aplica, portanto, a imprescritibilidade à 
responsabilidade financeira, cujo pressuposto subjetivo é a culpa e, muito menos, ao descumprimento de uma obrigação contratual (retorno de um bolsista do CNPQ ao país vide também item 13.1.6.).

Não é incomum, no dia a dia das Cortes de Contas Brasileiras, processos que se arrastam durante anos e deliberações que imputam débito ou aplicam multa por fatos ocorridos há mais de uma década, gerando, obviamente, grande insegurança juridica a quem responde o processo.

Diferentemente da Lei Orgânica do TCU, no Direito Português, a prescrição da responsabilidade financeira está minuciosamente regulada pelo art. 70, da Lei $\mathrm{n}^{\circ}$ 98/97:

\begin{abstract}
"Artigo 70.
Prazo de prescrição do procedimento

1 - É de 10 anos a prescrição do procedimento por responsabilidades financeiras reintegratórias e de 5 anos a prescrição por responsabilidades sancionatórias.

2 - O prazo da prescrição do procedimento conta-se a partir da data da infracção ou, não sendo possível determiná-la, desde o último dia da respectiva gerência.

3 - O prazo da prescrição do procedimento suspende-se com a entrada da conta no Tribunal ou com o início da auditoria e até à audição do responsável, sem poder ultrapassar dois anos.

4 - Nos casos a que se refere o n. ${ }^{\circ} 2$ do artigo $89 .^{\circ}$, o prazo de prescrição do procedimento suspende-se pelo período decorrente até ao exercício do direito de acção ou à possibilidade desse exercício, nas condições aí referidas".
\end{abstract}

Convém observar que o dispositivo supracitado, além de estabelecer os prazos prescricionais, define o momento de início do curso do prazo, as hipóteses de suspensão e, mais interessante, estabelece que a suspensão do prazo prescricional não poderá ultrapassar dois anos. Desta forma, a eventual delonga do Tribunal de Contas na apreciação do mérito do processo não prejudicará o responsável.

No Direito Espanhol, o tema está regulado na segunda e terceira disposições adicionais da Lei $\mathrm{n}^{\circ}$ 07/1988 ${ }^{138}$ (Ley de Funcionamiento del Tribunal de Cuentas). Carlos

\footnotetext{
138 "Segunda. Los Artículos 143 y 144.1 de la ley 11/1977, de 4 de enero, general presupuestaria, quedarán redactados en la forma siguiente:

Artículo 143. En el supuesto del apartado a) Del párrafo 1 del Artículo 141 de esta ley, la responsabilidad será exigida por el tribunal de cuentas mediante el oportuno procedimiento de reintegro por alcance de conformidad con lo establecido en su legislación especifica.

Artículo 144. uno. En los supuestos que describen los apartados b) Al g) Del párrafo 1 del Artículo 141 de esta ley, y sin perjuicio de dar conocimiento de los hechos al tribunal de cuentas a los efectos prevenidos en el
} 
Cubillo Rodriguez resume as principais disposições acerca da prescrição da responsabilidade contábil (RODRIGUEZ, 1999, p. 155-156):

\begin{abstract}
"a) Regla general: Las responsabilidades contables prescriben por el transcurso de 5 años contados desde la fecha en que se hubieren cometido los hechos que las originen.

b) Especialidades:

- Las responsabilidades contables detectadas en el examen y comprobación de cuentas o en cualquier procedimiento fiscalizador y las declaradas por sentencia firme, prescribirán por el transcurso de 3 años, contados desde la fecha de terminación del examen o procedimiento correspondiente o desde que la sentencia firme quedó firme.

- Las responsabilidades contables originadas como consecuencia de hechos constitutivos de delito, prescribirán de la misma forma y en los mismos plazos que las civiles derivadas de esos hechos.

c) Interrupción del plazo de prescripción: El plazo de prescripción se interrumpirá desde que se hubiese iniciado cualquier actuación fiscalizadora, procedimento fiscalizador, disciplinario, jurisdiccional o de otra naturaleza que tuviera por finalidad el examen de los hechos determinantes de la responsabilidad contable, y volverá a correr de nuevo desde que dichas actuaciones o procedimientos se paralicen o terminen sin declaración de responsabilidad".
\end{abstract}

Na Franca, a responsabilidade por multa no âmbito da Cour de Discipline Budgétaire et Financière (CDBF) prescreve no prazo de 5 anos, conforme art. L. 314-2, do CJF: "La Cour ne peut être saisie après l'expiration d'un délai de cinq années révolues à compter du jour où aura été commis le fait de nature à donner lieu à l'application des sanctions prévues par le présent titre". No âmbito da Cour des Comptes, a ação de declaração de gestão de fato prescreve para os atos constitutivos de gestão de fato ocorridos a mais de 10 anos antes da Corte ser acionada. Segundo art. L 131-2, do CJF: "L'action en déclaration de gestion de fait est prescrite pour les actes constitutifs de gestion de fait

Artículo 41.1 de la ley orgánica 2/1982, la responsabilidad será exigida en expediente administrativo instruido al interesado>.

Tercera. 1. Las responsabilidades contables prescriben por el transcurso de cinco años contados desde la fecha en que se hubieren cometido los hechos que las originen.

2. Esto no obstante, las responsabilidades contables detectadas en el examen y comprobación de cuentas o en cualquier procedimiento fiscalizador y las declaradas por sentencia firme, prescribirán por el transcurso de tres años contados desde la fecha de terminación del examen o procedimiento correspondiente o desde que la sentencia quedo firme.

3. El plazo de prescripción se interrumpirá desde que se hubiere iniciado cualquier actuación fiscalizadora, procedimiento fiscalizador, disciplinario, jurisdiccional o de otra naturaleza que tuviera por finalidad el examen de los hechos determinantes de la responsabilidad contable, y volverá a correr de nuevo desde que dichas actuaciones o procedimientos se paralicen o terminen sin declaración de responsabilidad.

4. Si los hechos fueren constitutivos de delito, las responsabilidades contables prescribirán de la misma forma y en los mismos plazos que las civiles derivadas de los mismos". 
commis plus de dix ans avant la date à laquelle la Cour des comptes en est saisie". O mesmo ocorre no âmbito das Chambres Regionales des Comptes, consoante art. L231-3, do CJF.

Na Itália, segundo o art. $1,2^{\circ}$ da Lei ${ }^{\circ} 20$, de 14 de janeiro de 1994, o direito ao ressarcimento do dano prescreve, em todo caso, em cinco anos, decorridos da data em que é verificado o fato danoso, ou, em caso de ocultamento doloso do dano, da data de sua descoberta (Il diritto al risarcimento del danno si prescrive in ogni caso in cinque anni, decorrenti dalla data in cui si è verificato il fatto dannoso, ovvero, in caso di occultamento doloso del danno, dalla data della sua scoperta).

Na Bélgica, o art. $8^{\circ}$, da Lei de 29.10.1846, não fala em prescrição, mas em quitação automática, se a condenação pelo Tribunal de Contas não é pronunciada no prazo de cinco anos, contados a partir da cessação das funções do agente responsável.

A Lei $n^{\circ} 8.443 / 93$, no Brasil, estabelece prazo para o julgamento das tomadas ou prestações de contas, processos em que pode ser efetivada a responsabilidade financeira. Nos termos do art. 14, da Lei $n^{\circ} 8.443 / 92$, "o Tribunal julgará as tomadas ou prestações de contas até o término do exercício seguinte àquele em que estas tiverem sido prestadas".

Como a Lei n 8.443/92, o art. 14, poderia-se cogitar, em analogia à Legislação Belga, em quitação automática ao gestor que não tivesse suas contas julgadas neste prazo. Apesar de considerar que o prazo contido no art. 14 não é meramente um "prazo impróprio" ${ }^{\prime 139}$, como afirmam alguns, entendo que o decurso deste prazo não concede uma quitação automática ao gestor.

Trata-se de prazo (aproximadamente 18 meses, considerando que os processos ingressam no Tribunal de Contas em meados do exercício seguinte ao que as contas se referem) que, em determinadas situações, pode não ser suficiente, bastando fazer uma simples comparação com a legislação estrangeira.

\footnotetext{
${ }^{139} \mathrm{O}$ decurso do prazo do art. 14 , da Lei $\mathrm{n}^{\circ}$ 8.443/92, concede ao gestor o direito de exigir do Tribunal de Contas o julgamento imediato do processo de contas no qual figura como responsável, afinal a quitação é um instituto também ligado à segurança jurídica do gestor.
} 
Supondo que o processo fosse julgado no prazo legal, caberia ainda Recurso de Revisão que poderia ser interposto pelo Ministério Público junto ao Tribunal, no prazo de 5 anos (art. 35, Lei $n^{\circ}$ 8.443/92). Interposto o Recurso, abre-se, novamente, o prazo do art. 14 (aproximadamente 18 meses) para o Tribunal julgar o Recurso de Revisão.

Portanto, na pior das hipóteses, os processos de contas devem ser julgados em aproximadamente 8 anos. Como a responsabilidade financeira só pode ser efetivada no âmbito dos processos de contas, tese que defendo no Capítulo 19, é este o prazo prescricional da responsabilidade, seja da modalidade reintegratória, seja da modalidade sancionatória.

\subsection{Relevação da Responsabilidade}

A relevação da responsabilidade financeira é um instituto do Direito Português, que importa em extinção da obrigação de repor ou de pagar (art. 69\%2, e, LOPTC).

Dispõe o art. 64\% $/ 2$ da LOPTC, que em caso de negligência, o Tribunal de Contas pode reduzir ou relevar a responsabilidade em que houver incorrido o infrator devendo fazer constar da Decisão as razões justificativas da redução ou da relevação. Na antiga Lei Orgânica do Tribunal de Contas de Portugal, a relevação da responsabilidade já estava prevista, conforme art. 50, da Lei n 86/89 (revogada): "O Tribunal pode relevar ou reduzir a responsabilidade financeira em que houver incorrido o infractor, quando se verifique a existência de mera culpa, devendo fazer constar do acórdão as razões justificativas da relevação ou redução".

A relevação da responsabilidade demonstra que a avaliação da culpabilidade não tem por finalidade somente a graduação da multa, mas também, a própria aplicação ou não da sanção financeira. 


\section{PARTE III - ASPECTOS PROCESSUAIS ASPECTOS PROCESSUAIS DA RESPONSABILIDADE FINANCEIRA}




\section{PRINCÍPIOS PROCESSUAIS}

A doutrina e a jurisprudência dominantes reconhecem a aplicação dos princípios do processo administrativo aos processos no âmbito dos Tribunais de Contas. Apesar de não lhe atribuir a natureza jurídica de processo administrativo (pois os Tribunais de Contas não exercem função administrativa típica, mas sim função de controle externo), não há como deixar de reconhecer a grande permeabilidade entre os princípios entre os dois institutos.

Não é sem propósito que a Professora Maria Sylvia Zanella Di Pietro reconhece, no tocante aos procedimentos no âmbito das Cortes de Contas, que (DI PIETRO, 1996, p. 33):

\footnotetext{
"As suas regras procedimentais aproximam-se muito mais das estabelecidas para os procedimentos administrativos do que daquelas fixadas para os processos judiciais; o mesmo se diga com relação aos princípios da gratuidade, oficialidade, pluralidade de instâncias, informalismo, aproveitamento dos atos processuais, todos típicos dos processos administrativos".
}

Não obstante, a autora também admite as diferenças entre as espécies, fato que, no nosso entendimento, é suficiente para afastar a tentativa de se enquadrar o processo no âmbito dos Tribunais de Contas como espécie do "processo administrativo" (DI PIETRO, 1996, p. 33):

"Contudo, apesar das semelhanças com a função administrativa, não se pode colocar a decisão proferida pelo Tribunal de Contas no mesmo nível que uma decisão proferida por órgão integrado à Administração Pública. Não teria sentido que os atos controlados tivessem a mesma força que os atos de controle".

Neste sentido, o STF, no julgamento do MS n 23.550-DF (Rel. Min. Sepúlveda Pertence, DJU 31.10.2001), entendeu que, nas lacunas da Lei $n^{\circ}$ 8.443/92, caberia aplicar a Lei Geral de Processo Administrativo Federal (Lei n 9.784/99):

"EMENTA: I. Tribunal de Contas: competência: contratos administrativos (CF, art. 71, IX e $\S \S 1^{\circ}$ e $2^{\circ}$ ). O Tribunal de Contas da União - embora não tenha poder para anular ou sustar contratos administrativos - tem competência, conforme o art. 71, IX, para determinar à autoridade administrativa que promova a anulação do contrato e, se for o caso, da licitação de que se originou. II. Tribunal de Contas: processo de representação fundado em invalidade de 
contrato administrativo: incidência das garantias do devido processo legal e do contraditório e ampla defesa, que impõem assegurar aos interessados, a começar do particular contratante, a ciência de sua instauração e as intervenções cabíveis. Decisão pelo TCU de um processo de representação, do que resultou injunção à autarquia para anular licitação e o contrato já celebrado e em começo de execução com a licitante vencedora, sem que a essa sequer se desse ciência de sua instauração: nulidade. Os mais elementares corolários da garantia constitucional do contraditório e da ampla defesa são a ciência dada ao interessado da instauração do processo e a oportunidade de se manifestar e produzir ou requerer a produção de provas; de outro lado, se se impõe a garantia do devido processo legal aos procedimentos administrativos comuns, a fortiori, é irrecusável que a ela há de submeter-se o desempenho de todas as funções de controle do Tribunal de Contas, de colorido quase - jurisdicional. $\underline{\mathrm{A}}$ incidência imediata das garantias constitucionais referidas dispensariam previsão legal expressa de audiência dos interessados; de qualquer modo, nada exclui os procedimentos do Tribunal de Contas da aplicação subsidiária da lei geral de processo administrativo federal (L. 9.784/99), que assegura aos administrados, entre outros, o direito a "ter ciência da tramitação dos processos administrativos em que tenha a condição de interessado, ter vista dos autos (art. $\underline{3^{\circ}, \text { II), formular alegações e apresentar documentos antes da decisão, os quais serão objeto de }}$ consideração pelo órgão competente". A oportunidade de defesa assegurada ao interessado há de ser prévia à decisão, não lhe suprindo a falta a admissibilidade de recurso, mormente quando o único admissível é o de reexame pelo mesmo plenário do TCU, de que emanou a decisão" (grifei)

Mais adiante, o STF reiterou este posicionamento, no MS n 24.519-DF (Rel. Min. Eros Grau, DJU 02.12.2005), reconhecendo que os procedimentos previstos no Regimento Interno do Tribunal de Contas devem respeitar os preceitos legais pertinentes ao Processo Administrativo:

"EMENTA: MANDADO DE SEGURANÇA. PROCESSO ADMINISTRATIVO. REGIMENTO INTERNO DO TRIBUNAL DE CONTAS DA UNIÃO. AFASTAMENTO DE OUTROS PRECEITOS LEGAIS. IMPOSSIBILIDADE. CONSTITUCIONAL. AUTONOMIA DAS INSTITUIÇÕES DE PESQUISA CIENTÍFICA E TECNOLÓGICA [ART. 207, CAPUT E $\S 2^{\circ}$ DA CB/88]. LEGITIMIDADE DE SUAS RESOLUÇÕES. FUNÇÃO REGULAMENTAR. OBRIGAÇÃO DE RETORNO DO BENEFICIÁRIO DE BOLSA DE ESTUDOS NO EXTERIOR COM FINANCIAMENTO PÚBLICO IMEDIATAMENTE APÓS O PERÍODO DE CONCESSÃO. REGRESSO APÓS ONZE ANOS. AFASTAMENTO DA RESPONSABILIDADE DE RESSARCIMENTO DO ERÁRIO. IMPOSSIBILIDADE. 1. Embora caiba ao Tribunal de Contas da União a elaboração de seu regimento interno [art. $1^{\circ}$, X, da Lei n., 8.443/92], os procedimentos nele estabelecidos não afastam a aplicação dos preceitos legais referentes ao processo administrativo, notadamente a garantia processual prevista no art. $3^{\circ}$, III, da Lei n. 9.784/99. Precedente [MS n. 23.550, Relator para o acórdão o Ministro SEPULVEDA PERTENCE, DJ 31.10.2001]. 2. O beneficiário de bolsa de estudos no exterior, às expensas do Poder Público, não pode alegar o desconhecimento de obrigação prevista em ato normativo do órgão provedor. 3. A legitimidade das resoluções do CNPq, bem como das demais instituições de pesquisa científica e tecnológica decorre da autonomia conferida pelo artigo 207, caput e $\S 2^{\circ}$, da Constituição do Brasil. 4. O retorno do impetrante ao Brasil onze anos após o encerramento do benefício não afasta --- ante a existência de preceito regulamentar que determinava o regresso imediatamente após o término do período de concessão da bolsa, sob pena de devolução integral dos valores recebidos --- sua responsabilidade pelo ressarcimento do erário. 5. Segurança denegada". (grifei) 
No âmbito dos Tribunais de Contas, existe grande variedade de processos, em atendimento à diversidade de competências legais e constitucionais que lhes foram atribuídas: processos de contas, processos de fiscalização, atos sujeitos a registro, solicitações do Congresso Nacional, representações, denúncias, apreciação das contas de governo, etc.

No âmbito federal, apenas nos processos de contas (tomada e prestação de contas e tomada de contas especial) poderá ser efetivada a responsabilidade financeira reintegratória (Nos processos desta natureza, também poderá ser aplicada multa ao responsável, isolada ou conjuntamente, com a imputação de débito). Caso apurado o débito em processos de outra natureza (por exemplo, nos processos de fiscalização), caberá a sua conversão em Tomada de Contas Especial (art. 47, caput, da Lei n 8.443/92), com vistas a permitir a reposição ao erário. Nos processos de fiscalização (auditorias, inspeções, representações e denúncias), o art. 43, inciso II, da Lei n ${ }^{\circ} 8.443 / 92$, permite a aplicação de multa. Entendo, entretanto, que a responsabilidade financeira deve ser efetivada nos processos de contas (salvo a responsabilidade sancionatória por atos não essencialmente financeiros), conforme argumentos constantes do capítulo 19.

A maior parte dos processos que tramitam nos Tribunais de Contas se aproxima do processo administrativo sem, entretanto, se confundir com estes. Vide, por exemplo, os atos sujeitos a registro. A concessão de aposentadoria é ato administrativo complexo, na visão do STF (MS n² 24.997).

Também não se confundem com o processo civil ou penal, em função do ser rigor e formalismo. Entretanto, nos processos de contas, nos quais pode ser efetivada a responsabilidade financeira, algumas garantias do processo judicial de origem constitucional merecem ser destacadas: a imparcialidade do julgador, a motivação e os princípios do contraditório e da ampla defesa.

Feitas estas considerações, acerca da permeabilidade entre os princípios do processo administrativo e judicial e os do processo contábil, passaremos à analise 
individualizada dos mesmos. Adoto a terminologia "processo contábil" para denominação dos processos que possam dar origem à responsabilidade financeira, em homenagem à doutrina italiana e para distingui-los dos processos de outra natureza: processo civil, penal, trabalhista e administrativo.

\subsection{Princípio da Imparcialidade do Julgador}

Imparcialidade é princípio da jurisdição em qualquer de suas manifestações. Nos processos civil, penal, trabalhista, administrativo ou contábil, há exigência da imparcialidade do julgador como requisito de legitimidade para o exercício desta função estatal.

Segundo Antônio Carlos de Araujo Cintra, Ada Pellegrini Grinover e Cândido Rangel Dinamarco (CINTRA; GRINOVER; DINAMARCO, 1997, p. 51-52):

\footnotetext{
"O caráter de imparcialidade é inseparável do órgão da jurisdição. O juiz coloca-se entre as partes e acima delas: esta é a primeira condição para que possa exercer sua função dentro do processo. A imparcialidade do juiz é pressuposto para que a relação processual se instaure validamente. É nesse sentido que se diz que o órgão jurisdicional deve ser subjetivamente capaz.

(...)

A imparcialidade do juiz é uma garantia de justiça para as partes. Por isso, têm elas o direito de exigir um juiz imparcial: e o Estado, que reservou para si o exercício da função jurisdicional, tem o correspondente dever de agir com imparcialidade na solução das causas que lhe são submetidas".
}

Segundo Fábio Alexandre Coelho, em se tratando de heterocomposição de conflitos, pressupõe-se que os terceiros sejam imparciais, solucionando o conflito conforme a justiça, a razão e o Direito. Salienta o autor que, caso o terceiro solucione o conflito de forma a favorecer uma das partes, mesmo que não tivesse razão, desapareceria sua qualidade de terceiro (COELHO, 2007).

Para Fábio Alexandre Coelho, o princípio da imparcialidade tem por fundamento o princípio da igualdade e o princípio democrático (COELHO, 2007):

"O primeiro, o princípio da igualdade, impõe ao juiz que atue de forma a conferir às partes - 
princípio democrático, por sua vez, impõe que o Estado exerça suas funções - executiva, legislativa e judiciária, - em prol de todas as pessoas, afastando-se, assim, tratamentos diferenciados, o que ocorreria caso o juiz agisse de forma parcial".

Dentre as consequências do princípio da imparcialidade, costuma-se citar o princípio da ação ou da demanda, o princípio do juiz natural, a proibição dos tribunais ou juízos de exceção e a impossibilidade de escolha do juiz que solucionará o conflito.

A Constituição Federal para assegurar a imparcialidade do magistrado, estabeleceu garantias e vedações, conforme art. 95, da CF/88, verbis:

"Art. 95. Os juízes gozam das seguintes garantias:

I - vitaliciedade, que, no primeiro grau, só será adquirida após dois anos de exercício, dependendo a perda do cargo, nesse período, de deliberação do tribunal a que o juiz estiver vinculado, e, nos demais casos, de sentença judicial transitada em julgado;

II - inamovibilidade, salvo por motivo de interesse público, na forma do art. 93, VIII;

III - irredutibilidade de subsídio, ressalvado o disposto nos arts. 37, X e XI, 39, $\S 4^{\circ}, 150$, II, 153, III, e 153, § 2º I. (Redação dada pela Emenda Constitucional nº 19, de 1998)

Parágrafo único. Aos juízes é vedado:

I - exercer, ainda que em disponibilidade, outro cargo ou função, salvo uma de magistério;

II - receber, a qualquer título ou pretexto, custas ou participação em processo;

III - dedicar-se à atividade político-partidária.

IV - receber, a qualquer título ou pretexto, auxílios ou contribuições de pessoas físicas, entidades públicas ou privadas, ressalvadas as exceções previstas em lei; (Incluído pela Emenda Constitucional $n^{\circ} 45$, de 2004)

$\mathrm{V}$ - exercer a advocacia no juízo ou tribunal do qual se afastou, antes de decorridos três anos do afastamento do cargo por aposentadoria ou exoneração. (Incluído pela Emenda Constitucional $n^{\circ} 45$, de 2004)"

Ocorre que as garantias, vedações e impedimentos também são extensíveis aos membros dos Tribunais de Contas, Ministros ou Conselheiros, por força do art. 73 , $\S 3^{\circ}$, da Constituição Federal e aos Auditores (Ministros ou Conselheiros-Substitutos), por força do art. $73, \S 4^{\circ}$, da CF/ $88^{140}$.

\footnotetext{
${ }^{140}$ A partir das garantias conferidas aos membros dos Tribunais de Contas, José Mauricio Conti conclui que as Cortes de Contas não podem ser consideradas meros órgãos auxiliares do Poder Legislativo (CONTI, 1998, p. 21): "O Tribunal de Contas é órgão colegiado, composto de Ministros ou Conselheiros que gozam das mesmas garantias atribuídas à Magistratura, visando, evidentemente, assegurar-lhes independência e tranquilidade para o exercício da função livres de quaisquer pressões que possam interferir na correção de suas decisões. Não teria sentido estabelecerem-se estas regras caso fosse mero órgão auxiliar do Poder Legislativo, a ele subordinado e sujeito às determinações dele oriundas. Portanto, não parece ajustar-se ao modelo estabelecido pela Constituição vigente a posição no sentido de que seja órgão integrante do Poder Legislativo".
} 
Esta extensão não é novidade no Direito Estrangeiro, pois os países que adotam Tribunais de Contas com função jurisdicional, via de regra, também asseguram aos membros do Tribunal de Contas as garantias da magistratura ordinária, no próprio texto constitucional ou na Lei.

Em Portugal, o art. $7^{\circ}$, da LOPTC, estabelece como garantias de independência do Tribunal de Contas: o autogoverno, a inamovibilidade e a irresponsabilidade de seus juízes e a exclusiva sujeição destes à Lei. Ademais, no art. $24^{\circ}$, da LOPTC, os juizes do Tribunal de Contas têm honras, direitos, categoria, tratamento, remunerações e demais prerrogativas iguais às dos juízes do Supremo Tribunal de Justiça, aplicando-se-lhes, em tudo quanto não for incompatível com a natureza do Tribunal, o disposto no Estatuto dos Magistrados Judiciais.

Na Espanha, o artigo 136.3, da Constituição Espanhola, dispõe que: "Los miembros del Tribunal de Cuentas gozarán de la misma independencia e inamovilidad y estarán sometidos a las mismas incompatibilidades que los Jueces".

Na Itália, os membros da Corte dei Conti são denominados de "magistrati contabili" (magistrados contáveis). São recrutados através de concurso público de provas e títulos em que os magistrados ordinários e administrativos, os advogados do Estado, os advogados militares, os funcionários e executivos públicos podem participar, desde que atendam aos requisitos definidos em $\mathrm{lei}^{141}$.

Os magistrados contábeis são agrupados nas seguintes categorias: Presidente; Procurador-Geral, Presidentes de Câmara, Conselheiros, Primeiros Referendários e Referendários. Os Conselheiros, uma vez nomeados, possuem os mesmos direitos, deveres e garantias de outros Magistrados ${ }^{142}$.

\footnotetext{
${ }^{141} \mathrm{http}: / / \mathrm{www} . c 0 r t e c o n t i . i t /$ English-co/story--org/index.asp

${ }^{142}$ http://www.corteconti.it/English-co/story--org/index.asp
} 
Na França, o art. L 120-1, do Code des Jurisdictions Financières (CJF), dispõe que: "Les membres de la Cour des comptes ont la qualité de magistrats. Ils sont et demeurent inamovibles" (Os membros da Corte de Contas tem a qualidade de Magistrados. Eles são inamovíveis). A Corte de Contas Francesa é dirigida por um Primeiro Presidente. O Ministério Público compreende um Procurador-Geral, assistido de Advogados-Gerais. A Corte é composta por sete câmaras, cujos membros são magistrados inamovíveis e recurtados diretamente da Escola Nacional de Administração.

Segundo Gérard Cornu, o termo inamovibilité, no Direito Francês, significa $^{143}$ :

"a situação jurídica daquele que, investido em uma função pública, não pode ser destituído, suspenso, deslocado ou aposentado prematuramente (salvo por falta disciplinar ou razão de saúde e, em casos idênticos, nas condições e formas previstas pela lei), todas vantagens consideradas como uma garantia de independência com relação aos poderes públicos e de imparcialidade no exercício da função. Por exemplo, a inamovibilidade expressamente reconhecida aos magistrados de assento na ordem judiciária e na Corte de Contas".

Na Bélgica, a situação é diferente. A Corte de Contas é composta por duas Câmaras, cada uma das quais composta por um Presidente, quatro Conselheiros e um Escrivão. Os membros são nomeados a cada 6 anos, pela Câmara de Representantes, que tem o direito de destituí-los (art. $1^{\circ}$, Lei de 29.10.1846) ${ }^{144}$.

Como estas garantias e vedações são instrumentais à garantia da imparcialidade do julgador, é forçoso concluir que o princípio da imparcialidade também vigora nos processos que tramitam nos Tribunais de Contas, e mais especificamente, nos processos em que se possa efetivar a responsabilidade financeira, haja vista estar em jogo direitos subjetivos do jurisdicionado à Corte de Contas.

Convém reforçar que o conflito submetido à apreciação do Tribunal de Contas é decorrente da pretensão do Estado à recomposição do dano ao Erário ou à aplicação da

\footnotetext{
143 "Situation juridique de celui qui, investi d'une fonction publique, ne peut être révoqué, suspendu, déplacé (même en avancement) ou mis à la retraite prématurément (sauf pour faute disciplinaire ou raison de santé et, en pareils cas, dans les conditions et les formes prévues par la loi), tous avantages considérés comme une garantie d' independance à l'egard des pouvoirs publics et d'impartialité dans l'exercise de la fonction. Ex. L'inamovibilité expressement reconnue aux magistrats du siège de l'ordre judiciaire et de la Cour des Comptes". ${ }^{144} \mathrm{http}: / / \mathrm{www} . c c r e k . b e$
} 
penalidade pecuniária ao responsável, em razão de violações às normas que regulam a gestão pública.

O membro do Tribunal de Contas ou os Auditores devem estar equidistantes em relação às partes no Processo: o Gestor Público, de um lado e, de outro, o Ministério Público junto ao Tribunal de Contas (ou Ministério Público de Contas) ou a Pessoa Jurídica integrante da Administração Pública. Pender para uma das partes significa retirar o atributo da terzietà e da legitimidade do julgador.

A aplicação do princípio nos processos de efetivação da responsabilidade financeira acarreta diversas conseqüências, as quais destaco a seguir.

Em primeiro lugar, a iniciativa dos processos não pode ser feita pelo próprio julgador. Trata-se da aplicação do princípio da ação ou da demanda no âmbito dos Tribunais de Contas.

Ocorre que os processos de contas são de remessa automática em função do mandamento constitucional: o dever de prestar contas (art. 70, parágrafo único, CF/88). Nada obstante, o art. 81, II, da Lei $\mathrm{n}^{\circ} 8.443 / 92^{145}$ (Lei Orgânica do TCU) dispõe que haverá audiência obrigatória do Ministério Público junto ao TCU nos processos desta natureza.

Em atenção a estas peculiaridades do processo contábil, portanto, a manifestação do Ministério Público no sentido da responsabilização deve ser entendida como condição de procedibilidade do processo de contas, ou seja, condição sine qua non para a instauração de uma fase contenciosa no âmbito do Tribunal de Contas.

\footnotetext{
${ }^{145}$ Art. 81. Competem ao procurador-geral junto ao Tribunal de Contas da União, em sua missão de guarda da lei e fiscal de sua execução, além de outras estabelecidas no regimento interno, as seguintes atribuições: (...) II - comparecer às sessões do Tribunal e dizer de direito, verbalmente ou por escrito, em todos os assuntos sujeitos à decisão do Tribunal, sendo obrigatória sua audiência nos processos de tomada ou prestação de contas e nos concernentes aos atos de admissão de pessoal e de concessão de aposentadorias, reformas e pensões;(...) Art. 82. Aos subprocuradores-gerais e procuradores compete, por delegação do procurador-geral, exercer as funções previstas no artigo anterior.
} 
Caso o Ministério Público manifeste-se no sentido de que não há nos autos elementos da responsabilidade financeira, não poderá o Tribunal de Contas responsabilizar o jurisdicionado, sob pena de violar o princípio da imparcialidade. Em aplicação analógica ao art. 29, do Código de Processo Penal, poderá, entretanto, o Relator encaminhar o processo ao Procurador-Geral.

Afinal, o Ministério Público de Contas é o titular da ação de efetivação da responsabilidade financeira em vários países. Em Portugal, a LOPTC determina a remessa de pareceres e relatórios das ações de controle ao Ministério Público para fins de efetivação das responsabilidades financeiras (art. 5\%/3, art. 57\% e art. 57\%/2). No art. 89\%1, o Ministério Público foi legitimado a requerer o julgamento dos processos de efetivação de responsabilidades financeiras com base nos relatórios de fiscalização. O MP dispõe de poderes instrutórios, para a realização de diligências complementares (art. 29\%6). Na Itália, o Ministério Público junto a Corte dei Conti tem titularidade exclusiva da Ação de Responsabilidade Administrativa (AVALLONE, TARULLO, 2002, p. 147). Na Espanha, o art. 16.2.d, da LFTCu, dispõe que o órgão Fiscalía tem competência para exercitar a ação de responsabilidade contábil e deduzir as pretenções desta natureza nos juízos de contas e nos procedimentos de reintegração por alcance.

Uma segunda consequência, na linha da anterior, diz respeito à definição dos órgãos ou entidades públicas a serem fiscalizados. Tal definição não pode partir dos membros do Tribunal de Contas que irão manifestar-se, posteriormente, sobre os resultados desta fiscalização.

Uma terceira consequência do princípio da imparcialidade diz respeito ao julgamento dos recursos das decisões. Caberá a outro órgão, pleno ou fracionário, do Tribunal de Contas, que não aquele que proferiu a decisão impugnada, deliberar sobre os recursos interpostos, salvo no caso de embargos de declaração. 
São, portanto, inconstitucionais os dispositivos do Regimento Interno do TCU que dispõem acerca do julgamento de recursos pelo órgão fracionário que proferiu a decisão impugnada.

Segundo o art. 15, II, e art. 17, inciso VII, do RITCU, compete ao Plenário ou às Câmaras o julgamento do pedido de reexame e o recurso de reconsideração contra as decisões proferidas pelo próprio órgão deliberativo inicial.

O único elemento de imparcialidade, no julgamento dos recursos pelo TCU, é a alteração de Ministro-Relator ${ }^{146}$, o que é insuficiente para o atendimento do preceito constitucional, pois, o órgão deliberativo é o mesmo, com a mesma composição daquele que deliberou inicialmente.

Convém observar que o art. 134, inciso III, do CPC, estabelece que é vedado ao Magistrado exercer suas funções (impedimento) no processo em que conheceu em primeiro grau de jurisdição, tendo-lhe proferido sentença ou decisão.

Uma última consequência diz respeito à aplicação aos membros do Tribunal de Contas e Auditores dos preceitos contidos nos arts. 134 e 138, do CPC, relativos ao impedimento e à suspeição de Magistrados.

\subsection{Princípio do Contraditório e da Ampla Defesa}

O princípio do contraditório e da ampla defesa tem fundamento no art. $5^{\circ}$, inciso LV, da CF/88. Seu escopo não está limitado ao processo cível ou penal, mas a qualquer atuação estatal que possa vir a afetar direitos ou interesses, incluindo, neste caso, o processo contábil.

\footnotetext{
${ }^{146}$ Segundo o art. 154, do RITCU, há sorteio de novo Relator para os Recursos de Reconsideração, de Revisão e de Pedido de Reexame, não participando do Sorteio o Ministro que houver proferido o voto condutor do Acórdão objeto dos recursos.
} 
Inerentes ao contraditório e à ampla defesa são as faculdades previstas no art. $3^{\circ}$, inciso II, III e IV, da Lei $n^{\circ} 9.784 / 99$ :

a) ter ciência da tramitação dos processos em que tenha a condição de interessado;

b) obter vistas dos autos;

c) obter cópias dos documentos neles contidos e conhecer das decisões proferidas;

d) formular alegações e apresentar documentos antes da decisão;

e) assistência facultativa por advogado.

Algumas faculdades inerentes ao exercício do contraditório e ampla defesa, encontram-se previstas no Regimento Interno do TCU (art. 163 a 167 - vista e cópia dos autos, art. 168 - sustentação oral, art. 145 - representação facultativa por advogado, art. 160 e 161 - alegações de defesa, razões de justificativa e juntada de novos documentos).

Outra faculdade relacionada ao exercício do contraditório e da ampla defesa é a possibilidade do advogado obter vistas dos autos fora do Tribunal. Esta faculdade foi reconhecida por precedente do STF (MS n² 22.314/MS, Rel. Min. Octavio Gallotti, DJU 07.02.1997):

"EMENTA: - Tribunal de Contas da União. Tomada de contas especial. Mandado de segurança deferido, para reconhecimento do direito do advogado constituído a ter vista dos autos, fora da repartição, com as cautelas de praxe, como facultado pelo art. $7^{\circ}, \mathrm{XV}$, da Lei $\mathrm{n}^{\circ}$ 8.906-94 (Estatuto da Advocacia)".

Tamanha a importância destes princípios no âmbito do processo contábil, que o Supremo Tribunal Federal tratou do tema em uma de suas primeiras Súmulas Vinculantes:

"Súmula Vinculante $n^{\circ} 03$

NOS PROCESSOS PERANTE O TRIBUNAL DE CONTAS DA UNIÃO ASSEGURAM-SE O CONTRADITÓRIO E A AMPLA DEFESA QUANDO DA DECISÃO PUDER RESULTAR ANULAÇÃO OU REVOGAÇÃO DE ATO ADMINISTRATIVO QUE BENEFICIE O INTERESSADO, EXCETUADA A APRECIAÇÃO DA LEGALIDADE DO ATO DE CONCESSÃO INICIAL DE APOSENTADORIA, REFORMA E PENSÃO". 
Indispensável no processo de contas, para a efetivação da responsabilidade financeira reintegratória, é a citação (que não se confunde com o ato processual homônimo do Código de Processo Civil), conforme dispõe o art. 12, inciso II, da Lei n ${ }^{\circ}$ 8.443/92:

\footnotetext{
"Art. 12. Verificada irregularidade nas contas, o Relator ou o Tribunal:

(...)

II - se houver débito, ordenará a citação do responsável para, no prazo estabelecido no Regimento Interno, apresentar defesa ou recolher a quantia devida;"
}

A citação, realizada de ofício pelo Relator ou Tribunal, ao mesmo tempo que dá ciência ao responsável da existência do processo contra ele e lhe oferece a oportunidade de defesa, concede-lhe também a oportunidade de quitar o débito imputado, simplificando o processo e permitindo a extinção antecipada do processo. Nas palavras de Jorge Ulisses Jacoby Fernandes (FERNANDES, 1998, p. 345-346):

\footnotetext{
"O que se destaca aqui, como peculiaridade, é o fato de logo no início do chamamento do envolvido ao processo os termos da convocação fazerem referência à faculdade de pagar antecipadamente. Há um fundamento teleológico em tal providência, na medida em que estão sempre subjacentes, em uma TCE, a aplicação de recursos públicos e a preservação da regularidade na composição do erário: quanto antes retornarem à sua integralidade, melhor será para a coletividade.

Desconhecendo essa peculiaridade, muitos causídicos desavisados, ao serem procurados por algum cliente com uma citação em um processo de TCE, destacam, como preliminar, que houve um prejulgamento, porque o chamamento foi para se defender ou pagar. Improcede tal argumentação de cerceamento de defesa, pois:

- O direito de defesa não está sendo prejudicado e a possibilidade de pagar existe como faculdade para o citado;

- a hipótese do pagamento é colocada, na citação, como lembrança de uma possibilidade jurídica de extinção do processo;

- a possibilidade de pagar, no momento da citação, existe nos processos do judiciário em que se discutem os efeitos patrimoniais do pedido;

- o pagamento, por si só, não implica o julgamento pela regularidade, mas garante ao citado o direito de quitação".
}

Para efetivação da responsabilidade financeira sancionatória, indispensável é a realização de audiência do responsável (art. 12, inciso III e art. 43, inciso II, da Lei $\mathrm{n}^{\circ}$ 8.443/92). Imprescindível, também, para o exercício do direito ao contraditório e da ampla defesa, que o responsável tenha ciência do ato ilícito a ele imputado (circunstâncias de fato) e da norma ou princípio infringido. Caso o ato ilícito seja caracterizado como "grave infração à norma legal ou regulamentar de natureza contábil, financeira, orçamentária, operacional e patrimonial", indispensável que o ato que ordene a audiência seja motivado, justificando o enquadramento do ato ilícito como "grave infração". Deve-se permitir, assim, que o acusado, 
no exercício do contraditório e da ampla defesa, ainda que reconheça o ilícito financeiro, se oponha ao seu enquadramento como "grave infração".

Em Portugal, o art. 13\%/2, da LOPTC, concede uma garantia ainda mais ampla, sendo assegurado aos responsáveis, previamente à instauração dos processos de efetivação de responsabilidades bem como dos processos de multa, o direito de serem ouvidos sobre os factos que lhes são imputados, a respectiva qualificação, o regime legal e os montantes a repor ou a pagar, tendo, para o efeito, acesso à informação disponível nas entidades ou organismos respectivos. A oitiva acerca do regime legal aplicável tem especial importância em gestão pública, considerada a complexidade da legislação e a sua pluralidade de fontes.

Ante o exposto, é ilegal e inconstitucional o disposto no art. $267, \S 2^{\circ}$, do RITCU:

\footnotetext{
"A multa aplicada com fundamento nos incisos IV, V, VI, VII ou VIII prescinde de prévia audiência dos responsáveis, desde que a possibilidade de sua aplicação conste da comunicação do despacho ou da decisão descumprida ou do ofício de apresentação da equipe de fiscalização".
}

A defesa oposta em decorrência de uma citação, incluindo seus documentos anexos, é denominada pela Lei n ${ }^{\circ} 8.443 / 92$ de "alegações de defesa". A defesa em resposta à uma audiência é denominada pelo mesmo diploma de "razões de justificativa".

Admite-se, nada obstante, a adoção de providências cautelares (suspensão do ato ou procedimento impugnado), sem o contraditório e a defesa prévios, em caso de urgência, de fundado receio de grave lesão ao erário ou a direito alheio ou, ainda, de risco de ineficácia da decisão de mérito, nos termos do art. 276, do Regimento Interno do TCU. Cumpre lembrar que o Poder Cautelar dos Tribunais de Contas foi reconhecido pelo STF, no bojo do MS n 24.510-DF (Rel. Min. Ellen Gracie, Informativo STF n 330).

A providência cautelar, adotada pelo Relator ou pelo Presidente do Tribunal, deverá ser referendada pelo Plenário. Caso confirmada pelo colegiado, será determinada a oitiva da parte ou interessado para que se pronuncie no prazo de 15 dias (art. 276, $3^{\circ}$, RITCU). 


\subsection{Princípio do Informalismo ou do Formalismo Moderado}

O princípio da informalismo significa que, dentro da lei, sem quebra da legalidade, pode haver dispensa de algum requisito formal, sempre que sua ausência não prejudicar terceiros nem comprometer o interesse público (FERRAZ; DALLARI, 2007, p. 102). O princípio da informalidade significa que devem ser observadas as formalidades estritamente necessárias à obtenção da certeza e da segurança jurídicas e ao atingimento dos fins almejados pelo sistema normativo. Deve-se dar maior prestígio ao espírito da lei que à sua literalidade, no tocante ao iter estabelecido pela norma jurídica deisciplinadora do processo (FERRAZ; DALLARI, 2007, p. 102).

Para Jorge Ulisses Jacoby Fernandes, justifica-se o abrandamento dos rigores formais em benefício dos responsáveis. Como conseqüências do princípio do "informalismo moderado", o autor cita o caso dos prazos (FERNANDES, 1998):

\footnotetext{
"Não é incomum que se releve, em caráter excepcional, o prazo de defesa, quando excedido por curto lapso temporal, seguido de justificativa. Nesse sentido, destaca-se o fato de que, fora do prazo recursal, dano entrada a prestação de contas - cuja omissão tinah ensejado a condenação da autoridade -, o Tribunal pode acolhê-la como recurso, mantendo a irregularidade, mas dando a quitação.

No âmbito do TCDF, na aplicação desse princípio, amparados em Diógenes Gasparini, sustentamos a possibilidade de se acolher, em caráter excepcional, defesa oferecida alguns dias fora do prazo, visando, no caso concreto, resguardar o direito de ampla defesa".
}

Outros exemplos de aplicação do informalismo moderado são apontadas pelo autor: defesa subscrita por procurador sem o instrumento do mandato, cópias sem autenticação e uso do fax para ingresso de recursos.

Nesta linha, o Acórdão TCU n 37/2007 - Plenário estatui que

"É possível, em caráter excepcional, relevar a ausência de preenchimento dos pressupostos de admissibilidade contidos no art. 35 da Lei 8.443/92, com fundamento nos princípios do formalismo moderado e da verdade material, sobretudo se detectado rigor excessivo no julgamento pela irregularidade das contas". 
Outra deliberação interessante é o Acórdão 1269/2005 - Primeira Câmara, a qual diz respeito ao esgotamento de prazo para interposição de recursos: "Constatando-se curto espaço de tempo entre o término do prazo previsto e a apresentação dos embargos declaratórios, devem estes ser conhecidos em homenagem ao princípio do formalismo moderado".

No mesmo sentido, o Acórdão n ${ }^{\circ}$ 1564/2006 - Plenário: "É possível, em caráter excepcional, relevar a intempestividade na interposição de recurso, com fundamento nos princípios do formalismo moderado e da verdade material, a fim de afastar qualquer alegação de cerceamento de defesa".

\subsection{Princípio da Motivação}

O princípio da motivação, no âmbito dos Tribunais de Contas, decorre de aplicação analógica do art. 93, inciso X, da CF/88.

No âmbito administrativo, o princípio da motivação determina que a autoridade administrativa deve apresentar as razões que a levaram a tomar uma decisão. 'Motivar' significa explicitar os elementos que ensejaram o convencimento da autoridade, indicando os fatos e os fundamentos jurídicos que foram considerados. Sem a explicitação dos motivos torna-se extremamente difícil sindicar, sopesar ou aferir a correção daquilo que foi decido. 'Motivação' não se confunde com 'fundamentação', que é a simples indicação da específica norma legal que supedaneou a decisão adotada (FERRAZ; DALLARI, 2007, p. 76-77).

No âmbito do Tribunal de Contas da União, dispõe o art. $1^{\circ}, \S 3^{\circ}$, da Lei $n^{\circ}$ 8.443/92 (Lei Orgânica do TCU) que:

\footnotetext{
"Art. $1^{\circ}(\ldots)$

$\S 3^{\circ}$ Será parte essencial das decisões do Tribunal ou de suas Câmaras:

I - o relatório do Ministro-Relator, de que constarão as conclusões da instrução (do relatório da equipe de auditoria ou do técnico responsável pela análise do processo, bem como do parecer das chefias imediatas, da unidade técnica), e do Ministério Público junto ao Tribunal; II - fundamentação com que o Ministro-Relator analisará as questões de fato e de direito; III - dispositivo com que o Ministro-Relator decidirá sobre o mérito do processo".
} 
Assim sendo, todas as deliberações dos Tribunais de Contas, no exercício de suas competências legais e constitucionais, incluindo a efetivação da responsabilidade financeira, deverão ser motivadas, exigindo-se que as deliberações atendam a estrutura especificada no dispositivo supracitado, muito semelhante ao que dispõe o art. 458, do Código de Processo Civil.

Ainda que não houvesse a previsão legal específica, a aplicação subsidiária da Lei $\mathrm{n}^{\circ}$ 9.874/99 importaria exigir motivação para os atos que "imponham ou agravem deveres, encargos ou sanções" (art. 50, II, Lei n 9.784/99). A motivação é exigida, inclusive, para deliberações colegiadas, nos termos do art. 50, $\S 3^{\circ}$, da Lei $n^{\circ} 9.784 / 99$.

A motivação, no processo contábil, além de ser mecanismo de garantia do responsável, é também meio de controle da conduta dos Ministros e Conselheiros dos Tribunais de Contas. Não é por outra razão que o art. $1^{\circ}, \S 3^{\circ}$, inciso I, da Lei $n^{\circ} 8.443 / 92$ exige que as conclusões da equipe técnica do Tribunal constem do Relatório do Acórdão do TCU. Assim, permite-se o confronto do Parecer Técnico com o que foi decidido pelo Colegiado.

\subsection{Princípio do Custo-Benefício do Controle}

O princípio da relação custo-benefício do controle é correlato ao princípio da economia processual e da instrumentalidade das formas do Direito Processual Civil.

Considerando que o processo é um instrumento destinado à solução de disputas, não se pode exigir um dispêndio exagerado em relação aos bens que estão em disputa. No processo civil, são exemplos de aplicação deste princípio o aproveitamento de atos processuais, a reunião de processos em casos de conexidade ou continência e os juizados especiais (CINTRA; GRINOVER; DINAMARCO, 1997, p. 73-74).

No âmbito do Controle da Gestão Pública, Jorge Ulisses Jacoby Fernandes (FERNANDES, 2003, p. 42) esclarece o conteúdo do princípio: 


\begin{abstract}
"Significa isso que o custo de um controle não pode exceder os benefícios que dele decorrem, ou o custo que haveria com o descontrole. Trata-se da aplicação de antiga regra de controle, inserida no Direito Positivo Pátrio, assim redigida: 'o trabalho administrativo será racionalizado mediante simplificação de processos e supressão de controles que se evidenciarem puramente formais ou cujo custo seja evidentemente superior ao risco'. (...) Deste modo, tanto pode justificar a expansão de determinada atividade de controle, como sua redução. De fato, sendo atividade meio, o controle não pode se sobrepor, em custos, aos órgãos que se dedicam à atividade fim, seja em estrutura material, seja no procedimento imposto".
\end{abstract}

Este princípio influencia a efetivação da responsabilidade financeira de forma a racionalizar a cobrança dos débitos ou das multas, consoante exemplos a seguir.

Em primeiro lugar, admite-se a execução administrativa do débito ou da multa, por meio de desconto da dívida nos vencimentos ou proventos do responsável, na forma da legislação pertinente (art. 28, I, da Lei n 8.443/92). Evita-se, assim, os custos e a morosidade envolvidos na execução judicial da dívida. Entretanto, só é possível quando o agente ainda mantém algum vínculo com a Administração Pública.

Outro exemplo é o do envio de processos de tomada de contas especiais ao Tribunal para julgamento (em valores inferiores a um mínimo fixado por ato normativo do tribunal) juntamente com o processo de contas anual do órgão ou entidade (art. $8^{\circ}, \S \S 2^{\circ}$ e $3^{\circ}$, Lei $n^{\circ}$ 8.443/92). Pressupõe-se que o processamento conjunto da Tomada de Contas Especial instaurada pelo órgão e entidade e do Processo de Contas Anuais seja menos onerosa que a tramitação em separado.

Por fim, há, ainda, a possibilidade de arquivamento do processo de efetivação da responsabilidade financeira, nos termos do art. 93, da Lei ${ }^{\circ}$ 8.443/92:

\footnotetext{
"Art. 93. A título de racionalização administrativa e economia processual, e com o objetivo de evitar que o custo da cobrança seja superior ao valor do ressarcimento, o Tribunal poderá determinar, desde logo, o arquivamento do processo, sem cancelamento do débito, a cujo pagamento continuará obrigado o devedor, para que lhe possa ser dada quitação".
}

Entretanto, o dispositivo em tela deve sofrer interpretação conforme à Constituição, ou seja, caso o TCU decida promover o arquivamento do processo, deverá 
também promover o cancelamento do débito, se não atendidos os princípios de direito processual aqui expostos. O princípio do custo-benefício do controle não pode implicar em prejuízo ao devido processo legal.

\subsection{Princípio da Inversão do Ônus da Prova}

Um aspecto que diferencia o processo contábil do processo administrativo é o do ônus da prova.

A doutrina processual costuma afirmar que as regras do ônus da prova não são regras procedimentais, mas regras de julgamento, cabendo ao julgador, quando da prolação da sentença, proferir julgamento contrário àquele que tinha o ônus da prova e dele não se desincumbiu (DIDIER JR, 2008b).

A inversão do ônus da prova, no âmbito do processo contábil, se dá na medida em que o gestor de recursos públicos é a pessoa mais adequada para provar a regularidade dos atos de gestão que praticou. É ele quem dispõe dos documentos e das informações detalhadas acerca dos atos que praticou.

Da mesma forma que na "responsabilità contabile" Italiana (vide item 6.4.), a responsabilidade financeira assemelha-se à responsabilidade do depositário, que, diante de uma perda ou falta constatada nos recursos sob sua administração e vigilância, deve demonstrar que cumpriu os deveres inerentes ao seu cargo ou que a falta constatada deve-se a caso fortuito ou de força maior.

Não admitida esta inversão, bastaria ao gestor público infrator destruir documentos pertinentes aos seus atos irregulares e permanecer em silêncio, para nunca ser responsabilizado pelo Tribunal de Contas, com os meios e instrumentos de prova que dispõe (não se admite no processo contábil a prova testemunhal, a quebra de sigilo bancário e a interceptação telefônica). 
Não presentes estes pressupostos (disponibilidade de documentos e informações detalhadas acerca dos atos praticados), não cabe inverter o ônus da prova, tal como, no caso da responsabilização de particulares que não sejam gestores públicos equiparados ou dos herdeiros e legatários que não têm acesso às informações e documentos.

O fundamento constitucional desta inversão está no art. 70, caput, da CF/88, ou seja, a inversão do ônus da prova é corolário do dever constitucional de prestar contas. O dever de prestar contas não é o mero encaminhamento de documentos e informações às autoridades administrativas e ao Tribunal de Contas. Compreende a demonstração de que os atos de gestão foram regulares, sob os aspectos da legalidade, legitimidade e economicidade.

Na legislação ordinária, esta inversão encontra-se prevista no art. 93, do Decreto-Lei n ${ }^{\circ}$ 200/67: "Art. 93. Quem quer que utilize dinheiros públicos terá de justificar seu bom e regular emprêgo na conformidade das leis, regulamentos e normas emanadas das autoridades administrativas competentes".

Ademais, o art. 113, caput, da Lei $\mathrm{n}^{\circ} 8.666 / 93$ dispõe que

\begin{abstract}
"Art. 113. O controle das despesas decorrentes dos contratos e demais instrumentos regidos por esta Lei será feito pelo Tribunal de Contas competente, na forma da legislação pertinente, ficando os órgãos interessados da Administração responsáveis pela demonstração da legalidade e regularidade da despesa e execução, nos termos da Constituição e sem prejuízo do sistema de controle interno nela previsto".
\end{abstract}

No Processo Contábil, são admitidas a prova emprestada e a prova documental, nos termos do art. 162, do RITCU, verbis: "Art. 162. As provas que a parte quiser produzir perante o Tribunal devem sempre ser apresentadas de forma documental, mesmo as declarações pessoais de terceiros".

O documento corresponde a "toda coisa que, por força da atividade humana, seja capaz de representar um fato" (DIDIER JR, 2008b, p. 131). A prova emprestada, por sua vez, é "a prova de um fato, produzida em um processo, seja por documentos, testemunhas, confissão, depoimento pessoal ou exame pericial, que é 
transladada para outro processo, por meio de certidão extraída daquele. A prova emprestada ingressa no outro processo sob a forma de prova documental" (DIDIER JR., 2008b, p. 51).

Quanto ao momento de produção da prova, o Acórdão n ${ }^{\circ} 2.926 / 2006-1^{\text {a }}$. Câmara define que a prova deve ser produzida na oportunidade da resposta à citação e audiência, sendo facultada a juntada de novos documentos até o término da instrução.

Entretanto, como no processo contábil, não há fase de saneamento, para que possa operar a inversão do ônus da prova, após realizada a citação e audiência, deverá ser concedida nova oportunidade de juntada de documentos, apontando-se os fatos considerados controvertidos pelo Tribunal de Contas. 


\section{PROCEDIMENTO NO ÂMBITO DOS TRIBUNAIS DE CONTAS}

Examinados os princípios que regulam o procedimento de efetivação da responsabilidade financeira, passamos a analisar mais detalhadamente a Lei Federal $\mathrm{n}^{\circ}$ 8.443/93 (LOTCU). Convém mencionar que, no tocante ao rito procedimental, pode haver enormes divergências entre os Tribunais de Contas dos Estados e o Tribunal de Contas da União.

São diversos os processos ${ }^{147}$ que podem tramitar no Tribunal de Contas. Cada um destes processos está associado a uma competência legal ou constitucional específica atribuída à Corte de Contas.

Segundo a Lei $n^{\circ} 8.443 / 92$, apenas os processos de contas e os processos de fiscalização ${ }^{148}$ podem efetivar a responsabilidade financeira. Os processos de contas são de três espécies: prestação de contas, tomada de contas e tomada de contas especial.

Estes conceitos não estão definidos em Lei, mas em Instrução Normativa do Tribunal de Contas da União.

A tomada de contas é o "processo de contas relativo à avaliação da gestão dos responsáveis por unidades jurisdicionadas da administração federal direta" (art. $1 .^{\circ}, \S$ 1. ${ }^{\circ}$ II, da Instrução Normativa TCU 57/2008).

A prestação de contas, por sua vez, é o "processo de contas relativo à avaliação da gestão dos responsáveis por unidades jurisdicionadas da administração federal indireta e por aquelas não classificadas como integrantes da administração federal direta" (art. 1. ${ }^{\circ}, \S 1 .^{\circ}$, III, da Instrução Normativa TCU 57/2008).

\footnotetext{
${ }^{147} \mathrm{O}$ termo "processo" aqui não é adotado no sentido técnico-processual. Nem todas os "processos" submetidos a apreciação do Tribunal de Contas referem-se à solução de litígios.

${ }^{148}$ Nada obstante, conforme será tratado a seguir, entendo que a responsabilidade financeira, em quaisquer de suas modalidades, só poderá ser efetuada no âmbito dos procesos de contas e não nos processos de fiscalização.
} 
Por fim, a Tomada de Contas Especial é "um processo devidamente formalizado, com rito próprio, para apurar responsabilidade por ocorrência de dano à administração pública federal e obtenção do respectivo ressarcimento" (art. 3. ${ }^{\circ}$, caput, Instrução Normativa TCU 56/2007).

As tomadas e prestações de contas devem ser encaminhadas de forma automática ao Tribunal de Contas, após o final de cada exercício financeiro. As tomadas de contas especiais, que não tem o caráter períódico, podem ser oriundas de conversão de processo de fiscalização em tramitação no Tribunal de Contas ou encaminhadas de forma automática pelo órgão ou entidade da Administração Pública responsável pela sua apuração nos termos do art. $8^{\circ}$, da Lei $n^{\circ} 8.443 / 92$ :

\footnotetext{
"Art. $8^{\circ}$ Diante da omissão no dever de prestar contas, da não comprovação da aplicação dos recursos repassados pela União, na forma prevista no inciso VII do art. $5^{\circ}$ desta lei, da ocorrência de desfalque ou desvio de dinheiros, bens ou valores públicos, ou, ainda, da prática de qualquer ato ilegal, ilegítimo ou antieconômico de que resulte dano ao erário, a autoridade administrativa competente, sob pena de responsabilidade solidária, deverá imediatamente adotar providências com vistas à instauração da tomada de contas especial para apuração dos fatos, identificação dos responsáveis e quantificação do dano".
}

Convém não confundir a "prestação de contas", espécie do gênero processo de contas, com a prestação de contas em sentido amplo, dever constitucional de todo aquele que efetue a gestão de bens, dinheiros e valores públicos (art. 70, parágrafo único, CF/88). Nem toda prestação de contas em sentido amplo é submetida a julgamento pelo Tribunal de Contas. Por exemplo, a prestação de contas lato sensu de um órgão subalterno pode ser consolidada no órgão superior na hierarquia administrativa, e a versão consolidada encaminhada para julgamento no Tribunal de Contas. A forma e a organização dos processos de tomada ou prestação de contas também é definida em Instrução Normativa do Tribunal de Contas, consoante o Poder Regulamentar conferido no art. $3^{\circ}$, da Lei ${ }^{\circ}$ 8.443/92.

Os processos de "apreciação das contas de governo" (art. 71, I, CF/88 e art. 36, Lei $n^{\circ} 8.443 / 92$ ), de consulta (art. $1^{\circ}$, inciso XVII, da Lei $n^{\circ} 8.443 / 92$ ), de apreciação de atos sujeitos a registro (atos de admissão, de concessão de aposentadorias, reformas e pensões - art. 71, III, CF/88 e 39 e 40, Lei n 8.443/92) e de solicitação de informações (art. 
71, VII, CF/88) não tem aptidão para imputar débito ou aplicar multa ao gestor público faltoso.

A Lei $n^{\circ} 8.443 / 92$ estabelece, também, que apenas nos processos de contas, é possivel efetivar a responsabilidade financeira reintegratória. Se verificados os pressupostos da responsabilidade financeira reintegratória em um processo de fiscalização, ele deverá ser convertido em Tomada de Contas Especial (art. 47, caput, Lei n 8.443/92).

Entendo que não é adequada a responsabilização financeira, em qualquer de suas modalidades (sancionatória ou reintegratória), em outros processos que não sejam os

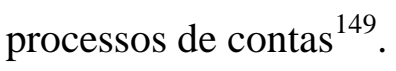

Em primeiro lugar, é o processo de contas o instrumento pelo qual se avalia a gestão de um responsável. Se a responsabilidade financeira é justamente uma censura à conduta adminstrativa-financeira de um responsável, nada mais natural que tanto a imputação de débito, quanto a aplicação de multa sejam conseqüencias da avaliação de sua gestão.

Em segundo lugar, a participação do Ministério Público junto ao TCU só é obrigatória nos processos de contas, conforme art. 81, II, da Lei n ${ }^{\circ}$ 8.443/92. Aplicar multa sem a atuação efetiva do Ministério Público é violar o princípio da imparcialidade, que tem por corolário o princípio da ação ou da demanda.

Em terceiro lugar, não há nos processos de fiscalização o instituto da quitação, que exonera o gestor dos deveres e obrigações relativas a uma determinada gestão.

Por fim, caso admitíssemos a possibilidade de aplicação de multa nos processos de fiscalização, seria necessária uma compatibilização entre o processo de fiscalização e o processo de contas correspondente ao exercício financeiro fiscalizado. Não

\footnotetext{
${ }^{149}$ Ressalvo, entretanto, a responsabilidade decorrente de violação de deveres de colaboração com o Tribunal, que não consiste na apreciação da gestão do responsável.
} 
faz sentido, por exemplo, censurar-se uma conduta no processo de fiscalização e depois julgar regulares as contas do responsável. A exigência de vinculação tem por finalidade a coerência entre as deliberações em ambos os processos e evitar a dupla penalização, uma vez que, nos processos de contas, são levados em consideração todos os atos que afetam aquela gestão.

Desta forma, seria mais racional e efetivo que apenas as medidas corretivas ou preventivas fossem adotadas nos processos de fiscalização. Os resultados das auditorias deveriam ser encaminhados ao Ministério Público para, caso julgue existir os pressupostos da responsabilidade financeira sancionatória, submeta ao Tribunal proposta de audiência dos responsáveis no processo de contas ordinárias (instaurando a fase contenciosa do processo de contas).

Deve-se, entretanto, excepcionar a aplicação de multas em decorrência de violação do dever de colaboração com o Tribunal. Neste caso, o sancionamento do responsável não tem relação com a sua gestão. Trata-se de responsabilidade financeira sancionatória por atos não essencialmente financeiros.

Feitas estas considerações iniciais, abordo o procedimento dos processos de contas nas seguintes etapas:
a) iniciativa;
b) medidas preliminares;
c) fase contenciosa;
c) julgamento de mérito
d) recursos no âmbito do Tribunal de Contas;
e) execução das decisões.

A iniciativa dos processos de contas é do próprio órgão ou entidade, nos termos do art. 70, parágrafo único, da CF/88 (dever constitucional de prestar contas). 
Conforme mencionei anteriormente, se as irregularidades foram constatadas em processos de fiscalização, entendo necessária a manifestação do Ministério Público para inclusão da matéria no processo de contas correspondente ou para conversão do processo em Tomada de Contas Especial, em respeito ao princípio da imparcialidade (item 18.1.).

Se o processo for de encaminhamento automático, o Ministério Público deve apreciar o processo e, caso julgue presentes irregularidades nas contas, deverá requerer ao ao Ministro-Relator a instauração da fase contenciosa.

Previamente à fase contenciosa, poderão ser adotadas medidas de saneamento, tais como, inspeção "in loco" ou a realização de diligência para obtenção de maiores informações que visem o esclarecimento de determinadas lacunas nos autos.

Segundo esclarece o art. 240, do RITCU, a Inspeção "é o instrumento de fiscalização utilizado pelo Tribunal para suprir omissões e lacunas de informações, esclarecer dúvidas ou apurar denúncias ou representações quanto à legalidade, à legitimidade e à economicidade de fatos da administração e de atos administrativos praticados por qualquer responsável sujeito à sua jurisdição".

Diligências são solicitações de informações e/ou documentos, por meio de Ofício dirigido aos responsáveis pelos órgãos ou entidades públicas, ou até mesmo, para instituições privadas, com vistas a supressão de lacunas dos autos. O não atendimento à diligência constitui violação ao dever de colaboração com o Tribunal ensejando a aplicação de multa (responsabilidade financeira sancionatória por ato não essencialmente financeiro).

Não observando irregularidades ou apenas falhas de caráter formal, caberá o Ministério Público junto ao TCU solicitar, de plano, o julgamento das contas regulares ou regulares com ressalvas, nos termos dos artigos 16, incisos I e II, da Lei n 8.443/92:

\footnotetext{
"Art. 16. As contas serão julgadas:

I - regulares, quando expressarem, de forma clara e objetiva, a exatidão dos demonstrativos contábeis, a legalidade, a legitimidade e a economicidade dos atos de gestão do responsável;
} 
II - regulares com ressalva, quando evidenciarem impropriedade ou qualquer outra falta de natureza formal de que não resulte dano ao erário;"

A quitação é a consequência do julgamento das contas pela regularidade ou pela regularidade com ressalvas, nos termos dos arts. 17 e 18, da Lei ${ }^{\circ}$ 8.443/92: "Art. 17. Quando julgar as contas regulares, o Tribunal dará quitação plena ao responsável.
Art. 18. Quando julgar as contas regulares com ressalva, o Tribunal dará quitação ao
responsável e lhe determinará, ou a quem lhe haja sucedido, a adoção de medidas necessárias
à correção das impropriedades ou faltas identificadas, de modo a prevenir a ocorrência de
outras semelhantes".

Se, pelo contrário, for instaurada a fase contenciosa, caberá ao Tribunal ou ao Ministro-Relator adotar as providências constantes do art. 12, da Lei ${ }^{\circ}$ 8.443/92:

\footnotetext{
"Art. 12. Verificada irregularidade nas contas, o Relator ou o Tribunal:

I - definirá a responsabilidade individual ou solidária pelo ato de gestão inquinado;

II - se houver débito, ordenará a citação do responsável para, no prazo estabelecido no regimento interno, apresentar defesa ou recolher a quantia devida,

III - se não houver débito, determinará a audiência do responsável para, no prazo estabelecido no regimento interno, apresentar razões de justificativa; não resulte dano ao erário; IV - adotará outras medidas cabíveis".
}

A audiência e a citação são medidas preliminares voltadas ao atendimento da ampla defesa e do contraditório, constante do art. $5^{\circ}$, LV, da CF/88.

No caso de rejeição das alegações de defesa, em que constatada a boa-fé do responsável e a inexistência de outra irregularidade nos autos, a Lei permite o pagamento do débito, desde que voluntariamente, somente com a atualização monetária, ou seja, sem a incidência de juros de mora, nos termos do art. 12, §2 , da Lei $n^{\circ}$ 8.443/92: "Reconhecida pelo Tribunal a boa-fé, a liquidação tempestiva do débito atualizado monetariamente sanará o processo, se não houver sido observada outra irregularidade nas contas". Nada obstante, para preservar a lealdade processual, o responsável deverá ser informado sobre esta possibilidade antes de efetuar o recolhimento. Após o recolhimento voluntário, as contas deverão ser julgadas regulares com ressalvas. 
Terminada a fase de instrução contenciosa, passa-se ao julgamento de mérito proferido pelo órgão colegiado. As contas poderão ser julgadas regulares, regulares com ressalvas ou irregulares, nos termos do art. 16, da Lei ${ }^{\circ}$ 8.443/92:

"Art. 16. As contas serão julgadas:

I - regulares, quando expressarem, de forma clara e objetiva, a exatidão dos demonstrativos contábeis, a legalidade, a legitimidade e a economicidade dos atos de gestão do responsável;

II - regulares com ressalva, quando evidenciarem impropriedade ou qualquer outra falta de natureza formal de que não resulte dano ao erário;

III - irregulares, quando comprovada qualquer das seguintes ocorrências:

a) omissão no dever de prestar contas;

b) prática de ato de gestão ilegal, ilegítimo, antieconômico, ou infração à norma legal ou regulamentar de natureza contábil, financeira, orçamentária, operacional ou patrimonial;

c) dano ao erário decorrente de ato de gestão ilegítimo ao antieconômico;

d) desfalque ou desvio de dinheiros, bens ou valores públicos.

$\S 1^{\circ}$ O Tribunal poderá julgar irregulares as contas no caso de reincidência no descumprimento de determinação de que o responsável tenha tido ciência, feita em processo de tomada ou prestarão de contas.

$\S 2^{\circ}$ Nas hipóteses do inciso III, alíneas c e d deste artigo, o Tribunal, ao julgar irregulares as contas, fixará a responsabilidade solidária:

a) do agente público que praticou o ato irregular, e

b) do terceiro que, como contratante ou parte interessada na prática do mesmo ato, de qualquer modo haja concorrido para o cometimento do dano apurado.

$\S 3^{\circ}$ Verificada a ocorrência prevista no parágrafo anterior deste artigo, o Tribunal providenciará a imediata remessa de cópia da documentação pertinente ao Ministério Público da União, para ajuizamento das ações civis e penais cabíveis".

Portanto, é somente com o julgamento das contas irregulares que o Tribunal de

Contas poderá efetivar a responsabilidade financeira. Com efeito, o art. 19, da Lei $\mathrm{n}^{\circ} 8.443 / 92$

dispõe que:

"Art. 19. Quando julgar as contas irregulares, havendo débito, o Tribunal condenará o
responsável ao pagamento da dívida atualizada monetariamente, acrescida dos juros de mora
devidos, podendo, ainda, aplicar-lhe a multa prevista no art. 57 desta lei, sendo o instrumento
da decisão considerado título executivo para fundamentar a respectiva ação de execução.
Parágrafo único. Não havendo débito, mas comprovada qualquer das ocorrências previstas nas
alíneas a, b e c do inciso III, do art. 16, o Tribunal aplicará ao responsável a multa prevista no
inciso I do art. 58, desta lei".

Os julgamentos devem ser motivados, nos termos do art. $1^{\circ}, \S 3^{\circ}$, da Lei $n^{\circ}$

$8.443 / 92$.

Das decisões de mérito em processos de contas, são cabíveis três espécies recursais: os embargos de declaração, o recurso de reconsideração e o recurso de revisão. Os recursos estão regulados nos artigos 32 a 35, da Lei $n^{\circ} 8.443 / 92$, que dispõem sobre o efeito 
suspensivo ou somente devolutivo, os prazos de interposição, as hipóteses de cabimento e os legitimados à interpor o recurso:

"Art. 32. De decisão proferida em processo de tomada ou prestação de contas cabem recursos de:

I - reconsideração;

II - embargos de declaração;

III - revisão.

Parágrafo único. Não se conhecerá de recurso interposto fora do prazo, salvo em razão da superveniência de fatos novos na forma prevista no regimento interno.

Art. 33. O recurso de reconsideração, que terá efeito suspensivo, será apreciado por quem houver proferido a decisão recorrida, na forma estabelecida no regimento interno, e poderá ser formulado por escrito uma só vez, pelo responsável ou interessado, ou pelo Ministério Público junto ao Tribunal, dentro do prazo de quinze dias, contados na forma prevista no art. 30 desta lei.

Art. 34. Cabem embargos de declaração para corrigir obscuridade, omissão ou contradição da decisão recorrida.

$\S 1^{\circ}$ Os embargos de declaração podem ser opostos por escrito pelo responsável ou interessado, ou pelo Ministério Público junto ao Tribunal, dentro do prazo de dez dias, contados na forma prevista no art. 30 desta lei.

$\S 2^{\circ}$ Os embargos de declaração suspendem os prazos para cumprimento da decisão embargada e para interposição dos recursos previstos nos incisos I e II do art. 32 desta lei.

Art. 35. De decisão definitiva caberá recurso de revisão ao Plenário, sem efeito suspensivo, interposto por escrito, uma só vez, pelo responsável, seus sucessores, ou pelo Ministério Público junto ao Tribunal, dentro do prazo de cinco anos, contados na forma prevista no inciso III do art. 30 desta lei, e fundar-se-á:

I - em erro de cálculo nas contas;

II - em falsidade ou insuficiência de documentos em que se tenha fundamentado a decisão recorrida;

III - na superveniência de documentos novos com eficácia sobre a prova produzida.

Parágrafo único. A decisão que der provimento a recurso de revisão ensejará a correção de todo e qualquer erro ou engano apurado".

Os embargos de declaração e o recurso de reconsideração possuem efeito suspensivo e o recurso de revisão apenas efeito devolutivo.

Segundo Luiz Orione Neto, o efeito suspensivo (ORIONE NETO, 2002, p.

127):

"é a propriedade do recurso que leva ao adiamento da produção dos efeitos normais da decisão hostilizada, a partir do momento em que é possível impugná-la. Essa qualidade subsiste até que ocorra a preclusão da decisão objeto de recurso. Assim, em razão do efeito suspensivo, o conteúdo da sentença não pode ser materializado até que se julgue o recurso respectivo" 
O efeito devolutivo, por sua vez, compreende "a transferência ao órgão ad quem do conhecimento da matéria impugnada, com o objetivo de reexaminar a decisão recorrida" (ORIONE NETO, 2002, p. 124).

O Recurso de Revisão e os Embargos de Declaração são recursos de fundamentação vinculada à semelhança do Recurso Especial e do Recurso Extraordinário no Processo Judicial. O recurso de reconsideração é um recurso de fundamentação livre.

Luiz Orione Neto distingue os recursos de fundamentação livre e os de fundamentação vinculada (ORIONE NETO, 2002, p. 27):

"Há casos em que a lei, ao estabelecer as hipóteses de cabimento do recurso, abstém-se de
fixar limites a essa crítica, deixando a parte livre para deduzir qualquer tipo de crítica em
relação à decisão; noutros, ao revés, cuida de discriminar o tipo de erro denunciável por meio
do recurso, impondo limites à sua fundamentação. Daí a distinção que se pode estabelecer
entre recursos de fundamentação livre e recursos de fundamentação vinculada".

Complementa Luiz Orione Neto que, nos recursos de fundamentação vinculada (ORIONE NETO, 2002, p. 28):

\footnotetext{
"A tipicidade do erro é, pois, pressuposto do cabimento do recurso (e, por conseguinte, da sua admissibilidade); se o erro não for típico, o órgão ad quem não conhecerá daquele. A existência real do erro é pressuposto para procedência do recurso; se o erro alegado, típico embora, não existir, o órgão ad quem conhecerá do recurso, mas lhe negará provimento. Nos recursos de fundamentação livre, o cabimento não depende do tipo de crítica que o recorrente faz à decisão; dependerá de outra(s) circunstância(s) (...)".
}

Convém mencionar que o recurso de revisão, em razão do tipo previsto no inciso III do art. 35 da Lei (superveniência de documentos novos com eficácia de prova produzida) e de seu longo prazo para interposição perante a Corte de Contas (cinco anos), permite a compatibilização da jurisdição contábil com as demais jurisdições. No caso de sentença penal absolutória por negativa de fato ou de autoria, caberá recurso de revisão, com fundamento no dispositivo citado, para rever eventual Acórdão do Tribunal de Contas que tenha julgado as contas irregulares e efetivado a responsabilidade financeira.

Não cabendo mais recurso no âmbito do TCU, pode o responsável, ainda, interpor Mandado de Segurança junto ao Supremo Tribunal Federal, nos termos do art. 102, 
inciso I, alínea c, da CF/88. O Mandado de Segurança exige prova pré-constituída do direito líquido e certo ${ }^{150}$ alegado e a impetração dentro do prazo decadencial de 120 dias (art. 18, de Lei $\left.\mathrm{n}^{\circ} 1.533 / 51\right)$.

Expirado este prazo decadencial ou denegado o Mandado de Segurança, a decisão do Tribunal de Contas que efetivou a responsabilidade financeira torna-se imutável.

Não satisfeito o débito ou a multa voluntariamente pelo responsável, a execução do Acórdão do TCU poderá ser feita de maneira administrativa ou judicial, conforme art. 28, da Lei ${ }^{\circ} 8.443 / 92$ :

\footnotetext{
"Art. 28. Expirado o prazo a que se refere o caput do art. 25 desta lei, sem manifestação do responsável, o Tribunal poderá:

I - determinar o desconto integral ou parcelado da dívida nos vencimentos, salários ou proventos do responsável, observados os limites previstos na legislação pertinente; ou

II - autorizar a cobrança judicial da dívida por intermédio do Ministério Público junto ao Tribunal, na forma prevista no inciso III do art. 81 desta lei".
}

A execução administrativa compreende o desconto das quantias referentes ao débito ou à multa na remuneração ou nos proventos do responsável, se este, ainda, mantiver vinculo com a Administração Pública, nos termos da legislação pertinente (vide, por exemplo, o art. 46, da Lei $\mathrm{n}^{\circ}$ 8.112/90, com alterações posteriores).

A execução judicial é promovida pela Advogacia da União ou pela Procuradoria da Entidade Autárquica, Fundacional ou pelo Departamento Jurídico da Empresa Estatal. O TCU entende que o débito deverá ser recolhido aos cofres da pessoa juridica que teve o seu patrimônio lesado, mas a multa, em qualquer caso, deve ser recolhido ao Tesouro Nacional.

\footnotetext{
${ }^{150}$ Segundo Hely Lopes Meirelles (MEIRELLES, 2004, p. 36-37), "direito líquido e certo é o que se apresenta manifesto na sua existência, delimitado na sua extensão e apto a ser exercitado no momento da impetração. Por outras palavras, o direito invocado para ser amparável por mandado de segurança, há de vir expresso em norma legal e trazer em si todos os requisitos e condições de sua aplicação ao impetrante (...). Quando a lei alude a direito líquido e certo, está exigindo que esse direito se apresente com todos os requisitos para seu reconhecimento e exercício no momento da impetração. Em última análise, direito líquido e certo é direito comprovado de plano. (...) Por se exigir situações e fatos comprovados de plano é que não há instrução probatória no mandado de segurança (...) O que se exige é prova pré-constituída das situações e fatos que embasam o direito invocado pelo impetrante".
} 


\section{PARTE IV - CATEGORIA AUTÔNOMA DA RESPONSABILIDADE FINANCEIRA COMO CATEGORIA JURÍDICA AUTÔNOMA}




\section{NATUREZA JURÍDICA}

Neste tópico, discuto a natureza jurídica da responsabilidade financeira. Verifico o seu enquadramento ou não nas modalidades consagradas de Responsabilidade (Responsabilidade Civil, Responsabilidade Penal, Responsabilidade Administrativa e Disciplinar e Responsabilidade por Ato de Improbidade Administrativa), salientando as suas semelhanças e diferenças.

\subsection{Responsabilidade Financeira como espécie de Responsabilidade Civil}

A Responsabilidade civil se assenta num dever jurídico originário ou prímário de não prejudicar a ninguém, ou seja, de não causar dano a outrem (neminem laedere).

Segundo Sérgio Cavalieri Filho, a violação do dever jurídico originário importa em um dever jurídico sucessivo, também chamado de secundário. Responsabilidade civil, segundo o autor, é um dever jurídico sucessivo que surge para recompor o dano decorrente da violação do dever jurídico originário. Acerca da função da responsabilidade civil, leciona Sérgio Cavalieri Filho que (CAVALIERI FILHO, 2002, p. 29):

\footnotetext{
"O anseio de obrigar o agente, causador do dano, a repará-lo inspira-se no mais elementar sentimento de justiça. O dano causado pelo ato ilícito rompe o equilíbrio jurídico-econômico anteriormente existente entre o agente e a vítima. Há uma necessidade fundamental de se restabelecer esse equilíbrio, o que se procura fazer recolocando o prejudicado no statu quo ante. Impera neste campo o princípio da restitutio in integrum, isto é, tanto possível, repõe-se a vítima à situação anterior à lesão".
}

A responsabilidade civil pode ser contratual ou extracontratual. Em ambos os casos, há violação de um dever jurídico preexistente. A distinção, consoante esclarece Sérgio Cavalieri Filho, está na sede deste dever (CAVALIERI FILHO, 2002, p. 32):

\footnotetext{
"Haverá responsabilidade contratual quando o dever jurídico violado (inadimplemento ou ilícito contratual) estiver previsto no contrato. (...) Haverá, por seu turno, responsabilidade extracontratual se o dever jurídico violado não estiver previsto no contrato, mas sim na lei ou na ordem jurídica".
} 
A restituição pode ser feita de forma direta, por meio da recomposição "in natura" (resconstituição específica da situação anterior à lesão) ou de forma indireta, compensando-se a lesão com equivalente indenização pecuniária.

A responsabilidade civil envolve a reparação do dano patrimonial e do dano moral. O dano patrimonial, por sua vez, engloba o dano emergente e os lucros cessantes.

Segundo Sérgio Cavalieri Filho, o dano emergente importa efetiva e imediata diminuição do patrimônio da vítima em razão do ato ilícito. A sua mensuração, segundo o autor, não envolve maiores dificuldades: "via de regra, importará no desfalque sofrido pelo patrimônio da vítima; será a diferença do valor do bem jurídico entre aquele que ele tinha antes e depois do ato ilícito" (CAVALIERI FILHO, 2002, p. 81)

O lucro cessante, por sua vez, consiste "na perda do ganho esperável, na frustração da expectativa de lucro, na diminuição potencial do patrimônio da vítima", apurada segundo critérios de razoabilidade e probabilidade (CAVALIERI FILHO, 2002, p. 81-82):

\footnotetext{
"Razoável é aquilo que o bom senso diz que o credor lucraria, apurado segundo um juízo de probabilidade, de acordo com o desenrolar normal dos fatos. Não pode ser algo meramente hipotético, imaginário, porque tem que ter por base um situação fática concreta".
}

Restrinjo, inicialmente, a análise à modalidade reintegratória. Descarto, de plano, que a comparação da responsabilidade civil com a modalidade sancionatória da responsabilidade financeira, pois as finalidades das sanções são diversas.

\begin{abstract}
Em primeiro lugar, convém destacar que os adeptos da tríplice Responsabilidade (civil, penal e administrativa) defendem o enquadramento da responsabilidade financeira como espécie de responsabilidade civil extracontratual.
\end{abstract}

Dentre os argumentos favoráveis ao enquadramento da responsabilidade financeira como espécie de responsabilidade civil, podemos citar: 
a) os pressupostos objetivos e subjetivos da responsabilidade financeira reintegratória assemelham-se aos da responsabilidade civil subjetiva, quais sejam, a conduta, o dano, o nexo de causalidade e a presença do elemento dolo ou culpa;

b) a função reparatória ou compensatória da responsabilidade civil é muito semelhante à da responsabilidade financeira reintegratória;

c) a semelhança entre as causas excludentes de responsabilidade.

Nesta linha de pensamento, dispõe o Relatório do Acórdão TCU n 953/2006 Primeira Câmara, que a responsabilidade financeira reintegração segue os fundamentos da responsabilidade civil subjetiva:

\footnotetext{
"Nesse passo, é importante ressaltar, de início, que a responsabilidade que se apura nos processos de Tomada de Contas Especial, com vistas à verificação da existência de débito e à identificação de seu responsável, segue os fundamentos da responsabilidade civil subjetiva. A propósito, são diversos os acórdãos proferidos pelo TCU cujos votos que os fundamentam explicitam essa compreensão (entre outros, Acórdãos 452/2004, 874/2004, 33/2005, 112/2005, 1856/2005 todos do Plenário).

E são três, em síntese, os pressupostos a serem satisfeitos para que sobre o agente incida o dever de reparação: i) a ocorrência de dano; ii) a presença de culpa, tomada em seu sentido amplo; e iii) a existência de nexo de causalidade, ligando a conduta culposa ao resultado (ao dano).

O Código Civil registra algumas hipóteses que retiram o caráter ilícito do fato e, em alguns casos e sob determinadas condicionantes, afastam o dever de indenizar. Uma das situações de exclusão de responsabilidade retratada na lei civil é justamente a ocorrência de caso fortuito ou força maior.

Consoante dispõe o artigo 393 do aludido codex, o devedor não responde pelos prejuízos resultantes de caso fortuito ou força maior, se expressamente não se houver por eles responsabilizado".
}

Carlos Cubillo Rodriguez analisa o enquadramento, no Direito Espanhol, da "responsabilidad contable" como modalidade de responsabilidade civil (RODRIGUEZ, 1999).

Aponta, inicialmente, que a jurisprudência da Sala de Justiça do Tribunal de Contas Espanhol mantém um critério jurisprudencial de classificar a responsabilidade contábil como uma variante da responsabilidade civil extracontratual. Tal posição é sustentada por autores como Javier Medina Guijarro e José Antonio Pajares Giménez, tomam como referência o paralelismo entre o conteúdo dos artigos 1902 do Código Civil Espanhol e 
o art. 38.1 da Lei Orgânica do Tribunal de Contas (Ley 2/82, de 12 de mayo) (RODRIGUEZ, 1999).

$\mathrm{Na}$ opinião de Rodriguez, este enquadramento não pode ser feito antes da solução de questões duvidosas. Em primeiro lugar, a responsabilidade civil aquiliana surge entre estranhos (entre extraños). Os possíveis vínculos preexistentes entre o causador do dano e a vítima, quando existem, são irrelevantes. Por sua vez, a responsabilidade contábil é uma responsabilidade entre conhecidos, pois só pode nascer entre os sujeitos previamente relacionados por um vínculo jurídico e o gestor de recursos públicos está unido ao titular do mesmo através de uma relação de supremacia especial (RODRIGUEZ, 1999).

Outro elemento que, na opinião do autor, analisa este enquadramento é a exigência de violação de norma de direito positivo, requisito que não é contemplado no art. 1902 do Código Civil Espanhol. A incidência dos princípios da legalidade e da tipicidade tende a distorcer a sua condição de meramente reparatória. Por esta razão, argumenta, a doutrina tem se preocupado em definir conceitos como infração contábil, transgressão à legalidade contábil, antijuridicidade formal na gestão de recursos, reprovabilidade das condutas gestoras, dentre outras (RODRIGUEZ, 1999).

No direito português, João Franco do Carmo discute a responsabilidade financeira como categoria jurídica autônoma e sua aproximação com a responsabilidade civil. Dentre as semelhanças entre os dois institutos, o autor aponta a existência de uma mesma matriz (pressupostos), o caráter patrimonial do vínculo surgido da responsabilidade e a função reparadora dos danos causados (CARMO, 1995). As diferenças se fundam na configuração do dano e na forma de calcular o seu montante. Vale a pena destacar o seguinte excerto do autor (CARMO, 1995, p. 70-71):

\footnotetext{
"Afirmou-se, mais acima, a proximidade da responsabilidade financeira relativamente à responsabilidade civil. Segundo cremos, esta contiguidade, sendo verdadeira (até porque a matriz da responsabilidade financeira é, necessariamente, a responsabilidade civil), não é de molde a contrariar a autonomia normativa daquele conceito de responsabilidade. Autonomia essa que não resulta sequer prejudicada na referência, com em França, à <<responsabilité civile des comptables >> ou, em Espanha, à <<subespecie de la responsabilidad civil en que la contable consiste(...) >> na Itália, a orientação, em certa altura perfilhada, no sentido de uma
} 
reductio ad unum das duas figuras, deveu-se mais à preferência na aplicação do esquema de responsabilidade civil <<interna〉> dos funcionários em geral, por mais flexível, que à negação formal da autonomia da responsabilidade dos 'agenti contabili' (embora visando o esvaziamento do regime de responsabilidade especialmente previsto para estes).

Tal como na responsabilidade civil, o vinculum iuris que brota da responsabilidade financeira reveste carácter patrimonial, ou pecuniário, desempenhando a função precípua de impor ao prevaricador a reparação dos danos causados a outrem (neste caso, ao Estado), resultantes da sua actuação desconforme ao direito ou violadora de um dever jurídico (ilícita). Esta desconformidade há-de traduzir-se, todavia, numa infracção financeira, praticada por um sujeito ou entidade a quem está especialmente cometida a guarda e o manejo de fundos públicos. E o dano que dessa infracção emerge será, normalmente, apurado no decurso de um processo de julgamento de contas, de forma muito mais linear que a responsabilidade civil em geral; com efeito, na responsabilidade financeira, é a própria lei que determina a configuração do dano e o modo de apurar o seu montante, sem haver necessidade de proceder ao cálculo do efectivo prejuízo indemnizável. Mas não é sequer necessária, nalguns casos, a existência de dano patrimonial como resultado da infracção, desempenhando então a responsabilidade financeira uma função marcadamente sancionatória e preventiva, (...)".

A distinção central apontada pelo autor corresponde à diferença entre o objeto da responsabilidade civil e o objeto da responsabilidade financeira. Trata-se da distinção entre a obrigação de indenizar e a obrigação de repor, respectivamente.

Segundo esclarece João Franco do Carmo (CARMO, 1995), a obrigação de repor tem uma configuração sancionatória. Além disso, não há também aplicação à regra "compensatio lucri cum damno". Pode acontecer de que da infração financeira advenha, em sede patrimonial, um ganho ou enriquecimento patrimonial, sem que, por isso, resulte prejudicada a condenação em responsabilidade financeira. Não haveria, segundo o autor, dedução do montante das quantias a repor dos eventuais benefícios eventualmente decorrentes da responsabilidade financeira ${ }^{151}$.

Não são tomados em conta, também, os lucros cessantes e os danos futuros eventualmente previsíveis. A restituição limita-se às quantias ou bens envolvidos na infração

151 A obra de João Franco do Carmo toma por base a antiga Lei Orgânica do Tribunal de Contas (Lei n ${ }^{\circ}$ 86/89), revogada pela Lei ${ }^{\circ}$ 98/97, de 26 de Agosto (Lei de organização e processo do Tribunal de Contas LOPTC). O item 4 do artigo 59 da Lei $n^{\circ}$ 98/97 dispõe que: "Não há lugar a reposição, sem prejuízo da aplicação de outras sanções legalmente previstas, quando o respectivo montante seja compensado com o enriquecimento sem causa de que o Estado haja beneficiado pela prática do acto ilegal ou pelos seus efeitos". Adveio, ainda, nova alteração legislativa. A Lei $n^{\circ}$ 48/2006 alterou a redação do dispositivo em questão, restringindo esta compensação às contraprestações relacionadas às atribuições da entidade em questão ou aos usos normais de determinada atividade: "Consideram-se pagamentos indevidos para o efeito de reposição os pagamentos ilegais que causarem dano para o erário público, incluindo aqueles a que corresponda contraprestação efectiva que não seja adequada ou proporcional à prossecução das atribuições da entidade em causa ou aos usos normais de determinada actividade". 
(acrescidas eventualmente de juros de mora e atualização monetária). Se os danos causados forem superiores ao valor destas quantias, o conhecimento deles fica reservado para a jurisdição cível. A indenização do juízo cível, entretanto, deve levar em conta as quantias repostas.

No Direito Brasileiro, a responsabilidade financeira reintegratória não é espécie da responsabilidade civil, apesar de sua proximidade. Em primeiro lugar, a responsabilidade financeira importa violação de um dever contido, explicita ou implicitamente, em norma de direito administrativo ou financeiro. A responsabilidade civil tem por base um dever geral de não causar dano a outrem. Em segundo lugar, a obrigação de repor não se confunde com a obrigação de indenizar. Aquela está limitada às "quantias envolvidas na infração", não abrangendo, portanto, os lucros cessantes e o dano moral causado ao ente público.

Convém mencionar que na Doutrina Estrangeira, a responsabilidade civil do Agente Público está ligada às relações externas à Administração Pública, ou seja, às situações em que o agente é obrigado a ressarcir os danos causados a terceiros, no exercício da função pública (responsabilità civile verso terzi).

\subsection{Responsabilidade Financeira como Responsabilidade Administrativa}

As sanções aplicadas pelos Tribunais de Contas são comumente referidas pela doutrina, jurisprudência e, até mesmo, pela legislação (vide art. 5 , Lei n 10.028/2000) como "sanções administrativas". A origem da referência não está na natureza da norma de direito violada, mas na qualificação atribuída aos Tribunais de Contas como Tribunais Administrativos, em oposição aos Tribunais Judiciários. Como não se adota, por aqui, a Jurisdição Administrativa, como em alguns países da Europa Continental, nada mais inadequado que denominar os Tribunais de Contas como Tribunais Administrativos (vide capítulo 21 - jurisdição contábil-financeira). 
De qualquer forma, encontro elementos de proximidade entre as espécies de responsabilidade. Em primeiro lugar, a Responsabilidade Financeira pode ser originária da violação de normas de Direito Administrativo, reguladoras da gestão de bens, dinheiros e valores públicos, com destaque para aquelas que embasam ou fundamentam a realização da despesa pública. Como exemplos, cito as normas de licitações e contratos da administração pública e as que regulam a remuneração dos agentes públicos. Outro argumento é a incidência de princípios do Direito Administrativo Sancionador à Responsabilidade Financeira.

Entretanto, contra o enquadramento, pesam fortes elementos. Em primeiro lugar, a responsabilidade financeira não faz uso dos Poderes administrativos e não está relacionada com a função administrativa.

Daniel Ferreira define sanção administrativa como "a direta e imediata conseqüência jurídica, restritiva de direitos, de caráter repressivo, a ser imposta no exercício da função administrativa, em virtude de um comportamento juridicamente proibido, comissivo ou omissivo" (FERREIRA, 2001, p. 34).

No mesmo sentido, Heraldo Garcia Vitta esclarece que: "somente será qualificada como 'sanção administrativa' a que possa ser imposta por autoridade administrativa, na função administrativa; ou por autoridades legislativa ou judiciária, quando exercerem funções administrativas" (VITTA, 2003, p. 66).

Desta forma, só se pode falar em Sanções Administrativas quando a autoridade competente para a sanção faz uso de algum dos Poderes Administrativos, tais como, o Poder de Polícia, o Poder Hierárquico ou Poder Disciplinar.

Ademais, a grande diversidade de espécies de sanções administrativas (sanções ambientais, fiscais, de trânsito, disciplinares ${ }^{152}$, sanitárias, trabalhistas, etc.) com

\footnotetext{
${ }^{152}$ A responsabilidade financeira também não se confunde com a responsabilidade disciplinar, espécie da responsabilidade administrativa. Incidem sobre sujeitos diversos: o conjunto dos agentes contábeis não coincide com o conjunto de agentes públicos, ligados por um vinculo empregatício ou estatutário, sujeitos ao Poder
} 
grandes variações nos seus regimes jurídicos recomenda a considerar a sanção financeira como categoria jurídica diferenciada.

\subsection{Responsabilidade Financeira como Ato de Improbidade Administrativa}

Alguns autores ${ }^{153}$ consideram o Ato de Improbidade Administrativa como espécie de Sanção Administrativa aplicada pelo Poder Judiciário. Entretanto, como tal sanção não é aplicada no exercício da função administrativa (vide item 20.2.), consideramos o ato de improbidade administrativa como categoria jurídica diferenciada.

Em favor do enquadramento da Responsabilidade Financeira como Ato de Improbidade Administrativa pesa um argumento muito forte. As sanções previstas na Lei de Improbidade Administrativa são muito semelhantes às referentes da responsabilidade no âmbito dos Tribunais de Contas. Com efeito, o ressarcimento integral do dano, a multa proporcional ao dano ao erário e a suspensão dos direitos políticos ${ }^{154}$ são comuns a estas duas categorias de responsabilização (vide as considerações acerca da compatibilidade entre os juízos - item 22.4.).

Além disso, alguns tipos definidos como atos de improbidade administrativa nos arts. 10 e 11, da Lei $n^{\circ}$ 8.429/92 importam em sanções financeiras. É comum, a este respeito, o Ministério Público Federal ingressar com ações de improbidade administrativa baseadas no resultado de Auditorias e Inspeções do Tribunal de Contas da União.

Disciplinar. Suas finalidades são diversas: a responsabilidade disciplinar tutela o bom andamento do serviço público, e a responsabilidade financeira tutela o patrimonio público e os princípios de gestão. Ademais, as sanções são materialmente distintas (vide item 22.1.).

153 Por exemplo, Fábio Medina Osório.

154 O Tribunal de Contas não aplica, efetivamente, a sanção de suspensão dos direitos políticos. Entretanto, o julgamento das contas do gestor pela irregularidade importa em inelegibilidade pelo prazo de 5 anos a contar da decisão, penalidade imposta pela Justiça Eleitoral. Com efeito, dispõe o art. $1^{\circ}$, inciso I, alínea g, da Lei Complementar $n^{\circ}$ 64/90: "Art. $1^{\circ}$ São inelegíveis: I - para qualquer cargo: (...) g) os que tiverem suas contas relativas ao exercício de cargos ou funções públicas rejeitadas por irregularidade insanável e por decisão irrecorrível do órgão competente, salvo se a questão houver sido ou estiver sendo submetida à apreciação do Poder Judiciário, para as eleições que se realizarem nos 5 (cinco) anos seguintes, contados a partir da data da decisão". 
Entretanto, os atos de improbidade administrativa são marcados pela desonestidade e pela má-fé, não bastando a mera ilegalidade. Ensina Marino Pazzaglini Filho que "(...) a conduta ilícita do agente público para tipificar ato de improbidade administrativa deve ter esse traço comum ou característico de todas as modalidades de improbidade administrativa: desonestidade, má-fé, falta de probidade no trato da coisa pública" (PAZZAGLINI FILHO, 2007, p. 18). Para a Responsabilidade Financeira, exige-se apenas a culpa.

Cumpre lembrar, ainda, que o enriquecimento ilícito não é pressuposto da responsabilidade financeira (pode se considerado como um agravante - dolo), mas, tão somente, dos atos de improbidade administrativa (art. $9^{\circ}$, da Lei ${ }^{\circ}{ }^{8.429 / 92}$ ).

O fundamento constitucional dos atos de improbidade administrativa também é diferente da responsabilidade financeira. Enquanto a improbidade administrativa está calcada no art. $37, \S 4^{\circ}$, da $\mathrm{CF} / 88$, a responsabilidade financeira está calcada no art. 71 , VIII, da $\mathrm{CF} / 88$.

Os sujeitos passivos dos atos de improbidade administrativa (arts. $2^{\circ}$ e $3^{\circ}$, Lei $\left.\mathrm{n}^{\circ} 8.429 / 92\right)$ também não coincidem com os "agentes contábeis" (art. 5, Lei n 8.443/92).

Além disso, os atos de improbidade administrativa são sancionados pelo Poder Judiciário e as infrações financeiras são sancionadas pelas Cortes de Contas, órgãos constitucionais que não integram nenhum dos Poderes da República.

\subsection{Responsabilidade Financeira como espécie da Responsabilidade Penal}

Neste tópico, restrinjo a análise à responsabilidade financeira sancionatória, tendo em vista, que apenas esta modalidade tem função eminentemente punitiva, tal como a responsabilidade penal. 
Como argumento favorável ao enquadramento, temos a incidência na Responsabilidade Financeira Sancionatória de diversos princípios de direito penal, tais como, a legalidade, pessoalidade e irretroatividade.

Entretanto, são fortes os elementos que nos permitem descartar esta possibilidade de enquadramento. Em primeiro lugar, os crimes e as contravenções são definidos em lei como tais, sendo seu rol exaustivo e não exemplificativo. As normas violadas na responsabilidade financeira não tem natureza penal. Excepcionalmente, as infrações financeiras também são infrações penais (crimes contra as licitações, crimes contra as finanças públicas, crimes contra a administração pública, etc.), que, na maioria dos casos, só admite modalidade dolosa. Na responsabilidade financeira sancionatória, exige-se apenas a conduta culposa.

Aspectos processuais também ajudam a distinguir as duas categorias de responsabilidade. A autoridade competente para aplicação da pena é a autoridade judiciária, enquanto que as sanções financeiras são aplicadas pelo Tribunal de Contas, órgão que não integra nenhum dos Poderes, conforme já ressaltado. Na responsabilidade financeira, há inversão do ônus da prova, corolário do dever de prestar contas, enquanto na responsabilidade penal vigora a presunção de inocência. Ademais, o procedimento adotado no âmbito dos Tribunais de Contas é orientado pelo formalismo moderado, o que não ocorre com o Processo Penal.

\subsection{Síntese}

Conforme foi objeto de discussão no item 2.4, os ilícitos e as sanções correspondentes devem ser classificados segundo o regime jurídico, material e processual, a que se submetem, o que abrange, inclusive, os fundamentos, os sujeitos, os pressupostos, a finalidade da sanção, o órgão competente para a sua aplicação e a eficácia do ato coator.

Do que foi exposto, pode-se tirar, dentre outras, as seguintes conclusões: 
a) o fundamento jurídico da responsabilidade financeira (art. 71, VIII, CF/88) são diversos da responsabilidade civil (neminen laedere), penal (art. $5^{\circ}$, XLVI, CF/88), administrativa (Poderes Administrativos) e por improbidade administrativa (art. $37, \S 4^{\circ}, \mathrm{CF} / 88$ );

b) os sujeitos da responsabilidade financeira também não coincidem com os sujeitos das demais categorias de responsabilidade;

c) há um pressuposto específico da responsabilidade financeira, que é a violação de normas ou princípios de gestão, inerentes ao Direito Administrativo ou Financeiro;

d) o órgão competente para aplicação da sanção financeira é o Tribunal de Contas, órgão que não integra os Poderes da República.

Considerando, ainda, o plexo de normas e princípios discutidos nas Partes II e III desta Dissertação, impende considerar a responsabilidade financeira como categoria jurídica autônoma, não enquadrável nas demais espécies de responsabilidade, apesar de, sob alguns aspectos, apresentar semelhanças com algumas destas categorias. 


\section{A JURISDIÇÃO CONTÁBIL-FINANCEIRA NO BRASIL}

O que pretendo discutir neste capítulo é a existência de um campo restrito e limitado, tanto sob o ponto de vista subjetivo, quanto material, no qual os Tribunais de Contas pronunciam-se em caráter exclusivo. Trata-se do Poder atribuído constitucionalmente aos Tribunais de Contas para a solução de controvérsias específicas: as pretensões do Estado à recomposição do seu patrimônio e ao sancionamento dos responsáveis em decorrência das infrações às normas de gestão pública ${ }^{155}$.

O produto da discussão tem importantes reflexos no processo contábil e no tópico a seguir, que versa sobre as interferências entre o juízo contábil-financeiro e o juizo penal e civil.

Convém mencionar que o caráter exclusivo da Jurisdição dos Tribunais de Contas é questão diversa da submissão das decisões do Tribunal de Contas ao crivo do Poder Judiciário e formação da coisa julgada, temas abordados posteriormente.

Alguns autores nacionais o denominam "jurisdição anômala" dos Tribunais de Contas e no Direito Estrangeiro denomina-se Jurisdição Financeira (Juridiction Financière) ou Jurisdição Contábil (Jurisdicción contable ou Giurisdizione contabile).

Na Espanha, a Sentença ${ }^{\circ} 187 / 1988^{156}$, do Tribunal Constitucional Espanhol foi um marco no reconhecimento da Jurisdição Contábil. Este entendimento foi reiterado

\footnotetext{
155 Trata-se de jurisdição unilateral, pois só serve às pretensões do Estado em face do agente contábil, relativamente ao sancionamento das infrações financeiras.

${ }_{156}$ Convém destacar trecho muito elucidativo da STC $n^{\circ}$ 187/1988: "El enjuiciamiento contable, por el contrario, aparece configurado como una actividad de naturaleza jurisdiccional. La Ley Orgánica, utilizando la expresión contenida en el art. 136.2, párrafo segundo de la Constitución, califica al enjuiciamiento contable de «jurisdicción propia» del Tribunal de Cuentas (art. 15.1), atribuyéndole las notas de «necesaria e improrrogable, exclusiva y plena» (art. 17.1), al mismo tiempo que garantiza la independencia e inamovilidad de sus miembros disponiendo, en concordancia también con lo establecido en el apartado tercero del mencionado precepto constitucional, que estarán sujetos a las mismas causas de incapacidad, incompatibilidad y prohibiciones fijadas para los Jueces en la Ley Orgánica del Poder Judicial (art. 33.1). La actividad de la Sección de Enjuiciamiento del Tribunal de Cuentas -que se organiza en Salas (art. 24)- consiste en aplicar la norma jurídica al acto contable, emitiendo un juicio sobre su adecuación a ella y declarando, en consecuencia, si existe o no responsabilidad del funcionario, absolviéndolo o condenándolo $\mathrm{y}$, en esta última hipótesis, ejecutando
} 
pelo ATC n 312/1996 e pela STC n 215/2000. A jurisdição contábil é necessária, plena, exclusiva e improrrogável. É limitada às infrações contábeis que dão origem à responsabilidade contábil, conforme esclarece Fabio Pascua Mateo ${ }^{157}$, nos comentários ao art. 136, da Constituição Espanhola:

\begin{abstract}
"El enjuiciamiento contable, por su parte, actividad de naturaleza jurisdiccional según ha reconocido la STC 187/1988, de 17 de octubre y el ATC 312/1996, y ha sido reiterado recientemente por la STC 215/2000, de 18 de septiembre, tiene por objeto ventilar la responsabilidad por alcances de caudales o efectos públicos y por infracción de las obligaciones accesorias constituidas en garantía de su gestión, en relación con quienes recauden, intervengan, administren, custodien o utilicen fondos públicos. Es necesaria, improrrogable, exclusiva y plena y se extiende a las cuestiones prejudiciales e incidentales salvo las de carácter penal, directamente relacionadas con la responsabilidad contable. No obstante, la amplitud de esta fórmula se ve mermada por el art. $16 \mathrm{LOTCu}$, que excluye de la jurisdicción contable los asuntos atribuidos a la competencia del Tribunal Constitucional y a la jurisdicción contencioso - administrativa, los hechos constitutivos de delito o falta y las cuestiones de índole civil, laboral o de otra naturaleza encomendadas al poder judicial. Además, el art. 17.3 precisa que la decisión que se pronuncie no produce efectos fuera del ámbito de la jurisdicción contable. Por lo tanto, las cuestiones que deben ventilarse ante la Sala de enjuiciamiento del Tribunal de Cuentas se limitan a determinar la indemnización de los daños y perjuicios a la que queda obligado el que por acción u omisión contraria a la ley origine el menoscabo de los caudales públicos, dentro de la cual está comprendida la responsabilidad civil derivada del delito en el caso de que la conducta ilícita estuviera tipificada como tal".
\end{abstract}

Na Itália, a Corte dei Conti exerce três espécies de jurisdição: a jurisdição em matéria de responsabilidade administrativa e contábil (giudizio di responsabilità), a jurisdição de contas (giudizio di conto) e a jurisdição em matéria de pensões (giudizio in.

Na França, denomina-se "jurisdictions financières" o conjunto de instituições que englobam a Corte de Contas, as Câmaras Regionais e Territoriais de Contas e a Corte de Disciplina Orçamentária e Financeira (Ensemble constitué par la Cour des comptes, les

coactivamente su decisión. Y todo ello a través de un procedimiento judicial, regulado en el Capitulo Tercero del Titulo V y desarrollado en la Ley de Funcionamiento del Tribunal, en el que aparecen los elementos objetivos, subjetivos y formales que caracterizan a un proceso. Por otra parte, sus resoluciones, en los casos y en la forma que determina su Ley de Funcionamiento, son susceptibles del recurso de casación y revisión ante el Tribunal Supremo (art. 49) y, si bien la Ley de Procedimiento Administrativo resulta supletoria de las normas reguladoras de los procedimientos fiscalizadores (Disposición final segunda, 1), para el ejercicio de las funciones jurisdiccionales se aplica supletoriamente la Ley reguladora de la Jurisdicción ContenciosoAdministrativa y las de Enjuiciamiento Civil y Criminal (Disposición final segunda, 2)".

157 Constitución Española: Sinopsis Artículo 136. Disponível em <http://narros.congreso.es/constitucion/>. Acesso em 01.10.2008. 
chambres régionales et territoriales des comptes et la Cour de discipline budgétaire et financière $^{158}$.

A Corte de Contas exerce uma atividade jurisdicional, que consiste no julgamento das contas dos "comptables publics", funcionários que asseguram o pagamento das despesas e a arrecadação das receitas do Estado ou de organismos públicos. Ela verifica se as receitas foram arrecadadas e se as despesas foram pagas de acordo com as regras em vigor. Por meio de uma Sentença, a Corte de Contas dá quitação ao comptable se as contas são regulares ou imputa-lhe débito se as receitas não foram arrecadadas ou se as despesas foram irregularmente efetuadas ${ }^{159}$. A Corte de Disciplina Orçamentária e Financeira é uma jurisdição administrativa encarregada de reprimir as infrações em matéria de finanças públicas. Ligada à Corte de Contas, ela constitui uma jurisdição financeira distinta e independente $^{160}$.

Convém advertir que muitos autores rejeitam, de plano, atribuir qualquer caráter jurisdicional às deliberações do Tribunal de Contas, independente do tipo de decisão proferida. Neste sentido, Fredie Didier Jr. afirma que (DIDIER JR., 2008a, p. 77):

\footnotetext{
"Raciocínio análogo pode ser aplicado às decisões do Tribunal de Contas, que, do mesmo modo, não exerce função jurisdicional, nem mesmo quando, por exemplo, julga as contas prestadas pelos agentes públicos (art. 71, II, CF/88). Sua atividade é eminentemente administrativa e, sobretudo, fiscalizatória".
}

Na mesma linha, Eduardo Lobo Botelho Gualazzi contesta a concepção ampla de Hely Lopes Meirelles acerca da jurisdição (GUALAZZI, 1992, p. 201-202):

\begin{abstract}
"Todavia, em 1973, Hely Lopes Meirelles frisava o seguinte: 'não se empregue 'controle jurisdicional' em lugar de 'controle judicial'. Jurisdição é atividade de dizer o direito, e tanto diz o direito o Poder Judiciário como o Executivo e até mesmo o Legislativo, quando interpretam e aplicam a lei. Portanto, todos os Poderes e órgãos exercem 'jurisdição', mas somente o Poder Judiciário tem o monopólio da jurisdição 'judicial', isto é, de dizer o direito com força de coisa julgada'

(...)

É evidente que Hely Lopes Meirelles exprime concepção singular, peculiar e latíssima de jurisdição. Enfim, Hely Lopes Meirelles parece perfilhar a concepção de que jurisdição é gênero, de que a jurisdição 'judicial' (com coisa julgada) é espécie. Tal concepção de
\end{abstract}

\footnotetext{
${ }^{158}$ http://www.ccomptes.fr/fr/JF/glossaire.html

${ }^{159} \mathrm{http} / / / \mathrm{www} . c$ comptes.fr/fr/CC/Missions.html.

${ }^{160}$ http://www.ccomptes.fr/fr/CDBF/Missions.html.
} 
jurisdição discrepa nitidamente da concepção dos especialistas em Teoria do Processo, cujo magistério, virtualmente unanime, aponta no sentido de que somente o Poder Judiciário exerce jurisdição, ou seja, jurisdição é a aplicação contenciosa do Direito, para dirimir lides concretas, com a produção de coisa julgada, formal e material. Nesta assunto, parece-nos, s.m.j. , que razão assiste aos processualistas; com efeito, a atividade administrativa pública realiza jusintegração administrativa, por meio da incessante recombinação de fatos e atos jurígenos em consonância com o Direito Objetivo, para a consecução do interesse público, legalmente qualificado, função pública substancial e funcionalmente diversa e distinta daquela de dizer o Direito aplicável a conflitos concretos de direitos subjetivos e interesses, em lides qualificadas por pretensões resistidas - a verdadeira jurisdição em sentido técnico-científico".

Gualazzi conclui que: "No Brasil, os Tribunais de Contas realizam parcela da jusintegração administrativa, jamais jurisdição. (...) emitem vereditos administrativos (res veredicta), mas não exercem jurisdição, privativa do Poder Judiciário" (GUALAZZI, 1992, p. 217-218).

A recusa de parte da Doutrina Brasileira em admitir a jurisdição dos Tribunais de Contas, no tocante à responsabilidade financeira, se baseia fundamentalmente em dois dispositivos da Constituição Federal: o art. $5^{\circ}$, inciso XXXV, da Constituição Federal, que dispõe que "a lei não excluirá da apreciação do Poder Judiciário lesão ou ameaça de lesão a direito" e do art. 92, da CF/88, que elenca os órgãos do Poder Judiciário, não incluindo os Tribunais de Contas.

$\mathrm{Na}$ opinião de muitos autores brasileiros, o art. 5, XXXV, da CF/88, fundamenta o princípio da inafastabilidade da jurisdição e da unidade da jurisdição ${ }^{161}$.

O dispositivo em questão fala em "lei não afastará", mas a própria Constituição excepciona explícitamente este princípio no art. $217, \S 1^{\circ}$, da $\mathrm{CF} / 88$ : "O Poder

161 J.J. Gomes Canotilho distingue os princípios da unidade e da pluralidade de jurisdições. O princípio da unidade de jurisdição implica na concentração de julgar em uma única organização judiciária. O princípio da pluralidade vigora "quando as funções judiciais são atribuídas a vários órgãos enquadrados em jurisdições diferenciadas e independentes entre si". Entende o autor que a Constituição Portuguesa de 1976, mormente com a Revisão Constitucional de 1989, adotou o princípio da pluralidade de jurisdições (CANOTILHO, 2003, p. 662): "A Constituição, embora consagre um tendencial pólo de actração em torno de magistratura ordinária, não adoptou o figurino do princípio da unidade de jurisdição. Depois da revisão de 1989, ficou claro que ao lado da magistratura ordinária existe uma magistratura administrativa e fiscal e uma magistratura constitucional com órgãos e funções independentes da magistratura ordinária. Desta forma, não existe, entre nós, um 'tribunal supremo', mas vários tribunais supremos (Supremo Tribunal de Justiça, Supremo Tribunal Administrativo, Tribunal Constitucional, Tribunal de Contas)". 
Judiciário só admitirá ações relativas à disciplina e às competições desportivas após esgotarem-se as instâncias da justiça desportiva, regulada em lei".

Aliás, a própria Constituição atribui, em caráter excepcional, a um determinado Poder, funções típicas de outros Poderes: funções administrativas aos Tribunais (art. 96, CF/88), normativas ao Poder Executivo e jurisdicionais ao Poder legislativo, no julgamento dos crimes de responsabilidade (processo de impeachment) pelo Senado Federal.

Neste sentido, José Mauricio Conti afirma que (CONTI, 2005, p. 27):

\begin{abstract}
"A interpenetração dos poderes, com funções típicas de um poder sendo exercidas por outro, em determinados casos, ou mesmo formas indiretas de influência, como um escolhendo membros que integram outro, é fato inconteste, que ocorre nos Estados que adotam o sistema da tripartição nítida dos poderes. O sistema de freios e contrapesos faz surgir, também uma série de mecanismos de controle de um poder sobre o outro, evidenciando a relatividade do conceito de separação entre os poderes. Isso, no entanto, nunca chegou a macular a teoria da tripartição de poderes".
\end{abstract}

Conclui o autor, que a separação de poderes é um princípio adotado na maior parte dos Estados, mas não é possível considerá-lo absoluto, na medida em que há uma interpenetração, com situações de exercício de funções que não são próprias a cada um dos poderes considerados (CONTI, 2005, p. 29).

Não cabe, assim, considerar absoluto o princípio da unidade da jurisdição.

$\mathrm{Na}$ Espanha, a unicidade da jurisdição não exclui a atribuição de "potestades jurisdiccionales", em caráter excepcional, a outros órgãos, conforme afirmou Vallès Vives (VIVES, 2001, p. 281-282):

\footnotetext{
"Tampoco queremos incidir en la compatibilidad entre la unidad jurisdiccional y la existencia de una jurisdicción propia del Tribunal de Cuentas. En el caso español, el artículo 3.1 de la Ley Orgánica 6/1985, de 1 de julio del Poder Judicial, reconoce que, si bien la jurisdicción es única y se ejerce por los Juzgados y Tribunales, de conformidad con el art. 117 de la Constitución, la propia Constitución ha reconocido potestades jurisdiccionales a otros órganos, entre los cuales pude incluirse el Tribunal de Cuentas".
}

Em Portugal, existem as "reservas especiais de jurisdição", conforme leciona J. J. Gomes Canotilho (CANOTILHO, 2003, p. 676): 
"A Constituição Portuguesa sugere a existência de reservas especiais de jurisdição no sentido de reservar a certos tribunais o julgamento de certos litígios. Assim, por exemplo, estabelece o art. $212 \%$ a competência dos tribunais administrativos e fiscais para o julgamento de questões de natureza administrativa e fiscal. No art. $214^{\circ}$, referente ao Tribunal de Contas, consagra-se a reserva deste Tribunal para a 'fiscalização da legalidade de despesas públicas' e do julgamento das contas que a lei mande submeter-lhe".

Ainda segundo o ilustre constitucionalista, a Constituição da República Portuguesa, substituiu a noção de "Poder Judicial" pela de "órgão de soberania", categoria na qual estão inseridos todos os Tribunais (O Tribunal de Contas está inserido na categoria dos Tribunais) e os órgãos de relevância constitucional, tais como, a Assembléia da República (CANOTILHO, 2003, p. 657):

\begin{abstract}
"A lei fundamental portuguesa não fala em poderes mas em órgãos de soberania nos quais se incluem os tribunais (artigo $110^{\circ} / 1$ ). A qualificação de tribunais como órgãos de soberania remonta à Constituição de 1911 que, no seu artigo $6^{\circ}$, considerava como 'órgão de soberania nacional' o 'poder judicial'. Diferentemente desta, porém, a Constituição de 1976 fala em 'órgão de soberania' mas não em 'poder judicial'. Trata-se de optar, logo a nível constitucional por uma ordenação dos órgãos de estado segundo as suas competências e funções."
\end{abstract}

Esta visão reflete uma concepção mais moderna da Separação de Poderes, que, conforme já mencionado, não é absoluta. Existem, entre nós, diversos órgãos, tais como, o Ministério Público e o Tribunal de Contas, com competências e funções delineadas na Constituição, gozando de autonomia funcional, administrativa e financeira, mas que não se encaixam em nenhum dos Poderes da República. Tal concepção sugere que os "checks and balances", no Estado Contemporâneo, baseam-se em uma divisão de competências e funções entre Órgãos Constitucionais e não entre Poderes.

Um outro ponto que leva a muitos equívocos de interpretação é a qualificação de "tribunal administrativo" atribuída aos Tribunais de Contas. Esta qualificação é muito difundida na Doutrina, na Jurisprudência e, até mesmo, dentro das Cortes de Contas. Mas o que significaria dizer que o Tribunal de Contas é um Tribunal Administrativo? Seria um órgão integrante da Administração Pública? Seria um órgão que exerce uma função administrativa? 
Mesmo nos países de contencioso administrativo, é erroneo atribuir o qualificativo administrativo aos Tribunais de Contas, pois, nestes países, as Cortes de Contas não integram a Jurisdição Administrativa Ordinária.

\begin{abstract}
Neste sentido, Antônio de Souza Franco pontifica (FRANCO, 1990, p. 30):
"o Tribunal de Contas não é um Tribunal Administrativo, não exerce actividade de contencioso administrativo nem julga acções administrativas, nem sequer se aproxima orgânica, estrutural ou funcionalmente, dos Tribunais Administrativos como outos tribunais que exercitam funções financeiras, quais sejam os Tribunais Fiscais. A sua actividade diferencia-se de todos estas por não dirimir litígios entre o Estado e os particulares levantados por estes como meio de garantia dos seus direitos e interesses legítimos, mas antes por dirimir litígios entre o Estado e os particulares suscitados, ex officio por imposição da lei ou por actuação do Ministério Público, como representante dos interesses do Estado ou como defensor da legalidade, arrancando de um intuito de proteger o interesse público, com verificação da responsabilidade de particulares, em regra conexos com o interesse público porque seus responsáveis de autoridade, funcionários, agentes, ou mesmo beneficiários de dinheiro público".
\end{abstract}

Em Portugal, existe, até mesmo, um Tribunal para solucionar conflitos de competências entre a Jurisdição administrativa e o Tribunal de Contas, o que reforça a nossa afirmação.

A qualificação de Tribunal Administrativo é, entre nós, oriunda do equivocado binômio Judicial - Administrativo difundido pela Doutrina, especialmente entre os Processualistas. Ou seja, o que não é Judicial, é administrativo e vice-versa. Ora, já mencionamos que os Tribunais de Contas não integram nenhum dos Poderes da República, pois não se encontram no Rol de órgãos constantes do art. 44, do art. 76 e art. 92, da CF/88. Logo, trata-se de órgão de natureza constitucional (em Portugal, órgão de soberania), que à semelhança do Ministério Público, não pode ser denominado de Administrativo ou Judicial.

Ademais, constuma-se equiparar os Tribunais de Contas aos Tribunais do Contencioso Fiscal, que recebem o atributo "Administrativo", em função de efetivamente integrarem a estrutura do Poder Executivo. Estes Tribunais resolvem conflitos específicos envolvendo a Administração e o Contribuinte, mas não possuem a estatura constitucional dos Tribunais de Contas, seus membros não têm as garantias e vedações da Magistratura e não 
gozam da autonomia financeira e administrativa de que gozam todos os Tribunais, seja as Cortes de Contas, seja os do Judiciário (arts. 96 e 99, da CF/88).

Outra fonte de confusão é o tratamento idêntico da doutrina às diversas competências legais e constitucionais das Cortes de Contas Brasileiras. Nem todas as competências são jurisdicionais ou administrativas.

No rol do art. 71, da CF/88, algumas destas competências inserem-se no âmbito da função administrativa, tal como, a de apreciar para fins de registro atos de concessão de aposentadoria, reformas e pensões (art. 71, IV, CF/88). Trata-se de um ato administrativo complexo, em que o tribunal de contas manifesta-se na própria fase de formação do ato ${ }^{162}$.

Entretanto, neste capítulo, está se a discutir, tão somente, a competência atribuída aos Tribunais de Contas de processar e julgar a pretensão do Estado à recomposição do seu patrimônio lesado ou ao sancionamento dos responsáveis por de atos de gestão que violem os preceitos aplicáveis à administração de bens, dinheiros e valores públicos. Esta competência não é administrativa, mas jurisdicional, pois compreende o "dizer o direito", no caso concreto, mediante provocação do interessado (Ministério Público).

Começo a análise a partir do conceito de jurisdição.

Comum entre as diversas definiçõoes de jurisdição, a seguir analisadas, é a atuação estatal imparcial, fazendo atuar o Direito no caso concreto, visando a solução de um conflito submetido à apreciação do órgão Estatal. Alguns autores acrescentam outros elementos à definição de jurisdição: a formação de coisa julgada material e o seu caráter substitutivo.

\footnotetext{
162 "O ato de aposentadoria configura ato administrativo complexo, aperfeiçoando-se somente com o registro perante o Tribunal de Contas. Submetido à condição resolutiva, não se operam os efeitos da decadência antes da vontade final da Administração." (MS 24.997, Rel. Min. Eros Grau, DJ 01/04/05)
} 
Na Enciclopedia del Diritto - Le Garzantine, o termo "Giurisdizione" é definido como (p. 629):

"una delle funzioni fondamentali dello stato, che ha per oggetto l'imparziale attuazione del diritto. Si differenzia dalla funzione legislativa perché questa crea le norme (generali e astratte), mentre la giurisdizione attua nel caso concreto. Si distingue anche dalla funzione amministrativa perché questa nell'attuare il diritto in concreto persegue un interesse (quello appunto della pubblica amministrazione), mentre la giurisdizione è attività disinteressata $\mathrm{e}$ trova la sua caratteristica essenziale proprio nella imparzialità o terziertà rispetto alla vicenda sulla quale interviene" [Uma das funções fundamentais do Estado, que tem por objeto a atuação imparcial do direito. Se diferencia da função legislativa por que esta cria as normas (gerais e abstratas), enquanto a jurisdição atua no caso concreto. Se distingue da função administrativa porque esta, ao atuar no caso concreto, persegue um interesse (aquele exatamente da administração pública), enquanto a jurisdição é atividade desinteressada e encontra a sua característica essencial própria na imparcialidade ou na sua posição de terceiro na demanda sobre a qual intervém.]

Segundo James E. Clapp, o termo "jurisdiction" é "the power and authority of a court or administrative tribunal to decide legal issues and disputes. The scope of a particular court's jurisdiction is determined by a combination of constitutional and statutory provisions" (o Poder ou autoridade de uma Corte ou Tribunal Administrativo para decidir questões legais e disputas. O escopo de uma jurisdição particular é determinada pela combinação de provisões legais e constitucionais) (CLAPP, 2000, p. 256).

Segundo Gérard Cornu, em francês, o termo "Juridiction" compreende a missão de julgar, o poder e o dever de prover a justiça pela aplicação do Direito ["Mission de juger; pouvoir et devoir de rendre la justice par application du Droit (en disant le Droit)"] (CORNU, 2005, p. 517).

Na Alemanha, segundo Eric Hilgendorf (HILGENDORF, 2003, p. 85) o termo Gerichtsbarkeit (jurisdição em sentido amplo) compreende o exercício da soberania estatal para regulação de questões de direito. A jurisdição em sentido amplo compreende a Jurisdição contenciosa (Rechtssprechung), bem como a Jurisdição voluntária (nichtstreitige Gerichtsbarkeit) $^{163}$. Em outra oportunidade, Hilgendorf define Gerichtbarkeit como a

163 "Gerichtsbarkeit is die Ausübung staatl. Hoheitsgewalt zur Regelung von Rechtsfragen. Dazu gehören sowohl die streitige Gerichtsbarkeit (Rechtssprechung), als auch die freiwillige (nichtstreitige) Gerichtsbarkeit (sonstige Rechtspflege)". 
atividade do Estado dirigida à realização do Ordenamento Jurídico vigente (HILGENDORF, 2003 , p. VII) ${ }^{164}$.

Steffen Detterbeck define o termo "Rechtssprechung" como o terceiro Poder Estatal conhecido, no art. 20 II 2 da Lei Fundamental Alemã. A jurisdição é largamente independente do Poder Legislativo e ao Poder Executivo, conforme salienta o art. 97, da Lei Fundamental. Ensina o autor que o monopólio estatal da justiça (Staatliches Gewaltmonopol), o direito (dever) de ser ouvido (Rechtsgehorsamspflicht) e a proibição da justiça privada (Verbot der Selbstjustiz) são elementos existentes em todo ordenamento jurídico e forma de estado civilizados. A estes elementos corresponde o direito (a garantia) de acesso à jurisdição (Justizgewährungsanspruch). Este direito obriga o Estado a pôr à disposição, em todas as áreas do Direito, um processo qualificado vinculante para a solução do conflito e assegura aos cidadãos a pretensão à tomada de uma decisão jurisdicional ${ }^{165}$ (DETTERBECK, 2008, p. 97)

Segundo Fredie Didier Jr. (DIDIER JR., 2008a, p. 65):

"A jurisdição é a função atribuída a terceiro imparcial (a) de realizar o Direito de modo imperativo (b) e criativo (c), reconhecendo/efetivando;protegendo/situações jurídicas (d) concretamente deduzidas (e), em decisão insuscetível de controle externo (f) e com aptidão para se tornar indiscutível".

Segundo Cândido Rangel Dinamarco, "conceitua-se a jurisdição, (...), como função do Estado, destinada à solução imperativa de conflitos e exercida mediante a atuação da vontade do direito em casos concretos" (DINAMARCO, 2001, p. 305) .

Segundo J.J. Gomes Canotilho, "a jurisdição (jurisdictio, jus dicere) pode, em termos aproximativos, ser qualificada como a actividade exercida por juizes e destinada à

\footnotetext{
164 "Gerichtsbarkeit nennt man die Tätigkeit des Staates, dia auf die Verwirklichung der bestehenden Rechtsordnung gerichtet ist".

165 "Die Rechtssprechung ist die dritte in Art. 20 II 2 GG gennante staatliche Gewalt. Sie ist gegenüber der Legislative und Exekutive weitgehend unabhängig; dies unterstreicht Art. 97 GG. Staatliches Gewaltmonopol, Rechtsgehorsamtpflicht und Verbot der Selbstjustiz sind Wesenselemente einer jeden zivilisierten Staatsform und Rechtsordnung. Dem korrespondiert der Justizgewährungsanspruch. Er verpflichtet den Staat, in sämtlichen Rechtsbereichen ein qualifiziertes Verfahren zur verbindlichen Streitentscheidung bereitzustellen, und gewährt den Bürgern einen Anspruch gegen die staatliche Gerichtsbarkeit auf gerechtliches Tätigwerden".
} 
revelação, extrinsecação e aplicação do direito num caso concreto" (CANOTILHO, 2003, p. $661)$.

Por sua vez, Athos Gusmão Carneiro elenca um conjunto de características da atividade jurisdicional (CARNEIRO, 2002).

Em primeiro lugar, a atividade jurisdicional é uma atividade provocada. Não há jurisdição sem ação: "os juizes não saem em busca das lides para resolvê-las, mas aguardam que os interessados, frustradas eventuais tratativas amigáveis, busquem espontaneamente a intervenção estatal, propondo a demanda" (CARNEIRO, 2002, p. 7).

Em segundo lugar, trata-se de atividade pública, constituindo, no sistema jurídico brasileiro monopólio do Poder Judiciário, salvante os restritíssimos casos de jurisdições anômalas. Na Constituição de 1988, o autor reconhece a existência de duas jurisdições anômalas: a do Processo de Impeachment e a do Tribunal de Contas (CARNEIRO, 2002).

Em terceiro lugar, a jurisdição é atividade substitutiva da atuação originária das partes (CARNEIRO, 2002). Em quarto lugar, a jurisdição é atividade indeclinável exercida pelo "juiz natural". Por fim, a coisa julgada material é um atributo específico da jurisdição (CARNEIRO, 2002, p. 13-14):

\footnotetext{
"Toda sentença, findo o prazo para recurso, ou esgotados os recursos interponíveis, faz coisa julgada formal, i.e., torna-se imodificável, inimpugnável dentro do processo. As sentenças de mérito (com algumas exceções) adquirem, além disso, também a autoridade de 'coisa julgada material': sua eficácia projeta-se para fora do processo em que tal sentença foi proferida, tornando-se imutáveis os efeitos da sentença. Transitada materialmente em julgado, não poderão mais as partes (ou seus sucessores) discutir ou reclamar, em processo posterior, quanto ao bem da vida que a sentença atribuiu, ou denegou, a qualquer delas. Esta é a eficácia vinculativa plena característica da atividade jurisdicional, e que só a atividade jurisdicional produz".
}

Analiso, a seguir os elementos que compõem a jurisdição, relativamente às deliberações dos Tribunais de Contas em matéria de responsabilidade financeira.

Em primeiro lugar, o Tribunal de Contas, ao imputar débito ou multa ao responsável, diz o Direito no caso concreto submetido à sua apreciação. O Tribunal de 
Contas aplica normas e princípios de Direito Administrativo e Financeiro, e subsidiariamente, de outros ramos do Direito, para verificar a irregularidade na gestão, identificar o responsável e quantificar a penalidade cabível.

Em segundo lugar, o Tribunal de Contas, ao efetivarem a responsabilidade financeira, soluciona uma lide específica: a pretensão do Estado à recomposição do Erário ou à aplicação da multa em decorrência de infração às normas de gestão, resistida pelo responsável, que, por sua vez, pretende ver reconhecida a quitação da sua gestão.

Tal atividade é atribuída a sujeitos imparciais, os membros dos Tribunais de Contas e os Auditores aos quais são conferidas as mesmas garantias e vedações da Magistratura (vide item 18.1.).

Em terceiro lugar, há que se acentuar o caráter substitutivo das decisões do Tribunal de Contas que imputem débito, pois, o dano poderia ser espontanea e voluntariamente recomposto pelo responsável pela gestão de recursos públicos.

Dentre os argumentos favoráveis ao reconhecimento da jurisdição contábilfinanceira no Brasil, podemos citar.

Segundo o art. 73, caput, da CF/88, o Tribunal de Contas da União dispõe de "jurisdição em todo território nacional", a mesma expressão utilizada nas referências do art. 92, $\S 2^{\circ}$, da CF/88, para o Supremo Tribunal Federal e para os Tribunais Superiores.

Na Interpretação do Supremo Tribunal Federal, as decisões dos Tribunais de Contas têm natureza "quase-jurisdicional" (STF, MS n 23.550/DF).

Não há, também, diferença material entre as Cortes de Contas e os Tribunais do Poder Judiciário. Com efeito, o Tribunal de Contas exerce, no que couber, as atribuições contidas no art. 96, da CF/88, referentes à autonomia administrativa dos Tribunais. Ademais, 
os membros das Cortes de Contas (Ministros e Conselheiros) e os seus Auditores detêm as garantias e vedações da Magistratura.

A eficácia de título executivo conferida pelo art. $71, \S 3^{\circ}$ da Constituição Federal ao Acórdão do Tribunal de Contas que impute débito ou aplique multa (ou seja, à deliberação que efetive a responsabilidade financeira), é um outro forte elemento no sentido do reconhecimento da jurisdição contábil. Apesar de ser qualificado como título executivo extrajudicial $^{166}$, por força do art. 585, do CPC, ele tem a mesma eficácia das sentenças judiciais, conforme se pode extrair da deliberação do Supremo Tribunal Federal:

\footnotetext{
"Ao apurar a alcance dos responsaveis pelos dinheiros publicos, o Tribunal de Contas pratica ato insusceptivel de revisão na via judicial a não ser quanto ao seu aspecto formal ou tisna de ilegalidade manifesta. Mandado de Segurança não conhecido. (STF, Pleno, MS nº 7280, Min. Henrique D'avilla, DJ 17.09.1962)
}

Um dos argumentos mais contundentes para o reconhecimento da jurisdição contábil é, entretanto, a possibilidade de conflitos entre as decisões do Tribunal de Contas e do Poder Judiciário acerca do mesmo fato.

Considerando que estas decisões têm eficácia semelhante, os conflitos entre as mesmas são fatores de insegurança jurídica para o gestor público. A mera possíbilidade destes conflitos é irrazoável dentro do nosso sistema jurídico.

Por exemplo, uma deliberação em uma ação de improbidade administrativa condenando o responsável ao pagamento da quantia de 150 reais e o Tribunal de Contas imputando um débito de 100 reais. Ou ainda, pode um Tribunal Judicial considerar o ato legítimo e não condenar o responsável e o Tribunal de Contas condená-lo, em relação ao mesmo fato.

\footnotetext{
${ }^{166}$ Previamente à reforma no Processo Civil, promovida pela Lei $\mathrm{n}^{\circ} 11.382 / 2006$, poderia o Devedor, em sede de embargos à execução fundada em título executivo extrajudicial, conforme redação original do art. 745 , do CPC, qualquer matéria de defesa que poderia ser alegada no processo de conhecimento. Nas execuções fundadas em título executivo judicial, as matérias que poderiam ser alegadas eram bem mais restritas (art. 741, do CPC).
} 
Admitir a possibilidade de conflitos entre a jurisdição contábil e a jurisdição civil significa tornar sem qualquer efeito o instituto da quitação (décharge, discharge, discarico), segundo o qual, o responsável que tem as contas julgadas regulares ou regulares com ressalvas, se vê liberado de qualquer obrigação pertinente a um determinado exercício financeiro.

Segundo informa o sítio da Corte de Contas da França ${ }^{167}$, "la décharge est prononcée par un arrêt (jugement, dans la cas d'une chambre regionale et territoriale des comptes), lorsqu'aucune charge ou obligation ne pèse plus sur un comptable public au titre d'un exercice donné".

Segundo o National Audit Office (Reino Unido), a quitação pode ocorrer no plano das contas individuais dos comptables ou no plano das Contas de Governo (REINO UNIDO, 2006) ${ }^{168}$ :

\begin{abstract}
"The process of the discharge of the accounts is clearly exemplified under the French system, where it takes place at two levels. At the level of individual public accountants - the comptables - personal discharge from responsibility for the public money in their care is given once their financial management has been judged and found to have been satisfactory by the Cour des Comptes. If comptables come to the end of their period in office satisfactorily, the bond on their property is released. At the national level discharge is given to the State Account by the legislature, which takes account of the report by the Cour des Comptes which includes a general declaration of the adequacy of and conformity with regulations and gives details of significant breaches of budgetary rules. A similar system operates in Belgium."
\end{abstract}

Portanto, a quitação é um instituto relacionado à segurança jurídica. Admitir a responsabilização do gestor já declarado quite naquele exercício financeiro, por outras vias, é um atentado à garantia constitucional de estabilidade das relações jurídicas. Neste sentido, não nos parece razoável o disposto no art. 20, inciso II, da Lei $\mathrm{n}^{\circ}$ 8.429/92, que preceitua que as

${ }^{167} \mathrm{http}: / /$ www.ccomptes.fr

${ }^{168} \mathrm{O}$ processo de quitação das contas é claramente exemplificado no sistema francês, em que ele ocorre em dois níveis. No nível dos gestores públicos individuais - os contábeis - a quitação é dada uma vez que a gestão tenha sido julgada e considerada satisfatória pela Corte de Contas. Se os contábeis alcancem o final do seu período satisfatóriamente, o ônus sobre o seu patrimônio é liberado. No nível nacional, a quitação é concedida às Contas Estatais pelo Parlamento, que analisa o relatório da Corte de Contas que inclui uma declaração geral de adequação e conformidade com as normas e fornece detalhes de violações significativas nas regras orçamentárias. 
sanções da Lei de Improbidade Administrativa são independentes "da aprovação ou rejeição das contas pelo órgão de controle interno ou pelo Tribunal ou Conselho de Contas".

Fernando da Costa Tourinho Filho tece comentários acerca dos conflitos entre a jurisdição civil e a jurisdição penal. Suas conclusões são perfeitamente aplicáveis aos possíveis conflitos entre a jurisdição civil e a jurisdição contábil (TOURINHO FILHO, 2001, p. 6-8):

\footnotetext{
"4. A ação penal e a ação civil são independentes?

Dissemos que, com a prática da infração penal, surgem, de regra, duas pretensões: a pretensão punitiva, que vai ensejar a propositura da ação penal e a pretensão de ressarcimento, que vai dar lugar à promoção da ação civil.

(...)

Se as responsabilidades penal e civil são independentes, poderíamos responder que, em princípio, deveriam ser propostas duas ações: a civil, na jurisdição civil, e a penal, na sede penal.

Mas não seria perigoso, atentando-se para a circunstância de $o$ fato gerador das responsabilidades, no caso, ser um só, viesse a Justiça Civil afirmar que o ofendido não faz "jus" ao ressarcimento, porque o réu não praticou o ato incriminado, e a Justiça Penal, apreciando esse mesmíssimo fato, viesse a condená-lo, afirmando, assim, a existência daquele mesmo fato?

(...)

Um conflito entre duas sentenças que apreciassem o mesmo fato gerador das responsabilidades, uma afirmando e a otra negando a sua existência, uma imputando a sua prática a $\mathrm{X}$ e a outra afirmando que $\mathrm{X}$ não o cometeu, criaria uma situação deveras embaraçosa e ridícula para o Estado.

(...)

Nesse caso, o fato gerador das duas responsabilidades é um só, e , assim, não teria sentido que as ações penal e civil fossem completa e absolutamente independentes, pois haveria a possiblidade de julgados inconciliáveis, que serviriam apenas para desprestigiar a própria dignidade da Justiça."
}

Uma proposta de solução destes conflitos, tratada no Capítulo 22, funda-se justamente a delimitação da competência (ou da jurisdição) de cada um destes "órgãos de soberania". Nesta delimitação, a jurisdição contábil assume um caráter bem restrito.

$\mathrm{Na}$ Espanha, a jurisdição contábil está delimitada no art. 49.1, da LFTCu, sendo expressamente excluídos do seu escopo os assuntos ou questões referentes à competência do Tribunal Constitucional ou às distintas órdens de jurisdição ordinária (art. 49.2, LFTCu). 
Yolanda Gómez Sánchez, mais detalhadamente, aponta que (SANCHEZ, 2001, p. 220):

"La jurisdicción contable no le corresponde el enjuiciamiento de:

a) Los assuntos atribuidos a la competencia del Tribunal Constitucional;

b) Las cuestiones sometidas a la jurisdicción contencioso-administrativa;

c) Los hechos constitutivos de delito o falta;

d) Las cuestiones de índole civil, laboral o de otra naturaleza encomendadas al conocimiento de los órganos del Poder Judicial (art. 16 LOTCu)".

Se os fatos forem constitutivos de crime, o juiz ou Tribunal competente para julgar a causa abster-se-á de conhecer a responsabilidade contábil derivada destes fatos, encaminhando os documentos necessários ao Tribunal de Contas para fins de concretização dos danos ou prejuízos causados nos bens e dinheiros públicos (art. 49.3, LFTCu).

Conforme preceitua o art. 50, da LFTCu, os conflitos suscitados entre a jurisdição contábil, a Administração Pública ou das restantes órdens jurisdicionais é resolvido segundo o disposto na "Ley Orgánica de Conflitos Jurisdiccionales" (Ley Orgánica 2/1987, de 18 de mayo).

Além disso, o art. 51, da LFTCu, prescreve a cooperação jurisdicional entre os juízes e Tribunais de todas as ordens e o Tribunal de Contas Español, para fins de exercício de sua função jurisdicional.

Em Portugal, conforme já mencionado, o art. 1\%3, da LOPTC, dispõe que:

\footnotetext{
"Sempre que se verifique conflito de jurisdição entre o Tribunal de Contas e o Supremo Tribunal Administrativo, compete ao Tribunal dos Conflitos, presidido pelo Presidente do Supremo Tribunal de Justiça e constituído por dois juízes de cada um dos tribunais, dirimir o respectivo conflito".
}

Resta-nos, ainda, enfrentar a questão da submissão das decisões dos Tribunais de Contas, em matéria de responsabilidade financeira, ao crivo do Poder Judiciário e a questão da coisa julgada.

A submissão das deliberações do Tribunal de Contas à apreciação do Poder Judiciário está garantida com fundamento no art. 102, inciso I, alínea c, da CF/88, segundo o 
qual compete ao Supremo Tribunal Federal, processar e julgar originariamente os Mandados de Segurança contra ato do Tribunal de Contas da União.

O fundamento constitucional desta submissão ao crivo do Poder Judiciário não está no art. $5^{\circ}$, inciso $\mathrm{XXXV}$, da $\mathrm{CF} / 88$, uma vez que este dispositivo refere-se à Lei e não à Constituição.

Conseqüência desta distinção é o foro privilegiado (STF) para impugnação das decisões do Tribunal de Contas da União. Este foro é compatível com a Estatura Constitucional do TCU, equiparado ao Superior Tribunal de Justiça. Ademais, o meio processual é o Mandado de Segurança, que exige prova pré-constituída do direito líquido e certo alegado e a impetração dentro do prazo decadencial de 120 dias (art. 18, de Lei $\mathrm{n}^{\circ}$ $1.533 / 51)$.

A Emenda Constitucional $n^{\circ}$ 45/2004 reforça a convicção de que o STF é o foro adequado para impugnação das decisões do TCU. Com base nesta Emenda Constitucional, foi criado o Conselho Nacional de Justiça, que tem por competência o controle da atuação administrativa e financeira do Poder Judiciário, cabendo-lhe, dentre outras atribuições (art. 103-B, $\S^{\circ}$, II, CF/88 c/ EC n 45/2004):

\footnotetext{
"zelar pela observância do art. 37 e apreciar, de ofício ou mediante provocação, a legalidade dos atos administrativos praticados por membros ou órgãos do Poder Judiciário, podendo desconstituí-los, revê-los ou fixar prazo para que se adotem as providências necessárias ao exato cumprimento da lei, sem prejuízo da competência do Tribunal de Contas da União".
}

Ao fazer referência ao Tribunal de Contas da União, a Emenda Constitucional resguardou as competências da Corte de Contas, que são semelhantes às do Conselho, mas ao mesmo tempo deu prevalência as decisões da Corte de Contas em relação às do CNJ. Caso contrário, poderiam surgir inúmeros conflitos entre decisões do $\mathrm{CNJ}$ e do TCU.

Por outro lado, a EC n 45/2004, fixou a competência originária do STF para o julgamento das ações contra as decisões do CNJ, conforme art. 102, I, r , da CF/88. 
Ora, se as decisões do TCU têm precedência sobre as do CNJ e estas são impugnáveis apenas no STF, faz sentido admitir também este foro privilegiado também para a Corte de Contas Federal.

Convém lembrar que este foro especial está compatível com o Direito Estrangeiro. Na Espanha, das decisões relativas à "responsabilidad contable", cabem recursos de cassação e revisão ao Tribunal Supremo. Na Itália, o artigo 111, da Constituição estabelece que contra as decisões da Corte dei Conti, é cabível recurso de Cassação à Corte de Cassazione, apenas por motivos inerentes à jurisdição (Contro le decisioni del Consiglio di Stato e della Corte dei conti il ricorso in Cassazione è ammesso per i soli motivi inerenti alla giurisdizione $)^{169}$. Na França, as deliberações da Cour des Comptes e da Cour de Discipline Budgétaire et Financière estão sujeitas à Cassação do Conselho de Estado ${ }^{170}$.

Semelhantes conclusões aplicam-se também aos Tribunais de Contas dos Estados, Distrito Federal e dos Municípios, que, por analogia ao modelo federal, tem foro privilegiado no Tribunal de Justiça do Estado ou do Distrito Federal.

O que não se pode admitir, considerando a Estatura Constitucional dos Tribunais de Contas, é que as suas decisões em matéria de responsabilidade financeira sejam impugnáveis pela via da Ação Declaratória de Nulidade no Juízo de Primeiro Grau.

Sendo o mandado de segurança junto ao STF ou ao Tribunal de Justiça do Estado ou Distrito Federal o único meio processual para impugnar as decisões relativas à responsabilidade financeira, decorrido o prazo decadencial de 120 dias ou se a ordem não for concedida, a decisão do Tribunal de Contas torna-se imutável, assemelhando-se ao que se denomina coisa julgada material.

\footnotetext{
${ }^{169}$ Segundo Pelino Santoro, "il ricorso per Cassazione è proponibile, per effecto dell'art. 111 Cost., per soli motivi inerenti alla giurisdizione e solo in relazione ai limiti esterni delle attribuizioni giurisdizionali, con esclusione delle questioni interni (errores in procedendo o in iudicando) alla giurisdizione, ovvero riguaardanti i procedimento o 1'interpretazione di norme giuridiche" (SANTORO, 2006, p. 611).

${ }^{170} \mathrm{http}: / /$ www.ccomptes.fr
} 
Em suma, ao se definir a controvérsia que deve ser solucionada pelo Tribunal de Contas, órgão imparcial, materialmente equiparado aos Tribunais do Poder Judiciário e cujas deliberações em matéria de responsabilidade financeira tem a eficácia de sentença judicial (art. 71, $3^{\circ}$, da $\mathrm{CF} / 88$ ), é forçoso reconhecer a existência de uma jurisdição contábil-financeira. É uma espécie de jurisdição exclusiva dentro do seu âmbito, subjetivo e material, e que deve ser interpretada de maneira restrita, de forma a torná-la compatível com as demais jurisdições.

Não subsiste, no Brasil, a jurisdição contábil voluntária, relativa à liberação de cauções e garantias dos gestores. Tal modalidade de jurisdição graciosa persiste em outros países como, por exemplo, a Espanha (expedientes de cancelamento de fianças). 


\section{COMPATIBILIDADE ENTRE AS SANÇÕES E JURISDIÇÕES}

Um mesmo fato pode ensejar a responsabilização do agente público em diferentes esferas (civil, penal, disciplinar, política, por improbidade administrativa e, também, financeira), conforme viole preceitos constantes de cada um destes setores do Direito.

A jurisprudência do Tribunal de Contas da União tem sustentado o princípio da independência das instâncias, segundo o qual, a responsabilização em uma esfera ocorre de maneira independente da outra. Ademais, não haveria relação de prejudicialidade entre os processos nas diferentes esferas, desta forma, entende o TCU, não cabe o sobrestamento do processo contábil em razão de processo judicial.

Tal independência implicaria na possibilidade de cumulação de sanções aplicadas nas diferentes instâncias. Nada obstante, em atendimento aos princípios da razoabilidade e do "ne bis in idem", não se pode admitir que o caráter absoluto da independência das instâncias.

Se, por um lado, os órgãos responsáveis pela apuração e processamento das infrações são independentes entre si, por outro, não se pode negar a existência de interferências de um juízo em outro.

Nosso ordenamento jurídico não regula o intercâmbio entre a sanção financeira e as demais sanções, o que nos faz socorrer dos critérios de compatibilização adotados no Direito Estrangeiro e no inter-relacionamento entre o nosso Direito Civil e o Direito Penal.

\subsection{Compatibilidade entre o Juízo Financeiro e o Juízo Disciplinar}

Não há coincidência exata entre os sujeitos passivos da responsabilidade financeira e os da responsabilidade disciplinar. A responsabilidade financeira tem como sujeitos os "agentes contábeis" definidos, no âmbito federal, pelo art. $5^{\circ}$, da Lei n 8.443/92. 
Por sua vez, os sujeitos da responsabilidade disciplinar são aos agentes públicos submetidos ao Poder Disciplinar com vínculo estatutário ou empregatício. Por exemplo, os particulares que realizam a gestão de recursos públicos (por exemplo, que recebem subvenções sociais) estão sujeitos à Responsabilidade Financeira, mas não a responsabilidade disciplinar. Por outro lado, há agentes públicos que não efetuam a gestão e só estão sujeitos à responsabilidade disciplinar (ex. telefonista ou o analista de sistemas de uma repartição pública).

As finalidades destas espécies de responsabilidade são diversas. A responasbilidade disciplinar tutela o bom andamento do serviço público, conceito mais amplo que o de gestão. A responsabilidade financeira tutela o patrimônio público, o bom emprego dos recursos públicos e os princípios da gestão pública.

Os deveres relacionados à infração disciplinar (vide, por exemplo, artigos 116, 117 e 132, da Lei $\mathrm{n}^{\circ}$ 8.112/90) são amplos e abrangem diversos aspectos da atuação do agente público, incluindo, por exemplo, a pontualidade, a cordialidade, etc., deveres que, no âmbito da responsabilidade financeira, não possuem qualquer relevância.

As sanções financeiras e disciplinares são materialmente distintas. A sanção financeira é a imputação de débito e a multa. As sanções disciplinares podem constituir, regra geral, de advertência, suspensão, demissão, destituição de cargo em comissão ou função de confiança e a cassação de aposentadoria.

Feitas estas distinções, as sanções financeira e disciplinar são perfeitamente cumuláveis e independentes. Não há, também, relação de prejudicialidade entre o processo contábil e o processo disciplinar.

Quanto à cumulação entre a sanção financeira de multa e a punição disciplinar, o STF já deliberou, por ocasião do julgamento do MS 22.728-PR que: 


\begin{abstract}
"Não implica bis in idem a cassação, pelo Presidente da República, de aposentadoria de servidor público com base nos mesmos fatos que ocasionaram a aplicação de multa pelo TCU, tendo em vista a independência entre a responsabilização administrativa dos servidores públicos e o controle externo das contas públicas. Com esse entendimento, o Tribunal indeferiu mandado de segurança, afastando a pretendida incidência da Súmula 19 ("É inadmissível segunda punição de servidor público, baseada no mesmo processo em que se fundou a primeira."), por ser necessário que as duas punições sucessivas sejam impostas no mesmo processo administrativo. Precedentes citados: RMS 8.084-SP (DJU de 25.4.62); RE 120.570-BA (RTJ 138/658)".
\end{abstract}

\title{
22.2. Compatibilidade entre o Juízo Financeiro e o Juízo Penal
}

No item 19.4., foram discutidas as semelhanças e as diferenças entre a Responsabilidade Financeira, mais especificamente a modalidade sancionatória, e a Responsabilidade Penal.

A possibilidade de cumulação entre a sanção penal e a sanção financeira reintegratória é imediata, haja vista, que as sanções têm finalidades distintas: a primeira, finalidade preventivo-repressiva e a segunda, precipuamente finalidade reconstitutiva.

A questão é mais complexa quanto à cumulação entre a responsabilidade penal e a responsabilidade financeira sancionatória.

Em primeiro lugar, o Código Penal comina, em grande parte dos crimes contra a administração pública (arts. 312 a 326, CP), a pena de multa juntamente com as penas restritivas de liberdade. Em segundo, os tipos penais nem sempre coincidem com as condutas inquinadas no âmbito do juízo financeiro.

O que, de plano, não se pode conceber é a imposição de multa no juizo penal, simultaneamente, à multa no juízo financeiro, em razão da mesma conduta específica. Seriam sanções materialmente idênticas, com a mesma finalidade, aplicadas ao mesmo sujeito em razão do mesmo fato, o que faz incidir os critérios de aplicação do "ne bis in idem" propostos por Coimbra Silva (item 10.5.). 
No TCU, a Jurisprudência tende reconhecer, em caráter absoluto, o princípio da independência das instâncias.

No Acórdão $n^{\circ} 566 / 2000$ - 2a . Câmara, foi aplicada a multa ao gestor em virtude de condenação penal. Deixou-se de aplicar multa no TCU, apenas imputou-se débito ao responsável.

No Acórdão $\mathrm{n}^{\circ}$ 1.358/2008 - Plenário, trata-se de desvio de recursos no Comando do Exército, mediante fraudes em sistemas de pagamentos de inativos e pensionistas. Houve condenação no âmbito da Justiça Militar Federal, pela prática do crime de estelionato (art. 251, CPM). Houve imputação de débito e aplicação de multa proporcional ao dano ao erário.

No Acórdão $\mathrm{n}^{\circ}$ 1.501/2003 - 2 ${ }^{\mathrm{a}}$. Câmara, trata-se de apropriação indébita de ex-empregada da Caixa Econômica Federal, mediante movimentações irregulares de contas contábeis em benefício próprio. A funcionária foi condenada pelo crime previsto no art. 312 , $\mathrm{CP}$, à pena de reclusão de 03 anos e 04 meses, substituída pela pena de prestação pecuniária de 40 salários mínimos à CEF, além da proibição de frequentar determinados lugares e à pena de multa de 10 dias-multa (valor do dia-multa correspondendo a 1/5 de salário-mínimo na data do fato). No âmbito do TCU, a ex-empregada pleiteou abatimento no valor de R\$ $8.000,00$, relativo à condenação penal sofrida pela responsável. Tal pleito, entretanto, não foi acatado pelo Tribunal. Houve imputação de débito e aplicação de multa no âmbito do TCU. A decisão toma por base, assim, uma interpretação absoluta do princípio da independência das instâncias.

No nosso ordenamento jurídico, apesar do princípio da independência das instâncias, não se pode negar uma prevalência do juízo penal sobre os demais juízos. É compreensível tal prevalência, pois, o juizo penal é o que tem maior disponibilidade de meios investigatórios, tal como, a interceptação telefônica (art. 5², inciso, CF/88). 
$\mathrm{O}$ art. 935, do Código Civil prega, por exemplo, a independência entre a responsabilidade civil e a responsabilidade penal. No entanto, o mesmo dispositivo ressalva que, não poderão mais ser discutidas no cível a existência do fato ou a autoria, quando estas questões forem decididas no juízo criminal. No Código Penal, o inciso I do art. 91 considera que é efeito secundário da condenação penal "tornar certa a obrigação de indenizar o dano causado pelo crime".

No mesmo sentido, dispõe o art. 65, do CPP, que faz coisa julgada no cível a sentença penal que reconhecer ter sido o ato praticado em estado de necessidade, legítima defesa, estrito cumprimento do dever legal e exercício regular de direito.

Em razão da precedência do juízo penal, as mesmas considerações valem também em relação ao juizo financeiro.

O mecanismo de compatibilização entre os juízos é o Recurso de Revisão (art. 35, da Lei $\left.\mathrm{n}^{\circ} 8.443 / 92\right)$.

Com efeito, a sentença penal absolutória por negativa de fato (art. 386, I, CPP) ou de autoria (art. 386, IV, CPP), ou por excludente de responsabilidade constitui documento novo (superveniente) com eficácia de prova produzida que enseja a revisão da deliberação no processo de contas (art. 35, III, Lei $n^{\circ} 8.443 / 92$ ), que, porventura, tenha julgado irregulares as contas e efetivado a responsabilidade financeira.

Por outro lado, a sentença absolutória por insuficiência de provas da materialidade do ilícito não afasta a competência sancionatória do TCU (Acórdão $\mathrm{n}^{\circ}$ 1.697/2007 - 2 $2^{\mathrm{a}}$. Câmara) e a condenação em débito no âmbito do TCU (Acórdão $\mathrm{n}^{\circ}$ $1.632 / 2004-2^{\mathrm{a}}$. Câmara).

A sentença condenatória (art. 387, do CPP), por sua vez, também produz impactos no juízo financeiro, devendo haver translado dos autos para o Ministério Público 
junto ao Tribunal de Contas, para que, da mesma forma, interponha recurso de revisão que tenha julgado as contas regulares ou regulares com ressalvas.

Com base nas considerações do capítulo 21, não cabe ao juiz penal a fixação do valor mínimo para a reparação (art. 387, IV, da CPP), nas hipóteses em que estiverem presentes os requisitos da responsabilidade financeira reintegratória. Caberá ao juiz penal encaminhar os autos ao Ministério Público junto ao Tribunal de Contas para adoção dos procedimentos cabíveis.

Aplica-se, portanto, analogicamente o disposto no art. 18.2 da Lei Orgância do Tribunal de Contas Espanhol (LOTCu), reiterado pelo art. 49.3, da Lei de Funcionamento do Tribunal de Contas (LFTCu), segundo a qual deverá o juiz penal abster de conhecer a responsabilidade contábil, dando translado dos autos ao Tribunal de Contas.

As decisões do juizo financeiro também podem impactar no juizo penal. $\mathrm{O}$ art. $16, \S 3^{\circ}$, da Lei $n^{\circ} 8.443 / 92$, dispõe que, no caso de contas julgadas irregulares em razão de dano ao Erário por ato ilegítimo ou antieconômico ou por desfalque, desvio de bens, dinheiros e valores, os autos serão encaminhados ao Ministério Público da União para ajuizamento das ações cabíveis.

\subsection{Compatibilidade do Juízo Financeiro e do Juízo Civil ${ }^{171}$}

Ao tratar da responsabilidade civil na Administração Pública, não se pode perder de vista os seus múltiplos aspectos.

Pode-se cogitar, inicialmente, na responsabilidade civil do agente público perante terceiros (responsabilidade externa, mediante ação regressiva do Estado) ou na responsabilidade civil em relação ao Estado (responsabilidade interna). Esta, por sua vez,

\footnotetext{
${ }^{171}$ Neste tópico, por juízo civil me refiro a todos os meios processuais em que seja possível a condenação por responsabilidade civil (Ação Popular, Ação Civil Pública, Ação Regressiva do Estado, etc.), salvo as por improbidade administrativa (vide item 22.4.).
} 
pode ser subdividida em responsabilidade no exercício da gestão pública (do agente contábil) e responsabilidade fora do exercício da gestão.

Há, ainda, a responsabilidade civil dos particulares perante o Estado, no exercício da gestão (é o caso do particular que recebe subvenções do Estado - agentes públicos por equiparação), ou em conluio com agente contábil, ou fora do exercício da administração de recursos públicos (por exemplo, particular que explode uma bomba em um prédio do Ministério, danificando bens ou que colide culposamente contra veículo da Administração pública).

Por fim, há a responsabilidade civil da Administração perante terceiros.

Apenas no caso da responsabilidade civil no exercício da gestão, ou de particulares em conluio com gestor público, é possivel vislumbrar incompatibilidade com a responsabilidade financeira reintegratória, em razão de ambas possuirem função precípua de reconstitutiva.

Convém lembrar que, nas suas intersecções, a possibilidade de cumulação de condenações divergentes entre o juízo civil e o juízo financeiro é nociva à segurança jurídica e torna inútil o instituto jurídico da quitação. Permitir que os Tribunais de Contas e os Tribunais do Poder Judiciário pronunciem-se sobre a mesma lide pode gerar conflitos de difícil solução. Por exemplo, o cálculo do dano ao erário efetuado por um Tribunal pode tomar por base os preços de mercado, enquanto outro os preços registrados no Sistema de Registro de Preços (art. 15, Lei $\mathrm{n}^{\circ}$ 8.666/93) ou, ainda, os preços constantes do Sistema SINAPI da Caixa Econômica Federal.

Nas demais situações, não há que se cogitar nesta possibilidade, tendo em vista que a responsabilidade financeira tem seus sujeitos passivos e pressupostos próprios, que não coincidem com os da responsabilidade civil. 
A incompatibilidade mencionada é apenas aparente. A obrigação decorrente da responsabilidade civil (obrigação de indenizar) é distinta da obrigação decorrente da responsabilidade financeira reintegratória (obrigação de repor). A primeira abrange o dano emergente, os lucros cessantes e o dano moral. A segunda apenas as quantias envolvidas na infração. Há na responsabilidade financeira uma referibilidade a certos bens, dinheiros ou valores públicos. O conceito de "dano ao erário" da responsabilidade financeira reintegratória, conforme já abordado no item 11.3.2., não é sinônimo de diferença entre a situação patrimonial projetada (se não houvesse o dano) e a situação patrimonial atual (após o dano).

Ademais, conforme discutido no capítulo 21, o Tribunal de Contas exerce jurisdição contábil-financeira sobre as pretensões relativas à responsabilidade financeira. Logo, havendo infração às normas de gestão, competirá ao Tribunal de Contas avaliar a responsabilidade no tocante às quantias envolvidas, e ao juízo civil competirá o julgamento da pretensão de lucros cessantes, de dano moral, de dano ambiental, de dano ao patrimônio histórico-cultural, de enriquecimento sem causa, porventura decorrentes do mesmo fato.

No juízo civil, também são tratadas as pretensões relacionadas às nulidades dos atos e contratos celebrados pela Administração, que não interferem no juízo financeiro, restrito à pretensão da responsabilidade financeira. É importante esclarecer que, ao sustar atos o ou contratos (art. 71, X, CF/88), o Tribunal de Contas não exerce competência de natureza jurisdicional, devendo prevalecer o julgamento proferido pelo Poder Judiciário (capítulo 21).

\subsection{Compatibilidade do Juízo Financeiro com o Juízo de Improbidade Administrativa}

A Improbidade Administrativa está regulada na Lei $\mathrm{n}^{\circ} 8.429 / 92$. Tem por fundamento o art. $37, \S 4^{\circ}$, da Constituição Federal, o qual dispõe que: "Os atos de improbidade administrativa importarão a suspensão dos direitos políticos, a perda da função pública, a indisponibilidade dos bens e o ressarcimento ao erário, na forma e gradação previstas em lei, sem prejuízo da ação penal cabível". 
A improbidade está relacionada à desonestidade e a má-fé do agente público, o que requer, via de regra, uma conduta dolosa do agente, conforme deliberação do STJ no Resp. $\mathrm{n}^{\circ}$ 939.142/RJ:

\footnotetext{
"Tanto a doutrina quanto a jurisprudência do STJ associam a improbidade administrativa à noção de desonestidade, de má-fé do agente público, do que decorre que a conclusão de que somente em hipóteses excepcionais, por força de inequívoca disposição legal, é que se admite a sua configuração por ato culposo (artigo 10, da Lei n 8.429/92)."
}

$\mathrm{Na}$ Lei $\mathrm{n}^{\circ}$ 8.429/92 são definidas três espécies de atos de improbidade administrativa: os atos de improbidade que importem em enriquecimento ilícito (art. $9^{\circ}$ ), atos que importem em dano ao Erário (art. 10) e atos que importem em violação aos princípios da administração pública (art. 11). Os atos que importam em enriquecimento ilícito são os mais graves e os atos que violam os princípios são os menos graves. Na hipótese de um ato enquadrar-se em mais de uma categoria, adota-se a categoria mais grave.

Dentre as sanções cabíveis em razão dos atos de improbidade administrativa, podemos citar (art. 12, da Lei n $\left.{ }^{\circ} 8.429 / 92\right)$ :

a) perda dos bens ou valores acrescidos ilicitamente ao patrimônio, quando houver;

b) ressarcimento integral do dano, quando houver;

c) suspensão dos direitos políticos;

d) pagamento de multa civil, proporcional ao valor do acréscimo patrimonial, ou ao dano ao erário, ou ao valor da remuneração do agente;

e) proibição de contratar com o Poder Público ou receber benefícios ou incentivos fiscais ou creditícios.

Pode haver incompatibilidade entre as sanções acima com as sanções financeiras, apenas no tocante ao ressarcimento do dano e no tocante à multa proporcional ao 
dano ao erário ${ }^{172}$. As demais sanções por improbidade administrativa são perfeitamente cumuláveis com as sanções financeiras.

Convém ressaltar que o escopo dos sujeitos passivos da improbidade administrativa (arts. $2^{\circ}$ e $3^{\circ}$, da Lei $n^{\circ}$ 8.443/92) é bem mais amplo que o dos agentes contábeis (art. $5^{\circ}$, da Lei $\left.n^{\circ} 8.443 / 92\right)$. Atos de improbidade administrativa não relacionados com a atividade de gestão não produzem qualquer impacto no juízo financeiro. Por exemplo, o fiscal da vigilância sanitária que recebe propina para não interditar determinado estabelecimento comete ato de improbidade administrativa que gera enriquecimento ilícito, mas não comete ilícito financeiro.

No tocante à multa proporcional, não há que se admitir a cumulatividade, pois é desrazoável e desproporcional aplicar duas penalidades, materialmente idênticas, com a mesma finalidade (punitiva ou repressiva) ao mesmo agente em razão do mesmo fato. No caso, estão atendidos os pressupostos apresentados por Coimbra Silva (item 10.5.) para aplicação do princípio "ne bis in idem", ainda que de natureza jurídica distinta: conduta ilícita única, identidade subjetiva e identidade teleológica ou identidade de fundamento.

Dentre as duas possibilidades, a multa proporcional ao erário aplicada pelos Tribunais de Contas tem previsão expressa na Constituição (art. 71, VIII, CF/88), o que não acontece com a multa prevista na Lei $n^{\circ} 8.429 / 92$. Com efeito, o art. 37 , $\S 4^{\circ}$, da $\mathrm{CF} / 88$ não a elenca a multa como penalidade inerente ao ato de improbidade administrativa.

Desta forma, deve prevalecer a multa proporcional ao dano ao erário aplicada pelos Tribunais de Contas.

No tocante ao dano ao erário, a compatibilidade entre as sanções e jurisdições torna-se de difícil solução. Ambas as jurisdições tem competência legal e constitucional para o ressarcimento do dano ao erário. No caso dos atos de improbidade administrativa, há

\footnotetext{
${ }^{172}$ A inelegibilidade em decorrência do julgamento das contas pela irregularidade é de competência da Justiça Eleitoral e não do Tribunal de Contas.
} 
previsão expressa no art. $37, \S^{\circ}$, da $\mathrm{CF} / 88$ e no caso das infrações financeiras, no art. 71 , II c/c $\S 3^{\circ}$, da $\mathrm{CF} / 88$ (imputação de débito - eficácia de título executivo).

Na solução proposta por Emerson Garcia e Rogério Pacheco Alves, eventual diferença entre as condenações ao ressarcimento do dano deverá ser resolvida complementando-se a importância fixada em outro juízo. Ou seja, a solução do conflito implica no pagamento da maior quantia em que o sujeito foi condenado (GARCIA; ALVES, 2006).

Nas palavras dos autores (GARCIA; ALVES, 2006, p. 488-489):

"Ao disciplinar as atribuições do Tribunal de Contas, estabelece a Constituição da República, em seu art. $71, \S 3^{\circ}$, que 'as decisões do Tribunal de que resulte imputação de débito ou multa terão eficácia de título executivo'. Assim, ainda que o Tribunal fixe importância a ser ressarcida aos cofres públicos ou aplique determinada multa ao ímprobo, estará ele sujeito à complementação do numerário estabelecido a título de ressarcimento e ao pagamento da multa prevista no art. 12 da Lei $\mathrm{n}^{\circ}$ 8.429/92. Nesta hipótese, será legitima a justaposição das penalidades pecuniárias: o ressarcimento até a integral reparação do dano e a multa de forma cumulativa, conforme expressa autorização do caput do art. 12".

Mônica Nicida Garcia, analisando a cumulação de sanções nos juízos civil, criminal, administrativo e de improbidade, admite a possibilidade da responsabilização do agente público ocorrer em mais de uma esfera (GARCIA, M., 2007, p. 321):

\footnotetext{
"Assim é que o ressarcimento do dano pode-se dar nas esferas civil e de improbidade; a perda dos bens e valores acrescidos ilicitamente, nas esferas criminal e de improbidade; a perda da função pública nas esfera criminal, administrativa e de improbidade; a suspensão dos direitos políticos na criminal e de improbidade".
}

A compatibilização das esferas, na opinião da autora, ocorre na fase da execução. Se as sanções impostas forem iguais, salienta, apenas uma deverá ser executada, devendo a outra ser oportunamente julgada extinta, por já ter sido cumprida (GARCIA, M., 2007). Nas palavras da autora (GARCIA, M., 2007, p. 322):

"Caberá ao agente público multissancionado invocar em sua defesa o cumprimento, em outra esfera, de sanção que lhe for imposta e estiver sendo executada em uma determinada esfera. Ressalte-se que o acionamento de várias esferas, concomitantemente, epor diversos órgãos, não constitui hipótese cerebrina, mas antes que ocorrência plenamente possível, cumprindo, por isso, procurar-se uma solução que compatibilize e torne eficazes as autuações, que têm, agora, se incrementado, no sentido da sempre desejada, mas nem sempre conseguida, responsabilização do agente público". 
Com a devida vênia, entendo não serem estas as soluções mais adequadas. Em primeiro lugar, a existência de mais de um órgão estatal competente para julgar o mesmo assunto é nociva à segurança jurídica. Em segundo lugar, há que se admitir que o art. $37, \S^{\circ}$, da $\mathrm{CF} / 88$ não definiu qual o órgão estatal competente para julgar a pretensão de ressarcimento do dano ao erário. Limitou-se a afirmar que o ressarcimento é consequência do ato de improbidade.

Em terceiro lugar, conforme discutido no capítulo 21, o Tribunal de Contas tem jurisdição exclusiva sobre a pretensão de responsabilidade financeira reintegratória, limitada às quantias efetivamente geridas.

A minha proposta é delimitar as competências e as jurisdições, permitindo, por conseguinte, a compatibilização entre as sanções financeira e as sanções por improbidade, da mesma forma que no item 22.3. E a delimitação envolve a utilização de diferentes noções para os danos ressarcíveis em cada uma das esferas jurisdicionais. No juizo financeiro, conceito de débito ou de dano ao erário (item 11.3.2.), que, conforme já mencionado, está limitado e referido aos bens, dinheiros e valores efetivamente geridos, não englobando os lucros cessantes, o dano moral e o enriquecimento ilícito do agente.

As parcelas não incluídas no conceito de débito devem ser ressarcidas pela via da ação civil de improbidade administrativa.

Reconheço que este posicionamento contraria a opinião dominante na doutrina e da jurisprudência (Basta verificar o número de Acórdãos do $\mathrm{STJ}^{173}$ que admitem a condenação ao ressarcimento ao dano ao Erário com base na Lei n 8.429/92). Entretanto, há precedente no STF $\left(\operatorname{RCL~n}^{\circ} 2138 / \mathrm{DF}\right)$, no qual a Egrégia Corte restringiu o escopo subjetivo da Lei $n^{\circ} 8.429 / 92$, mesmo contra a expressão literal da lei, impedindo a cumulação entre a responsabilização por improbidade e por crime de responsabilidade, o que pode sugerir uma

\footnotetext{
${ }^{173}$ Conforme Resp n ${ }^{\circ}$ 586.248/MG (Min. Francisco Falcão): "É pacífico o entendimento desta Corte no sentido de ser o Ministério Público legítimo para propor ação civil pública na hipótese de dano ao erário público".
} 
tendência de limitar o campo de atuação da Lei ${ }^{\circ}$ 8.429/92 em função de outras esferas de responsabilização. 


\section{CONCLUSÕES}

A responsabilidade financeira é uma espécie de responsabilidade jurídica presente nos Estados que adotam o Sistema de Tribunal de Contas com poderes de julgamento das contas dos responsáveis pela gestão de recursos públicos.

Origina-se na separação da gestão e da propriedade, típicas das organizações modernas, que impõe ao gestor de recursos alheios normas e princípios de gestão para manter a aderência aos objetivos traçados pelo titular destes recursos. Dentre estas normas, destaca-se o dever de prestar contas que, antes de ser mera formalidade, constitui ônus de comprovar a total e regular aplicação dos recursos públicos.

No Brasil, a responsabilidade financeira, tal como em Portugal, apresenta duas modalidades: reintegratória e sancionatória. A primeira de função essencialmente reparatória ou compensatória e a segunda de função essencialmente punitiva. Não se pode negar, ainda, a função de prevenção geral de ambas as modalidades.

Dentre as características das responsabilidade financeira, que a diferenciam das demais modalidades de responsabilidade, convém citar: ela incide exclusivamente sobre determinados agentes, os "agentes contábeis", gestores de bens, dinheiros e valores públicos; tem caráter patrimonial; é decorrente da atividade de gestão de bens, dinheiros e valores públicos; é vinculada às funções de fiscalização e julgamento das contas públicas e é processada e julgada pelos Tribunais de Contas, cujas deliberações que imputem débito ou apliquem multa geram título executivo apto à execução judicial.

A responsabilidade financeira encontra-se, atualmente, regulada pelas Leis Orgânica dos Tribunais de Contas, editadas no âmbito do ente federado ao qual estes se integram. Entretanto, com o advento da $\mathrm{EC} \mathrm{n}^{\circ}$ 40/2003, que alterou a redação do art. 163, inciso $\mathrm{V}$, da $\mathrm{CF} / 88$, e considerando que a atividade fiscalizatória e sancionatória dos Tribunais de Contas deve ser uniforme no território nacional, caberá ao Congresso Nacional editar Lei Complementar versando sobre normas gerais de responsabilidade financeira. 
Aplicam-se à Responsabilidade Financeira os chamados "princípios gerais $d a$ repressão", conjunto de direitos e garantias mínimas, oriundas do Direito Penal, que são aplicáveis à toda atividade punitiva do estado. A aplicação de Princípios do Direito Penal ao âmbito da Responsabilidade Financeira deve observar, entretanto, algumas cautelas, ou seja, deve-se observar as peculiaridades da atuação do Controle Externo.

A responsabilidade financeira submete-se aos princípios da legalidade, da tipicidade aberta, da vedação ao "bis in idem", da irretroatividade da norma estatuidora da infração.

É admitida a cumulação entre a responsabilidade por débito (reintegratória) e a responsabilidade por multa (sancionatória), sem que isso implique em "bis in idem".

A pessoalidade é só aplicável à responsabilidade financeira sancionatória, pois a obrigação de repor é transmissível aos sucessores até o limite do patrimônio transferido.

A responsabilidade financeira reintegratória segue os pressupostos da responsabilidade civil, embora com esta não se confunda. Não se exige a tipicidade das condutas para configuração desta modalidade de responsabilidade. Exige-se, entretanto, para a configuração da responsabilidade reintegratória, a violação de normas ou princípios de gestão pública.

A omissão no dever de prestar contas constitui hipótese especial de responsabilidade financeira reintegratória, eis que há presunção relativa de dano quando o gestor público deixa de dar satisfação sobre os recursos públicos a ele confiados.

O conceito de dano ao erário aplicável à responsabilidade financeira não se confunde com o dano emergente da responsabilidade civil, consistente na diferença patrimonial entre antes e depois da responsabilidade financeira. Não se tratando de contraprestação ao Estado, o dano será configurado se a ação estatal não gerar benefícios à sociedade. 
O dano ao erário (débito) limita-se às "quantias envolvidas na infração", não abrangendo, portanto, os lucros cessantes ao dano moral (dano à imagem da Administração Pública), os quais deverão ser objeto de reparação em outras instâncias juridiscionais.

A responsabilidade sancionatória (multa) pressupõe o enquadramento da conduta em um dos tipos legais:
a) dano ao erário;
b) hipóteses elencadas no art.58, da Lei no 8.443/92;
c) hipóteses elencadas no art. $5^{\circ}$, da Lei 10.028/2000.

A responsabilidade financeira é uma responsabilidade subjetiva. Em ambas as modalidades, exige-se culpa em sentido amplo, segundo aplicação analógica do preceito contido no art. 37, da CF/88, ante as lacunas da legislação existente.

A avaliação da culpabilidade do gestor corresponde a determinação do grau de reprovabilidade de sua conduta e deve levar em conta diversos fatores, tais como, a existência de dolo ou enriquecimento ilícito, as circunstâncias do caso concreto, o número de operações efetuadas pelo gestor, a disponibilidade de recursos humanos e materiais, a complexidade da legislação existente e o atendimento das determinações e recomendações do Tribunal de Contas. Esta avaliação tem duas funções: permitir a relevação da responsabilidade, no caso de culpa levíssima, ou, caso seja aplicada a penalidade de multa, a quantificação do seu montante.

Apenas um rol restrito de sujeitos, os "agentes contábeis", está submetido à responsabilidade financeira. Trata-se dos sujeitos jurisdicionados aos Tribunais de Contas (art. $5^{\circ}$, da Lei 8443/92 - no âmbito federal). Não poderá haver interpretação extensiva deste rol sob pena de invadir as esferas de outras jurisdições.

Na identificação do responsável por uma irregularidade na gestão, deve-se levar em conta os deveres de cautela que foram violados, a aptidão da conduta para 
influenciar o ato inquinada, o processo de formação do ato irregular e a natureza do agente envolvido.

O processo contábil não se confunde com o processo administrativo, apesar de muitos dos princípios aplicáveis à responsabilidade financeira guardarem notável semelhança com os deste tipo de processo: formalismo moderado e gratuidade. Entretanto, incidem também no processo contábil os princípios típicos do processo judicial, tais como, a imparcialidade do julgador.

Apesar da Lei $n^{\circ}$ 8.443/93 expressamente admitir a aplicação de multa em processos de fiscalização, entendo que apenas os processos de contas (tomada e prestação de contas e tomada de contas especial) são adequados para a efetivação da responsabilidade financeira, em qualquer das suas modalidades. Nestes, há participação obrigatória do Ministério Público junto ao Tribunal de Contas, cujo parecer é, nos termos do princípio da demanda, condição de sine qua non para a instauração da fase contenciosa, destinada à efetivação da responsabilidade financeira. Além disso, apenas nos processos de contas é possível conceder quitação ao gestor. E a quitação é um instituto relacionado ao princípio geral da segurança jurídica.

É peculiar ao processo de efetivação da responsabilidade financeira o princípio da inversão do ônus da prova. A inversão do ônus da prova é consequência do Dever de Prestar Contas (art. 70, caput, CF/88), do art. 113, da Lei $\mathrm{n}^{\circ}$ 8.666/93 e do art. 93, do Decreto-lei n 200/67.

A responsabilidade financeira é categoria jurídica autônoma e diferenciada das espécies tradicionais de responsabilidade (civil, penal, administrativa e por improbidade administrativa) apesar de contar com alguns pontos de intersecção.

Os fatores preponderantes que lhe conferem a autonomia são a limitação dos sujeitos passivos da responsabilidade, a forma de cálculo do dano ao erário e a sua função precípua de assegurar a boa e regular gestão dos recursos públicos. Trata-se de uma 
modalidade de responsabilidade relacionada à atuação regular, periódica e contínua de verificação das contas públicas.

Os Tribunais de Contas exercem uma jurisdição especial e limitada, relacionada às pretensões do Estado à Responsabilidade Financeira, o que em outros países é denominada jurisdição contábil ou financeira. Esta modalidade de jurisdição é compatível com as demais jurisdições, ainda que se sujeite a eventual controle pelo Poder Judiciário, restrito aos aspectos formais e de manifesta ilegalidade.

Esta Jurisdição não se confunde com o Contencioso Administrativo, nos países que o adotam. No Brasil, diferentemente do que ocorre com a Espanha, não subsiste a Jurisdição Voluntária dos Tribunais de Contas, relacionada à liberação das cauções e demais garantias apresentadas pelo gestor. 


\section{BIBLIOGRAFIA}

\subsection{Livros, Artigos e Pareceres}

ALEMANHA. Bundesinnenministerium. The Public Service in Germany. Disponível em <http://www.bmi.bund.de>. Acesso em 10.01.2009.

ALMEIDA, M. C. Auditoria: um curso moderno e completo. $5^{\text {a }}$. ed. São Paulo, Atlas, 1996. $417 \mathrm{p}$.

ALTOUNIAN, C. S. Obras públicas: licitação, contratação, fiscalização e utilização. Belo Horizonte: Fórum, 2007. 285 p.

AMED, F. J. ; NEGREIROS, P. J. História dos Tributos no Brasil. São Paulo: Sinafresp, 2000. $325 \mathrm{p}$.

ANTÔNIO, A. L. A.; ANTONIO, J. A. A. Derecho Constitucional Español. 4ª ed. Madrid: Editorial Universitas, 2006. 673 p.

ARAUJO, M. V. O Tribunal de Contas da União: uma análise histórica de causas e efeitos. Revista do Tribunal de Contas da União, Brasília, n² 21, p. 67-120. out/dez. 1990.

ASCENÇÃO, J. O. Introdução à Ciência do Direito. $3^{\mathrm{a}}$. ed. Rio de Janeiro: Renovar, 2005. $683 \mathrm{p}$.

AVALLONE, P.; TARULLO, S. Il giudizio di responsabilità amministrativo-contabile innanzi alla Corte dei Conti. Padova: Cedam, 2002. 255 p.

BECKERS, J. A Jurisdição do Tribunal de Contas Belga. Revista do Tribunal de Contas, Lisboa, $n^{\circ}$ 41, p. 85-108, jan/jul 2004.

BRACO, S. C. Responsabilità Amministrativa e Contabile. In: VVAA. Le responsabilità del Pubblico Impiegato: civile, penale, amministrativa-contabile, disciplinare e dirigenziale. Padova: Cedam, 2003, p. 26-127.

BRASIL. Tribunal de Contas da União: Instituto Serzedello Correa. Responsabilidade perante o TCU: prática e jurisprudência. Brasília: ISC, 2008. 225 p.

CANOTILHO, J. J. G. Direito Constitucional e Teoria da Constituição. $7^{\mathrm{a}}$. ed. Coimbra: Almedina, 2003. $1522 \mathrm{p}$.

CAPEZ. F. Curso de Direito Penal. vol. 1. 9a . ed. São Paulo: Saraiva, 2005. 589 p.

CARMO, J. F. Contribuição ao estudo da Responsabilidade Financeira. Revista do Tribunal de Contas, Lisboa, $\mathrm{n}^{\circ} 23$, p. 39-207, mar. 1995. 
CARNEIRO, A. G. Jurisdição e Competência. 12ª . ed. São Paulo: Saraiva, 2002. 429 p.

CAVAlCANTI, A. S. O processo de contas no TCU: o caso do gestor falecido. Revista do Tribunal de Contas da União, Brasília, n 81, p. 17-27, jul/set. 1999.

CAVALIERI FILHO, S. Programa de Responsabilidade Civil. $3^{\text {a }}$. ed. São Paulo: Malheiros, 2002. 503 p.

CHAVES, F. E. C. Controle Externo da Gestão Pública: a fiscalização pelo legislativo e pelos tribunais de contas. Niterói: Impetus, 2007. 357 p.

CINTRA, A. C. A.; GRINOVER, A.P.; DINAMARCO, C.R. Teoria Geral do Processo. $13^{\mathrm{a}}$. ed. São Paulo: Malheiros, 1997. 364 p.

CHAPP, J. E. Webster's Dictionary of the Law. New York: Random House, 2000. 528 p.

COELHO, F. A. Teoria Geral do Processo. 2a . ed. São Paulo: Juarez de Oliveira, 2007. 689 p.

CONTI, J. M. A Autonomia Financeira do Poder Judiciário no Brasil. 271f. 2005. Tese (Livre Docência) - Faculdade de Direito, Universidade de São Paulo, 2005.

Direito Financeiro na Constituição de 1988. São Paulo: Ed. Oliveira Mendes, 1998. $131 \mathrm{p}$.

CORNU, G. Vocabulaire Juridique. $7^{\mathrm{a}}$. ed. Paris: Presses Universitaires de France, 2005. 970 p.

CUNHA, J. B. Legitimidade Passiva de Municípios no âmbito do TCU. Revista do Tribunal de Contas da União, Brasília, n 89, p. 59-61, jul./set. 2001.

DELPINO, L.; GIUDICE, F. Diritto Amministrativo. 25 ${ }^{\mathrm{a}}$. ed. Napoli: Simone, 2008. 861 p.

DETTERBECK, S. Öffentliches Recht: Staatsrecht, Verwaltungsrecht, Europarecht mit Übungsfällen - ein Basislehrbuch. 6 ${ }^{\text {a }}$ ed. München: Verlag Franz Vahlen, 2008. 614 p.

DIDIER JR., F. Curso de Direito Processual Civil. vol. 1. 9ª ed. Salvador: Juspodivm, 2008. $593 \mathrm{p}$.

. Curso de Direito Processual Civil. vol. 2. 2a . ed. Salvador: Juspodivm, 2008.

$683 \mathrm{p}$.

DINAMARCO, C. R. Instituições de Direito Processual Civil. vol. I. São Paulo: Malheiros, 2001. 679 p.

DI PIETRO, M. S. Z. Coisa julgada: aplicabilidade a decisões do Tribunal de Contas da União. Revista do Tribunal de Contas da União, Brasília, n 70, p. 23-36, out/dez. 1996. 
Discricionariedade Administrativa na Constituição de 1988. 2a. ed.

São Paulo: Atlas, 2002. 242 p.

ENCONTRO DOS TRIBUNAIS DE CONTAS DA CPLP, I, 1995, Lisboa. Disponível em $<\mathrm{http}: / /$ www.tcontas.pt $>$. Acesso em 01.11.2008.

FERNANDES, J. U. F. J. Tomada de Contas Especial. 2a . ed. Brasília: Brasília Jurídica, $1998.747 \mathrm{p}$.

. Tribunais de Contas do Brasil: jurisdição e competência. Belo

Horizonte: Fórum, 2003. 889 p.

FERRAZ, S.; DALlARI, A. A. Processo Administrativo. 2a . ed. São Paulo: Malheiros, 2007. $207 \mathrm{p}$.

FERREIRA, D. Sanções Administrativas. São Paulo: Malheiros, 2001. 247 p.

FIGUEIREDO, M. Probidade Administrativa: comentários à lei $8.429 / 92$ e legislação complementar. $5^{\text {a }}$. ed. São Paulo: Malheiros, 2004. 414 p.

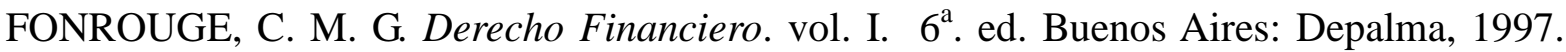
$650 \mathrm{p}$.

FRANCO, A. L. S. Finanças Públicas e Direito Financeiro. v. I. $4^{\text {a }}$. ed. Coimbra: Almedina, 2002. $504 \mathrm{p}$.

. Prefácio. In: TAVARES, J.; MAGALHÃES, L. Tribunal de Contas: legislação anotada. Coimbra: Almedina, 1990. p. 9-48.

GAGLIANO, P. S.; PAMPLONA FILHO, R. Novo Curso de Direito Civil. v. III. São Paulo: Saraiva, 2003. $430 \mathrm{p}$.

GARCIA, E.; ALVES, R. P. Improbidade Administrativa. $3^{\text {a }}$. ed. Rio de Janeiro: Lumen Juris, 2006. $981 \mathrm{p}$.

GARCIA, M. N. Responsabilidade do Agente Público. $2^{\mathrm{a}}$. ed. Belo Horizonte: Fórum, 2007. $463 \mathrm{p}$.

GIURISDIZIONE. In: ENCICLOPEDIA DEL DIRITTO. 2a . ed. Garzanti, 2001.

GOMES, E. C. S. Fundamentos das Transferências Intergovernamentais. Revista IOB de Direito Administrativo, São Paulo, nº 24, p. 66-86, dez. 2007. - Limitações da Contabilidade Pública como auxílio à apreciação das contas. In: CONTI, J. M. (org). Orçamentos Públicos: A Lei 4.320/1964 Comentada. São Paulo: RT, 2008. p. 269-271. 
GRANOF. M. H. Government and not-for-profit Accounting: concepts and practices. $3^{\mathrm{a}}$ ed. Hoboken: Wiley, 2005. 736 p.

GUALAZZI, E. L. B. Regime Jurídico dos Tribunais de Contas. São Paulo: RT, 1992. 230 p. HILGENDORF, E. Dtv-Atlas Recht. Band 1. München: Deutscher Taschenbuch Verlag, 2003. $251 \mathrm{p}$.

ISTITUZIONI di Diritto Pubblico. 17ª . ed. Napoli: Simone, 2008. 576 p.

JUSTEN FILHO, M. Comentários à Lei de Licitações e Contratos Administrativos. 11 a . ed. São Paulo: Dialética, 2005. 719 p.

KELSEN, H. Teoria Geral do Direito e do Estado. Tradução Luis Carlos Borges. $4^{\mathrm{a}}$. ed. São Paulo: Martins Fontes, 2005. 637 p.

. Teoria Pura do Direito. Tradução João Baptista Machado. 6 ${ }^{\mathrm{a}}$. ed. São Paulo: Martins Fontes, 1998. 427 p.

LAPATZA, J. J. F. Curso de Derecho Financiero Español. v. I. Madrid-Barcelona: Marcial Pons, 2004. 338 p.

LUCA, G. Contabilità di Stato e degli Enti Pubblici. 18a . ed. Napoli: Simone, 2008. 432 p.

MAGALHÃES, L. Era uma vez a responsabilidade financeira: algumas reflexões sobre o regime da responsabilidade financeira na Lei $n^{\circ}$ 98/97, de 26 de agosto. In: ENCONTRO DOS TRIBUNAIS DE CONTAS DE ESPANHA E PORTUGAL, I, 2003, Lisboa. I Encontro dos Tribunais de Contas de Espanha e Portugal. Lisboa: Tribunal de Contas, 2004, p. 33-41. MASTRONIANI, L. La nuove frontiere della responsabilità amministrativa: operatori pubblici e dano erariale. Disponível em <http://dirittoegiustiziaonline.it/>. Acesso em 04.02.2005.

MAURER, H. Direito Administrativo Geral. Tradução Luis Afonso Heck. 14a ${ }^{\mathrm{a}}$. ed. Barueri: Manole, 2006. 955 p.

MEIRELLES, H. L. Direito Administrativo Brasileiro. 19ª ed. São Paulo: Malheiros, 1994. $702 \mathrm{p}$. . Mandado de Segurança. $27^{\mathrm{a}}$. ed. São Paulo: Malheiros, 2004. 671 p.

MELLE, E. La responsabilità dei dipendenti e degli amministratori pubblici. 6 a . ed. Milano: Giuffre, 2004. 293 p.

MELlO, C. A. B. Curso de Direito Administrativo. 18ª ed. São Paulo: Malheiros, 2005. 1008 p. 
MERINO-BLANCO, E. Spanish Law und Legal System. $2^{\mathrm{a}}$ ed. Sweet \& Maxwell, 2006. $420 \mathrm{p}$.

MILESKI, H. S. O Controle da Gestão Pública. São Paulo: RT, 2003. 400 p.

MONTORO, A. F. Introdução à Ciência do Direito. 26a . ed. São Paulo: RT, 2005. 702 p.

MORAES, A. Direito Constitucional. 19ª ed. São Paulo: Atlas, 2006. 918 p.

NADER, P. Introdução ao Estudo do Direito. 25ª . ed. Rio de Janeiro: Forense, 2005. 436 p.

NERILO, L. F. L. Responsabilidade Civil dos Administradores: nas sociedades por ações.

Curitiba: Juruá, 2003. 197 p.

OLIVEIRA, R. F. Curso de Direito Financeiro. São Paulo: RT, 2006. 143 p.

. Delegação Administrativa. 227f. 1985. Tese (Livre Docência) - Faculdade de Direito, Universidade de São Paulo, 1985.

. Infrações e Sanções Administrativas. 2ª ${ }^{\mathrm{a}}$ ed. São Paulo: RT, 2005. 608 p.

ORIONE NETO, L. Recursos cíveis: teoria geral, princípios fundamentais, dos recursos em espécie, tutela de urgência no âmbito recursal, da ordem dos processos no tribunal. São Paulo: Saraiva, 2002. 790 p.

OSÓRIO, F. M. Direito Administrativo Sancionador. 2a . ed. São Paulo: RT, 2005. 560 p.

PAZZAGLINI FILHO, M. Lei de Improbidade Administrativa Comentada. $3^{\mathrm{a}}$. ed. São Paulo: Atlas, 2007. 324 p.

PIMENTA OLIVEIRA, J. R. Os princípios da razoabilidade e da proporcionalidade no Direito Administrativo Brasileiro. São Paulo: Malheiros, 2006. 582 p.

PORTALÉS, L. F. La jurisdicción Contencioso-Administrativa en España. Revista CEJ, Brasilia, $\mathrm{n}^{\circ}$ 34, p. 62-72, jul/set 2006. Disponível em <http://www.cjf.gov.br>. Acesso em $<01.12 .2008>$.

PORTUGAL. Conselho Consultivo da Procuradoria Geral da República. Parecer $n^{\circ} 1237$. Tribunal de Contas - Ministério Público - Infração Financeira - Responsabilidade Financeira. Relator Henrique Gaspar. 31 mai. 2001. Disponível em <http://www.dgsi.pt>. Acesso em 01.06.2006.

PORTUGAL. Tribunal de Contas. Controle Externo e Responsabilidade Financeira: O sistema portugues. In: XX CONGRESSO DOS TRIBUNAIS DE CONTAS DO BRASIL. Fortaleza, 1999.

PRADO, F. O. A. Improbidadade Administrativa. Malheiros: São Paulo, 2001. 242 p. 
PRADO, L.R. Comentários ao Código Penal: doutrina, jurisprudência selecionada e leitura indicada. $2^{\mathrm{a}}$. ed. São Paulo: RT, 2003. 782 p.

Curso de Direito Penal Brasileiro. vol. 1. 6 ${ }^{\mathrm{a}}$. ed. São Paulo: RT, 2006.

RAYA, F. J. C. Manual de Derecho Financiero. vol. III. Madrid: Ed. Tecnos, 1995. 180 p.

REINO UNIDO. National Audit Office. State Audit in European Union. Disponível em: <http://www.nao.gov.uk>. Acesso em 01.06.2006.

RESPONSABILITÀ. In: ENCICLOPEDIA DEL DIRITTO. 2ª ed. Garzanti, 2001.

RIVERO, J. Direito Administrativo. Tradução Rogério Ehrhardt Soares. Coimbra: Almedina, $1981.582 \mathrm{p}$.

RODRIGUEZ, C. C. La jurisdicción del Tribunal de Cuentas. Granada: Editorial Comares, $1999.323 \mathrm{p}$.

SANCHEZ, Y. G. El Tribunal de Cuentas: el control económico-f'inanciero externo en el ordenamiento constitucional español. Madrid-Barcelona: Marcial Pons, 2001. 293 p.

SANTORO, P. L'illecito contabile: disciplina sostanziale e processuale dei giudizi nelle materie di contabilità pubblica. Santarcangelo di Romagna (RN), Maggioli: 2006. 794 p.

SILVA, C. D. O. Lei Orgânica Nacional dos Tribunais de Contas: instrumento de aprimoramento das instituições brasileiras de controle externo. Disponível em <http://www.camara.gov.br>. Acesso em 01.10.2008.

SILVA, J. A. Comentário Contextual à Constituição. São Paulo: Malheiros, 2005. 1023 p.

SILVA, P. R. C. Direito Tributário Sancionador. São Paulo: Quartier Latin, 2007. 398 p.

SILVA, V. A. O proporcional e o razoável. Revista dos Tribunais, n 798, p. 23-50, abr. 2002.

STOCO, R. Tratado de Responsabilidade Civil. 7 . ed. São Paulo: RT, 2007. 1949 p.

TAVARES, J. F.F. O Tribunal de Contas - do visto, em especial: conceito, natureza e enquadramento na actividade da Administração. Coimbra: Almedina, 1998. p. 241.

TAVARES, J.; MAGALHÃES, L. Tribunal de Contas: legislação anotada. Coimbra: Almedina, 1990. 318 p.

TOLEDO, F. A. Princípios Básicos de Direito Penal. 5a . ed. São Paulo: Saraiva, 2002. 362 p. TOURINHO FILHO, F. C. Processo Penal. v. 2. 23 a . ed. São Paulo: Saraiva, 2001. 800 p. VIDAL, C. R. La responsabilidad contable y la gestión de los recursos públicos: análisis de la doctrina del tribunal de cuentas. $2^{\mathrm{a}}$. ed. Madrid: Civitas, 1999. 163 p.

VITTA, H. G. A Sanção no Direito Administrativo. São Paulo: Malheiros, 2003. 175 p. 
VIVES, V. Control Externo del Gasto Publico y Estado Constitucional. 2001. 631f. Tese (Doutorado em Direito) - Departament de Ciencia Politica i Dret Public, Universitat Autònoma de Barcelona, 2001.

\subsection{Jurisprudência dos Tribunais}

\subsubsection{Tribunal de Contas da União (TCU)}

Súmula $\mathrm{n}^{\circ} 187$

Acórdão n 153/1995 - Plenário

Decisão n 279/95 - Plenário

Acórdão n ${ }^{\circ}$ 386/1995 - 2 ${ }^{\text {a }}$. Câmara

Decisão nº 186/1996 - 2 ${ }^{\text {a }}$. Câmara

Acórdão n 293/1998 - 2a . Câmara

Acórdão n ${ }^{\circ}$ 92/1999 - $2^{\mathrm{a}}$. Câmara

Acórdão n 353/1999 - 2ª . Câmara

Decisão n 366/1999 - 2 a . Câmara

Acórdão n 371/1999 - 2a . Câmara

Acórdão n ${ }^{\circ} 114 / 2000$ - $1^{\text {a }}$. Câmara

Acórdão n 147/2000 - Plenário

Acórdão n 193/2000 - 1ª . Câmara

Decisão n ${ }^{\circ}$ 1.020/2000 - Plenário

Acórdão n 46/2001 - Plenário

Acórdão nº 149/2001 - Plenário

Acórdão nº 215/2001 - $1^{\text {a }}$. Câmara

Acórdão n 107/2002 - Plenário

Acórdão nº 231/2002 - Plenário

Acórdão n 261/2002 - $1^{\text {a }}$. Câmara

Acórdão n 312/2002 - Plenário

Acórdão n ${ }^{\circ}$ 592/2002 - $1^{\text {a }}$. Câmara

Acórdão n ${ }^{\circ} 830 / 2002$ - $1^{\text {a }}$. Câmara 
Acórdão n 67/2003 - 2ª . Câmara

Acórdão n ${ }^{\circ} 132 / 2003$ - 2 ${ }^{\text {a }}$. Câmara

Acórdão no 145/2003 - 2 ${ }^{\mathrm{a}}$. Câmara

Acórdão n 257/2003 - $1^{\text {a }}$. Câmara

Acórdão n 459/2003 - 2a ${ }^{\text {a }}$ Câmara

Acórdão $n^{\circ}$ 695/2003 - $1^{\text {a }}$. Câmara

Acórdão n 2.077/2003 - $1^{\text {a }}$. Câmara

Acórdão n 2.166/2003 - $1^{\text {a }}$. Câmara

Acórdão n 3.056/2003 - $1^{\text {a }}$. Câmara

Acórdão n 214/2004 - Plenário

Acórdão n 226/2004 - Plenário

Acórdão n ${ }^{\circ}$ 542/2004 - 2 ${ }^{\text {a }}$. Câmara

Acórdão $\mathrm{n}^{\circ}$ 1.032/2004 - $1^{\mathrm{a}}$. Câmara

Acórdão n 1.161/2004 - Plenário

Acórdão n 1.231/2004 - Plenário

Acórdão n 1.617/2004 - 1 ${ }^{\mathrm{a}}$. Câmara

Acórdão $n^{\circ}$ 1.652/2004 - 2a . Câmara

Acórdão n 2.020/2004 - 2a . Câmara

Acórdão n ${ }^{\circ}$ 115/2005 - 2a . Câmara

Acórdão n ${ }^{\circ}$ 127/2005 - 2 ${ }^{\mathrm{a}}$. Câmara

Acórdão n 416/2005 - 1ª . Câmara

Acórdão n ${ }^{\circ} 419 / 2005$ - $1^{\text {a }}$. Câmara

Acórdão n ${ }^{\circ}$ 1.269/2005 - $1^{\mathrm{a}}$. Câmara

Acórdão n 2.739/2005 - $1^{\text {a }}$. Câmara

Acórdão n ${ }^{\circ}$ 2.855/2005 - $1^{\text {a }}$. Câmara

Acórdão n 953/2006 - 1ª . Câmara

Acórdão n 1.559/2006 - Plenário

Acórdão $n^{\circ}$ 1.564/2006 - Plenário

Acórdão n 1923/2006 - Plenário

Acórdão n ${ }^{\circ}$ 1.978/2006 - 2ª . Câmara

Acórdão n² 2.006/2006 - Plenário 
Acórdão n 2.189/2006 - Plenário

Acórdão n 37/2007 - Plenário

Acórdão n 62/2007 - 2 ${ }^{\mathrm{a}}$. Câmara

Acórdão n 206/2007 - Plenário

Acórdão n 343/2007 - $1^{\text {a }}$. Câmara

Acórdão n 1.380/2008 - Plenário

Acórdão n 1.464/2008 - Plenário

Acórdão n 2.202/2008 - $1^{\text {a }}$. Câmara

\title{
24.2.2. Supremo Tribunal Federal (STF)
}

\begin{abstract}
$\mathrm{MS} \mathrm{n}^{\circ} 5490 / \mathrm{RJ}$
$\mathrm{MS} \mathrm{n}^{\circ} 20.335 / \mathrm{DF}$

$\mathrm{MS} \mathrm{n}^{\circ} 22.314 / \mathrm{MS}$

$\mathrm{MS} \mathrm{n}^{\circ} 22.728 / \mathrm{PR}$

$\mathrm{MS} \mathrm{n}^{\circ} 22.643 / \mathrm{SC}$

$\mathrm{MS} \mathrm{n}^{\circ} 24.067 / \mathrm{DF}$

MS n ${ }^{\circ} 23.550 / \mathrm{DF}$

MS n ${ }^{\circ} 23.875$

$\mathrm{MS} \mathrm{n}^{\circ} 24.073 / \mathrm{DF}$

$\mathrm{MS} \mathrm{n}^{\circ} 24.510 / \mathrm{DF}$

$\mathrm{MS} \mathrm{n}^{\circ} 24.519 / \mathrm{DF}$

MS n ${ }^{\circ} 24.584$

MS n² 24.631

MS n ${ }^{\circ} 24.997$

MS n ${ }^{\circ} 25.092$

MS n ${ }^{\circ} 26.210 / \mathrm{DF}$

$\mathrm{RCL} \mathrm{n}^{\circ} 2.138 / \mathrm{DF}$
\end{abstract}

AGCRAE ${ }^{\circ}$ 177.313/MG

SÚMULA VINCULANTE $\mathrm{n}^{\circ} 03$ 
24.2.3. Superior Tribunal de Justiça (STJ)

MS n ${ }^{\circ} 11.466$

$\mathrm{AgRg}$ no MS n ${ }^{\circ} 12.495$

RMS n ${ }^{\circ} 15.620 / \mathrm{PB}$

AgRg no Ag 682.599/RS

AgRg no Ag 993.527/SC

Resp n ${ }^{\circ} 2.821 / \mathrm{RJ}$

Resp n ${ }^{\circ} 325.622 / \mathrm{RJ}$

Resp n ${ }^{\circ} 586.248 / \mathrm{MG}$

Resp n ${ }^{\circ}$ 599.047/MA

Resp n 601.961/MG

Resp $\mathrm{n}^{\circ} 705.715 / \mathrm{SP}$

Resp $\mathrm{n}^{\circ} 719.738 / \mathrm{RS}$

$\operatorname{Resp~}^{\circ}{ }^{8} 858.511 / \mathrm{DF}$

24.2.4. Tribunal Superior Eleitoral (TSE)

ARO - 1132

24.2.5. Tribunal Constitucional Espanhol (TC)

$\mathrm{ATC}^{\circ} 312 / 1996$

$\mathrm{STC} \mathrm{n}^{\circ} 187 / 1988$

STC n ${ }^{\circ} 18 / 1991$

STC n ${ }^{\circ} 177 / 1999$

$\mathrm{STC}^{\circ} 215 / 2000$ 


\subsection{Legislação}

Brasil

Constituição Brasileira (1988)

Lei ${ }^{\circ} 11.705 / 2008$

Lei ${ }^{\circ} 10.028 / 2000$

Lei ${ }^{\circ}$ 9.784/99

Lei $\mathrm{n}^{\circ} 9.873 / 99$

Lei no 8.666/93

Lei $n^{\circ} 8.492 / 92$

Lei $\mathrm{n}^{\circ} 8.443 / 92$

Lei $n^{\circ} 8.112 / 90$

Lei $n^{\circ} 6.880 / 80$

Lei $\mathrm{n}^{\circ} 6.223 / 75$

Lei $n^{\circ} 4.320 / 64$

Lei Complementar $n^{\circ} 101 / 2000$

Lei Complementar no 64/1990

Lei Estadual no 12.600/2004 (PE)

Lei Estadual no 11.424/2000 (RS)

Lei Estadual n 2.423/1996 (AM)

Lei Complementar Estadual nº 269/2007 (MT)

Lei Complementar Estadual no 202/2000 (SC)

Lei Complementar Estadual nº 63/1990 (RJ)

Lei Complementar Estadual no 33/94 (MG)

Lei de Introdução ao Código Civil

Código Civil

Código Penal

Código Penal Militar

Código de Processo Civil

Código de Processo Penal

Código Tributário Nacional 
Regimento Interno do TCU

Instrução Normativa TCU n ${ }^{\circ}$ 57/2008

Decisão Normativa TCU no 57/2004

Decreto Lei $n^{\circ}$ 200/67

Legislação Revogada

Constituição Brasileira (1824)

Constituição Brasileira (1891)

Constituição Brasileira (1934)

Decreto n ${ }^{\circ} 966$ - A/1890

Decreto $\mathrm{n}^{\mathrm{o}} 1.116 / 1892$

Decreto no 2.409/1896

Decreto $n^{\circ} 3.454 / 1918$

Decreto no $13.147 / 1919$

Decreto Legislativo no 392/1896

Decreto - Lei $n^{\circ} 07 / 1937$

Decreto - Lei no $199 / 67$

Lei no 23/1891

Lei $n^{\circ} 156 / 1935$

Portugal

Constituição da República Portuguesa (1976)

Estatuto dos Tribunais Administrativos e Fiscais (Lei n ${ }^{\circ}$ 13/2002 de 19 de fevereiro)

LOPTC (Lei n 98/97)

Lei $n^{\circ} 86 / 89$

Ordenações Manuelinas

Ordenações Afonsinas

Espanha

Constituição Espanhola (1978) 
Texto Consolidado da Lei Geral Orçamentária (Real Decreto no 1091/1988, de 23 de setembro)

Lei Orgânica de Conflitos Jurisdicionais (Lei n ${ }^{\circ}$ 02/1987, de 18 de março)

Lei Orgânica do Tribunal de Contas Espanhol (Lei nº 02/82)

Lei de Santamaria de Paredes (1888)

Lei da Jurisdição Contencioso-Administrativa (1956)

Lei da Jurisdição Contencioso-Administrativa (LJCA - Lei nº 29/1998)

Lei de Funcionamento do Tribunal de Contas (LFTCU - Lei n 07/1988)

França

Constituição Francesa (1958)

Declaração dos Direitos do Homem e do Cidadão (1789)

Code des Juridictions Financières (CJF)

Code de Justice Administrative

Lei n ${ }^{\circ} 48$, de 25 de setembro de 1948

Lei de 23 de fevereiro de 1963

Decreto de 18 de Abril de 1996

Angola

Lei Orgânica do Tribunal de Contas (Lei n $05 / 96)$

Cabo Verde

Lei Orgânica do Tribunal de Contas (Lei no 84/IV/93 de 12 de julho)

Guiné Bissau

Lei Orgânica do Tribunal de Contas (Decreto-Lei nº $07 / 92$ de 27 de novembro)

Bélgica

Constituição Federal - 17/02/1994

Lei Orgânica do Tribunal de Contas ( Lei de 29/10/1846 
Itália

Constituição Italiana (1947)

\subsection{Sítios da Internet}

Associazione fra i Magistrati della Corte dei Conti - http://www.amcorteconti.it

Biblioteca Virtual de Direitos Humanos - USP - http://www.direitoshumanos.usp.br

Cámara de Comptos de Navarra (Espanha) - http://www.cfnavarra.es

Camara de Cuentas da Andalúcia (Espanha) - http://www.ccuentas.es

Camara de Cuentas de Madrid (Espanha) - http://www.camaradecuentasmadrid.es

Camara dos Deputados - http://www.camara.gov.br

Comissão Européia (União Européia) - http://ec.europa.eu

Conseil D' État (Bélgica) - http://www.raad-consetat.be

Consejo de Cuentas de Castilla e León (Espanha) - http://www.consejodecuentas.es

Conselho da Justiça Federal - http://www.cjf.gov.br

Consello de Contas de Galicia (Espanha) - http://www.ccontasgalicia.es

Corte dei Conti (Itália) - http://www.corteconti.it

Cour des Comptes (Bélgica) - http://www.ccrek.be

Cour des Comptes (França) - http://www.ccomptes.fr

Dizionari Online Simone - Dizionario Giuridico (Itália) - http://www.dizionarionline.it

Governo de Cabo Verde - http://www.governo.cv

Legifrance - Le Service Public de la Diffusion du Drout - http://www.legifrance.gouv.fr

Ministerio de Justicia (Espanha) - http://www.mjusticia.es

National Audit Office (Reino Unido) - http://www.nao.gov.uk

Portal Belgium.be (Bélgica) - http://www.belgium.be

Portal de la Constitución Española (Espanha) - http://narros.congreso.es/constitucion

Portal do Governo (Portugal) - www.portugal.gov.pt

Sindicatura de Comptes de Catalunya (Espanha) - http://www.sindicatura.org

Sindicatura de Comptes de la Comunitat Valenciana (Esp.) - http://www.sindicom.vga.es

Tribunal Constitucional (Espanha) - http://www.tribunalconstitucional.es

Tribunal de Contas de Angola - http://www.tcontas.ao 
Tribunal de Contas do Estado - http://www.tce.xx.gov.br ( $\mathrm{xx}$ = sigla do Estado) Tribunal de Contas de São Tomé e Príncipe - http://www.tribunal-contas-stp.net Tribunal de Contas da União - http://www.tcu.gov.br

Tribunal de Cuentas (Espanha) - http://www.tcu.es

Tribunal Vasco de Cuentas Públicas (Espanha) - http://www.tvcp.org

Superior Tribunal de Justiça (Brasil) - http://www.stj.jus.br

Supremo Tribunal Federal (Brasil) - http://www.stf.jus.br

Supremo Tribunal Administrativo (Portugal) - http://www.stadministrativo.pt

Supremo Tribunal de Justiça (Portugal) - http://www.stj.pt 